\title{
MEIO AMBIENTE E SUSTENTABILIDADE
}

\section{PESQUISA, REFLEXÕES E DIÁLOGOS EMERGENTES}

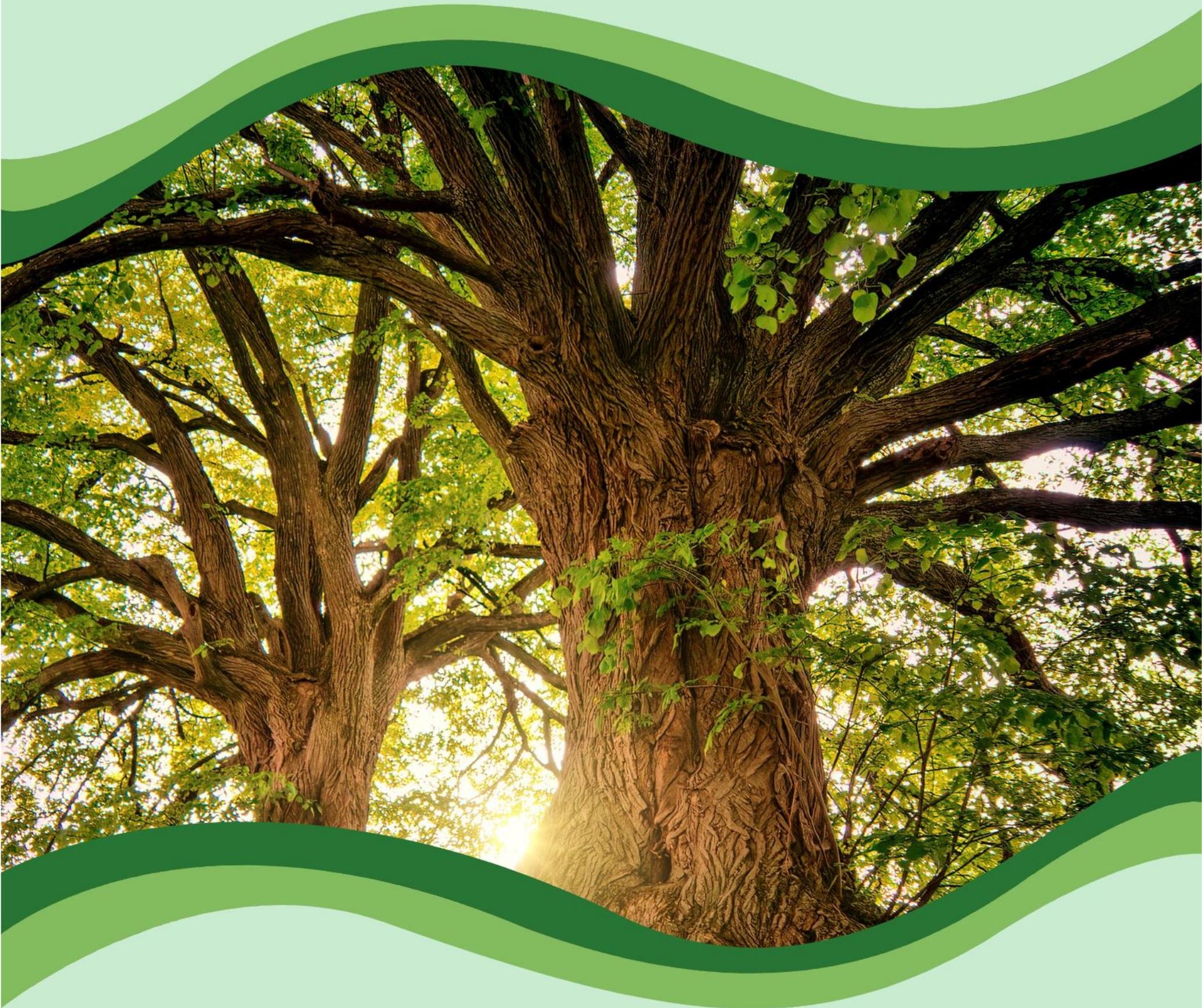




\section{MEIO AMBIENTE E SUSTENTABILIDADE}

\section{PESQUUISA, REFLEXÕES E DIÁLOGOS EMERGENTES}

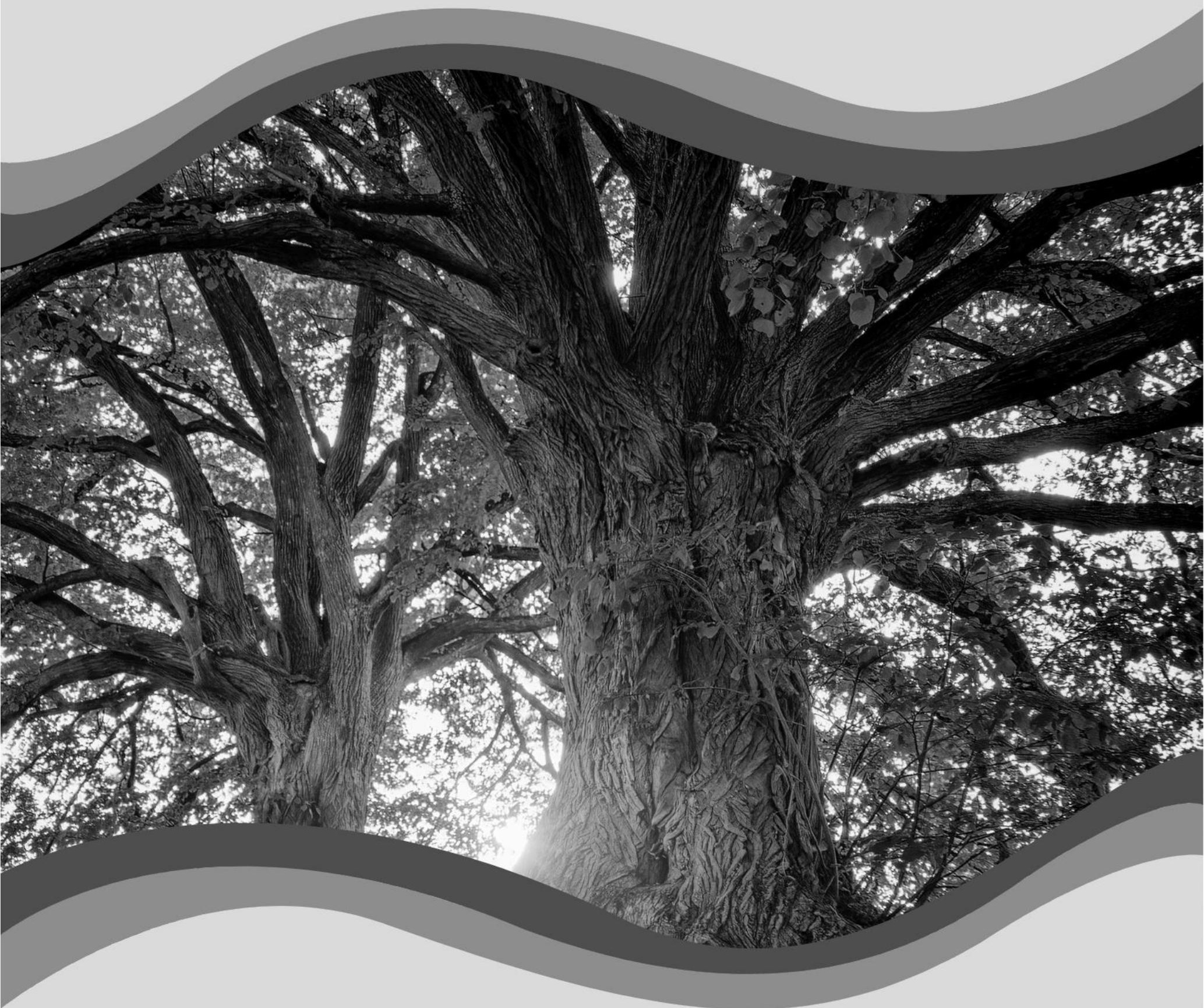

VOLUMEI

ORGANIZADORES HIGOR COSTA DE BRITO MANOEL MARIANO NETO DA SILVA YÁSCARA MAIA ARAÚJO DE BRITO 


\section{ZIMAPLLA}

2021 - Editora Amplla

Copyright @ Editora Amplla

Editor Chefe: Leonardo Pereira Tavares

Design da Capa: Editora Amplla

Projeto Gráfico: Editora Amplla

Diagramação: Higor Costa de Brito

Meio ambiente e sustentabilidade: pesquisa, reflexões e diálogos emergentes está licenciado sob CC BY 4.0 .

Esta licença exige que as reutilizações deem crédito ao criador. Ele permite que os reutilizadores distribuam, remixem, adaptem e construam o material em qualquer meio ou formato, mesmo para fins comerciais.

O conteúdo da obra e seus dados em sua forma, correção e confiabilidade são de responsabilidade exclusiva dos autores, não representando a posição oficial da Editora Amplla. É permitido o download da obra e o compartilhamento desde que sejam atribuídos créditos aos autores. Todos os direitos para esta edição foram cedidos à Editora Amplla.

ISBN: 978-65-88332-48-1

DOI: 10.51859/amplla.mas481.1121-0

Editora Amplla

Campina Grande - PB - Brasil contato@ampllaeditora.com.br www.ampllaeditora.com.br 


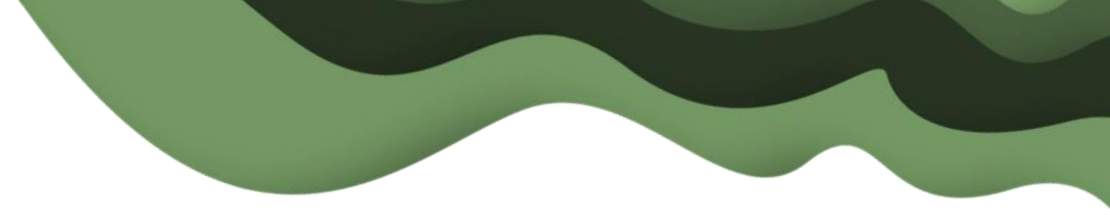

\section{CONSELHO EDITORIAL}

Andréa Cátia Leal Badaró - Universidade Tecnológica Federal do Paraná Andréia Monique Lermen - Universidade Federal do Rio Grande do Sul Antoniele Silvana de Melo Souza - Universidade Estadual do Ceará Bergson Rodrigo Siqueira de Melo - Universidade Estadual do Ceará Bruna Beatriz da Rocha - Instituto Federal do Sudeste de Minas Gerais Caio César Costa Santos - Universidade Federal de Sergipe Carina Alexandra Rondini - Universidade Estadual Paulista Carla Caroline Alves Carvalho - Universidade Federal de Campina Grande Carlos Augusto Trojaner - Prefeitura de Venâncio Aires Carolina Carbonell Demori - Universidade Federal de Pelotas Cícero Batista do Nascimento Filho - Universidade Federal do Ceará Clécio Danilo Dias da Silva - Universidade Federal do Rio Grande do Norte Daniela de Freitas Lima - Universidade Federal de Campina Grande Denise Barguil Nepomuceno - Universidade Federal de Minas Gerais Dylan Ávila Alves - Instituto Federal Goiano Edson Lourenço da Silva - Instituto Federal de Educação, Ciência e Tecnologia do Piauí Elane da Silva Barbosa - Universidade Estadual do Ceará Érica Rios de Carvalho - Universidade Católica do Salvador Gilberto de Melo Junior - Instituto Federal do Pará Higor Costa de Brito - Universidade Federal de Campina Grande Italan Carneiro Bezerra - Instituto Federal da Paraíba Ivo Batista Conde - Universidade Estadual do Ceará Jaqueline Rocha Borges dos Santos - Universidade Federal Rural do Rio de Janeiro Jessica Wanderley Souza do Nascimento - Instituto de Especialização do Amazonas João Henriques de Sousa Júnior - Universidade Federal de Santa Catarina João Manoel Da Silva - Universidade Federal de Alagoas

João Vitor Andrade - Universidade de São Paulo Joilson Silva de Sousa - Instituto Federal do Rio Grande do Norte José Cândido Rodrigues Neto - Universidade Estadual da Paraíba Jose Henrique de Lacerda Furtado - Instituto Federal do Rio de Janeiro Josenita Luiz da Silva - Faculdade Frassinetti do Recife Josiney Farias de Araújo - Universidade Federal do Pará Karina de Araújo Dias - SME/Prefeitura Municipal de Florianópolis Laíze Lantyer Luz - Universidade Católica do Salvador Lindon Johnson Pontes Portela - Universidade Federal do Oeste do Pará Lucas Capita Quarto - Universidade Federal do Oeste do Pará Lúcia Magnólia Albuquerque Soares de Camargo - Unifacisa Centro Universitário Luciana de Jesus Botelho Sodré dos Santos - Universidade Estadual do Maranhão Luís Paulo Souza e Souza - Universidade Federal do Amazonas Luiza Catarina Sobreira de Souza - Faculdade de Ciências Humanas do Sertão Central Manoel Mariano Neto da Silva - Universidade Federal de Campina Grande Marcelo Alves Pereira Eufrasio - Centro Universitário Unifacisa Marcelo Williams Oliveira de Souza - Universidade Federal do Pará Marcos Pereira dos Santos - Faculdade Rachel de Queiroz Marcus Vinicius Peralva Santos - Universidade Federal da Bahia Marina Magalhães de Morais - Universidade Federal de Campina Grande Nadja Maria Mourão - Universidade do Estado de Minas Gerais Natan Galves Santana - Universidade Paranaense Nathalia Bezerra da Silva Ferreira - Universidade do Estado do Rio Grande do Norte Neide Kazue Sakugawa Shinohara - Universidade Federal Rural de Pernambuco Neudson Johnson Martinho - Faculdade de Medicina da Universidade Federal de Mato Grosso Patrícia Appelt - Universidade Tecnológica Federal do Paraná 
Paulo Henrique Matos de Jesus - Universidade Federal do Maranhão Rafael Rodrigues Gomides - Faculdade de Quatro Marcos

Reângela Cíntia Rodrigues de Oliveira Lima - Universidade Federal do Ceará

Rebeca Freitas Ivanicska - Universidade Federal de Lavras

Renan Monteiro do Nascimento - Universidade de Brasília

Ricardo Leoni Gonçalves Bastos - Universidade Federal do Ceará

Rodrigo da Rosa Pereira - Universidade Federal do Rio Grande

Sabrynna Brito Oliveira - Universidade Federal de Minas Gerais

Samuel Miranda Mattos - Universidade Estadual do Ceará

Shirley Santos Nascimento - Universidade Estadual Do Sudoeste Da Bahia

Silvana Carloto Andres - Universidade Federal de Santa Maria

Silvio de Almeida Junior - Universidade de Franca

Tatiana Paschoalette Rodrigues Bachur - Universidade Estadual do Ceará

Telma Regina Stroparo - Universidade Estadual do Centro-Oeste

Thayla Amorim Santino - Universidade Federal do Rio Grande do Norte

Virgínia Maia de Araújo Oliveira - Instituto Federal da Paraíba

Virginia Tomaz Machado - Faculdade Santa Maria de Cajazeiras

Walmir Fernandes Pereira - Miami University of Science and Technology

Wanessa Dunga de Assis - Universidade Federal de Campina Grande

Wellington Alves Silva - Universidade Estadual de Roraima

Yáscara Maia Araújo de Brito - Universidade Federal de Campina Grande

Yasmin da Silva Santos - Fundação Oswaldo Cruz

Yuciara Barbosa Costa Ferreira - Universidade Federal de Campina Grande 


\section{ZIAMPLLA}

2021 - Editora Amplla

Copyright (C) Editora Amplla

Editor Chefe: Leonardo Pereira Tavares

Design da Capa: Editora Amplla

Projeto Gráfico: Editora Amplla

Diagramação: Higor Costa de Brito

Dados Internacionais de Catalogação na Publicação (CIP)

Sueli Costa CRB-8/5213

Meio ambiente e sustentabilidade [livro eletrônico]: pesquisa, reflexões e diálogos emergentes / organização Higor Costa de Brito... [et al.] - Campina Grande : Editora Amplla, 2021.

$2 \mathrm{~V}$.

Formato: $\mathrm{PDF}$

ISBN: 978-65-88332-48-1 (vol.1)

ISBN : 978-65-88332-49-8 (vol.2)

1. Recursos naturais 2. Poluição ambiental 3. Ecossistemas 4. Educação ambiental 5. Planejamento urbano I. Brito, Higor Costa de II. Título.

\section{Índices para catálogo sistemático:}

1. Meio ambiente 577

Editora Amplla

Campina Grande - PB - Brasil contato@ampllaeditora.com.br www.ampllaeditora.com.br 


\section{PREFÁCIO}

Devido às modificações no comportamento humano, em especial na maneira de produzir e consumir bens, nota-se uma série de modificações ambientais, das quais se destacam a intensificação da poluição ambiental, o esgotamento dos recursos naturais e consequente degradação dos ecossistemas, a ampliação dos conflitos e desigualdade social, além do aumento progressivo das temperaturas do planeta.

Ao tratar do Brasil, esta crise sanitária, deflagrada globalmente, é impulsionada pela crise política. Desta maneira, as políticas ambientais e sociais são gradualmente corroídas, culminando em graves retrocessos. Dentre os fatores mais relevantes, podese citar a invasão de terras indígenas, a expansão das atividades de mineração desenvolvidas de ilegalmente, violações às leis ambientais e aos direitos humanos, perdas da qualidade de vida e o aumento do desmatamento.

Tais questões, por sua vez, exigem da sociedade, em especial daqueles que desenvolvem a ciência, críticas e soluções para o enfrentamento desse quadro de irregularidades. Assim, o livro "Meio ambiente e sustentabilidade: pesquisa, reflexões e diálogos emergentes" contempla dois volumes que reúnem uma coletânea de 73 capítulos que permitem aos leitores o encadeamento de ideias e reflexões sobre o meio ambiente, abordando meios de convivência sustentável face ao uso dos mais diversos recursos naturais existentes. São elencadas as problemáticas já instauradas como também soluções resolutivas e mitigadoras.

O primeiro volume trata das leis ambientais associadas à sustentabilidade, destacando a necessidade da educação ambiental e os riscos atrelados à sua ausência. Conta também com a temática do uso de fertilizantes, que impulsionam a produtividade agrícola, com destaque para a cultura de soja. Esse uso tem como impacto a poluição do solo e da água, sendo necessário o tratamento de efluentes provenientes dessa produção, assunto também abordado ao longo dos capítulos.

Já o segundo volume, dá espaço ao estudo das áreas verdes e do conforto ambiental que estas proporcionam, com enfoque ao planejamento urbano. Por conseguinte, são abordadas as fontes de energias renováveis, a produção de alimentos, a ecologia e suas diversas paisagens, as mudanças climáticas e os impactos a elas 
associados. Os trabalhos apresentados denotam revisões bibliográficas e estudos empíricos sobre os temas citados.

Os organizadores do livro, assim como os autores dos capítulos, esperam que os trabalhos aqui apresentados possam contribuir para a construção de novas reflexões e pesquisas orientadas à sustentabilidade ambiental.

Desejamos a todos uma boa leitura!

Yáscara Maia Araújo de Brito

Engenheira Civil Doutoranda em Engenharia de Recursos Naturais

Manoel Mariano Neto Engenheiro Ambiental e Sanitarista Doutorando em Engenharia Civil e Ambiental

Higor Costa de Brito Engenheiro Civil Doutorando em Engenharia Civil e Ambiental 


\section{SUMÁRIO}

CAPÍTULO I - ANÁlISE dAS LEIS AMBIENTAIS BRASILEIRAS E SUA INTERFACE COM OS OBJETIVOS DO DESENVOLVIMENTO SUSTENTÁVEL - ODS.

CAPÍTULO II - A INTERNACIONALIZAÇÃO DA PROTEÇ̃̃o AMAZÔNICA: UM APARENTE EMBATE ENTRE A SOBERANIA NACIONAL E A COMUNIDADE INTERNACIONAL

CAPÍTULO III - DESENVOLVIMENTO SUSTENTÁVEL: COMPORTAMENTO DE CONSUMO DE PRODUTOS SUSTENTÁVEIS34

CAPÍTULO IV - PERSPECTIVAS E DESAFIOS DA ECONOMIA CIRCULAR NO BRASIL. 50

CAPÍTULO V - ANÁLISE DAS PRÁTICAS DE SUSTENTABILIDADE SOB A ÓTICA DO GLOBAL REPORT INITIATIVE (GRI): UM ESTUDO DE CASO EM UMA ORGANIZAÇ̃̃O DO SETOR DE AGRONEGÓCIO . .66

CAPÍTULO VI - DIAGNÓSTICO DE SUSTENTABILIDADE AMBIENTAL DE UMA UNIDADE PRODUTIVA NO MUNICÍPIO DE CASTANHAL/PA

CAPITULO VII - CONSIDERAÇÕES SOBRE O LICENCIAMENTO AMBIENTAL NO BRASIL: AVANÇOS E DESAFIOS .96

CAPITULO VIII - SISTEMAS DE GESTÃO AMBIENTAL (SGA) NAS INSTITUIÇÕES DE ENSINO SUPERIOR - ENFOQUE NAS CONTRIBUIÇÕES PARA IMPLEMENTAÇ̃̃O DE SOCIEDADES SUSTENTÁVEIS .108

CAPítulo IX - A UtILIZAÇ̃̃o dA COLETA SEletiva de LIXO NA EEeP RAIMUNDO SARAIVA COELHO. 119

CAPÍTULO X - EDUCAÇÃO AMBIENTAL NO CONTEXTO ESCOLAR: PROJETO APLICADO NA ESCOLA AGROAMBIENTAL DE CURRALINHO-PA. 130

CAPÍTULO XI - ARTE E EDUCAÇÃo EM PROL DO MEIO AMBIENTE. 151

CAPÍTULO XII - EDUCAÇÃO E SUSTENTABILIDADE. 165

CAPÍTULO XIII - CONEXÃO AMBIENTAL: CONSCIENTIZAÇ̃̃o dO LIXO E RECICLAGEM EM TEMPOS DE PANDEMIA NO MUNICÍPIO DE MACEIÓ-AL. . .174

CAPíTULO XIV - DESAFIOS DA EDUCAÇÃo AMBIENTAL DURANTE A PANDEMIA DA COVID-19: CONSCIENTIZAÇ̃̃̃O AMBIENTAL E DESENVOLVIMENTO SUSTENTÁVEL. . .182

CAPÍTULO XV - O AUTOCUIDADO NA SÍFLIS E HEPATITE C: AÇÃO EDUCATIVA COM TRABALHADORES DE MATERIAIS RECICLÁVEIS. 189

CAPÍTULO XVI - RISCOS AMBIENTAIS E ERGONÔMICOS NAS ATIVIDADES DE COLETA E EXTRAÇÃO DE MARISCOS NO NORDESTE PARAENSE. .200

CAPÍTULO XVII - UTILIZAÇ̃̃o DE EPI'S NA APLICAÇ̃̃o DE AGROQUíMICOS EM LAVOURAS DE SOJA NO MUNICÍPIO DE CHAPECÓ/SC. 219

CAPÍTULO XVIII - COMPONENTES DE RENDIMENTO DA SOJA MANEJADA COM A APLICAÇ̃̃o DE CÁLCIO E ENXOFRE 
CAPITULO XIX - CRESCIMENTO INICIAL DE CULTIVARES DE SOJA SEMEADOS EM DIFERENTES PROFUNDIDADES EM CASA DE VEGETAÇÃO

CAPITULO XX - NECESSIDADES NUTRICIONAIS DA SOJA E USO DE RESÍDUOS ORGÂNICOS NA AGRICULTURA .........269

CAPÍTULO XXI - USO DA CAMA AVIÁRIA COMO ALTERNATIVA DE FERTILIZANTE ORGÂNICO NA CULTURA DA SOJA 285

CAPÍTULO XXII - CONTROLE QUÍMICO DE CAPIM AMARGOSO (DIGITARIA INSULARIS (L.) FEDDE) COM DIFERENTES HERBICIDAS E APLICAÇÕES SEQUENCIAIS

CAPÍTULO XXIII - ANÁLISE COMPORTAMENTAL DE CULTIVARES DO FEIJÃO CAUPI COM A UTILIZAÇÃO DE DIFERENTES SUBSTRATOS ORGÂNICOS 310

CAPÍTULO XXIV - CONTAMINAÇÃO DO AR, DO SOLO E DA ÁGUA POR PESTICIDAS USADOS NA AGRICULTURA ........ 319

CAPÍTULO XXV - GESSO E COPRODUTOS DE MINERAÇÃO NA CORREÇ̃̃ DE UM SOLO SALINO-SÓDICO PARA PRODUÇÃO NO SEMIÁRIDO. 336

CAPÍTULO XXVI - USO SUSTENTÁVEL DE ABELHAS MELÍFERAS ( APIS MELLIFERA) E ABELHAS NATIVAS SEM FERRÃO (APIDAE: MELIPONIND NA POLINIZAÇÃO DE CULTURAS AGRÍCOLAS EM AMBIENTES PROTEGIDOS. 349

CAPITULO XXVII - IMPACTOS AMBIENTAIS DO HERBICIDA TEBUTHIURON E SOLUÇÕES BIOTECNOLÓGICAS DE REMEDIAÇÃO POR MICRORGANISMOS 361

CAPÍTULO XXVIII - NANOCOMPÓSITOS MAGNÉTICOS NA REMOÇ̃̃O DE COMPOSTOS ORGÂNICOS AROMÁTICOS......371

CAPÍTULO XXIX - SIMULAÇÃO DA CONCENTRAÇÃO DE MATÉRIA ORGÂNICA EM CANAIS URBANOS: ESTUDO DE CASO CANAL DO PRADO, CAMPINA GRANDE-PB

CAPÍTULO XXX - A APLICAÇ̃̃O DA QUITINA NO TRATAMENTO DE EFLUENTES DE INDÚSTRIA TÊXTIL: UM ESTUDO DE REVISÃO .408

CAPÍTULO XXXI - QUALIDADE E USO DA ÁGUA DE UM IGARAPÉ, UMA NASCENTE E UM RESERVATÓRIO NA ZONA RURAL DO MUNICÍPIO DE NOVA TIMBOTEUA - PA . 418

CAPÍTULO XXXII - ABORDAGEM MULTIDISCIPLINAR DAS CARACTERÍSTICAS DA ÁGUA DO RIO IGARASSU (PE, BRASIL) 445

CAPÍTULO XXXIII - FONTES RENOVÁVEIS DE ENERGIA NO BRASIL E SEU USO EM TECNOLOGIAS ELETROQUÍMICAS NO TRATAMENTO DE EFLUENTES 460

CAPÍTULO XXXIV - A INFLUÊNCIA DA ÁGUA NA QUEBRA DE DORMÊNCIA DA TECTONA GRANDIS L.F. 476

CAPÍTULO XXXV - IMPORTÂNICA DA QUANTIDADE E QUALIDADE DOS RECURSOS HÍDRICOS DE ÁGUA DOCE. 485

CAPÍTULO XXXVI - COBRANÇA PELO USO DA ÁGUA NA BACIA HIDROGRÁFICA DO RIO PARAíbA - PB: DESAFIOS E NECESSIDADES DE MELHORIAS. .500

CAPÍTULO XXXVII - ANÁLISE DOS IMPACTOS AMBIENTAIS SOBRE OS RECURSOS HÍDRICOS NO SEMIÁRIDO BRASILEIRO 516 
CAPÍTULO XXXVIII - DIAGNÓSTICO DO FECHAMENTO DE MINA DOS MUNICÍPIOS DE JANAÚBA E PORTEIRINHA ....528

CAPÍTULO XXXIX - CARACTERIZAÇÃO DA FAUNA TRIATOMÍNICA DA COMUNIDADE QUILOMBOLA DO CEDRO EM MINEIROS/GO E CONHECIMENTO DOS MORADORES SOBRE A DOENÇA DE CHAGAS .544 


\title{
CAPÍTULO
}

\section{AMÁIISE DAS LEIS AMBIENTAIS BRASIIEIRAS E SUA INIIERFACE COM OS OBJEIIVOS DO DESENVOLVIMENTO SUSTENTÁVELL - ODS}

DOI: 10.51859/amplla.mas481.1121-1

Nadege da Silva Dantas ${ }^{1}$

Isabel Lausane Fontgaland ${ }^{2}$

Janaína Barbosa da Silva ${ }^{3}$

Rebeca Letícia Matos da Silva ${ }^{4}$

\begin{abstract}
${ }^{1}$ Professora da Universidade Federal de Campina Grande. Doutoranda em Gestão de Recursos Naturais. Universidade Federal de Campina Grande - UFCG

2 Professora Titular da Universidade Federal de Campina Grande - UFCG. Pós-Doutora em Economia Ambiental pela Ohio University - EUA. Doutora em Economia pelo LIRHE/CNRS - UT1 - França. Professora e orientadora do programa de Pós-Graduação em Recursos Naturais - PPGRN - UFCG.

${ }^{3}$ Professora Adjunta da Universidade Federal de Campina Grande - UFCG. Pós-Doutora em Geografia. Professora e orientadora do programa de Pós-Graduação em Recursos Naturais - PPGRN - UFCG.

${ }^{4}$ Bacharelanda em Direito. Universidade Federal de Pernambuco - UFPE
\end{abstract}

\section{RESUMO}

A legislação ambiental brasileira constitui-se um elemento estratégico para o alcance do desenvolvimento sustentável, tendo em vista ser o principal instrumento de comando e controle que o Estado possui para regular as atividades produtivas e econômicas em geral, ao estabelecer os limites e normas na relação público-privado. Neste sentido, o objetivo do trabalho é analisar as principais leis ambientais brasileiras, apontando sua interface com os Objetivos do Desenvolvimento Sustentável, propostos pela ONU, e suas metas. Espera-se contribuir com futuros trabalhos nessa área, dada a jovialidade do tema, além de possibilitar um olhar mais objetivo sobre o assunto, utilizando-se como parâmetros os ODS que servirão de base para identificar os que se aproximam mais das questões ambientais, no sentido de contribuir para o alcance do desenvolvimento sustentável.

Palavras-chave: Legislação Ambiental. ODS. Sustentabilidade.

\section{INTRODUÇÃO}

Os Objetivos do Desenvolvimento Sustentável - ODS, que compõem a Agenda 2030, foram lançados em 2015, pela ONU (Nações Unidas, 2015), para acabar com a pobreza, proteger o meio ambiente e o planeta, bem como assegurar a prosperidade para todas as nações (ONU, 2015). Os ODS representam o núcleo da Agenda e deverão ser alcançados até o ano 2030. 
O documento foi assinado por 193 países-membros das Nações Unidas e contém 17 objetivos e 169 metas que identificam as prioridades globais de desenvolvimento sustentável e refletem, ao mesmo tempo, o compromisso oficial do mundo com a erradicação da pobreza extrema, reconhecendo, também, a necessidade de operar dentro dos limites ecológicos do planeta.

Segundo o Relatório criado pela Comissão Brundtland, em nome da ONU, intitulado: "O Nosso Futuro Comum", "o desenvolvimento sustentável atende às necessidades do presente sem comprometer a capacidade das gerações futuras de atender às suas próprias necessidades" (Comissão Mundial sobre Meio Ambiente e Desenvolvimento, 1988). A comissão destaca que "um planeta esgotado não será capaz de fornecer os insumos físicos necessários para as gerações futuras". .

Esta definição de desenvolvimento sustentável é reconhecida nas bases internacionais como a WWF, IUCN e PNUMA, respectivamente: "melhorar a qualidade de vida humana enquanto vive dentro da capacidade de suporte de ecossistemas" [WWF (Fundo Mundial para a Natureza), IUCN (Internacional Union for Conservation of Nature), e UNEP (United Nations Environment Program), 1991].

Com o passar dos anos, observa-se, no entanto, que alguns fatores como o uso ecológico excessivo, a perda de biodiversidade, nitrificação excessiva e mudanças climáticas, vêm afetando a capacidade dos recursos naturais, comprometendo os limites naturais do nosso planeta e ganharam mais destaque através da meta do Acordo Climático de Paris de 2015 de não exceder $2^{\circ} \mathrm{C}$ de aquecimento em relação às temperaturas pré-industriais, que são de, aproximadamente, $1,5^{\circ} \mathrm{C}$ (UNFCCC, 2015).

Além disso, o uso abusivo dos ecossistemas do planeta, pela humanidade, indica uma sobrecarga na capacidade disponível dos nossos recursos. As estimativas mais recentes, provavelmente conservadoras, indicam que a demanda da humanidade excede a capacidade disponível em mais de 68\% (Borucke et al., 2013).

Diante desse cenário, em 2017, a Rede WWF desenvolveu uma estratégia global, que abrange o período até 2030 , com o propósito de alterar a trajetória das curvas de perda de biodiversidade e do aumento das emissões de gases de efeito estufa (GEE) e conter a extinção de espécies e o desaparecimento de ecossistemas, assim como mitigar os principais causadores das mudanças climáticas (Rede WWF, 2017). 
No Brasil, as leis que tratam do meio ambiente estão entre as mais completas e avançadas do mundo. No entanto, de acordo com o III Relatório Luz, da Sociedade Civil da Agenda 2030 de Desenvolvimento Sustentável, lançado em 2019, pelo Grupo de Trabalho da Sociedade Civil para a Agenda 2030 (GT Agenda 2030), o acirramento das violações e o desrespeito aos direitos sociais, ambientais e econômicos em curso no Brasil coloca o país cada vez mais distante do caminho do desenvolvimento sustentável.

O Relatório mostra, ainda, que os retrocessos que vêm sendo promovidos no país agravam, principalmente, a vida das mulheres negras, das quilombolas e das indígenas, sem apresentar soluções para pacificar o país; diminui a transparência e os espaços de diálogo; e favorece forte tendência de que a judicialização firme-se como estratégia para a garantia de direitos (Relatório Luz, 2019).

Além desses problemas que afetam a população, principalmente as mais vulneráveis, outros temas voltados ao Meio Ambiente são apontados no referido documento, como por exemplo, a liberação de novos agrotóxicos, por parte do Ministério do Meio Ambiente, os desastres ambientais ocorridos em Minas Gerais, nos anos de 2015 e 2019, respectivamente, o que demonstra nosso distanciamento cada vez maior do plano de ação mundial que compõe os ODS, ferindo a cartilha do desenvolvimento sustentável, defendida e assinada por 193 países, incluindo o Brasil, nas Nações Unidas em 2015.

Essa realidade despertou-nos o interesse de realizar uma leitura minuciosa das principais leis ambientais brasileiras, destacando o principal objetivo de cada uma, sua natureza e principais conclusões, a fim de verificar a relação destas com o compromisso assumido pelo governo brasileiro, junto à Organização das Nações Unidas (ONU), de alcançar os 17 Objetivos do Desenvolvimento Sustentável até 2030, bem como se houve alguma atualização na referida legislação, no período pós-2015, visando o alinhamento com os 17 ODS.

É importante ressaltar que as leis ambientais são criadas com o intuito de proteger o meio ambiente e minimizar as consequências de ações que degradam o meio ambiente, todavia, a falta de conscientização da população, para o tema, e a baixa fiscalização são os principais fatores que influenciam negativamente nossa situação. 
Portanto, esta pesquisa justifica-se pela relevância em apresentar uma visão abrangente do panorama atual em torno da legislação ambiental brasileira e sua interface com os Objetivos do Desenvolvimento Sustentável (ODS).

\section{REVISÃO BIBLIOGRÁFICA}

\subsection{OS OBJetivos do DESENVOLVIMENTO SUSTENTÁVEL E A LEGISLAÇÃO AMBIENTAL BRASILEIRA}

Todo ser humano tem direito a viver num meio ambiente sadio e ecologicamente equilibrado para ter qualidade de vida. Esse princípio é expresso no texto da Constituição Federal, que no seu art. 225, totalmente dedicado ao meio ambiente e dispõe que "Todos tem direito ao meio ambiente equilibrado, bem de uso comum do povo e essencial à sadia qualidade de vida, impondo-se ao Poder Público e à coletividade o dever de defendê-lo e preservá-lo para as presentes e futuras gerações" (CF., 1988).

No Brasil, a Política Nacional do Meio Ambiente (PNMA) é regida pela Lei no 6.938/1981. Em 2004, foi criado, a partir da PNMA, o licenciamento ambiental, cujas propostas estão distribuídas em 16 apensados (ou substitutivos) que compõem o PL no $3.729 / 04$.

Este processo foi normatizado pelo Conselho Nacional do Meio Ambiente CONAMA e reconhecido como uma política pública que visa promover o desenvolvimento econômico, mantendo a qualidade do meio ambiente e a viabilidade social, com o objetivo final de promover o desenvolvimento sustentável.

A lei que define a PNMA foi considerada um marco para o nosso país, uma vez que colocou na política a importância de preservar o meio ambiente para futuras gerações, apoiando empreendimentos sustentáveis e diminuindo a degradação ambiental. Trata-se do primeiro documento jurídico que estabelece a obrigatoriedade do licenciamento ambiental quando da construção, instalação, ampliação e funcionamento de estabelecimentos de atividades utilizadoras de recursos ambientais, que possam poluir ou degradar o meio ambiente em território nacional, sendo assegurada por princípios ambientais essenciais para a almejada sustentabilidade, como o de Precaução, Prevenção e Poluidor-pagador (ALMEIDA, 2009). 
Com a criação da Lei n.o 9.605 (Lei de Crimes Ambientais), em 12 de fevereiro de 1998, a legislação ambiental no que toca à proteção ao meio ambiente passou a ser centralizada, em que as penas têm uniformização e gradação adequadas e as infrações são claramente definidas.

Nesse sentido, a legislação ambiental brasileira constitui-se um elemento estratégico para o alcance do desenvolvimento sustentável, tendo em vista ser o principal instrumento de comando e controle que o Estado possui para regular as atividades produtivas e econômicas em geral, ao estabelecer os limites e normas na relação público-privado.

Em alinhamento a esse contexto, a Organização das Nações Unidas (ONU) definiu uma série de metas por meio dos Objetivos do Desenvolvimento Sustentável (ODS) para acabar com a pobreza, proteger o meio ambiente e o planeta, bem como assegurar a prosperidade para todas as nações (ONU, 2015).

Os Objetivos do Desenvolvimento Sustentável buscam mudar as aspirações e práticas de desenvolvimento de várias maneiras. Os ODS são universais, ou seja, estabelecem uma base normativa única para todas as nações e se baseiam em premissas de interdependência no desenvolvimento de valores sociais, econômicos e ambientais, dando muito mais ênfase aos limites ecológicos da existência humana e aos perigos das mudanças climáticas.

Outro ponto é a estrutura de monitoramento e geração de relatórios dos ODS, possibilitada por inovações em ciências geoespaciais, modelagem complexa e análise de Big Data, que permite a integração de análises espaciais e estatísticas e o agrupamento de indicadores locais, nacionais e globais. Essa revolução tecnológica nos dados permite maior flexibilidade na seleção e geração de relatórios e, portanto, possibilita reformular as métricas do desenvolvimento global (SSDN, 2013). Vale ressaltar que, cada nação deve ajustar suas métricas para a realidade local, e no caso do Brasil, ainda há muitos desafios a serem vencidos, especialmente em relação à existência de indicadores que permitam o monitoramento dos ODS.

Esses objetivos buscam integrar, de modo equilibrado, as dimensões econômica, social e ambiental do desenvolvimento que causam impactos na sociedade e no meio ambiente. Nesse sentido, os governos precisam estar cientes dessas metas, 
considerando que existem muitos desafios para promover o desenvolvimento sustentável, especialmente nas cidades dos países em desenvolvimento, que geralmente tem governança fraca (Santos \& Ribeiro, 2015).

Nesse sentido, os países devem interpretar os ODS de acordo com as suas circunstâncias e níveis nacionais de desenvolvimento, considerando as diferenças geográficas, nível de governança e tecnologia (Nilsson, Griggs \& Visbeck, 2016). Portanto, a natureza holística da estrutura dos ODS implica que muitas interações potenciais entre as 169 metas devem ser consideradas pelos formuladores de políticas públicas (Costanza et al., 2016; Rickels et al., 2016). Essa relação entre as metas contribui para que o desenvolvimento seja atingido de forma equilibrada entre diversas áreas, mediante a elaboração de políticas públicas mais efetivas.

Com base no propósito estabelecido na Agenda 2030, este trabalho apresenta uma análise das 17 leis ambientais brasileiras, objetivando contextualizar sua relação com os Objetivos de Desenvolvimento Sustentável.

\subsection{A AGENDA 2030 E OS 17 OBJETIVOS DE DESENVOLVIMENTO SUSTENTÁVEL}

A Agenda 2030 é um plano de ação para as pessoas, o planeta e a prosperidade, que busca fortalecer a paz universal. O plano indica 17 Objetivos do Desenvolvimento Sustentável e 169 metas, para erradicar a pobreza e promover vida digna para todos, dentro dos limites do planeta, a saber:

1. Acabar com a pobreza em todas as suas formas, em todos os lugares.

2. Acabar com a fome, alcançar a segurança alimentar e melhoria da nutrição e promover a agricultura sustentável.

3. Assegurar uma vida saudável e promover o bem-estar para todos, em todas as idades.

4. Assegurar a educação inclusiva e equitativa e de qualidade, e promover oportunidades de aprendizagem ao longo da vida para todos.

5. Alcançar a igualdade de gênero e empoderar todas as mulheres e meninas.

6. Assegurar a disponibilidade e gestão sustentável da água e saneamento para todos.

7. Assegurar o acesso confiável, sustentável, moderno e a preço acessível à energia para todos. 
8. Promover o crescimento econômico sustentado, inclusivo e sustentável, emprego pleno e produtivo e trabalho decente para todos.

9. Construir infraestruturas resilientes, promover a industrialização inclusiva e sustentável e fomentar a inovação.

10. Reduzir a desigualdade dentro dos países e entre eles.

11. Tornar as cidades e os assentamentos humanos inclusivos, seguros, resilientes e sustentáveis.

12. Assegurar padrões de produção e de consumo sustentáveis.

13. Tomar medidas urgentes para combater a mudança climática e seus impactos.

14. Conservação e uso sustentável dos oceanos, dos mares e dos recursos marinhos para o desenvolvimento sustentável.

15. Proteger, recuperar e promover o uso sustentável dos ecossistemas terrestres, gerir de forma sustentável as florestas, combater a desertificação, deter e reverter a degradação da terra e deter a perda de biodiversidade.

16. Promover sociedades pacíficas e inclusivas para o desenvolvimento sustentável, proporcionar o acesso à justiça para todos e construir instituições eficazes, responsáveis e inclusivas em todos os níveis.

17. Fortalecer os meios de implementação e revitalizar a parceria global para o desenvolvimento sustentável.

\subsection{ANÅliSE dA LEGISLAÇÃo AMBIENTAL BRASILEIRA E SUA INTERFACE COM OS OBJETIVOS DO DESENVOLVIMENTO SUSTENTÁVEL}

Importa destacar que todas as leis ambientais brasileiras, estabelecem alguma relação com os ODS, seja de forma direta ou indiretamente, pois, a vida humana está intimamente ligada à natureza e completamente dependente desta, e o bem-estar social, garantido constitucionalmente, assegura um ambiente livre para viver, além de qualidade física e mental.

Assim, a partir da leitura das dezessete principais leis ambientais em vigor no Brasil, analisamos como cada uma destas se encaixa com os ODS da Agenda 2030 da ONU. Como explicitado no próprio site do Planalto: "a própria Resolução da ONU prevê a possibilidade de cada país decidir sobre a forma de implementação da Agenda em seu 
território1". Assim, apesar de o Brasil continuar vinculado às obrigações que assumiu, por uma própria questão de soberania, pode determinar como realizará tais ações em seu território.

Apesar de nenhuma das leis citadas ter sido modificada, em razão dos ODS, pode-se inferir que elas possuem uma harmonia com tais objetivos. Essa situação explicita que não haveria a necessidade de uma mudança legislativa, mas sim, da melhoria nas ações governamentais para que os objetivos sejam alcançados. As leis, a seguir, foram organizadas de forma cronológica, para uma melhor observação do desenvolvimento do Direito Ambiental brasileiro ao longo das últimas décadas.

Tais princípios amoldam-se à maioria dos Objetivos do Desenvolvimento Sustentável da Agenda 2030, especialmente aos ODS 11,13,14,15, ao salientar a obrigatoriedade do Poder Público, em todos os âmbitos, de garantir a proteção a preservação de todas as áreas de vegetação nativa, como garantia da biodiversidade e qualidade de vida, buscando assim uma sociedade mais ecológica e sustentável.

A tabela, a seguir, mostra a relação das leis ambientais brasileiras com os 17 ODS inseridos na Agenda 2030 da ONU (Quadro 1).

Tabela 1 - As leis ambientais brasileiras e sua relação com os ODS.

\begin{tabular}{|c|c|}
\hline Legislação Ambiental Brasileira & $\begin{array}{l}\text { Agenda } 2030 \text { - Objetivos do } \\
\text { Desenvolvimento Sustentável }\end{array}$ \\
\hline $\begin{array}{l}\text { Lei do Patrimônio Cultural - Decreto-Lei n²5, de } \\
\qquad 30 / 11 / 1937\end{array}$ & ODS 4 \\
\hline Lei da Fauna Silvestre - n॰ 5.197 de 03/01/1967 & ODS $7,8,14$ e 15 \\
\hline Lei das Atividades Nucleares - n॰ 6.453, de 17/10/1977 & ODS 7 \\
\hline $\begin{array}{l}\text { - Lei do Parcelamento do Solo Urbano - n॰ } 6.766 \text { de } \\
\qquad 19 / 12 / 1979\end{array}$ & ODS 11 \\
\hline $\begin{array}{l}\text { - Lei do Zoneamento Industrial nas Áreas Críticas de } \\
\text { Poluição - n॰ } 6.803 \text { de 02/07/1980 }\end{array}$ & ODS 9 \\
\hline $\begin{array}{l}\text { - Lei da Área de Proteção Ambiental (APA) - n॰ } 6.902 \text { de } \\
\qquad 27 / 04 / 1981\end{array}$ & ODS 14 \\
\hline
\end{tabular}

${ }^{1}$ Site oficial do Planalto, notícia veiculada em 30/01/2020. 


\begin{tabular}{|c|c|}
\hline $\begin{array}{l}\text { - Lei da Política Nacional do Meio Ambiente - n॰ } 6.938 \text { de } \\
\qquad 17 / 01 / 1981\end{array}$ & ODS $3,4,6,9,11,13$ e 15 \\
\hline - Lei da Ação Civil Pública - n॰ 7.347, de 24/07/1985 & ODS 3 e 16 \\
\hline - Lei do Gerenciamento Costeiro - no 7.661 de 16/05/1988 & ODS $3,6,7,11,14,15$ e 16 \\
\hline - Lei da criação do IBAMA - n. 7.735 de 22/02/1989 & ODS $1,6,7,13,14$ e 15 \\
\hline - Lei dos Agrotóxicos - n॰ 7.802 de 10/07/1989 & ODS $2,3,8$ e 12 \\
\hline Lei da Exploração Mineral - no 7.805 de 18/07/1989 & ODS $8,9,14$ e 15 \\
\hline - Lei da Política Agrícola - n॰ 8.171 de 17/01/1991 & $\begin{array}{c}\text { ODS } 1,2,3,6,7,8,9,10,11 \\
12,14 \text { e } 15\end{array}$ \\
\hline Lei de Recursos Hídricos - n॰ 9.433 de 08/01/1997 & ODS 6 e 14 \\
\hline - Lei de Crimes Ambientais - n॰ 9.605 de 12/02/1998 & ODS 13,14 e 15 \\
\hline $\begin{array}{l}\text { - Lei da Engenharia Genética - n॰ 8.974, de 05/01/1995 } \\
\text { (Revogada pela Lei de Biossegurança n॰ 11.105, de } 24 \text { de } \\
\text { março de 2005) }\end{array}$ & ODS $2,3,12$ e 17 \\
\hline $\begin{array}{l}\text { - Lei das Florestas - n. } 4.771 \text { de 15/09/1965 (Revogada } \\
\text { pelo Novo Código Florestal Brasileiro - n. 12.651, de } \\
\text { 25/05/2012) }\end{array}$ & ODS $11,13,14$ e 15 \\
\hline
\end{tabular}

Fonte: Autores (2021)

\section{RESULTADOS}

A partir dos objetivos propostos pelos ODS, bem como suas metas, observa-se que, nem todos se relacionam diretamente com o a dimensão ambiental, embora se reconheça que eles são integrados e indivisíveis.

O quadro a seguir, mostra como os 17 Objetivos mesclam, de forma equilibrada, as principais dimensões do desenvolvimento sustentável: a social, a econômica, a ambiental e a institucional. 
Quadro 1 - ODS segundo as dimensões do desenvolvimento sustentável

\begin{tabular}{|c|c|}
\hline $\begin{array}{c}\text { Dimensões do } \\
\text { desenvolvimento } \\
\text { sustentável }\end{array}$ & Objetivos do desenvolvimento sustentável \\
\hline Dimensão social & $\begin{array}{l}\text { ODS } 1 \text { - Acabar com a pobreza em todas as suas formas, em todos os lugares. } \\
\text { ODS } 2 \text { - Acabar com a fome, alcançar a segurança alimentar e melhoria da nutrição } \\
\text { e promover a agricultura sustentável. } \\
\text { ODS } 3 \text { - Garantir uma vida saudável e promover o bem-estar de todos em todas as } \\
\text { idades. } \\
\text { ODS } 4 \text { - Assegurar a educação inclusiva e equitativa e de qualidade, e promover } \\
\text { oportunidades de aprendizagem ao longo da vida para todos. } \\
\text { ODS } 5 \text { - Alcançar a igualdade de gênero e empoderar todas às mulheres e meninas. } \\
\text { ODS } 10 \text { - Reduzir a desigualdade dentro dos países e entre eles. }\end{array}$ \\
\hline $\begin{array}{l}\text { Dimensão } \\
\text { econômica }\end{array}$ & $\begin{array}{l}\text { ODS } 7 \text { - Garantir acesso à energia barata, confiável, sustentável e renovável para } \\
\text { todos. } \\
\text { ODS } 8 \text { - Promover o crescimento econômico sustentado, inclusivo e sustentável, } \\
\text { emprego pleno e produtivo, e trabalho decente para todos. } \\
\text { ODS } 9 \text { - Construir infraestrutura resiliente, promover a industrialização inclusiva e } \\
\text { sustentável, e fomentar a inovação. } \\
\text { ODS } 12 \text { - Assegurar padrões de produção e de consumo sustentáveis. }\end{array}$ \\
\hline $\begin{array}{l}\text { Dimensão } \\
\text { ambiental }\end{array}$ & $\begin{array}{l}\text { ODS } 6 \text { - Garantir disponibilidade e manejo sustentável da água e saneamento para } \\
\text { todos. } \\
\text { ODS } 11 \text { - Tornar as cidades e os assentamentos humanos inclusivos, seguros, } \\
\text { resilientes e sustentáveis. } \\
\text { ODS } 13 \text { - Tomar medidas urgentes para combater a mudança do clima e seus } \\
\text { impactos. } \\
\text { ODS } 14 \text { - Conservação e uso sustentável dos oceanos, dos mares e dos recursos } \\
\text { marinhos para o desenvolvimento sustentável. } \\
\text { ODS } 15 \text { - Proteger, recuperar e promover o uso sustentável dos ecossistemas } \\
\text { terrestres, gerir de forma sustentável as florestas, combater a desertificação, deter } \\
\text { e reverter à degradação da terra e deter a perda de biodiversidade. }\end{array}$ \\
\hline $\begin{array}{c}\text { Dimensão } \\
\text { institucional }\end{array}$ & $\begin{array}{c}\text { ODS } 16 \text { - Promover sociedades pacíficas e inclusivas para o desenvolvimento } \\
\text { sustentável, proporcionar o acesso à justiça para todos e construir instituições } \\
\text { eficazes, responsáveis e inclusivas em todos os níveis. } \\
\text { ODS } 17 \text { - Fortalecer os meios de implementação e revitalizar a parceria global para } \\
\text { o desenvolvimento sustentável. }\end{array}$ \\
\hline
\end{tabular}

Fonte: ONU (2015). Elaboração: Ipea.

Observa-se que, entre os dezessete ODS, seis estabelecem uma relação mais direta com a dimensão social: ODS 1, 2, 3, 4, 5 e 10, embora, indiretamente, relacionemse, também, com a dimensão ambiental. Quatro, relacionam-se com a dimensão econômica, a saber: os ODS 7, 8, 9 e 12. Os vinculados à dimensão ambiental são cinco: ODS 6, 11, 13, 14 e 15. Já os ODS 16 e 17, por sua vez, dialogam com a dimensão institucional do desenvolvimento sustentável e remetem à necessidade de adoção de estratégias e políticas adequadas, de recursos disponíveis e de outros meios fundamentais para a implementação dos objetivos. 
Vale destacar que o ODS 5 é o único que não apresenta interface com as leis aqui analisadas. Tal objetivo, relaciona-se, mais diretamente, com a dimensão social.

Alguns objetivos a serem cumpridos, pelo Brasil, até 2030, são classificados como ousados, como é o caso do ODS 01, que visa "Acabar com a pobreza em todas as suas formas, em todos os lugares". De acordo com dados do IPEA, é praticamente impossível reduzir a zero o número de pobres, qualquer que seja a linha de pobreza, além disso, a erradicação da pobreza extrema será atingida quando o percentual da população nesta condição estiver abaixo de 3\% (IPEA, 2018).

Além disso, o ODS 01 coaduna-se com a Lei da Política Agrícola, uma vez que busca, dentre suas metas, garantir que todos os homens e mulheres tenham direitos iguais aos recursos naturais, dentre outros, além de construir a resiliência dos pobres e daqueles em situação de vulnerabilidade, e reduzir a exposição e vulnerabilidade destes a eventos extremos relacionados com o clima e outros choques e desastres econômicos, sociais e ambientais que o planeta vem enfrentando, nos últimos anos. Nesse sentido, o conjunto de leis que rege o sistema ambiental também precisa ser revista, no sentido de atender às exigências dos desafios atuais em prol do desenvolvimento sustentável.

Importa perceber, também, que, no decorrer dos anos, não houve uma sucessão cronológica na elaboração das leis, porém, a cada novo problema ou demanda relacionada a aspectos ambientais, uma nova legislação foi criada, produzindo regras capazes de atender às exigências impostas pelas questões ambientais que surgissem. Nesse sentido, compreendemos que os ODS devem estar alinhados à realidade, às restrições de recursos e das mudanças climáticas, além de outras questões relacionadas ao meio ambiente.

Vale destacar que essas leis ambientais definem normas e infrações e devem ser conhecidas, entendidas e praticadas. Afinal, há um processo de mudança de comportamento na sociedade civil que não está associado apenas às eventuais penalidades legais, mas à adoção de uma postura de responsabilidade compartilhada entre todos para vencer os desafios ambientais, que já vivenciamos.

A partir das leituras realizadas no decorrer do trabalho, observamos que, no rol das leis aqui analisadas, a Lei das Florestas - n. 4.771 de 15/09/1965, foi revogada em 25/05/2012, pelo Novo Código Florestal Brasileiro - n. 12.651. Seu texto original foi 
modificado em alguns pontos pela Lei no 12.727 de 17 de outubro de 2012 em que algumas regulamentações foram dadas pelo Decreto no. 7.830 de 17 de outubro de 2012 (EMBRAPA, 2020).

Uma das inovações da Lei foi a criação do Cadastro Ambiental Rural (CAR) e a previsão de implantação do Programa de Regularização Ambiental (PRA) nos Estados e no Distrito Federal. O reconhecimento da existência de áreas rurais consolidadas em Áreas de Preservação Permanente, de Reserva Legal ou de Uso Restrito também foi um ponto de destaque na aplicação da nova Lei (EMBRAPA, 2020).

Além desta, a Lei da Engenharia Genética - no 8.974, de 05/01/1995, também fora revogada pela Lei de Biossegurança - n॰ 11.105, em 24 de março de 2005, em função da necessidade de se estabelecer normas para o uso das técnicas de engenharia genética e liberação no meio ambiente de organismos geneticamente modificados. Devido à sobreposição legal que versava sobre OGMs, em 2004, o Tribunal Regional Federal decide que a lei específica (Lei 8974/95) se sobrepõe à lei geral (Lei do Meio Ambiente).

Com base nos resultados, ora apresentados, espera-se poder contribuir com futuros trabalhos nessa área, dada a jovialidade do tema, além de possibilitar um olhar mais objetivo nas discussões em torno da legislação analisada, bem como dos ODS, que serviram de parâmetro para identificar os que se aproximam mais das questões que envolvem o meio ambiente, no sentido de contribuir para o tão sonhado "desenvolvimento sustentável". Reconhecemos a possibilidade de um exame mais aprofundado no contexto das leis ambientais brasileiras e sua interface com dos ODS, dada a sua abrangência, além de compreender que os resultados poderão ser diferentes, se os objetivos propostos também forem diferentes.

\section{REFERÊNCIAS}

BORUCKE, M., MOORE, D., CRANSTON, G., GRACEY, K., IHA, K., LARSON, J., et al. (2013). Contabilização da procura e oferta da capacidade regenerativa da biosfera: a metodologia e estrutura subjacentes das Contas da Pegada Nacional. Ecol. Índico 24, 518-533. doi: 10.1016 / j.ecolind.2012.08.005. 
BRUNDTLAND, Gro Harlem - "Our Common Future - The World Commission on Environment and Development" - Oxford University, Oxford University Press, 1987.

COMISSÃO MUNDIAL SOBRE MEIO AMBIENTE E DESENVOLVIMENTO (CMMAD). Nosso futuro comum. Rio de Janeiro: Fundação Getúlio Vargas, 1988.

Costanza, R., Fioramonti, L., \& Kubiszewski, I. The UN sustainable development goals and the dynamics of well-being. Frontiers in Ecology and the Environment, 14(2), 59-59, 2016.

EMBRAPA. Entenda a Lei $\mathbf{1 2 . 6 5 1}$ de 25 de maio de 2012. Código Florestal: Adequação ambiental da paisagem rural. Disponível. https://www.embrapa.br/codigoflorestal/entendao-codigo-florestal. Acesso em: 22 de outubro de 2020.

FIOCURZ Rondônia. Biossegurança; Comissão Interna de Biossegurança (ClBio). Disponível em: https://www.rondonia.fiocruz.br. Acessível em: 22 de outubro de 2020.

GIL, Antônio Carlos. Como elaborar projetos de pesquisa. 4. ed. São Paulo: Atlas, 2008.

IPEA. Desafios do Desenvolvimento: Objetivos de Desenvolvimento Sustentável: metas possíveis. Ano 12. Edição 86. 2015. Disponível em: https://www.ipea.gov.br/ods/. Acesso em: 12 de out. 2020.

MMA. Ministério do Meio Ambiente. Lei Complementar 140. 2018. Disponível em: <http://www.mma.gov.br/governanca-ambiental/sistema-nacional-do-meio ambiente/leicomplementar-140.html>. Acesso em: 12 out. 2020.

MONOSOWSKI, E. Políticas ambientais e desenvolvimento no Brasil. Cadernos Fundap: Planejamento e Gerenciamento Ambiental, São Paulo, v. 9, n. 16, 1989.

ONU - Organização das Nações Unidas (2015). Objetivos de Desenvolvimento Sustentável da ONU. Disponível em: https://sustainabledevelopment.un.org/sdgs. Acesso em: 17 de setembro de 2020.

- Transformando nosso mundo: a Agenda 2030 para o desenvolvimento sustentável. [s.I.]: ONU, 2015. Disponível em: 〈https://goo.gl/jcFMVC>.

Nilsson, M., Griggs, D., \& Visbeck, M. Policy: map the interactions between Sustainable Development Goals. Nature News, 534 (7607), 320. 2016.

O ECO. Entenda a Lei de Crimes Ambientais. Disponível em: https://www.oeco.org.br/dicionario-ambiental/28289. Acesso em: 05 de outubro de 2020. 
OLIVEIRA, Mauro Márcio \& ARAÚJO, José Cordeiro de. A POLÍTICA AGRíCOLA COMO MATÉRIA CONSTITUCIONAL. Disponível em: https://www12.senado.leg.br. Acesso em: 20 de outubro de 2020.

Plataforma Agenda 2030. Disponível em: http://www.agenda2030.org.br/os ods/. Acesso em: 06 de outubro de 2020.

III RELATÓRIO LUZ DA SOCIEDADE CIVIL DA AGENDA 2030 DE DESENVOLVIMENTO SUSTENTÁVEL - BRASIL. Disponível em: https://gtagenda2030.org.br/relatorioluz/relatorio-luz-2019/. Acesso em: 11 de setembro de 2020.

SANTOS, A. S., \& RIBEIRO, S. K. The role of transport indicators to the improvement of local governance in Rio de Janeiro City: A contribution for the debate on sustainable future. Case Studies on Transport Policy, 3(4), 415-420, 2015.

SSDN. SDSN Thematic Group on Sustainable Cities. Supported by UN-Habitat, UCLG, Cities Alliance, and ICLEI. Why the world needs an urban development goal, 2013. Disponível em: https://sustainabledevelopment.un.org/content/documents/2569130918SDSN -Why-the-World-Needs-an-Urban-SDG.pdf . Acesso em: 07 de outubro de 2020.

TRIVIÑOS, A. N. da S. Introdução à pesquisa em ciências sociais: a pesquisa qualitativa em educação. São Paulo: Atlas, 2008.

UNFCCC (2015). Acordo Climático de Paris. Disponível em:

http://unfccc.int/files/essential background/convention/application/pdf/englis h paris agr eement.pdf. Acesso em: 17 de setembro de 2020.

WWF (Fundo Mundial para a Natureza), IUCN (União Internacional para a Conservação da Natureza) e UNEP (Programa das Nações Unidas para o Meio Ambiente). (1991). Cuidando da Terra. Gland: WWF (Fundo Mundial para a Natureza), IUCN (União Internacional para a Conservação da Natureza) e UNEP (Programa das Nações Unidas para o Meio Ambiente).

WACKERNAGEL, Mathis, HASCOM, Laurel e LIN, David. Tornando os Objetivos de Desenvolvimento Sustentável consistentes com a sustentabilidade. Energy Res., 2017 | https://doi.org/10.3389/fenrg.2017.00018 


\section{CAPÍTULO II}

\section{A INIERRACIONALIZACÃO DA PROTECG̃̃O AMAZÔNICA: UM APARENIE EMBATE ENIRE A SOBERANIA NACIONAL E A COMUNIDADE INIERNACIONAL}

\section{DOI: $10.51859 / a m p l l a . m a s 481.1121-2$}

Rodrigo Gomes de Castro Vieira ${ }^{1}$

${ }^{1}$ Graduando do curso de Direito. Universidade Presidente Antônio Carlos (Campus Teófilo Otoni) - UNIPAC

\section{RESUMO}

O presente texto evidencia, a priori, um amplo enfoque atinente à questão amazônica, explicitando, de forma introdutória, sua extensão geográfica, importância social e incidência mundial. Neste aspecto introdutório, a principal justificativa reside na necessidade de expor ao leitor o atual cenário ambiental da Amazônia, demonstrando, de maneira didática, a extensão deste bioma, não apenas em aspectos geográficos, mas também em seus aspectos políticos e sociais, restando evidente a inferência de como a região amazônica reveste-se de um verdadeiro patrimônio global. Uma vez fixadas as premissas iniciais idôneas a promover a dialética desta obra, o presente trabalho explicita a dissonância havida entre o infindável movimento de desmatamento e degradação que assola a Amazônia e a legislação ambiental pátria que, de maneira infortuna, figura como mecanismo insuficiente a cessar tal deterioração. Por fim, expõese como se situam os debates entre o Brasil e a comunidade internacional a respeito de sua proteção. Ressaltando-se sua relevância no cenário global, define-se a razão de ser de tais discussões, bem como as teses de cada parte delas integrante

Palavras-chave: Amazônia. Desmatamento. Soberania. Internacionalização.

\section{INTRODUÇÃO}

Comumente alcunhada como o "pulmão do mundo", indubitavelmente, a região amazônica detém uma imensurável importância para o planeta. Estendendo-se por nove países (Brasil, Bolívia, Peru, Equador, Colômbia, Venezuela, Guiana, Suriname e Guiana Francesa), a floresta amazônica é o maior ecossistema tropical no planeta, abrangendo área superior a 6.8 milhões de $\mathrm{km}^{2}$ e sendo o lar de cerca de milhões de habitantes. 
Em que pese sua imponente e importante presença, tal região é incessante vítima de condutas nocivas e, muitas vezes, ilegais que tendem a provocar seu desmatamento, que caminha em uma marcha veloz. Situando-se, em maior parte, no território brasileiro, esta área é alvo de políticas públicas, por vezes ineficazes, insuficientes ou até mesmo omissas, fato que suscita incontáveis e acalorados debates nacionais, e, especialmente, internacionais.

O fator propagador desses debates reside na aparente contrariedade entre os institutos da soberania pátria e os clamores da comunidade internacional. O primeiro, em termos simples, clama que o país é o verdadeiro e único legitimado para a atuação na região amazônica, sendo intolerável a ingerência internacional. O segundo, por sua vez, alega tal bioma ser patrimônio mundial, e não exclusivo.

Assentando-se nessa discussão, o presente trabalho tem o propósito de, a priori, explicitar a importância que o bioma amazônico representa para o globo terrestre, sendo, de fato, uma espécie de ecossistema sui generis, ímpar em todo o planeta, não se restringindo apenas ao campo ambiental, de modo que transcende ao cenário político, econômico e afins. Em seguida, esta obra tem como fim a elucidação as controvérsias relacionadas ao bioma amazônico, apontando o incessante processo de desmatamento e o ordenamento jurídico ambientalista do país, e, pari passu, relacionalo com o dever de existência de efetivas políticas, nacionais e internacionais, que, tendo como pressupostos concomitantes a soberania nacional brasileira e a comunidade internacional, devem ter um fim uno: a tutela deste patrimônio mundial.

\section{METODOLOGIA}

Para a confecção deste trabalho, foi realizada ampla revisão literária, de maneira a selecionar uma diversificada gama de materiais bibliográficos aptos a contribuir, significativamente, para a elucidação do tema proposto por esta obra, com o precípuo fulcro de possibilitar o desejável entendimento por parte do leitor.

Em suma, foram manejadas fontes primárias consubstanciadas em diplomas legais, artigos científicos e livros sobre a temática suscitada, em formato digital e em aporte físico, presentes em plataformas acessíveis e influentes no contexto acadêmico. Para a produção deste trabalho, foram analisadas várias produções disponíveis em sítios 
digitais do campo jurídico muito aclamados no território nacional, ao exemplo da plataforma Âmbito Jurídico e Jus Navigandi. De igual maneira, para embasar este artigo, foram selecionados artigos jornalísticos provenientes de fontes de alta qualidade, ao exemplo da famosa BBC News Brasil, aptos a fornecer diversidade ao presente trabalho bem como elevar a qualidade da temática. Em razão da nítida internacionalização da problemática, nesta obra, suscitada, tem-se que, para a produção deste artigo, foram aplicados os entendimentos de obras que perpassam as fronteiras internacionais, sendo provenientes de autores extrafronteiras que em muito agregam ao valor do tema.

\section{DA IMPORTÂNCIA GLOBAL DA REGIÃO AMAZÔNICA}

Como supra mencionado, a floresta amazônica ocupa uma posição de destaque no mundo em razão de sua importância global. Inúmeros são as razões para tanto, desde questões pluviais até a capacidade de produção de produtos naturais. Em matéria divulgada pelo site DW - Made for minds, a autora Priscila Jordão (2019) enumera pontos que versam sobre a imprescindibilidade da Amazônia para o planeta, a saber:

Regime de chuvas: A Floresta Amazônica produz imensas quantidades de água para o restante do país e da América do Sul. Os chamados "rios voadores", formados por massas de ar carregadas de vapor de água gerados pela evapotranspiração na Amazônia, levam umidade da Bacia Amazônica para o Centro-Oeste, Sudeste e Sul do Brasil. Esses rios voadores também influenciam chuvas na Bolívia, no Paraguai, na Argentina, no Uruguai e até no extremo sul do Chile. [...]. Mudanças climáticas: A Amazônia e as florestas tropicais, que armazenam de 90 bilhões a 140 bilhões de toneladas métricas de carbono, ajudam a estabilizar o clima em todo o mundo. Só a Floresta Amazônica representa $10 \%$ de toda a biomassa do planeta. [...]. Equilíbrio ambiental: Como a maior floresta tropical do mundo, a Amazônia possui a maior biodiversidade, com uma em cada dez espécies conhecidas. Também há uma grande quantidade de espécies desconhecidas por cientistas, principalmente nas áreas mais remotas. [...]. Produtos da floresta: As espécies da Amazônia também são importantes pelo seu uso para produzir medicamentos, alimentos e outros produtos. Mais de 10 mil espécies de plantas da área possuem princípios ativos para uso medicinal, cosmético e controle biológico de pragas (JORDÃO, 2019) (Grifos nossos).

Nesse mesmo sentido, e em termos bastante objetivos, o professor Benigno Núñez Novo, leciona, de maneira cirúrgica, que:

Poucos lugares do mundo são tão importantes para a sobrevivência da humanidade quanto a Amazônia. Com quase 7 milhões de quilômetros quadrados, distribuídos por nove países, a floresta- símbolo da força da natureza tem um papel fundamental na estabilidade do clima e das chuvas. 
Nela vivem mais de 40 mil espécies de plantas, 400 espécies de mamíferos, 1300 espécies de pássaros e 3 mil espécies de peixes. Ela é também a região que concentra $1 / 5$ da água doce do mundo, com seus rios inigualáveis, que servem de estradas para os moradores (NOVO, 2019).

Ante ao exposto por este tópico, pretende-se que reste evidente ao leitor que a região Amazônica possui valor imensurável que transpõe as fronteiras nacionais, de modo a influir sobre todo o globo, de modo, assim, a revestir-se de uma temática não apenas ambiental, mas que permeia vários outros vários campos de discussão, desde sociais até políticos. Isto posto e prezando-se pela dialética, torna-se possível que o leitor tenha plena compreensão da problemática suscitada por este artigo, sendo objeto dos tópicos a seguir dispostos.

\section{DO CONTINUO PROCESSO DE DEGRADAÇÃo AMBIENTAL E A LEGISLAÇÃo AMBIENTALISTA NACIONAL}

Inconteste é o fato de que o desmatamento da região amazônica é um processo notório e preocupante, o que perturba as mentes de nacionais, bem como a de entes extra fronteiras. Como dito anteriormente, é pertinente reafirmar, uma vez mais, que, diante da dimensão das questões envolvendo o cenário atual da Amazônia, impossível seria que as repercussões destas se limitassem tão somente ao campo ambiental, especialmente em razão do fenômeno da globalização, cada vez mais fervoroso. Sobre esta temática, Camilla Costa (2020), em matéria destinada à BBC News Brasil expõe que:

Em 2019, a Pan-Amazônia, como é chamado o conjunto do bioma em todos os países, perdeu mais de 1,7 milhão de hectares de floresta primária, segundo os dados produzidos pelo sistema de monitoramento da Universidade de Maryland, nos EUA, e publicados pelo Global Forest Watch. Isso significa que pouco mais de três campos de futebol de mata virgem foram desmatados a cada minuto em 2018. A perda pode parecer insignificante perto da imensidão da floresta (representa cerca de 0,32\% do total), mas não é uma questão só quantitativa e, sim, qualitativa. [...]. Se o desmatamento e a degradação continuarem nos ritmos atuais, a Amazônia pode deixar de funcionar como um ecossistema tropical em breve, mesmo que parte dela continue de pé. Atualmente, pouco mais de $18 \%$ de toda a floresta original foi desmatada, de acordo com dados do projeto de monitoramento Mapbiomas, parceria entre universidades, ONGs, institutos de todos os territórios amazônicos e o Google. O número é perigosamente próximo do que o biólogo americano Thomas Lovejoy e o climatologista brasileiro Carlos Nobre, do Instituto de Estudos Avançados da USP, chamam de tipping point (ponto de não retorno, em inglês). Eles se referem ao momento em que o desmatamento, em conjunto com as mudanças climáticas e a vulnerabilidade a incêndios mudarão completamente a Amazônia. Esse ponto ocorrerá, segundo eles, quando entre $20 \%$ e $25 \%$ da floresta original estiverem destruídos (COSTA, 2020). 
De modo bastante infortuno, parece estar clarificado que a legislação ambiental brasileira é deficitária e aparenta figurar como mera norma simbólica, ante ao atual cenário da Amazônia. Nesse sentido, é pertinente expor que a Lei no 6.938/81, que instituiu a Política Nacional do Meio Ambiente e que representa o principal diploma legal ambientalista no cenário nacional, em seu art. 2ำ que elenca vários princípios a serem observados pelo país, e leciona, ainda, que a "política Nacional do Meio Ambiente tem por objetivo a preservação, melhoria e recuperação da qualidade ambiental propícia à vida, visando assegurar, no País, condições ao desenvolvimento sócio-econômico, aos interesses da segurança nacional e à proteção da dignidade da vida humana".

Seguindo o pensamento uníssono da doutrina nacional, depara-se com a imperiosa afirmação de que a referida política consubstancia-se em uma valorosa contribuição para o cenário ambientalista. Nesse sentido, Nathalia Mendes expõe que:

\footnotetext{
A ação governamental objetiva a manutenção do equilíbrio ecológico, sendo certo que o meio ambiente é um patrimônio público de uso coletivo e deve ser necessariamente protegido. Por isso é que a preservação, a recuperação e a revitalização do meio ambiente há de constituir uma preocupação do Poder Público e, consequentemente, do Direito, porque ele forma a ambiência na qual se move, desenvolve, atua e expande a vida humana (MENDES, 2016).
}

Ainda que seja uma legislação louvável, nota-se a presença clara do fenômeno do déficit de normatividade sobre o supra citado diploma legal. Ocorre que, ainda que sejam expostos, de maneira clara, os princípios e instrumentos aptos a efetivar os objetivos da Política Nacional do Meio Ambiente, tem-se que, no mundo fático, esta é negligenciada em praticamente sua integralidade, fato que fica evidente pelo problema suscitado nesse presente trabalho, qual seja o ininterrupto processo de degradação do bioma amazônico.

\section{DO EMBATE INTERNACIONAL}

A grande controvérsia internacional reside na aparente antinomia entre a soberania nacional e os preceitos da comunidade internacional. Em meio aos elementos constitutivos de um Estado, a soberania, indubitavelmente, é a que levanta as maiores discussões, pois, ao determina-se como soberano, o Estado, a priori, não detém a obrigação de submeter-se à nenhuma outra vontade interna ou externa. Ao produzir 
efeitos na ordem interna, vislumbra-se a autonomia estatal, a qual determina que o Estado possui jurisdição e competência próprias, o que possibilita que o mesmo institua suas normas fundamentais, como a forma de Estado, governo e afins. Sob a ótica externa, a soberania representa a independência estatal, que, por sua vez, estatui que o Estado é detentor do direito de convenção, o qual cria a possibilidade de celebração de celebrar tratados com outros Estado, por exemplo.

Em realidade, quando da análise da relação soberania estatal e comunidade internacional, observa-se que um instituto não extingue o outro, mas sim promove um juízo de ponderação, de modo que, in casu, define-se qual instituto irá preponderar. Conforme lições doutrinárias do Direito Internacional Público, tem-se que, em sede internacional, a soberania de um Estado encontra limites da soberania de outro, não podendo invadi-la.

Hodiernamente, a afirmação mais acertada indica que não é adequado o pensamento de que soberania reveste-se de um valor inalcançável e absoluto dos Estados, pois o direito contemporâneo não mais comporta espaços para o absolutismo, o qual encontra obstáculos intransponíveis em quaisquer ramos jurídicos, ao exemplo do direito internacional público, o qual aqui é pertinente.

Quando em comunidade internacional, tem-se que esta, representando um conjunto de Estados soberanos, é legitimada para impor-se a um Estado dela integrante, valendo-se do jus cogens. O que se infere com tal afirmação é que a soberania, de nenhuma maneira, é absoluta em cenário internacional, submetendo-se a restrições lógicas.

Nesse sentido, Baracho leciona que "as comunidades não compõem uma federação, uma vez que os Estados-membros preservam a individualidade enquanto sujeitos do Direito das Gentes, exceto no que se refere às competências transferidas para as comunidades" (1987, p. 100). Expondo tese semelhante, Mazzuoli dita que "à medida que os Estados assumem compromissos mútuos em convenções internacionais, que diminuem a competência discricionária de cada contratante, eles restringem sua soberania" (2002). Por fim, de acordo com a letra do Acórdão no 06/64 do Tribunal de Justiça das Comunidades Europeias, tem-se a afirmação de que: 
Ao criar uma comunidade de duração ilimitada dotada de instituições próprias, de personalidade, de capacidade jurídica, de capacidade de representação no plano internacional e, mais precisamente, de efetivos poderes oriundos de uma limitação de soberanias ou de uma transferência de poderes dos Estados para a Comunidades, estes limitaram seus poderes soberanos e, assim, criaram um corpo de leis aplicável tanto aos seus respectivos cidadãos como a eles próprios (1964).

Com o exposto supra, fica evidente que a comunidade internacional, quando valendo-se dos meios adequados para tanto, como por via da celebração de tratados, torna-se legitimada para proceder com o estabelecimento de normas e condutas tendentes a tutelar um objeto determinado, como o meio ambiente de determinado Estado.

\section{CONSIDERAÇÕES FINAIS}

Ante ao texto exposto, tem-se como incontroversos os pontos suscitados, dado sua inequívoca comprovação. Contudo, no derradeiro tópico, o qual versa sobre os debates internacionais, tem-se, ainda, acaloradas discussões.

Como visto, ainda que se situe, na maior parte, em território nacional, não podese afirmar que a floresta amazônica trata-se de um patrimônio exclusivamente brasileiro, sob pena de cometer-se um erro crasso e afirmar uma inverdade. Em que pese o sentimento de nação faça com que assim pense grande parte da população, o bioma amazônico é um bem global. Valendo-se das lições proferidas pelo Direito Público, seja interno ou externo, nota-se a presença marcante de vários axiomas, especialmente o princípio da supremacia do interesse público sobre o privado, que indica uma lógica muito pertinente ao tema, aqui, em discussão: a vontade de muitos, quando legítima, deve, inequivocamente, sobrepor-se à vontade de poucos, com vistas à conquista do famigerado bem coletivo.

Nesta senda, é imprescindível a disseminação de que a soberania não é antagônica aos interesses da comunidade internacional pois, em se submetendo ao regime do direito internacional público, ambas devem atuar conjuntamente com vistas a perquirir e satisfazer os anseios dos Estados-membro, sem, entretanto, ofender o que possuem de mais valioso: sua soberania.

Estando alinhados em uma um desígnio uno, o Brasil e a comunidade internacional devem celebrar tratados específicos e implementar políticas de atuação

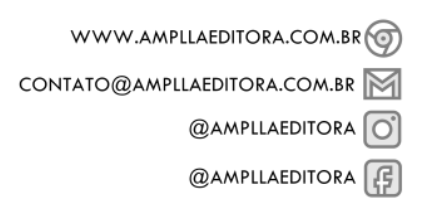


na área amazônica com o propósito de efetivar sua proteção bem como manter o tão almejado desenvolvimento sustentável.

\section{AGRADECIMENTOS}

Em primeiro lugar, agradeço à Deus, cujas bênçãos são-me concedidas todo dia, e sem as quais nada que eu fizesse teria valor, e seriam, sequer, possíveis.

Agradeço à minha amada família e namorada, que sempre me apoiam e me incentivam a trilhar a carreira acadêmica.

Por fim, presto meus sinceros agradecimentos à minha querida faculdade, que me ingressou no cenário acadêmico e que me forneceu todo o suporte e inspiração, ao exemplo de notáveis docentes, para, humildemente, ter a possibilidade de endossar e quiçá avançar no mundo científico.

\section{REFERÊNCIAS}

BRASIL. Lei no 6.938, de 31 de agosto de 1981. Diário Oficial da União, Brasília, DF. Disponível em: <http://www.planalto.gov.br/ccivil_03/leis/l6938.htm>.

BARACHO, José Alfredo de Oliveira. Teoria geral da soberania. Revista Brasileira de Estudos Políticos no 63/64. 1987.

COSTA, Camilla. 'A grande mentira verde': como a destruição da Amazônia vai além do desmatamento. BBC News Brasil. Disponível em: https://www.bbc.com/portuguese/brasil-51317040.

COSTA, Flamino. Acórdão do Tribunal de Justiça de 15 de Julho de 1964. Disponível em: https://eur-lex.europa.eu/legalcontent/PT/TXT/PDF/?uri=CELEX:61964CJ0006\&from=NL.

DE CARVALHO ROCHA, João Carlos; HENRIQUES FILHO, Tarcísio Humberto Parreiras; CAZETTA, Ubiratan. Política nacional do meio ambiente: 25 anos da Lei $\mathbf{n}$. 6,938/81. Editora del Rey, 2007.

FARIAS, Talden Queiroz. Aspectos gerais da política nacional do meio ambiente: comentários sobre a Lei no 6.938/81. Âmbito Jurídico, Rio Grande, IX, n. 35, 2006.

JORDÃO, Priscila. Por que a Amazônia é vital para o mundo? Disponível em: https://www.dw.com/pt-br/por-que-a-amaz\%C3\%B4nia-\%C3\%A9-vital-para-omundo/a-40315702. 
MAZZUOLI, Valério de Oliveira. Direitos humanos provenientes de tratados: exegese dos $\S \S 10$ e 2o do art 5o da Constituição de 1988. Disponível em: https://jus.com.br/artigos/1609.

MENDES, Nathalia. Política Nacional do Meio Ambiente (PNMA) - Lei no 6938/81. Disponível em: https://nathymendes.jusbrasil.com.br/noticias/321528492/politica-nacionaldo-meio-ambiente-pnma-lei-n-6938-81.

NOVO, Benigno Núñez. Amazônia: patrimônio natural da humanidade. Disponível em: https://benignonovonovo.jusbrasil.com.br/artigos/748026871/amazoniapatrimonio-natural-da-humanidade.

ROMANO, Rogério Tadeu. A proteção do bioma Amazônia e o direito internacional do meio ambiente. Disponível em: https://rogeriotadeuromano.jusbrasil.com.br/artigos/1126026584/a-protecaodo-bioma-amazonia-e-o-direito-internacional-do-meio-ambiente.

. Tribunal de Justiça das Comunidades Europeias. Acórdão de 15 de julho de 1964, Caso 06/64. Disponível em: http://eurlex.europa.eu/LexUriServ/LexUriServ.do? uri=CELEX:61964CO0006:EN:PDF 


\section{CAPITULO III}

\section{DESENVOLVIMENIO SUSTENTÁVIEL COMPORTAMENIO DE CONSUMO DE PRODUTOS SUSTENTÁVEIS}

\section{DOI: $10.51859 / a m p l l a . m a s 481.1121-3$}

Priscila Soares Moura ${ }^{1}$

Reginaldo Pedroso ${ }^{2}$

${ }^{1}$ Psicóloga, Mestre em Psicologia, Professora no Curso de Psicologia das Faculdades Associadas de Ariquemes/RO.

2 Psicólogo, Doutor em Psicologia, Professor no Departamento de Psicologia na Universidade Federal de Rondônia/RO.

\section{RESUMO}

A presente pesquisa objetivou verificar a disposição a pagar a mais por produtos que causam menos impactos ambientais, em dois grupos, um grupo que recebeu instruções acerca dos impactos que produtos não sustentáveis causam ao meio ambiente e um grupo que não recebeu instruções acerca dos impactos ambientais de produtos não sustentáveis. Participaram do estudo 240 consumidores, 120 em cada grupo. Foram utilizados dois Formulários, Sem Instrução e Com Instrução, para avaliar a disposição a pagar a mais por produtos sustentáveis. A escolha dos participantes foi por conveniência e a coleta de dados foi realizada individualmente. Os resultados demonstraram que a maioria dos participantes (de $71 \%$ a $90 \%$ ) estaria disposta a pagar a mais pelos produtos sustentáveis, para ambos os grupos. Não foi encontradas diferenças significativas entre os grupos, e a média do preço a pagar pelos produtos sustentáveis ficou acima de $22 \%$. Por ser uma situação hipotética, os resultados sugerem a necessidade de estender a investigação para avaliar quanto os consumidores pagariam por produtos sustentáveis em contexto de consumo real, bem como levantar algumas variáveis, como motivação a pagar a mais, e controlar questões socioeconômicas.

Palavras-chave: Desenvolvimento sustentável. Consumo sustentável. Comportamento do consumidor. Disposição a pagar.

\section{INTRODUÇÃO}

Devido à exploração industrial do meio ambiente, durante todo o século XIX e a maior parte do século $X X$, e ao comportamento de consumo de grande parte da sociedade mundial, a partir da década de 1970, foi possível perceber um processo de deterioração ambiental. Neste período, a humanidade percebeu que a possibilidade de 
esgotamento de determinados recursos naturais tornar-se-ia mais evidentes (DIAS, 2007).

Em 1983 foi criada, por meio da Organização das Nações Unidas (ONU), a Comissão Mundial sobre o Meio Ambiente e o Desenvolvimento (CMMAD), e em 1987 foi divulgado o Relatório de Brundtland, documento que também ficou conhecido como "Nosso Futuro Comum". Esse documento foi referência para diversos debates que ocorreram posteriormente e pela consolidação do conceito de Desenvolvimento Sustentável, no qual se passa a preocupar com as gerações futuras diante dos atuais impactos sobre o meio ambiente (DIAS, 2007).

Porém, é difícil pensar uma sociedade em que sua estrutura não se baseia no consumo. E o consumo é um dos principais "vilões" do meio ambiente, uma vez que, quanto mais a sociedade consome, mais recursos naturais são necessários para atender toda a cadeia de produção dos bens adquiridos. Para resolução de tal problema, é necessário que a população mundial adote uma atitude diferente. A adoção de um comportamento sustentável seria uma boa saída. No entanto, deve-se ponderar se a sociedade está disposta a mudar seu padrão de consumo diante de uma cultura capitalista que visa o consumo de bens e serviços com foco na geração de riquezas.

Com isso, a proposta para um mundo sustentável vem sendo discutida há mais de seis décadas, e pouco foi efetivamente definido, tanto nas questões teóricas quanto nas práticas. O que se observa é a responsabilização do consumidor para com a sustentabilidade, pela adoção de comportamentos, como a economia de energia e água, escolha por produtos sustentáveis, uso de produtos até o fim de sua vida útil. A falta de conhecimento das variáveis que controlam o comportamento do consumidor faz com que essas propostas sejam pouco eficazes. Mas será que o consumidor está disposto a investir em produtos que causam menos impactos ambientais? Sendo esses produtos, em sua maioria, mais caros, será que o consumidor pagaria a mais por esses produtos?

Produtos sustentáveis são oferecidos no mercado, mas seu custo de produção é maior que produtos substitutos que utilizam diretamente material prima. Dessa forma, o consumidor se depara com um cenário no qual deverá escolher entre um produto mais caro que traz como consequência menor impacto sobre o meio ambiente e o seu substituto mais barato que seu impacto é maior. Diante desse cenário, tornar-se-á 
necessário identificar se consumidores estão dispostos a pagar mais caro por um produto que agride menos o meio ambiente. Alguns estudos tentaram compreender como se dá o consumo de produtos sustentáveis, e entender a natureza psicológica de tal comportamento ((BLOK; WESSELINK; STUDYNKA; KEMP, 2015; MANIATIS, 2016; LANZINI; TESTA; IRALDO, 2016). Desta forma, neste estudo, será levado em consideração a teoria que estuda a Disposição a pagar (Willingness to pay), na qual tratase em levantar a intenção do consumidor a pagar a mais por produtos que, na sua linha de produção, provocam menos danos ambientais.

Portanto, o presente estudo objetivou verificar a disposição a pagar a mais por produtos que causam menos impactos ambientais, em dois grupos, um grupo que recebeu instruções acerca dos impactos que produtos não sustentáveis causam ao meio ambiente e um grupo que não recebeu instruções acerca dos impactos ambientais de produtos não sustentáveis.

\section{DESENVOLVIMENTO SUSTENTÁVEL}

Analisados em termos qualitativos e quantitativos, o cenário socioambiental pelo qual caracteriza as sociedades pós-modernas, o impacto que o meio ambiente sobre dos humanos, vem tornando-se cada vez mais complexo. Com isso, surge o termo desenvolvimento sustentável, alimentado por duas correntes: uma que critica o modelo de vida contemporânea dentro de uma visão ambientalista, e a outra que defende o corte radical do uso dos recursos naturais (JACOBI, 1999).

Nos países onde tiveram o desenvolvimento baseado no consumo e produção, as indústrias tornaram-se o centro do crescimento econômico. Consequentemente, a ampliação do capitalismo desencadeou a ampliação dos parques industriais, a intensificação de produção e a cultura do consumismo (SANTOS, 2005). Porém, a economia baseada no consumo tem gerado desequilíbrios, uma vez que, se por um lado há riqueza e fartura, por outro há degradação ambiental, aumento da poluição e miséria. Com isso, acrescenta o autor que os princípios de desenvolvimento sustentável ganham força (KON, 2013).

Em 1987 a ONU define o desenvolvimento sustentável como conjunto de aspectos culturais, econômicos, sociais e ambientais da sociedade humana, além de 
preencher as necessidades individuais e coletivas (BRUNDTLAND, 1991). Mendes (2009) aborda a sustentabilidade ambiental como aquela que preserva os recursos naturais na produção de renováveis e no limite do uso dos recursos que não são renováveis; redução do volume de resíduos e de poluição, por meio de conservação e reciclagem; limitação do consumo de combustíveis fósseis e de outros recursos esgotáveis ou ambientalmente prejudiciais, substituindo-se por recursos renováveis e inofensivos; preservação dos recursos naturais na produção de renováveis e na limitação de uso dos recursos nãorenováveis; autolimitação do consumo material; utilização de tecnologia limpas; definição de regras para proteção ambiental.

O conceito de desenvolvimento sustentável surge para buscar um equilíbrio nas atividades fundamentais à qualidade de vida, uma vez que o atual modelo gera desequilíbrios sociais. E, o desenvolvimento sustentável está sendo relacionado à esperança de um país que se mantém por muito tempo numa fase de crescimento, na qual a sustentabilidade é a capacidade deste país continuar uma atividade sem nunca esgotar seus recursos por longo prazo (ARAUJO; MENDONÇA, 2009).

Muller acrescenta (2002) que o desenvolvimento sustentável é a capacidade da sociedade conseguir manter um padrão de vida adequado, e um crescimento econômico num circuito virtuoso que seja de médio e longo prazo. A sustentabilidade é uma questão intertemporal e multidimensional que se trata de trazer melhorias aos ciclos econômicos com suas flutuações, melhoria no padrão de vida e a despeito das flutuações setoriais e crises econômicas localizadas.

O desenvolvimento sustentável deve ser compreendido como um processo de dualidade, no qual, de um lado estão as restrições mais importantes e relacionadas com a orientação do desenvolvimento tecnológico, a exploração dos recursos e o marco institucional, e de outro lado, são referenciados os aspectos qualitativos, como a geração de resíduos, o uso de recursos, a produção de energia e contaminantes (JACOBI, 1999).

\subsection{CONSUMO SUSTENTÁVEL}

Nos folhetos de campanhas de proteção ambiental e em manuais de educação ambiental, a expressão cuidar do ambiente aparece frequentemente, dando a entender que as pessoas utilizam e compreendem o real significado que a expressão carrega. 
Cuidado ambiental é uma categoria pouco estudada em pesquisas que tem por objetivo entender os comportamentos contra e pró ambientais das pessoas, e parece, para os autores, um elemento existente pela qual as pessoas agem e pensam acerca da relação com o ambiente (PINHEIRO; PINHEIRO, 2007).

Os estudos das ciências sociais que se dedicam à assuntos ambientais, têm o estudo das atitudes e das crenças do público como grande parte do seu acervo literário atualmente. Muitas publicações são feitas com essa vertente e que se enquadram nos conceitos e modelos da Sociologia, Psicologia, e Ciência Política em periódicos como o Environment and Behavior, Journal of Social Issues e Journal of Environmental Psychology. Essa vertente ganha relevância no fim da década de 1970, e tenta acompanhar a tendência da época na chamada "preocupação ambiental" do público (CASTRO, 2003).

Comportamento pró-ambiental consiste num conjunto de comportamentos julgados responsáveis pela manutenção da vida humana e pela preservação dos recursos naturais, bem como comportamentos de proteção e cuidado ao meio ambiente (CORRAL-VERDUGO; PINHEIRO, 1999).

O consumo sustentável está relacionado a economia de recursos como água e energia, utilização cuidadosa de materiais e equipamentos até o fim de sua vida útil, envolve a busca por produtos e serviços ecologicamente corretos, a reutilização sempre que possível e a correta destinação de materiais para reciclagem no fim do ciclo de vida dos produtos (RIBEIRO; VEIGA, 2011). O consumo consciente deve buscar minimizar os impactos negativos e maximizar os impactos positivos conforme os princípios da sustentabilidade (SILVA, 2012).

Para Bedante e Slongo (2004), a consciência ambiental é a atitude de um sujeito de forma negativa ou positiva na colaboração para o consumismo ecológico correto, sendo a atitude uma ação feita por um sujeito em relação a algo. A atitude acontece em determinada situação e revela a intensidade com que o componente afetivo, ou seja, a consciência ambiental, influencia no comportamento do indivíduo e expressa, ainda, certa correlação de como o sujeito se vê em relação ao mundo a sua volta e a percepção que o sujeito tem de si mesmo e, sendo essa uma dimensão comparativa entre e o comportamento atitudinal do ser que se diz ecologicamente correto e a consciência 
ambiental, onde o nível de consciência elevado supõe um maior grau de percepção do sujeito.

Pinheiro e Pinheiro (2007) realizaram um estudo com universitários, no qual, por meio da análise dos relatos dos participantes, puderam aferir quais ações representam o cuidado com o ambiente, como os cuidados relatados são realizados e quando pensam na questão, quais práticas lhes surgem. Conforme os resultados, os cinco comportamentos que tiveram maior expressão nos relatos foram: preservação de ecossistemas (13\%); controle de lixo e estética ambiental (29\%); economia de água (9\%); prática de reciclagem (16\%); vínculo a associações ecologistas (12\%). Esses cinco comportamentos, acrescidos de conscientização ambiental (11\%) estão entre os seis mais lembrados, e nessa pesquisa apareceram 11 dos 12 comportamentos próambientais citados na literatura.

Por fim, para que se consiga preservar o meio ambiente é de suma importância a educação do consumidor, com a conscientização da importância dos hábitos de consumo, uma vez que grandes problemas socioambientais são devidos aos padrões impostos pela economia capitalista exacerbada, movida pelo sentimento antropocêntrico, que ganha mais força através da publicidade, cominando num estilo insustentável de vida para a maioria da população (MARTINS, 2013). Pouco é conhecido sobre a magnitude com que a relação entre atitudes e valores humanos e comportamento pró-ambiental tem no contexto do Brasil (COELHO; GOUVEIA; TACIANO, 2006).

\section{MÉTODO}

\subsection{PARTICIPANTES}

O estudo foi realizado em uma cidade do interior de Rondônia com 240 participantes, divididos em dois grupos, Com Instrução e Sem Instrução, os quais continham 120 participantes cada. Todos os participantes aceitaram participar do estudo e assinaram o Termo de Consentimento Livre e Esclarecido (TCLE). 


\subsection{INSTRUMENTOS}

Foram utilizados dois formulários, de elaboração dos autores do estudo, Formulário 'Com Instrução' (ANEXO A) e Formulário 'Sem Instrução' (ANEXO B), nos quais visam levantar a disposição, dos participantes, a pagar por produtos que, em seu ciclo de produção, prejudicam menos o meio ambiente. Os produtos utilizados para essa pesquisa foram: tomate, calça jeans e papel higiênico.

3.2.1 FORMULARIO COM INSTRUÇÃO: foram apresentados, aos participantes deste grupo, uma instrução acerca dos impactos ambientais, nos quais cada um dos três produtos, causam ao meio ambiente durante a sua produção. Em seguida, foi apresentado um preço-base dos produtos e feitos dois questionamentos: "Você pagaria por (nome do produto), que na sua produção não utilizasse agrotóxico e não poluísse o meio ambiente? ." e "Quantos por centos você pagaria? ."

3.2.2 FORMULARIO SEM INSTRUÇÃO: aOs participantes, foram apresentados apenas os preço-base de cada produto e feitos os dois questionamentos: "Você pagaria por (nome do produto), que na sua produção não utilizasse agrotóxico e não poluísse o meio ambiente? ." e "Quantos por centos você pagaria?

\subsection{CONSIDERAÇÕES ÉTICAS}

O estudo foi realizado seguindo as recomendações da Resolução no 466/12, do Conselho Nacional de Saúde, em relação às Diretrizes e Normas Regulamentadoras de Pesquisas Envolvendo Seres Humanos.

\subsection{PROCEDIMENTOS}

A escolha dos participantes foi feita por conveniência, e a eles foram apresentados os objetivos da pesquisa, com o aceite, foram entregues o Termo de Consentimento Livre e Esclarecido (TCLE) e, após a assinatura, foi aplicado o Formulário (Com Instrução ou Sem Instrução). Como a coleta de dados fora feita com duas amostras, os participantes foram submetidos a apenas uma das condições, e a aplicação foi feita de 
forma individual. Cada participante levou em média 10 minutos para responder o formulário.

\subsection{ANÁLISE DOS DADOS}

Os resultados foram distribuídos em planilha do Excel e realizadas análises descritivas para caracterização da amostra (médias, porcentagem e frequência).

\section{RESULTADOS}

Conforme os resultados da Tabela 01, referentes a disposição a pagar por produtos que agridem menos o meio ambiente, pode-se observar que no item tomate, para o formulário Sem Instrução, 110 participantes afirmaram pagar uma média de $23,1 \%$ a mais por um tomate que tem na sua linha de produção menos impacto ao meio ambiente, e 10 participantes, desse grupo, afirmaram que não pagariam a mais por esse produto sustentável. No mesmo item, mas agora no formulário Com Instrução, 106 participantes relataram que pagariam a mais pelo produto que traz menos impactos ambientais, sendo que, em média pagariam 23,5\% a mais, e 14 participantes relataram que não pagariam a mais pelo tomate que tem, em sua produção, menos impactos ambientais. No total, $90 \%$ dos participantes, afirmaram ter disposição a pagar a mais por tomate sustentável, uma média de $23,3 \%$ para ambos os grupos.

No item calça jeans e formulário Sem Instrução, a maioria dos participantes, 81, disse que pagaria a mais por uma calça jeans que traria menos impactos ambientes; estes participantes afirmaram que pagariam, em média, 20,8\% a mais por esse produto, e 39 participantes relataram que não pagariam a mais. Referente à amostra Com Instrução, 90 participantes afirmaram pagar a mais por uma calça jeans que gera menos impactos ambientais, e pagariam uma média de $24,7 \%$ a mais, e 30 participantes afirmaram que não pagariam a mais por este produto. Cerca de $71 \%$ desses participantes pagariam a mais por uma calça jeans que a produção está alinhada com a redução de dados ambientais, na qual declarou disposição de pagar a mais $22,75 \%$ esse produto.

O resultado do item papel higiênico e da amostra Sem Instrução, também apontou que a maioria dos participantes, 107 deles, pagaria a mais pelo produto sustentável, 
sendo que esses participantes demonstraram disposição a pagar uma média de $22,1 \%$ a mais do valor do produto por ser sustentável, e apenas 13 participantes afirmaram que não pagariam a mais pelo produto sustentável. A amostra Com Instrução, apresentou resultados parecidos com a amostra Sem Instrução, na qual 105 participantes relataram que pagariam, uma média de $21,5 \%$ a mais, por esse produto sustentável, e 15 participantes afirmaram que não pagariam a mais pelo produto sustentável. Conforme os resultados, mais de $88 \%$ dos participantes, apresentaram disposição de pagar a mais pelo papel higiênico que causa menos impostos ambientais, uma média de quase $22 \%$ a mais do seu valor.

Tabela 01- Dados gerais acerca da disposição a pagar por produtos sustentáveis, tomate, calça jeans e papel higiênico

\begin{tabular}{|c|c|c|c|}
\hline Tipo de Formulário & N Pagaria a mais & Quanto \% pagaria a mais & N Não pagaria \\
\hline \multicolumn{5}{|c|}{ Tomate } \\
\hline Sem Instrução & 110 & $23,1 \%$ & 10 \\
\hline Com Instrução & 106 & $23,5 \%$ & 14 \\
\hline \multicolumn{5}{|c|}{ Calça jeans } \\
\hline Sem Instrução & 81 & $20,8 \%$ & 39 \\
\hline Com Instrução & 90 & $24,7 \%$ & 13 \\
\hline \multicolumn{5}{|c|}{ Papel higiênico } \\
\hline Sem Instrução & 107 & $22,1 \%$ & 15 \\
\hline Com Instrução & 105 & $21,5 \%$ & 30 \\
\hline
\end{tabular}

Fonte: Produção dos autores.

\section{DISCUSSÃO}

No presente estudo a maioria dos participantes, para ambos os grupos, apresentou disposição a pagar a mais por produtos que causam menos impactos ao meio ambiente. Dos 240 participantes, quase 85\% apresentaram disposição a pagar a mais por produtos que, em seu clico de produção, causam menos impactos ambientais, nos quais pagariam cerca de $22,60 \%$ a mais em cima do valor do produto, caso for sustentável. Esses resultados corroboram os achados da pesquisa realizada pela IBM (NYSE:IBM), em parceria com a National Retail Federation (NRFIBM), em 2020, na qual objetivou levantar a disposição a pagar a mais por bens de consumo sustentáveis e, para 
isso, entrevistou cerca de 19 mil pessoas, em vários países. De acordo com os resultados da pesquisa, 70\% dos participantes apresentaram disposição a pagar mais por produtos sustentáveis, adicionando cerca de $35 \%$ ao seu valor (ESTUDO IBM, 2020).

Atualmente, já é dado ênfase ao consumo ecologicamente correto pelos padrões de consumo, no qual o próprio mercado consumidor e a mídia têm tornado forte, de forma que os próprios consumidores estão mais afeitos a escolher por produtos ecológicos e, fazendo com que o mercado atue neste nicho. Assim, o consumidor consciente consiste naquele que demonstra atividades de comportamento próambiental negando a compra de produtos que afetam ao meio ambiente (DALLA, 2012).

Conforme pode-se verificar, os resultados demonstram que não houve efeito de instrução, ou seja, a quantidade de participantes que responderam que pagariam a mais pelo tomate, calça jeans e papel higiênico sustentáveis, para os grupos Sem Instrução e Com Instrução não apresentou diferenças estatísticas significantes, em relação as análises de cada produto e na análise do geral. Isso sugere-se que as pessoas estão empenhadas em investir em bens de consumo mais sustentáveis, como também, hoje temos maior acesso a informação acerca dos impactos ambientais que a produção causa ao meio ambiente. Desta forma, mesmo não obtendo informações sobre impactos negativos ao meio ambiente, o grupo Sem Instrução, possivelmente, já tinha conhecimento, pelas mídias, das diferenças entre produtos sustentáveis e produtos não sustentáveis. Coelho, Hanna e Todorov (2003), realizou um estudo em que utilizou a manipulação de instrução, e não demonstrou efeito sistemático sobre os valores subjetivos.

Kohlrausch, Campos e Selig (2009) salientam que o consumidor é o principal ator de mudança frente as questões ambientais, uma vez que possui o poder de escolha de compra e disposição a pagar por produtos que ofereçam, não apenas valor nutritivo e gastronômico, mas também segurança e qualidade, e que venham acompanhados de informações acerca do produto. Com isso, vê-se a importância da Educação Ambiental em todos os âmbitos e níveis da educação, na qual ela deve ser vista não como um meio para solucionar os problemas ambientais, mas sim como um instrumento de construção de conhecimento, bem como de desenvolvimento do senso crítico frente às questões ambientais e, com isso, o cuidado com o meio ambiente. 
Por mais que seja uma metodologia hipotética, os resultados permitem observar que consumidores estariam dispostos a pagar a mais por produtos sustentáveis, que nem sempre corrobora com a literatura. É importante realizar estudos em situações naturais para melhor compreensão do efeito dessas variáveis sobre o comportamento pró ambiental de consumidores.

\section{CONSIDERAÇÕES FINAIS}

As mudanças de atitudes frente às questões ambientais e adoção de comportamentos sustentáveis, como preservação, respeito e conservação de ambientes naturais e de uso comum, preferência por produtos ecologicamente corretos entre outros, devem levar em conta diversos fatores, não só a promoção e construção de tais atitudes, como também considerar que o desenvolvimento sustentável perpassa fatores éticos, sociais, políticos e ideológicos.

A adoção de comportamentos responsáveis, sustentáveis ou pró-ambientais, esbarra-se em questões que são empecilhos na aquisição de tais comportamentos, como, por exemplo, o interesse econômico, uma vez que depende do consumo predatório para manter-se. E, não só dessa direção, mesmo o estudo apontando uma direção à disposição a pagar a mais por produtos sustentáveis, deve-se considerar que, diante das crises econômicas, aumento da miséria, dizer pagar a mais pode estar relacionado ao poder aquisitivo do consumidor.

Diante disso, cabe salientar a importância de estudos que controlam características socioeconômicas, por exemplo, bem como que levantam a motivação a pagar a mais por bens de consumo sustentáveis.

\section{REFERÊNCIAS}

ARAÚJO, G. C.; MENDONÇA, P. S. M. Análise do processo de implantação das normas de sustentabilidade empresarial: um estudo de caso em uma agroindústria frigorífica de bovinos. RAM. Revista de Administração Mackenzie, 10(2). 2009.

BEDANTE, G. N.; SLONGO, L. A. O comportamento de consumo sustentável e suas relações com a consciência ambiental e a intenção de compra de produtos ecologicamente embalados. Porto Alegre. 2004. 
BLOK, V.; WESSELINK, R.; STUDYNKA, O.; KEMP, R. Encouraging sustainability in the workplace: a survey on the pro-environmental behaviour of university employees. Journal of Cleaner Production, v. 106, p. 55-67, 2015.

BRUNDTLAND (Org.). Nosso futuro comum: Relatório da Comissão Mundial sobre Meio Ambiente e Desenvolvimento. Rio de Janeiro: FGV. p. 46, 1991.

CASTRO, P. Pensar a natureza e o ambiente-alguns contributos a partir da teoria das representações sociais. Estudos de Psicologia, 8(2), 263-271, 2003.

COELHO, C.; HANNA, E. S.; TODOROV, J. C. Magnitude, atraso e probabilidade de reforço em situações hipotéticas de risco. Psicologia: Teoria e Pesquisa, 19(3), 269-278, 2003.

COELHO, J. A. P. M.; GOUVEIA, V. V.; TACIANO, L. M. Valores humanos como explicadores de atitudes ambientais e intenção de comportamento próambiental. Psicologia em estudo, 11(1), 2006.

CORRAL-VERDUGO, V.; PINHEIRO, J. Q. Condições para o estudo do comportamento próambiental. Estudos de Psicologia, 4(1), 7-22. 1999.

DALLA, C. B. Consumo consciente: O comportamento do consumidor por meio de uma análise psicográfica. Centro Universitário da FEI, 2012.

DIAS, R. Gestão ambiental: responsabilidade social e sustentabilidade. São Paulo: Atlas, 2007.

JACOBI, P. Meio ambiente e sustentabilidade. O Município no século XXI: cenários e perspectivas. Cepam-Centro de Estudos e Pesquisas de Administração Municipal, 175-183. 1999.

ESTUDO IBM: Consumidores pagarão em média 35\% a mais por produtos sustentáveis e de procedência transparente em 2020. IBM Comunica. 10 de jan. de 2020. Disponível em www.ibm.com/industries/retail-consumer-products Acesso em: 23 de maio de 2021.

KOHLRAUSCH, A. K.; CAMPOS, L. M. S; SELIG, P. M. O comportamento do consumidor de produtos orgânicos em Florianópolis: uma abordagem estratégica. Revista Alcance, 11,157-177, 2009.

KON, A. Responsabilidade social das empresas como instrumento para o desenvolvimento: a função da política pública. Planejamento e Políticas públicas, (41). 2013.

MANIATIS, P. Investigating factors influencing consumer decision-making while choosing green products. Journal of Cleaner Production, v. 132, p. 215-228, 2016 . 
MENDES, J. M. Dimensões da Sustentabilidade. Revista das Faculdades Santa Cruz, 7 (2). 2009.

MULLER, G. Desenvolvimento sustentável: necessidade e/ ou possibilidade? Em: MULLER, G. (Org.) Desenvolvimento Sustentável: notas para a elaboração de um esquema de referência. Santa Cruz do Sul: Edunisc, p. 121- 142. 2002.

PINHEIRO, J. Q.; PINHEIRO, T. F. Cuidado ambiental: ponte entre psicologia e educação ambiental? Psico, 38(1), 2007.

RIBEIRO, J. A.; VEIGA, R. T. Proposição de uma escala de consumo sustentável. Revista de Administração, 46(1), 45-60, 2011.

SANTOS, C. Prevenção a poluição industrial: Identificação de oportunidades, análise dos benefícios e barreiras (Tese de Doutorado) Universidade de São Paulo. 2005.

SILVA, M. E. Consumo Sustentável: A Articulação de um constructo sob a perspectiva do desenvolvimento sustentável. Revista Eletrônica de Ciência Administrativa, 11(2), 217, 2012. 


\section{ANEXO A}

\section{Formulário Sem Instrução}

$\mathbf{P}$

SEXO:

RENDA:

ESCOLARIDADE:

\section{TOMATE}

$1 \mathrm{~kg}$ de tomate custa em média $\mathrm{R} \$ 4,00$. Você pagaria por um tomate que na sua produção não utilizasse agrotóxico e não poluísse o meio ambiente? Quantos por centos você pagaria?

\section{CALÇA JEANS}

Uma calça jeans custa em média $\mathrm{R} \$ 120,00$. Você pagaria por uma calça jeans que na sua produção não prejudicasse o meio ambiente? . Quantos por centos você pagaria?

\section{PAPEL HIGIÊNICO}

Um pacote de papel higiênico custa em média $\mathrm{R} \$ 17,00$. Você pagaria por um papel higiênico que fosse oriundo de reflorestamento e que não precisasse desmatar a natureza, e que ocupasse menos espaço e menos plástico em suas embalagens, e com isso permitiria maior quantidade do produto em menos transporte e, consequentemente, lançasse menos $\mathrm{CO} 2$ no ar? . Quantos por centos você pagaria? 


\section{Formulário Com Instrução}

$\mathbf{P}$

SEXO:

RENDA:

ESCOLARIDADE:

\section{TOMATE}

A utilização de agrotóxicos é um dos recursos mais utilizados pelos agricultores para elevar a produtividade agrícola e o consumo destes produtos no Brasil é crescente. A degradação do meio ambiente tem consequências em longo prazo e seus efeitos podem ser irreversíveis. A aplicação de agrotóxicos pode contaminar o solo, a água e os animais, culminando numa degradação ambiental que teria como consequência sérios problemas para o futuro do planeta.

$1 \mathrm{~kg}$ de tomate custa em média $\mathrm{R} \$ 4,00$. Você pagaria por um tomate que na sua produção não utilizasse agrotóxico e não poluísse o meio ambiente? . Quantos por centos você pagaria?

\section{CALÇA JEANS}

Não irá demorar muito para a água se tornar o bem mais caro da humanidade, visto que a cada ano que se passa a quantidade de água potável vem diminuindo. Para a fabricação de uma única calça jeans são necessários uma quantidade de água suficiente para uma pessoa durante três dias, além do grande consumo de energia. Muitos são os impactos ao meio ambiente, onde durante a fabricação são adicionadas substâncias altamente nocivas ao meio ambiente, e que muitas vezes são lançadas ao meio ambiente sem nenhum tratamento, podendo levar a degradação do solo, morte da fauna e fora em que a água contaminada entra em contato.

Uma calça jeans custa em média R\$120,00. Você pagaria por uma calça jeans que na sua produção não prejudicasse o meio ambiente? . Quantos por centos você pagaria? 


\section{PAPEL HIGIÊNICO}

Durante todo o processo de produção de um produto gera impacto ao meio ambiente. O uso da matéria prima pode ser de fontes não renováveis, desmatamento, por exemplo. Na fabricação tem gatos com energia, água e outros produtos, sem contar poluição do ar gerada durante a fabricação e o transporte.

O papel higiênico é um problema para o meio ambiente em todo o seu processo de produção até o seu descarte na natureza. Algumas empresas vêm mudando seus processos de produção para se adequar às novas exigências dos problemas ambientais.

Um pacote de papel higiênico custa em média $R \$ 17,00$. Você pagaria por um papel higiênico que fosse oriundo de reflorestamento e que não precisasse desmatar a natureza, e que ocupasse menos espaço e menos plástico em suas embalagens, e com isso permitiria maior quantidade do produto em menos transporte e, consequentemente, lançasse menos $\mathrm{CO} 2$ no ar? . Quantos por centos você pagaria? 


\title{
CAPITULO IV
}

\section{PERSPECIIVAS E DESAFIOS DA ECONOMIA CRCULAR NO BRASIL}

\section{DOI: $10.51859 / a m p l l a . m a s 481.1121-4$}

\author{
Francisca Kennia Nunes dos Santos ${ }^{1}$ \\ José Henrique Maciel de Queiroz ${ }^{2}$ \\ Rokátia Lorrany Nogueira Marinho ${ }^{3}$ \\ Alesxandro Fernando do Carmo ${ }^{4}$ \\ Jorge Luis de Oliveira Pinto Filho ${ }^{5}$ \\ José Elesbão de Almeida ${ }^{6}$
}

\footnotetext{
1 Mestranda pelo Programa de Pós-Graduação em Planejamento e Dinâmicas Territoriais no Semiárido - UERN

${ }^{2}$ Mestrando pelo Programa de Pós-Graduação em Planejamento e Dinâmicas Territoriais no Semiárido - UERN

${ }^{3}$ Mestranda pelo Programa de Pós-Graduação em Planejamento e Dinâmicas Territoriais no Semiárido - UERN

${ }^{4}$ Mestrando pelo Programa de Pós-Graduação em Planejamento e Dinâmicas Territoriais no Semiárido - UERN

5 Professor Adjunto II do Departamento de Engenharias e Tecnologia. Universidade Federal do Rural do Semi-Árido UFERSA

${ }^{6}$ Professor Adjunto IV do Departamento de Economia. Universidade do Estado do Rio Grande do Norte - UERN
}

\section{RESUMO}

O uso sustentável dos recursos naturais é um dos desafios do mundo moderno, onde a geração de resíduos sólidos atinge volumes cada vez maiores. Dentre as possibilidades de repensar os modelos de produção e consumo da sociedade, surge a chamada Economia Circular (EC). Nesse sentido, o objetivo desse trabalho é analisar o conceito de EC, a sua meta de sustentabilidade e investigar na literatura as perspectivas e projeções futuras de sua utilização no Brasil. Como metodologia, foi utilizada a revisão bibliográfica sobre o tema, sob uma abordagem qualitativa. Constatou-se que a EC traz um leque de oportunidades para a economia brasileira, para a indústria e a sociedade como um todo. Destacam-se vantagens econômicas, de gestão e também ambientais proporcionadas pela EC, quando comparado com a tradicional economia linear. Quanto aos desafios, evidenciam-se as incertezas das empresas quanto aos resultados a curto prazo da adoção do modelo e a falta de incentivos e regulamentos oficiais sobre o tema no Brasil. Logo, espera-se que o país repense seus modelos econômicos para enfim aderir à tendência, visando incorporar no mercado práticas mais sustentáveis.

Palavras-chave: Sustentabilidade. Gestão Ambiental. Economia Circular.

\section{INTRODUÇÃO}

A Revolução Industrial, que ocorreu no século XVIII, foi um marco para mudança de comportamentos da população mundial, principalmente nos hábitos de consumo e de exploração da natureza, sendo este fato permanente até hoje. Então, na medida em 
que as cidades gradativamente cresciam observou-se que a geração dos resíduos sólidos obtinha volumes exacerbantes, superando o seu aumento populacional.

Através da intensa exploração de recursos do meio ambiente incentivada pelo crescimento urbano-industrial e da consequente escassez de diversas matérias-primas, o homem pôde perceber que a disponibilidade desses recursos é finita ou possui renovação em período de tempo acima de sua sobrevivência. Logo, diante da necessidade de utilização e da dependência desses recursos, as primeiras discussões ambientais surgiram com o intuito de minimizar os impactos ao meio biótico e garantir para as próximas gerações a existência desses recursos.

No fim da década de 1980, a Comissão Mundial sobre o Meio Ambiente e Desenvolvimento publicou um documento intitulado como Relatório Brundtland - Nosso Futuro Comum (1988, p. 49), que trouxe a definição de desenvolvimento sustentável como um processo de transformação "no qual a exploração dos recursos, a direção dos investimentos, a orientação do desenvolvimento tecnológico e a mudança institucional se harmonizam e reforçam o potencial presente e futuro, a fim de atender as necessidades e aspirações humanas". A sua elaboração reafirmou a necessidade de discutir sobre o uso excessivo dos recursos naturais e de propor iniciativas que limitassem essa exploração, alinhando o crescimento econômico com a preservação ambiental e bem-estar da sociedade.

A pressão por medidas de prevenção e conservação perdura-se na sociedade contemporânea objetivando reverter o cenário global. Assim, diversas mudanças estão sendo pensadas para revolucionar as organizações, como exemplifica Weetman (2019, p. 39), em que "a economia linear que emergiu das revoluções industriais anteriores, baseadas em extrair, produzir e descartar, está sendo substituída pela economia circular".

Foster et al. (2016) tratam sobre Economia Circular - EC, afirmando que o fechamento de ciclos é adotado em diversos processos produtivos, além disso, o tema vem crescendo na literatura científica, estabelecendo-se como modelo de gestão ambiental. Esse fechamento do processo linear reinsere os produtos no ciclo, minimizam a extração de matéria-prima e geração de resíduos a serem dispostos no meio ambiente, garantindo também a sua eficiência econômica. 
Sendo a EC um exemplo de gestão ambiental, essa solução engloba diversos modelos de gerenciamento pensados em uma administração voltada à redução de impactos ambientais. Além de trazer um viés relacionado ao meio ambiente, com melhor tratamento para os recursos naturais, as organizações que se utilizam dessa gestão buscam o rumo à sustentabilidade, a fim de alcançar o desenvolvimento sustentável, pelo tripé: ambiental, econômico e social.

Neste contexto, o artigo objetiva analisar o conceito de EC, a sua meta de sustentabilidade e investigar na literatura as perspectivas e projeções futuras de sua utilização no Brasil. O trabalho está organizado da seguinte forma: a próxima seção trata em tópicos definições da EC e a relação com o desenvolvimento sustentável, respectivamente. Posteriormente, têm-se a metodologia seguida dos resultados e discussões, e por fim as considerações finais.

\title{
2. REFERENCIAL TEÓRICO
}

\subsection{ECONOMIA CIRCULAR: CONCEITOS E DEFINIÇÕES}

Oliveira et al. (2020) mencionam que o conceito de EC aparece em diversas áreas do conhecimento e cada área possui autores com diferentes conceitos atribuídos. Esses estudos auxiliaram na formulação e definição do termo, sendo que entre eles há conformidade no significado de que a EC é um sistema de ciclo fechado, que visa reduzir a geração dos resíduos e aumentar a eficiência dos recursos, para viabilizar o desenvolvimento e crescimento econômico sem causar danos ao ecossistema.

Luz et al. (2017) afirmam que:

\begin{abstract}
A Economia Circular também procura otimizar o valor dos materiais e componentes durante seu ciclo de vida útil, baseando-se nas seguintes estratégias: reduzir o uso de matéria-prima e a utilização de recursos não renováveis, substituindo-os por recursos renováveis e insumos de base biológica; circular resíduos e subprodutos através de seu reúso e reciclagem dentro da mesma cadeia industrial ou repassá-los para uso em outras indústrias; e estender a vida útil dos produtos e ativos durante e após seu uso, de forma a preservar e maximizar seu valor (LUZ et al., 2017, p. 16).
\end{abstract}

A EC também pode ser denominada de economia restaurativa por natureza, tal qual aborda Azevedo (2015), cujo conceito foi elaborado na década de 1970 e instiga o rompimento do modelo econômico linear, como mostra a Figura 01. A autora afirma 
que existem dois grupos de materiais na EC, que são os biológicos, produzidos para reinserção na natureza e os técnicos, que necessitam de investimentos para serem desmontados e recuperados.

Figura 01 - Economia Linear.

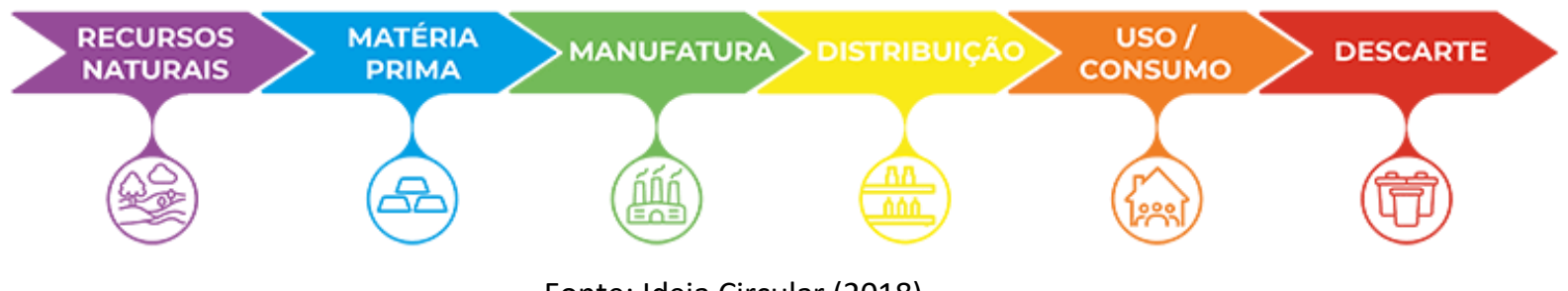

Fonte: Ideia Circular (2018).

A Ideia Circular (2018) traz artigos e estudos de caso sendo a primeira iniciativa no Brasil de educação, comunicação sobre design e economia circular. É visto através da Figura 02, elaborado pela empresa, como se dá o modelo do ciclo fechado, com a captação de recursos naturais, bem como a sua transformação no processo de manufatura, posteriormente ocorre a reinserção do material na cadeia produtiva, envolvendo a reciclagem, reuso, reparo, redistribuição e remanufatura dos produtos, que diminuirá assim o volume de resíduos descartados ao meio ambiente.

Figura 02 - Economia Circular.

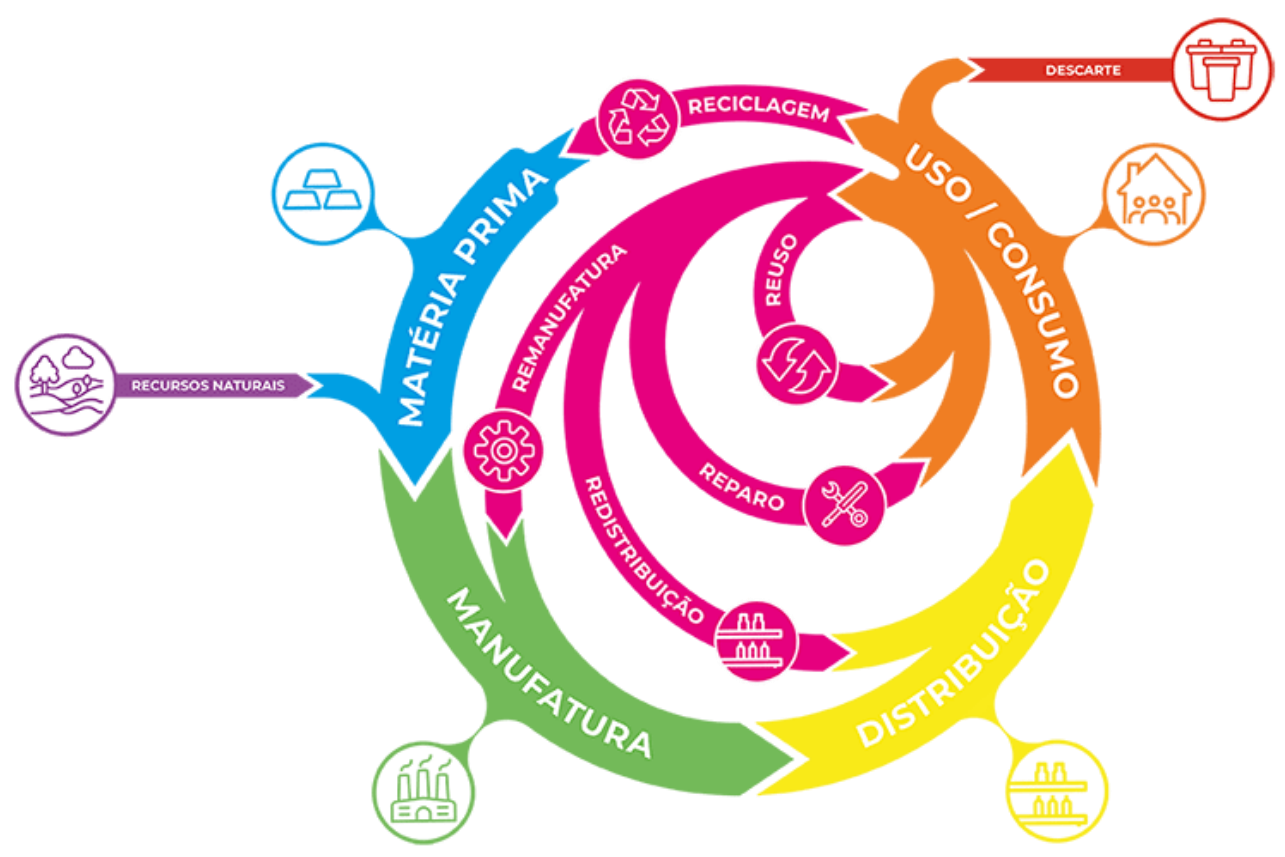

Fonte: Ideia Circular (2018). 
A Ellen MacArthur Foundation - EMF (2012), instituição do Reino Unido que atua na Europa, América do Norte, América Latina e Ásia, trabalha com empresas e organização objetivando acelerar a transição para a EC. A instituição virou referência no assunto e traz também diversos artigos e estudos de caso que aprofundam o tema levando o pensamento mais longe. Esse modelo de economia é inspirado nos eventos da cadeia alimentar da natureza, em que o e resíduo de uma espécie serve de alimento para outra e ao final gera-se energia. O site da EMF traz que a EC se baseia nos seguintes princípios: eliminar resíduos e poluição desde o princípio; manter produtos e materiais em uso; e regenerar sistemas naturais.

Santos (2019) menciona também que a EC é pautada nos princípios de ecoeficiência, não se restringindo apenas à gestão de resíduos, já que o modelo engloba todo o processo produtivo do ciclo, incluindo o projeto do produto, os materiais usados, produção, consumo e por fim o seu descarte. Outro fator abordado e que merece atenção é a conscientização dos consumidores.

\subsection{A ECONOMIA CIRCULAR COMO FERRAMENTA PARA DESENVOLVIMENTO SUSTENTÁVEL}

Luz et al. (2017) tratam que um sistema para ser considerado sustentável precisa levar em consideração diversos fatores, sendo eles a preservação da biodiversidade e inclusão social, sem privilegiar interesses próprios, além disso, os autores afirmam que a energia em uma economia circular é tida como renovável.

Sustentabilidade é um termo que não possui uma definição única, e sim interpretações feitas pelos estudiosos da área. Uma destas definições foi proposta por Elkington (2001, p. 20), para ele, é o "princípio que assegura que nossas ações de hoje não limitarão a gama de opções econômicas, sociais e ambientais disponíveis para as futuras gerações". De forma abrangente, a sustentabilidade pode ser interpretada como a manutenção da capacidade de produzir os bens necessários à realização das nossas atividades.

Para estar a favor da sustentabilidade, a EC visa alterar o sistema produtivo de extração, manufatura, consumo e despejo de resíduos, substituindo a sua linearidade 
para o sistema cíclico, por isso deve contar com a indução a inovações, além de possuir boa audiência dos seus princípios no meio corporativo e governamental (RAMOS et al., 2020). Praça e Azevedo (2018) também comentam sobre os benefícios da EC, afirmando que como resultado há a promoção da ecoinovação ou inovação para a sustentabilidade. Tais termos ainda podem ser substituídos por tecnologias verde, circular, sustentável e ambiental.

Tiossi, Simon e Milan (2019) analisaram em seus estudos que a EC é ponto necessário para o crescimento econômico sustentável, pois complementa a sustentabilidade em suas três dimensões. Esse tipo de economia foca na melhoria da qualidade do produto, reduz o gasto da matéria-prima, possibilita a manutenção dos materiais no mais alto nível de utilidade e auxilia na diferenciação entre os produtos biológicos e técnicos. É importante mencionar que, ainda segundo os autores, a relação entre os termos é pouco explorada e a sustentabilidade é mais ampla que a EC, logo, salienta-se a importância de mais pesquisas na área.

Aoki, Tiossi e Simon (2018) tratam que a EC e sustentabilidade não podem ser considerados sinônimos devido às diferenças de seus princípios gerais, porém essa economia circular surge como um complemento:

\footnotetext{
A economia circular surge como uma ferramenta de apoio à sustentabilidade e sua função é suprir as lacunas deixadas pela sustentabilidade em diversos aspectos. Destaca-se ainda como um modelo que visa à proteção ambiental, à prevenção da poluição, do desenvolvimento sustentável e da geração de emprego, buscando diminuir os custos na organização. Sua importância também se dá por gerar vantagem competitiva para empresas que implantarem práticas circulares. Pela literatura, nota-se que o conceito de economia circular é muito extenso, abstrato e ainda pouco conhecido pela sociedade e explorado pela academia científica (AOKI, TIOSSI E SIMON, 2018, p. 14).
}

A EC, portanto, abre excelentes perspectivas, como traz Leitão (2015), posto que este paradigma de sustentabilidade incentiva novas práticas de gestão e oferece inovações agregando valor à organização e aos clientes, respeitando acima de tudo o meio ambiente. Isso permite a redução da procura por recursos naturais e influencia diretamente na recuperação de desperdícios e resíduos. 


\section{METODOLOGIA}

De acordo com Prodanov e Freitas (2013), o método de abordagem utilizado na pesquisa, ou seja, o meio que se propõe a explicar a realidade através de procedimentos lógicos é o indutivo. Para esse tipo de raciocínio, analisou-se a situação atual da economia circular no âmbito brasileiro. Através do estudo dessas relações é possível induzir à realidade do fenômeno ou fato.

A pesquisa classifica-se quanto aos objetivos como exploratória e quanto aos procedimentos como bibliográfica e documental, ainda segundo os autores. Assim, do ponto de vista dos seus objetivos, visa explorar informações associadas à economia circular, sustentabilidade, projeções futuras para descobrir um novo enfoque acerca do tema trabalhado.

Já em relação aos procedimentos utilizados, isto é, as maneiras de obtenção de dados necessários para elaboração do estudo têm-se a pesquisa bibliográfica, cuja fonte foi buscada em material já publicado, como artigos científicos, livros, dissertações, sites da internet, etc. e a pesquisa documental, que também se vale de fontes de papel e não receberam tratamento analítico, mas são de suma importância para registro, como sites do governo, dados de órgãos estatais, documentos oficiais, dentre outros.

\section{RESULTADOS E DISCISSÃO}

\subsection{PERSPECTIVAS E DESAFIOS DA ECONOMIA CIRCULAR}

Leitão (2015) evidencia que a transição da economia linear para EC exige uma mudança sistêmica, com atenção para todos os intervenientes da cadeia de valor que podem vir a ser afetados e, nesse sentido os aspectos de inovações da tecnologia, organização e sociedade geral também devem ser levados em consideração. Para alcançar o objetivo faz-se necessário uma equipe capacitada, de pessoas com novas habilidades, que tenham em sua formação não apenas áreas da ciência, engenharia e tecnologia, pois deve se incluir uma base de design, publicidade e digital. Em seu estudo, afirma-se também que é preciso buscar uma nova tendência de gestão, para que a mudança realmente venha a ocorrer. 
Portanto, implementar a EC é uma tarefa árdua que exige inúmeras obrigações, como apontam Sales et al. (2019), em razão de envolver todo o sistema de adequação de empresas, de necessitar a mobilização dos poderes públicos e acima de tudo de conscientizar a população. Os autores consideram três níveis de implementação que facilitam a transição:

i. Macro: neste nível existe a escala mais abrangente, que representa a ação da localidade como um todo, sendo os países e eco-cidades os envolvidos, para isso, devem ser criados os planos estratégicos de desenvolvimento e evolução;

ii. Meso: é o nível médio do processo, vem abranger os laboratórios de pesquisas e parques tecnológicos que permitem realizar investigações e viabilizar melhorias a nível industrial; e

iii. Micro: trata-se da escala mais básica da EC, alcançando a base do processo, que são a população e pequenas empresas, através de uma conscientização ambiental, elaboração de políticas ambientais específicas e implementação da produção mais limpa.

Oliveira et al. (2019) tratam que a EC traz para as organizações diversas oportunidades e vantagens, sejam elas sociais, econômicas e ambientais, diretas e indiretas, que contribuem em várias dimensões de sustentabilidade para as frentes de desenvolvimento local. Porém, "a sua aplicação prática tem deixado muito a desejar. É muito importante passar da retórica à sua implementação" (LEITÃO, 2015, p.153).

Berardi e Dias (2018) comentam que a aplicação do modelo circular representa uma série de desafios, mas com a correta efetivação traz oportunidades a empresas de todos os portes, com benefícios ambientais, aumento de disponibilidade de emprego e poupança de recursos. A implementação, baseada na regeneração e restauração de materiais, demanda uma mudança que deve ir além do modelo de degradação e desperdício. Faz-se necessário um conjunto de competências político-econômicas, no âmbito privado e público, para tratar de questões como: conformidade legal e normativa, políticas públicas facilitadoras, lideranças empresariais e financiamentos. Outra exigência recai: aos consumidores, pela alteração na sua relação com o produto, que deve passar de propriedade para o uso pela funcionalidade do serviço. Esse é outro 
grande desafio, porque envolve questões culturais e sociais que são mais duras de serem perfuradas. Os autores também mencionam que existem desafios na cadeia produtiva, já que precisam de novas colaborações e parcerias para o estabelecimento de funções que venham incluir e agregar operações de manutenção e remanufatura, e isso aumenta a complexidade da logística. Mas, quanto às suas oportunidades, têm-se:

O modelo de EC permite influenciar todo e qualquer tipo e tamanho de negócio: em atividades de nível individual ou em microempresas, por meio do ecodesign e de abordagens de produção mais limpa; em operações intermediárias em empresas de médio porte, pela simbiose industrial com parcerias tanto funcionais quanto logísticas que tragam efeito no desenvolvimento regional; ou ainda em organizações de grande porte que possibilitem o redesenho sistêmico das cidades, no chamado conceito de sustainable cities. Prevê-se o aumento de postos de trabalho com a criação de novos fluxos logísticos e de serviços e mais investimentos em pesquisa e desenvolvimento de projetos para promover a inovação e aumentar a qualidade de produtos e serviços. Com as novas propostas de comportamento coletivo por parte do consumo, espera-se uma reflexão direta sobre a qualidade de vida por meio de melhorias sociais e ambientais que impactarão a saúde humana (BERARDI; DIAS, 2018, p. 37).

Izzepi (2019) menciona algumas barreiras existentes na implementação da EC que restringem o desenvolvimento do modelo circular, são elas: barreira econômica, pelo investimento a ser feito, resistência de investidores em inovações, dependência de produtores com a velha cadeia de negócio, etc.; barreira social, relacionada ao comportamento dos consumidores, que podem ter dificuldades de se adaptarem ao sistema, falta de senso de urgência, desmaterialização para romper com os paradigmas de uma sociedade consumista e falta de políticas e incentivos que favoreçam a transição; e barreira profissional, pela ausência de adoção de práticas que disseminem o conhecimento sobre o assunto e a existência de falhas nos setores e empresas que empacam de implantar os princípios da EC.

Outro desafio enfrentado pelas empresas, tal qual retrata Antunes (2018) é a incerteza dos custos associados a um modelo de negócio diferente do usual, trazendo também dificuldades na flexibilidade de aceite entre as organizações. Isso gera resistência nos parceiros e fornecedores de suprimentos, assim pode não ser rentável em curto prazo e pode também depender de comportamentos da sociedade no geral.

Já em relação às oportunidades geradas, como aborda Gonzalez (2018) a EC traz inúmeros benefícios que superam os desafios em peso, sendo: quanto a economia, há 
destaque para crescimento econômico, geração de empregos, criação de campo oportuno para inovações e redução de custo líquido; quanto ao meio ambiente, as oportunidades estão relacionadas à diminuição de emissão e do uso de materiais primários, incentivo a preservação ambiental, aumento da produtividade da terra e diminuição de externalidades negativas; e quanto ao âmbito social, as oportunidades serão percebidas pelos clientes, com o aumento de leque de opções no mercado e da qualidade dos modelos gerados, aumentando o tempo de vida de duração dos produtos e rompendo com a obsolescência programada, além de diminuir gastos com reparos e incentivar a mudança de pensamento na sociedade.

Ribeiro, Fonseca e Santos (2018) trazem algumas vantagens da EC para as empresas, que são: redução de custos com matéria-prima, redução de custos com a gestão de resíduos, potencial valor atribuído aos resíduos, potencial de diminuição de outros consumos, promoção da inovação, criação de novos produtos, geração de novos clientes e mercados, diferenciação competitiva, melhoria do desempenho financeiro, contribuição para um melhor propósito da empresa, cultura empresarial mais forte e novas competências na empresa.

Portanto, em síntese, muitos são os benefícios envolvidos com a adoção das práticas propostas pela economia circular, seja para a economia de forma mais ampla, seja para a os custos operacionais das empresas e seus modelos de gestão e principalmente para o meio ambiente, pois a redução na extração de recursos naturais, nas emissões geradas nos processos de manufatura e consequente minimização de impactos ambientais, favorecem a sustentabilidade e a qualidade ambiental e da vida da população. As incertezas das empresas e a falta de incentivos via políticas governamentais, no entanto, tem retardado a adoção do modelo.

\subsection{A ECONOMIA CIRCULAR NO BRASIL}

No Brasil, a EC não possui tanta expressão, já que não foi explicitada em uma política pública a nível federal, aborda Gonzalez (2018). No setor privado é possível observar alguns avanços no que tange à transição da economia linear para o modelo circular, menciona o autor, porém na esfera pública a presença da EC ainda é discreta e se pode afirmar que existem iniciativas isoladas assumidas pelo governo que podem ser interpretadas como mudanças. É o caso da Política Nacional de Resíduos Sólidos - PNRS,

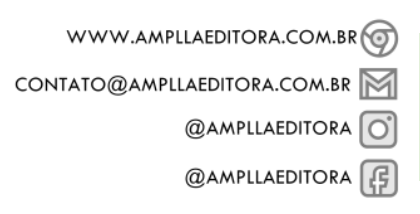


instituída pela Lei $N^{\circ} 12.305 / 2010$, que instaura a obrigatoriedade da Logística Reversa, definida como:

\footnotetext{
logística reversa: instrumento de desenvolvimento econômico e social caracterizado por um conjunto de ações, procedimentos e meios destinados a viabilizar a coleta e a restituição dos resíduos sólidos ao setor empresarial, para reaproveitamento, em seu ciclo ou em outros ciclos produtivos, ou outra destinação final ambientalmente adequada; (BRASIL, 2010, p.01).
}

Ainda na PNRS, seus princípios e objetivos demonstram certo compromisso com a sustentabilidade, porém sem menções à EC. Entre seus princípios estão, o desenvolvimento sustentável e a ecoeficiência, além de ter como um de seus objetivos o "estímulo à adoção de padrões sustentáveis de produção e consumo de bens e serviços" e a prioridade na aquisição e contratações governamentais de produtos reciclados e recicláveis, bens, serviços e obras que levem em conta critérios ambientalmente sustentáveis.

Porém, apesar de existir exemplos de aplicação da EC no Brasil, ainda há um longo caminho a se percorrer para substituir apenas casos isolados por uma rede de suprimentos em prol da sustentabilidade, afirma Azevedo (2015), assim sugere-se como pontapé inicial a revisão da legislação quanto à logística reversa, que já é instituído por lei.

Em comparativo com a China, Azevedo (2015) retrata que o país lidera no quesito EC, no entanto para que o Brasil possa alcançar patamar semelhante é necessário investimento em políticas públicas que estimulem o rompimento da economia linear. Os chineses cumprem esse objetivo com estabelecimento de redes de créditos, benefícios fiscais, rede de investidores e transparência para consumidores a fim de superar a dificuldade causada pela escassez de recursos naturais. Tal mudança pode ser exemplo para que os brasileiros possam se espelhar em elaboração de ações semelhantes.

Assunção (2019) também menciona em seu estudo alguns desafios enfrentados pelo país na implementação da EC: a questão da dispersão geográfica, já que as regiões possuem muitas diferenças econômicas e sociais e esse fato pode interferir na integração de processos entre empresas que venham a compartilhar a produção; e o 
sistema de tributação indireta, que possibilitará cobrança de tributos mais de uma vez sobre o mesmo valor inserido.

Ainda segundo o autor, para superar tais problemas é necessário que uma série de ações seja posta em prática, a fim de desenvolver uma conscientização sobre a urgência de mudanças para uma economia ecológica, assim, exige-se que tenham fortalecimento em políticas ambientais e investimento de educação ambiental para todos os níveis.

Cosenza, Andrade e Assunção (2020) também retratam que no Brasil existem inúmeros desafios enfrentados pelas políticas públicas e de estratégia econômica na meta de se alcançar condutas sustentáveis de acordo com a EC. Para realizar esse percurso em direção a uma política alinhada ao conceito analisado, precisaria de adoção de algumas práticas para uso eficiente de recursos, como a gestão e valorização de fluxos específicos de resíduos, eficiência energética e crescimento verde. Os autores ainda complementam que quanto mais resíduos forem recuperados e reutilizados, menor será a extração dos componentes e consequentemente a contaminação e poluição.

Já o Poder Público deve ter um cronograma de ações bem definido, que possa promover discussões entre as partes envolvidas, sobre a viabilidade socioeconômica e científica da EC, isso irá contribuir para uma aplicação eficiente dos recursos públicos em inovações e pesquisas de desenvolvimento (AZEVEDO, 2015).

Santos et al. (2018) retratam que o modelo atual de desenvolvimento econômico deve ser visto com outro viés, em relação ao mecanismo de produção e consumo, já que se trata de um sistema insustentável perante aos problemas ambientais. Logo, conhecendo a realidade do Brasil e dos inúmeros impactos negativos aos meios social, ambiental e econômico, torna-se evidente o seu estado de conturbação e, principalmente, a necessidade urgente de mudanças.

\section{CONSIDERAÇÕES FINAIS}

A Economia Circular, embora possua referências de sua concepção desde a década de 1970, ainda possui pouca difusão no Brasil, tanto quando se fala do conhecimento da sociedade sobre seus princípios, como também quanto é pensado nos 
modelos de produção adotados pela indústria nacional. Tal cenário é um reflexo dos aspectos abordados anteriormente, onde percebe-se um ambiente de pouco estímulo às mudanças nos modelos de produção e consumo de materiais no país.

Ficam notórias as oportunidades proporcionadas pela Economia Circular, em termos econômicos, em termos de gestão dos resíduos sólidos, dos custos com extração de matéria prima e processamento de materiais, em termos de proteção ambiental e redução de impactos negativos à natureza. Porém, também são muitos desafios a superar até a ampla adoção dos modelos de EC. Quando analisado o Brasil, observa-se a falta de regulamentos oficiais que tratem desse conceito e da viabilização da incorporação dos seus princípios nas empresas.

Enquanto outros países avançam na otimização da extração de recursos naturais, o Brasil ainda não conseguiu imprimir esforços suficientes para a adesão a modelos de produção mais sustentáveis como a EC. O que fica claro é a importância e a urgência em repensar essa economia baseada no fluxo linear de produção e consumo, pois haverá graves consequências que podem comprometer a qualidade de vida futura.

Por fim, conclui-se que os objetivos do trabalho foram alcançados, tendo abordado o conceito, oportunidades e desafios da EC, enfaticamente no Brasil. A contribuição deste se dá pela difusão dos conhecimentos relacionados a essa temática ainda pouco explorada nacionalmente e o texto pode auxiliar novos pesquisadores da área assim como empresas que tenham interesse em adotar o modelo proposto pela EC nas suas atividades produtivas.

\section{AGRADECIMENTOS}

O presente trabalho foi realizado com apoio da Coordenação de Aperfeiçoamento de Pessoal de Nível Superior - Brasil (CAPES) - Código de Financiamento 001.

\section{REFERÊNCIAS}

[ilustração] O que é economia circular?. Ideia Circular, 2018. Disponível em: $<$ https://www.ideiacircular.com/economia-circular>. Acesso em 19 jan. 21. 
ANTUNES, M. C. Economia Circular no Brasil: barreiras e oportunidade para o negócio de recuperação e reciclagem do óleo de cozinha residual. Rio de Janeiro, 2019. 180p. Dissertação de Mestrado - Departamento de Engenharia Civil e Ambiental, Pontifícia Universidade Católica do Rio de Janeiro.

AOKI, S.; TIOSSI, F. M.; SIMON, A. T. Economia Circular: Sua Relação E Contribuições Para A Sustentabilidade. Revista Funec Científica-Multidisciplinar-ISSN 2318-5287, 7(9). 2018.

ASSUNÇÃO, G. M. A gestão ambiental rumo à economia circular: como o Brasil se apresenta nessa discussão. Sistemas \& Gestão, Vol. 14, No. 2, pp. 223-231, 2019. Disponível em: http://www.revistasg.uff.br/index.php/sg/article/view/1543.

AZEVEDO, J. L. A Economia Circular Aplicada no Brasil: uma análise a partir dos instrumentos legais existentes para a logística reversa. In XI Congresso Nacional De Excelência Em Gestão (Vol. 13). 2015.

BERARDI, P.; DIAS, J. M. O mercado da economia circular. GV executivo, v. 17, n. 5, p. 34-37, 2018.

BRASIL, Ministério do Meio Ambiente. Lei no 12.305, de 2 de agosto de 2010. 2010. Disponível em: < http://www.planalto.gov.br/ccivil_03/_ato20072010/2010/lei/l12305.htm>. Acesso em: 03 jan. 2021.

COMISSÃO MUNDIAL SOBRE MEIO AMBIENTE E DESENVOLVIMENTO (CMMAD). NosSo futuro comum. Rio de Janeiro: Fundação Getulio Vargas, 1988.

COSENZA, J. P.; ANDRADE, E. M.; ASSUNÇÃO, G. M. Economia circular como alternativa para o crescimento sustentável brasileiro: análise da Política Nacional de Resíduos Sólidos. Rev. Gest. Ambient. e Sust. 9(1), 1-30, e16147. 2020. https://doi.org/10.5585/geas.v9i1.16147.

ELKINGTON, J. Canibais com garfo e faca. São Paulo: Makron Books. (2001).

FOSTER, A.; ROBERTO, S. S.; IGARI, A. T. Economia circular e resíduos sólidos: uma revisão sistemática sobre a eficiência ambiental e econômica. Anais do Encontro Internacional Sobre Gestão Empresarial e Meio Ambiente. São Paulo. 2016.

GONZALEZ, T. S. Economia circular: comparação dos avanços à transição entre Brasil e União Europeia. Trabalho de Conclusão de Curso. 2018.

IZEPPI, W. C. Estímulos e barreiras para a adoção da economia circular no Brasil: uma pesquisa quantitativa nos setores de agronegócio, construção civil e eletroeletrônico. / Wagner Colucci Izeppi, 201976 f.: il. 2019. 
LEITÃO, A. Economia circular: uma nova filosofia de gestão para o séc. XXI. Portuguese Journal of Finance, Management and Accounting. ISSN 2183-3826. Vol. 1, N. 2 (2015), p. 150-171.

LUZ, B. et al. Economia circular Holanda: Brasil: da teoria à prática; Available from <http://www.scielo.br/scielo.php?script=sci_arttext\&pid=S151870122019000401179\&Ing=en\&nrm=iso $>$. access on 19 Jan. 2021. Epub Dec 05, 2019. http://dx.doi.org/10.20435/inter.v20i4.1921.

OLIVEIRA, A. C. V.; SILVA, A. D. S.; MOREIRA, Í. T. A. Economia Circular: Conceitos E Contribuições Na Gestão De Resíduos Urbanos. Revista de Desenvolvimento Econômico, 3(44). 2020.

OLIVEIRA, F. R.; FRANCA, S. L. B; RANGEL, L. A. D. Princípios de economia circular para o desenvolvimento de produtos em arranjos produtivos locais. Interações. Campo Grande, v. 20, n. 4, p. 1179-1193, Dec. 2019.

PRAÇA, L. G.; AZEVEDO, J. N. Economia circular: o amanhã da sustentabilidade. In I Congresso Internacional em Planeamento Sustentável e Ordenamento Territorial. Universidade da Madeira. 2018.

PRODANOV, C. C.; FREITAS, E. C. Metodologia do trabalho científico: métodos e técnicas da pesquisa e do trabalho acadêmico. 2. ed. Novo Hamburgo: Feevale, 2013.

RAMOS, C.; ZILBER, M. A.; FREITAS, L. F. S.; LHAMA, P. G. Economia circular como caminho para inovação e sustentabilidade. Revista Livre de Sustentabilidade e Empreendedorismo, 5(3), 242-259. 2020.

RIBEIRO, A. V.; FONSECA, L.; SANTOS, S. Economia verde e economia circular: desafios e oportunidades. ISBN 989-95907. 2018.

SALES, G. F., DA ROSA, T. O. FARIA, T. L., PEDRUSSI, P. C., \& BLANCO, R. Desenvolvimento da Economia Circular no brasil: a aplicabilidade na indústria e nas demais organizações. IBEAS - Instituto Brasileiro de Estudos Ambientais. 2019.

SANTOS, G. M. A. Economia Circular Como Política Governamental De Gestão De Resíduos Sólidos: Implicações de sua Implementação no Brasil. Episteme Transversalis, [S.I.], v. 10, n. 1, abr. 2019. ISSN 2236-2649. Disponível em: <http://revista.ugb.edu.br/ojs302/index.php/episteme/article/view/1304>. Acesso em: 21 jan. 2021.

SANTOS, J. P. D. O.; SILVA, E. V. L.; SOUZA, A. L.; EL-DEIR, S. G. Economia circular como via para minimizar o impacto ambiental gerado pelos resíduos sólidos. Resíduos sólidos: Tecnologias e Boas Práticas de Economia Circular. Recife: EDUFRPE, 817. 2018. 
TIOSSI, F. M.; SIMON, A. T.; MILAN, W. W. Circular Economy: A Contribution To The Sustainable Development: Economia Circular: uma contribuição para o desenvolvimento da sustentabilidade. Brazilian Journal of Production Engineering-BJPE, 77-99. 2019.

TOWARDS the Circular Economy: Economic and Business Rationale for na Accelerated Transition. Ellen MacArthur Foundation, 2012. Disponível em: <https://www.ellenmacarthurfoundation.org/news/towardsthe-circulareconomy>.

WEETMAN, C. Economia circular: conceitos e estratégias para fazer negócios de forma mais inteligente, sustentável e lucrativa. 1 ed. São Paulo: Autêntica Business, 2019. 


\title{
CAPÍTULO V
}

\section{ANÁLISE DAS PRÁTICAS DE SUSTENTABIUDADE SOB A ÓTICA DO GLOBAL REPORT INITATIIVE (GRI): UM ESTUDO DE CASO EM UMA ORGANIZAGÃO DO SETOR DE AGRONEGÓCIO}

\section{DOI: 10.51859/amplla.mas481.1121-5}

\author{
Caroline Ferreira Pauline ${ }^{1}$ \\ Lesley Carina do Lago Attadia Galli ${ }^{3}$ \\ Glaucia Aparecida Prates ${ }^{3}$ \\ Elisangela Pereira Senno ${ }^{2}$ \\ Fernando da Silva Coimbra ${ }^{2}$ \\ Antonio Francisco Savi ${ }^{3}$
}

\begin{abstract}
${ }^{1}$ Graduada em Administração Universidade Estadual Paulista- UNESP
${ }^{2}$ Mestrando em Administração Programa de Pós-Graduação em Administração- UNESP

${ }^{3}$ Professor Assistente Doutor Universidade Estadual Paulista- UNESP
\end{abstract}

\section{RESUMO}

Este trabalho teve como objetivo analisar as práticas de sustentabilidade adotadas por uma organização multinacional do setor do agronegócio atuante no Brasil sob a ótica do Global Report Initiative (GRI). Como metodologia foi realizada uma pesquisa de natureza descritiva, caráter exploratório e abordagem qualitativa, além da utilização da base secundária de dados e das entrevistas semi-estruturadas com funcionários da organização. Desse modo, ficou evidente que a organização no setor do agronegócio é comprometida com os princípios do desenvolvimento sustentável e com o seu papel de empresa cidadã, ética e socialmente responsável, ao passo que foi relatado um bom desempenho das práticas de sustentabilidade através do nível de aplicação B do GRI, ou seja, onde mais de 20 indicadores de sustentabilidade foram respondidos (total de 56 , incluindo todas as dimensões) e sem autenticação externa. No entanto, é importante mencionar, que não foram cobertas todas as questões propostas pelos indicadores de sustentabilidade do GRI devido à dificuldade de acesso a algumas informações. Assim, como forma de somar as práticas de sustentabilidade já existentes, verifica-se a necessidade de maiores investimentos no departamento de sustentabilidade para construção de novos projetos; ênfase na criação e amplitude de projetos ambientais; maior divulgação de temas de corrupção e políticas públicas aos empregados; utilização da norma ISO 26000 para melhor gestão de práticas sociais; criação de mais projetos sociais em prol as comunidades agrícolas e continuação de ações legais voltadas aos direitos humanos, as pessoas e a cadeia produtiva. Portanto, foi constatado que a organização estudada tem a sustentabilidade em sua estratégia de negócios, pois contribui no fornecimento de alimentos saudáveis a sociedade, a preservação do meio ambiente e ao dinamismo da economia do país (através da geração de renda e emprego).

Palavras-chave: Agronegócio. Sustentabilidade . Global Report Initiative (GRI). 


\section{INTRODUÇÃO}

O capitulo tem como objetivo geral analisar as práticas de sustentabilidade adotadas por uma organização multinacional do setor do agronegócio atuante no Brasil, tomando como referência o GRI. Cabe ressaltar que diante da magnitude da organização, este trabalho concentrar-se-à na divisão de Ciências Agrícolas, a qual é uma das principais áreas de negócio da respectiva organização no Brasil.

Desse modo, sugere-se que a organização avalie e desenvolva novas estratégias ao longo do tempo através de indicadores de sustentabilidade.

Atualmente, o relatório GRI está em sua terceira versão de diretrizes, chamada de GRI G3, lançado em 2006 e baseada no conceito de TBL de sustentabilidade. A GRI (2012) desenvolveu a "Estrutura de Relatórios de Sustentabilidade" e as "Diretrizes para a Elaboração de Relatório de Sustentabilidade".

Para tanto, conforme consta no GRI (2012), cada dimensão dos indicadores de desempenho incluem informações sobre a forma de gestão e um conjunto correspondente de indicadores. Sendo assim, os objetivos dessas dimensões consistem em:

(a) Dimensão Econômica: aos impactos da organização sobre as condições econômicas de seus stakeholders e sobre os sistemas econômicos em nível local, nacional e global;

(b) Dimensão Ambiental: aos impactos da organização sobre sistemas naturais vivos e não-vivos, incluindo ecossistemas, terra, ar e água. Os indicadores ambientais abrangem o desempenho relacionado a insumos (como material, energia, água) e a produção (emissões, efluentes, resíduos). Além disso, abarcam o desempenho relativo à biodiversidade, à conformidade ambiental e outras informações relevantes, tais como gastos com meio ambiente e os impactos de produtos e serviços e;

(c) Dimensão Social: aos impactos da organização nos sistemas sociais nos quais opera. Os indicadores de desempenho social da GRI identificam aspectos de desempenho fundamentais referentes a práticas trabalhistas, direitos humanos, sociedade e responsabilidade pelo produto.

Logo, o processo de relato das informações do GRI G3 deve se basear em seus Princípios de modo a engajar os stakeholders para entender, debater, mensurar e 
melhorar os processos internos e externos, além de monitorar e comunicar o desempenho da organização em relação à sustentabilidade. Para isso, tem-se como base o apoio do processo de relato inspirada na publicação do Ciclo Preparatório para Elaboração de Relatórios de Sustentabilidade da GRI .

\subsection{SUSTENTABILIDADE NO AGRONEGÓCIO}

Em busca de uma gestão sustentável no agribusiness, a organização deve se basear em determinantes estratégicos deste setor através da compreensão dos conceitos básicos sobre agronegócio e gestão sustentável.

Quadro 1: Estímulos internos e externos na adoção de métodos de gestão sustentável

\begin{tabular}{|c|c|}
\hline \multicolumn{2}{|r|}{ Estímulos Internos } \\
\hline Redução de custos & $\begin{array}{l}\text { Uso racional e eficiente de energia, produtos e recursos da natureza (água, ar } \\
\text { e solo), evitando desperdícios e obtendo benefícios a médio prazo. }\end{array}$ \\
\hline Incremento da qualidade & $\begin{array}{l}\text { Por meio de investimentos na funcionalidade, confiabilidade, durabilidade e } \\
\text { outros atributos agregados aos serviços e produtos da organização. }\end{array}$ \\
\hline Incremento da Imagem & $\begin{array}{l}\text { Imagem fortalecida perante a confiança e fidelidade dos consumidores em } \\
\text { relação aos produtos e a organização. }\end{array}$ \\
\hline Inovação & $\begin{array}{l}\text { Através de instrumentos estratégicos de gestão sustentável e tecnologia que } \\
\text { garantam diferenciação e competividade para organização no mercado. }\end{array}$ \\
\hline Maior R S E & $\begin{array}{l}\text { O segmento gerencial tem adquirido maior preocupação com a preservação do } \\
\text { meio ambiente, o que inclui cuidados com: a diversidade, as necessidades das } \\
\text { gerações futuras e com os efeitos do processo produtivo da comunidade. }\end{array}$ \\
\hline $\begin{array}{l}\text { Sensibilização do pessoal } \\
\text { interno }\end{array}$ & $\begin{array}{l}\text { Com maior interação dos níveis operacional e estratégico da organização, há } \\
\text { melhores medidas corretivas e proativas em relação ao meio ambiente. }\end{array}$ \\
\hline \multicolumn{2}{|r|}{ Estímulos Externos } \\
\hline Demanda de mercado & $\begin{array}{l}\text { Aumento das exigências ambientais pelos clientes e consumidores finais, o que } \\
\text { obriga as organizações a melhorarem a sua forma de atuação, modificando } \\
\text { produtos e processos, e constituindo assim, uma cadeia produtiva } \\
\text { ambientalmente correta com fornecedores orientados nesse sentido. }\end{array}$ \\
\hline Concorrência & $\begin{array}{l}\text { Com a adoção de métodos de gestão sustentável, a organização consegue } \\
\text { maior desempenho (econômico e social) e capacidade de competição }\end{array}$ \\
\hline Legislação & $\begin{array}{l}\text { As pressões ambientais aumentaram. Cumprir a legislação ambiental tornou- } \\
\text { se requisito mínimo e necessário, e a legislação trabalhista, essencial. }\end{array}$ \\
\hline O meio sociocultural & $\begin{array}{l}\text { Envolve pressão dos stakeholders (empregados da empresa, comunidade, } \\
\text { clientes e outros envolvidos) de modo a propor uma gestão sustentável. }\end{array}$ \\
\hline Certificações e Projetos & $\begin{array}{l}\text { São estímulos externos de grande peso para as organizações perante a imagem } \\
\text { e competividade no mercado. Muitos clientes exigem. }\end{array}$ \\
\hline Fornecedores & $\begin{array}{l}\text { Aliados da organização para acrescentar serviços e produtos com maior valor } \\
\text { agregado (tecnologias e inovação ambientalmente e socialmente corretas). }\end{array}$ \\
\hline
\end{tabular}




\section{METODOLOGIA}

Primeiramente o presente trabalho buscou identificar e entender as práticas de sustentabilidade em uma organização do setor de agronegócio por meio de questões: como e por que essas práticas sustentáveis existem e funcionam, e posteriormente aprofundou esses questionamentos com base na coleta de dados.

Assim, este trabalho consistiu de uma natureza exploratória e descritiva.

No que se refere a coleta de dados, foram utilizados neste trabalho a pesquisa em base secundária de dados e a entrevista semi-estruturada.

No que se refere a entrevista semi-estruturada, a mesma foi realizada conforme roteiros apresentados no apêndice I, sendo que os empregados entrevistados foram:

(a) O Gerente Regional de Marketing, o qual relatou informações a respeito do seu dia a dia no trabalho, seu desenvolvimento profissional e sobre o Marketing ligado à sustentabilidade;

(b) O Coordenador da Qualidade, que mencionou dados da fábrica no que tange a energia, temperatura, certificados de gestão e reciclagem, além de ter relatado sobre o seu dia a dia de trabalho e a importância do departamento de Saúde, $\quad$ Segurança e Meio Ambiente;

(c) A Analista de Capacitação Comercial, a qual informou sobre a quantidade de empregados, seus perfis e os benefícios oferecidos para os mesmos (salários, prêmios, treinamentos, entre outros);

(d) A Coordenadora de Comunicação Social da América Latina, a qual relatou sobre sua rotina de trabalho, seu desenvolvimento profissional e a estratégia de sustentabilidade utilizada pela organização, envolvendo orçamento, projetos, teorias, e índices de sustentabilidade, e;

(e) A Gerente de Sustentabilidade Brasil, em que a mesma relatou como funciona o departamento de sustentabilidade da organização.

Desse modo, o estudo de caso foi analisado com base na metodologia e nos indicadores propostos pelo GRI G3 (2006), os quais estão sintetizados no quadro 2 a seguir. 
Quadro 2: Variáveis de Pesquisa

\begin{tabular}{|c|c|}
\hline Variável & Descrição \\
\hline Caracterização da organização & $\begin{array}{l}\text { - Caracterização da área de Ciências Agrícolas; } \\
\text { - Caracterização do departamento de sustentabilidade; } \\
\text { - Identificação das práticas de sustentabilidade. }\end{array}$ \\
\hline $\begin{array}{l}\text { Análise da área de Ciências } \\
\text { Agrícolas da organização pelos } \\
\text { indicadores de desempenho } \\
\text { ambiental do GRI }\end{array}$ & $\begin{array}{l}\text { Materiais usados; Materiais de reciclagem; Consumo de } \\
\text { energia direta e indireta por fonte de energia primária; } \\
\text { Energia economizada; Iniciativas para fornecer produtos e } \\
\text { serviços com baixo consumo de energia; Total de água } \\
\text { retirada por fonte; Fontes hídricas afetadas por retirada de } \\
\text { água; Água reciclada e reutilizada; Localização e tamanho } \\
\text { de área possuída, arrendada ou administrada dentro das } \\
\text { áreas protegidas; Descrição de impactos na biodiversidade } \\
\text { de atividades; Estratégias em vigor e planos futuros para } \\
\text { gestão de impactos da biodiversidade; Números de } \\
\text { espécies na lista vermelha da IUCN e outras listas nacionais; } \\
\text { Emissões diretas de gases de efeito estufa; Emissões de } \\
\text { substâncias destruidoras da camada de ozônio; Descarte de } \\
\text { água; Total de resíduos e derramamentos; Resíduos } \\
\text { tratados como perigosos; Identificação de biodiversidade } \\
\text { afetada por descarte de água e drenagem; Iniciativas para } \\
\text { mitigar impactos ambientais; Produtos e embalagens } \\
\text { recuperadas; Sanções de não conformidade e } \\
\text { Investimentos ambientais. }\end{array}$ \\
\hline $\begin{array}{l}\text { Análise da área de Ciências } \\
\text { Agrícolas da organização pelos } \\
\text { indicadores de desempenho social } \\
\text { do GRI }\end{array}$ & $\begin{array}{l}\text { Total de trabalhadores; Rotatividade de empregados; } \\
\text { Benefícios oferecidos; Empregos abrangidos por acordo de } \\
\text { negociação coletiva; Prazo para notificação de mudanças } \\
\text { operacionais; Empregados do comitê formal de saúde e } \\
\text { segurança; Taxa de lesões, doenças ocupacionais, } \\
\text { absenteísmo e óbitos; Programas de educação, } \\
\text { treinamento e controle de risco; Temas relativos a } \\
\text { segurança e saúde cobertos por acordos com sindicatos; } \\
\text { Horas ao ano de treinamentos; Programas para gestão de } \\
\text { competência e aprendizagem contínua; Empregados que } \\
\text { recebem análise de desempenho; Composição de grupos } \\
\text { responsáveis pela governança corporativa e Proporção de } \\
\text { salário base. }\end{array}$ \\
\hline $\begin{array}{l}\text { Análise da área de ciências agrícolas } \\
\text { da organização pela dimensão de } \\
\text { direitos humanos do GRI }\end{array}$ & $\begin{array}{l}\text { Contratos de investimentos; Empresas contratadas e } \\
\text { fornecedores críticos submetidos a avaliações; Horas de } \\
\text { treinamentos para empregados para políticas e } \\
\text { procedimentos; Casos de discriminação e medidas } \\
\text { tomadas; Opções em que o direito de exercer a liberdade } \\
\text { de negociação coletiva pode haver riscos; Operações de } \\
\text { trabalho infantil, forçado ou escravo e medidas tomadas; } \\
\text { Percentual do pessoal da segurança submetido a } \\
\text { treinamentos e Casos de violação de povos indígenas e } \\
\text { medidas tomadas. }\end{array}$ \\
\hline
\end{tabular}

Fonte: Elaborado pela autora 


\section{ESTUDO DE CASO}

Desse modo, é realizada uma análise das práticas de sustentabilidade da área de Ciências Agrícolas através dos indicadores de sustentabilidade do GRI G3 (2006) com fundamento nos documentos disponibilizados, nas entrevistas realizadas com alguns empregados e com informações do relatório global de sustentabilidade de todo o grupo organizacional.

Não obstante, é importante mencionar que a área de Ciências Agrícolas não possui um relatório global específico, e assim buscou se realizar uma análise mais minuciosa que possibilitasse uma gestão estratégica sustentável em prol as práticas de sustentabilidade dessa área no Brasil.

\section{DISCUSSÃO DOS RESULTADOS}

Conforme analisado através dos indicadores de sustentabilidade do Relatório Global de Sustentabilidade - GRI G3 (2006), foi constatado que a área de Ciências Agrícolas possui a sustentabilidade em sua estratégia de negócios.

Desse modo, de acordo com a análise do ambiente organizacional e das práticas voltadas à sustentabilidade, conclui-se que a área de Ciências Agrícolas possui um bom desempenho, pois foram respondidos 56 indicadores de desempenho (do total de 79 indicadores propostos pelo GRI), incluindo pelo menos um em todas as dimensões analisadas.

Assim, foi comunicado um Nível de Aplicação B para o relatório da área de Ciências Agrícolas, ou seja, para relatores intermediários (considerados em busca do desenvolvimento sustentável) e sem verificação externa por auditorias ou órgãos, o que demonstrou um cenário positivo, visto que esse relatório foi realizado com fins de pesquisa, não conseguindo acesso a algumas informações mais detalhadas e de valores numéricos.

Logo, é possível demonstrar esse resultado através das seguintes considerações das dimensões de sustentabilidade dos indicadores do GRI:

(a) Dimensão Econômica 
Os indicadores desta dimensão demonstraram que área de Ciências Agrícolas concedeu benefícios básicos e de desenvolvimento de carreira para seus empregados, como também, possuiu receita, lucros, investimentos em P\&D e projetos sustentáveis em valores relevantes, o que resultou em práticas de sustentabilidade em prol ao meio ambiente e a sociedade por meio de alimentos saudáveis, técnicas agrícolas sustentáveis, dinamismo na economia (geração de renda e emprego) e preservação da natureza. Tais ações puderam ser observadas a partir dos projetos sustentáveis demonstrados que a área de Ciências Agrícolas possui nas dimensões econômica, social e ambiental.

Além do mais, foi constatado que a área possui oportunidade diante de suas práticas sustentáveis em tecnologia e soluções adaptáveis a agricultura perante o cenário futuro de aumento populacional e condições climáticas favoráveis a produção de alimentos.

Desse modo, essa dimensão relatou um progresso econômico expressivo da área de Ciências Agrícolas a medida que demonstrou impactar de forma positiva em toda cadeia de stakeholders e no meio ambiente, mas não conseguiu ser analisada por completa, uma vez que teve 4 indicadores respondidos por completo, 2 indicadores respondidos parcialmente e 3 indicadores sem respostas. Os indicadores respondidos parcialmente foram: Valor econômico direto gerado e distribuído (EC1) - valores referentes a custos operacionais, remuneração dos empregados, doações, outros investimentos na comunidade e pagamento para provedores de capital e governo; e Contratação Local (EC7) - no que se refere a contratação perante a proporção de membros de alta gerência na comunidade local em unidades operacionais importantes, não foram disponibilizado informações. Já os indicadores não respondidos foram: Ajuda financeira significativa recebida do governo (EC4); Variação da proporção de salário mais baixo comparado ao salário mínimo local (EC5) e Práticas e proporção de gastos com fornecedores locais (EC6).

(b) Dimensão Ambiental

Os indicadores ambientais apontaram que a área de Ciências Agrícolas é comprometida com o meio ambiente, pois a mesma respeitou as conformidades legais, utilizou materiais e meios por meio de práticas de produção ecologicamente corretas e 
disseminou técnicas sustentáveis para produtores rurais e comunidades agrícolas. Desse modo, essas práticas puderam ser verificadas através das seguintes ações: utilização de embalagens sustentáveis smartlines; incineração por lei de produtos perigosos; destinação de $100 \%$ das embalagens vazias as centrais do INPEV; utilização de Certificados de Gestão (ISO 14001, ISO 9001 e o OHSAS 18001) e promoção dos Projetos Água, Nossa Água e Manejo Integrado.

Não obstante, há de se mencionar que não houve registros no período analisado de derramamentos e poluições significativos.

Desse modo, a partir das ações mencionadas e por meio índice Dow Jones Sustainability (em que a empresa é reconhecida como líder na redução de carbono) foi possível constatar o impacto positivo dessa dimensão perante o meio ambiente.

Logo, essa dimensão relatou um bom desempenho ambiental da área de Ciências Agrícolas, mas não conseguiu ser analisada por completa, uma vez que teve 22 indicadores respondidos por completo, 6 indicadores respondidos parcialmente e 2 indicadores sem respostas. Os indicadores respondidos parcialmente foram: Energia economizada devido a melhorias em conservação e eficiência e Iniciativas para reduzir o consumo de energia indireta (EN5 e EN6); Total de emissões diretas e indiretas de gases de efeito estufa por peso, Outras emissões indiretas relevantes de gases de efeito estufa por peso e Iniciativas para reduzir gases de efeito estufa e as reduções obtidas (EN16, EN17 e EN18) e Emissões de substâncias destruidoras da camada de ozônio por peso (EN19). Já os indicadores sem respostas foram: Materiais usados por peso ou volume (EN1); Localização e tamanho da área possuída, arrendada ou administrada dentro das áreas protegidas ou adjacentes a ela, como também, áreas de alto índice de biodiversidade fora das áreas protegidas (EN11) e Total de investimentos e gastos em proteção ambiental (EN30).

(c)

Dimensão Social

Essa dimensão identifica os impactos da organização nos sistemas sociais em que a mesma opera através dos aspectos de desempenho fundamentais referentes aos indicadores de práticas trabalhistas, de sociedade, de direitos humanos e responsabilidade pelo produto. 
Sendo assim, no que se refere aos indicadores da dimensão de práticas trabalhistas foi constatado que a área de Ciências Agrícolas possui políticas justas no que tange a contratos de trabalhos e normas internas que oferecem benefícios à saúde, família e desenvolvimento da carreira profissional dos empregados (benefícios básicos de saúde e alimentação; participação em lucros e planos de carreira e programas de apoio social e de saúde à família). Além do mais, há de mencionar que no período analisado não houve registros de taxa de lesões, doenças ocupacionais, dias perdidos, absenteísmos e óbitos relacionados ao trabalho. Desse modo, pôde se concluir um impacto positivo das práticas sociais em relação aos empregados, no entanto, não foi possível uma análise por completa a medida que foram respondidos 8 indicadores, respondido parcialmente 1 indicador e não foram respondidos 5 indicadores. 0 indicador respondido parcialmente foi: Total de trabalhadores por tipo de emprego, contrato de trabalho e região (LA1). Já os indicadores sem respostas foram: Percentual de empregos abrangidos por acordo de negociação coletiva (LA4); Percentual de empregados representantes do comitê formal de saúde e segurança compostos por gestores e trabalhadores que ajudam no monitoramento e aconselhamento sobre programas de saúde e segurança ocupacional (LA6); Média de horas de ano de treinamentos por funcionário, discriminado por categoria funcional (LA10); Percentual de empregados que receberam regularmente análises de desempenho e de desenvolvimento de carreira (LA12) e Proporção de salário base entre homens e mulheres por categoria funcional (LA14).

Os indicadores da dimensão sociedade demonstraram que área de Ciências Agrícolas proporcionou a sociedade educação profissional e técnicas sustentáveis rurais por meio das parcerias com PNUMA, Feira de Carreiras com universidades, Projetos Ambientais (Água, Nossa água e Manejo Integrado) e Projetos com Stakeholders (Valore, Mais Café e parcerias com cooperativas). Além do mais, informou que é através dos direitos e deveres contidos na Política de Conformidade Corporativa que a área dissemina as matérias de corrupção e política pública, de modo a deixar livre a filiação a partidos políticos dos seus empregados e não tolerando a corrupção (levado a demissões e justiça). Para tanto, pôde se concluir que os impactos nesta dimensão foram positivos tanto para os empregados quanto para a comunidade agrícola, mas 
podem ser impulsionados. Assim, foram respondidos 6 indicadores e 2 indicadores não possuíam informações. Estes últimos foram: Percentual e número total de unidade de negócios submetidas a avaliações de riscos relacionados a corrupção (SO2) e Percentual de empregados treinados nas políticas e procedimentos anticorrupção (SO3).

Já os indicadores de direitos humanos apontaram que a área de Ciências Agrícolas dissemina de forma clara e correta os direitos humanos à sociedade por meio da parceria com o PNUMA, da utilização do documento Nosso Futuro Comum (Comissão Brutland) em suas práticas de sustentabilidade, da divulgação de sua Política de Conformidade Corporativa e através de treinamentos e eventos concedidos aos seus empregados. Ademais, foi informado também, que não houve nenhum registro no período analisado de casos de discriminação, de violação de povos indígenas, trabalho infantil, forçado ou análogo ao escravo. Portanto, pôde se concluir que esses direitos tiveram impactos positivos na sociedade e devem continuar sendo disseminados. Logo, foram respondidos 7 indicadores e 2 indicadores não possuíam informações. Estes últimos foram: Percentual e número total de contratos de investimentos significativos que incluam cláusulas referentes a direitos humanos ou que foram submetidos a avaliações referentes a direitos humanos (HR1) e Percentual do pessoal de segurança submetido a treinamento nas políticas ou procedimentos da organização relativos a aspectos de direitos que sejam relevantes as operações (HR8).

E por fim, os indicadores de responsabilidade sobre o produto, o quais foram todos respondidos (9 indicadores) e demonstrou que a área de Ciências Agrícolas cumpriu corretamente as disposições legais e comerciais referente a sua cadeia produção por meio das seguintes ações: certificados de gestão (ISO 14000, ISO 9001, OHSA), políticas de tecnologias (máquinas e equipamentos modernos, consumo de energia e produtos inovadores), cumprimento do Decreto Nacional no 4074/2002 (o qual regulamenta toda cadeia produtiva até a publicidade) e o SAC (Serviço de Atendimento ao Cliente). Não obstante, é importante relatar que não houve nenhum registro no período analisado de multas por violação de privacidade e perda de dados do cliente, além das não conformidades de regulamentos e códigos, rotulagens, comunicação de marketing e publicidade. Para tanto, constatou-se um impacto positivo 
dessas práticas, o que deve ser preservado e estimulado, de maneira a garantir um produto com controle de qualidade para o consumidor e proteção ao meio ambiente.

Para tanto, há de se mencionar, que a área de Ciências Agrícolas não demonstrou claramente todos os impactos da sustentabilidade de suas práticas, pois não informou alguns dados numéricos em valores e em percentuais, como também, considerou como sustentáveis algumas práticas que são obrigatórias por lei e outras práticas que não causam efeito significativo na sociedade. Alguns exemplos: cumprimento mínimo de leis comerciais, ambientais, trabalhistas e outras; e projetos como: Trainee, Estágios, Direção Defensiva, Café do Conhecimento e Protegendo o Hoje e Amanhã.

Assim, constatou-se que apesar da área não ter disponibilizado todas as informações dos indicadores das dimensões de sustentabilidade do GRI de forma completa, a mesma realmente possui a sustentabilidade em sua estratégia de negócios, pois a sua cultura e política corporativa são norteadas de ações sustentáveis e há também, relevantes investimentos nas dimensões econômicas, sociais e ambientais em desenvolvimento.

Logo, a fim de somar as práticas de sustentabilidade já existentes da área de Ciências Agrícolas e orienta-la para uma comunicação à sociedade dos seus impactos sustentáveis de forma transparente e completa, segue algumas ações a serem impulsionadas conforme mostra o quadro 3 a seguir.

Quadro 3: Ações a serem impulsionadas

\begin{tabular}{|c|l|}
\hline Dimensões (GRI) & \multicolumn{1}{c|}{ Ações } \\
\hline Econômica & $\begin{array}{l}\text { Maior investimento no departamento de } \\
\text { sustentabilidade, a fim se construir mais projetos } \\
\text { sustentáveis; }\end{array}$ \\
\hline Ambiental & $\begin{array}{l}\text { Criação e expansão de mais projetos ambientais } \\
\text { pelo país; }\end{array}$ \\
\hline
\end{tabular}




\begin{tabular}{|c|c|}
\hline Sociedade & $\begin{array}{l}\text { Maior divulgação sobre matérias de corrupção e } \\
\text { política pública para os empregados por meio de } \\
\text { palestras; Utilização da norma de ISO } 26000 \text { para } \\
\text { contribuir com a gestão de melhores práticas } \\
\text { sociais e Criação de mais projetos sociais em prol } \\
\text { as comunidades agrícolas (escolas móveis, } \\
\text { treinamentos, palestras, técnicas e atividades que } \\
\text { orientam quanto a própria sustentabilidade no } \\
\text { campo). }\end{array}$ \\
\hline Direitos Humanos & $\begin{array}{l}\text { Continuação da implementação de políticas de } \\
\text { direitos humanos; }\end{array}$ \\
\hline Social & $\begin{array}{l}\text { Continuação da implementação das políticas } \\
\text { sociais; }\end{array}$ \\
\hline Responsabilidade sobre o produto & $\begin{array}{l}\text { Continuação de ações legais no processo } \\
\text { produtivo; }\end{array}$ \\
\hline
\end{tabular}

Fonte: Elaborado pela autora

Portanto, pôde ser verificado que a área de Ciências Agrícolas é comprometida com os princípios do desenvolvimento sustentável e com o seu papel de empresa cidadã, ética e socialmente responsável, ao passo que demonstrou estar envolvida e engajada com as práticas de sustentabilidade, as quais proporcionaram e proporcionam alimentos saudáveis a sociedade, preservação do meio ambiente e dinamismo da economia do país (através da geração de rendas e empregos).

\section{CONSIDERAÇÕES FINAIS}

Os resultados da pesquisa apontaram relevantes indícios para a constatação da influência positiva para o desenvolvimento da agenda da sustentabilidade através da conscientização e motivação da cadeia de stakeholders, eficientes ferramentas normativas e de análises, bases teóricas consistentes e responsabilidade social empresarial perante diversas ações (projetos sustentáveis, sistemas de gestão, inovações, investimentos, entre outras).

Assim, a análise demonstrou que apesar de não terem sido respondidos todos os indicadores das dimensões de sustentabilidade do GRI, a área de Ciências Agrícolas possui um bom desempenho das práticas de sustentabilidade, pois é comprometida e engajada com as ações sustentáveis existentes e já investe em ações futuras, as quais proporcionaram e continuam proporcionando eficiência na produtividade agrícola, 
proteção aos ecossistemas, fornecimento de produtos agrícolas de qualidade e dinamismo na economia do país (através da geração de renda e empregos).

Logo, como forma de somar as práticas de sustentabilidade da área de Ciências Agrícolas orientou-se maiores investimentos no departamento de sustentabilidade para construção de novos projetos; ênfase na criação e amplitude de projetos ambientais; maior divulgação de temas de corrupção e políticas públicas aos empregados; utilização da norma ISO 26000 para melhor gestão de práticas sociais; criação de mais projetos sociais em prol as comunidades agrícolas e continuação de ações legais voltadas aos direitos humanos, as pessoas e a cadeia produtiva.

Não obstante, há de se mencionar os estímulos externos e internos da gestão sustentável (DIAS, 2006) absorvidos pela área de Ciências Agrícolas no setor do agronegócio. O Gerente Regional de Marketing dessa área citou alguns desses estímulos. São eles:

(a)

Redução de Custos: através da utilização de semelhantes e eficientes programas de uso nas diferentes culturas, os quais proporcionam o uso racional de produtos no manejo dos diferentes problemas que ocorrem nas mesmas. Exemplo é o MIP - Projeto de Manejo integrado;

(b)

Incremento de Imagem: como exemplo a implementação do Programa Valore nos Grupos Guarani e Raízen, fortalecendo a parceria com os fornecedores locais através da Certificação Valore para culturas através do oferecimento e comprovação das boas práticas (técnicas, treinamentos, experimentos e outros) concedidos pela organização;

(c) Inovação: introdução de produtos com um número menor de aplicações propiciando benefícios no âmbito econômico, social e ambiental à medida que se evita e controla componentes poluentes no meio ambiente, e; Fornecedores: estes se beneficiam por estarem fornecendo insumos para uma empresa com visão sustentável e utilizam-se desta imagem.

\section{REFERÊNCIAS}

ASHLEY, P. Ética e responsabilidade social nos negócios. 2. ed. São Paulo: Saraiva, 2005. 
DIAS, Reinaldo. Gestão ambiental: responsabilidade social e sustentabilidade. 2. ed. atualizada e revisada. São Paulo: Atlas, 2011.

GLOBAL REPORTING INITIATIVE - GRI. Diretrizes para Relatórios de Sustentabilidade da Global Reporting Initiative. Versão Brasileira. São Paulo: Instituto Ethos e Uniethos, 2006. Disponível em: <http://www.ethos.org.br/_Uniethos/documents/gri_g3_portugues.pdf>. Acessado em: 12 de Junho de 2012. 


\title{
CAPITULO VI
}

\section{DIAGNÓSTICO DE SUSTENTABILDADE AMBIENTAL DE UMA UNIDADE PRODUTIVA NO MUNICÍPIO DE CASTANHAL/PA}

\author{
Deivid Natan Marciel Gabriel do Nascimento ${ }^{1}$ \\ José Carlos Virgínio dos Santos ${ }^{1}$ \\ Klewton Adriano Oliveira ${ }^{1}$ \\ Francimary da Silva Carneiro ${ }^{2}$ \\ Larissa Martins Barbosa D'arace ${ }^{2}$ \\ Brendo Luiz Araújo Alves²
}

\section{RESUMO}

Os problemas ambientais contribuem para o aumento de processos gradativos no solo. O manejo incorreto do solo destrói a sua estrutura e por consequência afeta diretamente a capacidade de produção. O objetivo deste trabalho foi adequar sustentavelmente uma pequena propriedade rural no município de Castanhal em aspectos socioeconômicos de comercialização de produtos agroflorestais para servir de modelo de preservação e conservação do meio ambiente. As pesquisas realizadas durante este trabalho, contribuíram para a tomada de decisão na recuperação das áreas da propriedade, que apresentavam irregularidades auxiliando na elaboração do projeto de recuperação ambiental. Dessa forma, buscando o equilíbrio entre o cumprimento da legislação ambiental brasileira e a obtenção dos resultados positivos para a questão da produção agrícola, associada à conservação do meio ambiente. Com o passar dos anos a recuperação da floresta é considerada satisfatória e as práticas utilizadas pela família fomentam sua qualidade de vida.

Palavras-chave: Adaptação Sustentável. Equilíbrio. Conservação Ambiental.

\section{INTRODUÇÃO}

Com a chegada do processo de urbanização da Amazônia, com o governo federal oferecendo lotes de terra para que as famílias viessem morar na região, promovendo a criação dos primeiros municípios e o povoamento da região. Após esse processo inicial surgiram nesse meio as indústrias, subsidiando o crescimento do comercio local, juntamente com a busca por novas áreas agrícolas para a obtenção da produção de alimentos e moradias (ALVES, 2012). 
A partir do período que a população mundial alcança uma expansão, a necessidade por alimentos, espaço e de condições para sobrevivência fica cada vez maior, fazendo com que as ações antrópicas ao ambiente sejam crescentes. A história do uso do solo mostra que, a alteração no ambiente nem sempre dá lugar a um novo sistema ecológico e sustentável, seja de lavouras ou de pastagens. Com isso, solos utilizados intensamente, e de forma inadequada, são levados à degradação (ALVES, 2001).

A atividade de agricultura de subsistência e pecuária vem sofrendo com a degradação dos ecossistemas ao longo das épocas, dessa forma, vários problemas ambientais vêm se instituindo, dentre eles o aquecimento global. Perante esta situação se torna cada vez mais necessária a restauração de áreas degradadas para diminuir os efeitos negativos da destruição dos ambientes naturais (KAGEYAMA et al., 2013). Um dos problemas é a interferência no solo promovidas pelo manejo incorreto na qual o mesmo fica exposto à ação de ventos, chuvas, raios solares e altas temperaturas, que destroem a estrutura do solo da propriedade, e que se contribui com a perda de capacidade produtiva.

De acordo com Amaral et al. (2016), o município de Castanhal pertencente ao nordeste paraense tem adquirido o papel de centro sub-regional devido as suas características de natureza demográfica, econômica e política, tendo certa autonomia da capital do estado, chamando a atenção para as questões socioambientais mantidas entre a capital e o município de Castanhal. Entretanto, o meio ambiente encontra- se em estágio avançado de degradação, com existências de poucos remanescentes de florestas, causados pela extração da madeira, queimadas e pela não preservação do meio ambiente prejudicando a agricultura de subsistência.

Embora protegidas legalmente desde a década de 60, nem mesmo as áreas de preservação permanente (APP) foram poupadas nesse processo de degradação. Hoje, uma grande parte da população de castanhal reside em áreas rurais, onde parte da água potável utilizada para o consumo humano vem de nascentes que, infelizmente, estão sendo contaminadas pela população.

Atualmente, existe uma grande preocupação da sociedade com a questão da preservação e conservação dos recursos naturais, principalmente da água, que 
proporcionam bem-estar humano. Contudo, se não houver esforços entre o poder público e os habitantes em combater essa degradação, as novas gerações podem sofrer com a escassez da água. Este trabalho teve como objetivo a implantação de técnicas de conservação e a proteção de solos, a pequenos produtores rurais, diagnosticando a recuperação dos solos degradados através de atributos químicos, físicos e biológicos, tendo em vista à readequação da propriedade as técnicas de uso do solo de forma sustentável.

\section{METODOLOGIA}

A propriedade está localizada na Latitude $01^{\circ} 14^{\prime} 55,70^{\prime \prime}$ S e Longitude $47^{\circ} 57^{\prime} 03,56^{\prime \prime} \mathrm{W}$ no Km 05, na agrovila de São Raimundo pertencente ao município de Castanhal no estado do Pará. Segundo Alves (2012) as margens da rodovia PA-TransCastanhal, região do nordeste do Pará que se localiza a 69 km da capital.

O clima do município é definido como Equatorial Ami, classificação de Koppen, com temperatura média de $25^{\circ} \mathrm{C}$ e máxima de $40^{\circ} \mathrm{C}$. A estação mais chuvosa ocorre de dezembro a maio e a menos chuvosa vai de junho a novembro, com umidade relativa do ar entre $85 \%$ e $90 \%$ Santos et al. (2006). O índice médio pluviométrico anual é de $2.604,4 \mathrm{~mm}$ e a quantidade de dias chuvosos durante o decorrer do ano chega em torno de 208 dias (SANTOS et al., 2012).

De acordo com a EMBRAPA (1999), a vegetação é composta, predominantemente, pela floresta equatorial subperenifólia densa. Portanto é caracterizada por apresentar fisionomia e estrutura variadas, na qual algumas espécies perdem as folhagens parcialmente na época de maior estiagem. Geralmente, é denominado de floresta densa de terra firme ou floresta tropical úmida com este tipo de revestimento florístico (SUDAM, 1988).

De acordo com a classificação adotada pelo Instituto Brasileiro de Geografia e Estatística (IBGE) esta vegetação é classificada como floresta ombrófila densa (VELOSO et al., 1982). Estas classificações são atribuídas à vegetação primária. A floresta equatorial higrófila de várzea margeiam os percursos d'água em menor proporção. E se configura por apresentar espécies que não perdem folhas em nenhuma época do ano. É importante este tipo de cobertura vegetal, principalmente pela grande concentração 
de espécies de palmeiras como o açaizeiro (Euterpe oleracea, Mart.) e buritirana (Mauritia aculeata, H.E.K.). O Instituto Brasileiro de Geografia e Estatística classifica esta vegetação como floresta ombrófila densa de planície aluvial (VALENTE et al., 2001). Em relação ao relevo do município é plano, com declividade que varia entorno de $0 \%$ a $3 \%$. Entretanto, ocorrem setores com relevo suave ondulado a ondulado com declividade variando de aproximadamente 3\% a 15\% (EMBRAPA, 1999).

Os solos que frequentemente são encontrados no Município de Castanhal são o Argissolo Amarelo Distrófico, o Argissolo Vermelho Amarelo Distrófico concrecionário, o Neossolo Flúvico Distrófico, o Gleissolo Háplico Distrófico e o Espodossolo Ferrocárbico Hidromórfico, outros tipos de solos que ocorrem em segundo plano nas intermediações são o Latossolo Amarelo Distrófico, o Neossolo Quartzarênico Hidromórfico e o Latossolo Vermelho-Amarelo Distrófico concrecionário (VALENTE et al., 2001).

\subsection{ECONOMIA}

De acordo com a Doutora em Economia Aplicada Maria Lúcia Bahia, baseada em dados do IBGE (2010), a economia do município está diretamente ligada a atividades de serviços, seguida pela industrialização e representando uma pequena escala a agropecuária. Segundo Miranda (2012) Castanhal apresenta um grau de desenvolvimento mais elevado que outras cidades localizadas na região metropolitana de Belém, dada a presença de 180 indústrias de transformação, 4 serviços industriais de utilidade pública, 959 estabelecimentos comerciais e 458 estabelecimentos de serviços em geral, a exemplo de hotéis e restaurantes. Em Castanhal, a produção de cereais é inexpressiva e as distâncias tornam a importação de grãos ou ração farelada inviáveis, as pastagens constituem a principal fonte de alimentos do rebanho leiteiro que é de baixa produtividade. A exploração leiteira é uma importante atividade pequenos produtores, devido à falta de alternativas agrícolas mais rentáveis (BENDAHAN et al., 2000)

\subsection{HISTÓRICO DA AGROVILA}

A agrovila São Raimundo originou-se com a chegada de algumas famílias cearenses após o início do povoamento do município de castanhal. Entre as famílias, os 
casais Rodolfo Carneiro e Maria Carneiro se destacaram por trazerem a imagem de São Raimundo Nonato, ao qual construíram uma capela por serem devotos desde santo e dando o nome a comunidade de Ramal São Raimundo, que antes era conhecido como Cabeceira do Rio Apeú.

Com o passar dos anos e com o crescimento do município, no dia 9 do mês de dezembro do ano de 1994, o Ramal São Raimundo, foi elevado à categoria de Agrovila São Raimundo, localizada no município de Castanhal estado do Pará, no KM 05 da Rodovia Transcastanhal. A população é de aproximadamente 328 habitantes. A maior parte das famílias moram em casa própria feita de alvenaria. Na comunidade são desenvolvidos alguns aspectos culturais como a festividade de São Raimundo Nonato que iniciasse dia 22 e vai até 31 de agosto de todos os anos.

A mesma tem como atividades comerciais a produção de hortaliças, o trabalho em fazendas com o cuidado da terra e dos animais e o comercio de alimentos e bebidas em balneários da localidade. Alguns moradores trabalham em empresas no centro da cidade e como domésticas na casa de famílias. Na agrovila existe uma associação de moradores que foi fundada no dia 31 de janeiro de 1994, com a finalidade de trazer melhorias e de manter o intercâmbio com as associações pertencentes a qualquer parte do território nacional, com isso a associação tem uma assembleia geral que é constituída de associados maiores de 18 anos.

No ano de 1994, quando a família adquiriu a propriedade se depararam com um conjunto de problemas. A área estava descampado, havia presença de poucas árvores na propriedade, a espaço era quente, sem ventilação, havia presença de pouquíssimos animais, o solo era bastante arenoso e cansado, pois os proprietários antigos não faziam nenhum tipo de manejo do solo, portanto plantaram por diversas vezes a cultura da mandioca, devido à inclinação o solo era bastante lavado e dificultava o plantio e formação de seus roçados, a nascente estava quase desaparecendo devido à declividade do solo o mesmo sofria com a lixiviação das águas das chuvas que cada vez mais aterravam a nascente, favorecendo assim que num futuro bem próximo não existisse mais o igarapé.

Os proprietários residem na localidade há 23 anos, quando chegaram à área possuía somente um pequeno córrego na extremidade do sitio, apenas uma pequena 
área de mata secundária com cerca de $20 \mathrm{~m}$, todo o restante da área era de um adensado capoeirão oriundo de um antigo plantio de mandioca, o solo possuía características que muito o assemelhavam com areia branca, o córrego que existia na área sofria constante lixiviação devido o terreno ser bem inclinado e a falta de árvores nas encostas do leito que também facilitava o assoreamento das nascentes de água, ou seja, a área consistia em uma grande área degradada e lixiviada, na qual não existia a presença de culturas que pudessem ajudar na produção de matéria orgânica, e assim basicamente o solo não era provido de nenhuma proteção contra ações diretas das chuvas fragilizando assim sua estrutura e a característica.

\subsection{COLETAS DE DADOS}

A pesquisa exploratória de dados secundários foi obtida por meio de consulta bibliográfica. A coleta de dados em fonte primária foi realizada através de entrevista pessoal individual do tipo não estruturada e observações diretas. O estudo de caso é uma investigação atual, onde o fenômeno pesquisado e o contexto não estão visivelmente evidentes, precisando de respostas contundentes. Segundo Prodanov (2013) a pesquisa exploratória proporciona maior familiaridade com o caso a ser estudado, o que poderá ocorrer através de levantamento bibliográfico, entrevistas com pessoas esclarecidas do problema pesquisado. Em regra, assume a forma de pesquisa bibliográfica e estudo de caso.

\section{RESULTADOS E DISCUSSÃO}

A pesquisa iniciou pela análise da situação atual da propriedade, para depois comparar com as informações coletadas dos proprietários de quando adquiriram a propriedade em 1994, onde se observou mudanças na infraestrutura de produção e a distribuição do arranjo do uso alternativo do solo existente hoje.

Grande parte das propriedades ao entorno possuem tal infraestrutura, geralmente apresentando sérios problemas de disponibilidade de mão de obra, máquinas e equipamentos, instalações adequadas e, até mesmo, meios de transporte. O igarapé que corta várias propriedades adjacentes não apresenta a mesma qualidade e quantidade de água da propriedade Sítio Recanto dos Rocha devido a não realização 
da proteção da mata ciliar do entorno, que veem sendo realizada desde a compra da propriedade.

As famílias da Agrovila São Raimundo apresentam baixa organização social, sendo a agricultura familiar e a coleta de produtos da floresta suas principais atividades de subsistência. A principal fonte de renda vem da agricultura, especialmente da mandioca seguida pelo milho, feijão e espécies de olericultura que consegue se desenvolver em poucos dias para serem comercializadas. Estas culturas compõem a base da alimentação familiar.

Parte destas famílias tem como atividade principal o comércio, o que thes permite um circuito de comercialização diferente do praticado pelos agricultores que, por sua vez, negociam sua produção com atravessadores. Que compram seus produtos por preços baixos, para comercializarem na feira, e poucos agricultores conseguem produzir e levar suas culturas para comercio local ou até mesmo a chamada feira do agricultor que se localiza no centro de Castanhal atraindo diversas clientelas. Esta feira já existe há mais de 30 anos e a sua finalidade é reunir os produtores rurais num único local para realizarem a venda de seus alimentos, para que não dependa de atravessadores para escoar a sua produção.

\section{1. ÁREA DE AGRICULTURA}

Ainda no primeiro ano a família mudou o caminho que levava até a casa do sitio, pois, a mesma cortava o sitio num ângulo de 45 graus, diminuindo assim a quantidade de terra aproveitável. A família aproveitou a área que era descampada para fazer seu roçado, e nessa área plantaram milho, feijão, melancia, maxixe, quiabo e macaxeira. Depois da colheita, toda matéria orgânica (pés de milho seco, restos cultura de feijão), são deixadas na área para decompor e incorporar ao solo como ciclagem de nutrientes. Partes dessas culturas que não eram comercializadas serviam como alimento a família e outra parte era destinada para os animais como o suíno e aves, que consumiam uma porção considerável do milho e uma parte do que sobrava das melancias e macaxeiras.

As frutas produzidas na propriedade são vendidas de forma "in natura", que segundo Alves (2001) tornam o produto menos viável economicamente do que se fosse vendido na forma de polpa de frutas ou doces e geleias. Os produtos, como a abóbora, 
banana, castanha de caju, maracujá e o açaí encontram comércio dentro da comunidade.

Os produtos como a manga e o ingá são comercializados em quantidades razoáveis a um valor muito baixo, desta forma desfavorável ao produtor, mas quando associados com outros produtos da propriedade como a jaca e a acerola, compensa a venda. A propriedade não produz frutos em grande quantidade, devido à diversidade de espécies na mesma. Devido a isso precisam agregar todos os diferentes frutos produzidos para que assim e consigam obter uma renda de $R \$ 2.108,50$.

\subsection{AREA DE FLORESTA}

Devido à problemática de não haver árvores nem animais e o calor ser muito intenso, à família resolveu plantar algumas espécies florestais para diminuir a temperatura e ao mesmo tempo tentar fazer com que a água da chuva não aterrasse a nascente. No entorno da cerca plantaram mudas de andiroba, e no ano seguinte foi observado que algumas espécies começaram a nascer no entorno do novo roçado, porém sem vigor.

A família utilizou esse espaço para formação de seus plantios trabalhando a agricultura até o terceiro ano, após esse período a família abandonou o espaço e permitiu que a área se recuperasse por conta própria, deixando a regeneração natural desenvolver. Hoje, contabilizam-se algumas espécies de uso comercial, medicinal e comestíveis na propriedade, como a sapucaia ou castanha , o ipê amarelo, o acapu e a andiroba .

De acordo Mendonça et al. (2007) a andiroba apresenta uso múltiplo, com grande aceitação na fabricação de móveis, construção civil, lâminas e compensado e as sementes para extração de óleo.

Segundo Souza Filho et al. (2000) o crescente interesse pelos sistemas agroflorestais como alternativa para a exploração de áreas tropicais, especialmente onde predominam os solos ácidos e de baixa fertilidade, tem contribuído para manter um equilíbrio sustentável no meio ambiente em uso. A utilização de espécies arbóreas com características desejáveis é fundamental para a estabilidade e o sucesso do sistema. Paralelamente, espécies com atividade alelopática podem desempenhar papel crucial 
na estabilidade dos sistemas agroflorestais, em especial na redução da infestação de plantas invasoras e no combate de doenças.

\section{3.ÅREA DE CRIAÇÃO DE ANIMAIS}

Os suínos foram trazidos da região das ilhas que pertencem ao município de Belém (Ilha das onças, Uriboca, Paquetá e Ilha nova) cuja raça é nativa dessas ilhas. No início, acreditou-se que seriam da raça cateto ou catitu (Pecari tajacu), porém, após pesquisas e análises junto à pesquisadora da EMBRAPA, chegou-se à conclusão que realmente são animais rústicos como os selvagens, portanto ao longo de seu processo de domesticação cruzaram com animais de raças industriais.

As galinhas foram adquiridas de vizinhos, em feiras do próprio município e com parentes e amigos da família. Não caracterizam uma raça definida, sendo conhecida popularmente como caipira. Contudo, no ano de 2017, foram adquiridos galos e galinhas da raça índio gigante, oriundos de um produtor rural de Tomé-Açú, para produzir descendentes para futuros consumos e/ou comercialização. Os perus chegaram à propriedade através de parentes que residem em outras agrovilas, não possuem uma raça definida, sendo conhecidas apenas como peru preto e peru branco.

Os peixes são na grande maioria tilápias, adquiridas na feira do peixe vivo na igreja de São Francisco em Castanhal. Após a compra alguns foram consumidos pela família e outros foram colocados em tanque escavado na propriedade, feitos de sacos de ráfia, entretanto após alguns dias, observou-se que apareceram vários alevinos e após isto a propriedade nunca mais deixou de produzir peixes.

Todos os animais mencionados acima recebem ração que é adquirida com a venda dos mesmos, e de produtos oriundos da propriedade como: macaxeira, milho, abóbora, manga e os excedentes são vendidos no comercio local. Há uma frequente procura atravessadores por animais, na qual alguns deles destinam esses animais nas feiras populares. Com isso, a margem de lucro total foi de $R \$ 3.818,50$. Aqui não foi possível verificar a dedução das despesas para calcular os custos fixos.

Peixes exóticos, ornamentais e silvestres

A criação de peixes iniciou através de projetos em parceria com a Universidade para que fosse criado um local de estudo para os alunos dos cursos técnicos. A família optou somente por essas duas espécies o Guppy (Poecilia reticulata) e o Véu de noiva 
(Carassius auratus Linnaeus) devido alguns fatores que julgam importantíssimos como: beleza, adaptabilidade e valor agregado, pois são animais que variam em diversas cores e devido a isso encantam os amigos visitantes e frequentadores da propriedade. A adaptabilidade desses animais em águas com $\mathrm{PH}$ baixo e $\mathrm{PH}$ pouco elevado respectivamente, sendo assim animais fáceis de criar e de se reproduzir. Esses animais são comercializados, por visitantes, amigos e frequentadores da propriedade. Em alguns casos esses visitantes compram bastante exemplares e negociam com comerciantes que trabalham com peixes ornamentais, e sua comercialização também potencializa a renda da família.

A Tilápia (Oreochromis niloticus) foi criada por ser uma espécie de alta resistência, pois tem a capacidade de se adaptar em lugares que outras espécies não sobreviveriam ou em condições que outros animais não se adaptariam, e também por conseguirem se reproduzir facilmente. Além disso, sua criação poder ser feita em pequenas áreas, tanques de alvenaria, tanque escavado no chão e outros. No entanto uma parte serve de alimentação da família e a outra é destinada a comercialização.

Os proprietários notaram a presença de algumas aves nativas que não se viam nos primeiros anos no sitio principalmente o arancuã (Ortalis guttata), coleiro (Sporophila caerulescens), caboco-lino (Sporophila bouvreuil), curió (Oryzoborus angolensis), beija flor (Trochilidae), pintada (Sporophila beltoni), sabiá (Turdus), pipira (Tachyphonus rufus), bem-te-vi (Pitangus sulphuratus), juntamente com outras espécies de mamíferos como a mucura (Didelphis marsupialis) e o morcego (Chiroptera) que na qual acreditam ser um dos agentes responsáveis pela ajuda do arranjo de muitas espécies que não se viam mais na região, alguns roedores foram presenciado como os ratos (Muridae), e algumas outras espécies de animais peçonhentos como o escorpião (Scorpiones), e a jararaca (Bothrops jararaca). Foram observados a presença de outros animais como a preguiça (Bradypus variegatus), macaco soim (Saguinus fuscicollis), tatupeba (Euphractus sexcinctus), jabuti (Chelonoidis carbonaria) e o quati (Nasua), que durante muitos anos foram extintos da propriedade, e através de um simples ato de recuperação da floresta consegue-se ver e presenciar os sons dos animais no decorrer do dia na mata recuperada. 
Segundo Ribaski et al. (2001) a recuperação de áreas degradadas era feita através da revegetação, com intervenção no substrato, vegetação e na fauna, visando o surgimento de um bosque. Hoje, a recuperação baseia-se no princípio da sucessão ecológica que consiste na implantação de espécies pioneiras, iniciais e tardias até chegar ao clímax; essa mudança temporal da composição florística se dava de forma gradativa, culminando em sistemas mais estruturados, diversos e complexos que os iniciais.

A difícil tarefa de transformar áreas degradas em florestas sustentáveis precisam que processos ecológicos sejam efetivados com característica que promovam as interações entre fauna e flora para promover condições de auto sustentabilidade à floresta implantada (BARBOSA, 2000). A propriedade durante muitos anos apresentou solo degradado e descampado e com poucos nutrientes, devido ao constante desmatamento e queimada para transformarem em áreas de pastos. A exposição do solo em épocas de chuva provocava erosão e assoreamento dos rios e desequilíbrios na flora e fauna.

Durante os primeiros anos a família trabalhou na preservação da nascente que estava quase desaparecendo, plantou nas margens espécies de ingá e açaí para minimizar a lixiviação. Os proprietários resolveram fazer uma barragem com o intuito de aumentar a altura da lâmina de água, e assim foi feito represaram a água e após cinco anos os açaizeiros estavam estabelecidos os pés de açaí se multiplicaram no entorno de todo o curso d'água.

A propriedade desde 1997, possuia uma nascente com um alto nível de assoreamento, devido a isso resolveram colocar pneus na borda do igarapé (muros de arrimo) e no decorrer de toda a propriedade em lugares onde foi observado que o fluxo de água era bastante significativo foram feitas barreiras com garrafas pet, e nessas áreas também foram plantados pés de açaí e ingá. Essas espécies foram escolhidas com duas razões específicas, o ingá é de rápido desenvolvimento (MATA, 2006), é um vegetal que facilmente e rapidamente forma galhos que por sua vez minimizariam o impacto da água das chuvas no solo, sua raiz a um primeiro momento minimizou o excesso de solo que era lixiviado em sentido ao igarapé.

Em 2017 nota-se que na área da nascente houve processo de recuperação, devido as práticas adotadas para conter o processo de degradação. Num segundo plano, 
esse sistema implantado, fez sombreamento, para o açaí que realmente era a espécie desejada devida sua raiz ser mais indicada para este tipo de caso, uma vez que suas raízes saem em busca de alimento e facilmente se expandem por toda a área reduzindo a problemática da lixiviação e encontra partida fornecendo a família mais um alimento e consequentemente renda através de seus frutos.

O ingá foi plantado com o intuito de se estabelecer proteção ao solo com a formação de uma copa significativa que impede o impacto direto das chuvas com o solo, fornecendo matéria orgânica abundante, sombra para o açaí nos primeiros anos além de fixar nitrogênio no solo. Ribaski et al. (2001).

Após isto, foi observado que a água das chuvas já não causava problemas diretos no igarapé e o solo começou a mudar sua coloração. A ciclagem de nutriente advindo da matéria orgânica dos vários componentes implantados na área passou a melhorar o solo e consequentemente os plantios. Hoje, o solo está diferente e conservado quando comparado com o mesmo solo das propriedades ao entorno.

\subsection{AREA RECUPERADA}

Com a chegada dos novos residentes no terreno, tiveram de imediato a ideia de recuperar a nascente que passa dentro da propriedade, criando um muro de arrimo para impedir o assoreamento do igarapé. Foram plantadas algumas espécies com raízes fasciculadas para servir de proteção dos mananciais. No entanto, todo este processo de recuperação tem 23 anos onde se observa, hoje, água cristalina.

A área total da propriedade encontra-se em processo de recuperação de seus recursos naturais. A obtenção de benefícios socioeconômicos e ambientais pelos proprietários da fazenda transcorre da preocupação dos mesmos em utilizar os recursos naturais de forma a respeitar os mecanismos de sustentação do ecossistema, para garantir a utilização do meio ambiente da propriedade por longas gerações através do manejo correto (SERAMIM, 2015).

A família tem uma pequena produção de frutos, animais e óleo. Porém, sabe-se que nas épocas de frutificação e produção divergem para cada espécie. Dificultando o lucro da família, pois não consegue o valor desejado, a vantagem é que, devido essa produção de animais e frutos durarem o ano todo, a família consegue renda para a própria manutenção da propriedade rural durante todo o ano. 
Silva (2013), afirma que pensar estrategicamente, significa planejar e tomar qualquer decisão pensando em longo prazo, ou seja, o produtor rural não se baseia somente em culturas de ciclo curto mais sim em formas organizadas e diversificadas de produção, onde possam obter solos ricos e férteis e onde possam produzir continuamente. Essa estratégia de diversificar culturas e espécies nas propriedades rurais fortalece a economia das famílias e ajuda a garantir recurso em épocas onde há menor produção de frutos.

\section{Alternativas Adotadas}

Uma das alternativas que pode ser criada na propriedade devido ela ter uma grande área recuperada, é um bosque de interação, na qual a sua funcionalidade é de servir como corredor ecológico para as espécies, local de descanso para as pessoas, com o meio ambiente, principalmente crianças, para que elas conheçam e convivam com espécies florestais e animais.

Os corredores ecológicos são de extrema importância para os animais, mostra a continuação da flora estabelecida, onde os animais que não eram mais presentes devido à derrubada das matas, voltam a se estabelecer em um espaço recuperado com diferentes espécies, portanto os pássaros e os animais são responsáveis de espalhar as sementes quebrar a dormência, pois eles são um dos principais agentes dispersores de sementes.

$\mathrm{Na}$ área de entorno do córrego foi toda utilizada como APP (área de preservação permanente), para tentar ajudar na recuperação do meio ambiente e futuramente minimizar os impactos sofridos por ações de insolação, ventos e chuvas; as áreas mais afastadas foram divididas em campos de plantio e pastagens. Onde, nas áreas de plantio foram inseridas culturas como ingá, açaí, pupunha, abacaxi, maracujá, cupuaçu, limão, manga, laranja, tangerina, abóbora, acerola e banana. Sendo que, em toda a área tem a presença dos ingazeiros que produzem bastante biomassa e que auxilia na fixação de nitrogênio por ser uma leguminosa. No entorno e no meio da área preservada existem algumas espécies de ipê amarelo, mogno, acapu, andiroba, jarana, sapucaia e angelim pedra. 


\section{CONSIDERAÇÕES FINAIS}

A transformação de floresta para agricultura ou pecuária tem contribuído para aumento do processo de erosão e assoreamentos de rios e igarapés, levando o mesmo a degradação do solo, na extinção de espécies da flora, fauna e nas mudanças climáticas. A utilização de mecanismos de proteção e recuperação de ambiente degradado, como reflorestar com espécies florestais nativas e agronômicas, favorecem uma melhor utilização do solo, o aumento de alimentos e a melhoria da qualidade de vida através dos serviços ambientais.

Pode-se afirmar que as práticas sustentáveis quando aplicadas na agricultura familiar fomentam em qualidade de vida, tais práticas permitem que saiam de um possível quadro de instabilidade econômica e ambiental para algo mais sólido e seguro, capaz de auxiliar e garantir tanto para si quanto para gerações futuras qualidade de vida e solos com capacidade de produção que perduram sem precisar agredir o meio ambiente, e garantindo a sua subsistência de forma sustentável devido a diversidade de recursos que conseguiram criar nesse processo de transformação do ambiente.

Com poucos anos de recuperação da floresta, podemos considerar satisfatório, pois ela traz benefícios diretos e indiretos, o sequestro de carbono ocasionado pelas plantas, a fixação de nitrogênio feito por algumas leguminosas, proteção do solo contra a chuva e a insolação evitando que não aconteça algum tipo de erosão, observar a flora estabelecida, os animais que não haviam antes, a temperatura que antes era abafado devido não ter nem um tipo de proteção florestal, o sol castigava muito os produtores, no entanto tudo isso passou e hoje o que podemos perceber é a alegria do agricultor em poder está na sua propriedade preservada para suas futuras gerações.

\section{REFERÊNCIAS}

ALVES, C. S. D.. Formas espaciais recentes da urbanização na Amazônia: a dinâmica sócio espacial do município de Castanhal em face do processo de dispersão metropolitana de Belém. Dissertação (Mestrado em Geografia) - Universidade Federal do Pará, Belém, 2012.

ALVES, M. C.. Recuperação do subsolo de um Latossolo Vermelho usado para terrapleno e fundação da usina hidrelétrica de llha Solteira. Tese (Doutorado) - Universidade Estadual Paulista, Ilha Solteira, 2001. 
AMARAL, M. D. B.; RIBEIRO, W. O.. Castanhal (PA): entre a dinâmica metropolitana e a centralidade sub-regional de uma cidade média. PRACS: Revista Eletrônica de Humanidades do Curso de Ciências Sociais da UNIFAP, Macapá, v.9, n.1, p.77105, 2016.

BARBOSA, L. M.. Manual sobre Princípios de Recuperação de Áreas Degradadas. São Paulo: SMA, 2000.

BENDAHAN, A. B.; VEIGA, J. B.. Avaliação das pastagens em propriedades leiteiras da microrregião de castanhal, estado do Pará. In: REUNIÃO ANUAL DA SBZ, 37. Anais. Viçosa, 2000. p.3.

EMBRAPA. Centro Nacional de Pesquisa de Solos. Sistema brasileiro de classificação de solos: 5 a aproximação. Rio de Janeiro: Embrapa Solos; Brasília: Embrapa Produção da Informação, 1999.

IBGE. Instituto Brasileiro de Geografia e Estatística. Diretoria de Pesquisas, Coordenação de População e Indicadores Sociais, Estimativas da população residente com data de referência 1ㅇ de julho de 2017. Rio de Janeiro: IBGE, 2010.

KAGEYMA, P. Y.; GANDARA, F. B.; OLIVEIRA, R. E. Biodiversidade e restauração da floresta tropical. In: KAGEYAMA, P. Y.; OLIVEIRA, R. E.; MORAES, L. F. D.; ENGEL,V.L.; GANDARA, F. B.. Restauração ecológica de ecossistemas naturais. Botucatu: FEPAF, 2003. p.27-48.

MATA, M. F.. Biometria e morfologia de frutos e sementes de Inga striata Benth e I. ingoides (Rich.) Willd. In: REUNIÃO NORDESTINA DE BOTÂNICA, 29. Anais. Mossoró, 2006.

MENDONÇA, A. P.; FERRAZ, I. D. K.. Óleo de andiroba: processo tradicional da extração, uso e aspectos sociais no estado do Amazonas, Brasil. Revista Acta Amazônica, v.37, n.3, p.353-364, 2007.

MIRANDA, R. R.. Interfaces do rural e do urbano em área de colonização antiga na Amazônia: estudo de colônias agrícolas em Igarapé-Açu e Castanhal (PA). Revista de Geografia Agrária, v.7, n.14, p.1-36, 2012.

PRODANOV, C. C.. Metodologia do trabalho científico: métodos e técnicas da pesquisa e do trabalho acadêmico. 2 ed. Novo Hamburgo: Feevale, 2013.

RIBASKI, J.; MONTOYA, L. J.; RODIGHERI, H. R.. Sistemas Agroflorestais: aspectos ambientais e socioeconômicos. Informe Agropecuário, Belo Horizonte, v.22, n.212, p.61-67, 2001.

RODRIGUES, R. R.; SHEPHERD, G.. Fatores condicionantes da vegetação ciliar. In: RODRIGUES, R. R.; LEITÃO FILHO, H. F.. Matas ciliares: conservação e recuperação. São Paulo: USP, 2000. p.101-107. 
SANTOS, J. S.; SILVA TANAKA, L. M.; COSTA, G. B.. Um estudo da precipitação pluviométrica no município de Castanhal-PA. In: CONGRESSO BRASILEIRO DE METEOROLOGIA, 14. Anais, Florianópolis, 2006.

SERAMIM, R. J.; LEISMANN, E. L.. A sustentabilidade na perspectiva da pequena propriedade rural: impactos com a adoção do Cadastro Ambiental Rural - CAR. In: CINGEN- CONFERÊNCIA INTERNACIONAL EM GESTÃO DE NEGÓCIOS, Anais. Cascavel: UNIOESTE, 2015. p.13.

SILVA, R. A. G.. Administração Rural: teoria e prática. 3 ed. Curitiba, 2013.

SOUZA FILHO, A. P. S.; e ALVES, S. M.. Potencial alelopático de plantas de acapu (Vouacapoua americana): efeitos sobre plantas daninhas de pastagens. Planta Daninha, Viçosa, v.18, n.3, p.435-441, 2000.

SUDAM. Superintendência do Desenvolvimento da Amazônia. Diagnóstico de recursos naturais da área: programa Guamá - Acará - Moju. I. Solos e aptidão agrícola das terras. Belém: SUDAM, 1988.

VALENTE, M. A.; SILVA, J. M. L.; RODRIGUES, T. E.; CARVALHO, E. J. M.; ROLIM, P. A. M.; SILVA, E. S.; PEREIRA, I. C. B.. Solos e Avaliação da Aptidão Agrícola das Terras do Município de Castanhal, Estado do Pará. EMBRAPA, 2001.

VELOSO, H. P.; GOES FILHO, L.. Fitografia brasileira: classificação fisionômica: ecologia da vegetação neotropical. Salvador: Projeto RADAMBRASIL, 1982 


\title{
CAPÍTULO VII
}

\section{CONSIDERACGÕES SOBRE O LCENCIAMENTO AMBIENTIAL NO BRASIL AVANCGOS E DESAFIOS}

DOI: 10.51859/amplla.mas481.1121-7

Larissa Nathane Lima de Morais ${ }^{1}$

Manoel Mariano Neto ${ }^{2}$

Gustavo Leite Gonçalves ${ }^{3}$

Sarah de Souza Cruz Mendonça ${ }^{4}$

Marcos Elias de Oliveira Júnior ${ }^{5}$

\begin{abstract}
${ }^{1}$ Bacharela em Ciência e Tecnologia e em Engenharia Ambiental e Sanitária), especialista em Consultoria e Licenciamento Ambiental. Faculdade Única de Ipatinga/MG (FUNIP).

${ }^{2}$ Bacharel em Ciência e Tecnologia e em Engenharia Ambiental e Sanitária, mestre em Planejamento e Dinâmicas Territoriais no Semiárido, doutorando em Engenharia Civil e Ambiental. Universidade Federal de Campina Grande (UFCG).

${ }^{3}$ Bacharel em Ciência e Tecnologia e em Engenharia Ambiental e Sanitária, mestrando em energias Renováveis (PPGER). Universidade Federal da Paraíba (UFPB).

${ }^{4}$ Bacharela em Engenharia Ambiental, mestranda em Uso Sustentável de Recursos Naturais. Instituto Federal de Educação, Ciência e Tecnologia do Rio Grande do Norte (IFRN).

5 Bacharel em Ciência e Tecnologia e em Engenharia Ambiental e Sanitária, pós-graduando em Topografia e Sensoriamento Remoto. Faculdade Única de Ipatinga/MG (FUNIP).
\end{abstract}

\section{RESUMO}

O licenciamento ambiental consiste em um procedimento administrativo destinado à mitigação ou compensação dos impactos ambientais negativos, oriundos dos empreendimentos e atividades com efetivo potencial poluidor e degradador. Assim, este trabalho tem por objetivo analisar o processo de construção do licenciamento ambiental no Brasil, considerando os aspectos históricos, jurídicos e as limitações político-institucionais. Para tanto, empregou-se a pesquisa bibliográfica, mediante consulta de livros e artigos científicos. Também foi empregada a análise documental, na qual foram consultadas as principais resoluções e leis que tratam da questão ambiental e do licenciamento, dentre elas, a Política Nacional do Meio Ambiente (PNMA), a Constituição Federal de 1988 e a Resolução no 237/1997, do Conselho Nacional do Meio Ambiente (CONAMA). Constatou-se que as principais limitações e desafios a serem superados são a (in)existência da Avaliação Ambiental Estratégica (AAE), a burocracia e o déficit estrutural, a crise institucional, as intervenções de órgãos externos e a falha na descentralização do licenciamento ambiental

Palavras-chave: Política ambiental. Avaliação Ambiental Estratégica. Crise ambiental. 


\section{INTRODUÇÃO}

As políticas ambientais brasileiras surgiram em um contexto de grande mobilização internacional em prol de mudanças quanto à postura dos países em relação ao meio ambiente. Essa cobrança parte da intensificação das problemáticas de magnitudes extraordinárias, decorrentes da inter-relação entre o crescimento populacional e seus hábitos de produção e consumo, que resultam em perdas tanto à biodiversidade quanto aos recursos naturais e ao bem-estar humano (SIRVINSKAS, 2018).

Assim, surgiram os primeiros órgãos e legislações com vistas à proteção ambiental, como a Política Nacional do Meio Ambiente (PNMA), instaurada a partir da Lei no 6.938/1981, no qual o licenciamento ambiental é citado como um dos instrumentos de gestão ambiental (BRASIL, 1981). Posteriormente, a Constituição Federal de 1988 institucionaliza o dever da preservação ambiental e prevê o direito ao ambiente ecologicamente equilibrado para as gerações atuais e futuras (BRASIL, 1988).

No que concerne ao licenciamento ambiental, esse instrumento configura um procedimento administrativo, direcionado aos empreendimentos e atividades que possuem potencial poluidor e degradador, pelo qual os órgãos ambientais autorizam a localização, instalação, operação e ampliação (BRASIL, 1997). Nesse sentido, possibilita ações de caráter preventivo, a partir das condicionantes previstas nas licenças ambientais.

Diante dessas questões, muitos são os desafios a serem superados nessa seara (HOFMANN, 2017; NASCIMENTO; FONSECA, 2017; BARCELOS, 2020). Assim, este trabalho tem por objetivo analisar o processo de construção do licenciamento ambiental no Brasil, considerando os aspectos históricos, jurídicos e as limitações políticoinstitucionais. Para tanto, empregou-se a pesquisa bibliográfica, mediante a consulta de livros, artigos científicos e outras referências publicados em fontes seguras, conforme indica Gil (2008). Nesse sentido, foram abordadas as obras de autores como Machado (2006), Sánchez (2008; 2017) e Câmara Neta et al. (2015).

Também foi empregada a análise documental, na qual foram consultadas as principais resoluções e leis que tratam acerca da questão ambiental e do licenciamento, dentre elas, a PNMA, a Constituição Federal de 1988 e a Resolução CONAMA no 
237/1997. Esta análise buscou elucidar o conteúdo dos documentos escolhidos para o corpus da pesquisa, de forma a contextualizar os assuntos e inscrevê-los no status científico (GARCIA JUNIOR; MEDEIROS; AUGUSTA, 2017). Para além deste texto introdutório, na sequência estão dispostas as seguintes seções: $A$ construção das políticas ambientais no Brasil, O licenciamento ambiental, Desafios para o licenciamento ambiental no Brasil, Considerações finais e, por fim, as referências consultadas.

\section{A CONSTRUÇÃO DAS POLITICAS AMBIENTAIS NO BRASIL}

As discussões acerca da questão ambiental se iniciaram a partir da Idade Média e ganharam maior ênfase com a Revolução Industrial. Nesta perspectiva, Sirvinskas (2018) afirma que o homem primitivo não produzia danos graves à natureza, uma vez que os recursos explorados tinham como única finalidade atender às necessidades básicas.

A partir da Revolução Industrial, os impactos causados ganharam escalas diferentes, até então não observadas, a ponto de atingir o meio local, regional e, em casos extremos, comprometer o equilíbrio ecológico do planeta. Como consequência da ausência de cuidados com o meio ambiente e a saúde humana, Machado (2006) cita alguns acontecimentos que marcaram o século XX e contribuíram para o surgimento da força motriz que posteriormente dá origem ao direito ambiental.

Dentre eles, ganham destaque o acidente da Baía de Minamata, no Japão, onde a intoxicação da água por mercúrio causou a morte de mais de duas mil pessoas entre as décadas de 1950 e 1960; o Acidente de Bophal, em 1984, na Índia, marcado pela liberação de gases tóxicos resultantes da produção de inseticidas, que causou asfixia em mais de três mil pessoas e os acidentes nucleares, com ênfase na usina de Chernobyl em 1986, que atingiu grau máximo na escala internacional e levou aproximadamente 2,4 milhões de pessoas a óbito (MACHADO, 2006).

Diante desses acontecimentos e em decorrência de fortes problemas ambientais vivenciados em todo o mundo, como as chuvas ácidas, Machado (2006) afirma que ocorreu a criação de instituições internacionais e, posteriormente, foram organizados eventos para discutir a questão ambiental global. Assim, o autor cita a criação da Organização das Nações Unidas (ONU) em 1945 que, 27 anos mais tarde, organizou a 
Primeira Conferência Mundial sobre o Homem e o Meio Ambiente, na Suécia, em junho de 1972.

Já em 1992, ocorreu no Brasil a Segunda Conferência das Nações Unidas sobre o Meio Ambiente - ECO-92; a Convenção sobre Mudanças Climáticas, em 1997, que criou o Protocolo de Quioto e a Rio+20, ocorrida em 2012 no Rio de Janeiro, quando se discutiu o desenvolvimento sustentável. Essas conferências marcaram a criação e o fortalecimento do direito ambiental em uma conjuntura internacional, que por sua vez, se reflete no posicionamento político-administrativo dos gestores de nações, causando assim impactos externos e internos em cada país (MACHADO, 2006).

Ao analisar a consolidação das políticas ambientais no Brasil, Lopes (2006) ressalta que se trata de um processo intensamente marcado por conflitos sociais. 0 autor relata que o primeiro órgão ambiental nacional só foi criado em 1973, em decorrência da Conferência de Estocolmo, que posteriormente fez surgir outros órgãos de controle ambiental como a Companhia Ambiental do Estado de São Paulo (CETESB) e a Fundação Estadual de Engenharia do Meio Ambiente (FEEMA), nos estados de São Paulo e Rio de Janeiro, respectivamente.

Diante disso, a questão ambiental ganha maiores dimensões, culminando na criação da Política Nacional do Meio Ambiente (PNMA), em 1981, a partir da Lei no 6.938 e, em 1986, foi instituído o Conselho Nacional do Meio Ambiente (CONAMA), que por sua vez instituiu as diretrizes para o licenciamento ambiental, Estudo de Impacto Ambiental (EIA) e Relatório de Impacto ao Meio Ambiente (RIMA).

Mais recentemente, em 1988 foi promulgada a Constituição Federal do Brasil, que em seu artigo 225 afirma que:

Todos têm direito ao meio ambiente ecologicamente equilibrado, bem de uso comum do povo e essencial à sadia qualidade de vida, impondo-se ao Poder Público e à coletividade o dever de defendê-lo e preservá-lo para as presentes e futuras gerações (BRASIL, 1988).

Sob esta prerrogativa, verifica-se que o Direito Ambiental se faz presente no maior instrumento jurídico do país. Isto permite a criação de novas bases na legislação, para proteger o meio ambiente e assegurar a qualidade de vida das gerações atual e futuras. Com isso, muitos pontos marcaram o contexto nacional após 1988: (I) a criação do Fundo Nacional do Meio Ambiente (FNMA, 1989), (II) início da atuação do Programa 
Nacional do Meio Ambiente (1991), (III) criação do Ministério do Meio Ambiente (MMA, 1992), (IV) aprovação da lei de crimes ambientais (1998) e (V) a criação da Política Nacional de Educação Ambiental (PNEA, 1999) (STEINBERGER, 2013).

Conforme Steinberger (2013), ainda nos anos 2000, percebe-se que o fortalecimento das políticas ambientais continua engajado, em que novos instrumentos jurídicos são implementados e novos órgãos ambientais são criados, tais como (I) o Sistema Nacional de Unidades de Conservação (SNUC, 2000), (II) a Agência Nacional das Águas (ANA, 2000), (III) a Agenda 21 (2002), (IV) o Instituto Chico Mendes para a Conservação da Biodiversidade (ICMBio, 2007), (V) a Política Nacional de Saneamento Básico (PNSB, 2007), (VI) a Política Nacional de Resíduos Sólidos (PNRS, 2010), (VII) o novo código florestal (2012) e (VIII) a Política Nacional de Combate à Desertificação (PNCD, 2015).

\section{O LICENCIAMENTO AMBIENTAL}

Para melhor fundamentar este trabalho, entende-se de que o licenciamento ambiental se configura enquanto um procedimento administrativo pelo qual o órgão ambiental autoriza a localização, instalação e operação de empreendimentos que demandam recursos ambientais e sociais (BRASIL, 1997; CÂMARA NETA et al., 2015).

Ao analisar como essa questão avança no Brasil, ainda em conformidade com Câmara Neta et al. (2015), a primeira medida jurídica que tratou do assunto estava presente na Lei no 6.803/1980, que tratava do zoneamento ambiental das áreas críticas de poluição. Com isso, é reconhecido, por parte das empresas brasileiras, em especial aquelas que propiciam o uso e degradação dos recursos naturais, a necessidade de incorporar a responsabilidade socioambiental nos princípios norteadores do desenvolvimento econômico.

O Art. 9o desse instrumento jurídico prevê a exigência do licenciamento para implantação, operação e ampliação de estabelecimentos industriais situados em áreas críticas de poluição, de modo a se adequar determinados aspectos aos padrões ambientais. Dentre esses padrões, citam-se: emissões gasosas, ruídos, vibrações ou radiação, modificações de tráfego devido ao volume de insumos e pessoas, modificações nos padrões de uso e ocupação do solo e a disponibilidade de serviços e 
infraestrutura essenciais, tais como as redes de abastecimento, energia elétrica, esgoto e comunicação (BRASIL, 1980). Posteriormente, com a elaboração da PNMA, regulamentada pelo decreto $\mathrm{n}$-99.274/1990, o licenciamento ambiental passou a ser tratado como um dos instrumentos da política ambiental: “Art 9o - São instrumentos da Política Nacional do Meio Ambiente: [...] IV - o licenciamento e a revisão de atividades efetiva ou potencialmente poluidoras" (BRASIL, 1981). Esse instrumento prevê que cabe ao CONAMA fixar os critérios básicos a serem atendidos nos estudos que antecedem o licenciamento, os quais devem conter o diagnóstico ambiental da área; a descrição da ação proposta e suas alternativas e a identificação, análise e previsão dos impactos significativos, positivos e negativos (BRASIL, 1990).

Nesse contexto, é ímpar ressaltar que os padrões ambientais, assim como o licenciamento ambiental, são elementos cuja responsabilidade está atribuída ao Instituto Brasileiro do Meio Ambiente e dos Recursos Naturais Renováveis (IBAMA), que se configura como um órgão ambiental da hierarquia federal, e aos demais órgãos ambientais dos estados e municípios (BRASIL, 1980).

Para além dos elementos básicos a serem exigidos nos estudos, o decreto $n$ 으 99.274/1990 também determina as modalidades de licenças: prévia (LP), de instalação (LI) e de operação (LO) (BRASIL, 1990). No que concerne à definição do que é a licença ambiental, a Resolução CONAMA 237/1997 a conceitua como:

\begin{abstract}
Ato administrativo pelo qual o órgão ambiental competente, estabelece as condições, restrições e medidas de controle ambiental que deverão ser obedecidas pelo empreendedor, pessoa física ou jurídica, para localizar, instalar, ampliar e operar empreendimentos ou atividades utilizadoras dos recursos ambientais consideradas efetiva ou potencialmente poluidoras ou aquelas que, sob qualquer forma, possam causar degradação ambiental (BRASIL, 1997).
\end{abstract}

Dadas as especificidades dos empreendimentos, principalmente no que se refere à regulação ambiental, outras licenças são comumente adotadas, como a licença simplificada (LS), de regularização de operação (LRO), de alteração (LA), de instalação e operação (LIO) e diária (LDI) (MINISTÉRIO DO MEIO AMBIENTE - MMA, 2016).

Em relação às especificidades de cada modalidade de licença, conforme o Serviço Brasileiro de Apoio às Micro e Pequenas Empresas (SEBRAE, 2015), a LP é concedida na fase de planejamento do empreendimento ou atividade, de modo a analisar a 
viabilidade ambiental e estabelecer as condicionantes a serem atendidas nas etapas seguintes. A LI, como o próprio termo sugere, autoriza a instalação do empreendimento, em conformidade com os planos e programas aprovados previamente.

No caso da LO, é permitido que o empreendimento entre em funcionamento, desde que todos os fatores exigidos nas etapas anteriores tenham sido atendidos. É também a LO que determina as condicionantes de controle ambiental e redução de impactos negativos gerados na fase de operação. Quanto à LS, muito comumente é destinada às atividades e aos empreendimentos com baixo potencial poluidordegradador, o que permite condensar a LP, LI e LO em um único documento (SEBRAE, 2015).

A LRO possui caráter corretivo e transitório e possibilita disciplinar empreendimentos e atividades em operação, mesmo sem licenciamento ambiental. Já a LA, por sua vez, destina-se aos casos em que o empreendimento sofre alterações, ampliações ou modificações. Em se tratando da LIO, ela é destinada aos casos em que a instalação e operação ocorrem simultaneamente. E a LDI é aplicável às atividades temporárias, que não exigem instalações permanentes (MMA, 2016).

\section{DESAFIOS PARA O LICENCIAMENTO AMBIENTAL NO BRASIL}

Ao analisar os fatores relacionados ao licenciamento ambiental e a forma como este processo se desenvolve no território brasileiro, é possível elencar uma série de limitações e desafios a serem superados. Assim, este trabalho busca discutir alguns desses gargalos: (I) a (in)existência da Avaliação Ambiental Estratégica (AAE), (II) a burocracia e o déficit estrutural, (III) a crise institucional, (IV) as intervenções de órgãos externos e (V) a falha na descentralização do licenciamento ambiental.

No contexto do licenciamento ambiental, a avaliação de impactos ambientais (AIA) ganha amplo destaque, uma vez que auxilia na tomada de decisão e permite que os empreendimentos e atividades tornem-se viáveis para além da questão econômica. Nesse interim, entende-se a AIA como sendo um conjunto de procedimentos, de caráter prévio e preventivo, que tem por finalidade identificar, prever, interpretar e comunicar informações sobre as consequências de um determinado empreendimento sobre a 
qualidade ambiental, produtividade e disponibilidade dos recursos naturais e sobre a saúde e bem-estar humanos (SÁNCHEZ, 2008).

Mais recentemente, observa-se a construção de uma discussão acerca da AAE, definida por Sánchez (2017) como sendo uma forma de AIA mais ampla, que permite englobar as consequências ambientais de planos, políticas e programas (PPP), sejam esses oriundos da iniciativa pública ou privada que, todavia, até então, não possuem regulamentação jurídica. Ainda em conformidade com o autor, trata-se de uma ferramenta de planejamento necessária por permitir a identificação e mitigação impactos socioambientais adversos decorrentes de PPP e por reconhecer as limitações existentes na AIA dos projetos.

Contudo, a AAE possui requisitos básicos para a efetivação, como maior transparência e melhor governança, que representam um grande obstáculo para o Brasil (SÁNCHEZ, 2017). Ao encontro dessa discussão, Holfmann (2017) afirma que na medida em que os planos de desenvolvimento regional mostram uma interdependência, notase que os planos setoriais e de infraestrutura apresentam uma pujante desarticulação, por serem geridos por instituições e organizações distintas. Esses fatores reforçam a necessidade de fortalecimento dos instrumentos de gestão e regulamentação da $A A E$, aspectos que permitiriam que o licenciamento ambiental alcançasse maior efetividade no cumprimento das funções às quais se destina.

Outro desafio a ser superado pelo licenciamento ambiental é a dificuldade em promover a descentralização desse processo. Esse aspecto surge com a Constituição Federal de 1998, onde o Art. 18 prevê que "a organização político-administrativa da República Federativa do Brasil compreende a União, os Estados, o Distrito Federal e os Municípios, todos autônomos, nos termos desta Constituição" (BRASIL, 1988).

Esse marco traz consigo mudanças profundas quanto ao modo de organização político-administrativo, uma vez que os municípios foram inclusos como entes federados (SOUZA, 2013). Quanto aos rebatimentos sobre o licenciamento ambiental, percebe-se que os municípios, em sua maioria, tendem a apresentar uma frágil capacidade institucional, que culmina em um quadro de licenciamento ambiental municipal precário devido à ausência de recursos financeiros destinados à gestão ambiental e à falta de apoio técnico (NASCIMENTO; FONSECA, 2017). 
Em relação às disfunções do modelo burocrático, estas podem fazer surgir uma gestão ambiental incongruente. Isto é, mesmo buscando a organização, controle e racionalização, limita as dinâmicas socioeconômicas e ambientais. Ao se tratar do licenciamento ambiental, as falhas na organização podem resultar no não cumprimento dos prazos, funcionamento irregular de empreendimentos e, por consequência, o surgimento ou agravamento de danos ambientais (BARCELOS, 2020). Contudo, é válido ressaltar que o déficit estrutural, seja em relação à infraestrutura física, política ou à carência de recursos humanos, contribui inexoravelmente para a ocorrência de falhas, morosidades e perdas na qualidade das atividades necessárias para que o licenciamento ocorra de maneira mais fluída nos órgãos ambientais (BARROS et al., 2017).

No tocante à crise institucional, a principal crítica realizada aponta para a fragmentação da atuação dos órgãos ambientais brasileiros. Este fato compromete o processo decisório por não haver relações hierárquicas. Outra questão pautada é a ausência de corpo técnico para avaliar a pertinência das condicionantes ambientais, em casos mais específicos, fazendo o licenciamento ambiental perder o sentido (HOLFMANN, 2017).

Dentre as reclamações mais comuns, cita-se a intervenção do Ministério Público no licenciamento ambiental. No entanto, é uma medida que muito comumente se faz necessária, sobretudo, devido à falta de transparência, pela participação social insuficiente, subjetividade na fundamentação dos pareceres, descumprimento das condicionantes e discordância quanto à suficiência das medidas mitigadoras e compensatórias (HOLFMANN, 2017).

Ao analisar a base jurídica, verifica-se que as ações do Ministério Público contra os causadores de danos ambientais estão resguardadas pela Lei $n^{\circ} 7.347 / 1985$, que, dentre outras questões, disciplina a ação civil pública de responsabilidade por danos causados ao meio ambiente (BRASIL, 1985). Assim, é uma questão que só será resolvida quando o licenciamento ambiental apresentar maior confiabilidade (HOLFMANN, 2017).

\section{CONSIDERAÇÕES FINAIS}

Este trabalho teve por objetivo analisar o processo de construção do licenciamento ambiental no Brasil, considerando os aspectos históricos, jurídicos e as 
limitações político-institucionais. Nesse sentido, fez-se necessário entender como as políticas ambientais evoluíram no país, bem como entender as especificidades do licenciamento ambiental.

Constatou-se que as políticas ambientais brasileiras começam a surgir em um contexto de forte pressão internacional, principalmente a partir da década de 1970, resultando na criação da PNMA, na discussão ambiental presente da Constituição Federal e na criação de órgãos e instituições ambientais. Já nas primeiras décadas do século XXI, percebe-se que o fortalecimento das políticas ambientais continua marcado principalmente pela implementação de novos instrumentos jurídicos.

Em relação ao licenciamento ambiental, trata-se de um instrumento de gestão, previsto na PNMA, consistindo em um procedimento administrativo com foco na mitigação ou compensação de impactos ambientais negativos, oriundos de empreendimentos e atividades com efetivo potencial poluidor-degradador, mediante 0 estabelecimento de condicionantes ambientais.

Nesse sentido, ao analisar os fatores que se relacionam com o licenciamento ambiental e à forma como este processo se desenvolve no território brasileiro, é possível elencar uma série de limitações e desafios que necessitam ser superados: a (in)existência de uma avaliação ambiental estratégica ( $A A E)$, a burocracia e o déficit estrutural, a crise institucional, as intervenções de órgãos externos e a falha na descentralização do licenciamento ambiental. Para trabalhos futuros, sugere-se que os esforços sejam dispendidos para identificar alternativas que permitam superar os desafios citados e discutidos no escopo deste trabalho.

\section{REFERÊNCIAS}

BARCELOS, E. Á. da S. Desregulação ambiental e disputas políticas: Uma breve retrospectiva do desmonte do licenciamento ambiental no Brasil. AMBIENTES: Revista de Geografia e Ecologia Política, v. 2, n. 2, p. 278.

BARROS, C. S.; SILVA, M. A. C.; BEZERRA, E. P.; RIBEIRO, R. M.; SOUSA, K. C. Análise do processo de licenciamento ambiental: um estudo de caso na cidade de SobralCE. ScientiaTec, v. 4, n. 1, p. 72-89, 2017.

BRASIL. Lei $\mathbf{n}^{\circ} \mathbf{6 . 8 0 3}$, de 2 de julho de 1980. Dispõe sobre as diretrizes básicas para o zoneamento industrial nas áreas críticas de poluição, e dá outras providências. 
Disponível em: http://www.planalto.gov.br/ccivil_03/leis/16803.htm. Acesso em: 02 mar. 2021.

BRASIL. Lei no 6.938, de 31 de agosto de 1981. Dispõe sobre a Política Nacional do Meio Ambiente, seus fins e mecanismos de formulação e aplicação, e dá outras providências.

Disponível

em: http://www.planalto.gov.br/ccivil_03/leis/l6938.htm. Acesso em: 02 mar. 2021.

BRASIL. Lei $\mathbf{n}^{\circ}$ 7.347, de 24 de julho de 1985. Disciplina a ação civil pública de responsabilidade por danos causados ao meio-ambiente, ao consumidor, a bens e direitos de valor artístico, estético, histórico, turístico e paisagístico (VETADO) e dá outras providências. Disponível em: http://www.planalto.gov.br/ccivil_03/leis/l7347orig.htm. Acesso em: 02 mar. 2021.

BRASIL. Constituição da República Federativa do Brasil de 1988. Disponível em: http://www.planalto.gov.br/ccivil_03/Constituicao/Constituicao.htm. Acesso em: 15 nov. 2020.

BRASIL. Decreto $n^{\circ}$ 99.274, de 6 de junho de 1990. Regulamenta a Lei $n=6.902$, de 27 de abril de 1981, e a Lei no 6.938, de 31 de agosto de 1981, que dispõem, respectivamente sobre a criação de Estações Ecológicas e Áreas de Proteção Ambiental e sobre a Política Nacional do Meio Ambiente, e dá outras providências. Disponível em: http://www.planalto.gov.br/ccivil_03/decreto/antigos/d99274.htm. Acesso em: 02 mar. 2021.

BRASIL. Resolução Conama no 237, de 19 de dezembro de 1997. Disponível em: http://www2.mma.gov.br/port/conama/res/res97/res23797.html. Acesso em: 02 mar. 2021.

CÂMARA NETA, M. DA S.; MOURA, K. C. D. F.; DIAS, N. S.; SOUZA, A. C. M.; MOURA, K. H. S. Licenciamento ambiental: Conflito de interesses. Revista Verde de Agroecologia e Desenvolvimento Sustentável, v. 10, n. 5, p. 13, 2015.

GARCIA JUNIOR, E. F.; MEDEIROS, S.; AUGUSTA, C. Análise documental: uma metodologia da pesquisa para a ciência da informação. Revista Tematica, João Pessoa, v. 13, n. 7, p. 138-150, jul. 2017.

GIL, A. C. Métodos e técnicas de pesquisa social. 6. ed. São Paulo: Editora Atlas, 2008.

HOLFMANN, R. M. Gargalos do licenciamento ambiental federal no Brasil. In: COSTA, M. A.; KLUG, L. B.; PAULSEN, S. S. (Org.). Licenciamento ambiental e governança territorial: registros e contribuições do seminário internacional. Rio de Janeiro: Ipea, 2017. p. $31-41$. 
LOPES, J. S. L. Sobre processos de "ambientalização" dos conflitos e sobre dilemas da participação. Horizontes antropológicos, v. 12, n. 25, p. 31-64, 2006.

MACHADO, P. A. L. Direito ambiental. São Paulo: Editora Malheiros, 2006.

MMA - MINISTÉRIO DO MEIO AMBIENTE (. Procedimentos de licenciamento ambiental do Brasil. Brasília/DF: MMA, 2016.

NASCIMENTO, T.; FONSECA, A. A descentralização do licenciamento ambiental na percepção de partes interessadas de 84 municípios brasileiros. Desenvolvimento e meio ambiente, v. 43, 2017.

SÁNCHEZ, L. E. Avaliação de impactos ambientais: conceitos e métodos. São Paulo: Oficina de Textos, 2008.

SÁNCHEZ, L. E. Por que não avança a avaliação ambiental estratégica no Brasil? Estudos Avançados, v. 31, n. 89, p. 167-183, 2017.

SEBRAE - SERVIÇO BRASILEIRO DE APOIO ÀS MICRO E PEQUENAS EMPRESAS. Licenciamento Ambiental. 2 Ed. Cuiabá: Sebrae, 2015.

SIRVINSKAS, L. P. Manual de direito ambiental. Editora Saraiva, 2018.

SOUZA, C. Instituições e mudanças: reformas da Constituição de 1988, federalismo e políticas públicas. In: HOCHMAN, G.; FARIA, C. A. P. (Org.). Federalismo e Políticas Públicas no Brasil. Rio de Janeiro: Editora FIOCRUZ, 2013. p. 91-118.

STEINBERGER, M. Território, Estado e políticas públicas espaciais. Brasília: Ler Editora, 2013. 328 p. 


\title{
CAPÍTULO VIII
}

\section{SISTIEMAS DE GESTÃO AMBIENTIAL (SGA) NAS INSTIIUICGÕES DE ENSINO SUPERIOR - ENFOQUE NAS CONIRIBUICÕES PARA IMPLEMENTACÃOO DE SOCIEDADES SUSTENTÁVEIS}

\author{
DOI: 10.51859/amplla.mas481.1121-8
}

\author{
Luciana Fabiano ${ }^{1}$ \\ Fábio Rogério de Morais ${ }^{2}$ \\ Gleimíria Batista da Costa Matos ${ }^{3}$
}

\begin{abstract}
1 Professora do Magistério Superior da Universidade Federal de Rondônia/UNIR, no Departamento Acadêmico de Ciências Sociais e Ambientais/DACSA. Bacharel em Gestão Ambiental. Especialista em Gestão de Recursos Humanos. Especialista em Ensino Superior. Especialista em Linguagem e Educação. Especialista em Administração Pública. Mestranda no Mestrado Profissional em Administração Pública - PROFIAP/UNIR. Pesquisadora do Grupo de Pesquisa em Energia Renovável Sustentável (GPERS-CNPq) e do Grupo de Estudos e Pesquisas em Ciências Sociais e Ambientais e Políticas Públicas (GEPCAP-CNPq).

2 Professor do Magistério Superior na Universidade Federal de Rondônia, no Núcleo de Ciências Sociais Aplicadas (NUCSA) e do Programas de Pós-Graduação em Administração PROFIAP/UNIR. Doutor (FEI/ SP), Mestre (Unihorizontes/MG), Especialista (Gama Filho/RJ) e Bacharel em Administração (FASC/MG).

3 Professora Adjunto da Universidade Federal de Rondônia. Bacharel em Ciências Contábeis, Mestrado em Desenvolvimento Regional e Meio Ambiente, Doutorado em Desenvolvimento Regional. Professora do PPGA Programa de Pós-Graduação em Administração; Membro do Grupo de Pesquisa CEDSA e Líder do GepOrg,
\end{abstract}

\section{RESUMO}

A pesquisa traz como tema a transformação de sociedades mais sustentáveis e a participação de instituições de ensino superior nesse processo, por meio das suas gestões administrativas. As gestões das universidades e faculdades refletem, na prática, as discussões teóricas sobre sustentabilidade, que se dão no âmbito de suas instituições de ensino superior? Esse questionamento insere o problema a ser pesquisado por este trabalho: De que forma as instituições de ensino superior, por meio de suas gestões, podem contribuir para a implementação de uma sociedade mais sustentável? O método de abordagem define o estudo como pesquisa qualitativa, segundo seu objetivo configura-se em pesquisa descritiva, e por sua vez, segundo a natureza e fontes de informação trata-se de uma pesquisa Bibliográfica. O fenômeno é analisado à luz da ciência Gestão Ambiental. O resultado aponta para a implementação de sistemas de gestão ambiental (SGA) nas instituições de ensino superior (IES), como forma de a comunidade acadêmica contribuir para a adequação de uma sociedade mais sustentável. Neste sentido, a sincronia entre o que se preconiza teoricamente nas IES, acerca da sustentabilidade, e o que se pratica enquanto comunidade acadêmica, pode ser viabilizado a partir de um modelo de sistema de gestão ambiental, adaptado de Tauchen e Brandli (2006).

Palavras-Chave: Gestão Ambiental. Sistemas de Gestão Ambiental. Instituições de Ensino Superior. Sociedades Sustentáveis. Sustentabilidade. 


\section{INTRODUÇÃO}

Em setembro de 2000 a Organização das Nações Unidas (ONU) instituiu os Objetivos de Desenvolvimento do Milênio (ODM), 8 (oito) ao todo. Dentre os objetivos o 70 refere-se a "Garantir a Sustentabilidade Ambiental". Os referenciais foram criados para propiciar qualidade ao destino comum da humanidade, tendo em vista o processo acelerado do crescimento populacional em todo o globo. Os objetivos tinham até 2015 para apresentar indicadores de evolução de desenvolvimento com responsabilidade.

Em setembro de 2015, no encontro da Cúpula das Nações Unidas sobre o Desenvolvimento Sustentável, os ODM, como ficaram mundialmente conhecidos, receberam nova parceria, os Objetivos de Desenvolvimento Sustentável (ODS). Estes, por sua vez, totalizam agora 17 (dezessete) metas voltadas para as três dimensões do desenvolvimento sustentável: a social, a econômica e a ambiental.

Ainda que nas conferências globais, iguais a Conferência das Partes da Convenção-Quadro da ONU Sobre Mudanças Climáticas (COP) de 2015, realizada em Paris, na França, muito do que se oficializa como acordo ambiental, na realidade sirva de influência para monopólios mercadológicos já consolidados, há que se extrair desse jogo de manipulações a real tendência universal da humanidade de necessitar se adaptar a novos sistemas sustentáveis de sobrevivência. Despontam deste cenário as organizações denominadas instituições de ensino superior (IES), enquanto órgãos possíveis de viabilizar a adaptação ao novo paradigma da sustentabilidade.

Por que as IES podem viabilizar uma adaptação ao paradigma da sustentabilidade? Porque as IES são órgãos oficiais de produção de conhecimento, de formação de indivíduos e capacitação na aquisição de novas habilidades. Neste sentido, as IES podem viabilizar a adequação e qualificação necessárias na transposição para um modelo mais sustentável de sociedade. Mas como viabilizar?

De que forma as instituições de ensino superior (IES), por meio de suas gestões, podem contribuir para a implementação de uma sociedade mais sustentável?

Para responder essa pergunta o estudo se propôs a:

a) realizar levantamento de referencial teórico-bibliográfico acerca da contribuição das IES na adaptação de sociedades mais sustentáveis; 
b) identificar de que forma, por meio da gestão em IES, pode-se contribuir para o processo de transformação de sociedades mais sustentáveis.

A relevância teórica da pesquisa provem da discussão sobre a construção de modelos de gestão, em diferentes tipos de organizações, possíveis de contribuírem na viabilização de meios sociais, econômicos e ambientais mais sustentáveis para todas as sociedades.

Para se discutir mais acerca da temática, a partir do parâmetro da sustentabilidade, faz-se necessário definir os principais conceitos com os quais esse estudo se identifica, como a gestão ambiental. A seguir uma breve conceituação nesse sentido.

\section{REFERENCIAL TEÓRICO}

A relevância em torno das questões sobre sustentabilidade do meio ambiente evidenciou a necessidade das organizações se adequarem ao novo paradigma da gestão ambiental sustentável. Tanto as organizações da área privada (empresas) quanto as organizações da área pública (órgãos públicos) constituem instituições que vem sofrendo pressões no sentido de se adaptar às exigências sobre a preservação dos recursos naturais (DONAIRE, 1999). É neste contexto que a gestão ambiental surge como alternativa para as organizações se incluírem no processo de proteção e preservação dos recursos naturais.

Este estudo considera o conceito atribuído por Donaire (1999), sobre o que vem a ser gestão ambiental: segundo o autor gestão ambiental é um conjunto de elementos procedimentais que contribuem para a administração e gestão de uma organização, a promover sua interação com o meio ambiente, configura a forma através da qual a instituição se manifesta interna e externamente de maneira a refletir o que aspira como qualidade ambiental.

Para Oliveira, Serra e Salgado o conceito de gestão ambiental recai em considerála como uma saída da qual organizações privadas em todo o globo se utilizam no sentido de aperfeiçoar e fiscalizar suas ações poluidoras, com o intuito de se tornar mais competitiva, economizar, evitar desperdícios, mantendo-se enquanto empresas modernas que poluem menos o meio ambiente. (OLIVEIRA; SERRA; SALGADO, 2010). 
Nesse contexto, no qual é preciso se adaptar ao mercado ambientalmente correto, as universidades despontam como ambientes de produção de conhecimento acerca do assunto, além de constituírem o rol das instituições que também desenvolvem atividades que poluem o meio ambiente: produzem resíduos sólidos, consomem energia, entre outros. As universidades então passaram a se preocupar com a discussão, não só da sustentabilidade como sobre seu papel diante do tema.

\subsection{O PAPEL DAS INSTITUIÇÕES DE ENSINO SUPERIOR FRENTE AO MEIO AMBIENTE SUSTENTÁVEL}

Em outubro de 1990 as universidades do mundo reuniram-se na França e publicaram a Declaração de Talloires na qual admitiam o papel mister das universidades na instauração de um ambiente sustentável. (ASSOCIATION OF UNIVERSITY LEADERS FOR A SUSTAINABLE FUTURE, 1990). Ela foi a primeira que envolveu instituições de ensino superior (IES) na discussão ambiental. Em consonância, outras universidades do mundo representadas pela ONU, inclusive o Brasil, proferiram em dezembro de 1991 no Canadá, a Declaração de Halifax, um texto de adesão ao repúdio a práticas de degradação do meio ambiente (TAUCHEN; BRANDLI, 2006).

As declarações supracitadas evoluíram para a criação da Organização Internacional de Universidades pelo Desenvolvimento Sustentável e Meio Ambiente (OIUDSMAE) no ano de 1995 em São José na Costa Rica. A organização resumia os objetivos das duas declarações, a de Talloires e a de Halifax.

Sendo assim, data do século passado o envolvimento das instituições de ensino superior com o tema sobre um meio ambiente mais sustentável. Para fazer um levantamento sobre "De que forma as instituições de ensino superior (IES), por meio de suas gestões, podem contribuir para a implementação de uma sociedade mais sustentável?" A seguinte metodologia foi desenvolvida:

\section{METODOLOGIA}

O protocolo de pesquisa adotado para este estudo tomou como referência as considerações de Gonçalves (2007). Neste sentido assume a seguinte estruturação: 


\subsection{SEGUNDO O MÉTOdO DE ABORDAGEM É UMA - PESQUISA QUALITATIVA}

A pesquisa qualitativa trabalha com o universo de significados, motivos, aspirações, crenças e atitudes - considera que há uma relação indissociável entre o mundo real e a subjetividade do sujeito.

\subsection{SEGUNDO SEUS OBJETIVOS É UMA - PESQUISA DESCRITIVA}

De acordo com os objetivos do estudo se apresenta como uma pesquisa descritiva, pois seu objeto de estudo é detalhado por descrições. Busca-se exaurir não ao máximo, mas de forma objetiva, uma apresentação descritiva do objeto de estudo em questão.

Esse tipo de pesquisa é responsável por atualizar caracteres sobre determinado objeto de estudo, os quais possuem poucas informações a seu respeito. Neste sentido descrever as características do objeto se faz extremamente útil vez que produz dados a contribuir para outros tipos de análises, as quais não seriam possíveis sem que houvesse primeiro ocorrido a descrição do fenômeno.

\subsection{SEGUNDO A NATUREZA E FONTES DE INFORMAÇÃO É UMA - PESQUISA BIBLIOGRÁFICA}

A pesquisa neste trabalho se delineia como uma pesquisa do tipo bibliográfica, em virtude das fontes de onde foram extraídos os dados coletados, tratarem-se de publicações sobre referencial teórico-bibliográfico acerca da contribuição das IES na adaptação de sociedades mais sustentáveis. Outra fonte é a literatura científica que discute a forma que se dá essa contribuição por meio da gestão das IES, em artigos, teses, dissertações e livros.

\subsection{SEGUNDO A NATUREZA dOS DADOS É UMA - PESQUISA QUALITATIVA}

Por fim, os dados coletados adquirem duas possíveis definições, segundo a natureza dos mesmos: ou são dados de ordem quantitativa ou dados de ordem qualitativa. 
Os dados de ordem quantitativa referem-se àqueles que se destinam a caracterizar numericamente, estatisticamente ou em percentuais os experimentos, além de Ihes atribuir valores, entre outros, que findam por confluir uma ordem numérica aos mesmos. Outra atribuição dos dados de ordem quantitativa é inferir a causa dos fenômenos, por este motivo manuseiam experimentos de forma controlada, através dos quais testam hipóteses e suas variantes pelo número de vezes que forem necessárias, a fim de comprovar a validar os resultados alcançados.

Por sua vez, os dados qualitativos são dados preocupados com a interpretação do fenômeno, de maneira a estabelecer relações deste com o meio do qual é oriundo, ou ainda, de forma a estabelecer relações deste com a compreensão que as pessoas têm do fenômeno e do meio no qual está inserido.

Pelo exposto no parágrafo anterior, esta pesquisa se define como uma pesquisa qualitativa, tendo em vista tomar a forma de uma abordagem hermenêutica, quando faz interpretações de conteúdos e princípios presentes no modo de gestão das IES presentes na literatura pesquisada, com o intuito de descobrir como podem contribuir para a implementação de uma sociedade mais sustentável.

\section{ANÁLISE DOS DADOS LEVANTADOS - DISCUSSÃO}

Em pesquisa sobre referencial teórico-bibliográfico que trata da contribuição das IES na adaptação de sociedades mais sustentáveis, dá-se destaque para os trabalhos de Careto e Vendeirinho (2003). Pode-se estabelecer uma relação de sociedades mais sustentáveis com a discussão levantada pelos autores sobre a instauração da sustentabilidade nos próprios campi das IES.

O estudo permite ainda levantar abordagem reflexiva sobre a tomada de conhecimento de dois produtos das IES, concebidos de forma empírica até então, a saber: a) o conjunto dos impactos ambientais causados ao meio ambiente decorrentes das ações funcionais das IES e b) o conjunto das ações de sustentabilidade realizadas nas e pelas IES, pelos sujeitos que as compõem.

O quadro situacional pode respaldar e nortear a razão de ser das próprias IES, a condição sine qua nom da indissociabilidade entre teoria e prática na produção do conhecimento. Careto e Vendeirinho (2003) afirmam que: 
as IESs precisam praticar aquilo que ensinam e a minimização dos impactos ambientais nas Universidades, por meio de Sistemas de Gestão Ambiental, é a parte da solução para a sustentabilidade dos campi universitários. (Apud MACHADO; FRACASSO; TOMETICH; NASCIMENTO, 2013, p. 37)

A construção de um SGA não se vale para inibir iniciativas originais de sustentabilidade, de modo a impor a adesão a um modelo engessado, mas sim, contribui para elucidar a percepção dos sujeitos que constituem as IES. Elucidar no sentido de eles perceberem o quão constituem referência para a sociedade sobre aquilo que teorizam, logo, precisam conciliar seus ensinamentos e aprendizagens teóricas com o exemplo de suas práticas.

A literatura registra que a primeira universidade a implantar um SGA foi a Universidade Mälardalen da Suécia (OELREICH, K., 2004). A universidade obteve bons resultados e chegou a ser certificada pela International Organization for Istandardization ISO 14001 (TAUCHEN; BRANDLI, 2006).

A ISSO 14001 certifica sistemas de gestão ambiental de organizações em todo o globo. Apesar de o segmento industrial ter sido o que mais se apropriou desse tipo de certificação por interesses comerciais, é equivocado o preconceito de que a norma tenha sido criada para esse fim. Atualmente outras universidades são certificadas pela ISO 14001, por exemplo, a Universidade da ONU, em Tóquio, no Japão.

No Brasil, a Universidade do Vale do Rio dos Sinos (UNISINOS), ao implementar seu SGA, foi a primeira universidade da América Latina a ser certificada pela ISO 14001 em 2004 (DE CONTO, 2012). Sobre a implantação do SGA na UNISINOS Tauchen e Brandli registram que "Um dos resultados mais relevantes alcançados foi a criação do curso de Gestão Ambiental no ano de 2005." (TAUCHEN; BRANDLI, 2006, p. 508).

Seguem o exemplo da UNISINOS, a Universidade Federal de Santa Catarina (UFSC) que denominou seu SGA de Coordenadoria de Gestão Ambiental, e a Universidade Regional de Blumenau (FURB), também no Estado de Santa Catarina. A FURB criou o Comitê de Implantação do SGA em março de 1998, e seguindo o modelo da ISO 14001 implantou seu SGA em 1999.

As bases teóricas que terminam por fundamentar o segundo objetivo desta pesquisa consubstanciam-se nos estudos desenvolvidos por Tauchen; Brandli (2006) e Alves (2017). 
Tauchen e Brandli discorrem sobre um modelo de gestão ambiental próprio para ser implantado em uma IES. O mérito do trabalho constitui a criação de um padrão de SGA que estabelece relação direta com o modelo das ISOs 14001 e 14004, as mais utilizadas pelas IES no âmbito internacional, como pré-requisito para reconhecimento e certificação dos SGA.

A base do SGA proposto por Tauchen e Brandli toma por referência o ciclo PDCA da ISO 14001:

- Planejar (PLAN): envolve o estabelecimento dos objetivos e processos necessários para atingir os resultados, de acordo com a política ambiental da organização;

- Executar (DO): envolve a implementação dos processos;

- Verificar (CHECK): envolve o monitoramento e medição dos processos em conformidade com a política ambiental, objetivos, metas, requisitos legais e outros, e relatar os resultados; e

- Agir (ACTION): envolve a execução de ações para melhorar continuamente o desempenho do sistema da gestão ambiental (TAUCHEN; BRANDLI, 2006, p. 507-508).

Por sua vez, Alves (2017) pesquisa quais os benefícios de um SGA em uma IES e apresenta uma lista de 32 benefícios. Apesar de a presente pesquisa concordar com todos os itens citados pelo autor, três deles em especial vão de encontro com a linha de pensamento deste estudo: a) mudança de comportamentos na gestão e iniciativas de práticas ambientais no campus das IES; b) critérios ambientais para fornecedores de materiais de consumo e c) plano de ação para melhoria contínua da sustentabilidade ambiental diminuindo os impactos ambientais (ALVES, 2017).

A exemplo de muitas instituições como a Universidade de São Paulo (USP), a Universidade de Campinas (UNICAMP), a Universidade Federal do Rio Grande do Sul (UFRGS), o Senado Federal e outras, cabe a qualquer órgão público a implantação do seu SGA com vistas a reduzir o impacto causado ao meio ambiente em virtude das ações funcionais que lhes são inerentes.

A USP apresenta seu SGA através da estrutura organizacional denominada Superintendência de Gestão Ambiental, através da qual, várias políticas e programas são desenvolvidos no intuito de alcançar índices cada vez melhores de sustentabilidade ambiental. Já o Senado Federal optou pela instituição de um plano: Plano de Gestão de 
Logística Sustentável do Senado Federal (PGLS). Seja por intermédio da instauração de um ambiente estrutural ou de um plano, urge a necessidade de se pensar um SGA nas IES.

\section{CONSIDERAÇÕES FINAIS}

Um dos vieses possíveis de implementar a sustentabilidade, registrada na bibliografia científica, consiste na criação dos chamados sistemas de gestão ambiental. Os SGAs podem ser implantados tanto em instituições públicas, quanto privadas.

Nas universidades e faculdades podem constar ainda, enquanto conteúdo, no currículo de diferentes áreas de formação: Administração, Gestão Ambiental, Engenharia Florestal, entre outras; e são bastante estimulados como uma possível via para alcançar a almejada sustentabilidade. A mesma sustentabilidade preconizada pela Primeira Conferência Internacional da ONU, a Conferência de Estocolmo, realizada em Estocolmo na Suécia, em 1972, e oficializada pela Comissão Mundial sobre Meio Ambiente e Desenvolvimento, em 1987, com a publicação do Relatório Nosso Futuro Comum.

Outros segmentos atingidos pela universidade são a preparação de jovens para a vida em sociedade e a preparação de toda ordem de profissionais para o mercado de trabalho. Ambos os segmentos, jovens e profissionais, carecem de capacitação para adquirir habilidades sustentáveis a fim de se adaptar ao parâmetro sustentável de sociedade.

Antes de instigarem quaisquer modelos de sustentabilidade, é premente às instituições praticarem aquilo que pregoam, como forma de manter a coerência entre teoria e prática.

O espaço da universidade é o espaço de excelência do conhecimento. Se a configuração da organização social se modifica e evolui, a academia é o lugar que materializa as capacitações e formações necessárias que possibilitam a sociedade acompanhar essas mudanças e manter-se atualizada. Neste sentido, as iniciativas fragmentadas, dispersas, isoladas e desconexas sobre gestão ambiental sustentável dentro da universidade, não são de todo prejudiciais, mas se essas mesmas iniciativas 
ganham a oficialização de suas ações sob o aporte institucional viabiliza-se um rumo em comum, facilitador de resultados mais positivos.

Um SGA consolida uma política unificada de sustentabilidade voltada para diminuição de impactos negativos ao meio ambiente, e, neste sentido, contribui para o processo de adequação e implementação de sociedades mais sustentáveis.

\section{REFERÊNCIAS}

ALVES, Alison da Rocha. Responsabilidade ambiental: os benefícios de um sistema de gestão ambiental (SGA) em instituições de ensino superior (IES). In: Revista da Universidade Ibirapuera. São Paulo: n. 13, p. 24-33, jan./jun. 2017. Disponível em:

http://webcache.googleusercontent.com/search?q=cache:Caj1mXAa7CcJ:seer. unib.br/index.php/rev/article/download/105/130+\&cd=1\&hl=pt-

$B R \& c t=c l n k \& g l=b r$. Acesso em: 2 mai. 2021.

ASSOCIATION OF UNIVERSITY LEADERS FOR A SUSTAINABLE FUTURE. The Talloires Declaration: 10 Point Action Plan. 1990. Disponível em: http://ulsf.org/wpcontent/uploads/2015/06/TD.pdf. Acesso em: 14 mai. 2021.

CARETO, H.; VENDEIRINHO, R. Sistemas de gestão ambiental em universidades: caso do Instituto Superior Técnico de Portugal. Relatório final de curso, 2003. Apud MACHADO, R. E.; FRACASSO, E. M.; TOMETICH, P.; NASCIMENTO, L. F. Práticas de gestão ambiental em universidades brasileiras. In: Revista de Gestão Social e Ambiental-RGSA. São Paulo: v. 7, n. 3, p. 37-51, out./dez., 2013. Disponível em: http://www.spell.org.br/documentos/ver/31929/praticas-de-gestao-ambientalem-universidades-brasileiras. Acesso em: 23 mar. 2021.

DE CONTO, S. M. Gestão de resíduos em universidades. Caxias do Sul, RS: EDUCS, 2010. 319 p. ISBN: 978-85-7061-598-5.

DONAIRE, D. Gestão ambiental na empresa. 2. Ed. São Paulo: Editora Atlas. 1999.

GONSALVES, Elisa Pereira. Conversas sobre iniciação à pesquisa científica. 4. ed. rev. e amp. Campinas, SP: Alínea, 2007. 93 p.

MACHADO, R. E.; FRACASSO, E. M.; TOMETICH, P.; NASCIMENTO, L. F. Práticas de gestão ambiental em universidades brasileiras. In: Revista de Gestão Social e Ambiental - RGSA. São Paulo: v. 7, n. 3, p. 37-51, out./dez., 2013. Disponível em: http://www.spell.org.br/documentos/ver/31929/praticas-de-gestao-ambientalem-universidades-brasileiras. Acesso em: 23 mar. 2021. 
OELREICH, K. Environmental certification at Mälardalen University. International Journal of Sustainability in Higher Education. 2004. v. 5, n. 2, p. 133-146. Disponível em: DOI 10.1108/14676370410526224.

OLIVEIRA, O. J.; SERRA, J. R.; SALGADO, M. H. A ISO 14001 funciona no Brasil? Journal of Cleaner Production. n. 1, v. 18, p. 1797-1806, 2010. http://dx.doi.org/10.1016/j.jclepro.2010.08.004.

TAUCHEN, Joel; BRANDLI, Luciana Londero. A gestão ambiental em instituições de ensino superior: um modelo para implantação em campus universitário. Gestão \& Produção, v. 13, n. 3, p. 503-515, set.-dez. 2006. Disponível em: https://doi.org/10.1590/S0104-530X2006000300012. Acesso em: 14 fev. 2021. 


\title{
CAPÍTULO IX
}

\section{A UTIUTAC̆̃O DA COLTAA SELITIVA DE LXO NA EEEP RAIMUNDO SARAIVA COELHO}

\section{DOI: 10.51859/amplla.mas481.1121-9}

\author{
Maria Francimar Teles de Souza ${ }^{1}$ \\ Rosa Cruz Macêdo ${ }^{2}$ \\ Antonia Lucelia Santos Mariano ${ }^{3}$ \\ José Oberdan Leite ${ }^{3}$ \\ Maria Jaqueline Ferreira da Silva ${ }^{3}$
}

\footnotetext{
' Mestra em Política e Gestão da Educação, Centro Latinoamericano de Economia Humana - CLAEH.

${ }^{2}$ Mestranda em Desenvolvimento Regional Sustentável, Universidade Federal do Cariri - UFCA.

${ }^{3}$ Especialista em Gestão Escolar, Universidade do Estado de Santa Catarina - UDESC e Especialista em Informática na Educação, Universidade Estadual do Ceará - UECE.

${ }^{3}$ Especialista em Língua Inglesa, Universidade Regional do Cariri - URCA.

${ }^{3}$ Especialista em Gestão da Educação Pública, Universidade Federal de Juiz de Fora - UFJF e Especialista em Coordenação Pedagógica, Universidade Federal do Ceará - UFC.
}

\section{RESUMO}

A preservação ambiental é um tema presente em todas as instâncias da sociedade. Na Escola Estadual de Educação Profissional Raimundo Saraiva Coelho, localizada em Juazeiro do Norte - Ceará, que oferta o ensino médio integrado à educação profissional não poderia ser diferente, já que desenvolve vários projetos para reutilização de materiais e descarte correto do lixo. Então, neste trabalho se tem como objetivo descrever como está o uso da coleta seletiva de lixo na EEEP Raimundo Saraiva Coelho e como se dá a reutilização de materiais para que não sejam descartados de maneira inadequada, destacando a importância da coleta seletiva e a necessidade da educação ambiental para atuação constante das pessoas na preservação do meio ambiente. Também se busca sensibilizar a comunidade sobre os problemas locais e regionais mostrando como cada um pode colaborar para diminuir esses impactos, disseminando boas práticas e orientando ações que possibilitam a preservação do meio ambiente. Para isso, aplicou-se um questionário para verificar o conhecimento da comunidade quanto à questão ambiental e depois se realizaram reuniões, palestras e oficinas para produção de materiais reciclados. Ficando evidente a necessidade de tornar a coleta seletiva de resíduos sólidos uma prática mais constante nesta unidade escolar. Mesmo já existindo ações para que isso aconteça, como mapeamento das possíveis destinações do material a ser coletado, parcerias com instituições coletoras e engajamento de professores e alunos no desenvolvimento de projetos para diminuição do lixo jogado no meio ambiente, bem como para sua reciclagem, ainda existem grandes desafios a serem superados. Este trabalho foi apresentado como Resumo Expandido, na modalidade Comunicação Oral, na V Jornada Cientifica PRODER/UFCA, no período de 03 a 04 de dezembro de 2019.

Palavras-chave: Coleta Seletiva. Reciclagem. Cidadania. 


\section{INTRODUÇÃO}

A coleta seletiva de lixo é uma proposta que vem sendo trabalhada há muitos anos nas escolas e nas comunidades para melhor preservação do meio ambiente. Entretanto, observamos que na grande maioria dos locais ela ainda não é uma realidade, pois cada vez mais se vê uma produção exacerbada de lixo, sem uma destinação coerente para ele.

Sabemos que o lixo pode trazer muitas doenças e que o seu acúmulo só pode trazer prejuízos ao meio ambiente e à população.

O uso da coleta seletiva traz benefícios para o meio ambiente - já que os materiais não terão a natureza como destino final - e para a própria comunidade, que frequentará ambientes mais limpos e agradáveis. Contudo, não basta espalhar lixeiras coloridas nos corredores da escola para colocar em prática o projeto. É preciso um planejamento cuidadoso e, principalmente, um trabalho em equipe para garantir que o cuidado com o meio ambiente seja constante. Para isso a escola desenvolve várias ações, desde a investigação sobre o impacto do descarte inadequado até a divulgação das pesquisas realizadas pelos alunos e dos resultados das ações, que estão sendo desenvolvidas pelos professores e alunos nas diversas disciplinas do currículo.

Nessa perspectiva, realizou-se um diagnóstico da escola, verificando a preocupação da comunidade escolar voltada às questões ambientais, em seguida, fezse a elaboração de materiais didáticos, para isto os professores realizam oficinas e palestras para a produção de objetos reciclados e reaproveitamento de materiais, desencadeando a realização de novos projetos, como o Recifacil, Logística Reversa e o Reciclapet.

Nesse contexto, este trabalho teve como objetivo descrever como está o uso da coleta seletiva de lixo na EEEP Raimundo Sarava Coelho, situada em Juazeiro do Norte, Ceará, e como se dá a reutilização de materiais para que não sejam descartados de maneira inadequada. 


\section{METODOLOGIA}

Inicialmente o trabalho foi desenvolvido tendo como principal fonte de apoio, pesquisas bibliográficas, feita em documentos e livros, além de consulta a trabalhos e artigos científicos e consultas a sites de empresas e associações relacionadas ao tema em questão.

Em seguida foi realizado um levantamento na escola com professores e alunos, com a realização de um questionário para verificação da preocupação da instituição voltada para as questões ambientais.

A população da pesquisa teve representantes de alunos de todas as turmas e a participação de todos os professores.

Para um melhor esclarecimento sobre o trabalho desenvolvido na escola, utilizamos apresentação de slides sobre coleta seletiva; informações sobre Educação Ambiental e a destinação do lixo domiciliar no município de Juazeiro do Norte - Ceará. Também foram expostas as condições visuais e uma pequena apresentação das condições sanitárias do arredor da instituição de ensino, apontando algumas das causas e efeitos das principais ações que prejudicam o meio ambiente e a saúde da população, o que despertou interesse de alguns participantes das reuniões e iniciou-se o desenvolvimento de vários projetos na área de educação ambiental, além da implantação nesse ano de 2019 da primeira turma do Curso de Meio Ambiente na escola.

\section{DESENVOLVIMENTO}

\subsection{A REALIDADE BRASILEIRA E CEARENSE}

Segundo o IBGE (2012), 32,3\% dos municípios brasileiros têm coleta seletiva de lixo, outros $42,7 \%$ não têm nenhuma ação para separar material descartado e não possuem qualquer atividade de coleta seletiva de lixo. Em 3,3\% das prefeituras, há projeto-piloto apenas em uma área restrita da cidade, enquanto 2,5\% dos municípios informam que tiveram ações de coleta seletiva, mas elas foram interrompidas. Segundo a pesquisa, divulgada no dia treze de novembro de dois mil e onze, em $19,2 \%$ dos municípios brasileiros projetos desse tipo estão em fase de elaboração e que as cidades 
com mais de 500 mil habitantes são as que mais possuem programa em atividade: $78,9 \%$. Apenas $30 \%$ das cidades com até 5 mil habitantes têm coleta seletiva em andamento.

Não é a realidade que desejamos, mas que mostra o quão necessário se faz uma ação para transformá-la, pois a pesquisa também identifica que em $30,7 \%$ cidades os gestores dizem ter conhecimento sobre a existência de cooperativas ou de associações de catadores de materiais recicláveis. Porém, em apenas 14,8\% das cidades há, de fato, parceria formal entre prefeitura e os catadores para a coleta seletiva.

O que vemos na maioria das cidades brasileiras é que a disposição dos resíduos sólidos é feita em locais inadequados, como os lixões, mesmo existindo uma lei que exige que todo gestor tenha um plano de resíduos, desde 2 de agosto de 2012, no art. 55 da Lei 12.305.

Conforme o Instituto de Pesquisa Econômica Aplicada - IPEA, ainda existem no Brasil 2.906 lixões, distribuídos em 2.810 municípios. Desses, 1.598 lixões estão no Nordeste, sendo 300 só no Ceará. Considerando que temos 184 municípios, isso corresponde a 1,6 lixões por cada município do Estado (CARIRI, 2019).

\subsection{COletA SELETIVA}

A educação ambiental é uma forma de educar a todos, como diz SATO (2003) citado pela Conferência de Estocolmo (1972): um processo de reconhecimento de valores e clarificação de conceitos, objetivando o desenvolvimento das habilidades e modificando as atitudes em relação ao meio, para entender e apreciar as inter-relações entre os seres humanos, suas culturas e seus meios biofísicos. Por isso precisamos sensibilizar as pessoas, embora sejam as crianças e os jovens o foco principal, pois eles ainda não têm muitos vícios e estão começando a aprender. Mas como fazer isso? Não adiantaria incluir uma matéria a mais na grade curricular falando de coleta seletiva, pois aprenderiam sobre o assunto e ao chegar a suas casas, fariam exatamente o contrário, pois a realidade é outra.

CASCINO (1999, p.52) explica:

Educar crianças, educar jovens, educar. Mais que uma tarefa, mais que militância política, trabalho, dedicação. Criar planos de ação, considerar 
conceitos, teorias, reflexões, interações do desejo, da necessidade e da possibilidade, usar o bom senso, o senso de limites, repensar os espaços e as tarefas educacionais, formais e não formais.

Assim, precisamos cuidar da educação desses jovens para que a exploração dos recursos naturais não continue a ser feita de forma demasiadamente intensa, a ponto de pôr em risco a sua renovabilidade. Sabe-se que a cada dia a necessidade de se entender mais sobre os limites da renovabilidade de recursos básicos como a água, por exemplo é essencial na educação escolar e familiar, já que onde moravam algumas famílias, consumindo pouca quantidade de água e produzindo poucos detritos, agora moram milhões de famílias, exigindo a manutenção de imensos mananciais e gerando milhares de toneladas de lixopor dia, que não são descartados corretamente.

Sabe-se que a coleta seletiva é uma das muitas formas de aproveitar esse lixo que é produzido pela população e são muitas as vantagens ambientais desse tipo de coleta, dentre elas Waite (1995), destaca: a redução do uso de matéria-prima virgem e a economia dos recursos naturais renováveis e não renováveis; a economia de energia no reprocessamento de materiais se comparada com a extração e produção a partir de matérias-primas virgens e da valorização das matérias-primas secundárias, e a redução da disposição de lixo nos aterros sanitários e dos impactos ambientais decorrentes.

Assim, além de contribuir significativamente para a sustentabilidade urbana, a coleta seletiva vem incorporando gradativamente um perfil de inclusão social e geração de renda para os setores mais carentes e excluídos do acesso aos mercados formais de trabalho (SINGER, 2002).

Já aconteceram várias reuniões internacionais em busca de uma melhoria na vida da população e do meio ambiente, e uma das principais conclusões assumidas é "[...] a recomendação de investir numa mudança de mentalidade, conscientizando os grupos humanos da necessidade de adotar novos pontos de vista e novas posturas diante dos dilemas e das constatações feitas nessas reuniões (BRASIL, 1997, p. 14)".

Essa é uma preocupação que não deve ser apenas das instituições de mais relevância no mundo, deve começar desde as séries iniciais, pois como afirmam os Parâmetros Curriculares Nacionais (1997, p. 22) 


\begin{abstract}
A preocupação em relacionar a educação com a vida do aluno - seu meio, sua comunidade - não é novidade. Ela vem crescendo especialmente desde a década de 60no Brasil. Exemplo disso são atividades como os "estudos do meio". Porém, a partir da década de 70, com o crescimento dos movimentos ambientalistas, passou-se a adotar explicitamente a expressão "Educação Ambiental" para qualificar iniciativas de universidades, escolas, instituições governamentais e não-governamentais por meio das quais se busca conscientizar setores da sociedade para as questões ambientais. Um importante passo foi dado com a Constituição de 1988, quando a Educação Ambiental se tornou exigência a ser garantida pelos governos federal, estaduais e municipais (artigo 225, § 1으, VI).
\end{abstract}

Mesmo com essa exigência sabe-se que nas escolas pouco se toca nessa questão, a não ser quando está se aproximando a semana do meio ambiente ou outras datas que são bem divulgadas através da mídia. Mas precisamos mudar esta realidade, pois como afirmam os PCNs - Ensino Médio (2002, p. 94) “[...] Condutas ambientalistas responsáveis subentendem um protagonismo forte no presente, no meio ambiente imediato da escola, da vizinhança, do lugar onde se vive[...]". E a escola é o melhor lugar para a realização permanente de atividades de conservação e preservação do meio ambiente, pois é na escola que se formam cidadãos conscientes capazes de agir responsavelmente e com sensibilidade, na conservação de um ambiente saudável não só no presente, mas também para o futuro, já que todos sabem que existem obrigações que devem ser cumpridas, mas é preciso a cobrança e o respeito aos direitos próprios e os de toda a comunidade, tanto local como internacional para que como pessoas possam encontrar acolhida e ampliar a qualidade de suas relações intra e interpessoais com o ambiente tanto físico quanto social (PCNs, 1997, p.23).

\title{
4. RESULTADOS E DISCUSSÕES
}

Fala-se muito a respeito de meio ambiente atualmente. Porém, poucos sabem, na prática, que importância tem, pois apenas em Juazeiro do Norte são recolhidas em média 240 toneladas de resíduos por dia. O que se torna um desafio devido ao grande desenvolvimento dessa cidade. E não é diferente em outras cidades, que como Juazeiro ainda utilizam lixões como depósito de lixo (CARIRI, 2019).

Segundo Lemos et al. (1999, p. 72) "Abordar a problemática da produção e destinação do lixo no processo de educação é um desafio, cuja solução passa pela compreensão do indivíduo como parte atuante no meio em que vive". Então para que 
tenhamos uma melhoria na qualidade de vida precisamos criar situações onde o aluno comece a vivenciar a sustentabilidade dentro da própria escola e esse é um trabalho que precisa ser iniciado o mais rapidamente possível, pois a maioria dos entrevistados joga o lixo no lixo, sem reaproveitá-lo de nenhuma forma, como podemos observar na figura abaixo:

Figura 1: Destino do Lixo Produzido

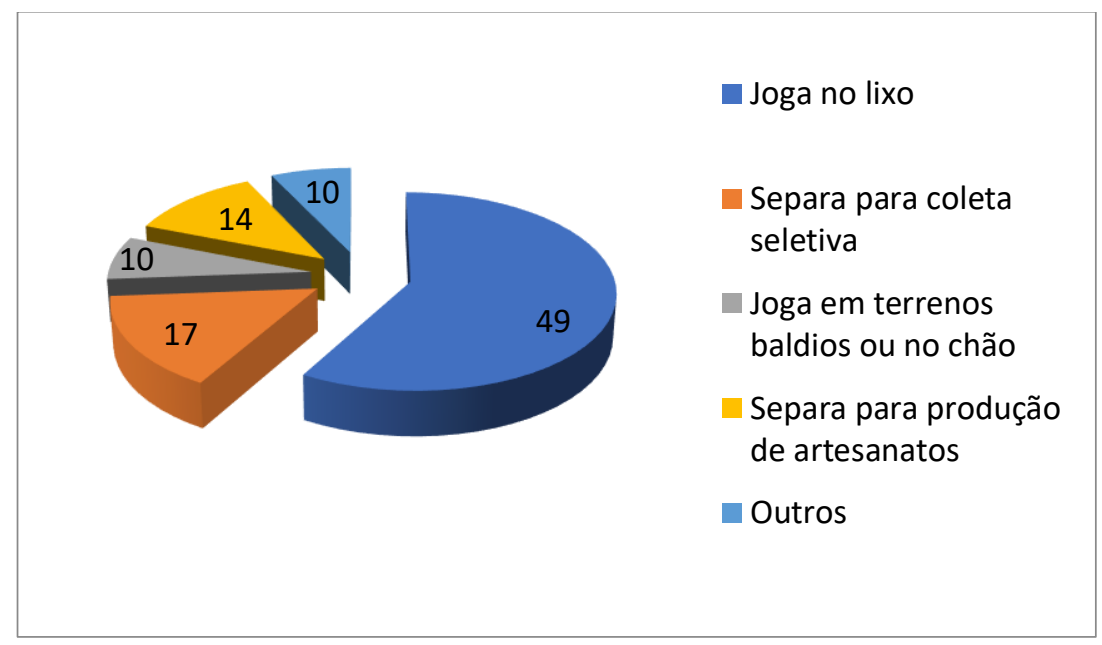

Fonte: Autoria Própria

Também foi perguntado se eles sabem o destino do lixo da escola e a maioria não sabe o destino que tem esse lixo, como se pode ver na figura abaixo.

Figura 2: Destino do Lixo da Escola

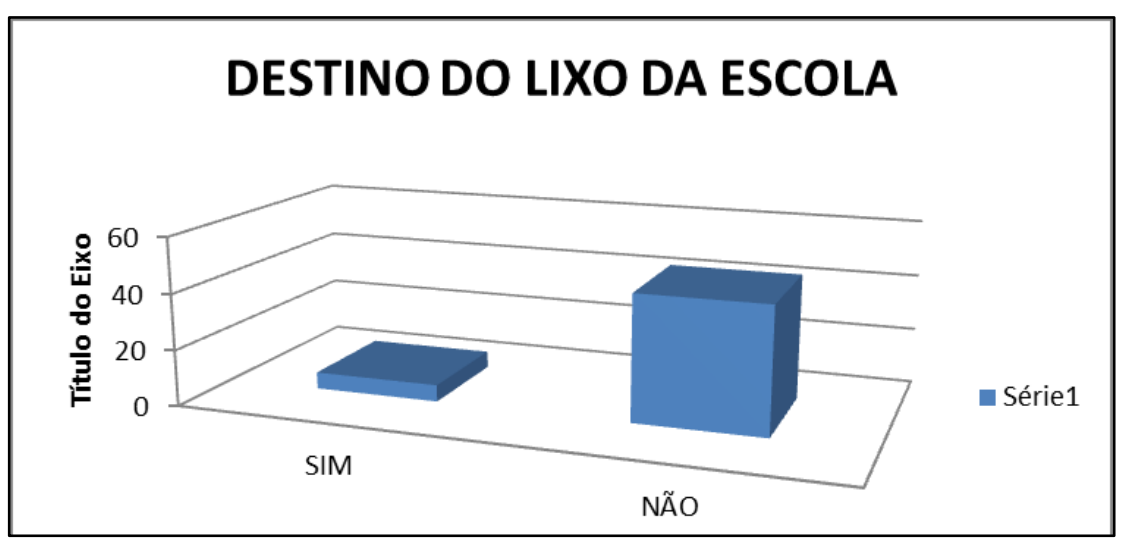

Fonte: Autoria Própria 
Quanto aos conhecimentos sobre coleta seletiva, a maioria informou que tem conhecimento sobre ela, o que se pode observar na figura 3, mas a maioria não utiliza em casa porque sabe que o carro coletor vai misturar tudo.

Figura 3: Conhecimento Sobre Coleta Seletiva

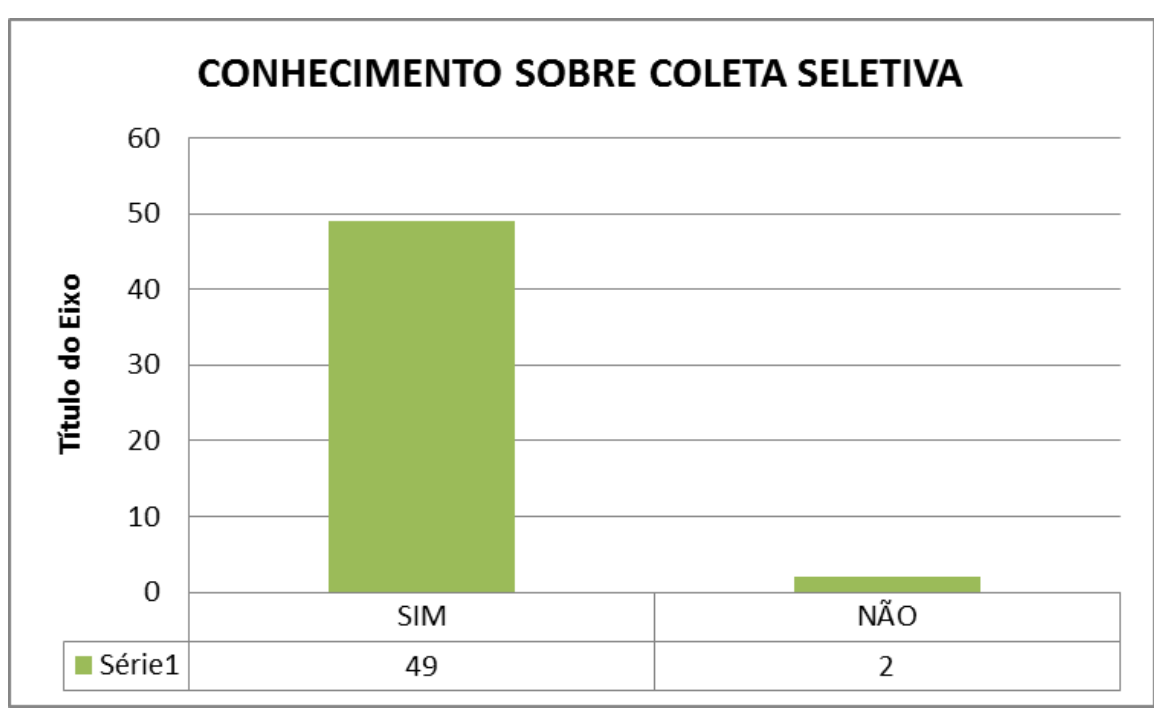

Fonte: Autoria Própria

Também afirmaram ter conhecimento sobre as cores da coleta seletiva, uma vez que apenas dois dos entrevistados não tinham esse conhecimento. E usam esse conhecimento para fazer uso dos coletores disponíveis na escola, como podemos ver na figura 4.

Figura 4: Uso dos Coletores da Escola

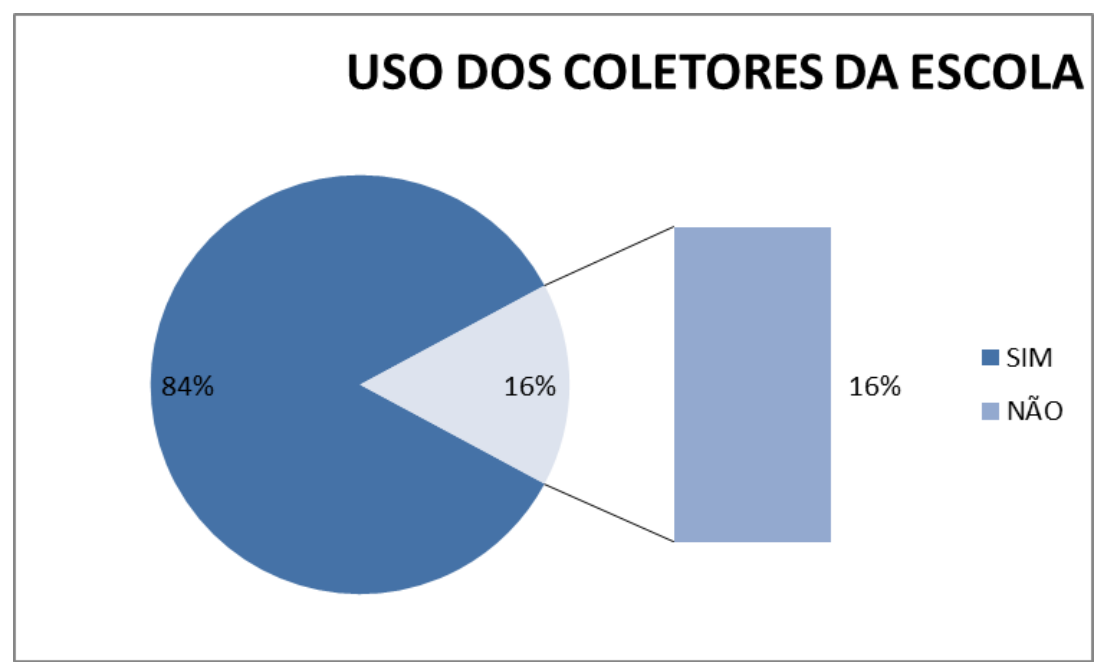

Fonte: Autoria Própria 
Tendo em vista que o que existe no meio ambiente é fundamental para o desenvolvimento do bem estar de toda população fica evidente a necessidade de tornar uma prática constante a coleta seletiva de resíduos sólidos na Escola Estadual de Educação Profissional Raimundo Saraiva Coelho.

Nessa perspectiva a escola já viabilizou ações para que isso aconteça, mapeando as possíveis destinações do material a ser coletado, bem como parcerias com instituições coletoras. E os professores juntamente com os alunos vêm desenvolvendo projetos para diminuição do lixo jogado no meio ambiente, bem como para sua reciclagem.

Investigaram-se também os grupos de catadores organizados da cidade para saber se eles fariam a coleta ou se seria necessário a escola levar para a sede das instituições, bem como a periodicidade da coleta, pois quanto mais perto o destino do lixo reciclável, melhor, para evitar o aumento do custo do transporte do material. Já se sabe que o custo do transporte é um grande vilão na coleta seletiva.

Na verdade, todos sabem que a educação ambiental nos seus mais diversos aspectos, tem sido um desafio mundial, mesmo sendo recomendada por todas as conferências internacionais, exigida pela Constituição e declarada como prioritária por todas as instâncias de poder. É uma educação que está longe de ser uma atividade tranquilamente aceita e desenvolvida, mas que deve ser trabalhada e acompanhada por todos da sociedade, pois ela implica mudanças profundas e significativas para toda população. Além disso, se bem realizada, pode levar a mudanças de comportamento que influenciará não só na vida pessoal e atitudinal de cada pessoa, mas que reforçará valores de cidadania que podem ter fortes impactos na sociedade.

\section{CONCLUSÕES}

É notório o quanto há profissionais e alunos na escola que são interessados em promover ações para melhoria do meio ambiente para a consciência dos alunos e da comunidade escolar em geral, para que esteja sensibilizada em relação ao meio em que vive.

Por isso, as ações desenvolvidas na escola não são restritas a ela, pois a educação dos brasileiros deve orientá-los para que ajam de modo responsável e com 
sensibilidade, conservando o ambiente saudável no presente e para o futuro. Desse modo, saber exigir e respeitar os direitos próprios e os de toda a comunidade, tanto local como internacional faz parte de uma série de conhecimentos e atitudes para que se modifiquem tanto interiormente, como pessoas, quanto nas suas relações com o ambiente.

Com isso, pôde-se proporcionar a todos, a troca de informações sobre as ações da equipe para melhorar a qualidade de vida dos estudantes e da escola em relação ao meio em que vivem. Também se envolveu a comunidade local para com pequenas atitudes, haver a transformação de conceitos, a explicitação de valores e a inclusão de procedimentos, sempre vinculados à realidade cotidiana da sociedade, de modo que obtenha cidadãos mais participantes e cônscios da capacidade de intervenção de todos para modificar e acima de tudo melhorar a realidade, transformando-a sem deixar de considerar as características da natureza ou mesmo a utilização das tecnologias que mediam as várias dimensões da vida atual sem prejudicar o meio ambiente.

Desse modo, buscou-se contribuir para a formação de cidadãos conscientes, aptos a decidirem e atuarem na realidade socioambiental que estão inseridos de modo comprometido com a vida, com o bem-estar de cada um e da sociedade, local e global.

Nessa perspectiva, o espaço das relações deve ser estabelecido considerando os fatores físicos do ambiente, o uso dos seus recursos e a preservação dos seus elementos sem desconsiderar os fatores sociais sem pensar apenas nas relações econômicas, culturais, políticas.

\section{REFERÊNCIAS}

BRASIL. Secretaria de Educação Fundamental. Parâmetros curriculares nacionais - meio ambiente, saúde. Brasília, 1997. Disponível em: http://portal.mec.gov.br/seb/arquivos/pdf/livro091.pdf. Acesso em 03 mar 2019.

BRASIL. Secretaria de Educação Média e Tecnológica. Parâmetros curriculares nacionais: ensino médio/ Ministério da Educação, Secretária de Média e Tecnológica. Brasília: MEC; SENTEC, 2002. 360 p.

CARIRI, Revista. Cariri Sustentável: 0 lixo em nossas mãos. Disponível em: https://caririrevista.com.br/o-lixo-em-nossas-maos-2/. Acesso em 10 out 2019. 
CASCINO, Fabio. Educação Ambiental. São Paulo: Senac, 1999.

G1. 32,3\% dos municípios brasileiros têm coleta seletiva de lixo, diz IBGE. Disponível em: $\quad$ http://g1.globo.com/brasil/noticia/2012/11/323-dos-municipiosbrasileiros-tem-coleta-seletiva-de-lixo-diz-ibge.html. Acesso em 20 de abril de 2018.

LEMOS, Jureth Couto; LIMA, Samuel do Carmo. Segregação de resíduos de serviços de saúde para reduzir os riscos à saúde pública e ao meio ambiente. Bioscience Journal. Vol.15, n.2. Uberlândia: Universidade federal de Uberlândia, 1999.

SATO, Michèle. Educação ambiental. São Carlos: RiMa, 2003.

SINGER, P. A recente ressurreição da economia solidária no Brasil. In: SANTOS, Boaventura de Souza (Org.) Produzir para viver: os caminhos da produção não capitalista. Rio de Janeiro: Civilização Brasileira; 2002. p.81-126.

WAITE, R. Household waste recycling. London: Earthscan Publications, 1995. 


\section{CAPITULO X}

\section{EDUCACÃO AMBIENTAL NO CONIEXTO ESCOLAR: PROJETO APLCADO NA ESCOLA AGROAMBIENTAL DE CURRAUNHO-PA}

\section{DOI: 10.51859/amplla.mas481.1121-10}

${ }^{1}$ Instituto Federal do Pará-IFPA

${ }^{2}$ Secretaria estadual de Meio Ambiente e Sustentabilidade-SEMAS-PA

${ }^{3}$ Universidade Federal do Pará-UFPA

Sabrina de Oliveira Farias ${ }^{1}$ Larissa Martins Barbosa D'Arace ${ }^{2}$ Klewton Adriano Oliveira Pinheiro ${ }^{1}$

Francimary da Silva Carneiro ${ }^{2}$ Aline Cecy Rocha de Lima $^{3}$ Marcio Braga Amorim ${ }^{2}$

\section{RESUMO}

Esta pesquisa teve como objetivo avaliar como a educação ambiental está sendo aplicada na rede pública de ensino, e expor de forma didática para os alunos sobre os cuidados que devemos ter com o meio ambiente dentro e fora da escola. Foram feitas palestras, oficinas e atividades recreativas dentro e fora da sala de aula, mostrando uma nova abordagem sobre a educação ambiental, onde se buscou tais ações a fim de despertar noções sobre alimentação saudável, gerenciamento de resíduos e cuidados com o meio escolar em que vivem, visando a urgência necessidade que se têm em inserir a educação ambiental nas diversas áreas de ensino. Ao final do projeto encontrou-se nesses alunos mudanças de atitudes, incentivos para a cooperação e a solidariedade, praticando o respeito afim de que busquem resgatar valores éticos através da Educação Ambiental.

Palavras-chave: Horta escolar. Responsabilidade social. Coleta seletiva. Reciclagem. Atividades recreativas.

\section{INTRODUÇÃO}

A questão ambiental requer novas formas de abordagem, integrando as várias áreas de conhecimentos e tendo como foco principal o despertar da consciência, principalmente das crianças e dos adolescentes, para que assim novos hábitos possam ser formados, direcionando a espécie humana a utilizar os recursos naturais de forma sustentável (SOUZA, et al, 2013). 
Nesta perspectiva, a Educação Ambiental apresenta várias soluções para os problemas em nossa vida (SOUZA et al, 2013). É necessário que desde cedo os alunos saibam a importância que o meio ambiente tem para nossa sobrevivência e tenham consciência de que cuidando dos recursos naturais irão estar sempre disponíveis e por mais tempo para todos.

Neste contexto, entra o papel do professor como educador de servir como agente fundamental nessa tarefa de transformação e aprendizagem, principalmente, para as crianças e jovens que podem se tonar a solução para este problema. Portanto, necessita-se inserir a educação ambiental nos mais diversos lugares da sociedade, visto que é algo de extrema importância para a continuação da vida humana (CICHELLA et al., 2007).

O trabalho de Educação Ambiental deve ser desenvolvido a fim de ajudar os alunos a construírem uma consciência global das questões relativas ao meio para em relação à sua proteção e melhoria. Para isso é importante que possam atribuir significado àquilo que aprendem sobre a questão ambiental. E esse significado é resultado da ligação que o aluno estabelece entre o que aprende e a sua realidade cotidiana e da possibilidade de utilizar o conhecimento em outras situações. (BRASIL, 2002, p.128).

Logo, o projeto teve como finalidade levar a conscientização aos alunos da Escola Agroambiental Prof. a Lindalva Pinho sobre os cuidados com o meio ambiente dentro e fora da escola, buscando um melhor aprendizado e interação desses alunos com o meio ambiente. Como toda forma de aprendizado, os alunos precisam ser motivados ao aprendizado da educação ambiental.

Para tanto, acredita-se que a educação ambiental seja a maneira mais eficaz de enfrentar tal crise, visto o poder de transformação da realidade que esta possibilita. Assim como nos demais espaços educativos, a prática da educação ambiental no contexto escolar é bastante importante, pois corresponde um espaço de trabalho fundamental para iluminar o sentido da luta ambiental e fortalecer as bases da formação para a cidadania, procurando contribuir para o processo de construção de uma sociedade sensibilizada, capaz de formar cidadãos que apresentem uma nova visão entre homem e natureza, Corroborando com (SANTOS, 2014). 
Considerando a hipótese: se a educação ambiental for implantada nas escolas públicas do ensino fundamental, logo os alunos terão mais consciência da preservação do meio ambiente. Diante disso, este trabalho teve como objetivo avaliar o comportamento dos alunos dentro da sala de aula diante de uma nova abordagem sobre a Educação Ambiental, envolvendo palestras sobre lixo, coleta seletiva, reutilização de objetos, reciclagem de materiais encontrados no lixo e destino para o lixo não reciclável, de uma escola pública.

\section{MATERIAIS E MÉTODOS}

\section{1. ÁREA DE ESTUDO}

O Projeto de Educação Ambiental foi executado na Escola Municipal de Ensino Fundamental Agroambiental Professora Lindalva Pinho, que fica localizada na Av. Floriano Peixoto, S/N, Bairro do Cafezal, Cidade de Curralinho - Marajó - Pará. A referida escola atende uma clientela de alunos do $1^{\circ}$ ano 9o ano e EJA de $1^{\circ}$ a $4^{\circ}$ Etapa. O públicoalvo do projeto foram cerca de 60 alunos de duas turmas do 50 ano, divididos em dois turnos (manhã e tarde).

\subsection{MÉTODOS}

O projeto foi desenvolvido em uma semana (05 dias) através de atividades de palestras e oficinas. As palestras foram executadas no período da manhã, nos dois primeiros dias de realização do projeto. A primeira palestra tratou-se sobre: $A$ importância da preservação da fauna e da flora, racionamento da água, poluição do solo, da água e do ar, crimes ambientais e a biodiversidade local. No segundo dia de palestra foram abordados temas sobre: $O$ lixo no planeta, o destino final para o lixo sólido e orgânico, reciclagem e adubo a partir dos resíduos orgânicos em hortas escolares, de uma forma lúdica e dinâmica para que não se tornasse cansativo para aos alunos, fazendo sempre uma reflexão e uma pequena atividade com a turma. As palestras foram estendidas pela manhã.

As oficinas foram realizadas no decorrer da semana, durante o período da manhã, sempre com intervalo para o lanche, descritas a seguir: 
10- Oficina da Coleta Seletiva: Foram confeccionadas lixeiras com as cores da coleta seletiva a partir de recipientes de descarte comercial, para serem implantadas nas dependências da escola. Para isso foram feitos trabalhos com pintura e colagens. E posteriormente foi feito o trabalho de coleta de lixo dentro da escola e sua adequada separação nas lixeiras.

20- Oficina de Reciclagem: Onde foram trabalhados princípios de reciclar o lixo, orientações e pôr fim a confecção dos objetos e brinquedos a partir dos materiais recicláveis que os alunos trouxeram de casa e outros resíduos encontrados na escola. Foram feitos trabalhos de corte, pintura e colagens.

30- Oficina de Plantio: Foi realizada esta oficina no último dia com os alunos, onde já existia uma horta nas dependências da escola, mas até então sem uso, e os alunos tiveram a oportunidade de ter o contato com o ambiente natural, aprenderam o processo de adubagem da terra, dicas de como plantar sementes e mudas, como regar e cuidar da planta, para futuramente servir como complemento para a merenda escolar.

\section{RESULTADOS E DISCUSSÕES}

\subsection{1 $1^{\circ}$ DIA - 06/06 (SEGUNDA-FEIRA): APRESENTAÇÃO DO PROJETO, FALA DO DIRETOR E PRIMEIRA PALESTRA.}

O primeiro dia de atividades foi muito mais para desinibir os alunos com a presença do projeto, foram feitos diálogos sobre os temas e perguntas básicas à turma, sobre: O que entendem por Meio Ambiente? Qual a relação com o Meio Ambiente? Quais as atividades de educação ambiental já desenvolveram na escola? E assim os alunos foram criando uma confiança e despertando perguntas. O vídeo foi uma grande novidade na sala de aula, no qual inclusive, pediram para que reproduzisse pela segunda vez.

$\mathrm{O}$ aspecto afetividade influi no processo de aprendizagem e o facilita, pois nos momentos informais, os alunos aproximam-se do professor, trocando ideias e experiências várias, expressando opiniões e criando situações para, posteriormente, serem utilizadas em sala de aula. (MULLHER, 2002).

A primeira etapa do trabalho constou-se da palestra do projeto, da qual tiveram contatos com conceitos de meio ambiente, biodiversidade, fauna e flora, para depois 
discutir sobre sustentabilidade. Outros temas foram tratados como: biodiversidade, cultura amazônica, diversos tipos de poluição, suas causas e consequências, espécies ameaçadas de extinção, racionamento de água, dicas de como poupar água, desmatamento e crimes ambientais, onde os professores acrescentaram e relembraram os temas que já havia sido trabalhado em sala de aula.

Surgiram colocações, curiosidades e perguntas por parte dos alunos. Posterior ao debate na palestra foi reproduzido um vídeo sobre: Economia de água, o qual falava sobre maus hábitos com o desperdício de água e dicas de como poupá-la. Ao final da manhã foram distribuídas aos alunos duas atividades relacionadas à palestra do dia, uma delas foi para encontrarem as palavras em um diagrama e com as palavras encontradas formarem frases, algumas das palavras encontradas foram: peixes, rios, floresta, animais, ar, e a segunda atividade foram para eles desenharem em um papel em branco, como eles veem e conhecem o meio ambiente em que vivem.

\section{2. $2^{\circ}$ DIA - $07 / 06$ (TERÇA-FEIRA): SEGUNDA PALESTRA.}

No segundo dia, as atividades iniciaram com uma dinâmica envolvendo uma canção em sala para testar a capacidade de memória e coordenação motora dos alunos. A canção falava sobre o comportamento dos homens em uma tribo indígena, foi escolhida, pois era uma linguagem fácil de ser entendida pelos alunos, tendo em vista que o projeto foi desenvolvido em uma região amazônica, na ilha do Marajó. Foi importante para que os alunos observassem os cuidados que os homens deviam tomar, estando em um ambiente natural, onde os índios viviam em harmonia com os animais e árvores.

Segundo Guimarães (1995) o processo de Educação Ambiental a conjunção do aspecto lúdico e criativo das atividades e dos procedimentos, são importantes para envolver o educando. Reforça, inclusive, que a "sensibilização deverá ser seguida com uma relação prazerosa dele com o processo".

Foi ministrada a segunda palestra, que serviu como base teórica aos trabalhos que seriam executados ao longo do projeto durante a prática nas oficinas. Os temas abordados foram: O lixo no planeta, classificação dos tipos de lixos e destino final para eles, conceito de coleta seletiva e sua finalidade, reciclagem, minimização de lixo e a política dos 3R's que segue a ordem de Reduzir o consumo de enlatados, recipientes de 
vidro, caixas de longa vida, materiais descartáveis e sacolas plásticas, Reaproveitar tudo que for possível antes de jogar no lixo, por exemplo, uma garrafa pet para armazenar água e Reciclar o lixo, transformando-o em algum outro objeto para ser utilizado, conceito de compostagem e seu processo até chegar ao adubo final e a importância da horta nas escolas desde seu processo educacional até a alimentação saudável dos alunos.

Um vídeo (Figura 1 A) foi exibido sobre coleta seletiva e ainda foi exposto um banner com informações sobre coleta seletiva. Com a finalidade de testar a atenção dos alunos para com o tema, foram distribuídas balas de doces para todos e ao final do dia seria feita a reflexão dessa dinâmica.

Como reforço ao conteúdo apresentado, junto com a reprodução do vídeo abrimos a roda para perguntas e reflexão dos alunos sobre o tema, em seguida os alunos confeccionaram cartazes com temas relacionados às palestras (Figura 1B). Ao final das atividades foi questionado: onde eles haviam jogado a embalagem das balas? Alguns haviam jogado na lixeira da sala, mas a maioria jogou no chão da sala, o que despertou certo constrangimento e imediatamente todos recolheram seu lixo, e voltamos a discutir sobre nossos hábitos em relação ao lixo, a dinâmica serviu como forma de reflexão e muitos ficaram sensibilizados e envergonhados com a atitude.

Figura 1. Alunos assistindo o vídeo (A) e confeccionando cartazes para divulgarem nos corredores da escola o que aprendido em sala de aula (B).

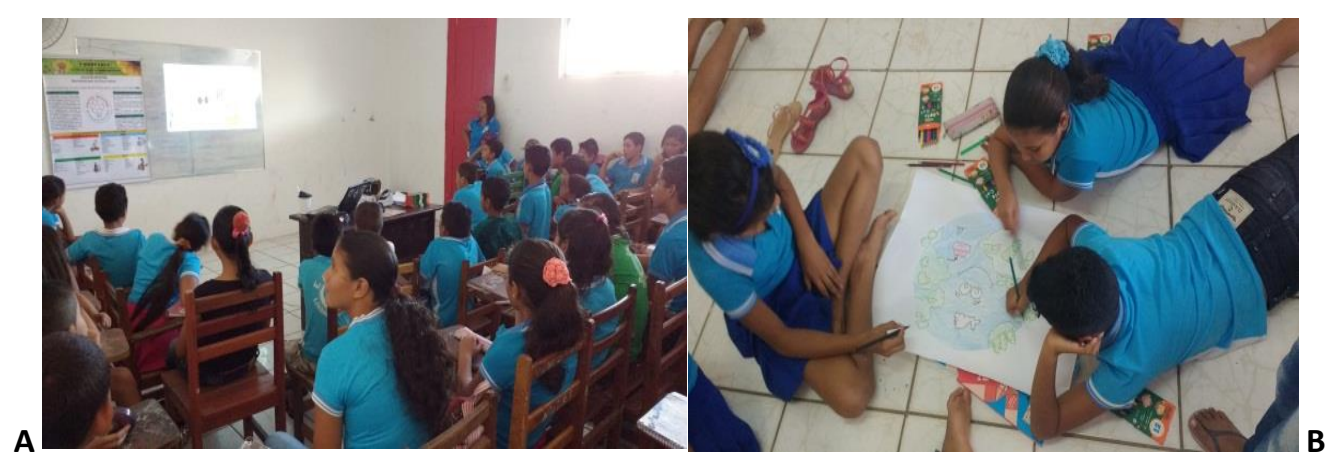

O contato com os alunos no segundo dia, já era de fácil aceitação, chegaram cedo e muito animados para as novidades que o projeto traria naquele dia. Notou-se grande empenho durante a dinâmica que envolveu a canção, houve muitas gargalhadas e 
muitos abraços, o que serviu para aproximar de alguma forma a turma que convive durante um ano. Os professores elogiaram a forma como o projeto estava mudando o comportamento dos alunos em sala e como o respeito entre os colegas e com os professores.

A educação ambiental deve ser acima de tudo um ato político voltado para a transformação social, capaz de transformar valores e atitudes, construindo novos hábitos e conhecimentos, defendendo uma nova ética, que sensibiliza e conscientiza na formação da relação integrada do ser humano, da sociedade e da natureza, aspirando ao equilíbrio local e global, como forma de melhorar a qualidade de todos os níveis de vida (CARVALHO, 2006).

\section{3. $3^{\circ}$ DIA - 08/06 (QUARTA-FEIRA): PRIMEIRA OFICINA (OFICINA DA COLETA SELETIVA)}

No terceiro dia de atividades, foi iniciada a primeira oficina, onde foi instigada a mente dos alunos a verem a mesma como instrumento de zelo pela escola e trabalho em equipe. Para a oficina, foram distribuídos às crianças, luvas de plástico e sacos para lixo a cada cinco alunos, formadas as equipes e dadas às orientações de como se realizaria a atividade, tratamos sobre a importância de utilizar luvas ao recolher qualquer tipo de lixo por conta de suas contaminações, e o descarte correto, tratandose especialmente de vidros quebrados, latas cortadas e lixo do banheiro.

Já devidamente preparados, com os materiais de coleta em mãos foram direcionados para fora da sala e orientados a recolher todo o lixo que fosse encontrado nas dependências da escola (FIGURA 2A), e junto aos outros alunos que estavam no horário do intervalo ajudaram a fazer uma "varredura" na escola, recolhendo todo lixo que se encontravam, dada a tarefa de qual seria a equipe a recolher mais lixo, e como forma de mutirão, os professores, funcionários e outros alunos ajudaram nessa tarefa que serviu como incentivo para todos tomarem consciência e manter limpo e conservado o ambiente escolar. Ao final da tarefa o lixo recolhido foi encaminhado para os grandes recipientes onde são acolhidos todo o lixo da escola, no retorno para a sala foi feita a reflexão com a turma sobre a atividade executada. 
De acordo com SILVA (2007), o lixo é um elemento presente na vida de qualquer pessoa, sendo um tema a ser trabalhado com os alunos, de forma interdisciplinar, objetivando a conscientização e a mudança de atitudes dentro e fora da sala de aula, assumindo um papel preponderante na formação do sujeito e na sua inserção social, agindo com consciência e atitude perante os problemas do meio ambiente.

Após a reflexão, os alunos receberam a tarefa de confeccionar os próprios lixeiros para a coleta seletiva, com o objetivo de ressaltar a eles a importância da coleta e separação do lixo. Com médios recipientes com tampa, os alunos pintaram nas cores da coleta seletiva e nomearam os respectivos para que fossem colocados dentro da escola e servissem de incentivo aos outros alunos de utilizarem as lixeiras feitas pelos colegas (FIGURA 2B).

A mais cansativa e de grande absolvição de conhecimento, é ousado dizer até de construção cidadã dos alunos, foi a oficina de coleta seletiva. Foram feitos muitas colocações e perguntas sobre o resíduo orgânico e notou-se a grande apreciação deles com o fato de se separar o lixo por cores, de como pode ser divertido trabalhar com o lixo, no momento de receber as luvas e as sacolas de lixo, houve grande empenho e compromisso em coletar todo o lixo que encontrassem, deixando a escola mais limpa.

Figura 2. Alunas fazendo a coleta do lixo na escola, e recebendo ajuda de alunas de outras turmas no mutirão feito na escola (A). Recipientes transformados em lixeiras, e distribuídos nas dependências da escola (B).

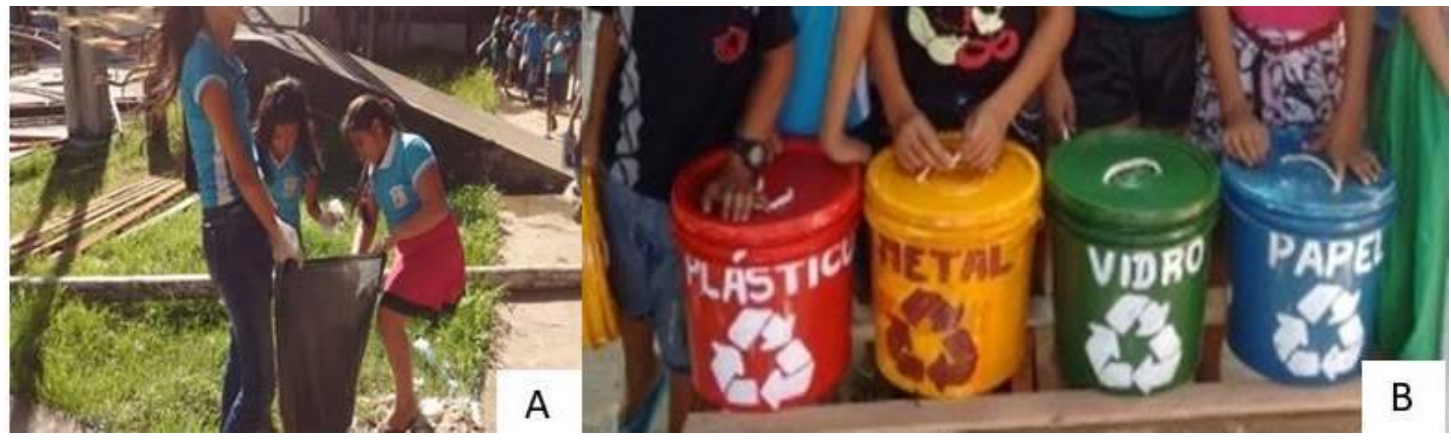

Durante a pesquisa foi observado que os discentes estavam mais atentos aos problemas que o acúmulo de lixo pode causar ao meio ambiente, as professoras cumpriram o próximo passo de incentivá-los a pensar em possíveis soluções para essa questão, mobilizando-os a separar o lixo em materiais recicláveis e não recicláveis, 
separando de acordo com a classificação universal (explicando que cada cor, em qualquer lugar do mundo, corresponde a um material: amarelo para metal; vermelho para plástico; azul para papel; verde para vidro; branco para lixo orgânico; e preto para outros tipos de materiais).

\section{4. $4^{\circ}$ DIA - 09/06 (QUINTA-FEIRA): SEGUNDA OFICINA (OFICINA DA RECICLAGEM)}

Foi executada a oficina de reciclagem, que baseada nas palestras sobre lixo, trabalhou-se a educação ambiental como forma de reaproveitamento do nosso lixo e suas infinitas possibilidades de transformação. As crianças foram orientadas a trazer para este dia todo o lixo que eles conheciam como reciclável, onde na palestra já havíamos tratado dos lixos recicláveis e não recicláveis, para então dar início a oficina de reciclagem dos lixos tragos pelas crianças (FIGURA 3).

Notou-se uma grande satisfação por parte das crianças, em estar trazendo para escola o material que se tornaria um brinquedo ou objeto para seu uso, e em mostrar aos seus colegas o quão estavam aprendendo com as oficinas, tendo em vista de que quando foram percebendo que aquele "lixo" por eles tragos, de repente e com um pouquinho de criatividade se transformavam em objetos dignos de ser exposto com orgulho à apreciação pública (FIGURA 4).

Um fato marcante observado durante a realização das oficinas foi a mudança de comportamento dos alunos com relação ao lixo. Isso foi observado quando se solicitou aos alunos que trouxessem para a primeira oficina as garrafas PET para serem aproveitadas e, apesar de todas as orientações com relação à limpeza das garrafas, a maioria dos alunos trouxeram-nas sujas e ficavam me aguardando no lado de fora do colégio, para que nenhum colega os visse chegar com o "lixo". Isso demonstrou a visão distorcida que os alunos possuíam do lixo, confirmando nossa hipótese de que eles percebiam o lixo como algo depreciativo, sujo, do qual eles se envergonhavam. Para a grande maioria deles, não estava associada ao lixo a ideia de matéria-prima e de fonte de criação de novos materiais e obras de arte. Nos primeiros dias do trabalho proposto, apesar da contextualização sobre o tema "lixo", a maioria dos participantes demonstrava certa resistência em trazer as "matérias-primas" (garrafas PET, 
embalagens longa vida e outros) solicitadas para o reaproveitamento, pois o constrangimento era maior, e frases como "eu não sou catador de lixo, professora"!", era muito comum. CASTRO (2008).

Nota-se que este fato se deu, devido à falta de uma preparação maior dos alunos para com o propósito de se trazer a garrafa pet, uma motivação a mais sobre o que seria feito e de que forma seria reproduzido para os outros alunos, pois a prática da Educação Ambiental pode ser repassada de diversas formas, cabe ao professor organizar e mediar o conteúdo ensinado, mobilizando afeto e desejo do aluno para que o mesmo se aproprie e transforme o conhecimento.

Para que os alunos iniciassem a confecção dos objetos a serem reciclados, foi feita uma amostra em vídeo de alguns objetos transformados a partir de garrafa pet, cd's, diversos recipientes, papeis e outros, e ensinados alguns os quais eles se identificassem e escolhessem, depois de dadas as orientações cada grupo se responsabilizou por um brinquedo ou objeto a confeccionar e com a ajuda dos professores para ferramentas de corte e cola com refil quente (FIGURA 3).

Figura3. Materiais trazidos pelos alunos para serem reciclados na oficina $(A)$ e brinquedos e objetos confeccionados pelos alunos durante a oficina (B).

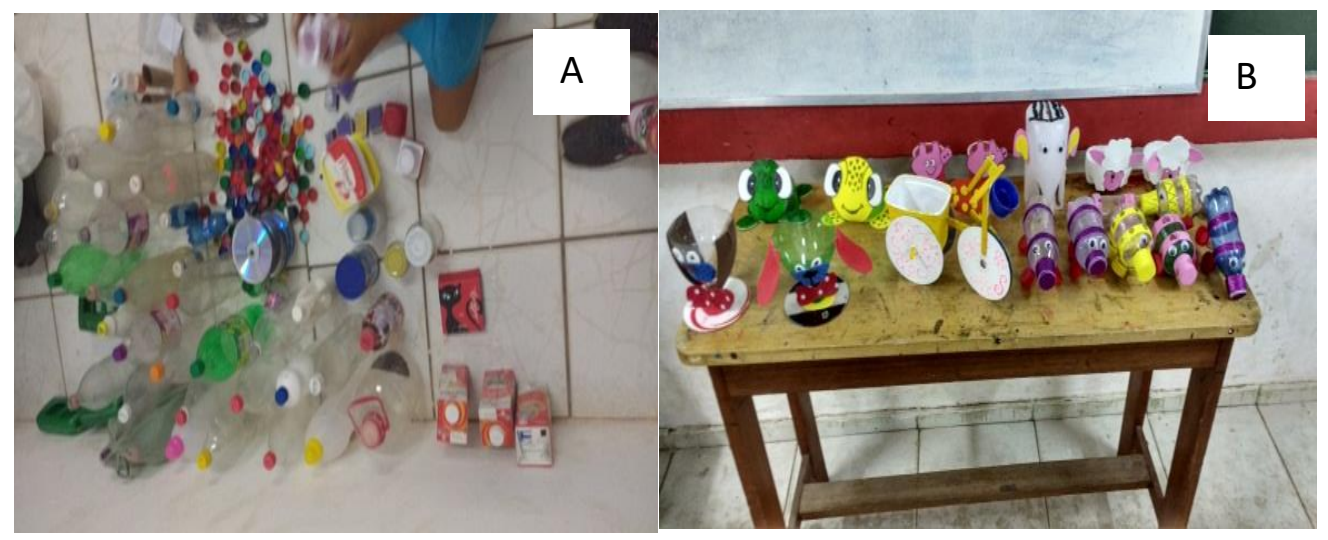

A ideia inicial do projeto de reciclar e reaproveitar matérias foram uma das possibilidades para se evitar a disposição inadequada dos resíduos sólidos disponíveis dentro da escola, e o empenho dos alunos com as atividades do projeto, foram as mais surpreendentes, dado até ao fato de muitos pedirem para que o projeto durasse mais tempo na escola ou que fosse feito de novo depois das férias de julho, é oportuno 
também comentar, que a mudança de comportamento foi observada nos professores e em outras pessoas que nem estavam observando as atividades do projeto, como as auxiliares da cozinha e os secretários. Quando estes funcionários da escola começaram a ver a movimentação dos alunos e o seu entusiasmo, começaram também a participar e incentivar os outros.

\section{5. $5^{\circ}$ DIA - 10/06 (SEXTA-FEIRA): TERCEIRA OFICINA (OFICINA DE HORTA E PLANTIO)}

Para esta oficina foram colocados em prática alguns conceitos aplicados em sala nas palestras, de como plantar e como cuidar de uma horta. Com o auxílio do responsável pela horta, a qual já era existente na escola, mas um pouco descuidada. Antes de iniciar as atividades, em duas semanas anteriores já havia feito um trabalho de limpeza, adubação e plantio das mudas (FIGURA 5), para que no dia da oficina as crianças apenas fossem plantar e regar as mudas.

Tratando-se de educação ambiental e redução de lixo, a ideia foi elaborar uma horta suspensa feita com garrafas pet, enfatizando a ideia de se reaproveitar todo o lixo encontrado. Foram cortadas as garrafas e pregadas em um painel de madeira, todas foram furadas para que o oxigênio e água circulassem sem interferir no desenvolvimento das mudas, em seguida cada criança em sua vez apanhava a terra já adubada para preparar o espaço que a planta ficaria, e assim foram preenchidos todos os recipientes de garrafa pet, após essa etapa, cada criança ficou com uma muda para plantar nas garrafas, e com cuidado de uma em uma elas foram orientadas do cuidado de tirar as mudas dos copos para outro ambiente (FIGURA 5). Outras mudas foram plantadas nos espaços que já existiam na horta, para serem reaproveitadas. Todas as mudas plantadas foram de hortaliças, dentre elas: Brassica oleracea L. (couve), Cucumis anguria L (maxixe), Allium schoenoprasum L. (cebolinha), Cucumis sativus L. (pepino), Lactuca sativa L. (alface), Phaseolus vulgaris L. (feijão) e Coriandrum sativum Lineu (coentro). 
Figura 5. Mudas plantadas em copos plásticos com 02 semana antes de serem utilizadas na oficina de plantio.

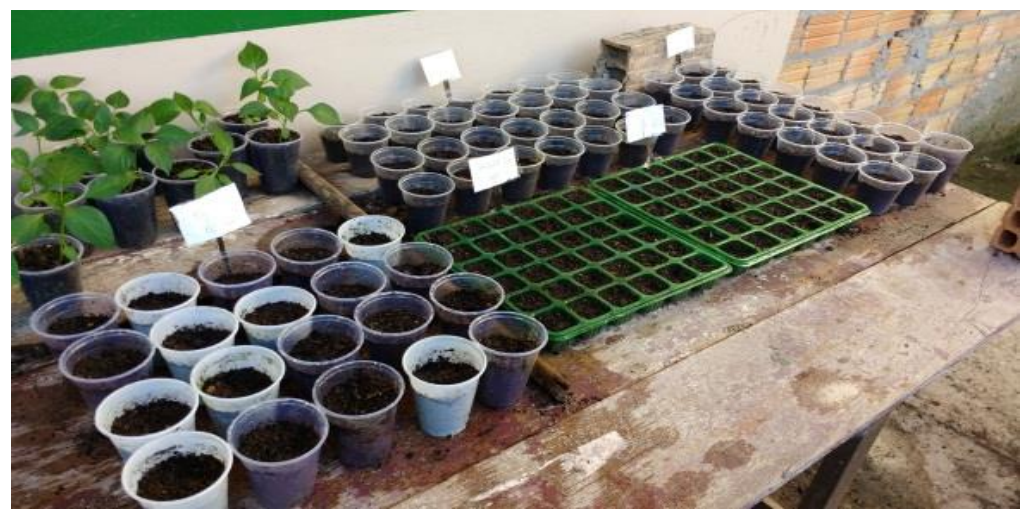

Ao final da oficina foi feito uma reflexão da importância da horta na escola, tanto para educação ambiental dos alunos como para a sua própria educação alimentar, de como as hortaliças que eles plantaram na escola seria servido na merenda escolar que era consumido na escola. A oficina possibilitou o contato direto dos alunos com a terra, podendo preparar o solo, conhecer e associar os ciclos alimentares de semeadura, plantio, cultivo ter cuidado com as plantas, além de ser um momento em que os alunos aprenderam a respeitar a terra.

"A horta inserida no ambiente escolar pode ser um laboratório vivo que possibilita o desenvolvimento de diversas atividades pedagógicas em educação ambiental e alimentar unindo teoria e prática de forma contextualizada, auxiliando no processo de ensino-aprendizagem e estreitando relações através da promoção do trabalho coletivo e cooperado entre os agentes sociais envolvidos." (MORGADO, 2008)

O Trabalho de construção da horta, o contato dos alunos com a terra e com as ferramentas utilizadas no manuseio e preparação da terra, foi bem recebido pelos, visto que a maioria é filho de agricultor ou em casa a mãe costuma cultivar hortaliças para o consumo da família e as crianças, principalmente as meninas acompanham esse processo e executam com satisfação.

É importante ressaltar a valorização da agricultura familiar, inserida na execução da oficina, pois, faz com que o aluno aprenda também na escola, a valorizar o trabalho da família na agricultura, construindo uma visão sustentável e econômica de plantar e colher, produtos saudáveis e de boa qualidade. Segundo FRISK, 2008: Através deste projeto os alunos terão a oportunidade de conciliar teoria à prática, aplicando o que se 
aprende na sala de aula. Assim levarão uma experiência valiosa para vida, já que a saúde do homem está ligada a uma alimentação saudável e rica em vegetais.

\subsection{QUESTIONÁRIO DE AVALIAÇÃO}

O questionário teve a intenção de avaliar a percepção dos discentes envolvidos na execução do Projeto de Educação Ambiental realizado na Escola Agroambiental Professora Lindalva Pinho, no Município de Curralinho - Pará.

O questionário teve como vantagem economizar tempo, abranger grande número de dados, atingir maior número de respostas mais rápidas e exatas, mais tempo para responder; horário favorável, tornando-se um instrumento de coleta de dados constituído por uma série de perguntas, que devem ser respondidas por escrito. As perguntas foram utilizadas no levantamento das informações de avaliação dos alunos em relação ao desenvolvimento do projeto, aplicadas de forma direta com auxílio dos professores, como podemos observar a seguir:

\subsubsection{O QUE VOCÊ ACHOU DO PROJETO DE EDUCAÇÃO AMBIENTAL NA ESCOLA?}

Conforme entrevista 28 (70\%) alunos afirmam ser excelente a iniciativa do projeto, $9(22,5 \%)$ alunos acham bom e $2(5 \%)$ alunos acham ruim, somente um aluno não respondeu essa pergunta, alguns afirmam que o projeto foi inovador e dinâmico.

\footnotetext{
"Eu gostei, porque a gente nunca teve nenhum trabalho assim na escola e agora sabemos por que devemos cuidar da escola e deixar ela limpa."

(Rana, aluna do 5ㅇ ano/tarde).
}

Houve grande acolhimento do projeto na escola, todos os alunos e professores e até mesmo os que estão apenas assistindo, como funcionário e outros alunos e professores agradeceram e deixaram o espaço escolar à disposição para quando houver futuros projetos, este será bem-vindo à escola. Foi de fato, um instrumento de transformação tanto no comportamento em sala de aula, quanto na relação deles com o meio ambiente, fazendo valer que a escola ficava na orla da cidade de frente para o rio e muitos deles passaram a observar as coisas erradas que outras pessoas faziam ali, despejando lixo no rio. 
Assim sendo é fundamental que a educação ambiental seja trabalhada e discutida nas escolas, pois desta forma os alunos não apenas conhecerão o meio ambiente como se ensina em algumas disciplinas específicas, mas aprendam a valorizar, preservar, respeitar o meio ambiente que ele mesmo se encontra, de forma com que sejam agentes ativos e modificadores, capazes de tomar posição e reverter a situação degradante que vivemos.

\subsubsection{VOCÊ APRENDEU ALGO IMPORTANTE PARA SUA VIDA?}

Observa-se que 36 (90\%) aprenderam a separar o lixo de acordo com a sua classificação, para não jogar lixo no lugar errado e não misturar resíduo orgânico do sólido, a reduzir e reciclar o lixo na escola, através das oficinas de reciclagem, onde ao fim da exposição cada um levou para casa seu trabalho, para construir mais objetos e brinquedos e compartilhar o aprendizado com outros colegas. Um fato marcante observado durante a realização das oficinas foi a mudança de comportamento dos alunos com relação ao lixo, notou-se essa mudança já no terceiro dia de atividades.

Por outro lado, foram observadas as duas atividades que mais os alunos gostaram a oficina de plantio, onde puderam mexer com a terra, construir a horta e cada um plantar a sua muda, na esperança que futuramente venha encontrar as hortaliças em sua merenda escolar e a oficina de reciclagem, onde puderam conhecer e aprender várias formas de se transformar o lixo. Três alunos $(7,5 \%)$ relataram que não aprenderam nada no curso, infelizmente houve certo desinteresse da parte de alguns alunos que no dia das palestras, saíram da sala e se recusaram a participar das oficinas, e somente um aluno não respondeu essa pergunta.

\subsubsection{VOCÊ INDICA AS ATIVIDADES DO PROJETO PARA OUTRAS TURMAS E ESCOLAS?}

Nesta pesquisa,38 alunos (95\%) dos entrevistados falaram que sim, afirmando que gostaram da iniciativa dizendo que nunca viram nada igual em outro estabelecimento escolar. E somente (2) $5 \%$ afirmam que não.

\footnotetext{
"Seria muito bom se a escola toda e outras escolas do município pudessem participar do projeto, para que aprender a fazer brinquedos e jogos a partir do nosso lixo."

(Vinicius de Carvalho Moraes, aluno do $5^{\circ}$ ano/tarde).
} 
Adotar o projeto em outras escolas representaria um grande benefício na formação dos alunos, aprendendo metodologias sustentáveis e se tronando multiplicadores, passando a trabalhar a educação ambiental, não só como forma de projeto, mas como disciplina na sua grade curricular.

Com a publicação da Lei 9.795 , de 27/4/99, que dispõe sobre a educação ambiental, institui a Política Nacional de Educação Ambiental e dar outras providências, a questão tomou força, pois a implantação e aplicação da Educação Ambiental como disciplina passou a ser obrigatória. A citada lei define juridicamente Educação Ambiental como "o processo por meio do qual o indivíduo e a coletividade constroem valores sociais, conhecimentos, habilidades, atitudes e competências voltadas para a conservação do meio ambiente, bem de uso comum do povo, essencial à sadia qualidade de vida e sua sustentabilidade" (art.1으).

\subsubsection{O PROJETO AJUDOU NAS SUAS ATIVIDADES ESCOLARES?}

Nota-se que $97,5 \%$ dos alunos aceitaram as atividades desenvolvidas no projeto e demonstraram boa aceitação e que ajudaram nas atividades da escola, tanto como forma de avaliação escolhida pelos professores, como no trabalho em conjunto exercido dentro e fora da escola e somente 1 aluno relatou que não, porque não conseguiu acompanhar e finalizar nenhuma atividade juntos com os outros alunos.

A prática da Educação Ambiental pode ser repassada de diversas formas, cabe ao professor organizar e mediar o conteúdo ensinado, mobilizando afeto e desejo do aluno para que o mesmo se aproprie e transforme o conhecimento. É de suma importância a base emotiva na relação professor e aluno, pois surge a dedicação e compromisso que complementam os conhecimentos na busca do indivíduo por uma melhor qualidade de vida. TRINDADE, (2011)

Segundo os professores, os alunos passaram a falar mais durante os assuntos na sala, questionar e acrescentar opiniões sentiram que os alunos ficaram mais desinibidos com as dinâmicas que o projeto estabelecia a eles, em momentos que cada um devia falar e escutar. $O$ entra e sai de sala também não se notava mais, o ato de arrumar as cadeiras da sala quando chegavam durante o projeto, hoje ainda continua fazendo em alguns dias. Isso demonstra como foi modificador e positiva a passagem do projeto na turma. 


\subsubsection{EM SUA OPINIÃO, ESSAS ATIVIDADES SÃO SUFICIENTES?}

Identifica-se que $52,5 \%$ dos entrevistados (21alunos) afirmam que sim, pois desencadearam uma serie de aprendizado com os trabalhos desenvolvidos e durante as palestras muitos mostraram domínios dos assuntos abordados, e que as palestras serviram muito mais para reforçar o conhecimento deles, do que ensinar, e 47,5\% (19) afirmam que não.

Devido ao curto tempo de duração das atividades que foram em apenas 06 dias, muitos deles pediram para que se estendesse por mais dias, pois estavam gostando e aprendendo, mas o tempo disponibilizado pela escola foi apenas de 06 dias, mais do que isso poderia atrapalhar as avaliações das turmas. Em virtude disso, foi feito o convite para que o projeto fosse executado em toda a escola, abrangendo todas as turmas e professores, tendo em vista que a escola trazendo uma proposta Agroambiental, não exercia nenhuma atividade de tal gênero.

\subsubsection{VOCÊ PRÁTICA ALGUMAS DAS ATIVIDADES DE EDUCAÇÃO}

\section{AMBIENTAL DO PROJETO?}

Para 90\% (36) dos alunos entrevistados, relatam que praticam as atividades de deposição do lixo em lugares adequados, economizam água e energia em casa e incentivam sua família a seguir da mesma forma, e observam as ações certas e erradas ao seu redor em relação à educação ambiental.

\footnotetext{
"Agora eu ando na rua e fico olhando quem joga lixo no chão e fico feliz quando alguém procura uma lixeira e não joga lixo no rio."

(Sadrak Nogueira Cavalcanti, aluno do $5^{\circ}$ ano/tarde).

"eu sempre que tomo banho ou escovo os dentes, desligo a água pra não estragar, e a minha mãe briga e diz que não pode desperdiçar água."

(Beatriz, aluna do 5o ano/tarde).
}

Entretanto 10 alunos (4\%) não praticam. Isso se deu a grande preocupação dos educadores e pais dos alunos em participarem com temas sobre a sustentabilidade do meio em que vivem.

A Educação Ambiental, não se faz somente durante o projeto na sala de aula, é um processo contínuo, em que haja prática e prazer em tomar atitudes que vá trazer 
melhorias ao meio ambiente em que vivemos. E foi notado que muitos daqueles alunos, ao final do projeto teriam atitudes diferentes em relação a jogar lixo no lugar certo, economizar água, ser mais consciente e educado, se policiar quanto a seus hábitos e de seus colegas. Dessa forma, as mudanças comportamentais, segundo REIGOTA (1994), devem acima de tudo, "levar os indivíduos e os grupos a adquirir o sentido dos valores sociais, um sentimento profundo de interesse pelo meio ambiente e a vontade de contribuir para a sua proteção e qualidade".

O resultado do projeto é evidentemente positivo. Considerando a participação dos alunos nas atividades do projeto, pode-se dizer que, a princípio, realizou-se com certo grau de desconfiança por parte deles. Fato este que se evidencia pelo pequeno número de alunos que não se interessaram com afinco pelo trabalho. Mas, logo no início do segundo dia de atividades já se podia notar o grau de interesse e conscientização por parte dos alunos através do diálogo e interação com eles mesmos, que se indagavam a respeito do que faziam e até denunciavam quem jogava lixo fora do lugar adequado. Houve também grande assimilação do conteúdo proposto nas palestras, que pôde ser percebido nas oficinas executadas, onde muitos alunos pareciam instigados a participar da construção de uma escola mais limpa e preservada.

Para responder a temática buscou-se apresentar a importância da reciclagem do lixo dentro da educação nas escolas. Buscando despertar a sociedade para a grande necessidade de se preocupar com o meio ambiente e com o futuro do nosso planeta. Houve grande desempenho nas oficinas de Coleta Seletiva e Reciclagem, percebeu-se o momento que os alunos se sentiram mais agentes colaboradores de um ambiente limpo e abraçaram com grande afinco as mudanças de hábitos dentro da escola, com entusiasmo e trabalho em equipe. O projeto culminou com uma exposição dos trabalhos de reciclagem (anexos 4, 5 e 6) feitos pelos alunos que participaram da intervenção na escola no qual foram apresentados aos pais, colegas, professores e toda a comunidade que foi apreciar o trabalho desenvolvido.

Foi observado que os professores preocupados em seguir rigorosamente o planejamento curricular da disciplina, não criam espaços para a discussão ambiental. Quando esses momentos são organizados nas escolas, é comum que se modifique a organização habitual da sala de aula, nas quais os alunos ficam sentados e em silencio. 
Assim atividades extracurriculares ou que fogem do conteúdo tradicional são entendias como indisciplina. O próprio desconhecimento dos professores acerca do tema meio ambiente e educação ambiental contribuem para as percepções distorcidas. CASTRO (2008)

Dar-se a entender que a ideia de trabalhar a educação ambiental, é uma perda de tempo, atrapalha o desenvolvimento dos conteúdos, eles fazem uma relação direta e imediata com algum conteúdo especifica da disciplina, que esteja no seu conteúdo programático, é como se eles precisassem de uma "licença" para trazer a discussão ambiental para dentro das suas aulas, pois não está presente na sua grade curricular.

Foi constata a ausência dessa temática, do uso de técnicas em que o professor trabalhasse a educação ambiental em sala de aula e fora dela, conforme relatado pelos professores, o Projeto de Educação Ambiental foi a primeira programação a ser trabalhada exclusivamente com práticas fora da sala de aula e com dinâmicas acessíveis para os alunos, onde a maioria conseguiu assimilar a proposta do projeto e houve grande participação.

\section{CONCLUSÕES}

Formar cidadãos conscientes e opinantes sobre questões ambientais, capazes de se sensibilizar com qualquer problema que surgir em seu ambiente escolar ou em casa, aderindo aos conhecimentos adquiridos ao longo do projeto. Alcançar o número máximo de alunos esperados para a realização das atividades do projeto, e obter ajuda dos professores, pais, gestores e comunidade, que será de grande incentivo para despertar nos alunos a vontade de melhorar a situação do meio ambiente. Executar todas as tarefas previstas postas neste projeto com o máximo de aproveitamento de todos.

Espera-se que ao final das atividades realizadas durante a execução do projeto, os alunos e professores que participarão diretamente possam levar aos seus colegas e familiares a importância de cuidar e preservar do meio ambiente. Que as palestras sirvam como base de esclarecimento e melhor conhecimento dos assuntos a serem abordados. 
As atividades de coleta seletiva e oficinas de reciclagem e plantio sejam de total aproveitamento e sejam levadas para outros espaços, e que a escola dê continuidade junto às famílias e que sirva de exemplo para outras escolas desenvolverem práticas de melhoria sustentável, com o mesmo propósito que este projeto está sendo aplicado para a formação de cidadãos conscientes da preservação do meio ambiente, e estarem aptos a executar pequenas ações coletivas de cuidados com o meio em que vivem para que no futuro construam uma sociedade sustentável.

Trabalhar com um tema bastante inovador e ainda pouco trabalhado no contexto escolar como a Educação Ambiental foi muito desafiador e ao mesmo tempo prazeroso. O crescimento e difusão da Educação Ambiental é extremamente importante para podermos dar condições melhores de vida às futuras gerações. Propõe-se que a Educação Ambiental deixe de ser um tema transversal e passe a ser uma disciplina separada, assim, se daria uma importância maior ao tema e se teria mais tempo para trabalhar com a conscientização das pessoas desde a escola, fazendo com que o trabalho pedagógico, então, deva se concentrar nas realidades de vida social mais imediatas, tendo em vista os grandes problemas ambientais que surgem a cada dia no planeta.

Podemos afirmar que a autoestima de cada aluno foi acrescida a partir do lixo, no exato momento em que perceberam a capacidade e o potencial de cada um em criar e fazer lindos objetos, um momento mágico em que se tornaram verdadeiros artistas. Esse fato associa-se também à valorização humana e a transformação dos modos de relação dos seres humanos com o seu ambiente, princípios essenciais da Educação Ambiental.

Conclui-se, então, que a necessidade de formar e aperfeiçoar docentes de todos os níveis é imprescindível para que se projete no futuro um profundo envolvimento da educação formal com o meio ambiente. Só assim será possível gerar reflexões, discussões e práticas que, efetivamente, conduzirão a uma Educação Ambiental de qualidade. 


\section{REFERÊNCIAS}

AMBIENTE BRASIL. Educação ambiental. Manaus - AM, 2008. Disponível em: www.ambientebrasil.com. Acesso em: 17 de Mai. De 2016

BRASIL. Ministério da Educação. Secretaria da Educação Fundamental. Média e Tecnológica. Parâmetros Curriculares Nacionais $+(\mathrm{PCN}+)$-. Meio ambiente, saúde. Vol.9. Brasília: MEC, 2002. 128p.

BRASIL. Política Nacional de Educação Ambiental. Lei no 9.795 de 27 de abril de 1999. Dispõe sobre a educação ambiental, institui a Política Nacional de Educação Ambiental e dá outras providências. Diário Oficial da União, Brasília, DF, 28 de abril de 1999. Seção 1, p.41. Disponível em: <EDUCAÇÃO AMBIENTAL\PNEA 2.pdf>. Acesso em 17. Abr. 2016.

CARVALHO, I. C. M. Educação ambiental: a formação do sujeito ecológico. 2.ed. São Paulo: CORTEZ, 2006. (Coleção Docência em formação). Disponível em: < file://C:/Users/Sabrina/Downloads/659-2697-1-PB.pdf> Acesso em: 09 de Ago. de 2016

CASTRO, M. A. de. A Reciclagem no contexto escolar. Ponta Grossa - PR, 2008. Disponível em: < EDUCAÇÃO AMBIENTAL\reciclagem no contexto escolar.pdf> Acesso em: 09 de ago de 2016

CHALITA, G. Educação: a solução está no afeto. São Paulo: Editora Gente, 2002. [S.I.] p. 272.

CICHELLA, F.; COELHO, J. M. S.; RESENDES, L. M. Educação ambiental: Direcionando a busca. 2007. http://www.satc.edu.br/satc/fotos/2007/860/3_forum_ambiental.pdf> Acesso em: 22 Mai 2016.

CUBA, M. A. Educação Ambiental nas escolas. ECCOM, v. 1, n. 2, p. 23-31, jul./dez., 2010. EDUCAÇÃO AMBIENTAL\CUBA educação ambiental nas escolas artigo.pdf> . Acesso em 15. Mai. 2016.

EFFTING, Tânia Regina. EDUCAÇÃO AMBIENTAL NAS ESCOLAS PÚBLICAS: REALIDADE E DESAFIOS. Monografia apresentada ao Curso de Especialização "Planejamento para o Desenvolvimento sustentável", da Universidade Estadual do Oeste do Paraná,2007. Disponível em: EDUCAÇÃO AMBIENTAL\educação ambiental nas escolas, desafios - artigo.pdf> Acesso em: 20 de abril de 2016.

EFFTING; T.R. Educação ambiental nas escolas públicas: realidade e desafios. Monografia. Curso de Especialização: Planejamento para o Desenvolvimento Sustentável. Universidade Estadual do Oeste do Paraná. 2007. Disponível em:<EDUCAÇÃO AMBIENTALleducação ambiental nas escolas, desafios artigo.pdf >Acesso em: 17 Mai 2016. 
FRISK, P. R; Horta na Escola; Publicado, 2008. <EDUCAÇÃOAMBIENTAL \friskdesenvolvimento escolar HORTA.pdf> Acesso em 02 de ago de 2016.

GUIMARÃES, M. A dimensão ambiental na educação. Campinas. Papirus, 1995. 107p. (Coleção Magistério: Formação e trabalho pedagógico). Disponível em: A dimensão ambiental na educação. Campinas. Acesso em: 20 de abril de 2016.

MORGADO, F; S. A Horta Escolar na Educação Ambiental e Alimentar: Experiência do Projeto Horta Viva nas Escolas Municipais de Florianópolis, 2008. Disponível em: http://www.extensio.ufsc.br/20081/A-hortaescolar. pdf> Acesso em 02 de ago 2016.

MULLER, L. S. A interação professor-aluno no processo educativo. São Paulo, 2002. $276 p$.

http://www.usjt.br/proex/arquivos/produtos_academicos/276_31.pdf> Acesso em: 20 de abril de 2016.

REIGOTA, M. O que é Educação Ambiental? São Paulo: Ed. Brasiliense, 1994.

SALERA JUNIOR, G. Educação ambiental. Gurupi - TO, 2009. Disponível em: < http://www.recantodasletras.com.br/e-livros/1966292> Acesso em: 15 Abr. de 2016

SANTOS, A. S. Como a educação ambiental está sendo trabalhada em cabedelo? Um estudo de caso na escola municipal silvana oliveiraponteS. Cabedelo-PB, 2014. Disponível em: EDUCAÇÃO AMBIENTALISANTOS- A. S. Como a Educação Ambiental...pdf> Acesso em: 20 de abril de 2016.

SILVA, D. T. S. Educação Ambiental: Coleta Seletiva e Reciclagem de Resíduos Sólidos na Escola. Cachoeirinha-RS: FASB, 2007.

SOUZA, G. S. de.; MACHADO, P. B.; REIS, V. R. dos.; SANTOS, A. S. dos.; DIAS, V. B. Educação ambiental como ferramenta para o manejo de resíduos sólidos no cotidiano escolar. RevBea, Rio Grande, V. 8, N. 2:118-130, 2013.

SOUZA, P. P. S. de; PEREIRA, J. L. de G. Representação social de meio ambiente e educação ambiental nas escolas públicas de Teófilo Otoni - MG. RevBea, Rio Grande, n. 6, p. 35-40, 2011. Disponível em: http:/www.seer.furg.br/revbea/article/view/2031/1040>. Acesso em: 20 de maio de 2016

TRINDADE, N. A. D. Consciência ambiental: coleta seletiva e reciclagem no ambiente escolar. Itapetinga - BA, 2011. ENCICLOPÉDIA BIOSFERA, Centro Científico Conhecer - Goiânia, vol.7, n.12; 2011. 


\section{CAPÍTULO XI}

\section{ARTE E EDUCACÃO EM PROL DO MEIO AMBIENIE}

\section{DOI: 10.51859/amplla.mas481.1121-11}

Joslaine Aparecida Regióli de Angelis ${ }^{1}$ Marco Antonio de Andrade Belo ${ }^{2}$

\footnotetext{
'Mestre em Ciências Ambientais, Universidade Brasil (UB), Campus de Fernandópolis,SP.

2 Professor Titular. Programa de Pós-Graduação em Ciências Ambientais, Universidade Brasil (UB), Campus de Fernandópolis,SP.
}

\section{RESUMO}

Marcado pelo significativo crescimento de resíduos sólidos descartados no meio ambiente e na necessidade de criar uma consciência coletiva de proteção ambiental, o presente trabalho teve como objetivo demonstrar a importância da arte na educação e formação da nova geração, dando um novo significado aos resíduos sólidos da zona rural do município de Auriflama, São Paulo, promovendo uma estratégia de conciliar as atividades de arte na educação juvenil à consciência de preservação do meio ambiente. As aulas iniciam-se junto às caçambas de coleta de resíduos sólidos dos bairros da zona rural, local em que os alunos são expostos à realidade do descarte, muitas vezes, de forma incorreta, tornando-se um momento de conscientização e reflexão das novas dinâmicas sociais e seus efeitos deletérios, assim como, criando um campo fértil de discussão de possíveis estratégias para minimizar os impactos negativos destes resíduos. Neste contexto, os alunos são estimulados a buscarem nos resíduos sólidos objetos para o desenvolvimento de aulas de arte, os quais devem receber uma transformação artística, ganhando novos sentidos, para retornar com outra utilidade, em forma de arte e proteção ao meio ambiente. Os resíduos coletados durante as aulas são limpos e modificados, abandonando o seu sentido original, e reproduzidos em novas peças, como arte. Uma releitura se tornou possível, através do novo. Contudo, os resultados deste estudo demonstraram a eficácia desta nova dinâmica pedagógica na formação dos jovens, promovendo educação ambiental através da arte transformadora, constituindose como uma estratégia didática promissora para semear nas futuras gerações a necessidade de preservação do meio ambiente.

Palavras-chave: Arte. Educação. Resíduos sólido. Meio ambiente. Zona rural.

\section{INTRODUÇÃO}

A destinação dos resíduos sólidos da atividade humana é um dos maiores problemas que afetam os municípios brasileiros (WALDMAN, 2010). O crescimento 
populacional e o desenvolvimento tecnológico favorecem cada vez mais ao aumento destes materiais, até mesmo na zona rural que teve sua população diminuída pelos fluxos migratórios para os centros urbanos (HOGAN, 1993).

A educação ambiental deve ser um processo sistematizado, que engloba o pensamento num todo, responsável por formar indivíduos preocupados com 0 ambiente desde a processo educacional infantil (GRZEBIELUKA et al., 2014), que busquem a estratégia de orientar para conservação e preservação dos recursos naturais, além incutir a filosofia de responsabilidade social e sustentabilidade. E estar preparado para abordar os seus aspectos socioeconômicos, sociais, tornando-se a base para uma ação política transformadora na sociedade (VARGAS, 2005).

Instituído pelo governo federal, os parâmetros curriculares nacionais (PCNs) constituem-se em diretrizes elaboradas para orientação dos educadores, estabelecendo normatizações e protocolos para as diversas disciplinas e segundo RIGOTTI et al. (2019), a disciplina de arte deve ser vista na escola como uma atividade integradora de personalidade, pois o aluno deve usar sua percepção, seus conceitos, sua emoção, sua intuição, entre outros. Enfim integrar um complexo de sentimentos na sua manifestação artística. Neste contexto, conciliar aulas de arte à educação ambiental representam uma ferramenta importante de ação incentivadora da criatividade e desenvolvimento de diferentes percepções e sensibilidades que auxiliam na conscientização e ações transformadoras para melhorar a gestão de resíduos sólidos na sociedade (ARAÚJO \& ALVES, 2021).

O presente trabalho teve como objetivo demonstrar a importância da arte na educação e formação da nova geração, dando um novo significado aos resíduos sólidos da zona rural, tornando as aulas de arte um momento de conscientização e reflexão das novas dinâmicas sociais e seus efeitos deletérios, buscando estratégias didáticas para minimizar os impactos negativos destes resíduos na sociedade.

\section{REVISÃO BIBLIOGRÁFICA}

\subsection{RESIDUOS SÓLIDOS}

De acordo com a Lei no 12.305 (BRASIL, 2010), a definição de resíduos sólidos está expressa no art. 3ㅇ, inciso XVI: 


\begin{abstract}
"XVI-resíduos sólidos: material, substância objeto ou bem descartado resultante de atividades humanas em sociedade, a cuja destinação final se procede, se propõe proceder ou se está obrigado a proceder, nos estados sólido ou semissólido, bem como gases contidos em recipientes e líquidos cujas particularidades tornem inviável o seu lançamento na rede pública de esgotos ou em corpos d'água, ou exijam para isso soluções técnica ou economicamente inviáveis em face da melhor tecnologia disponível."
\end{abstract}

A população da zona rural produz resíduos sólidos com características significativamente diferentes quando comparadas ao lixo de populações urbanas. Segundo Cruz et al. (2013), o problema na área rural é expressivo, poisos resíduos sólidos apresentam significativo descarte de resíduos oriundos atividade agropecuária de produção vegetal e animal. E de acordo com este autor, os habitantes da zona rural nem sempre contam com sistema de coleta de lixo ou de esgoto, fato que precariza ainda mais a situação no campo.

Os resíduos lançados no meio ambiente provocam profundas alterações, contaminando recursos naturais de água, prejudicando a saúde e a qualidade de vida no planeta. Muitos esgotos são bloqueados com resíduos descartados nas beiras dos caminhos que levam a zona rural, prejudicando o escoamento da água. As queimadas prejudicam ainda mais a poluição do ar e sem contar que os resíduos descartados provocam a poluição visual. Portanto, podem causar poluição dos solos, águas, ar, contribuir com o aquecimento global e destruição da camada de ozônio.

Assim, mesmo a população rural representando uma porcentagem menor em relação à urbana, os malefícios decorrentes de resíduos sólidos são prejudiciais ao meio ambiente, sendo responsabilidade de todos os segmentos da sociedade civil e do poder público buscar soluções que amenizem estes problemas.

\title{
2.2. EDUCAÇÃO AMBIENTAL
}

A educação ambiental foi incluída pela primeira vez no Plano Plurianual do governo federal, em 1996. E no ano de 1999, a Lei 9.795 que institui a Política Nacional de Educação ambiental. E a Resolução das Nações Unidas no 57/254 que estabeleceu a década da Educação para o desenvolvimento Sustentável, entre os anos de 2005 e 2014. 
Antes da estruturação do PDDE- Programa Dinheiro Direto na Escola Sustentável, a educação ambiental, estava restrita a pouquíssimas disciplinas ou a datas comemorativas, como a Semana da Água, Dia da árvore e outras.

Para Capra (2008), as pesquisas iniciadas há décadas passadas apontam que expor crianças a um ambiente rico em experiências sensoriais e desafios cognitivos tem efeitos positivos no desenvolvimento da criança.

Segundo os Parâmetros Curriculares Nacionais (PCN), a concepção de ensino de arte é a Metodologia triangular, onde as aulas devem atingir o fazer, contemplar e contextualizar e assim, informar e desenvolver os alunos. Ou seja, preparar os sujeitos para serem cidadãos ativos e agir com responsabilidade. De acordo com Oliveira e Hérnandez (2015), diante da cultura visual, não há receptores nem leitores, mas construtores e intérpretes na medida em que a apropriação não é passiva nem dependente, mas interativa e de acordo com as experiências que cada indivíduo tenha experimentado fora da escola.

Assim, através da arte é possível desenvolver nos alunos senso de observação, conhecimento da cultura e o desenvolvimento como um todo. $O$ aluno passa a ser o sujeito responsável pela arte e pelo ambiente que vive e qualidade de vida da sociedade.

Portanto, as alterações podem ser comparadas com a vida do homem, que passa por várias mudanças, e a cada uma levando a reconstrução. Sendo assim, a arte se assemelha a vida humana, dependendo do olhar de cada ser, uma analogia.

Oliveira et al. (2017) discutiram que a produção da arte não precisa ser tradicional, ela pode ser produzida através de elementos residuais. Assim, os resíduos sólidos, marcados de acontecimentos durante os anos, podem ganhar uma grande ação utilitária ou meramente artística.

É de extrema importância levar ao observador a reflexão da vida atual, e pela renovação de sentidos, desconsiderando o passado e aproveitamento da essência, e estar apto ao novo, criar novos caminhos e possibilidades. Harvey (2012) relata sobre a observação significativa, quando mencionou as criações inesperadas. Ou seja, resíduos, se engrandece através da criatividade do artista.

No passado, o lixo e a arte tinham seus sentidos bem definidos e distantes, já no século XX o movimento artístico, o dadaísmo, encontrou no lixo uma forma de 
transgressão e insensatez humana. São vários artistas plásticos que trabalham com resíduos, Jac Leirner, Cildo Meireles, Hélio Oiticia e um grande exemplo é o documentário Lixo Extraordinário, sobre a obra de Muniz, que faz renascer objetos que descartamos, o artista plástico produziu telas gigantescas com o lixo coletado.

A escola é o local mais propicio para que as crianças tenham a orientação, no Ensino Fundamental I que eles buscam se aproximar do mundo dos adultos, para edificarem seu próprio mundo.

Segundo Ana Mae Barbosa (2020):

\begin{abstract}
“Apesar de ser um produto da fantasia e imaginação, a arte não está separada da economia, política e dos padrões sociais que operam na sociedade. Ideias, emoções, linguagens diferem de tempos em tempos e de lugar para lugar e não existe visão desinfluênciada e isolada. Construímos a história a partir de cada obra de arte examinada pelas crianças, estabelecendo conexões e relações entre outras obras de arte e outras manifestações culturais".
\end{abstract}

Palhaci et al. (2012) diz que, a cultura moderna valoriza apenas o novo. 0 reaproveitamento de resíduos é um incentivo à criatividade para transformação e minimização de impactos ambientais. Já para Vicini (2006), o trabalho com resíduos, oferece comunicação entre as pessoas e leva a reflexão, tornando o material construído um canal de comunicação. .

\title{
3. MATERIAIS E MÉTODOS
}

A pesquisa foi realizada no Bairro Santa Lourdes-Auriflama/SP, a partir dos resíduos encontrados no fundo de quintais, estradas, plantações e caçambas. Segundo secretário da administração pública, o município possui uma população total de 14.205 habitantes, dos quais 1.255 vivem na área rural, sendo o Bairro Santa Lourdes escolhido por apresentar diversidades de cultura agrícola e o maior contingente populacional rural do município. Foi enviado ao Prefeito à carta convite e esclarecimento sobre a pesquisa, depois o Termo de Consentimento Livre e Esclarecido.

Os resíduos foram coletados nas caçambas (Figura 1) e propriedades, com a autorização dos proprietários, como implementos agropecuários e agrícolas e de residências rurais, tambores de plástico e papelão, frascos plásticos, disco de arados, pneus, rolos de lona, e assim conduzidos a escola. 
Figura 1 - Aula de arte iniciando com a coleta de peças de resíduos sólidos e conscientização dos alunos do descarte incorreto e destinação do lixo, realizada no Bairro Santa Lurdes, zona rural do município de Auriflama, SP (Fonte: Joslaine de Angelis, 2019).

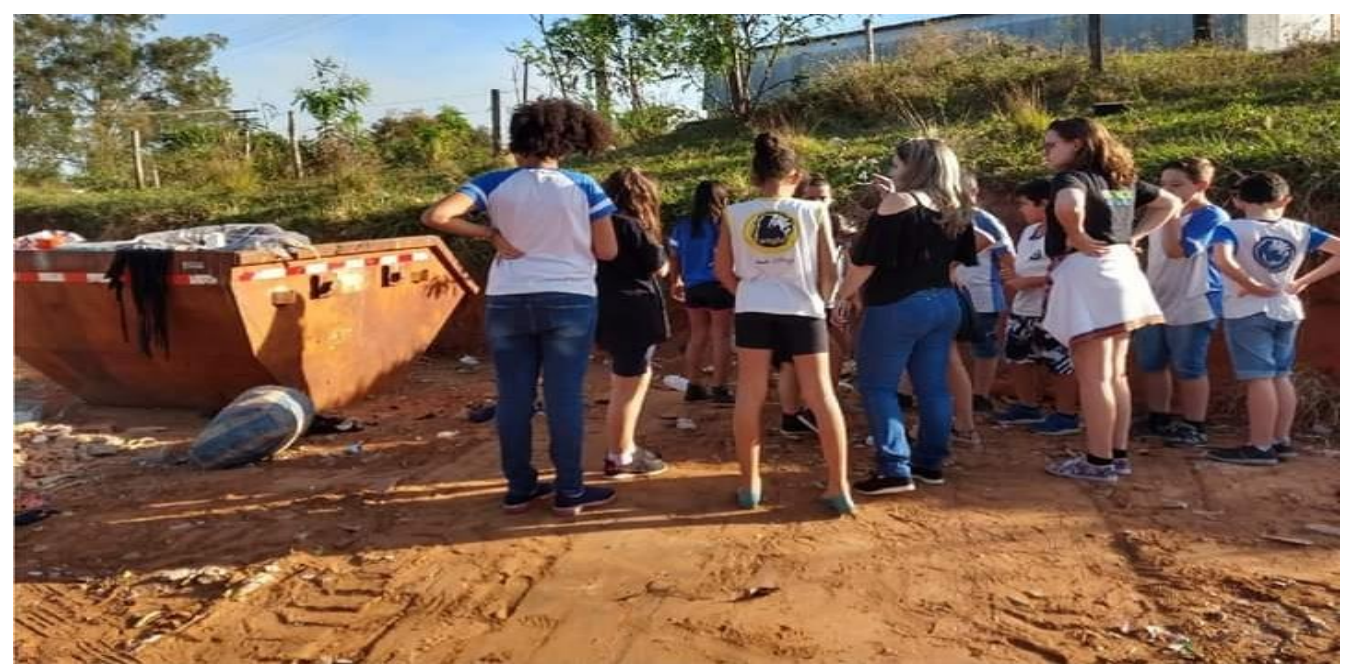

Após limpeza foram separados os maiores, mais pesados e que necessitam de mais técnica e segurança para permaneceram no Ateliê localizado na zona rural do bairro, os menores com maior facilidade de transporte e armazenamento levados para o Colégio Lázaro Silva, localizado na cidade de Auriflama.

No Ateliê as peças foram trabalhadas uma a uma, algumas lixadas para depois serem reinventadas, como os tambores de papelão e plástico, disco de arados e rolos de lona, depois encaminhadas para a escola. Os tambores de papelão receberam a tinta primer, pva e toques de betume e acessórios como pés, puxadores nas tampas e fitas de espelho, e tornaram cestos de roupas. Já os tambores plásticos foram envolvidos com restos de sisal recolhidos nas máquinas de feno e se transformaram em cachepôs para vasos.

Os discos de arados foram diversificados em várias peças, fruteiras revestidas com sisal, pintura com goma laca e purpurina dourada envelhecida ou suportes para vasos após serem anexadas cordas trançadas ou correntes para pendurar. Os pneus foram anexados de dois em dois com parafusos, receberam espumas e capas de tecido, tornaram pufes. Os rolos de lona maiores foram serrados e passaram pelo mesmo processo dos tambores de papelão e tornaram lixeiras, porta trecos, dentre outros, apresentando um efeito de madeira rústica após a finalização. 
Antes dos resíduos serem coletados, os alunos visitaram algumas propriedades rurais, estradas e a caçamba localizada na entrada do bairro rural, fotografaram e fizeram anotações sobre materiais encontrados descartados na natureza.

Após passeio pela zona rural os resíduos menores foram levados para a escola e apresentados aos alunos do Fundamental I, contextualizados com as disciplinas de Arte e Ciências. Após serem limpos e lixados os frascos plásticos foram decorados pelas crianças e serviram de vasinhos para agregar plantas. Os potes de sorvete e de alumínio foram trabalhados e tornaram potinhos que abrigaram kit de sementes (Figura 2A) para serem distribuídos no Dia da Árvore, com sementes de ipê, coco gabiroba e girassol (Figura 2 B). Muitos já plantados e florescendo (Figura 2C e 2D).

Figura 2 - Ações de educação ambiental. (A) Potes com sementes distribuídos aos alunos no Dia da Árvore. (B) Sementes de coco e ipê coletadas no dia do passeio. (C) Mudas de ipê plantadas por alunos que receberam o kit no Dia da Árvore. (D) As sementes de girassol distribuídas juntamente com as outras no Dia da Árvore e plantadas pelos alunos, produzindo flores e abrigando abelhas. A imagem relata a alegria do aluno do quarto ano ao observar a planta que cultivou (Fonte: Joslaine de Angelis,

2019).
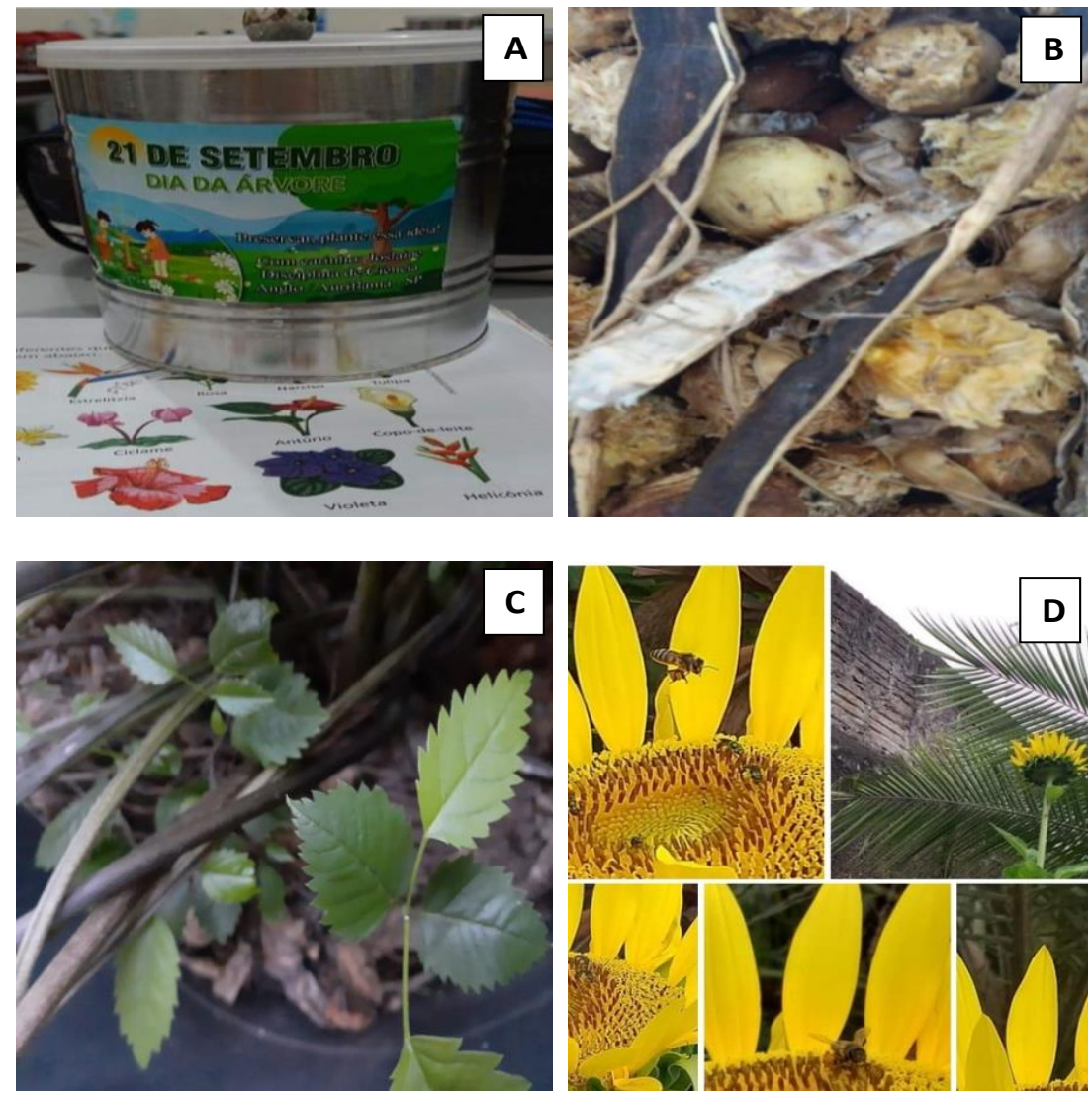

WWW.AMPLLAEDITORA.COM.BR $(7)$ CONTATO@AMPLLAEDITORA.COM.BR 
Já os rolos menores de lona após serem cortados, passaram pela mesma técnica do balde de papelão, realizado pela professora e alunos do fundamental I e depois no Dia das Crianças foram entregues aos alunos, com bombons.

Os alunos foram direcionados em três momentos, o primeiro para a visita nas propriedades rurais, estradas e caçambas, com pesquisa investigativa. E no segundo momento a contextualização com as disciplinas de Arte e Ciências e assim a confecção dos trabalhos, priorizando o trabalho em grupo. O terceiro a apreciação das peças pelos trabalhos que necessitaram mais técnica e segurança que foram iniciadas no Ateliê e levados para a escola, onde ficaram expostos juntamente com relatórios redigidos pelos alunos e professora, para apreciação de toda comunidade escolar.

\section{RESULTADOS E DISCUSSÃO}

O trabalho "Arte e educação em prol do meio ambiente", realizado no bairro Santa Lourdes com alunos do fundamental I e colaboração do Ateliê Jô, permitiu vários resultados pedagógico no ensino de Artes Visuais e ao meio ambiente, que serão refletidos nas famílias dos alunos, professores, funcionários e a todas as pessoas envolvidas com a pesquisa diretamente ou indiretamente. Visto que a ferramenta mais eficiente é o alcance de novos comportamentos das pessoas.

O trabalho se desenvolveu frente à proposta de reconstrução e busca de novos sentidos aos resíduos, material que não é mais utilizado e que já serviu para determinada função. Assim, deveria ser parte da educação consciente nas escolas, percepção ecológica, reaproveitamento de resíduos, oportunidade de ferramenta educacional e assim uma vida adulta melhor.

As palavras de Harvey (2012) sobre as criações inesperadas, onde o resíduo se engrandece através da criatividade do artista veem ao encontro da pesquisa, uma proposta de transformação, de utilidade. A mobilização da comunidade para práticas correta quanto à utilização de resíduos pela arte, pode ser mais efetiva direta nas escolas, casa da agricultura, igrejas, associações e sendo um forte instrumento para resultados ambientalmente corretos, a curto, médio e longo prazo.

Um grande exemplo são os enfeites de Natal da cidade de Santa Fé/SP, o poder público mobiliza as escolas e consequentemente toda a população passa a reciclar os 
resíduos para os enfeites da cidade, economia nos cofres públicos, beleza apresentada com os enfeites e o mais importante que a atividade estimula a educação ambiental em todos os setores e se adéqua a todas as classes e idades.

E assim, salientamos uma pesquisa realizada sobre os artigos da Revista Brasileira de Educação Ambiental no período de 2010 até 2017, constatando que dos 645 trabalhos publicados 75\% eram teóricos e uma minoria (167 artigos) apresentavam práticas pedagógicas aplicadas no estudo e ainda, Letras e Arte foram às áreas do conhecimento que menos publicaram seus resultados de pesquisas.

Os métodos utilizados no trabalho realçam o que os PCN propõem dentro da disciplina de Arte, e leva a participação também das outras disciplinas, interação entre alunos e professores e mais atuação no meio que vivem. Os alunos começam imaginar as situações que nem pensavam existir, principalmente na questão rural e meio ambiente, aproximando pessoas de situações e contextos diferentes. Podemos afirmar que o trabalho proporcionou crescimento e conscientização, a escola envolveu-se com a pesquisa, levando e trazendo propostas, permitindo aos envolvidos que eles sentissem mais responsáveis e importantes diante do trabalho apresentado (Figura 3).

Figura 3 - Alunos utilizando potes coletados para fazer mudas das plantas para depois serem plantadas e ao mesmo tempo conhecendo os tipos de solo, contextualizando com apostila de ciências (Fonte: Joslaine de Angelis, 2019).

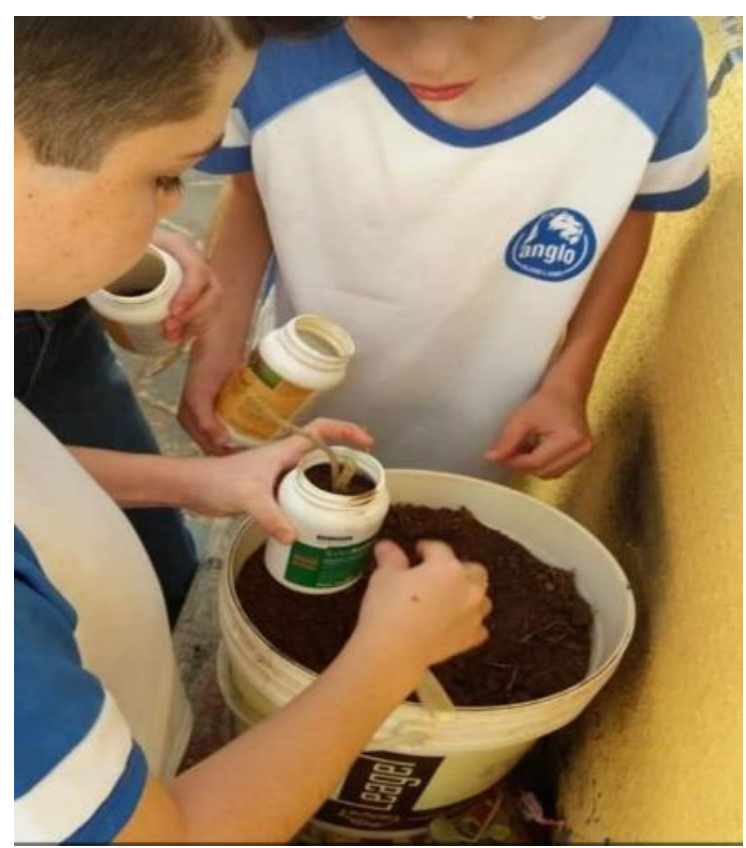


Utilizando como referência o tambor que abrigava a cola utilizada na lavoura de melancia (Figura 4), o material papelão e alumínio, após ser limpo foi lixado e assim começando o processo de reconstrução. A criatividade anuncia o novo surge mais uma peça, mais um olhar e também mais uma utilidade como já foi dito no presente trabalho.

Figura 4 - Material coletado na lavoura de melancia, após ser limpo e lixado foi utilizada a técnica de pintura recomendada pela professora, apresentando um novo visual e utilidade (Fonte: Joslaine de Angelis, 2019).
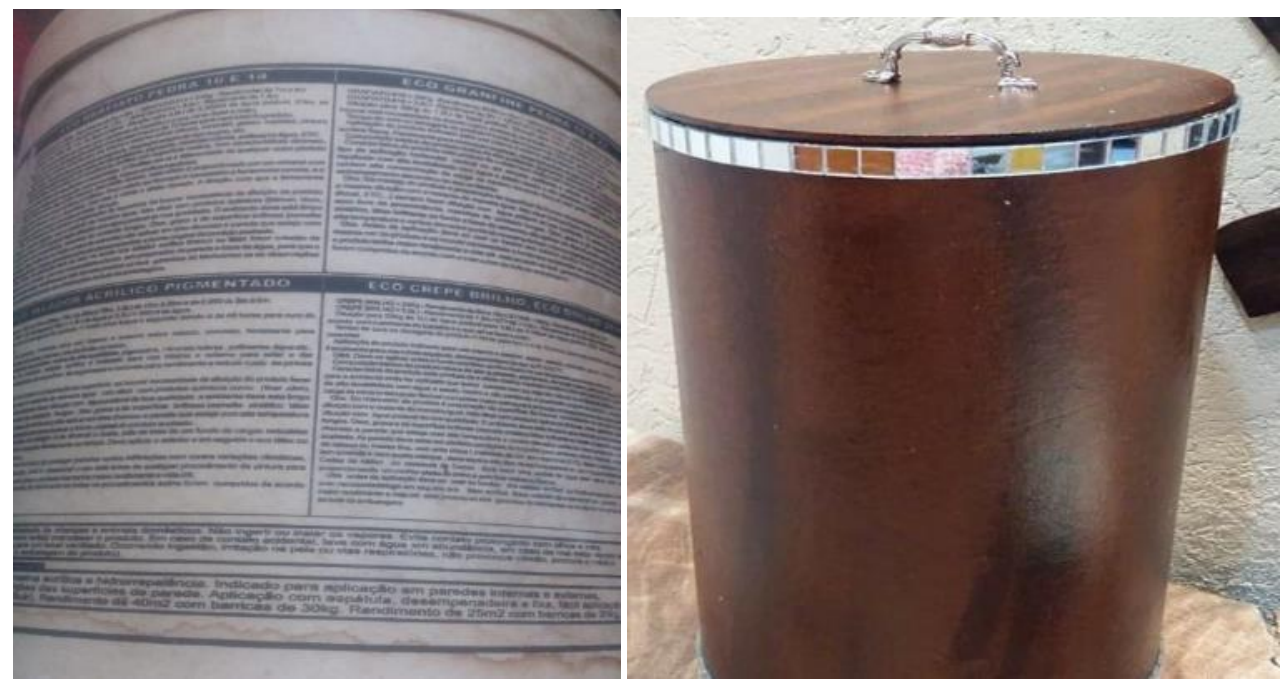

O disco de arado foi muito encontrado durante a pesquisa (Figura 5), devido ao grande uso pelos vários produtores no preparo do solo. O ferro que ficaria por vários anos na natureza segue um novo caminho, um novo olhar. Destacamos outras utilidades aos discos, além das que foram desenvolvidas no presente trabalho, como suporte de bexigas para festas e caçarolas para fritura de alimentos.

Figura 5 - Disco de arado, muito encontrado nas propriedades e transformado em caçarola(Fonte: Joslaine de Angelis, 2019).

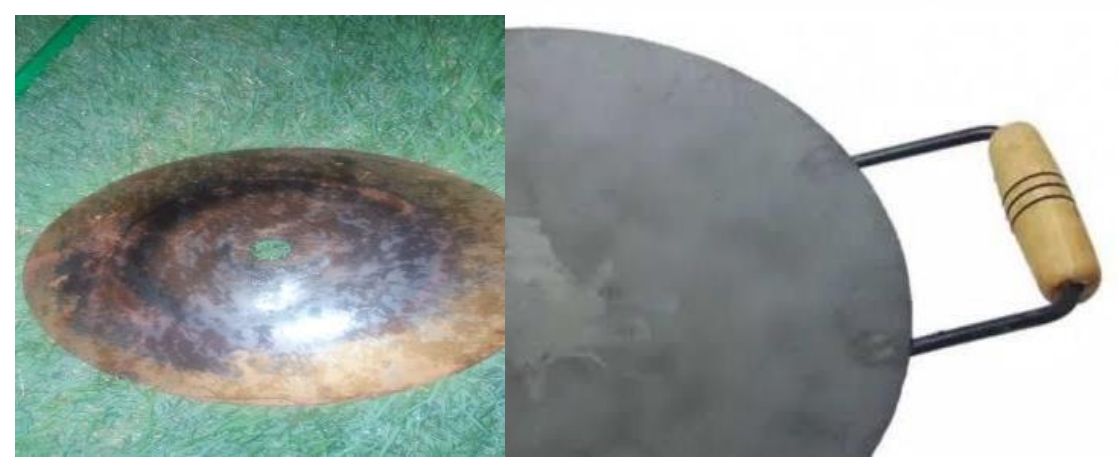


Assim, o pneu também muito encontrado (Figura 6), praticamente em todas as propriedades, nas caçambas e estrada do bairro, segue o mesmo processo, se desliga da utilidade de criação e da poluição ambiental que seria durante muitos anos e se transforma em pufe, demonstrando que através da arte é possível resgatar o resíduo que ficaria no meio ambiente, entendemos que não seja a solução, mas agrega a todas as já descobertas como a massa asfáltica e muitas outras ações que possam ser feitas.

Figura 6- Pneu, coletado em propriedades, estradas e caçambas transformados em pufe. (Fonte: Joslaine de Angelis, 2019).
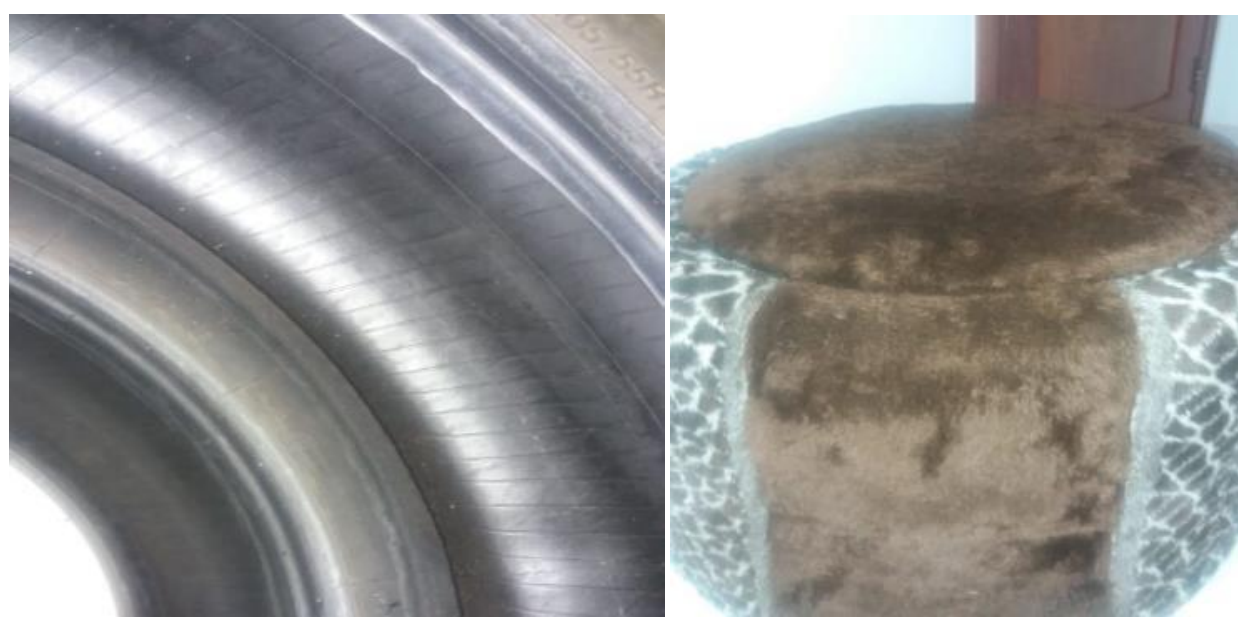

O pensamento de Loureiro e Torres (2014) relata sobre a necessidade de assumir uma prática crítica como compromisso para implementação de uma educação ética e transformadora, a Educação Ambiental e os preceitos freiriano descritos no livro são inseparáveis.

Acredita-se que uma educação ambiental deva desenvolver a partir de um processo educativo que se contextualize com relações existentes entre sociedade, cultura, meio ambiente e política.

\section{CONSIDERAÇÕES FINAIS}

O trabalho apresentado desenvolveu um tema muito discutido na atualidade, a questão do meio ambiente, porém, aborda arte e educação em prol desse meio em que vivemos na perspectiva do reaproveitamento dos resíduos sólidos da zona rural, lugar 
este não tão observado pelas escolas, e que também em sua maioria descarta sem nenhum cuidado ou atenção necessária.

Quando pensamos em resíduos, a sensibilização é a parte mais difícil para equacionar. Afinal, todos devemos nos perguntar. Para onde vai nosso lixo? Minhas atitudes são ambientalmente corretas? Sendo de extrema importância trabalhar interdisciplinarmente a arte com várias áreas do conhecimento principalmente a Educação Ambiental. O presente trabalho mostrou a relação entre os dois, como o lixo pode ser transformado a partir do olhar artístico, ou seja, para questionar o fazer artístico e para provocar reflexões sobre os malefícios dos resíduos para o meio ambiente. Neste contexto, tudo pode ser potencialmente transformado em arte, o maior desafio é transformar a maneira como convivemos com os objetos. Desse modo, acredita-se que uma educação ambiental deva desenvolver a partir de um processo educativo que se contextualize com relações existentes entre sociedade, cultura, natureza e política sobre a realidade vivida e a ser transformada.

O resultado será um aluno ativo artisticamente possibilitando ações de reaproveitamento para diminuir a poluição do meio ambiente, beneficiando a formação de um novo pensamento ambiental. Confirmando que o trabalho realizado incentiva a formação de um novo pensamento ambiental com a aplicação de novas técnicas que estimulem a criatividade da arte, que representará um instrumento de motivação à preservação do meio ambiente, além de forte instrumento de promoção da educação ambiental, principalmente por se constituir uma nova estratégia pedagógica em sala de aula.

\section{REFERÊNCIAS}

ARAÚJO, M.M.; ALVES, C.J.C. Educação: Minorias, Práticas e Inclusão. Ponta Grossa: Atena, 2021, $309 \mathrm{p}$.

BARBOSA, A. M. A imagem no ensino da arte. Porto Alegre:Perspectiva, 2020, 184p.

BRASIL. Lei 9.795- Lei de Educação Ambiental de 27 de abril de 1999. Política Nacional de Educação Ambiental. Brasília, DF: 1999.

BRASIL. Ministério da Educação. Resolução no 2 de 15 de junho de 2012. Estabelece as diretrizes curriculares nacionais para a Educação Ambiental. Conselho Nacional de Educação, Brasília, DF: 2012. 
CAPRA, F. Alfabetização Ecológica: O desafio para a educação do século 21. In: TRIGUEIRO, A. et al. Meio ambiente no século 21: 21 especialistas falam da questão ambiental nas suas áreas de conhecimento. 5. Ed., Campinas: Armazém do Ipê (autores Associados), 2008. Cap.1, p.19-33.

CRUZ, S. S.; SOUSA, F. Q.; OLIVEIRA, C. J.; ALVES, C. A. B.; SOUTO, J. S.; NUNES, E. N. Vulnerabilidade socioeconômica em comunidades rurais do município de Areia, Estado da Paraíba. Scientia Plena, São Paulo, v.9, n.5, p.1-10, 2013.

DICKMAN, I.; RUPPENTHAL, S. Educação Ambiental Freiriana: pressupostos e método. Revista de Ciências Humanas, Frederico Westphalen, v.18, n.30, p.117-135, 2017.

GRZEBIELUKA, D.; KUBIAK, I.; SCHILLER, A. M. Educação Ambiental: A importância deste debate na Educação Infantil. Revista Monografias Ambientais, Santa Maria, v.13, p. 3881-3906, 2014.

HARVEY, D. Condição pós-moderna: Uma Pesquisa sobre as Origens da Mudança Cultural. São Paulo: Loyola (21a Ed.), 2012, 349 p.

HOGAN, D. J. Crescimento populacional e desenvolvimento sustentável. Lua Nova: Revista de Cultura e Política, v.31, p. 57-78., 1993.

OLIVEIRA, M.M.D.; MENDES, M.; HANSEL, C.H.; DAMINIANI, S. Cidadania, Meio Ambiente e Sustentabilidade. Caxias do Sul, RS : Educs, 2017, 538 p.

OLIVEIRA, M.O.; HÉRNANDEZ, F. A formação do professor e o ensino das Artes visuais. Santa Maria: UFSM, 2015. 296 p.

PALHACI, M. D. C. J. P.; PALHACI, T. P.; HELLMEISTER, L. A. V.; NICOLA, R. L. A importância da arte como meio de reciclagem e como formação de um novo pensamento ambiental. In: Proceedings of $\mathbf{V}$ World Congress on Communication and Arts. Portugal, p. 553-557, 2012.

PENTEADO, H. D. Meio Ambiente e formação de professores. 7 ed. São Paulo: Cortez, 2010, 128 p.

RIGOTTI, G. F.; PEREIRA, V. C.; COELHO, T. P.; ROSA, A. Arte na escola: os documentos como mapas. Revista de Educação, v.10, n.10, p. 6-14, 2019.

RODRIGUES, G. S.; PINTO, B. C. T.; FONSECA, L. C. DE S.; MIRANDA, C. C. (2019). O estado da arte das práticas didático-pedagógicas em Educação Ambiental (período de 2010 a 2017) na Revista Brasileira de Educação Ambiental. Revista Brasileira De Educação Ambiental, v.14, n.1, p. 9-28, 2019. 
VARGAS, L. A. Educação ambiental: A base para uma ação político/transformadora na sociedade. Revista Eletrônica do Mestrado em Educação Ambiental, Rio Grande do Sul, v. 15, p. 72-79, 2005.

VICINI, M. S. Arte de Joseph Beuys: Pedagogia e hipermídia. Comunicação \& Educação, São Paulo, v.14, n. 1, p.23-32, 2009.

WALDMAN, M. Lixo: Cenários e Desafios: Abordagens Básicas para Entender os Resíduos Sólidos. São Paulo: Cortez Editora, 2010, 231 p. 


\title{
CAPÍTULO XII
}

\section{EDUCACÃO E SUSTENTABIUDADE}

\section{DOI: 10.51859/amplla.mas481.1121-12}

\author{
Verônica Maria de Moraes Alexandre Santana ${ }^{1}$ \\ Rosinaldo Silva Campelo ${ }^{2}$
}

\footnotetext{
${ }^{1}$ Especialista em Psicopedagogia e Supervisão Escolar - Faculdade Cândido Mendes-FACAM e em Geohistória Instituto Educacional Superior Franciscano - IESF.

${ }^{2}$ Especialista em Docência do Ensino Superior - Instituto de Teologia Aplicada - INTA
}

\section{RESUMO}

O presente artigo busca fazer uma análise do papel da escola enquanto espaço de reflexão e construção de conhecimento, lugar onde se veiculam informações e se discutem ações educativas transformadoras. Portanto, é na escola que acontece o ensinamento capaz de promover mudanças de comportamento, de fazer com que sejam percebidos os problemas ambientais e entendido a necessidade de promover ações para melhorar o futuro. Nessa Linha, destaca-se a temática Educação e Sustentabilidade que dever ser trabalhada no ambiente escolar no sentido de promover uma formação cidadã pautada na preservação da vida e do planeta. É nessa perspectiva que são sugeridos os Projetos Didáticos enquanto metodologia capaz de aproximar o estudante da sua realidade e estimular o protagonismo estudantil, tornando-os militantes na luta pela sustentabilidade em todas as suas dimensões.

Palavras-chave: Escola. Educação e Sustentabilidade. Projeto Didático.

\section{INTRODUÇÃO}

A escola é vista como um espaço de reflexão e construção de saberes, portanto, lugar onde se veiculam informações, instituindo-se enquanto sistema dinâmico e abrangente. É na escola que se discutem ações educativas transformadoras e que se busca, sobretudo, o enfrentamento de desafios dos mais diversos e, em especial, das demandas na perspectiva de uma ética ambiental que considera a complexidade e a integração de saberes.

A educação escolar torna-se estimuladora de práticas que busquem a superação das injustiças ambientais e da apropriação da natureza como objeto de exploração e consumo baseada na premissa de que, com conhecimento e informação, 
é possível criar condições de legitimação e reconhecimento da educação ambiental para além do seu universo específico, propondo atender aos vários sujeitos que compõem os meios sociais, culturais e econômicos na preocupação com a sustentabilidade socioambiental.

Sendo assim, considerando que o futuro do planeta vem sendo discutido desde a década de 60, com o aparecimento das primeiras problemáticas ambientais advindas do modelo de desenvolvimento em que se vê claramente a evolução econômicoindustrial em contradição com os elementos da natureza, é que se questiona o avanço de tal modelo predatório chamando a atenção para as questões ambientais.

Essas transformações afetam tanto o mundo da produção e do trabalho quanto o mundo da educação e da formação, de tal forma que ambos os mundos começam a se interpenetrar. É nesse contexto que se deve pensar Sustentabilidade e Educação, haja vista a sustentabilidade ser mais do que um qualitativo do desenvolvimento, tornandose uma perspectiva que vai além da preservação dos recursos naturais e da viabilidade de um desenvolvimento sem agressão ao meio ambiente, implicando em integração harmônica consigo mesmo, com o outro e com o ambiente, podendo assim, fecundar a compreensão da educação com o conceito de Sustentabilidade e de Desenvolvimento Sustentável.

\section{EDUCAÇÃO E SUSTENTABILIDAD}

Educação pode ser tecnicamente conceituada como processo contínuo do desenvolvimento humano por meio do ensino e da aprendizagem que se associa à formação escolar. Sendo assim, nas ações educativas desenvolvidas no ambiente escolar o "termo sustentabilidade" estar associado à necessidade de encontrar soluções para os problemas ligados ao desenvolvimento, sendo encarado como um desafio conjunto entre todas as esferas, que devem atuar de forma integrada em prol do presente e do futuro da humanidade, dos seres vivos e do planeta.

Nesse entendimento, a Sustentabilidade consiste na capacidade de uma atividade ou sociedade se manter por tempo indeterminado, sem colocar em risco o esgotamento, a qualidade e o uso abusivo de seus recursos naturais. E propõe ainda, uma reflexão sobre as dimensões da sustentabilidade previstas na Agenda 21, quais 
sejam: sustentabilidade ambiental/ecológica, sustentabilidade econômica, sustentabilidade social, sustentabilidade cultural e educativa e sustentabilida de espacial e territorial.

Nesse contexto, é papel da escola planejar ações pedagógicas e educativas a partir das cinco dimensões previstas na Agenda 21, incentivando o protagonismo dos estudantes para pensar o seu local com olhar na posteridade e na sustentabilidade. Convém destacar que a sustentabilidade assume cada vez mais uma função transformadora, na qual a corresponsabilidade dos indivíduos torna-se um objeto essencial para promover um novo tipo de desenvolvimento - o desenvolvimento sustentável. Entende-se, portanto, que a educação para a sustentabilidade é condição necessária para modificar um quadro de crescente degradação socioambiental. Nesse entendimento, Tamaio afirma que:

É necessário reconhecer que esses problemas estão intimamente relacionados aos conflitos de interesses socioeconômicos. Portanto, a Educação Ambiental não é condição suficiente para modificar essa realidade, mas sim mais uma ferramenta da mediação necessária entre culturas, comportamentos diferenciados e interesses de grupos sociais para a construção das transformações almejadas. (TAMAIO, 2000, p. 9)

Seguindo esse raciocínio, Jacobi acrescenta:

[...] a problemática da sustentabilidade assume neste novo século um papel central na reflexão sobre as dimensões do desenvolvimento e das alternativas que se configuram. $\mathrm{O}$ quadro socioambiental que caracteriza as sociedades contemporâneas revela que o impacto dos humanos sobre o meio ambiental tem tido consequências cada vez mais complexas, tanto em termos quantitativos quanto qualitativos. (JACOBI, 1997, p. 193).

Neste sentido, o conceito de desenvolvimento sustentável surge para enfrentar a crise ecológica quanto a problemática da sustentabilidade propondo um desenvolvimento econômico e social, promovido por uma sociedade que procura satisfazer as necessidades atuais sem utilizar os recursos renováveis acima da capacidade de regeneração natural dos mesmos, da mesma forma que se evita um excesso de poluição/contaminação acima da capacidade natural de depuração do ambiente. Sendo papel da educação escolar, promover tais reflexões, bem como implementar ações educativas nessa perspectiva. 
Nos anos 80, mais precisamente no ano de 1985, a convenção de Viena remodelou o debate a respeito do meio ambiente para um enfoque agora preventivo, dado que seus principais objetivos eram proteger a saúde humana e o meio ambiente contra os efeitos adversos causados pelo desenvolvimento, bem como garantir os recursos naturais necessários para a sobrevivência das gerações futuras, nascendo, então, o conceito de desenvolvimento sustentável que emerge do Relatório de Brundtland, conhecido também como NOSSO FUTURO COMUM, o qual foi elaborado de no ano de 1987 - tendo como objetivo a busca concomitantemente de eficiência econômica, justiça social e harmonia ambiental, no sentido de que "o desenvolvimento sustentável atende às necessidades da geração presente sem comprometer as possibilidades das gerações futuras de atender às suas necessidades". (RELATÓRIO BRUNDTLAND, 1987, p. 9).

Nesse contexto, Almeida faz uma interessante abordagem acerca do desenvolvimento sustentável pontuando o que foi destacado anteriormente:

Desenvolvimento sustentável passa a ser mais que um conceito, sendo um processo de mudança onde a exploração de recursos, a orientação dos investimentos, os rumos do desenvolvimento ambiental e a mudança institucional devem levar em conta as necessidades das futuras gerações. (ALMEIDA, 1996, p.13).

Nesse entendimento, o desenvolvimento sustentável é a busca do equilíbrio entre o crescimento econômico e o desenvolvimento humano. Consiste num processo de transformação no qual a exploração dos recursos, a direção dos investimentos, a orientação do desenvolvimento tecnológico e a mudança institucional se harmonizam e reforçam o potencial presente e futuro.

Sendo assim, faz-se necessário pensar a sustentabilidade e o desenvolvimento sustentável considerando a conjuntura local. Lançando um olhar questionador para a forma e execução de alguns elementos que já causam prejuízos ambientais em nosso entorno, a exemplo do desmatamento, principalmente na cabeceira dos rios, causandoIhes o assoreamento, as queimadas com a produção do $\mathrm{CO}$ e $\mathrm{CO} 2$, a extração da madeira, a pesca predatória, o aprisionamento e o tráfico de animais silvestres, dentre outros elementos que carecem de ações de sustentabilidade para que na posteridade as gerações possam usufruir dessas riquezas naturais. 
Mahatman Gandhi, há 50 anos na Índia, dizia que "a Terra era suficiente para todos, mas não para a voracidade dos consumistas". Vendo por essa ótica, não podemos nos acomodar diante das ameaças vivenciadas em nosso contexto e que podem trazer sérias consequências ao Planeta, visto que é nosso compromisso conservá-lo para que a vida continue brotando. Portanto a educação pode e deve ter um peso na luta pela sustentabilidade ambiental, econômica, política e social.

\section{PROJETOS DIDÁTICOS}

Os Projetos didáticos são vistos como uma das formas de se construir o conhecimento com sentido e profundidade, pois, envolve o estudante estimulando seu protagonismo e sua autonomia enquanto sujeito e objeto na construção do conhecimento e na intervenção do seu entorno. É um tipo de instrumento que alinhado ao planejamento envolve uma situação-problema com o objetivo de articular propósitos didáticos e propósitos sociais, culminando com um produto final que é a apresentação de ações resolutivas ao problema detectado, impactando sobremaneira na realidade estudada.

O Projeto Didático EDUCAÇÃO E SUSTENTABILIDADE, construído pela Secretaria Municipal de Educação de Bacuri para ser desenvolvido pelas escolas da sua rede de ensino apresenta-se enquanto proposta a ser trabalhada no decorrer deste ano letivo com o intuito de discutir ações educativas que viabilizem a participação ativa dos estudantes nas tomadas de decisões quanto ao desenvolvimento econômico e social da sua realidade, nos termos do que sugere os Parâmetros Curriculares Nacionais:

\footnotetext{
Propõe-se que ações humanas ocorram dentro das técnicas e princípios conhecidos de conservação, estudando seus efeitos para que se aprenda rapidamente com os erros. Esse processo exige monitoração das decisões, avaliação e redirecionamento da ação. E muito estudo. Portanto, traz implicações para o trabalho do professor e responsabilidades para a escola como uma das instâncias da sociedade que pode contribuir para o mesmo processo. (PCN's - TEMAS TRANSVERSAIS, 1998 p. 239).
}

Neste sentido, a implementação do Projeto Didático: Educação e Sustentabilidade na Rede Municipal de Ensino de Bacuri requer o desenvolvimento de um trabalho pedagógico alinhado às ações do Projeto Político Pedagógico de cada escola 
no qual a sustentabilidade seja discutida de forma conceitual e praticável no chão da sala de aula e em sintonia com a vivência dos estudantes.

O Projeto Didático Educação e sustentabilidade estar voltado para atender as inquietudes dos estudantes, considerando as suas necessidades de aprendizagem, em que será absorvida a ideia da Sustentabilidade e a aplicabilidade do Desenvolvimento Sustentável. Sendo assim, seu principal objetivo é desenvolver atitudes, comportamentos e princípios éticos que favoreçam uma ampla reflexão conceitual e praticável acerca da sustentabilidade, discutindo as responsabilidades de cada um com a conservação da vitalidade e da diversidade do Planeta Terra a partir do equilíbrio entre atividades humanas e o mundo natural, de forma que as gerações futuras possam dar respostas às suas próprias necessidades.

Quanto aos procedimentos metodológicos, as escolas da Rede Municipal de Ensino de Bacuri desenvolverão seu trabalho pedagógico buscando promover aprendizagens conceituais, procedimentais e atitudinais acerca da sustentabilidade enquanto novo critério básico e integrador que estimula responsabilidades ao reconsiderar os aspectos relacionados com equidade e justiça social. Nesse sentido, fora sugerido enquanto desdobramentos para que o referido Projeto seja executado, a apresentação das dimensões da sustentabilidade como eixos temáticos: sustentabilidade ambiental/ecológica, sustentabilidade econômica, sustentabilidade social, sustentabilidade cultural e educativa e sustentabilidade espacial e territorial. Cada uma das referidas dimensões, também tivera seu desdobramento em subtemas com o intuito de subsidiar o trabalho pedagógico e a organização das pesquisas in loco, conforme se apresenta:

SUSTENTABILIDADE AMBIENTAL/ECOLÓGICA: Consiste no uso intensivo dos potenciais relativos aos diferentes ecossistemas, em compatibilidade com sua mínima deterioração, devendo possibilitar que a natureza desenvolva novos equilíbrios, por meio de processos de utilização que respeitem o seu ciclo temporal. Consiste na preservação das fontes de recursos naturais e energéticos. Foram elencados os seguintes subtemas: Fontes de energia alternativa. O cuidado com o uso das energias renováveis. As substancias tóxicas no meio ambiente. A preservação da biodiversidade e dos ecossistemas. O risco e as ameaças à vida no planeta. As relações entre os seres 
vivos. O ser humano e o meio ambiente. Os impactos ambientais causados pelo ser humano (queimadas, desmatamento, poluição). Preservação do capital natural. A capacidade de autodepuração dos ecossistemas. Mudança climática/Aquecimento Global. A agricultura e o uso de fertilizantes e agrotóxicos. A concentração de coliformes fecais em água potável. A abundância das espécies protegidas. O reflorestamento em áreas desmatadas. A autosustentação da vida enquanto provedora de recursos e enquanto ambiente para a disposição de resíduos (muitas vezes produzidos desnecessariamente). Redução na utilização de combustíveis fósseis.

SUSTENTABILIDADE ECONÔMICA: o aspecto econômico deve estruturar-se em uma distribuição e gestão mais eficiente dos recursos e, por um fluxo regular de investimento público e privado. Foram elencados os seguintes subtemas: Organização das estruturas econômicas enquanto resposta às exigências de sistemas estáveis. A preservação dos capitais reais, tais quais infraestruturas e edifícios. A estabilização do valor monetário enquanto prevenção à inflação. A restrição parcial ou total do endividamento pessoal. O uso eficaz dos recursos. O desenvolvimento econômico equilibrado. Segurança alimentar e nutricional. Modernização contínua da produção. Autonomia da pesquisa científica e tecnológica. Intensidade de consumo das matérias primas. Investimento em ações de energias renováveis e não renováveis. Intensidade do uso da energia. Gerenciamento do lixo industrial, doméstico e outros resíduos urbanos.

SUSTENTABILIDADE SOCIAL: o sistema deve funcionar de forma que haja uma redução significativa nas desigualdades sociais, devendo abranger todo aspecto de necessidades materiais não materiais. Foram elencados os seguintes subtemas: O papel dos indivíduos e da sociedade na Sustentabilidade. A Sustentabilidade e a noção de bemestar. A estabilidade social é benefício para gerações futuras. A garantia da autodeterminação dos povos e dos direitos humanos. A garantia de segurança e justiça através de um sistema judicial fidedigno e independente. A melhoria da qualidade de vida dos cidadãos. A promoção da igualdade de oportunidades. A promoção da autonomia da solidariedade e da capacidade de autoajuda dos cidadãos. A garantia de meios de proteção social fundamentais para os indivíduos mais necessitados. A homogeneidade social. A distribuição de renda. Empregos bons. Igualdade no acesso aos recursos e serviços sociais. Percentagem da população vivendo abaixo da linha da 
pobreza. Taxa de desemprego. Razão do salário feminino médio pelo salário masculino médio. Expectativa de vida. Coeficiente de mortalidade até 05 anos de idade. Percentagem da população com acesso a água tratada. Percentagem da população com acesso às unidades de atenção primária à saúde. Imunização contra doenças infecciosas. Coeficiente de prevalência contraceptiva. Área construída de moradia por pessoa. Numero de crimes registrados na população. Taxa de crescimento da população. População urbana e moradias formalmente regularizadas e/ou irregulares.

SUSTENTABILIDADE CULTURAL E EDUCATIVA: os aspectos culturais e educativos desempenham um papel fundamental para a sustentabilidade, pois, incorporam os princípios básicos da sociedade e sua forma de vida, respeitando as especificidades de cada ecossistema, de cada cultura e de cada local. Foram elencados os seguintes subtemas: A diversidade cultural. Condições favoráveis ao desenvolvimento da personalidade de crianças, adolescentes e jovens. Garantia de condições mínimas como estruturas apropriadas, condições de bem-estar, solidariedade, justiça e liberdade. A transmissão de valores fundamentais e do sentido de responsabilidade e ordem social. A atenção dada pela sociedade à complexidade dos sistemas e à dinâmica de mudanças criando competências para enfrentar os seus riscos e desafios. O facultar a educação com objetivos profissionais e investir no desenvolvimento de um sistema de educação sólido entre gerações. O equilíbrio entre respeito à tradição e à inovação. Projetos Nacionais e Locais. Percentagem das crianças fora da escola. Nível de educação média entre adultos. Taxa de analfabetismo de adultos.

SUSTENTABILIDADE ESPACIAL, TERRITORIAL E POLÍTICA: sugere minimizar a densidade geográfica, a ocupação desordenada de populações, a concentração de atividades e a centralização do poder, objetiva o equilíbrio na relação cidade-campo. Foram elencados os seguintes subtemas: Melhoria no ambiente urbano. Estratégias para áreas ecologicamente frágeis. A distribuição espacial dos recursos, das populações e das atividades. Direitos humanos garantidos. Coesão social. Prevenção de guerras e garantia de paz. Cooperação internacional. 
Além dos eixos temáticos e seus subtemas já mencionados, a escola deve abordar outros temas de relevância como: Sustentabilidade e Terra; Sustentabilidade e Água; Sustentabilidade e Ar.

A partir desses desdobramentos, se busca com os estudantes, construir um conhecimento sistemático acerca da Sustentabilidade visando despertar atitudes e ações conscientes voltadas para o consumo sustentável dos recursos naturais e a sustentabilidade do Planeta.

\section{CONSIDERAÇÕES FINAIS}

Fez-se uma abordagem sobre Educação e Sustentabilidade, destacando o papel da escola enquanto espaço de construção de sabres e o projeto didático enquanto instrumento de desenvolvimento de ações educativas que favoreçam discussões e ensinamentos capazes de promover mudanças comportamentais, a partir do entendimento da sustentabilidade em sua essência que é a sobrevivência: sobrevivência dos recursos naturais, empreendimento e da própria sociedade. Portanto, é importante saber utilizar a natureza para atender as necessidades da sociedade sem comprometer as gerações futuras de modo que elas também possam utilizar os recursos naturais.

\section{REFERÊNCIAS}

ALMEIDA, Luciana Togueiro de. Política Ambiental: uma análise econômica. São Paulo: Unesp, 1998.

BRASIL, Secretaria de Educação Fundamental. Parâmetros Curriculares Nacionais: terceiro e quarto ciclos: apresentação dos termos transversais. BRASILIA: $\mathrm{MEC} / \mathrm{SEF}, 1998$.

JACOBI, Pedro. Cidade e meio ambiente. São Paulo: Annablume, 1999.

RELATÓRIO BRUNDTLAND. Comissão Mundial Sobre Meio Ambiente e Desenvolvimento. Nosso Futuro Comum. Rio de Janeiro: FGV.1988.

TAMAIO, Irineu. Mediação do professor na construção do conceito de natureza: uma experiência de educação ambiental na Serra da Cantareira e Favela do Flamengo. Campinas, 2000. Dissertação de Mestrado. FE/UNICAMP. 


\title{
CAPÍTULO XIII
}

\section{CONEXÑO AMBIENTAL CONSCIENIIZACÃO DO LXXO E RECICLAGEM EM TEMPPOS DE PANDEMIA NO MUNICÍPIO DE MACEIÓ-AL}

\section{DOI: 10.51859/amplla.mas481.1121-13}

\author{
Camila Alexandre Cavalcante de Almeida ${ }^{1}$ \\ Alexsandro Gonçalves Pacheco ${ }^{2}$ \\ Edja Santos de Araújo $^{3}$ \\ Gustavo Belchior de Barros 4 \\ Mikael Oliveira da Silva ${ }^{5}$ \\ Andréa de Vasconcelos Freitas Pinto ${ }^{6}$ \\ Maria José de Holanda Leite ${ }^{7}$
}

\footnotetext{
${ }^{1}$ Doutoranda em Proteção de Plantas. Programa de Pós Graduação em Proteção de Plantas. Universidade Federal de Alagoas - UFAL

${ }^{2}$ Mestrando em Proteção de Plantas. Programa de Pós Graduação em Proteção de Plantas. Universidade Federal de Alagoas - UFAL

${ }^{3}$ Graduando em Engenharia Florestal. Universidade Federal de Alagoas - UFAL

4 Graduando em Engenharia Florestal. Universidade Federal de Alagoas - UFAL

${ }^{5}$ Graduando em Engenharia Florestal. Universidade Federal de Alagoas - UFAL

${ }^{6}$ Professora Adjunta do Centro de Ciências Agrárias. Universidade Federal de Alagoas - UFAL

7 Professora de Engenharia Florestal. Universidade Federal de Alagoas - UFAL
}

\section{RESUMO}

A reciclagem se destaca como uma das práticas mais abordadas pelos educadores. Isto é bem notável, pois com o crescimento da globalização e do crescimento populacional, a quantidade de lixo e a poluição também crescem sem controle, por essa razão, torna-se cada vez mais importante a realização de trabalhos educacionais em favor do meio ambiente. Porém, em virtude da pandemia global, causada pelo COVID-19, projetos de extensão voltados a educação ambiental tiveram que ser adaptados para forma remota, de forma a dar continuidade na contribuição de ensino e aprendizado para jovens e crianças. O objetivo do trabalho foi realizar a conscientização socioambiental através de palestras em forma remota, sobre os problemas do lixo e a reciclagem, bem como, a realização de oficinas online visando formar alunos capazes de atuar de forma crítica e pensante na sociedade na qual se insere afim de minimizar os impactos ao meio ambiente. O trabalho foi realizado nas instituições Lar Batista Marcolina Magalhães e Lar das Meninas, situados no município de MaceióAL. As oficinas foram conduzidas através da Plataforma Google Meet, onde foram realizadas palestras, jogos e atividades online de forma lúdica para as crianças. Foi observado que a metodologia aplicada foi adequada e eficiente. Foi notória a apropriação pelas crianças dos conteúdos trabalhados, e a sua mudança de atitude como agentes transformadores, ao longo do processo. Conclui-se que as atividades, palestras e oficinas realizadas nas instituições, facilitam a compreensão da importância em proteger o meio ambiente. Estas crianças demostraram interesse em mudar suas práticas, e torná-las conservacionistas, influenciando também amigos e familiares a não degradar o meioambiente. Assim, serão capazes de atuar de forma crítica na sociedade, minimizando os impactos ao meio ambiente.

Palavras-chave: Coleta Seletiva. Covid- 19. Educação. 


\section{INTRODUÇÃO}

Ao longo do desenvolvimento da humanidade, vivenciamos no decorrer de várias épocas amplas mudanças sociais, econômicas, políticas e ambientais. Juntamente com estes avanços, ocorre consequentemente a degradação de diversos recursos naturais. Sendo assim, nasce a necessidade de colocar limites à ação humana para evitar sua autodestruição. Sendo necessário disseminar uma nova relação entre os homens e a natureza que privilegie a qualidade de vida juntamente com um desenvolvimento capaz de gerar uma sadia qualidade de vida para as gerações futuras (VIEGAS; CABRAL, 2014).

Nesse contexto é necessário buscar formas de educar e de abrir as mentes das pessoas para provocar mudanças e atitudes que evitem a destruição do meio ambiente. A Educação Ambiental (EA) contribui para o desenvolvimento de propostas que visam sensibilizar, mudar o comportamento, ampliar a capacidade de avaliação e intervir os estudantes na sua realidade local, com principal propósito promover uma formação cidadã (SANTOS et al., 2017).

Para que a Educação Ambiental nas escolas seja promissora, é importante que além de informações e conceitos, a escola se disponha a trabalhar com atitudes, com formação de valores e com ações práticas e teóricas para que os estudantes possam aprender a amar, respeitar e praticar ações voltadas à conservação ambiental (MELO et al., 2020).

E dentre estas práticas de conservação ambiental, a reciclagem se destaca como uma das mais abordadas pelos educadores em relação a minimizar os impactos causados pelo homem. Isto é bem notável, pois com o crescimento da globalização e do crescimento populacional, a quantidade de lixo e a poluição também crescem sem controle, por essa razão, torna-se cada vez mais importante a realização de trabalhos educacionais em favor do meio ambiente (COSTA et al., 2020).

Porém, em virtude da pandemia global ocasionada por um novo vírus, a COVID19 , foi decretado a quarentena em todo país, no qual foi determinado o fechamento de escolas, bares e qualquer outro local responsável por causar aglomerações, isso mudou radicalmente a vida das pessoas, nos quais tiveram que se adaptar aos novos costumes, isto incluindo aulas e até trabalhos em plataformas digitais (BRASIL, 2020). Ademais, 
projetos de extensão voltados a educação ambiental tiveram que ser adaptados para forma remota, de forma a dar continuidade na contribuição de ensino e aprendizado para jovens e crianças.

Dentre estas problemáticas abordadas, o objetivo do trabalho foi realizar a conscientização socioambiental através de palestras em forma remota, sobre os problemas do lixo e a reciclagem, bem como, a realização de oficinas online visando formar alunos capazes de atuar de forma crítica e pensante na sociedade na qual se insere afim de minimizar os impactos ao meio ambiente. A proposta da educação ambiental nos abrigos de crianças surgiu através da necessidade de conscientizar e ensinar a responsabilidade de cada indivíduo na conservação do meio em que vive.

\section{MATERIAIS E MÉTODOS}

\subsection{LOCAL DO ESTUDO}

As atividades do projeto Educambiental do Campus de Engenharias e Ciências Agrárias, deram início em agosto de 2020 e decorreram até novembro do mesmo. Tais atividades ocorreram no Lar Batista Marcolina Magalhães e no Lar da Menina, ambos estão localizados no município de Maceió, AL.

A cidade de Maceió (9³9' 57" S; 3544' 06" O), capital de Alagoas, estálocalizada na região nordeste do país. Ocupa uma área de 509,5 km², uma elevação de $7 \mathrm{~m}$ do mar e cerca de 1.025.360 habitantes (IBGE, 2020).

A estrutura econômica de Maceió corresponde predominantemente aos setores de comércio, serviços, turismo, e atividade agropecuária. Uma menor participação é referente aos setores da indústria e construção civil. Constata-se em 2013 que 52,3\% não concluíram o ensino fundamental e 14,6\% são analfabetos, ou seja, a escolaridade é baixa e o índice de analfabetismo é alto.

\subsection{LEVANTAMENTO DOS DADOS}

Devido a Pandemia da COVID-19 a conscientização ambiental foi conduzida por palestras e oficinas de forma remota através da plataforma Google Meet (Figura 1). No primeiro momento de apresentação, a aula foi direcionada para as crianças do Lar Batista Marcolina Magalhães, uma organização sem fins lucrativos que acolhe crianças 
entre três a onzes anos de idade em situações de vulnerabilidade, situado no bairro de Tabuleiro dos Martins, em Maceió- AL (Figura 1).

Figura 1- Encontro virtual realizado no Lar Batista Marcolina Magalhães.

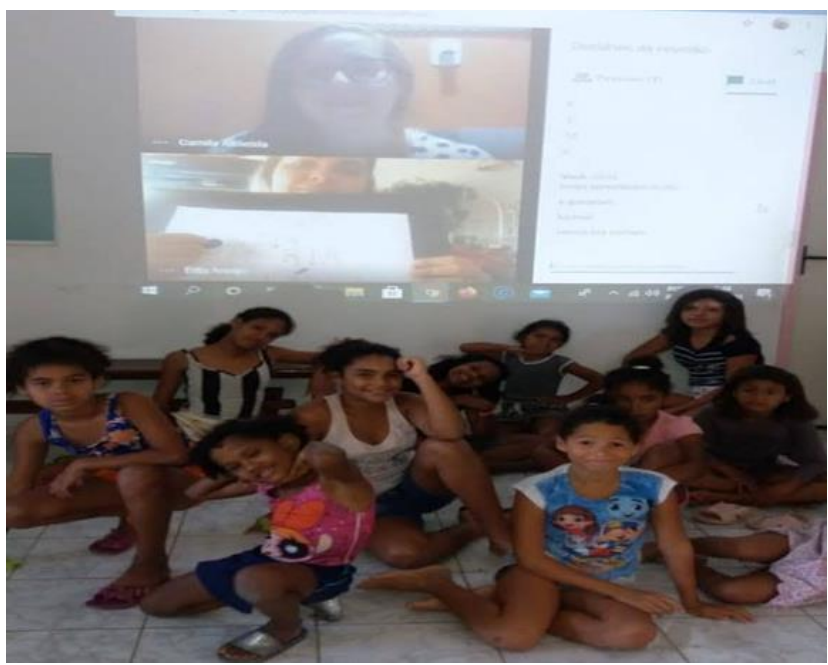

Fonte: Autoria Própria

A palestra proferida foi intitulada: A importância da Reciclagem (Figura 2), no qual foi abordada sobre os materiais recicláveis e não recicláveis, além de discutir sobre o destino do lixo e seus cuidados para manutenção da saúde. Também foi realizada uma gincana com as meninas do lar batista para verificar o conhecimento que haviam adquirido sobre como separar os materiais e seu destino adequado nos cestos da coleta seletiva.

Figura 2- Palestra realizada via Google meet para crianças do Lar Batista Marcolina Magalhães.

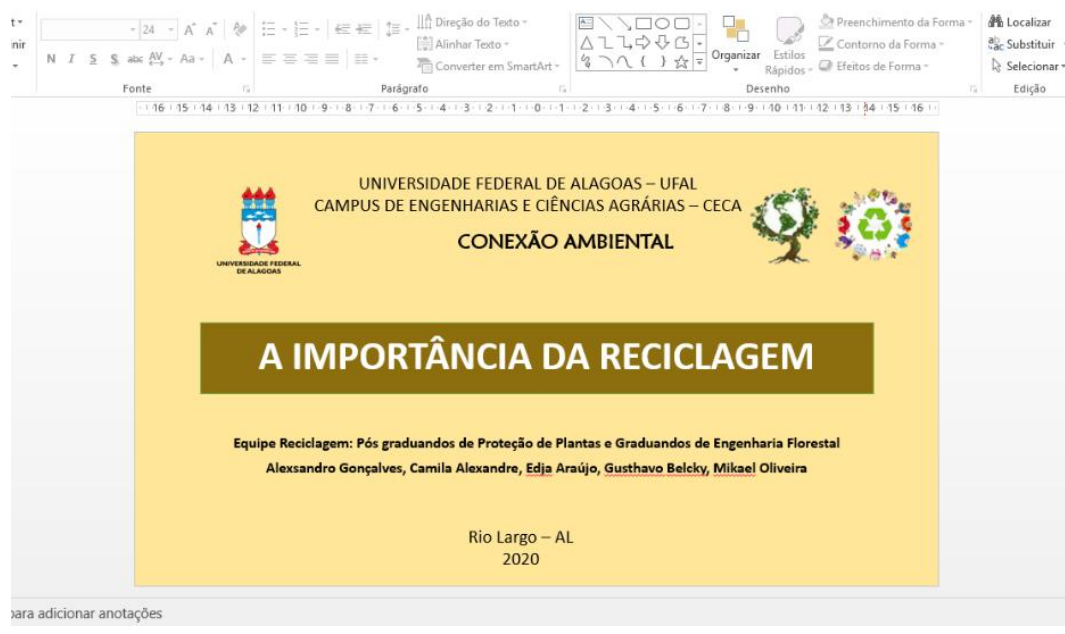

Fonte: Autoria Própria 
Ao fim da palestra foi realizado um jogo educativo chamado "Jogo da memória Reciclável" no qual foi feito com tampinhas de garrafa PET, essas tampinhas eram pintadas no fundo, pares de tampinhas com as mesmas cores eram colocadas sob uma mesa e as meninas escolhiam afim de encontrar os pares, essa atividade lúdica teve como objetivo mostrar que materiais recicláveis podem ser utilizados para o divertimento de crianças (Figura 3).

Figura 3- Jogo da Memória Reciclável realizado via Google meet para crianças do Lar Batista Marcolina Magalhães.

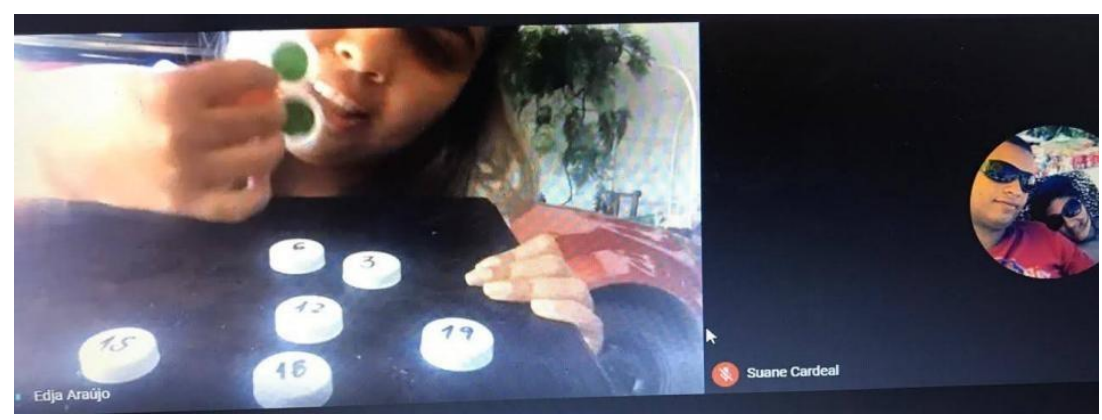

Fonte: Autoria Própria

O segundo encontro foi realizado no Lar das Meninas, que é uma entidade filantrópica que acolhe meninas em situação de risco, localizado na Rua Eurico Acyole Wanderley, no municipío de Maceió-AL.

A oficina foi realizada via online pela plataforma Google Meet, com uma palestra intitulada: Consequências do Lixo Mal Descartado (Figura 4). Foi abordado sobre como o lixo pode afetar na vida das pessoas quando é mal distribuido e não reciclado, além de abordar sobre poluição e suas consequências e sobre as doenças que o lixo acumulado pode nos trazer.

Seguidamente, foi realizado uma atividade onde as crianças fizeram uma pintura e desenhos sobre o tema abordado pelos palestrantes (Figura 5). 
Figura 4- Palestra realizada via Google meet para crianças do Lar das Meninas.

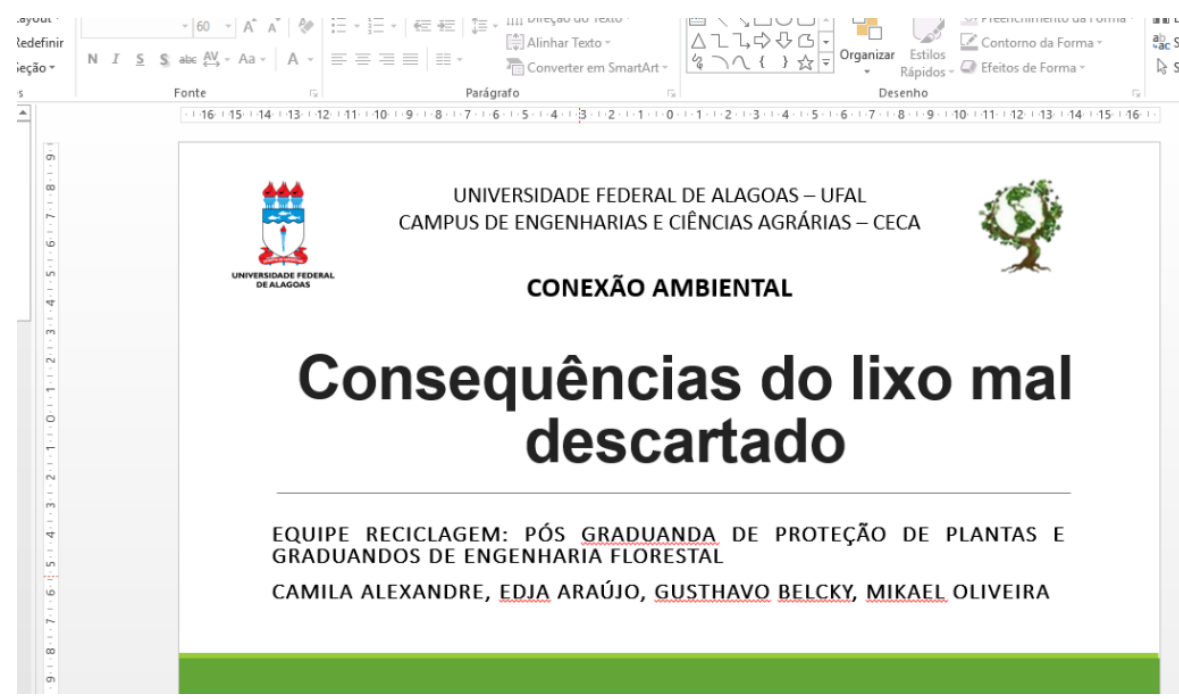

Fonte: Autoria Própria

Figura 5- Encontro e atividade virtual realizado no Lar das Meninas.

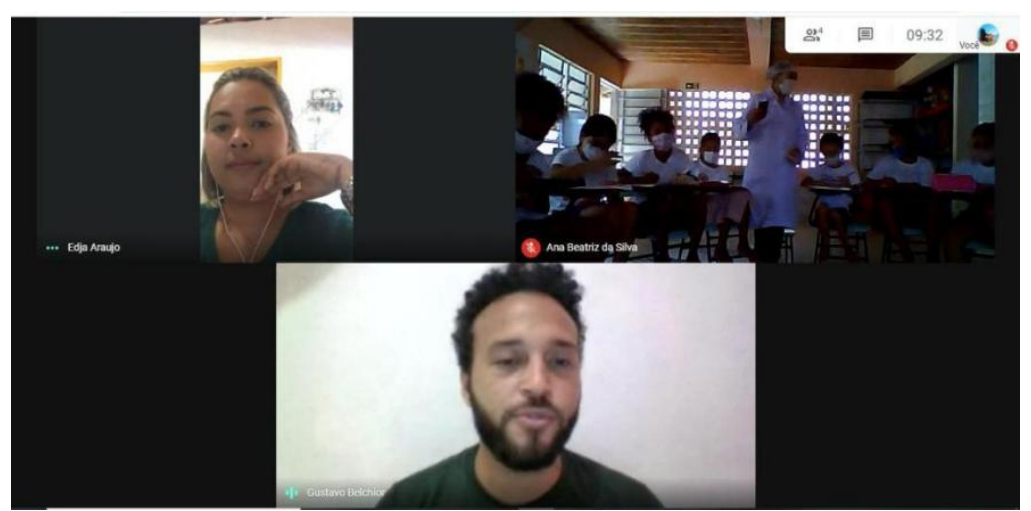

Fonte: Autoria Própria

\section{RESULTADOS E DISCUSSÃO}

O desenvolvimento das atividades foi plenamente satisfatório, indicando que a metodologia aplicada foi adequada e eficiente. Foi notória a apropriação pelas crianças dos conteúdos trabalhados, e a sua mudança de atitude como agentes transformadores, ao longo do processo.

Durante os seminários, onde foram apresentados os termos mais utilizados quando nos referimos à reciclagem e educação ambiental de forma mais ampla, as crianças demonstraram grande interesse nos temas discutidos, uma vez que estavam curiosas, resultado da metodologia aplicada em jogos e vídeos educativos, que 
estimulam essa curiosidade ao mesmo tempo em que aborda e envolve uma temática tão complexa de maneira lúdica. Algumas delas buscaram inclusive, informações fora do ambiente escolar para repassar às suas colegas, e contribuir ainda mais para o trabalho, o que demonstrou a eficiência desta atividade no sentido de prender a atenção das crianças.

No decorrer das oficinas com materiais recicláveis, notou-se uma grande disposição das crianças em desenvolver essa atividade, e a total integração entre elas juntamente com 0 orientador presente. Fazendo as crianças associarem 0 conhecimento adquirido nas atividades anteriores com o desenvolvimento de produtos próprios.

Relativo às atividades aplicadas, constatou-se um maior interesse e aplicação dos conceitos abordados por parte das crianças durante a confecção dos brinquedos recicláveis, porém as crianças demonstraram grande interesse e participação também durante a explanação teórica e atividades por escrito que foram aplicadas (relacione as colunas; ligue os pontos; pintura, etc.).

A visão das crianças sobre o lixo e material reciclável teve uma grande mudança, pois elas puderam observar e compreender que o que antes era considerado "inútil" agora se torna um recurso para seus brinquedos e objetos funcionais, ao mesmo passo em que diminuem a quantidade desses materiais que seriam descartados no meio ambiente, contribuindo para a preservação do mesmo.

Nesse sentido, Miranda (2008) destaca que jovens e crianças constituem o público-alvo mais promissor no processo de Educação Ambiental, pois sua consciência ambiental pode ser internalizada de maneira mais bem sucedida do que em adultos já formados e com comportamentos enraizados. Além de representarem as futuras gerações que irão compor a nova sociedade, eles também são multiplicadores e facilitadores eficazes na ação de estimular a análise crítica das questões ambientais e sociais na comunidade.

\section{CONSIDERAÇÕES FINAIS}

Conclui-se que as atividades, palestras e oficinas realizadas nas instituições, abriu as mentes das crianças, assim como proporcionou mudança de atitude como agentes 
transformadores, estes alunos serão capazes de atuar de forma crítica na sociedade, minimizando os impactos ao meio ambiente.

\section{REFERÊNCIAS}

BRASIL. Constituição da República Federativa do Brasil, 1988. Disponível em: <http://www.planalto.gov.br/ccivil_03/constituicao/constituicao.html>. 2020.

COSTA, R. C. P; FARDIM, S. V. S; MACHADO, M. A. G; MOÇO, F. S; OLIVEIRA, L. P. F; ORÉQUIO, V. R. T; SOUZA, R. R. Reciclagem: uma ferramenta para se trabalhar a Educação Ambiental de forma interdisciplinar nas escolas, promovendo a conscientização sobre a preservação do meio ambiente. Revista Brasileira De Educação Ambiental (RevBEA), 15(5), 173-183, 2020.

IBGE - Instituto Brasileiro de Geografia e estatística. PAS - Pesquisa Anual de Serviços. 2020.

MELO, J.R.; CINTRA, L, S; LUZ, C, N. M. Educação ambiental: reciclagem do lixo no contexto escolar. Revista Multidebates, v.4, n.2 Palmas-TO, jun, 2020.

MIRANDA, A. M. Percepção ambiental: 0 despertar para o conhecimento científico através de uma horta educativa. In 10 Encontro de Educação do Colégio Gonçalves Dias (10 EEGD) (pp. 1-11). Nova Iguaçu, RJ, 2008.

SANTOS, G.M; PRADO, G.M; TEIXEIRA, M.C. Educação ambiental em escolas do entorno do parque estadual de Itaúnas-ES. Kiri-kerê: Pesquisa em Ensino, n. 3, nov, 2017.

VIEGAS, S. F. S.; CABRAL, E. R. Práticas de Sustentabilidade em Instituições de Ensino Superior: Evidências de Mudanças na Gestão Organizacional. In: Sustainability Practices in Higher Education Institutions: Evidence of Changes in Organizational Management. Gual, Florianópolis, v. 8, n. 1, p.236-259, 2015. 


\title{
CAPÍTULO XIV
}

\section{DESAFIOS DA EDUCACÃO AMBIENTIL DURANIIE A PANDEMIA DA COVID-19: CONSCIENIIZACÃOO AMBIENTAL E DESENVOLVMIENTO SUSTENTÍYVEL}

\section{DOI: 10.51859/amplla.mas481.1121-14}

\author{
Amanda Freitas de Oliveira ${ }^{1}$ \\ Carllos Mozart Silva Almeida ${ }^{2}$ \\ Jéssica Malaquias da Silva ${ }^{3}$ \\ Miryam Torres dos Santos Cunha ${ }^{4}$ \\ Maria José de Holanda Leite ${ }^{5}$ \\ Andréa de Vasconcelos Freitas Pinto ${ }^{6}$
}

\begin{abstract}
${ }^{1}$ Graduanda em Engenharia Florestal. Universidade Federal de Alagoas - UFAL
${ }^{2}$ Graduando em Engenharia Florestal. Universidade Federal de Alagoas - UFAL

${ }^{3}$ Graduanda em Engenharia de Energia. Universidade Federal de Alagoas - UFAL

${ }^{4}$ Graduanda em Engenharia de Energia. Universidade Federal de Alagoas - UFAL

${ }^{5}$ Professora de Engenharia Florestal. Universidade Federal de Alagoas - UFAL
\end{abstract}

\section{RESUMO}

A busca por tecnologias e plataformas digitais de ensino se tornaram crescentes, principalmente após o cenário pandêmico que estamos enfrentando, para atender as demandas atuais da sociedade se fez necessário a adoção da educação à distância e a implementação do ensino EAD, como ferramenta para da continuidade na educação de milhares de pessoas. Dentre os assuntos estudados nos últimos tempos, têm se investido cada vez mais na educação ambiental, principalmente pelo crescimento na exploração aos recursos naturais, onde a mesma se mostra necessária para modificar um quadro de crescente degradação socioambiental fomentando a conscientização ambiental e a busca pela implementação de fontes de energias renováveis, que beneficiem o meio ambiente e a sociedade. Diante deste cenário, o objetivo desse trabalho foi disseminar a educação ambiental como uma ferramenta de melhoria e conscientização do ser humano, o fazendo refletir sobre a sociedade em que ele vive, de forma sustentável e, em paralelo, propiciar a educação ambiental como um alicerce para a sociedade.

Palavras-chave: Educação. Energia renovável. Educação ambiental.

\section{INTRODUÇÃO}

Diante de um cenário global de pandemia, universidades e escolas tiveram que se reinventar no modo de ensino aprendizagem, diante da impossibilidade de aulas 
presenciais e de modo a evitar "aglomerações" o Ministério da Educação (MEC) lançou no dia 17 de março de 2020 uma portaria manifestando-se sobre a substituição das aulas presenciais por aulas em meios digitais, enquanto durar a situação de pandemia da COVID-19.

Com a educação remota implementada, a busca por tecnologias e plataformas digitais de ensino se tornaram crescentes, o que mostrou também um certo déficit de uma parcela dos alunos em lidar com tais tecnologias.

As práticas de educação remota cresceram no mundo todo por conta da pandemia e se caracterizam por atividades mediadas por plataformas digitais assíncronas e síncronas, com encontros frequentes durante a semana, seguindo o cronograma das atividades presenciais realizadas antes do distanciamento imposto pela pandemia (ALVES, 2020).

Apesar da atual situação, a busca pela Educação Ambiental (EA) se torna importante, pois desenvolve de técnicas e métodos para a formação consciente do cidadão, capacitando-o e sensibilizando-o para o uso dos recursos naturais de maneira que não degradem o meio ambiente, possibilitando a preservação para as gerações futuras (SILVA, 2010).

A EA vem sendo muito comentada atualmente, por existirem questionamentos sobre os meios de utilização dos recursos naturais que causam problemas ambientais. Várias conferências internacionais foram realizadas na tentativa de se chegar a um discernimento ou alguma maneira para que o ser humano pudesse construir um pensamento crítico, juntamente com bases em estudos científicos (VIEIRA, 2011).

Diante deste cenário, o objetivo desse trabalho foi disseminar a educação ambiental como uma ferramenta de melhoria e conscientização do ser humano, o fazendo refletir sobre a sociedade em que ele vive, de forma sustentável e, em paralelo, propiciar a educação ambiental como um alicerce para a sociedade.

\section{REVISÃO BIBLIOGRÁFICA}

\subsection{EDUCAÇÃO A DISTÂNCIA}

A educação é uma ação histórica e transitória que reflete as transformações da base da sociedade, ou seja, que sofre alterações de acordo com as condições e o 
contexto sócio econômico em que atua, fazendo-se necessário se adequar as necessidades dos que necessitam de aprendizado.

A Educação a Distância (EAD) é uma forma/modalidade de ensino que rompe com a forma tradicional e aponta para um novo paradigma. É uma modalidade de realizar o processo de construção do conhecimento de forma crítica, criativa e contextualizada, no momento em que o encontro presencial do educador e do educando não ocorrer, promovendo-se, então, a comunicação educativa através de múltiplas tecnologias (HACK, 2011).

A denominação "modalidade" para a EAD nos leva a refletir se a mediação tecnológica dos processos de ensino e aprendizagem significaria dizer que o meio é que determina a relação pedagógica e que os recursos pedagógicos é que ditariam a ação docente (LEMGRUBER, 2012).

Segundo Petri (2000), historicamente a Educação a Distância surgiu na pósrevolução russa, ou seja, na década de vinte, do século passado, para suprir deficiências da escola formal, que, por ter sido até então elitista, atingia um número restrito de pessoas.

No Brasil há dois modelos de educação a distância que são aplicados. O primeiro modelo o professor ministra o conteúdo através de tele aulas, em sua forma tradicional de atuação. No segundo, o professor orienta os alunos através de tutorias e interage com os alunos através dos materiais impressos e ferramentas digitais disponíveis (MORAN, 2009).

Pensando em ampliar o acesso à educação, mesmo que remotamente, se faz necessário procurar alternativas, com isto a instituição escolar precisa manter seu papel de disseminadora formal dos conhecimentos a todos, já que esse é o papel que a sociedade lhe incumbe (GOMES, 2013).

Almeida (2003) ressalta que, mais do que vencer distâncias e simplesmente substituir o ensino presencial, o Ensino a Distância deve inovar no processo de ensinar e aprender, já que dispõe de diversas ferramentas para essa finalidade. 


\subsection{EDUCAÇÃO AMBIENTAL: IMPORTÂNCIA PARA SOCIEDADE}

O crescimento científico e tecnológico dos últimos tempos proporcionou não só benefícios para a humanidade, como também uma exploração aos recursos naturais, bem como a emissão de poluentes que são lançados na atmosfera e rios (EFFING, 2007).

Como estratégias para mitigar esses danos, Effting (2007) aborda que a Educação Ambiental (EA) é um método de aprendizagem que melhora as relações entre a sociedade humana e o meio ambiente de forma integrada e sustentável. Este método expõe à relação do homem com a natureza, trazendo ao conhecimento do homem maneiras de preservar, conservar e administrar seus recursos de uma forma mais adequada e sustentável. Nesse contexto, a escola funciona como uma ferramenta de promoção da cidadania e respeito ao meio ambiente, pois propicia ao homem uma visão crítica, global e uma posição participativa e consciente na proteção ao meio ambiente.

Sendo assim, a educação ambiental se mostra necessária para modificar um quadro de crescente degradação socioambiental, onde se faz necessário a implementação de atividades práticas e rotineiras que venham a auxiliar a formação e conscientização do ser humano, para que assim possa compreender a atual realidade e formar conceitos valorizando a preservação ambiental (GODINHO, 2009).

\subsection{ENERGIA RENOVÅVEL: POR UM FUTURO SUSTENTÁVEL}

De acordo com Silva (2019), as energias renováveis são aquelas naturais, inesgotáveis, limpas e que se regeneram em pouco tempo sem impactar o meio ambiente, são obtidas a partir de recursos da natureza, como sol, ar, água, chuva, oceanos, rios, ondas, calor da terra, matéria orgânica, entre outros.

Na busca por fontes alternativas, o Brasil apresenta diferencial em relação a outros países, pois a sua imensa biodiversidade, permite a geração de energia por vários meios, através de fonte de energias renováveis como a hidrelétrica, solar, eólica e a busca pelo desenvolvimento de fontes alternativas como a utilização da biomassa, para produção de combustíveis renováveis, como o álcool e o biodiesel (AGRONEGÓCIOS, 2006).

Segundo dados do Ministério de Minas e Energia, no Brasil, cerca de $45 \%$ da sua matriz energética é renovável, fazendo com que o Brasil tenha um grande potencial para 
elevar esse percentual e investir ainda, pois possuí características bastante favoráveis, como a extensão territorial, a mão-de-obra e o desenvolvimento tecnológico, que possibilitariam tanto complementar o abastecimento das tradicionais redes elétricas como produzir combustíveis (BRASIL, 2018).

Sendo a nova ordem mundial a busca pela autossuficiência em geração de energia, aliada a uma diversificação da matriz energética, ou seja, a procura por diferentes fontes de energias alternativas que supram a demanda interna dos países (IGNATIOS, 2006).

As vantagens ambientais da energia renovável é que diminuem as emissões de gases de efeito estuda (GEE) e outros poluentes que contribuem para as mudanças climáticas, ajudam a reduzir doenças respiratórias relacionadas à poluição, reduzem a necessidade de indústrias extrativistas, não precisam utilizar apenas a água como fonte de energia elétrica (SILVA, 2019).

Deste modo, traz benefício não só ambientais e sociais, como também econômicos. Silva (2019) afirma que as energias renováveis geram impactos positivos econômicos através da redução de tarifas nos serviços de eletricidade, água e gás, também proporciona a geração de empregos indiretos e diretos, e redução de custos para os municípios nos serviços de consumo público como iluminação pública, bombeamento de água e edifícios públicos.

\section{CONSIDERAÇÕES FINAIS}

Como foi mencionado anteriormente, a educação á distância tem sido uma ferramenta muito importante para atender a atual demanda por educação e alcançar o maior número de pessoas para que tenham acesso a educação, mesmo que de forma remota.

Desta maneira, a educação ambiental possui um papel importante no desenvolvimento do ser humano, principalmente nas condições atuais, onde o meio ambiente vem enfrentando uma exploração pelos recursos naturais.

Para que o desenvolvimento sustentável aconteça se faz necessário implementar ações e práticas que sejam sustentáveis e inovadoras, uma delas é o uso de energias 
renováveis, que traz benefícios não somente para o meio ambiente, mas também para a sociedade.

\section{REFERÊNCIAS}

AMORIM, M. F. A importância do ensino à distância na educação profissional. Disponível

em:

<http://portalrevistas.ucb.br/index.php/raead/article/viewFile/3218/2232>.

Acesso em: 08 mar. 2021.

ALMEIDA, F. J.; ALMEIDA, M. E. B. Educação a distância em meio digital: novos espaços e outros tempos de aprender, ensinar e avaliar. In: VIRTUAL EDUCA, Miami, 2003.

ALVES, L. Educação à distância: conceitos e história no Brasil e no mundo. Disponível em:

<http://www.abed.org.br/revistacientifica/Revista_PDF_Doc/2011/Artigo_07.p df>. Acesso em: 08 ar. 2021.

ALVES, L. Educação remota: entre a ilusão e a realidade. In: Interfaces Científicas, v.8, n.3, 2020.

BRASIL. Ministério da Educação. Conselho Nacional de Educação. Proposta de parecer sobre reorganização dos calendários escolares e realização de atividades pedagógicas não presenciais durante o período de pandemia da COVID-19. 28 de abril de 2020. Brasília, DF, 2020.

BRASIL. Ministério de Minas e Energia. Empresa de Pesquisa Energética. Matriz energética e elétrica. Disponível em: https://www.epe.gov.br/pt/abcdenergia/matriz-energetica-e-eletrica Acesso em : 08/03/2021

EFFTING, T. R. Educação ambiental nas escolas públicas: realidade e desafios. 2007. 90 f. Monografia (Pós Graduação em "Latu Sensu" Planejamento Para o Desenvolvimento Sustentável) - Centro de Ciências Agrárias, Universidade Estadual do Oeste do Paraná, Paraná. 2007. Disponível em: http://www.diaadiaeducacao.pr.gov.br/diaadia/diadia/arquivos/File/taniaregin a.pdf Acesso em 07/03/2021.

GODINHO, N. C. A importância da educação ambiental na escola para despertar uma consciência sustentável relacionada aos resíduos sólidos domésticos na sociedade. 2009.58f. Monografia. (Graduação em Ciências Biológicas) Faculdade Patos de Minas, Patos de Minas.

GOMES, L. F. Tendências e desafios da educação superior: EAD no Brasil: Perspectivas e Desafios. v. 18, n. 1, p. 13-22, mar. 2013. 
HACK, J. R. Introdução à educação à distância. Florianópolis: LLV/CCE/UFSC, 2011.

LEMGRUBER, Márcio Silveira. Educação a distância: para além dos caixas eletrônicos. Portal do MEC. Disponível em: <http://portal.mec.gov. br/arquivos/conferencia/documentos/marcio_lemgruber.pdf $>$. Acesso em: $8 \mathrm{de}$ março de 2021.

MORAN, J. M. Aperfeiçoando os modelos de EAD existentes na formação de professores. $<$ http://revistaseletronicas.pucrs.br/ojs/index.php/faced/article/download/577 5/4196>. Acesso em: 08 mar. 2021.

PETRI, O. Autonomia do aprendiz na educação a distância: significados e dimensões. In: Educação a Distância: construindo significados. Cuiabá, 2000.

SILVA, T. G. A importância do estudo sobre o aquecimento global na educação ambiental de alunos do ensino fundamental e o papel do educador desse processo. 2010. 50f. Monografia. (Graduação em Ciências Biológicas). Faculdade Patos de Minas.

SILVA, S. Qual a importância e benefícios das fontes da energia renovável? Disponível em:< https://respostas.sebrae.com.br/qual-a-importancia-e-beneficios-dasfontes-de-energia-renovavel/> Acesso: 08/03/2021

VIEIRA, E. R. Educação Ambiental e a questão do lixo em uma escola pública municipal de Juiz de Fora: contribuições do projeto Rota Verde. Rio de Janeiro, 2011.

WEIR, K. What did distance learning accomplish?. American Psychological Association, v.51, n. 6, 2020. 


\title{
CAPITTULO XV
}

\section{O AUTOCUIDADO NA SIIFILS E HEPATIIIE C. ACÃO EDUCATIVA COM TRABALHADORES DE MATERIAIS RECICLÁVEIS}

\section{DOI: 10.51859/amplla.mas481.1121-15}

\author{
Fernanda Soares de Aguir ${ }^{1}$ \\ Bruna Borges de Oliveira ${ }^{1}$ \\ Airton José Melchiors ${ }^{1}$ \\ Carolini Aguiar da Silva Sartori ${ }^{1}$ \\ Fernando Silva da Silva ${ }^{1}$ \\ Talitta da Silva Copetti ${ }^{1}$ \\ Vivian Lemes Lobo Bittencourt ${ }^{2}$ \\ Sandra Leontina Graube ${ }^{2}$ \\ Jane Conceição Perin Lucca ${ }^{3}$
}

\footnotetext{
${ }^{1}$ Graduando do curso de Enfermagem. Universidade Regional Integrada do Alto Uruguai e das Missões - URI/Santo Ângelo

${ }^{2}$ Enfermeira. Mestre em Atenção Integral à Saúde. Docente no curso de graduação em Enfermagem na Universidade Regional Integrada do Alto Uruguai e das Missões - URI/Santo Ângelo.

${ }^{3}$ Enfermeira. Mestre em Ensino Científico e Tecnológico. Docente no curso de graduação em Enfermagem na Universidade Regional Integrada do Alto Uruguai e das Missões - URI/Santo Ângelo.
}

\section{RESUMO}

Introdução: O trabalhador de resíduos sociais está exposto a um ambiente insalubre, o que ocasiona práticas danosas à saúde, que se agravam pela escassez de políticas públicas. Neste sentido, é relevante que sejam feitos estudos que abordem a temática, assim como a elaboração de protocolos educativos que estimulem a qualidade de vida. Objetivo: Promover o conhecimento sobre o autocuidado dos trabalhadores de materiais recicláveis por meio de uma ação educativa sobre a IST Sífilis e Hepatite C. Métodos: Relato de experiência, qualitativo, descritivo, em uma cooperativa de reciclagem no Noroeste do estado do Rio Grande do Sul, no segundo semestre de 2020. Critérios de inclusão: estar trabalhando na cooperativa e presente no dia da ação em saúde. Critérios de exclusão: não aceitar participar do projeto. 14 colaboradores participaram da ação educativa. Primeiramente foram realizados testes rápidos, seguida de consulta simplificada de enfermagem, divulgação em rede social e por fim fixação de pôster lúdico e disponibilização de dispensers de preservativos. Resultados e discussão: Do total de participantes, 57\% eram homens e 43\% mulheres, com idade entre 20 e 50 anos, e 7,14\% testaram positivo para Sífilis. Grande parte dos trabalhadores referiu não procurar atendimento na rede de atenção à saúde de forma regular. Em contrapartida, mencionaram utilizar automedicação; entre as mulheres evidenciou-se desconhecimento sobre planejamento familiar. Considerações finais: Percebeu-se a importância de oportunizar discussões dentro desses estabelecimentos por profissionais e acadêmicos da área de saúde, contribuindo para a melhoria da qualidade de vida, possibilitando reflexões sobre o autocuidado e a promoção da saúde.

Palavras-chave: Autocuidado. Catadores. Doenças Sexualmente Transmissíveis. Educação em Saúde. Enfermagem. 


\section{INTRODUÇÃO}

Desde o surgimento da raça humana, o homem convive diretamente com a carência, escassez e pobreza, entre outras mazelas. O surgimento dos primeiros recicladores ocorreu na antiguidade clássica, eram pessoas com pouco ou nenhum prestígio social e que desempenhavam atividades de manusear o lixo. Estes reutilizavam e reaproveitavam roupas, ferramentas de trabalho e utensílios domésticos que outras pessoas descartavam, tornando essas ações fonte de renda e prática econômica (BOSI, 2016).

É importante frisar que o cotidiano dos catadores de resíduos é pouco estudado pela saúde pública no Brasil, mas as pesquisas existentes evidenciam que o ambiente de labor precário, ao qual estão expostos, ocasionam práticas danosas à sua saúde e à qualidade de vida, pois impõem muitos riscos ocupacionais, principalmente no manuseio manual de agentes biológicos, como vírus, bactérias, fungos, protozoários e artrópodes, podendo adquirir doenças infectocontagiosas (ARAÚJO; FURTADO; SANTOS, 2018).

Conforme Bortoli (2009), a inclusão da profissão de catador no Código Brasileiro de Ocupações não melhorou as condições de vida ou de trabalho desses profissionais, sendo que esses atuam de forma frequente, sem vínculo empregatício e, consequentemente, sem direitos assegurados. Essa prática oportuniza o descuido destes com suas condições de saúde física e mental, tornando irrelevante situações de agravos, que ao longo do tempo podem comprometer de forma irreversível o organismo desses trabalhadores.

Apesar do grande número de trabalhadores distribuídos por todo o território nacional e a função econômica, social e ambiental que executam, não deixa de ser uma contradição o fato de que, ao mesmo tempo em que o termo "sustentabilidade" está em alta nos discursos, e também na legislação, os profissionais que trabalham com a reciclagem ainda sofrerem com precárias condições de vida, além do estigma social pela atividade que executam (IPEA, 2017).

Vale ressaltar que a ideia de reutilizar e tornar sustentável a prática laboral milenar surgiu da necessidade de manutenção financeira do sujeito, e não do pensamento de preservação dos recursos naturais e prevenção do meio ambiente, 
como por vezes é rasante percebida (BOSI, 2016). Ainda que esses trabalhadores necessitem desse trabalho e dessa renda, é necessário que medidas administrativas sejam implementadas pelo poder público, como políticas apropriadas para ofertar melhores condições de trabalho.

Diante do exposto, muitas vezes observa-se que o catador também não valoriza ou minimiza as questões relacionadas aos cuidados com sua saúde. Sobre o somatório das perspectivas, é possível pensar que a escassez de recursos, a desinformação e os moldes formados ao longo da história são observados como impedimentos para oferta de saúde ou de autocuidado, e esta é uma realidade que precisa ser alterada. O cuidado é um princípio importante para o ser humano, desde o nascimento até o final de sua vida, sua falta acarreta em debilidade e desorganização (BOFF, 2017).

No decorrer da vida, com o amadurecimento da cognição, o ser humano aprendeu a responsabilizar-se e, assim, autocuidar-se. Desta forma, o autocuidado emerge como uma função regulatória, que possibilita aos indivíduos autonomia para desempenharem papéis que promovam ações de preservação à saúde, vida, bem-estar e evolução (PETRY et al., 2019).

O autocuidado realizado de forma efetiva auxilia no funcionamento normal e no desenvolvimento do ser humano (OREM, 1991). A "Teoria do Autocuidado", elaborada pela enfermeira Dorothea Orem, possibilita à enfermagem trabalhar questões de promoção e manutenção da saúde, empoderando os indivíduos acerca da importância das atitudes que levem ao autocuidado. Para isso, é necessário que o enfermeiro realize intervenções educacionais, com o intuito de estimular o autocuidado, visando diminuir o grau de dependência, tornando o indivíduo o principal autor na promoção da sua saúde (BEZERRA, 2019).

As ações educativas em saúde também oportunizam trocas de conhecimentos entre os profissionais da enfermagem e essa classe trabalhadora vulnerável, buscando promover o autocuidado e prevenir doenças, além de assegurar e consolidar os princípios fundamentais do Sistema Único de Saúde (SUS), na participação social, na integralidade, na universalidade e na equidade. Em virtude disso, oportunizar informações sobre temas relacionados às doenças que desafiam a integridade, e que existem mecanismos para seu controle, prevenção e tratamento, como é o caso das 
infecções sexualmente transmissíveis (IST), é uma realidade que cada vez mais necessita ser implementada (BRASIL, 2020).

A Sífilis desafia a séculos a humanidade, e embora seja curável, por meio de tratamento eficaz e de baixo custo, transformou-se em um sério problema de saúde pública. Essa doença é causada pela bactéria Treponema Pallidum e apresenta diversas manifestações clínicas em seus estágios (Sífilis primária, secundária, latente e terciária), com maior possibilidade de transmissão nos estágios primário e secundário (BRASIL, 2020). Sua transmissão ocorre via relação sexual, sem proteção, com uma das pessoas infectadas, ou durante a gestação ou parto (Sífilis congênita); dessa forma, evidencia-se que sua prevenção ocorre por meio do uso correto e regular do preservativo feminino e/ou masculino e acompanhamento das gestantes durante o pré-natal para o controle da Sífilis congênita (BRASIL, 2020).

O diagnóstico pode ser realizado pela rede de atenção primária à saúde, por meio de teste rápido (TR) de Sífilis, com leitura de no máximo 30 minutos. Caso TR positivo, deve ser efetuada uma nova coleta de amostra de sangue e encaminhada para teste laboratorial não treponêmico, para confirmação de diagnóstico. Quanto ao tratamento, é indicada penicilina benzatina (benzetacil), e a administração medicamentosa ocorre na unidade de saúde, durante a consulta com o profissional responsável (BRASIL, 2020).

Ainda no que se refere à IST, destaca-se com elevada prevalência a Hepatite C (HCV), a qual consiste em um processo inflamatório e infeccioso no fígado, causado pelo vírus C da Hepatite, apresentando-se de forma aguda ou crônica; sua transmissão ocorre pelo contato com sangue contaminado, pelo compartilhamento de agulhas, seringas e outros objetos para uso de drogas (cachimbos) (BRASIL, 2020). Já o diagnóstico em geral ocorre após teste rápido de rotina ou por doação de sangue, e caso o teste de anti-HCV apresente resultado positivo, é necessário realizar exame de carga viral (HCV-RNA) para confirmação. Caso ocorra a confirmação, o paciente inicia o tratamento com antivirais de ação direta, ofertado gratuitamente pelo SUS, tratamento esse que tem período estimado entre 8 e 12 semanas e possibilita a eliminação da infecção (BRASIL, 2020).

À luz desta análise, a integralidade do cuidado, realizada pela equipe de enfermagem na promoção, prevenção, diagnóstico e tratamento da IST, assim como as 
ações educativas, incorporam atividades com os trabalhadores de material reciclável da cooperativa, com o propósito de agregar a esses indivíduos novos saberes, que farão a diferença no cuidado consigo e parceiros(as).

A partir desse contexto, a promoção da saúde faz-se necessária pela constante expectativa de uma nova saúde pública. Visto que, dentre os conceitos discutidos na Conferência de Ottawa e publicados por meio da Carta de Ottawa (1986), constatou-se que a saúde depende de fatores políticos, econômicos, sociais, culturais, ambientais, comportamentais e biológicos. Assim como ela também é o principal recurso para uma vida social, econômica, mental e pessoal melhor. Dessa forma, as ações de promoção da saúde precisam fazer com que as condições descritas sejam favoráveis.

Conforme publicado no relatório da 16ạ Conferência Nacional de Saúde, em 2019, a promoção da saúde não deve pensar apenas em não estar doente, mas é necessário refletir sobre as condições de vida, de saúde e de trabalho do nosso usuário/cliente. Entre elas: se ele possui casa, trabalho, salário condigno, água, vestimenta, educação, informações sobre sua condição de saúde (CNS, 2019).

Essas tornam-se relevantes para a promoção do autocuidado e configuram-se como uma estratégia para auxiliar na identificação dos riscos de exposição presentes na vida desses trabalhadores que favorecem o adoecimento. Frente a isso, destaca-se a atuação da enfermagem, com o papel de promoção e de manutenção da saúde, considerando o aspecto holístico em relação ao indivíduo. Nesse contexto, o estudo tem por objetivo promover o conhecimento sobre o autocuidado dos trabalhadores de materiais recicláveis por meio de uma ação educativa sobre a IST Sífilis e Hepatite C.

\section{METODOLOGIA}

Trata-se de um relato de experiência, com abordagem qualitativa, descritiva. A ação educativa descrita neste estudo foi realizada em uma cooperativa de reciclagem, no Noroeste do estado do Rio Grande do Sul. No dia 3 de novembro de 2020 foi desenvolvida a ação educativa na cooperativa de triagem de resíduos sólidos, estruturada com um galpão de triagem, um escritório, uma sala de lazer para os trabalhadores e uma área livre (pátio). Como critérios de inclusão elencamos: estar efetivamente trabalhando na cooperativa, estar presente no dia ação em saúde e não 
estar em licença médica. Critérios de exclusão: não aceitar participar do projeto. A cooperativa possui 15 trabalhadores de materiais recicláveis, dos 15 trabalhadores que perfazem o quadro funcional da empresa 14 preencheram os critérios de inclusão e participaram da intervenção.

A ação educativa foi desenvolvida por cinco alunos do oitavo semestre do curso de Graduação em Enfermagem de uma universidade privada localizada na mesma região da cooperativa de reciclagem. O planejamento e execução da ação educativa foi acompanhado pela docente responsável pela disciplina curricular "Projeto de intervenção profissional".

Após o aceite dos colaboradores em participar da ação educativa, foram realizados os testes rápidos de Sífilis individualmente. Na etapa seguinte, foi realizada uma consulta simplificada de enfermagem, desenvolvida pelos acadêmicos autores, de forma individual. Nessa foram realizadas anamnese, associada a escuta ativa e orientações referentes a prevenção de IST, uso de preservativos, vida sexual saudável, rastreamento do câncer de colo de útero anualmente e uso de anticoncepcional.

Ainda, foi divulgada na rede social Instagram a importância da prevenção, diagnóstico, tratamento da Sífilis e os trabalhadores foram convidados para visitar a página. A ação educativa foi concluída com a fixação de um pôster lúdico em uma das paredes da sala de lazer da cooperativa de reciclagem com informações sobre IST, já repassadas verbalmente. E para prevenção da IST foi disponibilizado dois dispensers confeccionados de material reciclável pelos acadêmicos, com preservativos masculinos e femininos cedidos pela 12a Delegacia Coordenadoria de Saúde do município.

\section{RESULTADO E DISCUSSÕES}

Participaram da ação 14 trabalhadores. Em um primeiro momento, o grupo de cinco acadêmicos de enfermagem e a docente da disciplina foram recebidos e acolhidos pela coordenadora da cooperativa de reciclagem, que apresentou o projeto aos demais cooperados. A acolhida ocorreu de forma agradável, e o grupo pode organizar as atividades conforme as condições estruturais permitiram e, então, a docente do projeto fez uma breve explanação aos trabalhadores, orientando o que ocorreria a seguir para que as atividades dessem início. 
A organização inicial aconteceu da seguinte maneira: dois acadêmicos ficaram responsáveis pela realização dos TR de Sífilis, Hepatite B, Hepatite C e HIV. Para Neves et al. (2015), o teste rápido é um procedimento diagnóstico, realizado por meio da punção na polpa digital e coleta do sangue através de uma pipeta, com posterior distribuição em membrana de teste de imunocromatografia; na sequência, coloca-se a solução tampão e aguarda-se para fazer a leitura. A formação de duas linhas coloridas (área teste T e área controle C) é considerado reagente, e a não coloração da área de controle é compreendida como não reagente, sendo de fácil aplicação e o resultado de 10 a 30 minutos, agilizando o aconselhamento necessário.

A ordem dos trabalhadores para a realização dos testes foi aleatória. Outros dois acadêmicos permaneceram nas consultas de enfermagem, atividade conduzida na mesma ordem de realização dos TR, e o 5o acadêmico permaneceu como observador, realizando anotações, conforme a atividade se desenvolvia. A consulta de enfermagem é uma atividade exclusiva do enfermeiro, que visa orientar sobre a necessidade de adotar um estilo de vida saudável, corroborando para importância do autocuidado, prevenindo, desta forma, doenças e agravos, com a aplicação do processo de enfermagem como maneira de promoção da saúde (MANZINI; SIMONETTI, 2009).

No total foram catorze $(n=14)$ participantes, destes $57 \%(n=8)$ homens e $43 \%$ $(n=6)$ mulheres, com idade entre 20 e 50 anos. A média de idade masculina foi de 38 anos e a feminina de 29 anos. Houve uma boa aceitação entre os trabalhadores em participar da atividade proposta.

As ações educativas contribuem como uma ferramenta de informação e conhecimento, que promovem e previnem situações de agravos à saúde dos indivíduos, ficando evidente pela participação e depoimentos dos participantes, registrados em diário de campo. Tanto profissionais como acadêmicos da área da saúde utilizam-se da educação como um instrumento de trabalho, na construção da relação com a comunidade, possibilitando desenvolver indivíduos com consciência da responsabilidade por sua saúde e seu autocuidado; essa interligação do profissional com a população transforma os indivíduos, levando-os a buscar pelos serviços oferecidos, em resposta às necessidades de prevenção e promoção de sua saúde, bem como ao controle das doenças (SANTOS et al., 2011). 
Outro fato relevante é que eles não realizavam os exames de sorologias, como os TRs para doenças transmissíveis, e desconheciam a importância da realização desses. Assim, apesar dos TRs serem disponibilizados de forma gratuita pelo SUS sem a necessidade de agendamento prévio, com resultado em poucos minutos, os índices de procura de TRs é inferior ao desejável, o que pode estar relacionado a aspectos sociais, econômicos e compreensão de saúde (ANDRADE; CAUS, 2020).

Durante a ação educativa, ocorreram trocas de saberes através dos diálogos, o que oportunizou momentos de questionamentos e reflexões dos trabalhadores com os acadêmicos. A Política Nacional de Educação Popular em Saúde, no âmbito do Sistema Único de Saúde, traz a importância do diálogo e a construção compartilhada do conhecimento em ações com a comunidade, contribuindo para ampliar a noção crítica, para o processo de transformação e de humanização, e para compreender o coletivo (BRASIL, 2013).

Após a realização dos TRs e das consultas de enfermagem, foi fixado um banner educativo na sede da cooperativa, como forma de instrução contínua sobre a importância da prevenção de IST. Também foram colocados dispensers de preservativos nos banheiros da associação, e os colaboradores foram orientados sobre a importância da reposição do material, o qual foi disponibilizado para a instituição.

Parte dos participantes se reconhecia como sujeito saudável, no entanto um número significativo referiu que costuma realizar automedicação com antiinflamatórios e analgésicos, que podem ser adquiridos sem prescrição médica, os quais foram advertidos sobre o risco que esse comportamento errôneo pode trazer à sua saúde. Ademais, ficaram perceptíveis as exposições cotidianas aos perigos no ambiente de labor e o quanto esses trabalhadores estão à margem da sociedade. Com relação a automedicação, essa se baseia no uso de medicações sem a devida orientação e prescrição médica, onde a pessoa acredita, baseada em sugestões de pessoas próximas ou saberes populares, que o uso de certo medicamento lhe será eficaz (PEREIRA et al., 2017).

Ao realizar a leitura dos TRs, 7,14\% $(n=1)$ testou positivo para Sífilis. Na consulta de enfermagem, apenas o usuário que teve o teste reagente repetiu-o para confirmação 
e o resultado se manteve. Após foram esclarecidas dúvidas e o mesmo foi encaminhado para a unidade de saúde de referência.

$\mathrm{Na}$ ação educativa ficou evidente que as mulheres não tinham conhecimento sobre planejamento familiar. Foram queixas frequentes durante as consultas de enfermagem: cefaleia, dor no baixo ventre e vertigem. Referiram ainda fazer uso de plantas medicinais na forma de chás e compressas baseados em saberes populares.

Ao finalizar a ação educativa, foi realizado um agradecimento aos coordenadores da cooperativa, por oportunizar este momento de troca de saberes, que serve como incentivo não apenas aos colaboradores da cooperativa de reciclagem, mas também aos acadêmicos de enfermagem, valorizando ainda mais a profissão em ações que visam a prevenção e a promoção da saúde.

\section{CONSIDERAÇÕES FINAIS}

A partir deste estudo surgiram reflexões sobre a importância de valorizar e prestar serviços a esses trabalhadores que estão suscetíveis. Considera-se importante oportunizar a discussão dentro desses estabelecimentos pelos profissionais e acadêmicos da área de saúde, podendo assim contribuir com a melhoria da qualidade de vida, possibilitando refletir sobre o autocuidado e a promoção da saúde de forma eficaz.

Por fim, percebe-se que é necessária uma participação mais efetiva da enfermagem, por meio de estratégias e ações educativas em saúde, visando essa classe de trabalhadores, pois dentre esses há um público-alvo que muitas vezes o sistema não consegue alcançar. Por meio dessas ações conseguimos ampliar a atenção para eles e promover o fortalecimento do autocuidado. Ações educativas corroboram com informações e conhecimento para incentivar o autocuidado, bem como a prevenção de doenças como a Sífilis e a Hepatite C.

Além disso, ressignificar o papel desses trabalhadores e de sua importância para a sustentabilidade oportuniza, por meio de ações educativas, esclarecer dúvidas que contribuem para melhorar a qualidade de vida, o autocuidado e diminuir a exclusão social, ações nas quais a enfermagem pode assumir seu compromisso de levar 
conhecimento e informação para todos os ambientes de trabalho, principalmente no que foi alvo deste estudo, tão carente de acesso e cuidados.

\section{REFERÊNCIAS}

ANDRADE, J. A. CAUS, E. C. M. AVALIAÇÃO DA REALIZAÇÃO DO TESTE RÁPIDO NA CONSULTA DE ENFERMAGEM COMO ENFRENTAMENTO DA SÍFILIS. Saúde e meio ambiente Rev. Interdisciplinar. Universidade do Contestado. V. 9 p. 106-119. SC, 2020.

ARAÚJO, N.H; FURTADO G. D.; SANTOS G. D. VIABILIDADE DA RECICLAGEM NO ESTADO DA PARAÍBA. 2018.

BEZERRA, M. L. R.; et al. Aplicabilidade da teoria do déficit do autocuidado de ordem no Brasil: uma revisão integrativa. JMPHC | Journal of Management \& Primary Health Care | ISSN 2179-6750, v. 9, 11 jan. 2019.

BOFF, Leonardo. Saber Cuidar: Ética do Humano, compaixão pela terra. 20. ed. Rio de Janeiro: Vozes, 2017.

BORTOLI, M. Catadores de materiais recicláveis: a construção de novos sujeitos políticos. Revista Katálysis, Florianópolis, v. 12, n. 1, p. 105-114, jan./jun. 2009.

BOSI A. P. História dos catadores no Brasil. 2016.

BRASIL. PORTARIA № 2.761, DE 19 DE NOVEMBRO DE 2013. 2013.

BRASIL. Ministério da Saúde. Secretaria de Atenção à Saúde. Departamento de Atenção Básica. Saúde sexual e saúde reprodutiva. Brasília: Ministério da Saúde, 2013. 300 p. Cadernos de Atenção Básica, n. 26.

BRASIL. Prevenção Combinada.

CONSELHO NACIONAL DE SAÚDE. Relatório da 16ạ conferência nacional de saúde. Brasília, DF, 2019.

Instituto de Pesquisa Econômica Aplicada. Texto para discussão. Brasília: Rio de Janeiro: Ipea, 2017.

MANZINI, Fernanda Cristina; SIMONETTI, Janete Pessuto. Consulta de enfermagem aplicada a clientes portadores de hipertensão arterial: uso da teoria do autocuidado de orem. Rev. Latino-Am. Enfermagem, Ribeirão Preto , v. 17, n. 1, p. 113-119, Feb. 2009. 
MINISTÉRIO DA SAÚDE. SECRETARIA DE VIGILÂNCIA EM SAÚDE. DEPARTAMENTO DE DOENÇAS DE CONDIÇÕES CRÔNICAS E INFECÇÕES SEXUALMENTE TRANSMISSÍVEIS. INDICADORES E DADOS BÁSICOS DA SÍFILIS NOS MUNICÍPIOS BRASILEIROS.

MINISTÉRIO DA SAÚDE. Hepatite C.

MINISTÉRIO DA SAÚDE. PRIMEIRA CONFERÊNCIA INTERNACIONAL SOBRE PROMOÇÃO DA SAÚDE: Ottawa, novembro de 1986.

MINISTÉRIO DA SAÚDE. Sífilis: o que é, causas, sintomas, tratamento, diagnóstico e prevenção.

NEVES, M.; MARCELO CARVALHO DOCKHORN, D. TESTES RÁPIDOS PARA DIAGNÓSTICO DE HIV: uma revisão narrativa da literatura. Revista da Graduação, v. 8, n. 1, 18 maio 2015.

OREM, D.E. (1991). Nursing: Concepts of practice. (4th ed.). St. Louis: Mosby.

Pereira, FGF et al. (2017). Automedicação em idosos ativos. Rev. enferm. UFPE online.

PETRY, Stéfany; PADILHA, Maria Itayra; KUHNEN, Adriana Eich. Saberes de estudantes de enfermagem sobre a prevenção de Infecções Sexualmente Transmissíveis. Rev. Bras. Enferm., Florianópolis, v. 72, n. 5, p. 1145-1152, set./2019.

SANTOS, F. P. D. A. et al. Estratégias de enfrentamento dos dilemas bioéticos gerados pela violência na escola. Physis, Rio de Janeiro, v. 21, n. 1, p. 267-281, jan./2011. 


\title{
CAPÍTULO XVI
}

\section{RISCOS AMBIENTAIS E ERGONÔMICOS NAS ATTYIDADES DE COLETA EXTRACÃO DE MARISCOS NO NORDESTE PARAENSE}

\section{DOI: 10.51859/amplla.mas481.1121-16}

\author{
Juciane Araujo Ipiranga ${ }^{1}$ \\ Larissa Paz de Abreu ${ }^{1}$ \\ Ester dos Reis Dias ${ }^{1}$ \\ Klewton Adriano Oliveira Pinheiro ${ }^{1}$ \\ Francimary da Silva Carneiro ${ }^{2}$ \\ Larissa Martins Barbosa D'Arace ${ }^{2}$
}

${ }^{1}$ Instituto Federal do Pará-IFPA

${ }^{2}$ Secretaria estadual de Meio Ambiente e Sustentabilidade-SEMAS-PA

\section{RESUMO}

O objetivo deste trabalho foi avaliar os principais riscos ambientais, os impactos na saúde dos trabalhadores, o seu grau de conhecimento em relação a esses riscos, e recomendação de medidas que possam diminuir os problemas verificados das atividades de extração de poupa de caranguejo e coleta de camarão e sarnambi, em duas comunidades do município de Maracanã-Pará. Foi realizado o acompanhamento in loco das atividades, para o levantamento dos danos ambientais ocorridos e consequentes impactos a saúde do trabalhador. Após as observações foi aplicado um questionário socioeconômico aos trabalhadores. Foi percebido que os extratores de poupa de caranguejo e coletores de camarão e sarnambi estão expostos a diversos riscos ambientais em suas áreas de trabalhos, e adquiriram diversos problemas físicos acarretados por esta exposição. Os trabalhadores avaliados possuem pouca informação em relação aos riscos ambientais pelos quais estão expostos e as suas complicações. É recomendada a organização em associações para a melhoria das condições de trabalho. A utilização de equipamentos de proteção individual e coletiva, o estabelecimento dos Programas de Prevenção de Riscos Ambientais e Saúde Ocupacional, são alternativas bastantes viáveis para a melhor qualidade de vida dos extratores de poupa de caranguejo e coletores de camarão e sarnambi.

Palavras-chave: Pesca artesanal. Qualidade Laboral. Saúde ocupacional.

\section{INTRODUÇÃO}

Algumas comunidades obtêm do litoral os recursos necessários para sua sobrevivência, criando mecanismos e ferramentas para facilitar o extrativismo de produtos alimentícios encontrados nessas áreas, como os mariscos. A população 
humana, principalmente, as que vivem ao entorno de regiões marítimas, buscam alimentos para si e uma forma de completar a renda familiar, através de coletas de mariscos e outros frutos do mar. Contudo, existe uma preocupação crescente com a sustentabilidade e o equilíbrio nessas regiões.

No estado do Pará, a extração de mariscos é uma atividade que apresenta grande relevância para a economia de muitos munícipios, sendo, não apenas a base alimentícia dos moradores dessas áreas, mas também, uma importante fonte de renda. Em todo o litoral paraense, os mariscos exercem forte influência na culinária, preservando a cultura alimentar local. Um exemplo desta realidade é o Município de Maracanã, que tem uma população de aproximadamente 28.296 habitante (IBGE, 2007), o qual tem como uma das principais atividades econômicas a mariscagem, que se caracteriza pela captura ou apanha de marisco.

Segundo os dados do ICMBio (Instituto Chico Mendes de Conservação da Biodiversidade) Maracanã pertence a uma área de reserva, onde possuem populações tradicionais cuja sobrevivência baseia- se na pesca artesanal e agricultura de subsistência sendo criada pelo decreto federal $n^{\circ} 4.340$ do ano de 2002 (MMA et al., 2000). Em Maracanã, a atividade de mariscagem é praticada na sede municipal e em comunidades mais afastadas. Sendo o camarão (Litopenaeus vannamei), sarnambi (Phacoides pectinatus) e caranguejo (Ucides cordatus), os principais produtos explorados.

No Brasil, as comunidades que se localizam as margens dos estuários e manguezais, utilizam apetrechos artesanais para coletar mariscos, fazer a pesca no mar e a criação em locais chamados de currais (SEWELL, 1978). Nesses ambientes de zona costeira, destacam-se mulheres que retiram do meio natural, a sua sobrevivência através da coleta de marisco, uma prática simples realizada com instrumentos arcaicos para manipulação da retirada do material no seu ambiente natural (NORDI, 1992). Essa atividade proporciona movimentos repetitivos e posturas inadequadas, podendo prejudicar a saúde dos trabalhadores.

A coleta de mariscos, em geral, envolve saberes que são adquiridos através do contexto social em que as pessoas estão inseridas, das tradições locais, e no contato com a natureza. Apesar de ter aparecido inúmeras profissões, a coleta tem sido a 
principal atividade econômica que garante a sobrevivência de muitas pessoas, em áreas condizentes. Segundo Bensoussan (2010), as atividades de mariscagem apresentam insalubridade de grau médio, caracterizado como trabalho em locais alagados ou encharcados, com umidade excessiva e que possa produzir danos à saúde do trabalhador. No entanto, os trabalhadores estão sujeitos a uma série de potenciais riscos ocupacionais, sejam eles físicos (ruído, calor, umidade, radiação solar); ergonômicos (postura inadequada, excesso de jornada de trabalho, esforço físico, repetitividade); biológicos (vírus, bactérias, fungos); químicos (poeiras, gases, vapores, compostos e substâncias químicas) ou de acidentes (iluminação inadequada, equipamentos sem proteção, equipamento improvisados, animais aquáticos) (BRASIL, 2001).

A atividade pesqueira está regulamentada pela Norma Regulamentadora (NR) 31, que tem por objetivo estabelecer os preceitos a serem observadas na organização do ambiente de trabalho, de forma a tomar compatível o planejamento e o desenvolvimento das atividades da agricultura, pecuária, silvicultura, exploração florestal e aquicultura com a segurança, saúde e meio ambiente do trabalho. Dessa forma, o presente estudo tem por objetivo avaliar os principais riscos ambientais inerentes a atividade, os impactos na saúde dos trabalhadores, o seu grau de conhecimento em relação a esses riscos, bem como a recomendar medidas que possam amenizar os problemas verificados das atividades de extração de poupa de caranguejo e coleta de camarão e sarnambi, em duas comunidades do município de MaracanãPará.

\section{METODOLOGIA}

\subsection{LOCALIZAÇÃo dA ÁREA DE ESTUdO}

O estudo foi realizado em duas comunidades localizadas no Município de Maracanã: Vila Nova e Curuçazinho. Maracanã pertence à região Nordeste do Estado do Pará, situando-se a 190 km da capital Belém (Figura 1). A comunidade de Vila Nova está localizada no centro da cidade de Maracanã. Curuçazinho, por sua vez, situa-se dentro de área de unidade de conservação Reserva Extrativista marinha de Maracanã (Figura 
2) para chegar até a comunidade gasta-se aproximadamente duas horas de tempo, tendo um único meio de transporte o barco.

Figura 1: Localização do município de Maracanã estado do Pará, Brasil.

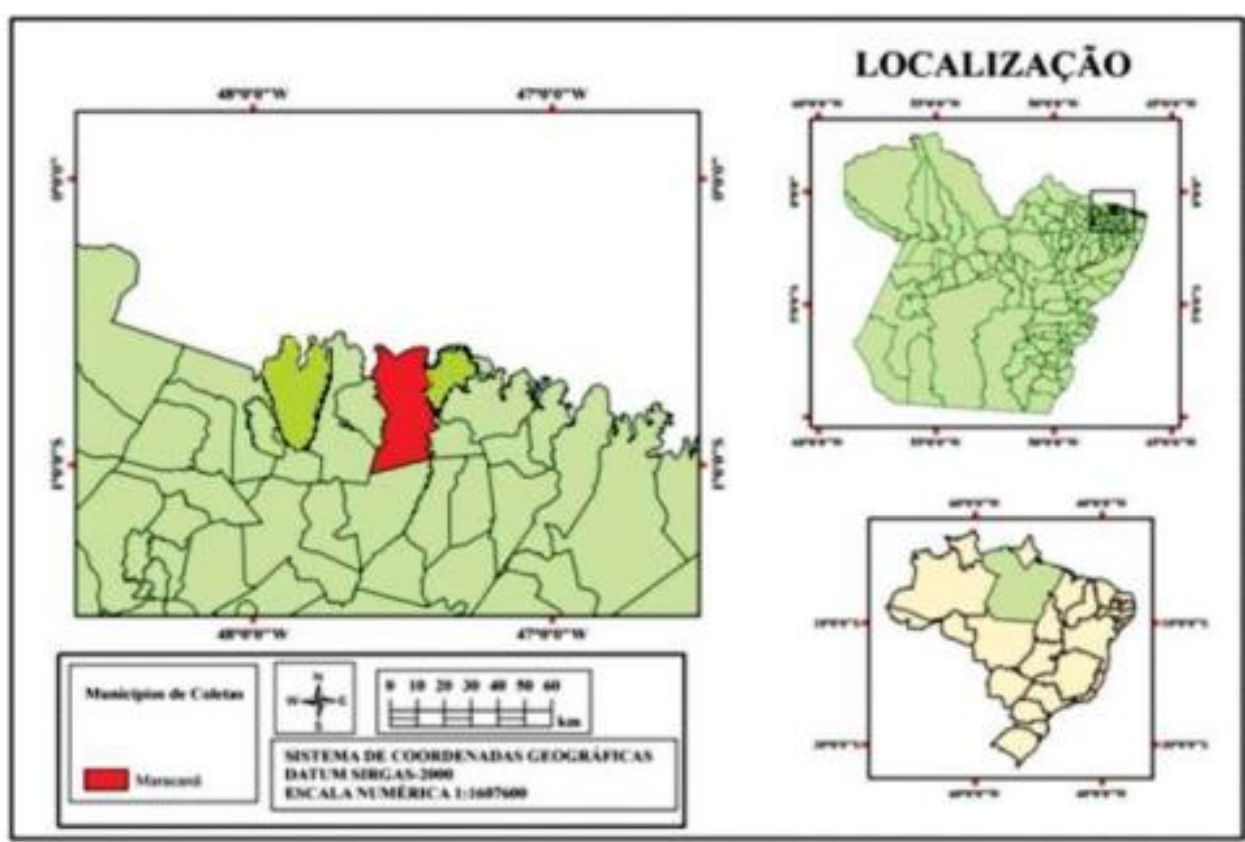

Fonte: Laboratório de Geoprocessamento/IFPA, Campus Castanhal.

Figura 2: Reserva Extrativista de Maracanã estado do Pará.

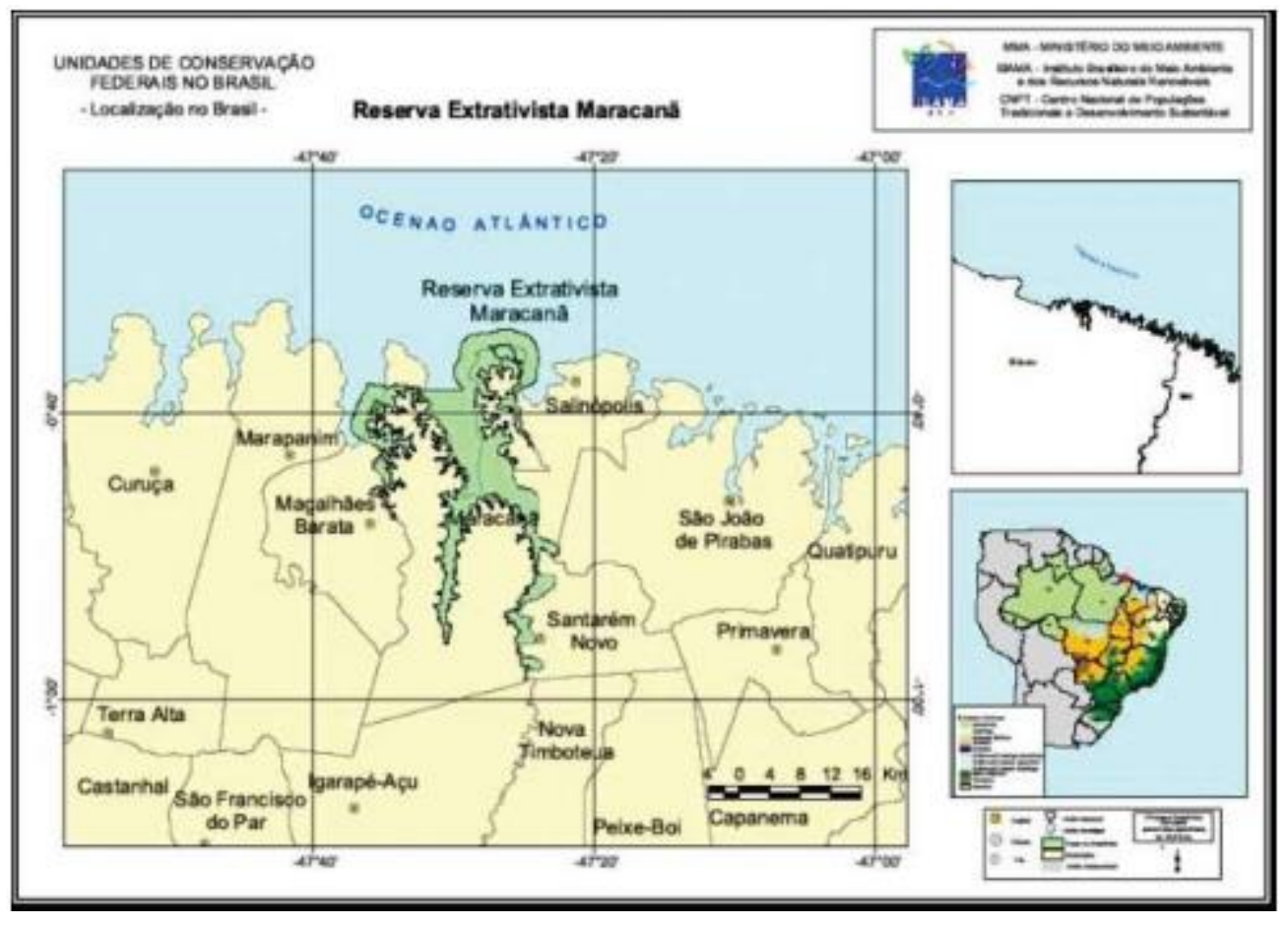

Fonte: Laboratório de Geoprocessamento/IFPA, Campus Castanhal. 
A seleção dessas comunidades se baseou em sua representatividade econômica no contexto da atividade marisqueira regional. Estas comunidades fazem a retirada de camarão (Litopenaeus vannamei), sarnambi (Phacoides pectinatus) e caranguejo (Ucides cordatus), que serve como base alimentar e para complementar a renda familiar do excedente para venda.

\subsection{COLETAS DOS DADOS}

Nos dias 18 e 19 de maio de 2017 foram realizadas visitas técnicas às comunidades selecionadas, para levantamento dos dados da Pesquisa. No primeiro dia de visita, acompanhou-se a extração de sua poupa do caranguejo (Figura 3), na localidade de Vila Nova. No dia seguinte, a equipe se deslocou para a comunidade de Curuçazinho para o acompanhamento das atividades de coleta de caranguejos $(A)$, camarão (B), sarnambi (C).

Figura 3: Caranguejo (A), camarão (B) e sarnambi (C).

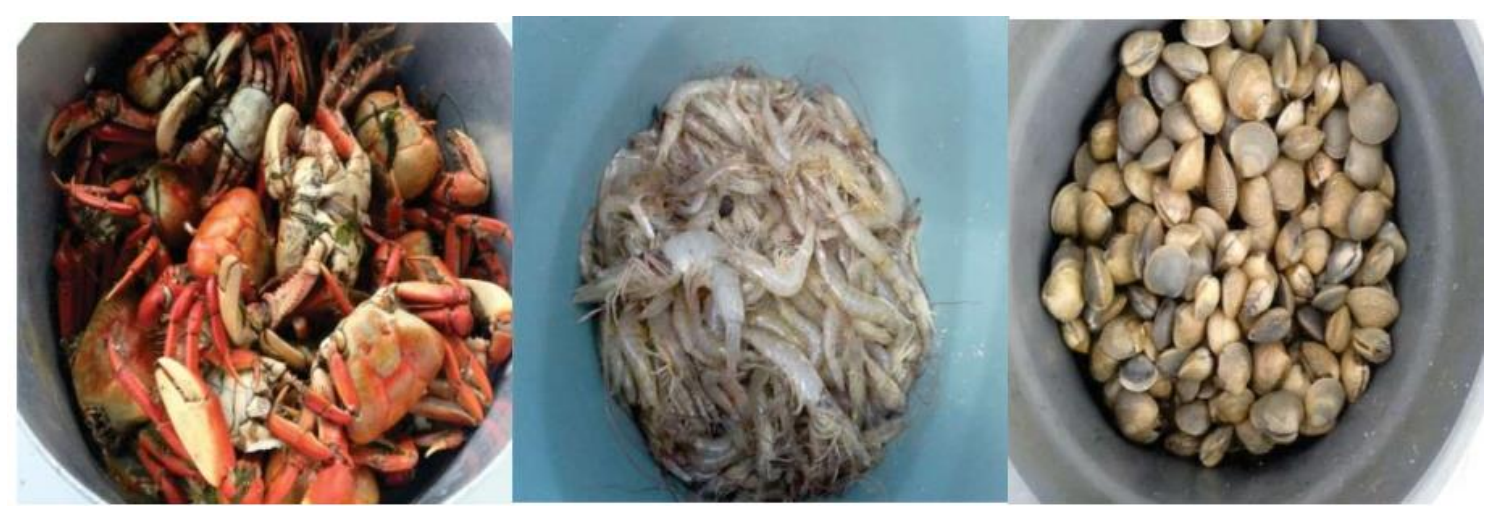

Fonte: Os autores

Em todas as atividades acompanhadas foram levantadas informações in locun quanto às condições de trabalho dos coletores de mariscos (marisqueiros) bem como os riscos ambientais aos quais estes estão expostos, de acordo com a sua natureza: físicos, químicos, biológicos, ergonômicos e mecânicos. Ao término de cada atividade, foi aplicado um questionário socioeconômico a todos os trabalhadores que estavam participando das coletas nas áreas.

A confecção do questionário buscou associar o fenômeno observado a contextos específicos como direitos e deveres, valorização da profissão e a saúde dos 
trabalhadores com enfoque em lesões por esforços repetitivos (L.E.R) e Distúrbios Osteomusculares (D.O.R.T.E). O questionário foi pautado nas seguintes perguntas: 1) Gênero: ( ) Masculino ( ) Feminino; 2) Você sabe a quais riscos ambientais está exposto? 3) Você utiliza algum tipo de equipamento de proteção individual? Qual região do corpo que você sente mais dor? 5) quais métodos você utiliza para combater as dores? 6) Você já recebeu algum tipo de treinamento para melhorar as condições de trabalho?.

Com as informações coletadas através dos questionários, foram confeccionados gráficos, com o auxílio do programa Excel, para a melhor apresentação dos resultados levantados. Em seguida, foram indicadas possíveis medidas para a mitigação dos impactos dos riscos ambientais aos coletores de mariscos, com embasamento na literatura e legislação vigente.

\section{RESULTADOS E DISCUSSÃO}

\subsection{EXTRAÇÃO DA POUPA DE CARANGUEJO}

Ao chegar à área de beneficiamento, os caranguejos são quebrados ao meio, o que resultará em sua morte, com a separação do tronco com as patas e as gorduras (Figura 4). Esta etapa do processo é realizada por homens, que ficam sentados de 5 a 9 horas por dia.

Figura 4: Esquartejamento do caranguejo.

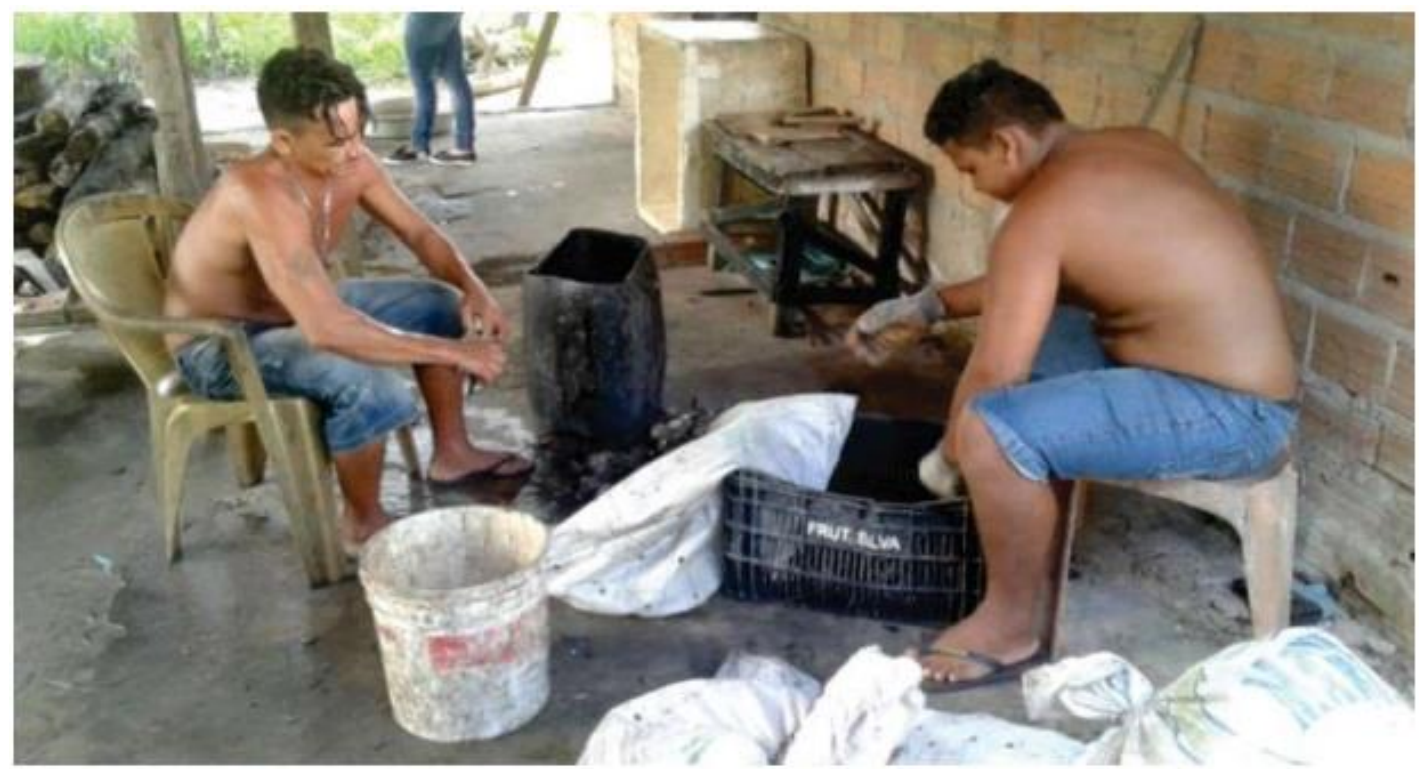

Fonte: Os autores 
Posteriormente, esse material é levado para lavagem em água fria (Figura 5A) e encaminhado para cozimento (Figura 5B). Este cozimento é feito por tempo suficiente para a garantia da retirada da poupa. Após o tempo determinado, o caranguejo é colocado para esfriamento, ficando em condições de retirada da sua carne.

Figura 5: A) Processo de lavagem do caranguejo para o cozimento e B) O cozimento do caranguejo.
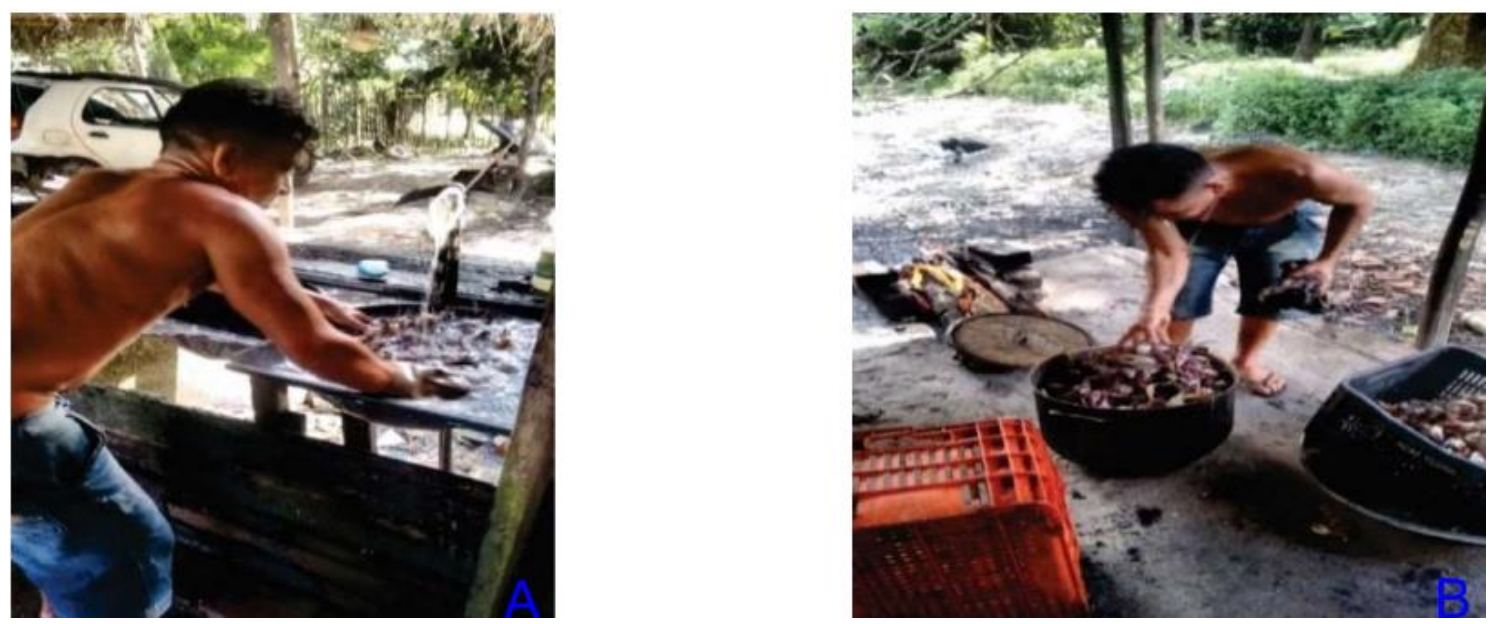

Fonte: Os autores

A extração da massa do caranguejo é utilizada ferramentas artesanais, como: facas e batedores de madeira, em cima de pequenas tábuas. O material extraído é acondicionado em sacos plásticos, para posterior, encaminhamento ao mercado. Não sendo verificada a utilização de qualquer equipamento de proteção individual ou coletivo para a realização das atividades. O processo de extração da poupa de caranguejo é realizado tanto por homens e mulheres, sem distinção de idade e porte físico (Figura 5B).

\subsection{COLETA DO CAMARÃO}

A coleta do marisco é uma tarefa que necessita de bastante empenho, e força de vontade, porque muitas etapas são realizadas em pé com o corpo submerso na água, durante todo período de execução da atividade. Sendo alvo de possíveis problemas relacionado à ergonomia NR-17 (VIEIRA, 2008). As tarefas tornam repetitivas e cansativas, pois, 50\% permanecem horas dedicadas a atividade dentro da água. No que consta "doença do trabalho é definida legalmente como adquirida ou desencadeada em função de condições especiais em que o trabalho é realizado e com ele se relacione diretamente", conforme a Lei no 8.213 de 24de julho de 1991 (BENSOUSSAN, 2010). 
A coleta do camarão depende muito da influência da maré, devido haver os ciclos de inundação e dissecação. Porém o trabalho é realizado no período da dissecação, onde os trabalhadores precisam emergir o membro inferior do corpo na água, podendo entrar na maré qualquer hora até mesmo no período de madrugada (Figura 7A). Para executar o trabalho, eles utilizam um apetrecho cujo nome é chamado de pulsar. Essa atividade é realizada por duas pessoas que permanecem num período de duas a três horas, em pé, para finalizar o trabalho. Na atividade de coleta de camarão, o trabalhador permanece a maior parte do tempo com a postura inclinada e torcida; ambos os braços no nível ou acima dos ombros; permanecendo muito tempo na água e realizando esforço devido a força que a maré exerce. Decorrido as duas ou três horas, os trabalhadores retiram da água o pulsar, avaliam o material fazendo posteriormente, a retirada dessa matéria prima que fica no final do pulsar (Figura 7B).

Figura 7: A) Atividade de coleta do camarão utilizando o arraste contra a maré; B) Finalização do processo de coleta com o levantamento do pulsar.

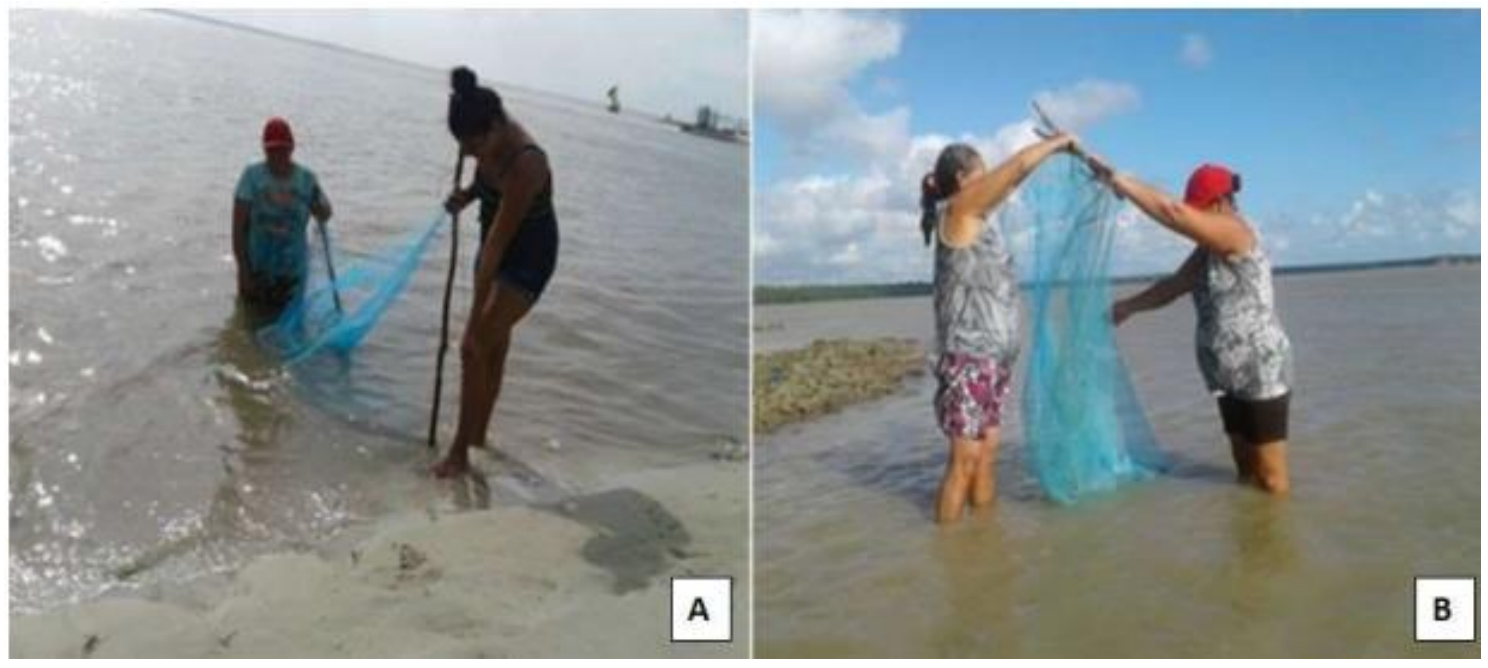

Fonte: Os autores

\subsection{COLETA DO SARNAMBI}

A coleta de Sarnambi é realizada durante o período de dissecação, onde os trabalhadores ficam sentados ou agachados com as pernas dobradas realizando esforço. Para realizar a atividade se usa alguns objetos sendo eles, uma faca ou algum objeto que seja pontiagudo para facilitar a extração do material que fica embaixo de pequenas pedras e um balde para colocar o marisco. 
Figura 8: Atividade de coleta do sarnambi na região da prainha na Ilha de Curuçazinho, Município de Maracanã/PA.

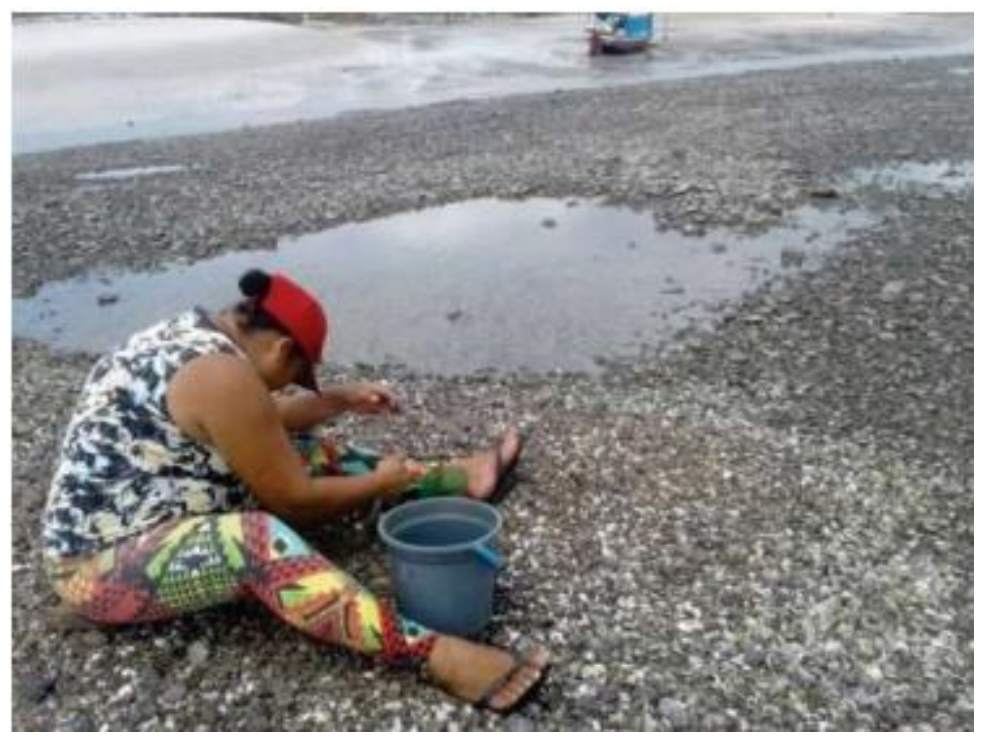

Fonte: Os autores

Os trabalhadores ficam com suas costas inclinadas e sua cabeça abaixada durante um período de três a quatro horas por dia podendo ser realizada nos períodos da manhã ou da tarde. A atividade se prolonga mais tempo devido ser um processo mais lento onde é preciso tirar de um em um Sarnambi para poder ter uma boa porção.

\subsection{GÊNERO DOS CATADORES}

A coleta dos mariscos é realizada por homens e mulheres. Dos 40 entrevistados, foram verificados 31 coletores do sexo feminino e 9 do sexo masculino (Gráfico 1). Pelo resultado, é possível observar que as atividades avaliadas são executadas culturalmente por mulheres, onde estas podem ser caracterizadas como pescadoras artesanais por desenvolverem seu trabalho como forma de subsistência ou para fins comerciais, porém em pequena escala. As mulheres assumem papel fundamental na atividade de mariscagem, muitas vezes, elas trabalham de forma individual (autônoma), sendo as responsáveis por seus instrumentos de trabalho e por todas as etapas do processo de produção, o que significa a noção da divisão sexual do trabalho (PENA et al., 2014). 0 trabalho da marisqueira compreende desde a preparação dos materiais para a coleta do marisco até chegar ao produto para a venda, sendo realizadas no domicílio e ambiente extradomiciliar. De acordo com Pena et al. (2011), elas não possuem férias, descanso 
semanal e feriados remunerados. Seu adoecimento pode provocar prejuízos no trabalho, comprometendo sua segurança alimentar. De acordo com Rios et al. (2011), as atividades realizadas por marisqueiras, como a cata de crustáceos e moluscos, ao longo da costa brasileira, podem ocasionar agravos à saúde dessas trabalhadoras. Elas estão sujeitas à sobrecarga muscular no pescoço, ombros, dorso, membros superiores e região lombar, além do excesso rítmico centrado no punho durante as atividades repetitivas, logo, as atividades desenvolvidas pela marisqueira, configuram- se em um risco ergonômico para essas trabalhadoras.

Gráfico 1: Número de entrevistados nas comunidades de Vila Nova e Curuçazinho.

Conhecimento dos riscos ambientais aos quais estão expostos

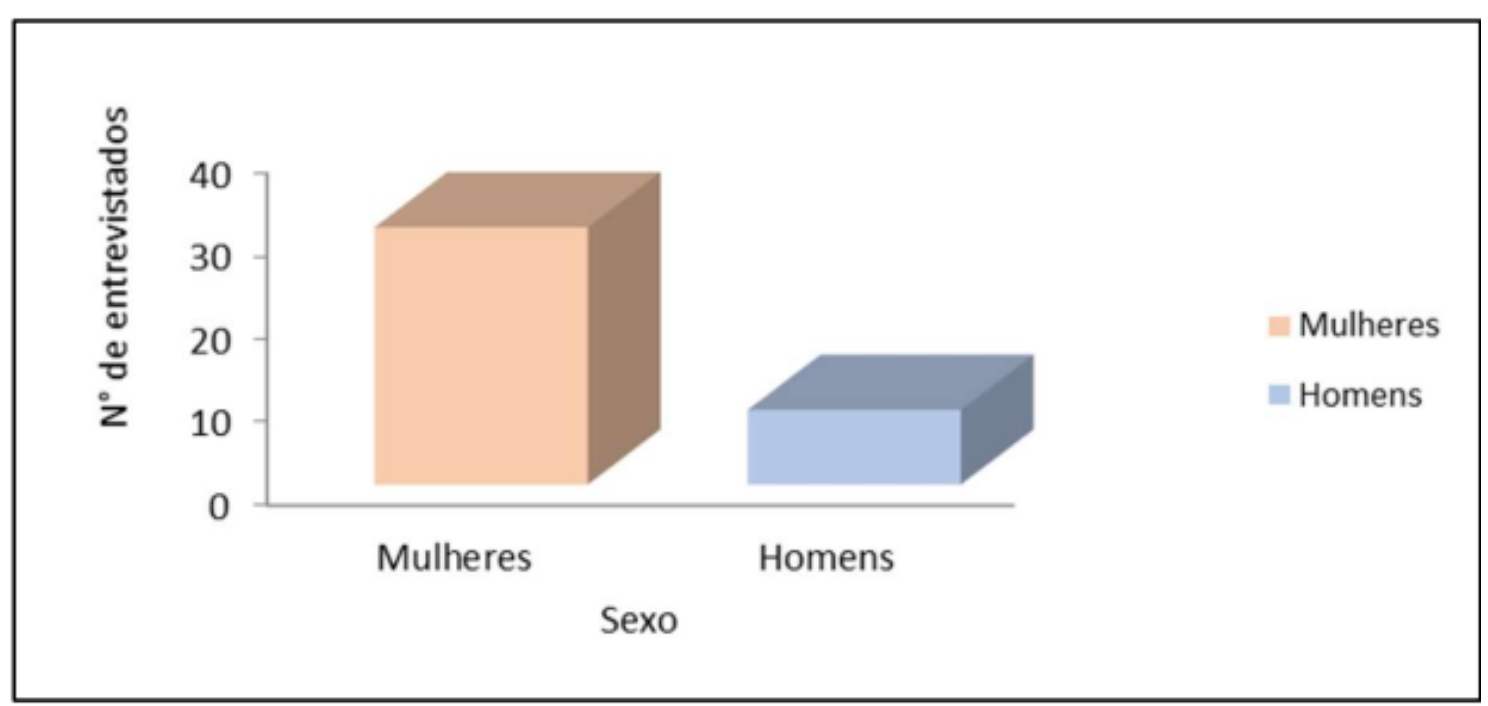

Pelo exposto no gráfico 2, foi possível observar que a maioria dos trabalhadores que realizam a coleta de mariscos nas comunidades de Vila Nova e Curuçazinho, desconhecem os riscos ambientais que estão expostos quando realizam esta atividade. A falta de informação em relação aos riscos ambientais é um dado que resulta em grande preocupação, pois estes trabalhadores ficam mais vulneráveis aos impactos que estes podem acarretar a sua saúde, uma vez que, o desconhecimento do perigo é um dos principais fatores que levam o coletor a sofrer danos exultantes dos riscos ambientais aos quais são submetidos. Os riscos ambientais existentes nos ambientes de trabalho são capazes de causar danos à saúde do trabalhador (BENSOUSSAN, 2010). Sendo necessário fazer uma avaliação destes. Ao ter essas informações o trabalhador 
poderá se precaver e usar os equipamentos de proteção individual EPI. Dessa forma, melhorando sua qualidade de vida.

Gráfico 2: A) Conhecimento dos coletores de mariscos, de duas comunidades localizadas no Município de Maracanã- Pará, quanto aos riscos ambientais aos quais estão expostos na execução desta atividade.

B) Riscos ambientais mais frequentes na vida dos trabalhadores da comunidade de Vila Nova e Curuçazinho.
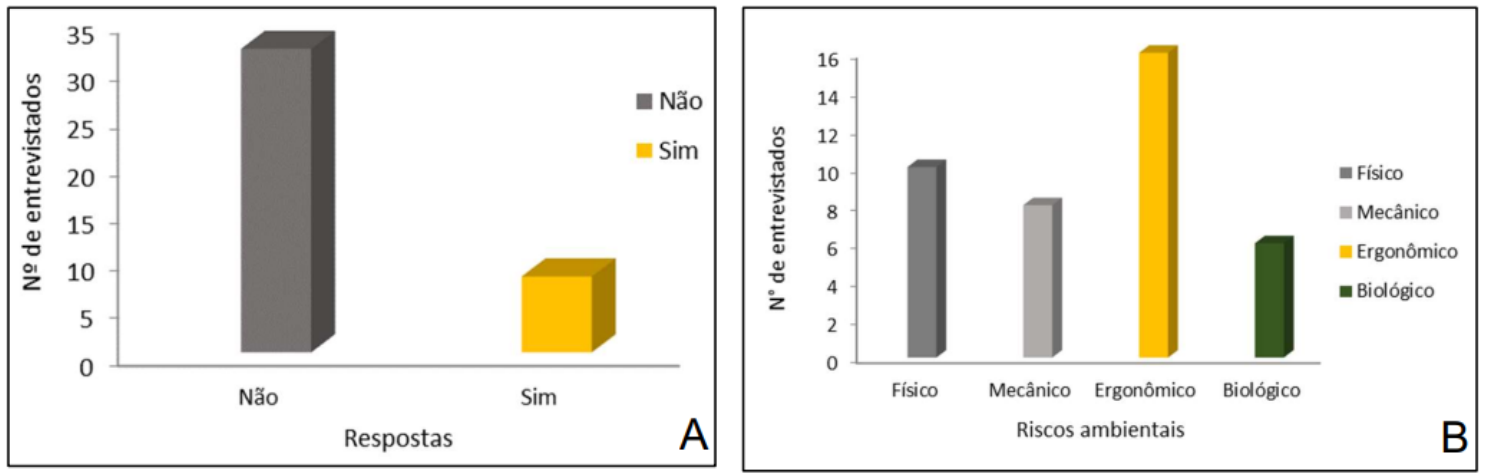

Em relação à estratificação dos riscos, observa-se que o risco ergonômico devido a postura forçada, a repetitividade, o levantamento e transporte de peso foram os fatores mais frequentemente relatados, seguido dos riscos físicos e mecânicos (Gráfico 2B). Foi analisado que os trabalhadores sofrem mais com os riscos ergonômicos devido as posturas inadequadas, controle rígido de produtividade e jornada de trabalho prolongada

Motivos para a não utilização de equipamentos de proteção individua (EPI)

Os trabalhadores reconhecem que as condições de trabalho das comunidades estão aquém do esperado. Embora exista esse consenso, percebe-se que a maioria dos entrevistados não compactua com a utilização de equipamentos de proteção individual. Os motivos elencados pelos entrevistados são apresentados no gráfico 3.

Os entrevistados relataram que não utilizam EPI, principalmente, pelo incômodo que estes causam no momento de execução da atividade. Devido a este fato, o grau de riscos a que os profissionais estão sujeitos é muito grande (NISHIDE et al., 2004). Por isso, se faz importante da orientação e educação dos trabalhadores em controlar os agentes de risco, com a utilizar os EPI's e participação em programas voltados para este fim. 
De acordo com a Norma Regulamentadora - NR 6, os equipamentos de proteção individual (EPI) são ferramentas para de uso individual do trabalhador, portanto, é destinado à proteção de riscos vulnerável de ameaças à segurança e a saúde no trabalho (BRASIL, 2001). No entanto, este equipamento deve ser aprovado por órgão capacitado pelo Ministério do Trabalho e Emprego (MTE), sendo obrigatório o provimento gratuito, aos trabalhadores que dele tem a necessidade de usar. Tanto Fabricante ou importador, empregado e empregador têm obrigações com relação a seu uso (BRASIL, 2004). O kit ideal para os coletores de mariscos seria composto por: camisa manga comprida, calça, boné, bota ou sapatilhas emborcadas e luvas.

Gráfico 3: Motivos alegados pelos coletores de mariscos das comunidades de Vila nova e Curuçazinho Município de Maracanã/Pará, para a não utilização de equipamentos de proteção individual.

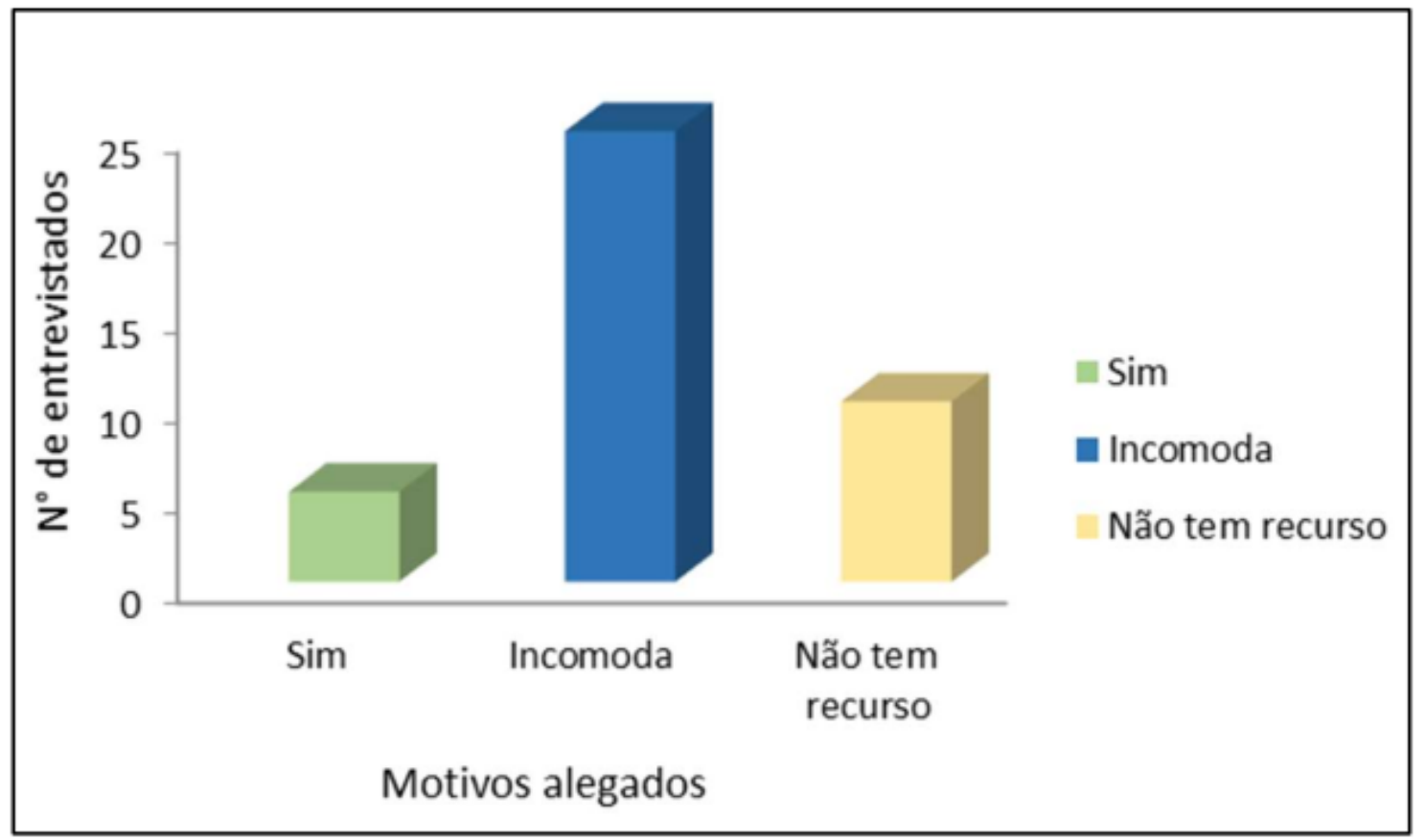

O uso de EPIs para a manutenção da integridade física do trabalhador durante o desenvolvimento das atividades laborais, como por exemplo, a luva, que protege as mãos contra agentes abrasivos, agentes cortantes, perfurantes e agentes biológicos entre outros, devendo ser de material resistente e apropriado para a atividade (NASCIMENTO et al., 2009). Assim como os óculos ou protetor facial, que servem para proteger contra impacto de partículas volantes, luminosidade intensa e radiação 
ultravioleta (RAMOS, 2009). Outros EPI's que podem ser indicados para proteger são: chapéu, camisa de manga comprida, protetor solar etc.

Região do corpo onde são percebidos com maior intensidade os reflexos da realização da coleta de mariscos

Entre os problemas apresentados pelos trabalhadores em decorrência da atividade de coleta de mariscos nas condições verificadas neste estudo, a maioria dos entrevistados relatou sentir dores nas regiões Lombar e Dorsal da coluna, com mais intensidade nos músculos esqueléticos (Gráfico 4). Este fato, está relacionado a forma como os trabalhadores realizam as coletas de mariscos, pois, são submetidos a várias horas exercendo movimentos repetitivos em posição de inclinação da coluna.

Gráfico 4: Região do corpo em que os coletores de mariscos das comunidades de Vila Nova e Curuçazinho, Maracanã/Pará, mais sentem dores resultantes das suas atividades laborais.

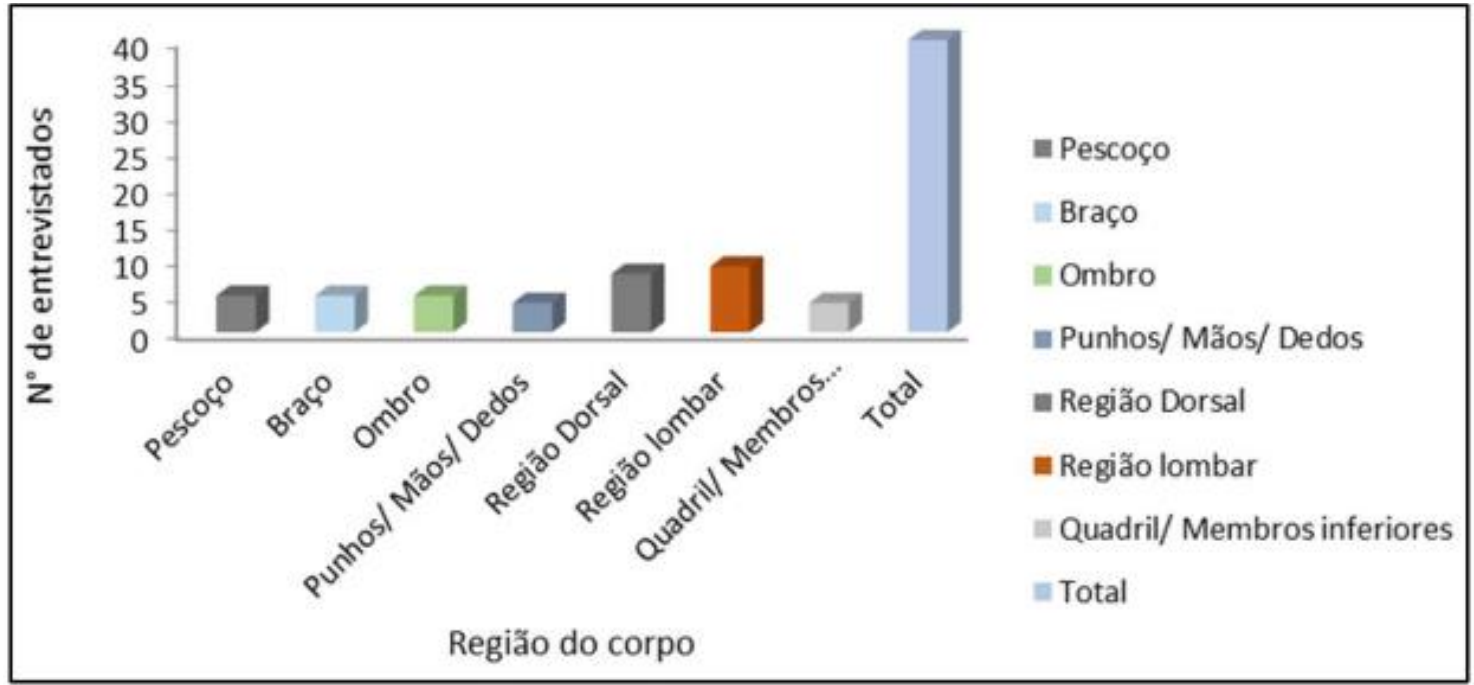

O resultado verificado é preocupante, pois dores não são agradáveis, e nessa região, podem ser potencializadas. Essa situação pode levar ao surgimento ou agravamento de problemas de lombalgia ou o mais comum entre os casos a dor na coluna. De acordo com a legislação, para atividades laborais realizadas em pé, devem ser garantidas pausas para descanso, a fim de evitar varizes, dor lombar e sensações dolorosas nas superfícies de contato articulares que suportam o peso do corpo (pés, joelhos, quadris) (CICCO et al., 1982). Na qual as varizes são mais frequentes no sexo 
feminino relacionado a antecedentes familiares, ocorrendo à sensação de peso nas pernas (LOMBA et al., 2005).

Métodos que os coletores de mariscos utilizam para combater as dores no corpo, derivadas desta atividade.

Para combater as dores, os trabalhadores relataram que utilizam remédios comprados na farmácia e caseiros (Gráfico 5), poucos executam atividade durante o desenvolvimento do trabalho para aliviá-las, como por exemplo o descanso em determinadas horas e alongamento do corpo. De acordo com os entrevistados, os métodos mais utilizados para aliviar as suas dores são os medicamentos, como: analgésicos e anti-inflamatórios. Esses medicamentos, no entanto, são utilizados sem a orientação médica e avaliação, podendo levar esses trabalhadores a apresentar diversas reações, que podem afetar sua saúde.

Gráfico 5: Métodos utilizados pelos coletores de mariscos das comunidades Vila Nova e Curuçazinho.

Maracanã/Pará, para minimizar as dores no corpo, derivadas das atividades laborais exercidas.

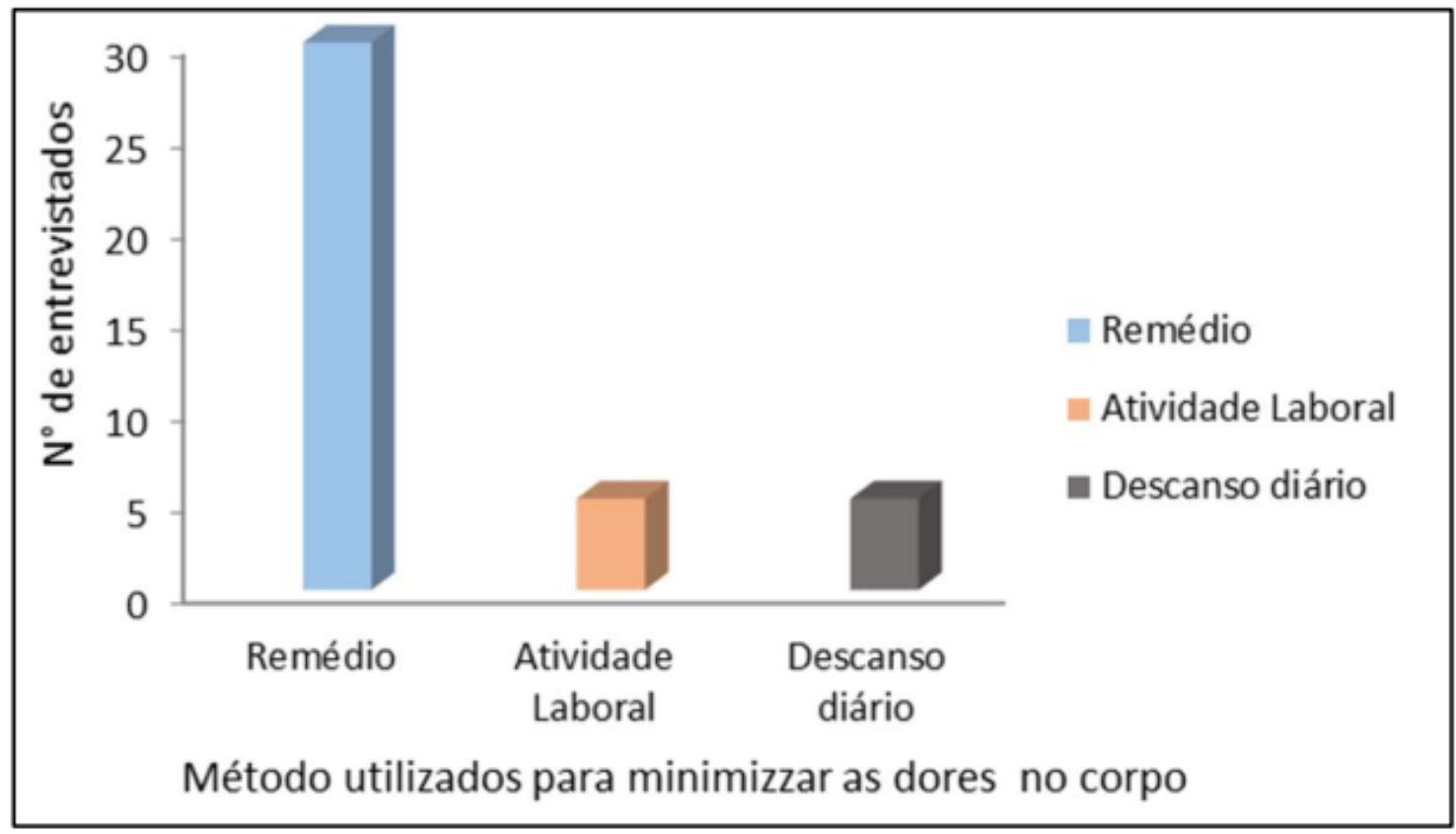

\subsection{TREINAMENTO PARA MELHORAR AS CONDIÇÕES DE TRABALHO}

Do total de entrevistados, 8 trabalhadores afirmaram que já receberam treinamento, e 32 relataram que não receberam nenhum tipo de treinamento (Gráfico 6). Este resultado constata que a maioria dos trabalhadores não possuem informação 
sobre como melhorar as condições de trabalho. É importante aplicação de treinamentos, uso dos equipamentos de proteção individual (EPIS) e equipamentos de proteção coletiva (EPCs). As atividades laborais não devem ser realizadas de qualquer forma, visando somente a obtenção de lucro. É necessário, que estas sejam realizadas de uma maneira que o trabalhador seja preservado e reconhecido como um agente determinante para que o trabalho aconteça. Dessa forma, o treinamento é a oportunidade de os trabalhadores conhecerem melhores maneiras de realizar suas atividades, sem que haja um comprometimento da sua produtividade.

Gráfico 6: Número de coletores de mariscos das comunidades Vila Nova e Curuçazinho. Maracanã/Pará, que receberam treinamento para melhorar as suas condições de trabalho.

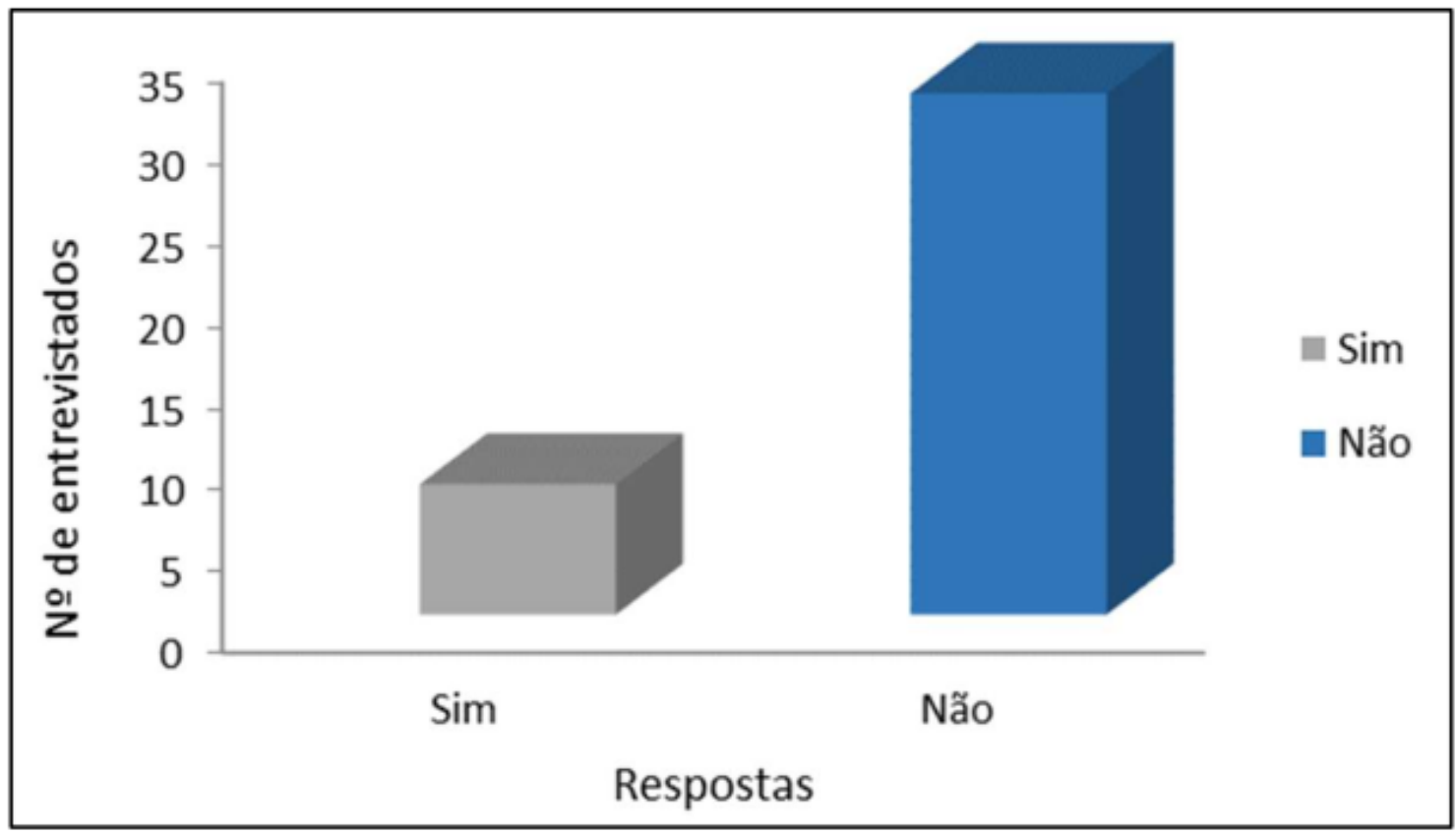

Medidas recomendadas para a minimização dos impactos causados a saúde dos coletores derivados da exposição aos riscos ambientais diante das observações feitas durante o acompanhamento das atividades de mariscagem, seguem algumas medidas propostas para que os problemas causados pelos riscos ambientais inerentes a esta atividade seja minimizada:

Organização em Associação: A coleta de mariscos nas comunidades avaliadas é realizada sem organização oficial por parte dos trabalhadores que a executam. O que constatado é que, alguns revendedores solicitam os mariscos aos coletos e estes 
realizam a coleta e repassam, sem algum amparo legal. Dessa forma, não há preocupação com a forma que o trabalho é realizado o que resulta em diversos problemas. Os coletores, são desprovidos de acompanhamento para melhoria da execução de seu trabalho.

Estabelecimento de um Programa de Prevenção de Riscos Ambientais - PPRA: O PPRA é um conjunto de ações aplicadas nos ambientes laborais com o objetivo de preservar a saúde e integridade dos trabalhadores, pela antecipação, reconhecimento, avaliação e controle da ocorrência de riscos ambientais nestas áreas. A norma regulamentadora 09 expressa todas as características e peculiaridades em relação a elaboração e efetivação do PPRA. Este instrumento é indicado, principalmente, para apresentação por empresas que possuem empregados contratado no regime da Lei de Consolidação das Leis Trabalhistas - CLT.

Utilização de bancada adequada para a realização lavagem do caranguejo: A bancada para lavagem do deve ser instalada ao nível que se equipare ao membro superior do corpo, para que o trabalhador não fique com a parte dorsal do corpo inclinada, já que na maioria das vezes os trabalhadores precisam fazer flexão e rotação de tronco para pegar a basqueta com caranguejo no chão, podendo minimizar o esforço físico e as lesões decorrentes da atividade diminuindo o tempo do ciclo de produção, proporcionando assim, melhor qualidade de vida para os mesmos. Diante disso, estimularia e possibilitaria o desenvolvimento das atividades, sem muitos empasses relacionados aos riscos ambientais, principalmente ergonômicos.

A bancada poderá ser feita de material inox, comumente seria mais viável, para trabalhadores que fazem a separação e esquartejamento do caranguejo e posteriormente a lavagem das patas manualmente, com o uso de luvas, para a realização do cozimento por alguns minutos, e as mulheres que fazem a retirada da massa. A sugestão pela bancada de aço inox é devido ser um material bastante higiênico e resistente a altas temperaturas, onde proporcionaria melhores condições de trabalho, uma vez que deve haver os cuidados para a sua conservação. É importante ressaltar que o preço pode variar, dependendo da espessura e qualidade do material, ficando com maior valor quanto a resistência e a acabamento da peça. 
Utilização de EPI e EPC: É recomendada a utilização de um Kit de EPI, por parte dos coletores extratores de poupa. Este kit poderá ser composto por: luvas para proteger as mãos contra agentes perfurantes- cortante, sapatilhas emborrachadas, propiciando a proteção de seus pés na hora da coleta de mariscos, calça e camisas com manga comprida, ambas feitas de material térmico, proporcionando minimização da incidência solar no período da tarde entre outros, e avental.

A camisa com manga comprida poderia ser confeccionada com material conhecido como neoprene. Esse material protege contra os raios UV (ultravioleta) e ajuda contra a insolação, minimizando a incidência de câncer de pele e o envelhecimento precoce e cortes nas mãos e pés. De acordo com a NR-6, o Equipamento de proteção individual (EPI) é todo de uso individual, destinado a proteger a saúde e a integridade física do trabalhador (ATLAS, 2009).

Preparação para execução do trabalho: Os trabalhadores devem realizar a ginástica laboral para a prevenção de doenças e melhoria da qualidade de vida. De acordo com Lima (2004), a Ginástica Laboral como é a execução de exercícios, praticado em conjunto, no decorrer do período de trabalho, ordenado, segundo com a função exercida pelo trabalhador, tendo como intuito a prevenção de doenças ocupacionais, proporcionando o bem-estar individual, por intermédio da consciência corporal: respeitar, conhecer, amar e estimular o seu próprio corpo. Também, é recomendado que os coletores realizem uma reunião antes de começar cada coleta, para que juntos eles possam pensar a melhor forma de realizar a atividade. Pois, dessa forma, podem garantir uma melhor produtividade e qualidade do trabalho. Rodizio de tarefas evitando excesso de atividades repetitivas: Interessa que os trabalhadores sejam treinados para aprender a realizar qualquer fase da coleta dos mariscos, pois, assim, será possível realizar o revezamento entre estes. Algumas etapas da extração da poupa de caranguejo e coleta dos outros mariscos, são bastante repetitivas, o que pode acarretar diversos problemas a saúde dos trabalhadores que tem partes do seu copo bastante fadigadas. O revezamento poderá minimizar esta situação, pois em tempos predeterminados os coletores podem trocar a atividade e fazer outra menos desgastante, preservando sua integridade física. 


\section{CONCLUSÕES}

Foi possível observar que as atividades de extração de poupa e coleta de mariscos nas comunidades de Vila Nova e Curuçazinho expõem os coletores a diversos riscos ambientais, e consequentemente, a diversos impactos em sua saúde física e mesmo psicológicos. Porém, a conscientização desses trabalhadores em relação a estes riscos, ainda é muito deficiente, o que provoca um grande agrave na situação. Sendo preciso à adoção de algumas medidas como treinamento, para melhorar esta condição. É recomendado que os trabalhadores se organizem em associações comunitárias ou cooperativas. É necessário que essas cooperativas sejam geridas e fiscalizadas de forma competente, visando o bem de associados, assegurando condições de ascensão social, priorizando a saúde dos trabalhadores.

Uma outra medida relevante, seria a implementação de um Programa de Prevenção de Riscos Ambientais em consonância com o programa de saúde ocupacional, visando maior segurança e conforto durante as atividades de coleta. Tal programa consiste na prevenção de doenças que possam se originar no ambiente de trabalho, visando melhorias na qualidade de vida tanto no bem-estar físico e emocional dos trabalhadores.

\section{REFERÊNCIAS}

ATLAS. Segurança e medicina do trabalho. 64 ed. São Paulo: ATLAS S.A., 2009.

BENSOUSSAN, E.. Manual de gestão e prática em saúde ocupacional. Rio de Janeiro: GZ, 2010.

BRASIL. Ministério da Saúde. Organização Pan-Americana de Saúde. Doenças relacionadas ao trabalho: manual de procedimentos para os serviços de saúde. Série A: normas e manuais técnicos, n.114. Brasília: Ministério da Saúde, 2001.

BRASIL. Ministério do Trabalho e Emprego. Secretaria de inspeção do trabalho. Texto dado pela Portaria SIT n. 25, de 15 de outubro de 2004. Brasília: Ministério do Trabalho e Emprego, 2004.

CICCO, F. M. G. A. F.; PESCE, R. A.; MARTHA, G. B.; SOTO, J. M. O. G.; SEKI, C. T.; FREIRE, N. B.; SIMÃO, C. M.; MORAIS, N. M.; ABREU, S. M. S.. Segurança, higiene e medicina do trabalho na construção civil: nível superior. 2 ed. São Paulo: FUNDACENTRO, 1982. 
IBGE. Instituto Brasileiro de Geografia e Estatística. Pesquisa Nacional por Amostragem de Domicílios. Rio de Janeiro: IBGE, 2007.

LIMA, G. D.. Ginástica laboral: metodologia de implantação de programas com abordagem ergonômica. Jundiaí: Sextante, 2004.

LOMBA, M.; LOMBA, A.. Objetivo saúde: espacialidades médicas. Olinda: Grupo Universo, 2005.

MMA; IBAMA; CNPT. Ministério Do Meio Ambiente; Instituto Brasileiro Do Meio Ambiente E Dos Recursos Naturais Renováveis; Centro Nacional De Pesquisa E Conservação Da Sociobiodiversidade Associada A Povos E Comunidades Tradicionais. Estudo socioeconômico e laudo biológico das áreas de manguezal do município de Maracanã/PA. Belém: UFPA, 2000.

NASCIMENTO, A. M. A.; ROCHA, C. G.; SILVA, M. E.; SILVA, R.; CARABETE, R. W.. A Importância do Uso de Equipamentos de Proteção na Construção Civil. Monografia (Técnico de Segurança do Trabalho) - Escola Técnica Estadual Martin Luther King, Tatuapé, 2009.

NISHIDE, V. M.; BENATTI, M. C. C.; ALEXANDRE, N. M. C. Ocorrência de acidente do trabalho em uma Unidade de Terapia Intensiva. Revista Latino-Americana de Enfermagem, v.12, n.2, p.204-211, 2004.

NORDI, N.. Os catadores de caranguejo-uçá (ucides cordatus) da região de várzea nova (PB) uma abordagem ecológica e social. São Paulo: UFSC, 1992.

PENA, P. G. L.; GOMEZ, C. M.. Saúde dos pescadores artesanais e desafios para a Vigilância em Saúde do Trabalhador. Revista Ciência \& Saúde Coletiva, v.19, n.12, p.4689-4698, 2014.

PENA, P. L. G.; FREITAS, M. C. S.; CARDIM, A.. Trabalho artesanal, cadências infernais e lesões por esforço repetitivo: estudo de caso em uma comunidade de mariscadeira nas ilhas de maré, Bahia. Ciência Saúde, v.16, n.8, p.3383-3392, 2011.

RAMOS, P.. Análise do Programa de Prevenção de Acidentes: Quase Acidente: e a Viabilidade da Aplicação Direta na Construção Civil: Estudo de Caso. Monografia (Bacharelado) - Universidade do Extremo Sul Catarinense, Criciúma, 2009.

RIOS, A. Q.; REGO, R. C. F.; PENA, P. G. L.. Doenças em trabalhadores da pesca. Revista Baiana de saúde pública, v.35, n.1, p.175-188, 2011.

SEWELL, G. H.. Administração e Controle da Qualidade Ambiental. São Paulo: Universidade de São Paulo, 1978.

VIEIRA, I. S.. Manual de Segurança do Trabalho. 2 ed. São Paulo: LTR, 2008. 


\title{
CAPITULO XVII
}

\section{UTIUZAGÃO DE EPI'S NA APUCACÃO DE AGROQUIIMICOS EM LAVOURAS DE SOJA NO MUNICÍPIO DE CHAPECÓ/SC}

DOI: 10.51859/amplla.mas481.1121-17

\author{
Alyson Paulo Pozzan ${ }^{1}$ \\ Caroline Olias ${ }^{2}$ \\ Aline Vanessa Sauer ${ }^{3}$ \\ Gean Lopes da Luz ${ }^{4}$ \\ Leocemar de Andrade Bellé 5 \\ Cristiano Reschke Lajús ${ }^{6}$
}

\begin{abstract}
Engenheiro Agrônomo. Egresso do Curso de Agronomia. Universidade Comunitária da Região de Chapecó (Unochapecó), Campus de Chapecó.

${ }^{2}$ Acadêmica do Curso de Agronomia. Universidade Comunitária da Região de Chapecó (Unochapecó), Campus de Chapecó.

${ }^{3}$ Doutora em Agronomia. Universidade Estadual de Maringá (UEM), Campus Maringá. Coordenadora e Docente do Curso de Agronomia na UNOPAR - Universidade Pitágoras Unopar, Campus Bandeirantes.

4 Doutor em Agronomia. Universidade Federal de Santa Maria, Campus Santa Maria. Docente e Pesquisador do Programa de Pós-Graduação Stricto Sensu em Tecnologia e Gestão da Inovação. Universidade Comunitária da Região de Chapecó (Unochapecó), Campus de Chapecó.

${ }^{5}$ Egresso do Curso de Agronomia. Discente do Programa de Pós-Graduação Stricto Sensu em Tecnologia e Gestão da Inovação. Universidade Comunitária da Região de Chapecó (Unochapecó), Campus de Chapecó.

${ }^{6}$ Doutor em Agronomia. Universidade de Passo Fundo (UPF), Campus Passo Fundo. Docente e Pesquisador do Programa de Pós-Graduação Stricto Sensu em Tecnologia e Gestão da Inovação. Universidade Comunitária da Região de Chapecó (Unochapecó), Campus de Chapecó.
\end{abstract}

\section{RESUMO}

Os Equipamentos de Proteção Individual (EPI's) foram criados para manter a integridade física do trabalhador, em qualquer situação de risco, a fim de reduzir a exposição dos produtores rurais aos agrotóxicos. Sendo assim surge-se a necessidade de realizar uma pesquisa focalizada neste contexto. A mesma foi realizada no município de Chapecó, situado no oeste do estado de Santa Catarina. Estando situado a 674 metros de altitude, em relação ao nível do mar, tendo uma área de $625,4 \mathrm{Km}^{2}$ e coordenadas geográficas com, latitude 270 05' 17" S e longitude 52 $37^{\prime}$ '06" W. Envolvendo agricultores das linhas Cabeceira da Divisa, Faxinalzinho, Tafona, Rodeio Bonito, Colônia Cela, Faxinal dos Rosa, Alto da Serra, Borman, Efapi, relacionando estas comunidades com a utilização de EPI's na aplicação de agroquímicos em lavoura de soja. $O$ objetivo desta pesquisa foi analisar utilizando uma abordagem quantitativa e qualitativa, verificando a área total (em hectares) de cada produtor, total de horas que são destinadas a aplicação de defensivos agrícolas por dia, determinação do número de aplicações por ano, quais os Epi's utilizados, e quando são substituídos. Para essa avaliação foram aplicados questionários autoaplicáveis junto aos agricultores. Os produtores entrevistados demonstraram conhecimento em relação à importância do uso de Epi's, em sua maioria usam, mas de forma parcial, e quase na totalidade dos entrevistados o desconhecimento é em relação aos danos e sua agressividade provocada pela intoxicação.

Palavras-chave: Epi's. Risco. Agroquímicos. Tecnologia de Aplicação. Soja. 


\section{INTRODUÇÃO}

A atividade exercida no meio rural é principalmente familiar, passado de geração para geração, ou seja, de pai pra filho, neste sentido é muito importante conhecer e também saber ensinar ao sucessor das atividades, técnicas de preparo, manuseio dos produtos, e destinação das embalagens, pois é de responsabilidade passar corretamente essas informações para que exista uma continuidade e uma melhor conscientização de todas as gerações futuras. Essa função em específico, é uma das mais perigosas e que pouco se têm cuidado ao executá-la. (SCHMIDT; GODINHO, 2006).

A utilização de EPIs é indispensável para o produtor rural, já que os mesmos são capazes de evitar a intoxicação aguda (logo após o contato com o agrotóxico) e crônica (acúmulo de produto em larga escala de tempo sendo infectado), tendocomo um exemplo grave de doença o câncer (SIMONETTI, 2016).

Devido ao crescimento significativo do uso de agroquímicos, tanto em relação ao número de aplicações, quanto na dosagem por aplicação, associado à negligência em relação a utilização correta de Epi's, acaba somando negativamente para altos índices de intoxicações, muitas vezes afastando o trabalhador rural prematuramente de suas atividades (SIMONETTI, 2016).

Entretanto, além de detalhar as informações gerais dos produtores de soja, verificar a área em hectare de cada produtor, analisar o total de horas por dia em que é realizada a aplicação de agroquímicos, determinar o número de vezes por ano que ocorre a aplicação, tem-se como objetivo principal avaliar a utilização de EPI's na aplicação de agroquímicos em lavouras de soja no município de Chapecó/SC.

\section{REVISÃO BIBLIOGRÁFICA}

\subsection{EPI'S}

Cada vez mais a tecnologia é aliada do ser humano, neste sentido os EPI's foram criados para manter a integridade física e mental do trabalhador, em qualquer situação de risco, e podem ser classificadas como medidas de proteção: protetiva, preventiva, promocional, assistencial e de apoio à saúde (VEIGA, et al., 2007). 
A utilização dos Epi's de forma parcial ou incompleta representa grande perigo a saúde do aplicador, causando uma elevação significativa no número e no nível de intoxicação. Contudo, exige-se que haja uma sinalização para a área tratada (MONQUERO, 2009).

Pesquisas e levantamentos já foram feitos sobre o assunto, ou seja, sobre o uso habitual ou não, de equipamentos de proteção individual (EPI's), se a utilizaçãoé parcial ou completa dos mesmos, enfim, os números obtidos apontam problemas futuros e danos irreversíveis ao agricultor que negligência ou desconhece as recomendações de aplicação dos produtos (SIMONETTI, 2016).

Se manuseados de maneira correta, os Epi's podem resistir até 30 lavagens, antes do descarte devem ser lavados para a retirada dos resíduos, se forem de algodão hidro-repelentes, no caso das vestimentas, podem ter descarte comum, no caso de não serem de tecido, devem ser incinerados para não causar danos ao meio ambiente (SIMONETTI, 2016).

\subsection{AGROQUIMICOS}

Utilizados desde o inicio da década de 20, os agroquímicos eram considerados armas químicas, isso no período da Segunda Guerra Mundial. Em 1960, suas ações se tornaram evidentes para controle de vetores na agricultura, coisa que até então não se era dada real importância. (LEITE; TORRES, 2008).

Nos últimos anos cresceu de forma exponencial a utilização de agroquímicos, tanto em número de aplicações quanto na dosagem por aplicação. Desde 2008 o Brasil está no topo da lista dos países que mais consomem agrotóxicos no mundo, nos últimos doze meses, o mercado brasileiro desses produtos teve um aumento de 190\%, assim conseguindo esse feito nada interessante para o país. (ABREU; ALONZO, 2014).

Quase todo o manejo da safra de soja e de outras culturas é mecanizado e automatizado, diminuindo drasticamente a mão de obra pesada. (CARDOSO, 2017).

Para soja existem apenas três produtos registrados, espiromesifeno, diafentiurom e profenofós+lufenurom, sendo assim, devido à dificuldade de controlee altos custos associados aos tratamentos, podem trabalhar com medidas de manejo integrado (EMBRAPA, 2018). 
De acordo com Reis e Bresolin (2007), os fungicidas são substâncias químicas de origem natural ou sintéticas utilizadas para controle de doenças das plantas, quando aplicados via foliar protegem-nas da penetração e/ou do posteriordesenvolvimento de fungos patogênicos em seus tecidos.

Os herbicidas são compostos químicos utilizados na agricultura para controlar o desenvolvimento das plantas daninhas, ou seja, atuar destruindo as mesmas. (EMBRAPA, 2018).

A divisão desses produtos é feita de forma geral em duas classes no que diz respeito à forma de aplicação: ao solo e as folhas. Os foliares ainda são divididos emde contato e sistêmico, o primeiro age apenas no local do contato e o segundo é absorvido pela planta e translocado pelo xilema e floema aos sítios de ação, e o de aplicação ao solo se movem das raízes para as folhas translocado via xilema(MARCHI; MARCHI; GUIMARÃES, 2008).

Os inseticidas são compostos químicos utilizados para controle de insetospraga infestantes responsáveis por grandes perdas nas lavouras, se bem manuseado e aplicado dentro das recomendações, ele pode atingir vários alvos, como lagartas, percevejos e outros insetos, ainda podendo ser utilizado em diferentes culturas, especialmente em grão. (EMBRAPA, 2004).

De acordo com a Agência Nacional de Vigilância Sanitária (ANVISA), quantoao grau de toxicidade, os agroquímicos classificam-se em:

a) Classe I - extremamente tóxico (rótulo com faixa vermelha).

b) Classe II - altamente tóxica (rótulo com faixa amarela).

c) Classe III - medianamente tóxica (rótulo com faixa azul)

d) Classe IV - pouco tóxica (rótulo com faixa verde).

Sua principal forma de aplicação é a pulverização, que pode ser manual, ou seja, pulverizadores costais, tratorizados ou autopropelidos, ou por meio de aviação, que não é a realidade pra nossa região.

\subsubsection{OJA}

Originária do continente asiático, para ser mais exato, na China, a soja vem sendo cultivada a mais de cinco mil anos e logo espalhou-se pelo mundo. No Brasil ela apareceu 
no século XX, mas foi nos anos 70 que explodiu, devido os Estados Unidos, grande produtor da leguminosa não suprir a demanda mundial e tambémpor uma importante contribuição Russa, com a quebra de sua safra (MISSÃO, 2006).

Nos anos 70, a cultura se consolidou como a principal para o agronegócio brasileiro, passando de 1,5 milhões de toneladas (1970), para mais de 15 milhões (1979). Crescimento este que se deu pelo aumento da área cultivada (1,3 para 8.8 milhões de hectares) e principalmente graças às novas tecnologias disponibilizadas aos produtores pela pesquisa brasileira, possibilitando aumento de (1,14 para 1,73 t/ha) (EMBRAPA, 2004).

A soja está entre os quatro grãos mais consumidos no mundo, além de ser a oleaginosa mais produzida. Tem como principal destino o esmagamento, onde cercade $90 \%$ da produção é destinada à óleo de soja (para alimentação humana e biocombustíveis) e o farelo se torna matéria prima de ração animal. (JANIK; NASSAR; TACHINARDI, 2005).

\subsection{PRINCIPAIS DOENÇAS CAUSADAS POR AGROQUIMICOS}

Segundo Fagundes (2010), dentre as várias doenças causadas pelos agroquímicos, podemos citar algumas que chamam a atenção por sua agressividade e difícil tratamento, dessas pode-se citar o Câncer, Infertilidade, Transtorno do Déficit de Atenção e Hiperatividade (TDAH), Mal de Alzheimer, Danos ao Fígado, Depressão, e Mal formação de Feto.

\subsection{PRINCIPAIS DOENÇAS CAUSADAS POR AGROQUIMICOS}

O Brasil possui uma das legislações ambientais mais avançadas do mundo, e a desobediência das mesmas, acabam provocando ações contra o meio ambiente, fato que em nosso país são punidos com multas e até mesmo prisão do responsável, sejam elas praticadas por pessoas físicas oujurídicas (SOUZA; PALLADINI, 2005).

O capítulo 7 da Constituição Federal de 1988, Segurança e Medicina do Trabalho, têm como intuito minimizar os riscos de acidentes de trabalho, através da prevenção. Oferecendo assim uma melhor qualidade de vida a qualquer cidadão que em seu trabalho tenha qualquer tipo de risco eminente (FREITAS, 2016).

Para se iniciar qualquer atividade que se trabalhe de forma direta e/ou até 
mesmo indireta com agrotóxicos, sempre se começa com a utilização correta dos equipamentos de proteção individual (EPI'S), que devem ser usados durante omanuseio destes visando a segurança dos trabalhadores e também por ser uma exigência da legislação brasileira, regida por um conjunto de leis e normas reguladoras (NR) (SOUZA; PALLADINI, 2005).

Um dos setores mais fortemente regulamentados e controlados são os setores de agroquímicos, já que eles podem afetar desde os animais, a água, o solo, a vegetação, mas principalmente o conjunto disso tudo, afeta de forma muito mais agressiva o ser humano. Foi à lei no 7.747/1982, no Rio Grande do Sul, implementando a primeira norma regulamentadora sobre agrotóxicos, passando posteriormente para os três estados do sul do Brasil.

Esta mesma lei estabelece como deverão funcionar quaisquer tipos de negociações acerca dos agrotóxicos, novas composições, rótulos, como vender, transportar, utilizar. Também prevê multa de até 1.000 vezes o valor do produto comercializado fora destes parâmetros, bem como a inutilização e destruição destes agroquímicos.

A lei $\mathrm{n}$ 9.974 de 2000, também responsabiliza os fabricantes e comerciantesde agrotóxicos a executar programas de educação e controle, incluindo o recolhimento de embalagens vazias dos agrotóxicos.

\section{MATERIAL E MÉTODOS}

\subsection{DESENHO DA PESQUISA}

Trata-se de uma pesquisa de caráter observacional transversal descritivo, dentro de uma abordagem quantitativa e qualitativa. A importância de se utilizar ambos os métodos qualitativos e quantitativos se dá pelo fato de que um complementa o outro.

Segundo Gerhardt et al., (2009) a pesquisa descritiva/ qualitativa exige uma série de informações relacionadas à pesquisa que o investigador deseja trabalhar, estabelecendo uma interligação entre os objetivos e dados analisados, esta apresenta aprofundamento em determinado grupo social ou organização em que se pretende estudar, explicando a realização da pesquisa, produzindo informaçõesaprofundadas e 
ou ilustradas. As principais características fundamentais são as ações de descrever, compreender e explicar o mesmo.

Contudo, a entrevista seguiu um roteiro, ou seja, uma lista de tópicos elaborada pelo entrevistador a ser aplicado, abordando uma técnica na coleta de dados da realidade local (GERHARDT; SILVEIRA 2009).

\subsection{CONSIDERAÇÕES ÉTICAS}

O projeto de pesquisa foi encaminhado ao Comitê de Ética e Pesquisa (CEP) da Universidade Comunitária da Região de Chapecó - UNOCHAPECÓ para análise e aprovado sob número do parecer X, conforme Resolução 466/2012 do Conselho Nacional de Saúde.

Os sujeitos da pesquisa receberam um Termo de Consentimento Livre e Esclarecido (TCLE) que os informou sobre os objetivos, benefícios e possíveis riscosda pesquisa, esclarecendo-os para que tomem sua decisão de forma justa e sem constrangimentos sobre a participação na pesquisa.

Este termo foi assinado em duas vias, onde uma ficará com os pesquisadores e a outra com o sujeito da pesquisa, ambas contendo nome e telefone do responsável pela pesquisa, para qualquer dúvida ou esclarecimento.

A participação não envolve nenhum custo financeiro por parte dos indivíduos. As respostas serão mantidas de forma confidencial, podendo os mesmos recusar-se,a qualquer momento, a participar da pesquisa.

\subsection{CARACTERIZAÇÃO dO AMBIENTE DA PESQUISA}

A pesquisa foi realizada no município de Chapecó, situado no oeste do estado de Santa Catarina. Estando situado a 674 metros de altitude, em relação ao nível do mar, tendo uma área de 625,4 Km² e coordenadas geográficas com, latitude 270 05' 17" S e longitude 52 37' 06" W. Esta envolvendo agricultores das linhas Cabeceira da Divisa, Faxinalzinho, Tafona, Rodeio Bonito, Colônia Cela, Faxinal dos Rosa, Alto da Serra, Borman, Efapi e suas relações com a utilização de EPI's na aplicação de agroquímicos em lavoura de soja.

Tendo em vista que já foram feitos trabalhos semelhantes em municípios vizinhos, em Chapecó, município com mais de 220 mil habitantes e com uma boa 
condição industrial, é o pioneiro, assim contemplando melhorias no setor produtivo na questão de prevenção e qualidade de vida pro homem do campo.

A pesquisa contou com a participação de 29 agricultores, esta amostra se deu pelo fato de que o município de Chapecó - SC, possui em sua totalidade 258 produtores rurais que trabalham com a cultura da soja, destes tiramos uma amostra representativa, totalizando 29 produtores, levando em consideração a realidade das propriedades, ou seja, o tamanho da área de cada propriedade destinada ao cultivo da soja, com a separação por grupos, por exemplo: propriedades com áreas de até 50 há, de 50 a 100 há e acima de 100 ha e também o tempo que trabalha com a atividade.

\subsection{COLETA E ANÁLISE DOS DADOS}

Para avaliar a utilização de Epi's na aplicação de agroquímicos em lavouras de soja no município de Chapecó foram aplicados questionários autoaplicáveis, junto aos agricultores.

A coleta dos dados foi feita pessoalmente pelo pesquisador, e também por alguns acadêmicos que se propuseram a auxiliar na aplicação dos questionários, devido atuarem diariamente na região da pesquisa e principalmente por manterem um bom relacionamento com os entrevistados. Na aplicação do respectivo, o aplicador acompanhou o processo, estando disponíveis para ajudar na leitura, preenchimento e no esclarecimento de possíveis dúvidas.

Não foi realizado o registro de imagens ou voz do participante. A pesquisa também envolverá apenas agricultores maiores de 18 anos.

Após coleta das informações foi construído um banco de dados no programa Microsoft Excel 2007, feita a tabulação de todos os resultados dos questionários e posteriormente uma interpretação e montagem gráfica.

\section{COLETA E ANÁLISE DOS DADOS}

\subsection{INFORMAÇÕES GERAIS}

As informações gerais dos 29 produtores de soja que foram entrevistados no município de Chapecó - SC, resalta-se que que foram 29 produtores de 9 localidades diferentes, a faixa etária ficou entre 23 à 71 anos, ou seja, uma média de idade de 45 
anos mais ou menos.

Em relação ao estado civil apenas 3 produtores são solteiros, os outros 26 são casados.

O nível de escolaridade dos entrevistados oscila do ensino fundamental, médio até superior.

Foram também perguntados sobre o tempo de cada um na atividade agrícola, e $100 \%$ dos entrevistados inclusive o mais novo deles que no caso nasceu no meio rural, relataram que tem mais de 15 anos na atividade.

\subsection{APLICAÇÃO DE AGROQUIMICOS}

É possível perceber que a área que cada produtor realiza a semeadura da soja no município de Chapecó - SC, está pré disposto pelo critério estabelecido para seleção e escolha das propriedades, as áreas utilizadas para soja foram bem heterogênias em se tratando de tamanho, teve a menor com 8 ha e a maior com 200 ha, assim podemos avaliar as diferenças na utilização de agroquímicos e também na utilização dos Epi's na aplicação dosmesmos.

Sobre as aplicações dos produtos, questionou-se sobre os métodos de aplicação utilizado.

A maioria dos produtores utiliza pulverizador de arrasto para aplicação de agroquímicos nas lavouras de soja, sendo 26 dos entrevistados,os 3 outros utilizam o método autopropelido.

Segundo Gasques; \& Bastos (2003), os maquinários vêm aumentando suas tecnologias e consequentemente a produtividade. Na região de Chapecó as condições de áreas cultivadas e a realidade da maioria dos produtores claramenteos detêm ao método de arrasto em relação ao autopropelido, pois ainda este método supre as exigências propostas no momento, certamente quando houver um aumento significativo de área e produção, virão novas tecnologias para suprir este aumento.

Sobre o maquinário utilizado para a aplicação de agroquímicos, os agricultores foram questionados se gabinadas ou não. Dos 29 produtores de soja entrevistados, 23 utilizam máquinas gabinadasquando na aplicação dos produtos e 6 fazem a aplicação com o maquinário desprovido de cabine. 
Os produtores de soja foram questionados sobre em quantas horas por dia realizam a aplicação de agroquímicos, dos 29 produtores de soja entrevistados 16 produtores realizam a aplicação de agroquímicos em 2 horas diárias, 10 produtores em 3 horas, 1 produtor em 4 horas e 2 produtores em mais de 4 horas diárias.

Em estudos, Veiga (2007), afirma que o tipo de EPI influencia no tempo que um trabalhador poderia ficar exposto as condições ambientais de aplicação, ou seja, de acordo com a qualidade e conforto dos EPI's, é que sabemos o tempo máximo que podemos fazer uma aplicação sem interrupção e de qualidade dentro da faixa de conforto.

Os produtores na entrevista foram questionados sobre quantas vezes por ano os agroquímicos são aplicados nas plantações de soja e tivemos $100 \%$ dos produtores respondendo que fazem mais de 5 aplicações por ano.

Segundo EMBRAPA (2004), hoje em dias é comum utilizar no ciclo de culturas como a soja, pelo menos 5 aplicações de produtos. A maioria dos produtoresutilizam aplicações na dessecação pré-plantio, dessecação pós-plantio, utilizam geralmente de 4 a 6 tratamentos e a dessecação pré-colheita.

Durante a entrevista os produtores de soja foram questionados sobre os horários em que são realizadas as aplicações dos agroquímicos, os 29 produtores de forma unânime, falaram que geralmente aplicam os agroquímicos nas horas maisamenas (ao amanhecer e ao entardecer) do dia.

Em relação à pergunta se mais alguém da família realiza a aplicação dos agroquímicos na lavoura, do número total de produtores entrevistados todos responderam que não tem nenhum integrante da família que realiza a aplicação dos agroquímicos além dos mesmos.

\subsection{UTILIZAÇÃO DE EPI'S}

Em relação à pergunta que foi realiza aos produtores se eles usam os EPI's necessários para aplicar os agroquímicos, os dados coletados foram que $100 \%$ dos entrevistados utilizam os EPI's (Máscara, luva, bota, jaleco, óculos, boné, macacão), e o motivo do uso é sempre a segurança e preservação da integridade física emental do aplicador. 
Sobre as instruções de uso e lavagem dos EPI's houve controvérsias.

Quanto às instruções de uso e lavagem dos EPI's, dos 29 produtores entrevistados, 25 usam os EPI's e seguem as instruções de uso e higienização, como por exemplo, lavar os EPI's separadamente das roupas dafamília, em água corrente e com sabão especial. 1 produtor usa os EPI's, mas não segue nenhuma instrução de uso e lavagem, faz apenas o que é de seu conhecimento, sem importar-se se é certo ou errado. E 3 produtores fazem o uso e seguem as informações somente as vezes quando tem tempo para tal procedimento.

Em relação à forma de uso, se total ou parcial, houve praticamente um empate, mas talvez por falta de uma melhor informação em relação aos mesmos podemos dizer que quase ninguém utiliza de forma total os EPI's, mas sim parcial, semprefalta algum, por desatenção do aplicador ou por não conhecimento da legislação referente ao uso. Os mais citados na pesquisa foram os seguintes EPI's: luvas, máscara, jaleco, óculos e bota.

Os EPI's mais utilizados foram as luvas e máscaras, com 100\% de utilização pelos aplicadores, seguidas do jaleco com $82 \%$, bota com $75 \%$, óculos com $51 \%$ e boné com uma menor utilização, $27 \%$.

O motivo para a não utilização de alguns Equipamentos de proteção individual segundo 2 dos entrevistados é a dificuldade para realização das atividades, o desconforto foi relatado como o principal problema por 13 dos 29 entrevistados e a falta de costume foi a mais votada com 14 votos.

Mas é importante destacar que mesmo dificultando o trabalho, sendo desconfortável e existindo uma falta de costume, os Epi's são utilizados pelos agricultores.

De acordo com Schmidt e Godinho (2010), uma das justificativas para o não uso equipamentos de proteção, por agricultores é o incômodo que estesequipamentos causam.

Segundo Delgado e Paumgartten (2004), 92\% de cinquenta e dois agricultores entrevistados em um município do Rio de Janeiro não faziam o uso de EPI's agrícola, por motivos de calor e desconforto.

Em relação à pergunta que foi realiza aos 29 produtores sobre a cada quanto 
tempo realizam a substituição dos EPI's para aplicar os agroquímicos, foram obtidos os seguintes resultados expressados abaixo.

Destaca-se ainda, que 12 produtores realizam a troca dos EPI's todo o ano, 15 produtores realizam a cada dois anos, e somente 2 fazem a substituição do mesmo quando rasgar.

O preço dos equipamentos para fazer as substituições, nem foi comentado pelos entrevistados, deste modo a demora a realização da troca ou a negligência porparte dos produtores nesse sentido é preocupante quando se descarta a questão financeira, que poderia ser um fator determinante.

Para ANDEF (2007), a substituição dos equipamentos de proteção individual devem ser sempre de acordo com as especificações que estão nos próprios produtos, alguns tem uma vida útil maior e consequentemente mais vezes poderão ser utilizados, enquanto outros deverão ser descartados prematuramente.

Pode observar que dos 29 entrevistados, 19 produtores responderam que a máscara é o EPI mais desconfortável, 2 produtores disseram que é o macacão e 8 produtores responderam que as luvas são o EPI mais desconfortável. Fato que chama a atenção, pois a máscara e a luva em gráficos anteriores foram relatadas como as mais utilizadas e neste como as desconfortáveis.

Em relação à pergunta se os EPI's no momento da aplicação dos agroquímicos reduzem a contaminação, foram obtidos resultados expressivos, onde em sua totalidade acreditam que o uso dos equipamentos reduzem significativamente as contaminações. A inobservância e o grande desconhecimento da legislação sobre o uso dos EPI's, dos 29 entrevistados, 26 não tem o conhecimento das várias penalidades pelo não uso dos equipamentos e somente 3 sabem ou pelo menos já ouviram falar.

Segundo a NR31, as medidas de controle são adotadas a fim de trazer mais segurança e saúde no trabalho na agricultura, pecuária, silvicultura, exploraçãoflorestal e aquicultura, assim sendo muito importante aplica-las em nosso local de trabalho para que não ocorram riscos de acidentes prejudiciais à vida.

Em relação ao descarte correto das embalagens dos defensivos agrícolas, todos os entrevistados realizam o descarte das embalagens da melhor forma possível, 25 devolvem na revenda e os outros 4 queimam as respectivas embalagens. 
Segundo o INPEV (2007), cabe a indústria a responsabilidade dentro do sistema de destinação final: recolher as embalagens devolvidas às unidades de recebimento; dar à correta destinação final as embalagens vazias (reciclagem e incineração); e orientar e conscientizar o agricultor.

\section{CONSIDERAÇÕES FINAIS}

Por meio do questionário que foi aplicado aos 29 produtores de soja selecionados do município de Chapecó - SC, ficou bem claro que a utilização de Epi's de forma correta é de extrema importância, para não dizer a principal alternativa de minimizar os riscos de intoxicações por agrotóxicos. Mesmo os produtores entrevistados terem dito acreditar que os EPI's reduzem as contaminações por agroquímicos, muitas vezes os mesmos, não usam, ou quando usam os EPI's é de forma parcial ou incorreta, assim diminuindo sua proteção contraagroquímicos.

Geralmente os produtores quando não usam os EPI's é devido ao desconforto, sendo que a máscara foi a mais citada como EPI mais desconfortável, mas em contra partida, também foi citada como EPI mais importante para ser usado durante uma aplicação de agroquímicos.

Em quase sua totalidade os produtores entrevistados responderam que para melhorar o conforto dos EPI's, as vestes deveriam ser mais confortáveis em relação ao calor, sendo que precisariam ser feitas com um tecido menos quente e também as luvas deveriam ser mais confortáveis, pois atrapalham no momento da realização das atividades.

Portanto se analisarmos que hoje em dia, independente da cultura, utilizamos algum tipo de produto, podendo ser ele para controle de pragas, de doenças, fertilizantes, hormônios, enfim, se não manuseado de forma correta e se não houver uma proteção adequada por parte da pessoa que está em contato com o mesmo, certamente haverá algum tipo de contaminação, que varia de leve até uma mais severa, que poderá provocar danos irreversíveis, e os EPI's são a melhor maneirade se proteger contra esse mal.

Pode-se pensar em melhorar o conforto e a qualidade dos equipamentos, para ainda mais incentivar seu o uso, sei que não depende apenas de nós e também 
usarou não é uma questão pessoal, não podemos obrigar ninguém a faze-los diferente para satisfazer nossa vontade, quanto muito impor a utilização, mas pelo menos podemos tentar trabalhar com a conscientização das pessoas, pois não queira paraos outros o que você não quer pra si mesmo.

\section{REFERÊNCIAS}

ABREU, P. H. B.; ALONZO, H. G. A., Trabalho rural e riscos a saúde: uma revisão sobre o "uso seguro" de agrotóxicos no Brasil, Revista Ciência e Saúde Coletiva, out 2014.

AGOSTINETTO, D. et al,. UTILIZAÇÃO DE EQUIPAMENTOS DE PROTEÇÃOINDIVIDUAL E INTOXICAÇÃO POR AGROTÓXICOS ENTRE FUMICULTORES DO MUNICÍPIO DE PELOTAS - RS, Revista de Ecotoxicologia e Meio Ambiente, Curitiba - PR, v. 8, p. 45-56, 1998.

AMBROSI, J. N.; MAGGI, M. F., Acidentes de trabalho relacionados às atividades agrícolas, Revista Acta Iguaçu, Cascavel - PR, v. 2, n. 1, p. 1-13, 2013.

ANVISA - Agência Nacional de Vigilância Sanitária.

Disponível em: <https://www.anvisa.br>. Acesso em 24 de out. de 2018.

ANDEF - ASSOCIAÇÃO NACIONAL DE DEFESA VEGETAL. Manual de uso correto de Equipamento de Proteção Individual. Campinas, SP: Línea Creativa,2003. $26 \mathrm{p}$.

BALASTREIRE, Luiz Antônio. Máquinas agrícolas. São Paulo: Editora Manole, 1990.

BELO, M. S. da S. P. et al,. Uso de agrotóxicos na produção de soja do Estado do Mato Grosso: um estudo preliminar de riscos ocupacionais e ambientais, Revista Brasileira de Saúde Ocupacional, São Paulo - SP, v. 37, n. 125, p. 78-88, 2012.

BRASIL, Lei no 7.802, de 11 de julho de 1989, Brasília - DF, mar 1989.

CARDOSO, F. D. P. et al,. EXPANSÃO RECENTE DA FRONTEIRA AGRÍCOLA E O CONSUMO DE PRODUTOS AGROQUÍMICOS: INDICADORES E POSSÍVEIS IMPACTOS NA SAÚDE DO TRABALHADOR DO CAMPO EM PORTO NACIONAL - TOCANTINS, Revista de Administração e Negócios da Amazônia, PortoNacional - TO, v.9, n.3, 2017.

CHAGAS, A. M. de R.; SALIM, C. A.; SERVO, L. M. S., Saúde e segurança no trabalho no Brasil: aspectos institucionais, sistemas de informação e indicadores, 1a Edição. Local de publicação: Ipea, 2011. 
DELGADO, I. F.; and PAUMGARTTEN, F. J. R.; Intoxicações e uso de pesticidas por agricultores do Município de Paty do Alferes, Rio de Janeiro, Brasil. Cad. Saúde Pública, Fev 2004, vol.20, no.1, p.180-186.

EMBRAPA. Empresa Brasileira de Pesquisa Agropecuária. Plantas Daninhas. Disponível em: <https://www.embrapa.br/tema-plantas-daninhas/sobre-o-tema. Acesso em 24 de out. de 2018.

EMPRESA BRASILEIRA DE PESQUISA AGROPECUÁRIA - EMBRAPA. Sistema Brasileiro de classificação de solos. 3.ed. Brasília, 2004.

FREITAS, L. C., SEgURANÇA E SAÚDE DO TRABALHO, 3a Edição. Local de publicação: Editora Sílabo, 2016.

GARCIA, E. G.; FILHO, J. P. A., ASPECTOS DE PREVENÇÃO E CONTROLE DE ACIDENTES NO TRABALHO COM AGROTÓXICOS, 1ạ Edição. Local de publicação: Fundacentro, 2005.

GASQUES, J. G.; BASTOS, E. T. Crescimento da Agricultura. IPEA - Nota Técnica - Boletim de Conjuntura 60, Brasília, mar. 2003.

NPEV - Instituto Nacional de Processamento de Embalagens Vazias. São Paulo, SP. 2007. Disponível em: <http:// http://http://www.inpev.org.br. Acesso em 10 de mar.De 2019.

JANIK, M. S.; NASSAR, A. M.; TACHINARDI, M. H., Dossiê Brasil Rural Agronegócio e comércio exterior brasileiro, Revista USP, São Paulo - SP, n. 64,p. 14-27, 2005.

LEITE, K. C.; TORRES, M. B. R. O uso de agrotóxicos pelos trabalhadores rurais do assentamento Catingueira Baraúna - RN. Revista Verde, Mossoró, v.3, n.4, p.0628, out/dez 2008.

Lei no 7.747, de 1982, Normas Regulamentadoras NR 1 a 32, Portaria no 3214 de 1983, Legislação Complementar. 59 ed. São Paulo, SP: Atlas 2006.

Lei no 9.974 de 2000, Normas Regulametadoras, Legislação Complementar 59 ed. São Paulo, SP: Atlas 2006.

LEME, M. F. P. Concentração e internacionalização de capital na indústria brasileira de alimentos. Piracicaba: Esalq, 1999.

MARQUES, C. R. G.; NEVES, P. M. O. J.; VENTURA, M.U. Diagnóstico do Conhecimento de informações básicas para o uso de agrotóxicos por produtores de hortaliças na região de Londrina. Londrina, PR: 2010 
MATTANA, Juliana. Ácaros - como afetam as plantas e como tratar. São Paulo. 2018. Disponível em: <http:// http://www.manejebem.com.br/novidade/acaroscomo- afetam-as-plantas-e-como-tratar. Acesso em: 24 out. 2018.

MISSÃO, R. M., SOJA: ORIGEM, CLASSIFICAÇÃO, UTILIZAÇÃO E UMA VISÃO ABRANGENTE DO MERCADO, Maringá Management: Revista de Ciências Empresariais, v. 3, n.1 - p.7-15, jan./jun. 2006.

MONTEIRO, A. Mecanização agrícola no Brasil, 2010. Disponível em: <http://agribrasil.blogspot.com.br/>: Acesso em: 17. fev. 2019.

MOTA, F. S.; BEIRSDORF, M. I. C.; GARCEZ, J.R. B. Zoneamento agroclimático do Rio Grande do Sul e Santa Catarina. Porto Alegre: 104 Ministério da Agricultura, Departamento Nacional de Pesquisa Agropecuária do Sul, 1971.

NETO, J. A. A indústria de máquinas agrícolas no Brasil - origens e evolução. Rev. adm. empres. São Paulo, 1985. Disponível em: <http://www.scielo.br/scielo. Acesso em: 17. fev. 2019.

OLIVEIRA; SILVA, J. J; Influência de fatores socioeconômicos na contaminação por agrotóxicos, Brasil. Saúde Pública, v. 35, n. 2, p.130-135, 2001.

PEROSSO, B. G.; VICENTE, G. P. Destinação final de embalagens de agrotóxicos e seus possíveis impactos ambientais. 2007. 95 f. Monografia (Graduação em Engenharia Civil)- Fundação Educacional de Barretos, Barretos, 2007.

RAMOS, P. Análise do programa de prevenção de acidentes, Campinas SP,2006.

REIS, E. M.; BRESOLIN, A. C. R. Fungicidas: aspectos gerais. Revista Plantio Direto, ed. 97. Passo Fundo-RS. Jan/fev 2018. Disponível em: <http://www.plantiodireto.com.br/?body=cont_int\&id=777>. Acesso em:28 de abril. 2019.

SCHMIDT, M. L. G.; GODINHO, P. H., Um breve estudo acerca do cotidiano do trabalho de produtores rurais: intoxicações por agrotóxicos e subnotificação. Revista Brasileira de Saúde Ocupacional, Fundação Jorge Duprat Figueiredo de Segurança e Medicina do Trabalho - FUNDACENTRO, São Paulo - SC, v. 31, n. 113, p. 27-40, 2006.

TOURINO, M. C. C; REZENDE, P. M. de; SALVADOR, N., Espaçamento, densidade e uniformidade de semeadura na produtividade e características agronômicas da soja, Pesquisa Agropecuária Brasileira., Brasília - DF, v. 37, n. 8,p. 1071-1077, 2002. 
VEIGA, M. M.; et al,. A contaminação por agrotóxicos e os Equipamentos de Proteção Individual (EPIs), Revista Brasileira de Saúde Ocupacional, São Paulo - SP, v. 32, n. 116, p. 57-68, 2007.

VELASCO, L. O. M. de; CAPANEMA, L. X. de L., O SETOR DE AGROQUímiCOS, 1a Edição. Local de publicação: BNDES Setorial, Rio de Janeiro, n. 24, p. 69-96, 2006. 


\title{
CAPITULO XVIII
}

\section{COMPONENTES DE RENDIMENTO DA SOIA MANEIADA COM A APUCACÃO DE CÁLCIO E ENXOFRE}

DOI: 10.51859/amplla.mas481.1121-18

\author{
Maurício Voikolesco ${ }^{1}$ \\ Caroline Olias ${ }^{2}$ \\ Aline Vanessa Sauer ${ }^{3}$ \\ Sandro Silva de Oliveira ${ }^{4}$ \\ Leocemar de Andrade Bellé 5 \\ Cristiano Reschke Lajús ${ }^{6}$
}

\begin{abstract}
1 Engenheiro Agrônomo. Egresso do Curso de Agronomia. Universidade Comunitária da Região de Chapecó (Unochapecó), Campus de Chapecó.

${ }^{2}$ Acadêmica do Curso de Agronomia. Universidade Comunitária da Região de Chapecó (Unochapecó), Campus de Chapecó.

${ }^{3}$ Doutora em Agronomia. Universidade Estadual de Maringá (UEM), Campus Maringá. Coordenadora e Docente do Curso de Agronomia na UNOPAR - Universidade Pitágoras Unopar, Campus Bandeirantes.

${ }^{4}$ Mestre em Ciências da Computação. Universidade Federal de Santa Catarina (UFSC), Campus Florianópolis. Docente do Curso de Ciências da Computação na Unochapecó. Universidade Comunitária da Região de Chapecó (Unochapecó), Campus de Chapecó.

${ }^{5}$ Egresso do Curso de Agronomia. Discente do Programa de Pós-Graduação Stricto Sensu em Tecnologia e Gestão da Inovação. Universidade Comunitária da Região de Chapecó (Unochapecó), Campus de Chapecó.

${ }^{6}$ Doutor em Agronomia. Universidade de Passo Fundo (UPF), Campus Passo Fundo. Docente e Pesquisador do Programa de Pós-Graduação Stricto Sensu em Tecnologia e Gestão da Inovação. Universidade Comunitária da Região de Chapecó (Unochapecó), Campus de Chapecó.
\end{abstract}

\section{RESUMO}

O fornecimento de uma boa nutrição vegetal pode ser realizado quando há um complemento da adubação de base disponibilizando elementos nutricionais, que antes devido ao manejo, a resposta e disponibilidade não eram imediatas. A presente pesquisa tem como objetivo avaliar os componentes de rendimento da soja manejada com a aplicação de cálcio e enxofre. O experimento foi implantado no Município de Trindade do Sul - RS, situado na região Noroeste do estado do Rio Grande Do Sul. O delineamento utilizado no trabalho foi o delineamento em Blocos Casualizados (DBC), com 4 tratamentos e 5 repetições, totalizando 20 parcelas. Os tratamentos foram T1 Testemunha (adubação de base 07-33-12) $250 \mathrm{~kg} \mathrm{ha}^{-1} ; \mathrm{T} 2-50 \%$ da dose recomendada (70 kg ha-1) via sulco de $\mathrm{CALZ}+\mathrm{S}^{\circledast}$, fertilizante a base de $\mathrm{CaO}(40 \%)$ e $\mathrm{S}(5 \%) ; \mathrm{T} 3-100 \%$ da dose recomendada $\left(140 \mathrm{~kg} \mathrm{ha}^{-1}\right)$ e T4 $-200 \%$ da dose recomendada $\left(280 \mathrm{~kg} \mathrm{ha}^{-1}\right)$. As variáveis respostas do experimento foram: número de vagens por planta, número de grãos por vagem, peso de mil grãos e rendimento. Nas condições em que o experimento foi conduzido, é possível concluir que ao aplicar doses crescentes de $C A L Z+S^{\circledR}$ ocorrem incrementos lineares positivos nos principais componentes de rendimento da soja, sendo que, as mesmas influenciam em $74,67 \%$ no número de vagens por planta, $83,81 \%$ no peso de mil grãos e $87,38 \%$ no rendimento, respectivamente, garantindo assim, a sustentabilidade do respectivo sistema de produção.

Palavras-chave: Cultura da Soja. Nutrição Vegetal. Rendimento. 


\section{INTRODUÇÃO}

A cultura da soja destaca-se em um cenário a nível mundial participando como um produto de grande importância para a economia de diversos países. No Brasil a soja tem o maior volume de extensão de área e volume de produção, a produção chegou aos 114,843 milhões de toneladas com uma área de 35,822 milhões de hectares de plantio (CONAB, 2019). A soja pode ser empregada em diferentes segmentos como alimentação de animais, alimentação humana e fabricação de combustíveis fazendo com que tenha uma grande participação na economia do País. Estados como Mato Grosso, Rio Grande do Sul, Paraná, Goiás e Mato Grosso do Sul destacam-se com enormes produções concentrando $75 \%$ da área cultivada e cerca de $77 \%$ de toda produção nacional conforme dados apresentados da Conab (CONAB, 2017).

A soja é uma cultura muito exigente em todos os macronutrientes essenciais. Para que os nutrientes possam ser eficientemente aproveitados pela cultura, devem estar presentes no solo em quantidades suficientes e, em relações equilibradas (SFREDO, 2008).

A deficiência de enxofre ocorre em algumas regiões do Brasil devido à baixa fertilidade do solo associada à pequena quantidade de matéria orgânica, aumento de exportação dos nutrientes pelos grãos causados por produtividades elevadas, uso de fertilizantes que contêm pouco ou nenhum S em sua composição, lixiviação de sulfato e também a redução do uso de produtos fitossanitários que apresentam enxofre (VOGEL, 2014).

A busca de melhores resultados de produção desperta o interesse em realizar manejos diferenciados, onde é necessário implementar produtos e doses diferenciadas a fim de obter resultados almejados.

A presente pesquisa tem como objetivo avaliar os componentes de rendimento da soja manejada com a aplicação de cálcio e enxofre. Neste sentido, a utilização dos macronutrientes nutrientes Ca e S na cultura da soja, aplicados em diferentes doses irão gerar aumento expressivo nos componentes de rendimento da cultura? 


\section{REVISÃO BIBLIOGRÁFICA}

\subsection{ECOFISIOLOGIA DA SOJA}

Ao se objetivar uma produtividade com qualidade, deve-se levar em conta que cada cultura necessita de condições favoráveis durante todo o seu ciclo vegetativo, exigindo determinados limites de temperatura nos vários estádios do ciclo, uma quantidade mínima de água e um período seco no estádio de maturação e colheita (PEREIRA et al., 2002).

O rendimento final das culturas está diretamente ligado a variabilidade dos elementos meteorológicos durante o ciclo de desenvolvimento, pois o clima altera as várias interações comportamentais em um ecossistema e fatores como a temperatura do ar, a precipitação pluviométrica e a radiação solar são os elementos que mais atuam sobre o desenvolvimento vegetal e, consequentemente, na produtividade (ARAUJO et al., 2010).

A planta de soja apresenta melhor adaptação a temperaturas do ar entre $20^{\circ} \mathrm{Ce}$ $30^{\circ} \mathrm{C}$; a temperatura ideal para seu crescimento e desenvolvimento está em torno de $30^{\circ} \mathrm{C}$, assim como esta é a faixa de temperatura ótima para uma emergência rápida e uniforme da semente (EMBRAPA, 2013).

O crescimento vegetativo das plantas de soja torna-se pequeno ou nulo a temperaturas menores ou iguais a $10^{\circ} \mathrm{C}$. E já temperaturas acima de $40^{\circ} \mathrm{C}$ possuem efeito adverso na taxa de crescimento, provocando distúrbios na floração e diminuindo a capacidade de retenção de vagens. Esses fatores acentuam-se com a ocorrência de déficits hídricos (EMBRAPA, 2013).

A temperatura do ar é o principal elemento a influenciar no desenvolvimento e crescimento vegetal, e uma forma de analisar as interações clima-planta é por meio do uso do sistema de unidades térmicas, ou graus-dia, que traduzem a energia à disposição da planta, em cada dia. Isto porque as plantas apresentam limites de temperatura que acionam dispositivos metabólicos, e abaixo destes, suas atividades fisiológicas são interrompidas (SOUZA et al., 2009).

A disponibilidade da radiação solar é um dos fatores que mais limitam o crescimento e desenvolvimento das plantas. Toda energia necessária para a realização 
da fotossíntese, processo que transforma o $\mathrm{CO} 2$ atmosférico em energia metabólica, é proveniente da radiação solar (TAIZ; ZIEGER, 2017).

A planta de soja é típica de dias curtos, onde as noites longas favorecem o florescimento, tendo uma resposta quantitativa e não absoluta, onde o florescimento ocorre de qualquer forma, adiantando à medida que os dias se tornam mais curtos e, atrasando progressivamente, à medida que o fotoperíodo excede o fotoperíodo crítico que, em média fica em torno de 13 a 14 horas, e que é normalmente específico para cada genótipo (FARIAS et al., 2009).

A água, é um fator imprescindível nos processos fisiológicos e bioquímicos da planta de soja, principalmente nos períodos entre a germinação-emergência e a floração e enchimento de grãos. A demanda hídrica da soja atinge seu máximo valor durante o período de floração-enchimento de grãos requerendo até mais de $7 \mathrm{~mm}$ por dia em condições potenciais (ZANON et al., 2018).

Estima-se que as perdas na safra de soja devido ao déficit hídrico alcançam valores de 93\%, o que ocasiona uma variação interanual significativa na produtividade e produção total de grãos (BERLATO; FONTANA, 2003). A soja tem dois períodos críticos à falta de água, desde a semeadura à emergência e principalmente no enchimento de grãos.

Tanto o excesso como a falta de água durante a germinação, são prejudiciais no estabelecimento da cultura, sendo que nesse período os excessos hídricos são mais limitantes que os déficits, porém, é mais prejudicial a ocorrência da falta de água durante o período de enchimento dos grãos do que durante a floração (BRUN, 2019).

O desenvolvimento da planta e rendimento da soja são resultado da influência mútua entre o potencial genético e o ambiente. O potencial máximo de rendimento, presente em todas as cultivares, é determinado geneticamente. O clima, tem grande influência na expressão do potencial genético em condições de campo, entretanto, através de práticas de manejo de correção do solo, pode-se diminuir essa influência sobre a produção principalmente sobre o estresse hídrico (STORCH, 2017). 


\subsection{NUTRIÇÃO VEGETAL}

As plantas superiores para crescerem e completarem o seu ciclo de vida necessitam de dezessete elementos: carbono $(C)$, oxigênio $(O)$, hidrogênio $(H)$, nitrogênio $(N)$, fósforo $(P)$, potássio $(K)$, cálcio $(\mathrm{Ca})$, magnésio $(\mathrm{Mg})$, enxofre $(\mathrm{S})$, cloro $(\mathrm{Cl})$, manganês $(\mathrm{Mn})$, boro $(\mathrm{B})$, zinco $(\mathrm{Zn})$, ferro $(\mathrm{Fe})$, cobre $(\mathrm{Cu})$, níquel $(\mathrm{Ni})$ e molibdênio (Mo).

Desses, os três primeiros são retirados do ar e da água, sendo chamados de elementos não minerais e constituindo mais de $95 \%$ da matéria seca das plantas. Os quatorze restantes são retirados da solução do solo pelas raízes, sendo chamados de elementos minerais ou nutrientes minerais (FERREIRA, 2012).

Apesar de constituírem menos de $5 \%$ da matéria seca das plantas, são considerados essenciais ao seu desenvolvimento (BARBOSA et al., 2009). Os nutrientes minerais são classificados em macro e micronutrientes, de acordo com a concentração encontrada em seus tecidos. Os encontrados em 'grandes' concentrações são designados de macronutrientes, sendo eles $\mathrm{N}, \mathrm{P}, \mathrm{K}, \mathrm{Ca}, \mathrm{Mg}$ e S. Já os encontrados em 'pequenas' concentrações são os micronutrientes, sendo eles $\mathrm{Cl}, \mathrm{Mn}, \mathrm{B}, \mathrm{Zn}, \mathrm{Fe}, \mathrm{Cu}, \mathrm{Ni}$ e Mo (WARAICH et al., 2011).

Mesmo em pequenas quantidades, os micronutrientes são essenciais à sobrevivência das plantas. De acordo com a "Lei do Mínimo", - "o rendimento da colheita é limitado pela ausência de qualquer um dos nutrientes essenciais, mesmo que todos os demais estejam disponíveis em quantidades adequadas". Essa lei explica que a produção é limitada pelo nutriente que se encontra em menor disponibilidade, mesmo que todos os outros estejam disponíveis em quantidades adequadas (NOVAIS et al., 2007).

A deficiência de nutrientes minerais nos solos, acarreta uma série de problemas para a produção, causando alterações no metabolismo e no suprimento adequado do elemento (GIRACCA; NUNES, 2016).

Os nutrientes mais exigidos pelas plantas são o nitrogênio e o potássio, vindo e seguida o fósforo, o cálcio e o magnésio (SOUSA et al., 2010). Com calagem e adubação aplicadas corretamente, é possível elevar a produtividade da cultura (SIMIC et al., 2010). 
O cálcio é um macronutriente secundário essencial para diversas culturas, entretanto, sua demanda é muito variável em função da espécie vegetal, sendo exigido em maiores quantidades para o grupo das dicotiledôneas. A demanda de cálcio pela cultura da soja apresenta uma variação entre 10 até 200 kg ha-1, esta variação também ocorre em função do estádio fenológico da espécie (SFREDO, 2008).

O cálcio quando presente no solo, na maioria das situações não está no estado ativo, isto ocorre por que o elemento é constituinte de rochas. As principais fontes de cálcio que são utilizadas na agricultura são o calcário e o gesso. O cálcio é absorvido pelas plantas na sua forma iônica $\mathrm{Ca}^{2+}$ através da solução do solo, e o principal mecanismo envolvido é o fluxo de massa (FAQUIN, 2005).

A grande sensibilidade que a cultura da soja apresenta ao cálcio deve-se ao fato de que o elemento, assim como o boro, é imóvel, desta forma a distribuição do nutriente na soja, não ocorre uniformemente. A deficiência de cálcio geralmente é observada em soja cultivada em solos pobres e ácidos que não receberam calcário. Os sintomas resultam de uma combinação da deficiência de cálcio com toxicidade de alumínio e manganês (SFREDO, 2008).

Uma calagem eficiente, além de neutralizar o Al do solo, também fornece Ca e magnésio (Mg) como nutrientes (SOUSA; LOBATO, 2004).

As exigências de enxofre pelas culturas variam muito de acordo com a espécie e com a produtividade esperada. No grupo das culturas de média/alta exigência incluemse as leguminosas, que de um modo geral, são mais exigentes que as gramíneas, em função de seu teor mais elevado de proteínas (ALVAREZ et al., 2007).

A soja é uma cultura exigente neste nutriente, e há possibilidade de resposta à adubação com S. A. deficiência de S pode ser observada em algumas regiões do Brasil, em razão da baixa fertilidade do solo, associada à pequena quantidade de $\mathrm{MO}$, ao aumento da exportação de $\mathrm{S}$ pelos grãos, causados por produtividades elevadas, e à lixiviação de sulfato, acentuada pela aplicação de calcário e P (VITTI et al., 2007).

Na solução do solo, o sulfato é facilmente lixiviado, pois é fracamente retido por meio do mecanismo de adsorção por coordenação (ISHIGURO; MAKINO, 2011), sendo que a sua adsorção é maior em solos mais argilosos e ricos em óxidos de ferro e alumínio (JUNG et al., 2011). 
A soja consegue aproveitar o enxofre somente na forma de sulfato (SO4-2), a qual está presente em alguns fertilizantes e também no gesso agrícola. O sulfato de amônio (22 a $24 \%$ de enxofre), o superfosfato simples (10 a 12\% de enxofre), gesso agrícola (15 a 18\% de enxofre), o sulfato de K (15 a 17\% de enxofre), o sulfato de $\mathrm{K}$ e magnésio ( 22 a $24 \%$ de enxofre), o sulfato de cálcio ( $13 \%$ de enxofre) são as fontes mais comuns desse nutriente (RAIJ et al.,1996).

A dinâmica deste elemento está bastante relacionada com a dinâmica da matéria orgânica e, desta forma, a manutenção de teores adequados de matéria orgânica pode auxiliar no suprimento gradual de $S$ às plantas, através da sua mineralização. (BROCH; RANNO, 2008).

\section{MATERIAL E MÉTODOS}

\subsection{CARACTERIZAÇÃO dO AMBIENTE DA PESQUISA}

O experimento foi implantado no Município de Trindade do Sul - RS, situado na região Noroeste do estado do Rio Grande Do Sul. A altitude da área é de $640 \mathrm{~m}$. Latitude $27^{\circ} 30^{\prime} 42.3^{\prime \prime S}$ longitude $52^{\circ} 54^{\prime} 03.2^{\prime \prime W}$ (GOOGLE EARTH, 2019).

O clima predominante na região segundo a classificação de Köppen, é do tipo Cfa, clima subtropical, mesotérmico úmido, estações bem definidas, sem períodos de secas definidos, e com verão quente com temperatura acima de $22{ }^{\circ} \mathrm{C}$, com precipitaçãomédia anual de $1700 \mathrm{~mm}$ e temperatura média de 22 a $27{ }^{\circ} \mathrm{C}$ no verão e 12 a $17^{\circ} \mathrm{C}$ no inverno (MENDOÇA; DANNI-OLIVEIRA, 2007).

As condições climáticas (temperatura máxima, média e mínima e precipitação acumulada) do período experimental foram obtidas no Sistema de Monitoramento Agrometeorológico (AGRITEMPO, 2020).

O solo da área é classificado como LATOSSOLO Vermelho (EMPRESA BRASILEIRA DE PESQUISA AGROPECUÁRIA, 2013).

\subsection{ESTRATÉGIA E DELINEAMENTO DA PESQUISA}

Segundo Duarte et al. (2009), o delineamento de pesquisa é caracterizado como: quanto à abordagem: consiste em uma pesquisa quantitativa; quanto ao enfoque:consiste em uma pesquisa explicativa e com relação aos procedimentos, 
consiste em uma pesquisa experimental.

\subsection{TÉCNICAS DE COLETAS DE DADOS}

I. Delimitação Experimental e Tratamentos

O delineamento utilizado no trabalho foi o delineamento em Blocos Casualizados

(DBC), com 4 tratamentos e 5 repetições, totalizando 20 parcelas (Figura 01).

Figura 01 - Croqui do experimento

\begin{tabular}{|c|c|c|c|c|}
\hline B1 & $\mathrm{T} 1$ & T2 & T3 & T4 \\
\hline B2 & $\mathrm{T} 4$ & T3 & T2 & $\mathrm{T} 1$ \\
\hline B3 & T2 & $\mathrm{T} 4$ & $\mathrm{~T} 1$ & T3 \\
\hline B4 & T3 & $\mathrm{T} 1$ & $\mathrm{~T} 4$ & $\mathrm{~T} 2$ \\
\hline
\end{tabular}

\begin{tabular}{|l|c|c|c|c|}
\hline B5 & T1 & T2 & T3 & T4 \\
\hline
\end{tabular}

Fonte: elaborado pelos autores.

Os tratamentos foram:

I T1 - Testemunha (adubação de base 07-33-12) $250 \mathrm{~kg} \mathrm{ha}^{-1}$;

1 $\mathrm{T} 2-50 \%$ da dose recomendada $\left(70 \mathrm{~kg} \mathrm{ha}^{-1}\right)$ via sulco de CALZ+S ${ }^{\oplus}$, fertilizante abase de $\mathrm{CaO}(40 \%)$ e $\mathrm{S}(5 \%)$;

I $\mathrm{T} 3-100 \%$ da dose recomendada $\left(140 \mathrm{~kg} \mathrm{ha}^{-1}\right)$ via sulco de $\mathrm{CALZ}+\mathrm{S}^{\odot}$, fertilizante abase de $\mathrm{CaO}(40 \%)$ e S (5\%);

1 $\mathrm{T} 4-200 \%$ da dose recomendada $\left(280 \mathrm{~kg} \mathrm{ha}^{-1}\right)$ via sulco de CALZ+S ${ }^{\oplus}$, fertilizante abase de $\mathrm{CaO}(40 \%)$ e $\mathrm{S}(5 \%)$.

\section{Tratos Culturais}

A dessecação das plantas daninhas foi realizada no dia 05 de novembro 2019, com herbicida Zap QI 620 (Glifosato Potássico), com a aplicação de 2 L ha-1 com 100 $\mathrm{L} \mathrm{ha}^{-1}$ de volume de calda. A adubação de base utilizada foi de $250 \mathrm{~kg}$ de adubo com formulação 07-33-12 para todas as parcelas. E aplicou-se $150 \mathrm{~kg}$ de $\mathrm{KCl}$ (Cloreto de Potássio) a lanço, após 15 dias da data do plantio.

O plantio foi realizado em 30 de novembro de 2019, após a colheita do milho silagem. A semeadora-adubadora foi tracionada por um trator Jhon Deere $5078 \mathrm{E}^{\oplus} \mathrm{com}$ 
$78 \mathrm{CV}$ de potência operando com velocidade entre 4,5 a $5 \mathrm{~km} / \mathrm{h}$. A semeadora adubadora utilizada foi da marca STARA, modelo Ceres $2210^{\circ}$ de seis linhas com espaçamento de 0,45 , com rompedor de solo do tipo haste a fim de formar o sulco de semeadura, a distribuição de semente no solo foi efetivada por discos duplos de 16 polegadas de diâmetro.

O cultivar de soja semeado foi o DM57I52 IPRO .

A semente foi tratada com inseticida sistêmico e de ingestão, Dermacor (Clorantraniliprole) com a dosagem de $100 \mathrm{ml}$ p.c.100 kg de sementes. Também foi usado fungicida sistêmico composto por princípios ativos Fludioxonil, Metalaxil-m e Tiabendazol com nome comercial de Maxim Advanced ${ }^{\circledR}$ (primeira aplicação de produtosfitossanitários). Também foi utilizado o inoculante Bioma Brady Turfoso ${ }^{\circledR}$ Formulado à base das Cepas SEMIA 5079 e SEMIA 5080, da bactéria fixadora de nitrogênio Bradyrhizobium japonicum.

Após 35 dias da semeadura foi realizado a aplicação de herbicida com nome comercial Zap QI $620^{\circ}$ (Glifosato Potássico) na dose de $2 \mathrm{~L} \mathrm{ha}^{-1}$ para controle de plantas daninhas.

No momento de fechamento de fileiras (V6) foi realizada a segunda aplicação de produtos fitossanitários (fechamento entre as fileiras). Na aplicação foi utilizado o fungicida de nome comercial Fox ${ }^{\oplus}$ (Trifloxistrobina+Protioconazol) que é um fungicida mesostêmico e sistêmico na dose recomendada de 0,3 L p.c. ha-1 e com a adição de óleo metilado de soja Aureo ${ }^{\circledR}$ na dose recomendada de $0,5 \mathrm{~L} \mathrm{ha}^{-1}$. Na mesma aplicação foi usado o inseticida sistêmico de nome comercial Orthene $750 \mathrm{BR}^{\circledR}$ (Acefato) na dose recomendada de $1 \mathrm{~kg}$ p.c. ha ${ }^{-1}$ para controle principalmente de pragas.

Aos 20 dias após a segunda aplicação de produtos fitossanitários foi realizada a terceira aplicação, fazendo a repetição de produtos e doses anteriores de fungicida mesostêmico sistêmico de nome comercial Fox (Trifloxistrobina+Protioconazol) e o inseticida sistêmico de nome comercial Orthene $750 \mathrm{BR}^{\circledR}$ (Acefato), para controle de pragas e doenças que atacam a cultura neste estádio. Aproximadamente após 22 dias da terceira aplicação de produtos fitossanitários foi realizada a quarta e última aplicaçãoonde os produtos utilizados foram o fungicida sistêmico de nome comercial Aproach Prima ${ }^{\oplus}$ (Picoxistrobina+Ciproconazol) na dose recomendada de 0,3 L p.c. ha ${ }^{-1}$ 
e o inseticida de contato e ingestão com nome comercial Mustang ${ }^{\circledR}$ (Zetacipermetrina) na dose de 0,2 L p.c. ha-1 . Desta maneira as aplicações de inseticidas e fungicidas foram conduzidas de forma preventiva para que não ocorresse o estabelecimento de patógenos que poderiam interferir nos resultados. O volume de calda utilizado em todasas aplicações foi de $140 \mathrm{~L} \mathrm{ha}{ }^{-1}$ e a ponta de pulverização utilizada era um duplo leque.

\section{Variáveis Respostas}

Quando as plantas entraram em maturação de campo (26/03/2020) foi realizadaa colheita. Os componentes de rendimento (número de vagens por planta, número de grãos por vagem, peso de 1000 grãos e rendimento), foram determinados conforme metodologia proposta pelo MAPA (2009) e Pioneer (2017).

\subsection{TÉCNICA DE ANÁLISE E INTERPRETAÇÃO DOS DADOS}

\section{Análise Estatística}

Os dados coletados foram submetidos à Análise de Variância (ANOVA) pelo teste $F(p \leq 0,10)$, para as doses de $C A L Z+S^{\oplus}$ foi realizada a análise de regressão $(p \leq 0,10)$ com a escolha dos modelos matemáticos através o coeficiente de determinação $\left(R^{2}\right)$. O aplicativo computacional utilizado foi o SISVAR - Sistema de análise de variância para dados balanceados (FERREIRA, 2010).

\section{RESULTADOS E DISCUSSÃO}

A análise de variância revelou efeito significativo $(p \leq 0,10)$ das doses de $C A L Z+S^{\oplus}$ em relação às variáveis respostas número de vagens por planta, peso de 1000 grãos e rendimento, ou seja, existe um modelo matemático que explica a influência da variável $X$ (doses de $C A L Z+S^{\circ}$ ) em relação à variável $Y$ (número de vagens por planta, peso de 1000 grãos e rendimento). A análise de variância não revelou efeito significativo $(p>0,10)$ das doses de $C A L Z+S^{\oplus}$ em relaçãoà variável resposta número de grãos por vagem.

É possível constatar que as condições climáticas (temperatura e precipitação) ocorridas no respectivo experimento influenciaram nos estádios fisiológicos de V5 (quarta folha trifoliolada completamente desenvolvida), R1 (início do florescimento, 
uma flor aberta em qualquer nó do caule - haste principal), R3 (início da formação da vagem, vagem com $5 \mathrm{~mm}$ de comprimento num dos quatro últimos nós do caule com folha completamente desenvolvida), R5 (início do enchimento de grãos, grão com 3 $\mathrm{mm}$ de comprimento em vagem num dos quatro últimos nós do caule com folha completamente desenvolvida) e o estádio de R8 (maturação plena,95\% das vagens com coloração de madura) (FLOSS, 2011; FLOSS, 2013) determinando diferentes comportamentos em relação às variáveis respostas quantitativas (número de vagens por planta, P1000G e rendimento, os quais apresentaram uma relação de causa e efeito entre as doses de de $C A L Z+S^{\oplus}$ ) quando comparado à variável resposta número de grãos por vagem, que não apresentou uma relação de causa e efeito.

Como o rendimento da cultura da soja é considerado a principal variável respostatécnica, resultante do somatório das variáveis quantitativas e em função das condições climáticas, as análises apresentaram comportamentos lineares positivos, sendo que, as doses de $C A L Z+S^{\oplus}$ influenciaram em $74,67 \%$ no número de vagens por planta, $83,81 \%$ no peso de mil grãos e $87,38 \%$ no rendimento, respectivamente, garantindo assim, a sustentabilidade do respectivo sistema de produção.

Visando garantir a sustentabilidade do sistema de produção da soja, na presente pesquisa foram aplicadas diferentes doses de $C A L Z+S^{\circledast}$ (fertilizante mineral misto, recomendado para corrigir deficiências de cálcio e enxofre no solo, com um pH alcalino com leve poder de neutralização). Assim, foi possível perceber, nas condições em queo experimento foi conduzido, que ao aplicar doses crescentes de CALZ+S ${ }^{\bullet}$ ocorrem incrementos produtivos, pois o respectivo produto influência nos seguintes parâmetros (ZARCOS FERTILIZANTES, 2020; FLOSS, 2011; FLOSS, 2013):

- Favorece o desenvolvimento do sistema radicular e redução da severidade de doenças fúngicas e bacterianas;

- Maior tolerância ao stress e diminuição dos distúrbios fisiológicos causados peladeficiência de Ca;

- Menor efeito nocivo do alumínio e menor fixação de fósforo no solo;

- Favorece a mineralização da matéria orgânica no solo, aumentando a liberação denutrientes para as plantas, com aproveitamento dos fertilizantes aplicados (NPK);

- Plantas com processos fisiológicos mais eficientes devido ao melhor equilíbrio denutrientes; 
- Melhora nos processos de produção de proteínas e consequentemente a qualidadedos produtos (grãos).

Tais parâmetros foram observados, principalmente na cultura da soja, pois a absorção do $\mathrm{S}$ ocorre, predominantemente, na forma de sulfato $\mathrm{S}-\mathrm{SO}_{4}{ }^{2-}$, podendo, também, ser absorvido como S orgânico, $\mathrm{SO}_{2}$ (ar) e S molhável (defensivos) pelas folhas. Apresenta-se, em grande maioria na planta, sob a forma orgânica (cistina,cisteína, metionina, proteínas, glicosídeos e vitaminas). As assimilações de nitrogênio e enxofre são bem coordenadas, ou seja, a deficiência de um elemento reprime a via assimilatória do outro (EPSTEIN; BLOOM, 2006). O S é um nutriente com o transportea longa distância ocorrendo, principalmente, pelo xilema e com baixa mobilidade no floema. Por isto, os primeiros sintomas de deficiência aparecem nas folhas novas, em forma de uma clorose uniforme, semelhante à deficiência de N (SFREDO; BORKERT, 2004). As folhas superiores, principalmente as mais novas, são os principais drenos fisiológicos do enxofre, de acordo com Silva et al. (2003). As fontes de $S$ encontradas são o gesso agrícola, o superfosfato simples, o enxofre elementar ( $\left.S_{0}\right)$ ou formulações de N-P-K com adição de S (FLOSS, 2011; FLOSS 2013).

Nogueira e Melo (2003) avaliaram, em condições de campo, o efeito de doses degesso agrícola nos teores foliares dos macronutrientes e na produtividade de grãos durante dois ciclos da cultura da soja. Não encontraram diferença na produtividade da soja e, à exceção do S no segundo ano, não alteraram o teor foliar de macronutrientes. Porém, atentam para um monitoramento do nutriente, devido ao seu rápido deslocamento no perfil do solo.

Vitti et al. (2007) buscaram avaliar a assimilação de enxofre elementar (So), aplicado nas folhas de soja, e sua eficiência comparada à adubação realizada diretamente ao solo, de acordo com a dose e a natureza da fonte do nutriente. A aplicação foliar apresentou assimilação pela planta, acarretando um aumento no teor deproteína total na folha. Todas as fontes de $S$ aplicadas às folhas aumentaram a produção de grãos, semelhantemente à aplicação ao solo. Neste caso, porém, utilizouse um solo com teores baixos de $\mathrm{S}$.

Na deficiência, são afetados os pontos de crescimento, tanto da raiz como da parte aérea; os sintomas aparecem nas partes mais novas da planta, atrofiando o sistema radicular, matando a gema apical; há o retardamento da emergência das folhas 
primárias que, quando emergem, adquirem forma de taça, chamado de encarquilhamento; ocorre, também, colapso do pecíolo pela desintegração da parede celulósica; geralmente, esses sintomas ocorrem em solos ácidos e estão associados às toxicidades de alumínio e de manganês (FLOSS, 2011; FLOSS, 2013).

Via foliar, a aplicação de cálcio aumentou o peso de grãos por planta e não afetou a qualidade fisiológica das sementes produzidas, sendo que as maiores respostas de $\mathrm{Ca}$ nos componentes de rendimento foram verificadas nas fases de floração e pós-floração (BEVILAQUA; SILVA FILHO; POSSENTI, 2002).

\section{CONSIDERAÇÕES FINAIS}

Nas condições em que o experimento foi conduzido, é possível concluir que ao aplicar doses crescentes de $C A L Z+S^{\oplus}$ ocorrem incrementos lineares positivos nos principais componentes de rendimento da soja, sendo que, as mesmas influenciam em $74,67 \%$ no número de vagens por planta, $83,81 \%$ no peso de mil grãos e $87,38 \%$ no rendimento, respectivamente, garantindo assim, a sustentabilidade do respectivo sistema de produção.

\section{REFERÊNCIAS}

AGRITEMPO. Sistema de monitoramento agroecológico, 2020. Disponível em: <https://www.agritempo.gov.br/agritempo/jsp/Grafico/index.jsp?siglaUF=RS>. Acesso em: 29 nov. 2020.

ALVAREZ, V. H. et al. Enxofre. In: NOVAIS, R. F. et al. (Ed). Fertilidade do solo.Viçosa, MG: Sociedade Brasileira de Ciência do Solo, p. 595-644. 2007.

ARAÚJO, D. A. et al. Propriedades físicas dos grãos de amendoim durante a secagem. Revista Brasileira de Engenharia Agrícola e Ambiental, v. 18, n. 3, p.279-286, 2014.

BARBOSA, J. G. et al. Mineral nutrition and fertilization of ornamental plants. Informe Agropecuário, v. 30, n. 249, p. 16- 21, 2009.

BERGAMASCHI, H. Fenologia. In: BERGAMASCHI, H.; BERGONCI, J. I. As Plantas e o Clima: Princípios e Aplicações. Guaíba: Agrolivros, 2017.

BEVILAQUA, G. A. P.; SILVA FILHO, P. M.; POSSENTI, J. C. Aplicação foliar de cálcioe boro e componentes de rendimento e qualidade de sementes de soja. Ciência Rural, 
Santa Maria, v. 32, n. 1, p. 31-34, 2002.

BOARD, J. E.; KAHLON, C. S. Soybean yield formation: what controls it and how itcan be improved. In: EL-SHEMY, H.A. Soybean physiology and biochemistry.

Croatia: InTech, 2011.

BROCH, D. L., RANNO, S. K. Fertilidade do solo, adubação e nutrição da cultura dasoja. Tecnologia de produção de soja e milho, p. 5-36, 2009.

BRUN, J. A. L. Épocas de semeadura e sua influência no potencial produtivo dacultura da soja em regiões produtoras do estado do Paraná, Brasil. Dissertação (Mestrado). USP / Escola Superior de Agricultura "Luiz de Queiroz". Piracicaba, 157, p. 2019.

AMARGO, P. N.; SILVA, O. Manual de adubação foliar. São Paulo, Herba. 1975.

COMISSÃO DE QUIMICA E FERTILIDADE DO SOLO - RS/SC. Manual de adubação e calagem para os estados do Rio Grande do Sul e Santa Catarina. 10 ed. PortoAlegre. SBCS - Núcleo Regional Sul. 400p., 2004.

DUARTE, E. N. et al. Estratégias metodológicas adotadas nas pesquisas de iniciação científica premiadas na UFPB: em foco a Série "Iniciados". Revista Eletrônica de Biblioteconomia e Ciência da Informação, Florianópolis, v. 14, n. 27, p.170-190, 2009.

EMBRAPA. Sistema Brasileiro de Classificação de Solo. 3 ed. Brasília. EMBRAPA,2013.

EMBRAPA. Tecnologias de produção de soja: Região Central do Brasil 2014.Londrina: Embrapa Soja; 268 p., 2013.

EPSTEIN, E.; BLOOM, A. Nutrição mineral de plantas: princípios e perspectivas. 2.ed. Londrina: Editora Planta, p.169-201, 2006.

FARIAS, J. R. B. et al. Ecofisiologia da soja. Londrina: EMBRAPA SOJA, 2007.

FERREIRA, D. F. SISVAR - Sistema de análise de variância. Versão 5.3. Lavras-MG:UFLA, 2010.

FLOSS, E. L. Agronegócio e Desenvolvimento: "pontos de vista". 1. ed. Passo Fundo: Instituto de Ciências Agronômicas, 2013.

FLOSS, E. L. Fisiologia das plantas cultivadas: o estudo do que está por trás do quese vê. 5. ed. Passo Fundo: UPF, 2011.

GIRACCA, E. M. N.; NUNES, J. L. S. Nutrientes. 2016.

KHAN, A. Z. et al. Seed quality and vigor of soybean cultivar as influenced by canopy 
temperature. Pakistan Journal of Botany, v. 43, n. 1, p. 643-648, 2011.

MALAVOLTA, E. ABC da adubação. São Paulo: Ceres, 304p., 1989.

MALAVOLTA, E. Elementos de nutrição mineral de plantas. São Paulo: Ed. 300 Agronômica Ceres, 251p., 1980.

MALAVOltA, E. Manual de Nutrição Mineral de Plantas. 1 ed. São Paulo: Editora Agronômica Ceres, 638 p., 2006.

MALAVOLTA, E.; GOMES, P. F.; ALCARDE, J. C. Adubos e adubações. SãoPaulo: Nobel, 200 p., 2002.

MALAVOlTA, E.; VITTI, G. C.; OLIVEIRA, S. A. Avaliação do estado nutricional das plantas: princípios e aplicações. 2. ed. Piracicaba: Associação Brasileira para Pesquisa da Potassa e do Fosfato, 318 p., 1997.

MAPA. MINISTÉRIO DA AGRICULTURA PECUÁRIA E ABASTECIMENTO. Regras

para análise de sementes. Brasília: Mapa/ACS, 2009. Disponível em: <www.mapa.gov.br>. Acesso em: 30 nov. 2020.

MENDONÇA, F. DANNI-OLIVEIRA, I. M. Climatologia: noções básicas e climas doBrasil. São Paulo: Oficina de Textos, 2007.

MONTE SERRAT, B. et al. Amostragem do solo: perguntas e respostas. Curitiba: Universidade Federal do Paraná, Departamento de Solos e Engenharia Agrícola, 17 p.,2002.

NOGUEIRA, M. A.; MELO, W. J. Enxofre disponível para a soja e atividade de arilsulfatase em solo tratado com gesso agrícola. Revista Brasileira de Ciência doSolo, Viçosa, v. 27, n. 4, p. 655-663, 2003.

NOVAIS, R. F. et al. Fertilidade do solo, Viçosa, SBCS, 1017 p., 2007.

PIONNER SEMENTES. Como estimar a produtividade do milho. 2017.

PRIMO, J. P. et al. Efeito da adubação com enxofre na cultura da soja. Cultivando oSaber. Cascavel, v. 5, n. 3, p. 74-80, 2012.

RHEINHEIMER, D. S. et al. Resposta de culturas à aplicação de enxofre e a teores de sulfato num solo de textura arenosa sob plantio direto. Ciência Rural, Santa Maria, v. 35, n. 3, p. 562-569, mai.-jun. 2005.

SENTELHAS, P. C. et al. The soybean yield gap in Brazil: Magnitude, causes andpossible solutions. Journal of Agricultural Science, v. 153, p. 1394-1411, 2015.

SFREDO, G. J. Soja no Brasil: calagem, adubação e nutrição mineral. EMBRAPASoja, 
Londriina, n. 305, 148 p., 2008.

SILVA, D. J. et al. Translocação e redistribuição de enxofre em plantas de milho e desoja. Pesquisa Agropecuária Brasileira, Brasília, D. F., v. 38, n. 6, p. 715-721, jun. 2003.

SOUZA V. Q. et al. Caracteres morfofisiológicos e produtividade da soja em razãoda desfolha no estádio vegetativo. Científica, Jaboticabal, v. 42, n. 3, p. 216-223, 2014

$\mathrm{STORCH}, \mathrm{M}$. Fatores determinantes para o aumento da produtividade da soja no centro-oeste do Brasil. In: FANCELLI, A.L. Soja: Condicionantes da Alta Produtividade. Piracicaba: USP/ESALQ/LPV, p. 31-51, 2017.

TAIZ, L.; ZEIGER, E. Fisiologia e desenvolvimento vegetal. Porto Alegre: Artmed,888 p., 2017.

VITTI. G. et al. Assimilação foliar de enxofre elementar pela soja. PesquisaAgropecuária Brasileira, v. 42, n. 02, p. 225-229, 2007.

VOGEL, P. T. Estratégias de aplicação e fontes de fertilizantes na cultura da soja. Dissertação (mestrado). Universidade Federal de Santa Maria, RS. 2014.

WARAICH, E. A. et al. Role of mineral nutrition in alleviation of drought stress inplants. Australian Journal of Crop Science, v. 5, n. 6, p. 764-777, 2011.

YAKLICH, R. W. et al. Analysis of seed protein and oil from soybean Northern and Southern region uniform tests. Crop Science, v. 42, n. 5, p. 1504- 1515, 2002.

ZANON, A. J. et al. Ecofisiología da soja: Visando altas produtividades. 1ed. SantaMaría, RS: 136 p., 2018. 


\title{
CAPÍTULO XIX
}

\section{CRESCIMENTO INICIAL DE CULTIVARES DE SOJA SEMEADOS EM DIFERENIIES PROFUNDIDADES EM CASA DE VEGETACG̃̃O}

\section{DOI: 10.51859/amplla.mas481.1121-19}

\author{
Camila Luana Borsa ${ }^{1}$ \\ Caroline Olias $^{2}$ \\ Aline Vanessa Sauer ${ }^{3}$ \\ Gean Lopes da Luz ${ }^{4}$ \\ Leocemar de Andrade Bellé 5 \\ Cristiano Reschke Lajús ${ }^{6}$
}

\begin{abstract}
${ }^{1}$ Engenheira Agrônoma. Egressa do Curso de Agronomia. Universidade Comunitária da Região de Chapecó (Unochapecó), Campus de Chapecó.

${ }^{2}$ Acadêmica do Curso de Agronomia. Universidade Comunitária da Região de Chapecó (Unochapecó), Campus de Chapecó.

${ }^{3}$ Doutora em Agronomia. Universidade Estadual de Maringá (UEM), Campus Maringá. Coordenadora e Docente do Curso de Agronomia na UNOPAR - Universidade Pitágoras Unopar, Campus Bandeirantes.

${ }^{4}$ Doutor em Agronomia. Universidade Federal de Santa Maria, Campus Santa Maria. Docente e Pesquisador do Programa de PósGraduação Stricto Sensu em Tecnologia e Gestão da Inovação. Universidade Comunitária da Região de Chapecó (Unochapecó), Campus de Chapecó.

${ }^{5}$ Egresso do Curso de Agronomia. Discente do Programa de Pós-Graduação Stricto Sensu em Tecnologia e Gestão da Inovação. Universidade Comunitária da Região de Chapecó (Unochapecó), Campus de Chapecó.

${ }^{6}$ Doutor em Agronomia. Universidade de Passo Fundo (UPF), Campus Passo Fundo. Docente e Pesquisador do Programa de PósGraduação Stricto Sensu em Tecnologia e Gestão da Inovação. Universidade Comunitária da Região de Chapecó (Unochapecó), Campus de Chapecó.
\end{abstract}

\section{RESUMO}

A soja, Glycine max (L.) Merrill (Fabaceae), é uma leguminosa, de sistema radicular pivotante de caule herbáceo e ereto. Objetivando-se avaliar o crescimento inicial de cultivares de soja submetidas a profundidades de semeadura em casa de vegetação. $O$ experimento foi conduzido durante o mês de março e abril de 2019, no Viveiro Florestal da Universidade Comunitária da Região de Chapecó (UNOCHAPECÓ), no município de Chapecó - SC. Usando o DIC em esquema fatorial $(3 \times 3)$ como delineamento fatorial, usando três cultivares de soja (CV1: Pioneer 5909, CV2: Pioneer 95R51RR e CV3: Nidera 5445), com três profundidades de semeadura ( $2 \mathrm{~cm}, 4 \mathrm{~cm}$ e $6 \mathrm{~cm}$ ) e três repetições, totalizando 27 unidades experimentais. As análises inciaram aos 10 dias, caracteriando as plântulas normais, plântulas anormais, plântulas mortas, comprimento e diâmetro do hipocótilo e a massa seca da parte aérea e do sistema radicular. Estes submetidos à análise de variância (teste $F$ e as médias comparadas pelo teste Tukey $(P \leq 0,05)$ para as cultivares) e análise de regressão para as profundidades de semeadura, utilizando o Sisvar. 0 cultivar Pioneer 95R51RR ${ }^{\circledR}$ produziu maior massa seca da parte aérea e o cultivar Nidera $5445^{\circledR}$ produz mais massa seca do sistema radicular, o melhor resultado de plântulas mortas tem sido dos cultivares Pioneer $5909^{\circledR}$ e Pioneer $95 R 51 R R^{\circledR}$. A porcentagem de plântulas anormais é igual para os cultivares Pioneer $5909^{\circledR}$ e Nidera $5445^{\circledR}$. O cultivar Pioneer $95 R 51 R R^{\circledR}$ apresenta maior média de comprimento do hipocótilo e o cultivar Nidera $5445^{\circledR}$ apresenta maior média de diâmetro do hipocótilo.

Palavras-chave: Glycine max (L.) Merrill. Crescimento inicial. Plântulas. 


\section{INTRODUÇÃO}

A cultura da soja é de grande importância para alimentação animal, humana e, também, como fonte bioenergética. O cultivo dessa oleaginosa sempre tevegrande interesse na maioria dos produtores rurais do Brasil e do mundo. Atualmente, os produtores estão obtendo um meio de cultivo e de produção mais eficiente, por conta da demanda crescente tanto do mercado interno como do mercado internacional (FIORESE, 2013).

A profundidade ideal de semeadura para a cultura da soja é de 3 a $5 \mathrm{~cm}$, independente do tipo de manejo do solo (ESALQ, 2016). É recomendado que o mesmo seja bem manejado e sem presença de torrões, o que serve para garantir condições de semeadura satisfatórias, bem como, de germinação, emergência das plântulas, desenvolvimento e rendimento das plantas (SANTOS, 2005).

O solo tem quatro fatores físicos que devem ser considerados quando são avaliadas as respostas das culturas a um determinado tipo de preparo, os quais são: umidade, temperatura, aeração e resistência do solo à penetração. Lembrando quea compactação do solo pode influenciar nesses fatores, prejudicando a planta durante seu ciclo de desenvolvimento (SANTOS, 2005).

Um dos fatores que deve ser considerado, na realização da semeadura, é a profundidade de deposição de sementes, para que isso não afete a emergência de plântulas (SILVA et al., 2008).

É importante exercer o estudo do crescimento vegetal para avaliar os efeitos dos diferentes sistemas de manejo sobre as plantas (URCHEl et al., 2000) e também, suas relações com as variáveis de crescimento (PEDÓ et al., 2014). A determinação do número de plântulas emergidas e a estimativa das diferentes variáveis de crescimento ocasionam a interferência do efeito da profundidade de semeadura sobre o vigor das sementes e o desempenho de plântulas em uma determinada condição de ambiente (AISENBERG, 2014).

Dessa forma, estudos básicos sobre a profundidade de semeadura da soja faz-se necessário, tendo em vista que é uma cultura que está sempre evoluindo.

O objetivo deste estudo foi avaliar o crescimento inicial de cultivares de soja semeados em diferentes profundidades em casa de vegetação. 


\section{REVISÃO BIBLIOGRÁFICA}

\subsection{A CULTURA DA SOJA}

A soja é uma planta que pertence ao reino Plantae, divisão Magnoliophyta, classe Magnoliopsida, ordem Fabales, família Fabaceae (Leguminosae), subfamília Faboideae (Papilionoideae), gênero Glycine, espécie Glycine max e forma cultivada Glycine max (L.) Merril (FIORESE, 2013), tem como provável progenitor a espécie Glycineus suriensis (COSTA, 1996).

Há discordância entre autores sobre a origem dessa cultura. As regiões centro, oeste e nordeste da China podem ser originárias da soja, mas todos concordam que o centro de origem é a região leste da Ásia (MIYASAKA; MEDINA, 1981).

Considerada uma das culturas mais a antigas, plantada pelo menos a cincomil anos, foi se espalhando pelo mundo por meio de viajantes ingleses e por imigrantes japoneses e chineses (EMBRAPA, 2005).

A soja foi introduzida no Brasil, em 1882 na Bahia e levada para São Paulo em 1892. No Rio Grande do Sul foi cultivada pela primeira vez em 1900 e em 1936 ocorre o início da expansão desta cultura no estado. Na década de 1980 foi introduzida na região dos Cerrados, tornando-se a cultura anual de maior área plantada no país (COSTA, 1996).

A soja é uma das plantas mais importantes do mundo na atualidade, é considerado um dos grãos mais ricos em proteínas (em torno de 40\%) e óleo (em torno de $20 \%$ ). A variedade cultivada no Brasil possui um teor médio de $38 \%$ de proteína e 19\% de óleo (SEDIYAMA, 2009).

Apesar de o primeiro cultivo de soja no Brasil ter sido em Santa Rosa - RS no ano de 1914, a soja só adquiriu importância econômica no final dos anos 40 . O primeiro registro estatístico nacional de produção de soja, com produção de 457 toneladas, foi no ano de 1941. (DALL'AGNOL, 2016).

Por motivo da grande diversidade do uso dessa oleaginosa e o aumento da demanda global por alimentos, a área para cultivo de soja está aumentando anualmente. Além disso, o investimento em pesquisa e no desenvolvimento de 
cultivares mais resistentes tem ajudado na produção e melhorado o rendimento (SEAB, 2012).

As exportações mundiais de soja em grão crescem a cada ano. Seguindo a produção e a exportação, a importação da soja segue em uma tendência crescente nas últimas safras (SEAB, 2012).

Os principais produtores mundiais dessa oleaginosa em ordem crescente são Argentina, Brasil e Estados Unidos. As alterações na produtividade ou na área desses três países afetam todo o complexo soja a nível global, pois representam mais de $80 \%$ da produção (ALAMBERT, 2010).

O mercado dessa cultura sofre com vários fatores que fazem com que os preços possam oscilar para cima ou para baixo. Nesses fatores podemos destacar que os países produtores: Estados Unidos, Brasil e Argentina - grandesfornecedores de matéria-prima - seguem nessa ordem em volume de produção; o primeiro e o terceiro país contam com uma produção de grãos geneticamente modificados em sua grande maioria, e no Brasil temos uma participação na safra nacional de aproximadamente $20 \%$ desse tipo de grão (MISSÃO, 2006).

No Brasil, o desenvolvimento das variedades de soja geneticamenteadaptadas aos diferentes solos, condições climáticas e latitude permitiram o cultivo desta leguminosa em todas as regiões do país e, também é explorada em quase todos os estados (ALAMBERT, 2010).

No Brasil, a cadeia da soja é o exemplo que ilustra melhor o movimento mundial de aumento na procura por grãos, tanto como fonte de nutrientes para uso na alimentação quanto para aplicação na geração energia (MISSÃO, 2006).

Os fatores climáticos e ambientais que influenciam diretamente na cultura da soja, são: a luz, a umidade e a temperatura (FIORESE, 2013).

As exigências térmicas para produção de sementes de alta qualidade fisiológica da oleaginosa requer temperatura média diária igual ou abaixo de $22{ }^{\circ} \mathrm{C}$, por isso regiões tropicais eram impróprias. No entanto, uma pesquisa identificou que áreas tropicais localizadas acima de 700 metros de altitude têm aptidão climática para a produção de sementes de soja, o que possibilitou a implantação de uma indústria sementeira nas regiões tropicais brasileiras de baixa latitude e boa altitude, o que 
favoreceu a expansão do cultivo de soja pelo Centro-Oeste, Norte e Nordeste do Brasil (DALL'AGNOL, 2016).

A colheita deve ser feita quando o grau de umidade da semente estivesse em certa de $13 \%$ no processo de maturação, esse grau de umidade é determinante para evitar danos mecânicos à semente, bem como, manter o vigor e a germinação alto. (DALL'AGNOL, 2016).

A necessidade de água se faz maior em dois momentos da produção de soja que é o da germinação-emergência e floração-enchimento de grãos. Na germinaçãoemergência tanto o excesso quanto a falta são prejudiciais, pois é nessa fase que a soja vai obter uma boa uniformidade e precisa de $50 \%$, no mínimo, de seu peso em água para uma boa germinação, mas a água no solo não deve ultrapassar $85 \%$ do total máximo de água (EMBRAPA, 2011).

Na floração-enchimento de grãos a necessidade de água aumenta para 7 a 8 $\mathrm{mm} / \mathrm{dia}$, depois dessa fase decresce, se durante esse período essa média for inferior podem ocorrer alterações fisiológicas (fechamento estomático e enrolamento de folhas) na planta podendo causar a queda prematura de flores e folhas e abortamento de vagens o que, consequentemente, provoca uma redução de rendimento (EMBRAPA, 2011).

Para a cultura da soja, o bom preparo do solo é de extrema importância. 0 preparo é realizado para assegurar condições adequadas de semeadura, germinação, emergência das plântulas, desenvolvimento e rendimento das plantas (SANTOS, 2005).

A compactação do solo sobre a fileira de semeadura faz-se de grande importância, pois ocasiona alterações em seu interior, modificando parte do ambiente físico onde a cultura se desenvolve. Os quatro fatores físicos do solo que necessitam ser considerados são: umidade, temperatura, aeração e resistência mecânica do solo à penetração, sendo que a compactação do solo pode influenciar em todos esses, prejudicando a planta durante seu desenvolvimento (SANTOS, 2005).

Segundo Fiorese (2013), um fator muito importante para a cultura da soja, é a época de semeadura, pois é uma planta sensível à luz e outras condições como temperatura, umidade e altitude, logo a época de semeadura determinará a menor ou maior exposição da soja às variações dos fatores climáticos que influenciam diretamente 
na sua fotossensibilidade. Outro fator importante no manejo da lavoura de soja é o cálculo da quantidade de sementes necessárias para a semeadura, para isso precisa-se saber o poder germinativo do lote de sementes em questão.

Outro fator que deve ser considerado é a profundidade de deposição das sementes. A semente deve ser semeada a uma profundidade que permita umcontato adequado com o solo úmido, o que vai resultar em um percentual deemergência alto (MODOLO et al., 2010).

A profundidade da semeadura é fundamental, pois influencia o estande, o ciclo, a altura da planta, o acamamento e a produtividade de grãos da lavoura. Prejudica, também, na porcentagem de plântulas emergidas. A profundidade ideal em solos argilosos é de 2 a $3 \mathrm{~cm}$ e a em solos arenosos é de 3 a $5 \mathrm{~cm}$ (FIORESE, 2013).

O rápido e uniforme estabelecimento das plântulas estabelece um pré-requisito importante para alcançar um estande adequado, assegurando produtividades maiores (NASCIMENTO et al., 2011).

O desempenho produtivo correto da planta condiciona uma relação com a emergência de plântulas, que resultará em uma população adequada de plantas, no melhor desenvolvimento da cultura (GROTTA et al., 2008) e também em uma eficiência maior de competição com plantas daninhas (FLECK et al., 2003).

Semeadura rasa demais leva a uma alta ocorrência de raízes de aranha, as quais se desenvolvem horizontalmente abaixo da superfície do solo e que são de baixa qualidade (MAPA, 2009).

Semeadura profunda possui diversos efeitos no crescimento de plântulas. Pode haver um aumento no tempo entre a germinação de sementes e a emergência de plântulas (LI, 1997).

\section{MATERIAL E MÉTODOS}

\subsection{CARACTERIZAÇÃO DO AMBIENTE DA PESQUISA}

O estudo foi conduzido na casa de vegetação, com ambiente controlado, com temperatura \pm 25 o C e umidade $\pm 80 \%$, durante o mês de março e abril de 2019 , no Viveiro Florestal da Universidade Comunitária da Região de Chapecó - UNOCHAPECÓ, no município de Chapecó - SC. 


\subsection{TRATAMENTOS E DELINEAMENTO EXPERIMENTAL}

O delineamento experimental utilizado foi o delineamento inteiramente casualizado em esquema fatorial $(3 \times 3)$, sendo que no fator $A$ foram alocados os cultivares (CV1: Pioneer 5909, CV2: Pioneer 95R51RR e CV3: Nidera 5445) e no fator B foram alocadas as profundidades de semeadura $(2 \mathrm{~cm}, 4 \mathrm{~cm}$ e $6 \mathrm{~cm})$, com três repetições, totalizando 27 unidades experimentais.

\subsection{TRATOS CULTURAIS E VARIÅVEIS RESPOSTAS}

Foi utilizado sementes de soja, Glycine max (L.) Merrill (Fabaceae), de três cultivares diferentes, os quais são: Pioneer 5909, Pioneer 95R51RR e Nidera 5445.

A areia de textura utilizada para o preenchimento dos vasos foi esterilizada, por um período de 24 horas em estufa de secagem a $150^{\circ} \mathrm{C}$ e umedecida com água.Foram semeadas 50 sementes de soja por vaso, os vasos foram regados diariamente com água visando manter a capacidade de campo do solo.

Todos os vasos foram preenchidos com uma base, após, conforme cada tratamento foi realizada a cobertura com areia em camadas conforme as profundidades $(2,4$ e $6 \mathrm{~cm})$. Os com profundidade de dois centímetros tiveram base de oito centímetros, os com profundidade de quatro centímetros tiveram base de seis centímetros e os com profundidade de seis centímetros tiveram base de quatro centímetros, assim totalizando dez centímetros em cada vaso.

A semeadura foi realizada manualmente e a irrigação foi realizada conforme a necessidade monitorando a capacidade de campo.

O número de plântulas normais foi analisado no décimo dia após o semeio, ou seja, aquelas que apresentaram o coleóptilo sobre a superfície da areia.

Aos 10 dias após a semeadura foram realizadas as seguintes avaliações: diâmetro do hipocótilo que foi obtida com paquímetro e comprimento do hipocótilo que foi obtido com uma régua (SANTANA et al., 2018; NOGUEIRA et al., 2019).

Para determinar a massa seca da parte aérea, as plântulas foram cortadas rente ao solo, acondicionadas em sacos de papel e levadas à estufa termoelétrica a 65 으, por 72 horas, até atingir massa constante (FLOSS, 2011).

O sistema radicular foi lavado em água corrente, utilizando uma peneira para 
evitar perdas de raízes mais finas, passando pelo mesmo procedimento da parte aérea, até obtenção da massa seca. Todo material vegetal foi pesado em balançade precisão (LAJUS et al., 2016)

\subsection{ANÁLISE ESTATISTICA}

Os dados coletados foram submetidos à análise de variância, utilizando-se o teste $\mathrm{F}$ e as médias comparadas pelo teste Tukey $(P \leq 0,05)$ para as cultivares, e análise de regressão para as profundidades de semeadura, utilizando-se o software Sisvar (FERREIRA, 2008).

\section{RESULTADOS E DISCUSSÃO}

\subsection{PLÂNTULAS NORMAIS}

A análise de variância não revelou efeito significativo $(P>0,05)$ dostratamentos em relação à variável resposta plântulas normais (Tabela 01).

Tabela 01 - Massa seca do sistema radicular do experimento (Chapecó - SC, 2019).

\begin{tabular}{|c|c|}
\hline \multirow{2}{*}{ Tratamentos } & MS sistema radicular \\
\hline & ----------(g)--------- \\
\hline Pioneer $5909^{\oplus}$ Prof. $2 \mathrm{~cm}$ & $0,40 \mathrm{a}$ \\
\hline Pioneer $5909^{\circledR}$ Prof. $4 \mathrm{~cm}$ & $1,19 \mathrm{a}$ \\
\hline Pioneer $5909^{\circledR}$ Prof. $6 \mathrm{~cm}$ & $0,40 \mathrm{a}$ \\
\hline \multicolumn{2}{|c|}{ Pioneer 95R51RR ${ }^{\oplus}$ Prof. $2 \mathrm{~cm} \mathrm{0,45} \mathrm{a}$} \\
\hline \multicolumn{2}{|c|}{ Pioneer 95R51RR ${ }^{\oplus}$ Prof. $4 \mathrm{~cm} \mathrm{0,89} \mathrm{a}$} \\
\hline \multicolumn{2}{|c|}{ Pioneer $95 R_{51 R R}^{\oplus}$ Prof. $6 \mathrm{~cm} \mathrm{0,77} \mathrm{a}$} \\
\hline Nidera $5445^{\circ}$ Prof. $2 \mathrm{~cm}$ & $0,82 \mathrm{a}$ \\
\hline Nidera $5445^{\circ}$ Prof. $4 \mathrm{~cm}$ & $0,80 a$ \\
\hline Nidera $5445^{\circ}$ Prof. $6 \mathrm{~cm}$ & $1,15 \mathrm{a}$ \\
\hline CV (\%) & 73,69 \\
\hline
\end{tabular}

Médias seguidas de mesma letra não diferem entre si pelo teste de Tukey $(P \leq 0,05)$.

Fonte: elaborado pelos autores.

Não foi constatada diferença significativa da profundidade de semeadura sobre 
a massa seca do sistema radicular nas profundidades de dois, quatro e seis centímetros (Tabela 01). Para o cultivar Pioneer $5909^{\circ}$ semeado com dois centímetros de profundidade foi verificado maior massa seca de raiz e a menor massa seca de raiz foi verificado, também, para o cultivar Pioneer $5909^{\circ}$ mas quando semeado em dois e seis centímetros de profundidade.

O comportamento do acúmulo de massa seca é o mesmo para todos os órgãos. A massa seca de raízes e caule atinge um ponto máximo e estabiliza-se até o final do ciclo (ALAMBERT, 2010).

A massa de raízes da cultura da soja (Tabelas 5), não diferiu entre as profundidades de semeadura e a mobilização do solo, discordando de Barber (1971)e Adeoye (1982), que afirmam que é possível melhor enraizamento com maior mobilização do solo.

Segundo Bayer (2004), a matéria orgânica presente no solo auxilia bastante no crescimento radicular, pois atribuir aos solos uma capacidade maior de resistir a perturbações, melhora a infiltração e armazenamento de água, aeração do solo, ciclagem de nutrientes e proporciona uma resistência menor ao crescimento radicular, além de melhorar o desenvolvimento da microbiota do solo.

O desenvolvimento radicular das culturas pode ser afetado em solos mais compactados, como os sob semeadura direta em campo nativo submetido a pastejo direto por bovinos (TREIN et al., 1991).

Há estudos que afirmam que, a campo, solos mais compactados aumentam o desempenho dos pneus ao exercerem tração, mas precisam de mais esforço para serem mobilizados, aumentam o desgaste das máquinas e equipamentos e podem prejudicar e até impedir o desenvolvimento radicular das plantas (REINERT et al., 1998).

Não foi constatada influência da densidade do solo e da profundidade de semeadura sobre a massa seca do sistema radicular na camada de 0 - 15 centímetros, em estudo conduzido por Ferreira et al. (2018), que avaliaram o crescimento inicial da soja semeado em diferentes profundidades em solo compactado.

\subsection{COMPRIMENTO DO HIPOCÓTILO}

A análise de variância revelou efeito significativo $(P \leq 0,05)$ dos tratamentos em relação à variável resposta comprimento do hipocótilo (Tabela 02). 
Tabela 02 - Comprimento do hipocótilo do experimento (Chapecó, SC - 2019).

\begin{tabular}{|c|c|}
\hline \multirow{2}{*}{ Tratamentos } & Comprimento \\
\hline & ---------(cm)-------- \\
\hline Pioneer 5909 ${ }^{\oplus}$ Prof. $2 \mathrm{~cm}$ & $10,92 a b$ \\
\hline Pioneer $5909^{\oplus}$ Prof. $4 \mathrm{~cm}$ & $9,30 \mathrm{a}$ \\
\hline Pioneer $5909^{\circledR}$ Prof. $6 \mathrm{~cm}$ & $10,48 a b$ \\
\hline \multicolumn{2}{|c|}{ Pioneer 95R51RR ${ }^{\oplus}$ Prof. $2 \mathrm{~cm} \mathrm{12,14} \mathrm{b}$} \\
\hline \multicolumn{2}{|c|}{ Pioneer 95R51RR ${ }^{\circledR}$ Prof. $4 \mathrm{~cm} 11,30 \mathrm{ab}$} \\
\hline \multicolumn{2}{|c|}{ Pioneer $95 R^{2} 1 R^{\circledR}$ Prof. $6 \mathrm{~cm} \mathrm{10,23} \mathrm{ab}$} \\
\hline Nidera $5445^{\oplus}$ Prof. $2 \mathrm{~cm}$ & $10,20 \mathrm{ab}$ \\
\hline Nidera $5445^{\circ}$ Prof. $4 \mathrm{~cm}$ & $10,10 a b$ \\
\hline Nidera $5445^{\circ}$ Prof. $6 \mathrm{~cm}$ & $10,64 a b$ \\
\hline CV (\%) & 8,26 \\
\hline
\end{tabular}

Médias seguidas de mesma letra diferem entre si pelo teste de Tukey $(P \leq 0,05)$.

Fonte: elaborado pelos autores.

Conforme observado na Tabela 02, as médias de comprimento do hipocótilo diferiram significativamente entre si, sendo a maior no cultivar Pioneer 95R51RR ${ }^{\circledR}$ semeado na profundidade de dois centímetros e a menor média no cultivar Pioneer $5909^{\circ}$ mas semeado na profundidade de quatro centímetros.

O comprimento do hipocótilo dos cultivares testados não seria limitante a emergência da soja, quando semeada de acordo com as recomendações para a cultura. A profundidade de semeadura recomendada para soja é de 2,5 a 5,0 centímetros (REUNIÃO..., 1998).

À medida que aumentou a profundidade de semeadura houve redução dos valores de comprimento do hipocótilo (Tabela 6), devido principalmente à barreira física proporcionada pelas camadas mais profundas, em razão de que profundidades excessivas afetam a germinação, a emergência e o desenvolvimento da plântula, por conta da diminuição da temperatura e disponibilidade de $\mathrm{O}_{2}$ e, consequentemente, acumulo de $\mathrm{CO}_{2}$ (TILLMANN et al., 1994; PRADO et al., 2002).

Vanzolini e Carvalho (2002) constataram que as sementes mais vigorosas produziram maior comprimento da raiz primária e comprimento total das plântulas.

A maior velocidade de emergência e a produção de plântulas com maior 
tamanho, provenientes das sementes vigorosas, podem proporcionar ao dossel vantagens no aproveitamento de água, luz e nutrientes (PANOZZO et al., 2009).

O hipocótilo é uma das principais estruturas que contribuem com a emergência dos cotilédones e do epicótilo. Fatores como encrostamento do solo (aumento da densidade da camada superficial) e profundidade de semeadura, contrariam a emergência acarretando na redução populacional da lavoura dado o impedimento da elevação da plântula, isto posto, um maior hipocótilo tende a superar estas limitações com maior facilidade (SANTANA et al., 2018).

O hipocótilo é importante na emergência das plântulas de soja, pois é responsável pela elevação dos cotilédones e do epicótilo acima da superfície do solo (KNITTLE; BURRIS, 1979).

O comprimento do hipocótilo das plântulas é uma medida de crescimento que está relacionada com a capacidade das mesmas em emergir, vencendo esta barreira, uma vez que o hipocótilo deve crescer em comprimento, de modo a superar a profundidade de semeadura (COSTA et al., 1999).

A International Seed Testing Association - ISTA (HAMPTON; TEKRONY, 1995), a Association of Official Seed Analysis - AOSA e Nakagawa (1999) recomendam a análise do crescimento das plântulas como uma forma de avaliar o vigor das sementes. $O$ teste de comprimento de plântulas tem como base que lotes de sementes que originam plântulas com maior comprimento são mais vigorosos (NAKAGAWA, 1999).

\subsection{DIÂMETRO DO HIPOCÓTILO}

A análise de variância revelou efeito significativo $(P \leq 0,05)$ dos tratamentos em relação à variável resposta diâmetro do hipocótilo (Tabela 03). 
Tabela 03 - Diâmetro do hipocótilo do experimento (Chapecó - SC, 2019).

\begin{tabular}{|c|c|}
\hline \multirow{2}{*}{ Tratamentos } & Diâmetro \\
\hline & -----------(cm)---------- \\
\hline Pioneer $5909^{\oplus}$ Prof. $2 \mathrm{~cm}$ & $0,19 a$ \\
\hline Pioneer $5909^{\circ}$ Prof. $4 \mathrm{~cm}$ & 0,29 cde \\
\hline Pioneer $5909^{\circ}$ Prof. $6 \mathrm{~cm}$ & 0,28 bcde \\
\hline $\begin{array}{l}\text { Pioneer 95R51RR }{ }^{\oplus} \text { Prof. } \\
2 \mathrm{~cm}\end{array}$ & $0,21 b$ \\
\hline $\begin{array}{l}\text { Pioneer 95R51RR }{ }^{\oplus} \text { Prof. } \\
4 \mathrm{~cm}\end{array}$ & $0,22 a b c$ \\
\hline $\begin{array}{l}\text { Pioneer 95R51RR }{ }^{\circ} \text { Prof. } \\
6 \mathrm{~cm}\end{array}$ & 0,31de \\
\hline Nidera $5445^{\circ}$ Prof. $2 \mathrm{~cm}$ & $0,23 \mathrm{abcd}$ \\
\hline Nidera $5445^{\circ}$ Prof. $4 \mathrm{~cm}$ & 0,25 abcd \\
\hline Nidera $5445^{\circ}$ Prof. $6 \mathrm{~cm}$ & 0,33 e \\
\hline CV (\%) & 10,17 \\
\hline
\end{tabular}

Médias seguidas de mesma letra diferem entre si pelo teste de Tukey $(P \leq 0,05)$.

Fonte: elaborado pelos autores.

Apresentou diferença significativa entre as médias de diâmetro do hipocótilo, onde a maior média foi para o cultivar Nidera $5445^{\circledR}$ semeado na profundidade de seis centímetros e a menor média de diâmetro foi para o cultivar Pioneer $5909^{\circledR}$ semeado na profundidade de dois centímetros.

Independentemente do cultivo, a profundidade e a posição de semeadura devem ser adequados para garantir a germinação das sementes, a emergência e o desenvolvimento das plântulas (MARTINS; CARVALHO, 1993; MARTINS et al., 1999).

O diâmetro do hipocótilo na cultura do feijão apresenta alta correlação genética de alto efeito direto com nota de arquitetura de plantas, de modo que plantas mais eretas possuem valores de diâmetro do hipocótilo maiores (MOURA et al., 2013).

Rocha (2012) aborda que a relação observada entre diâmetro do hipocótilo e nota de arquitetura de plantas ocorre em virtude de genes com efeitos pleiotrópicos.

Costa et al., (1999), afirmam que o diâmetro do hipocótilo das plântulas é uma medida do crescimento que está relacionada com a capacidade das plântulas 
emergirem, passando essa barreira, uma vez que o hipocótilo deve crescer em diâmetro para aumentar sua força e habilidade de suportar sem deformações, as resistências ocasionadas pelo peso dos cotilédones e pelo aumento da densidade da camada superficial.

Logo, concluíram que, em solos com encrostamento superficial, o engrossamento do hipocótilo pode ser uma adaptação favorável à emergência das plântulas sob pressão contrária e que hipocótilo com diâmetro maior torna a plântula mais competente em emergir nesta situação adversa (COSTA et al., 1999).

O hipocótilo das plântulas de soja responde às resistências físicas com a diminuição e o aumento do diâmetro. Entretanto, o diâmetro do hipocótilo é mais importante no caso do solo apresentar uma crosta superficial (KNITTLE; BURRIS, 1979).

Esses mesmos autores, também, observaram que o diâmetro do hipocótilo aumenta com o acréscimo da pressão feita sobre ele (KNITTLE; BURRIS, 1979).

No estudo de Rampim et al., (2012), os resultados da correlação de Pearson demonstram que o crescimento da parte aérea é proporcional ao desenvolvimento do hipocótilo e das raízes, ao passo que um maior diâmetro nesta parte da planta influencia negativamente seu comprimento.

Em estudo conduzido em casa de vegetação com condições controladas, avaliando a profundidade de semeadura de plantas de soja, foi concluído que a profundidade de semeadura não influenciou o diâmetro do hipocótilo, o que pode indicar que nas profundidades utilizadas (1, 2 e 3 centímetros) não resultaram em pressão contraria significativa que implicasse na necessidade de a plântula aumentar o diâmetro do hipocótilo para se adaptar visando a superação da resistência proporcionada pelo solo (NOGUEIRA et al., 2019).

\section{CONSIDERAÇÕES FINAIS}

O cultivar Pioneer 95R51RR ${ }^{\circledR}$ produz mais massa seca da parte aérea e o cultivar Nidera $5445^{\circledR}$ produz mais massa seca do sistema radicular, comparados com os outros cultivares e profundidades.

O melhor resultado de plântulas mortas tem sido dos cultivares Pioneer $5909^{\circledR} \mathrm{e}$ Pioneer 95R51RR ${ }^{\circledR}$. A porcentagem de plântulas anormais é igual para os cultivares 
Pioneer $5909^{\circledR}$ e Nidera $5445^{\circledR}$, porém os três cultivares semeados em quatro e seis centímetros apresentou melhor resultado. E a maior porcentagem de plântulas normais é do cultivar Nidera $5445^{\circledR}$, comparadas com os outros cultivares e profundidades.

O cultivar Pioneer 95R51RR ${ }^{\circledR}$ apresenta maior média de comprimento do hipocótilo e o cultivar Nidera $5445^{\circledR}$ apresenta maior média de diâmetro do hipocótilo, sendo assim as plântulas que apresentam tal características mostraram-se com maior potêncial de resistência à possíveis adversidades ao longo do ciclo vital, graças as suas características momorfo-fisiológicas.

\section{REFERÊNCIAS}

AISENBERG, G. R.; PEDÓ, T.; AUMONDE, T. Z.; VILLELA, F. Vigor e desempenho de crescimento inicial de plantas de soja: efeito da profundidade de semeadura. Enciclopédia Biosfera, Centro Científico Conhecer - Goiânia, v.10, n.18; p.3081, 2014.

ALVES, A. U.; CARDOSO, E. DE A.; ALIXANDRE, T. F.; CAVALCANTE, Í. H. L.;BECKMANNCAVALCANTE, M. Z. Emergência de plântulas de fava em função de posições e profundidades de semeadura. Bioscience Journal, Uberlândia, v. 30, n. 1, p. 3342, 2014.

BAYER, C. Manejando os solos agrícolas para alta qualidade em ambientes tropicais. In.: REUNIÃO BRASILEIRA DE FERTILIDADE DO SOLO E NUTRIÇÃO DE PLANTAS, 26., REUNIÃO BRASILEIRA SOBRE MICORRIZAS, 10., SIMPÓSIO 55 BRASILEIRO DE MICROBIOLOGIA DO SOLO. REUNIÃO BRASILEIRA DE BIOLOGIA DO SOLO, 1CDROM, Lages. SBCS: UDESC Lages, 2004.

BORDIN, I. et al. Matéria seca, carbono e nitrogênio de raízes de soja e milho em plantio direto e convencional. Pesquisa Agropecuária Brasileira 43: 1785-1792, 2008.

CAMARGO, O. A.; ALLEONI, L. R. F. Compactação do solo e o desenvolvimento das plantas. Piracicaba: Esalq, 1997. 132p.

CARVALHO, N. M.; NAKAGAWA, J. Sementes: ciência, tecnologia e produção. Jaboticabal: FUNEP, 2000. 588 p.

COSTA, J. A. Cultura da Soja. Porto Alegre. Evangraf. 1996. 233p.

DALL'AGNOL, A. A Embrapa Soja no contexto do desenvolvimento da soja no Brasil: histórico e contribuições. Brasília, DF: Embrapa, 2016. 72 p., 1ạ edição Publicação digitalizada, 2016. 
EMBRAPA. Tecnologias de produção de soja: região central do Brasil 2012 e 2013. Londrina: Embrapa Soja, 264 p. (Sistema de Produção, 15), 2011.

FALCONER, D. S.; MACKAY, T. F. C. Introduction to quantitative genetics. 4 ed. New York: Longman, 464p.,1996.

FAN, J. et al. Root distribution by depth for temperate agricultural crops. Field Crops Research 189: 68-74, 2016.

FIORESE, K. F. Avaliação das características agronômicas e produtividade de cultivares de soja em diferentes sistemas de semeadura. 2013. 24 F. Monografia (Graduação em Agronomia) - Universidade de Brasília - UnB, Brasília, 2013.

KNITTLE, K.H., BURRIS, J.S. Soybean hypocotyl growth under field conditions.Crop Science, Madison, v. 19, n. 1, p. 37-41, 1979.

KRZYZANOWSKI, F. C.; VIEIRA, R. D.; FRANÇA NETO, J. B. Vigor de sementes: conceitos e testes. Associação Brasileira de Tecnologia de Sementes. Londrina: ABRATES, 218p, 1999.

LAJÚS, C. R.; MAFFESSONI, J.; SEGATTO, C.; ECHER, G.; FERRAZZA, A.; VERONA, R. B.; LUZ, G. L. Crescimento inicial de cultivares de milheto submetidas a profundidades de semeadura em casa de vegetação. RAMVI, Getúlio Vargas, v. 03, n. 05, jan./jul. 2016.

LI, T. S. Efeito da profundidade de semeadura e da textura do solo na emergência de plântulas e no formato radicular do ginseng americano. Coreano J Ginseng Sci. 1997; 21: 115-118.

LORENZI, H. Plantas daninhas do Brasil: terrestres, aquáticas, parasitas, tóxicas e medicinais. Nova Odessa, s.ed, 425 p., 1982.

LOVATO, A.; VIGGIANI, P. Laboratory germination and field emergence of some weed species. Rev. Agronomia, 8:108-12, 1974.

LÖVENSTEIN, H.; LANTINGA, E.A.; RABBINGE, R.; VAN KEULEN, H. Principles of Production Ecology. Wageningen: Syllabus of Chair Group Theorical Production Ecology, 121 p., 1995.

MACHADO, R. F. Desempenho de aveia-branca (Avena sativa L.) em função do vigor de sementes e população de plantas. Pelotas, 2002. 46p. Dissertação(Mestrado em Ciência e Tecnologia de Sementes) - Faculdade de Agronomia "Eliseu Maciel" Universidade Federal de Pelotas.

MAGALHÃES, C. M. Soja no Estado do Rio Grande do Sul. In: MIYASAKA, S.; MEDINA, J. C. A soja no Brasil. ITAL, Campinas: 1981. 
MAPA - Ministério da Agricultura, Alimentação e Assuntos Rurais de Ontário. Recomendações de produção para o ginseng: publicação 610. Ministério de Agricultura, Alimentação e Assuntos Rurais de Ontário; Toronto: 2009

NASCIMENTO, W. M.; DIAS, D. C. F. S.; SILVA, P. P. Qualidade fisiológica da semente e estabelecimento de plantas de hortaliças no campo. XI Curso sobre Tecnologia de Produção de Sementes de Hortaliças, Porto Alegre/RS, 2011.

NOGUEIRA, J. P. G.; CAMPOS, N. S.; CAMARGOS, R. V. C.; BOMTEMPO, G. L.; FERREIRA, S. C.; CECON, P. R.; MATSUO, E. Análise do diâmetro do hipocótilo em plantas de soja. Nucleus, v.16, n.1, abr. 2019.

PEREIRA, C. S.; SERAFIM, R. C.; ZANATTO, I. B.; FIORINI, I. V. Germinação e crescimento inicial de plantas de soja submetidas ao déficit hídrico. Global Science and Technology, Rio Verde, v.09, n.01, p.33 - 40, jan/abr. 2016.

POSTMA, J. A. et al. Dynamic root growth and architecture responses to limiting nutrient availability: linking physiological models and experimentation. Biotechnology Advances 32: 53-65, 2014.

REZENDE, A. V.; ANDRADE, L. P.; ALMEIDA G. B. S.; RABELO, C. H. S.; RABELO, F. H. S.; LANDGARF, P. R. C.; VILELA, H. H. Efeito da profundidade e da mistura de sementes ao adubo químico na emergência de plântulas de espécies forrageiras. Revista Agrarian, v. 5, n. 16, p. 115-122, 2012.

ROCHA, G. S. Causas de correlação entre caracteres e efeito de ambientes na predição do potencial de populações segregantes no melhoramento do feijoeiro. 68p. Tese (Doutorado em Genética e Melhoramento) - Universidade Federal de Viçosa, Viçosa - MG, 2012.

SANTANA, A. J. O.; NOGUEIRA, A. P. O.; NUNES, B. M.; BERNARDES, F. S.; PERDONÁ, F. G.; BORGES, B. A. M.; MARTIN, J. A.; SILVA, A. F. E. Análise Genética para Comprimento do Hipocótilo em Soja. Ciência \& Tecnologia: Fatec- JB, Jaboticabal, v.10, n.2. 2018.

SEAB - Secretária de Estado da Agricultura e do Abastecimento. Soja - Análise da Conjuntura Agropecuária. Outubro, 2012.

SILVA, F. C. S. et al., Identification of new descriptors for differentiation of soybean genotypes by Gower algorithm. African Journal of Agricultural Research, v.11, n.11, p. 961-966, 2016.

SOUZA, N. M.; NETO, P. H. W. Teste para indicador alternativo da profundidade de semeadura da soja. Eng. Agríc. Jaboticabal, v. 35, n. 1, p. 128-133, fevereiro de 2015. 
TREIN, C. R.; COGO, N. P.; LEVIEN, R. Métodos de preparo do solo na cultura do milho e ressemeadura do trevo, na rotação aveia + trevo/milho, após pastejo intensivo. Revista Brasileira de Ciência do Solo, Campinas, v.15, n.1, p.105-11, 1991. 


\title{
CAPÍTULO XX
}

\section{MECESSIDADES NUTRICIONAIS DA SOIA E USO DE RESÍDUOS ORGÂMICOS NA AGRICULTURA}

\section{DOI: 10.51859/amplla.mas481.1121-20}

\author{
Gabriel Brom Vilela ${ }^{1}$ \\ Lidiane Antunes Assis Carvalho ${ }^{1}$ \\ Eric Mateus Nascimento de Paula ${ }^{1}$ \\ Wilson Wagner Ribeiro Teixeira ${ }^{2}$
}

\begin{abstract}
${ }^{1}$ Docente do Curso Superior em Tecnologia do Agronegócio. Universidade Estadual de Goiás - UEG.
2 Doutor em Ciências do Solo pela Universidade Federal do Paraná - UFPR.
\end{abstract}

\section{RESUMO}

O plantio contínuo da soja (Glycine max (L) Merrill) tem sido relacionado com as deficiências nutricionais do solo das regiões do Cerrado Brasileiro. Desta forma, conhecer as necessidades nutricionais da soja em relação ao solo, torna-se imprescindível para o sucesso desta cultura. Além disso, tem crescido o movimento da sustentabilidade no campo, por meio da utilização da resíduos orgânicos nessa recuperação do solo. Sendo assim, o objetivo do presente trabalho é discorrer sobre as necessidades nutricionais da cultura da soja, bem como o uso de resíduos orgânicos, como a cama aviária de peru, para a reposição de nutrientes ao solo. Para tanto foi desenvolvida uma revisão de literatura nas bases de dados Google Acadêmico, SciELO e Periódicos Capes. As plantas necessitam de 17 elementos essenciais para o crescimento e desenvolvimento. Sob o ponto de vista nutricional podemos dividir os elementos essenciais em macro e micronutrientes, de acordo com a quantidade de nutriente requerida pela planta. Os resíduos gerados pelas aves são ricos em elementos minerais e podem ser utilizados na lavoura para aumento da fertilidade do solo e redução de fertilizantes minerais, que por sua vez constituem a maior parte do custo de produção das lavouras. Como possibilidade de resíduos orgânicos para recuperação do solo, a cama de peru demonstra resultados promissores, além de alcançar os benefícios sustentáveis.

Palavras-chave: Adubo orgânico. Cama aviária. Glycine max (L) Merrill. Solo. Sustentabilidade. 


\section{INTRODUÇÃO}

A soja se tornou a mais importante produto agrícola brasileiro. Atualmente, o Brasil só está atrás, no ranking, do Estados Unidos na produção de soja e sua a taxa de crescimento é duas vezes maior do que a taxa global. O aumento da produção de soja está sendo estimulada pela crescente demanda por ração animal na Europa, que importa quase $70 \%$ da produção brasileira exportação de soja (CAVALETT e ORTEGA, 2009).

A produção e processamento da soja são altamente dependentes de recursos não renováveis da economia, como combustíveis fósseis, bens, eletricidade, fertilizantes químicos, pesticidas, herbicidas e sementes híbridas. Os problemas ambientais e sociais relacionados com o atual modelo de produção de soja tem sido amplamente notado, tais como diminuição da fertilidade do solo, intoxicação de pessoas e vida selvagem por agroquímicos, expulsão de pequenos agricultores de suas terras, floresta destruição de novas áreas de cultivo, contaminação do solo e da água, solo perda por erosão, perdas de biodiversidade e contribuições para o global aquecimento (ORTEGA et al., 2005).

A soja é uma leguminosa valiosa porque fornece todos os aminoácidos essenciais para humanos; no entanto, é relativamente baixo em aminoácidos contendo enxofre, cisteína e metionina. É uma das poucas leguminosas que pode ser consumida como proteína completa. A soja é composta de aproximadamente $37-42 \%$ de proteína (O'KEEFE, 2015).

Contudo, os solos dos Cerrados brasileiro possuem uma certa deficiência de potássio (K) por serem altamente intemperizados, tal situação faz com que as reservas deste nutriente, nesses solos, não suportem cultivos sucessivos devido às grandes quantidades extraídas pela soja. Deste modo, a sua restituição no solo deve ser feita mediante a adubação (SERAFIM et al., 2012).

Resíduos orgânicos são fontes valiosas e importantes de nutrientes para plantas e condicionadores de solo. Agricultores há muito reconheceram a importância de repor nutrientes e matéria orgânica que podem ser esgotados durante o cultivo contínuo. Atualmente, há um interesse em "reciclagem de nutrientes", devido ao alto custo dos fertilizantes minerais e a crescente necessidade de métodos de descarte adequados para as grandes quantidades de resíduos orgânicos (ODLARE et al., 2013). 
Sendo assim, o presente trabalho tem por objetivo discorrer sobre as necessidades nutricionais da cultura da soja, bem como o uso de resíduos orgânicos, como a cama aviária de peru, para a reposição de nutrientes ao solo.

\section{MATERIAL E MÉTODOS}

Foi desenvolvida uma revisão bibliográfica em que foram consultadas a principais bases de dados, como Google Acadêmico, SciELO e Periódicos Capes. Em que foram empregados os descritores e seus respectivos sinônimos em inglês e espanhol: soja, necessidade nutricional, adubação e resíduos orgânicos. Deu-se preferência por artigos científicos em primeira escolha, e em segundo momento livros e boletins técnicos. Assim com os descritores, foram selecionados trabalhos acadêmicos em português, inglês e espanhol.

\section{REVISÃO BIBLIOGRÁFICA}

\subsection{DEMANDA NUTRICIONAL DA SOJA}

Na soja, a absorção de nutrientes é medida pelo acúmulo de nutriente na planta, e, é crescente até atingir o ponto de máximo acúmulo em R6. A partir daí, o acúmulo é decrescente, devido à translocação dos nutrientes para os grãos em formação (Cordeiro et al., 1979). Segundo Bohrer \& Hungria (1998), a soja é uma cultura que tem uma grande demanda de nutrientes, principalmente de $\mathrm{N}$, em condições de alta produtividade. Além do $\mathrm{N}, \mathrm{K}$ também é extraído em grande quantidade pela soja, seguidos do $\mathrm{Ca}, \mathrm{P}, \mathrm{Mg}$ e S. Para os micronutrientes, o Fe é o mais extraído seguido $\mathrm{Cl}, \mathrm{Mn}, \mathrm{B}, \mathrm{Zn}$ e Cu (Embrapa, 2001).

Nos grãos, a ordem de remoção, é bastante alterada. O P é o mais translocado, seguidos do $\mathrm{N}, \mathrm{K}, \mathrm{S}, \mathrm{Mg}$, Ca. Para os micronutrientes a ordem de remoção é $\mathrm{Zn}, \mathrm{Cl}, \mathrm{Cu}$, B e Fe. Para garantir que ocorra uma nutrição adequada em que proporciona níveis altos de produção, devem ser disponibilizados nutrientes em quantidades suficiente e equilibrados. A insuficiência ou desequilíbrio entre os nutrientes pode resultar numa absorção deficiente de alguns e excessiva de outros (Oliveira et al., 2007). 


\subsection{NUTRIENTES ESSENCIAIS PARA CULTURA DA SOJA}

As plantas necessitam de 17 elementos essenciais para o crescimento e desenvolvimento: carbono $(C)$, hidrogênio $(H)$, oxigênio $(O)$, nitrogênio $(N)$, fósforo $(P)$, potássio $(\mathrm{K})$, cálcio $(\mathrm{Ca})$, magnésio $(\mathrm{Mg})$, enxofre $(\mathrm{S})$, cloro $(\mathrm{Cl})$, boro $(\mathrm{B})$, ferro $(\mathrm{Fe})$, zinco $(\mathrm{Zn})$, manganês $(\mathrm{Mn})$, cobre $(\mathrm{Cu})$, níquel $(\mathrm{Ni})$ e molibdênio $(\mathrm{Mo})$. O cobalto (Co) é classificado como benéfico, no entanto ele tem uma grande importância no processo da FBN, pois é componente da vitamina B12 e cobamida (Sfredo et al., 1997).

Sob o ponto de vista nutricional podemos dividir os elementos essenciais em macro e micronutrientes, de acordo com a quantidade de nutriente requerida pela planta. Os macronutrientes ( $\mathrm{N}, \mathrm{P}, \mathrm{K}, \mathrm{Ca}, \mathrm{Mg}$ e $\mathrm{S}$ ) são requeridos em maiores quantidades pelas plantas em relação aos micronutrientes ( $\mathrm{Cl}, \mathrm{B}, \mathrm{Fe}, \mathrm{Zn}, \mathrm{Mn}, \mathrm{Cu}, \mathrm{Ni}$ e $\mathrm{Mo})$. Apesar da menor exigência pelas plantas os micronutrientes são importantes para crescimento e desenvolvimento da cultura da soja (Oliveira et al., 2007).

\section{2.\% MACRONUTRIENTES}

\subsection{1.\% NITROGÊNIO}

O $\mathrm{N}$ é considerado o nutriente mais abundante da atmosfera terrestre. Os teores de $\mathrm{N}$ no solo na forma mineral são pequenos, variando desde traços até $5 \mathrm{~g} \mathrm{~kg}^{-1}$ nas camadas superficiais dos solos, diminuindo com a profundidade. $\mathrm{O}$ teor de $\mathrm{N}$ depende também do tipo de solo, da temperatura e da pluviosidade. O N disponível no solo se encontra, principalmente na forma de $\mathrm{NO}_{3}{ }^{-}$e $\mathrm{NH}_{4}{ }^{+}$(Taiz e Zeiger, 2013).

A principal via de absorção de $\mathrm{N}$ na cultura da soja é pela fixação biológica do nitrogênio (FBN) com bactérias do gênero Bradyrhizobium. Além da FBN a soja pode absorver $\mathrm{N}$ - mineral na forma de $\mathrm{NO}_{3}{ }^{-} \mathrm{e} \mathrm{NH}_{4}{ }^{+}$(Amado et al., 2010).

As principais funções do $\mathrm{N}$ é síntese de clorofila e está envolvido no processo da fotossíntese (Novais et al., 2007). É constitui de enzimas, proteínas. O N é um componente essencial para o incremento de fitomassa das plantas (Gianello \& Giasson, 2004) é considerado o nutriente mais demandado para a obtenção de altas produtividades (Amado et al., 2010). 


\subsubsection{FÓSFORO}

No solo, o P pode ser encontrado em formar orgânicas e inorgânicas. O P de compostos orgânicos (Po) é encontrado na forma de fosfolipídios, ácidos nucleicos e fosfatos de inositol. O Po deve ser mineralizado antes de ser absorvido pelas plantas. $\mathrm{O}$ $\mathrm{P}$ de compostos inorgânicos ( $\mathrm{Pi}$ ) encontre-se sob várias formas, as quais depende do $\mathrm{pH}$ (Malavolta, 2006).

As principais vias de absorção de $\mathrm{P}$ do solo são $\mathrm{H}_{2} \mathrm{PO}_{4}{ }^{-}$e $\mathrm{HPO}_{4}{ }^{2-} . \mathrm{O} \mathrm{pH}$ do solo controla a disponibilidade para as plantas das formas iônicas do fosfato. O ânion monovalente $\mathrm{H}_{2} \mathrm{PO}_{4}{ }^{-}$tem sua disponibilidade aumentada em valores de $\mathrm{pH}$ abaixo de 7 , enquanto o ânion $\mathrm{HPO}_{4}{ }^{2-}$ tem sua disponibilidade aumentada em valores de $\mathrm{pH}$ acida de 7 (Sengik, 2003).

As principais funções do $P$ é transferência de energia como parte do trifosfato de adenosina (ATP), como componente de muitas proteínas, coenzimas, ácido nucleico e substratos metabólicos. Além disso, é responsável pelo desenvolvimento das raízes e de plântulas no início do seu desenvolvimento, na resistência às doenças, sendo importante para a colheita e qualidade das culturas (Malavolta, 2006).

\subsubsection{POTÁSSIO}

O K é encontrado no solo em minerais primários e intemperizados, bem como nas formas: trocável, não trocável e solúvel e água. Para nutrição das plantas, as formas disponíveis no solo são a trocável e o $\mathrm{K}$ em solução. A forma não trocável atua como uma reserva do nutriente no solo (Silva et al., 2008).

As principais funções do $K$ têm elevada contribuição para o potencial osmótico da planta. O processo de abertura e fechamento dos estômatos é regulado pela concentração de $\mathrm{K}$ nas células guarda. Além disso, é importante para a fotossíntese e respiração da planta, consequentemente pelo crescimento celular (Dechen \& Nachtigall, 2007).

\subsubsection{CÁLCIO}

O Ca é encontrado em calcita, gesso, conchas de ostras e corais. Os minerais primários de Ca mais importante são a anortita e os piroxênios. O Ca também está presenta também em apatitas. As principais formas de absorção de Ca são na forma de 
$\mathrm{Ca}^{2+}$. O Ca depois de absorvido é transportado no xilema e em parte no floema. Depois de transportado para as folhas, o Ca se torna imóvel na planta (Blankenau, 2007).

As principais funções do Ca são na estrutura da planta da planta, pois é um dos principais integrantes da parede celular. E possui funções de crescimento e desenvolvimento vegetal (Taiz \&. Zeiger, 2013).

\subsubsection{MAGNÉSIO}

O Mg encontra-se no solo nas formas: não trocável, trocável e na solução do solo. Na forma não trocável é encontrado principalmente em minerais primários e secundários, como a biotita, augita, horblenda, olivina, serpentina, clorita, montmorilonita, ilita, vermiculita, e nos carbonatos e minerais, como dolomita e Magnesita (Sampaio \& Almeida, 2009).

$\mathrm{O} \mathrm{Mg}$ é absorvido pelas plantas na forma de $\mathrm{Mg}^{2+}$. Por suas características, a absorção do $\mathrm{Mg}$ pode ser fortemente afetada pela disponibilidade de $\mathrm{K}^{+}, \mathrm{NH}_{4}{ }^{+}, \mathrm{Ca}^{2+} \mathrm{e}$ $\mathrm{Mn}^{2+}$ (Oliveira et al., 2007).

As principais funções do Mg são ativadoras de reações de enzimas. Dentre as reações das quais participa o $\mathrm{Mg}$, estão as de transferência de fosfato ou nucleotídeos, de grupos carboxílicos. O Mg tem papel estrutural sendo na formação da molécula de clorofila (Sfredo \& Borkert, 2004).

\subsubsection{ENXOFRE}

O S está nos solos nas formas inorgânicas e orgânicas. Na solução do solo, o S está presenta como íon sulfato (Nascimento \& Morelli, 1980). O S é absorvido pelas plantas na forma de $\mathrm{SO}_{4}{ }^{2-}$ depois e reduzido e incorporado a compostos orgânicos. $\mathrm{Na}$ reciclagem do S, este retorna ao solo na forma orgânica, onde se mineraliza por ação de microrganismos antes de ser utilizados pelas plantas superiores (Costa, 1980).

As principais funções do S são formação de aminoácidos, proteínas, clorofila e é um componente de vitaminas e de alguns hormônios de planta. Embora a quantidade de $S$ nas plantas seja de 3 a 5\% da quantidade encontrada de nitrogênio, esses nutrientes compartilham grande versatilidade em reações de oxidação-redução, atributo esse que os torna fundamentais no metabolismo das plantas, além do mais, o enxofre é constituinte de alguns aminoácidos e de várias coenzimas (Sengik, 2003). 


\subsubsection{MICRONUTRIENTES}

\subsubsection{BORO}

$\mathrm{Na}$ fase solida do solo, o B é encontrado nos minerais silicatados, adsorvido em argilominerais, na matéria orgânica e nos hidróxidos de Al e Fe. Diversos fatores influenciam a disponibilidade de B no solo entre eles: $\mathrm{pH}$ do solo, mineralização da $\mathrm{MO}$, textura do solo. É um elemento que apresenta um limite estreito entre o teor adequado e o nível tóxico nas plantas o que exige, portanto, uma adubação cautelosa (Faquin, 2005).

$\mathrm{O} B$ é absorvido como ácido bórico $\left(\mathrm{H}_{3} \mathrm{BO}_{3}\right)$ e, provavelmente, como ânion borato $\left(\mathrm{B}(\mathrm{OH})_{4}^{-}\right)$em valores de $\mathrm{pH}$ elevados, tanto por via radicular como via foliar. $\mathrm{O}$ mecanismo de contato de $B$ com as raízes é por meio do fluxo de massa, até que ocorra um equilíbrio entre concentrações do nutriente nas raízes e na solução. Em decorrência dessa absorção passiva, pode-se se verificar situações em que quantidades toxicas são absorvidas pelas plantas, quando o teor de B na solução é alto. O B, em geral, é considerado imóvel nas plantas (Novais et al., 2007).

As principais funções do B são a translocação de açucares e metabolismo de carboidratos. Além disso, desempenha papel importante no florescimento, crescimento do tubo polínico, nos processos de frutificação, no metabolismo do $\mathrm{N}$ e na atividade de hormônios (Novais et al., 2007).

\subsubsection{CLORO}

$\mathrm{O} \mathrm{Cl}$ é encontrado na natureza principalmente como ânion cloreto $\left(\mathrm{Cl}^{-}\right)$. Em solos próximos ao mar ou naqueles que recebem tratamentos com águas com excesso de sais, estes teores de $\mathrm{Cl}$ podem ser muitos superiores. $\mathrm{O} \mathrm{Cl}$ pode ter como origem a decomposição do material de origem, decomposição de restos orgânicos, contribuições pelas chuvas, contribuições pelas águas de irrigação, presença de fertilizantes e inseticidas. Encontra-se sempre em disponibilidade suficiente para as plantas (Novais et al., 2007). O Cl é absorvido pelas plantas na forma de $\mathrm{Cl}^{-}$, podendo ser absorvido pela raiz ou pela parte aérea. A principal função do $\mathrm{Cl}$ é liberação de $\mathrm{O} 2$ por cloroplastos isolados, no fotossistema II da fotossíntese (Novais et al., 2007). 


\subsubsection{MANGANÊS}

O Mn no solo é componente de óxidos, carbonatos, silicatos e sulfetos. Os óxidos e sulfetos de $\mathrm{Mn}$ são as principais formas encontradas com mais frequência nos solos, sendo comum à sua ocorrência em associação com o Fe. O Mn nos solos tem valências 2, 3 e 4. Na solução do solo e na forma trocável está principalmente como $\mathrm{Mn}^{2+}$, enquanto $\circ \mathrm{Mn}^{3+}$ e $\mathrm{Mn}^{4+}$ formam óxidos praticamente insolúveis. A presença de $\mathrm{Mn}$ disponível $\left(\mathrm{Mn}^{2+}\right)$ depende tanto do $\mathrm{pH}$ como do potencial redox do solo (Novais et al., 2007).

As principais funções do $\mathrm{Mn}$ estão relacionadas com a ativação de enzimas. Participa no funcionamento do fotossistema II da fotossíntese, sendo responsável pela fotólise da água. O Mn pode atuar no balanço iônico como um contra-íon, reagindo com grupos aniônicos. Grande número de enzimas são atividades pelo $\mathrm{Mn}$, especialmente aquelas envolvidas em metabolismos intermediários (Novais et al., 2007).

\subsubsection{ZINCO}

No solo, o Zn apresenta-se em três formas principais, responsáveis pelo seu suprimento as plantas: (1) Zn na solução do solo, (2) Zn trocável, adsorvidos pelos coloides, (3) Zn fixado. O Zn fixado pode atingir valores importantes, já que o Zn é capaz de substituir alguns elementos da estrutura da argila (Al, Mn e Fe), permanecendo indisponível para a planta. O conteúdo de $\mathrm{Zn}$ pode ser afetado pelo $\mathrm{pH}$ do solo, de forma que o $\mathrm{Zn}$ se encontra mais disponível em solos com pH baixo (solos ácidos) que em solos com $\mathrm{pH}$ altos (solos alcalinos), apresentando sua mínima disponibilidade em $\mathrm{pH}$ acima de 7 (Novais et al., 2007).

O Zn é absorvido pelas plantas na forma de $\mathrm{Zn}^{2+}$ tanto por via radicular como foliar. A mobilidade de redistribuição do Zn na planta é muito pequena, de forma que se encontra concentrado em grande parte na raiz, enquanto, nos frutos, seu conteúdo é sempre menor (Novais et al., 2007).

As principais funções do Zn na planta são como constituinte estrutura de enzimas como desidrogenases, como álcool, lactado, malato e glutamato-desidrogenase, superóxido-dmismutase e anidrase carbônica. Participa na ativação enzimática da trifosfato-desidrogenase, enzima essencial na glicólise, bem como nos processos de 
respiração e fermentação. Além disse sua falta afeta a síntese de auxinas, hormônios vegetais envolvidos no crescimento (Novais et al., 2007).

\subsubsection{FERRO}

No solo, o Fe apresenta-se na forma di $\left(\mathrm{Fe}^{2+}\right)$ e trivalente $\left(\mathrm{Fe}^{3+}\right)$, dependendo do estado de oxirredução do sistema. Muitos solos cultivados apresentam baixo teor de Fe, tanto na solução do solo como adsorvido em forma trocável.O Fe é absorvido do solo como $\mathrm{Fe}^{2+}, \mathrm{Fe}^{3+}$ e como Fe-quelatado, sendo a sua absorção pelas plantas metabolicamente controladas (Novais et al., 2007).

As principais funções do Fe á a ativação de enzimas, atuando como grupo prostético. Participa em reações fundamentais de óxidorredução, tanto em hemoproteínas como em proteínas não-hémicas com ligação Fe-S como ferrosoxina e enzimas redutase, nitrogenase e sulfato - redutase. O Fe catalisa a biossíntese da clorofila, já que faz parte constituinte de enzimas responsáveis pela sua formação (Novais et al., 2007).

\subsubsection{COBRE}

$\mathrm{O} \mathrm{Cu}$ no solo encontra predominantemente como constituinte das estruturas cristalinas dos minerais primários e secundários. Considera-se que a maior parte do $\mathrm{Cu}$ em solução esteja formando complexos solúveis com ácidos orgânicos, tais como o cítrico e oxálico. O Cu é absorvido do solo como $\mathrm{Cu}^{2+}$ e $\mathrm{Cu}$-quelatado, sendo pequeno o seu teor nos tecidos da planta. A absorção do Cu pelas plantas ocorre via processo ativo e existem evidências de que este nutriente iniba fortemente a absorção de $\mathrm{Zn}$ (Novais et al., 2007).

As principais funções do $\mathrm{Cu}$ estão ligadas a plastocianina e alguma fração proteica ocorrendo também, acúmulo do nutriente em órgãos reprodutivos das plantas, contudo, existem variações entre espécie. O Cu é constituinte de certas enzimas, incluindo a oxidase do ácido ascórbico (vitamina C), citocromo-oxidase e a plastocianina, que se encontram nos cloroplastos. Além disto, o $\mathrm{Cu}$ influencia a fixação do $\mathrm{N}_{2}$ atmosférico pelas leguminosas, e é essencial no balanço de nutrientes que regulam a transpiração na planta (Novais et al., 2007). 


\subsubsection{MOLIBDÊNIO}

O Mo no solo está sob três formas: na solução do solo como íons molibdato, $\mathrm{MoO}_{4}{ }^{2-}$ ou $\mathrm{HMoO}_{4}^{-}$, absorvidos em formas lábil e não-lábil, como constituintes dos minerais do solo e da matéria orgânica. O Mo é absorvido pelas plantas na forma de ânion $\mathrm{MoO}_{4}{ }^{2-}$ e sua absorção é proporcional a sua concentração na solução do solo, que pode ser reduzida pelo efeito competitivo do $\mathrm{SO}_{4}{ }^{2-}$. Embora não existam evidências diretas, é aceito que o Mo seja absorvido metabolicamente (Novais et al., 2007).

Grande parte do Mo encontra-se na enzima nitrato redutase das raízes e colmos das plantas superiores, a qual catalisa a redução do íon $\mathrm{NO}_{3}{ }^{-}$a $\mathrm{NO}_{2}{ }^{-}$. A nitrato redutase das plantas superiores é encontrada como uma molibdoflavoproteina solúvel, que, nas folhas pode estar associada a atividade dos cloroplastos. O Mo também participa das enzimas sulfito-redutase e xantin-oxidase. A deficiência de Mo repercute negativamente na formação de ácido ascórbico, no conteúdo de clorofila e na atividade respiratória (Novais et al., 2007).

\subsection{UTILIZAÇÃO DE RESIDUO ORGÂNICO DA AGRICULTURA}

Na década de 80, em decorrência do acúmulo de resíduos derivados da atividade humana no meio urbano e rural, foi evidenciada a necessidade de dar destino adequado aos resíduos urbanos e industriais, principalmente o lodo de esgoto, o lixo urbano e os resíduos de curtume devido aos problemas gerados pela crescente população e pelo seu acúmulo no ambiente (Class \& Maia, 1994).

Quando esses dejetos são utilizados racionalmente, tornam-se excelente alternativa para adubação de forragens, gramíneas e leguminosas. Ou seja, podem ser alternativa para a melhoria da fertilidade do solo, desde que, sob manejo criterioso e com embasamento científico (Menezes et al., 2007). A reutilização destes produtos possui vantagens como redução no custo das adubações químicas, além da melhoria da qualidade do solo e redução da poluição (Pinto et al., 2012).

A cama de aviário é produzida em larga escala no sudoeste goiano e o seu destino muitas vezes é inadequado podendo assim causar problemas de contaminação ambiental. Sendo assim, o aproveitamento desse resíduo pode reduzir a contaminação do solo e fontes de água, além do seu retorno econômico voltado ao aumento de produção relacionado com a sua junção a atividades agropecuárias (Lima et al., 2011). 
Os resíduos gerados pelas aves são ricos em elementos minerais e podem ser utilizados na lavoura para aumento da fertilidade do solo e redução de fertilizantes minerais, que por sua vez constituem a maior parte do custo de produção das lavouras (Richetti, 2011). O uso de resíduos orgânicos proporciona maior renda e sustentabilidade da atividade agrícola em comparação à aplicação isolada de fertilizantes minerais (Bhattacharyya et al., 2010). Assim, a utilização de fontes alternativas de adubos é estratégica para países como o Brasil, dependentes de matériaprima importada para fabricação de fertilizantes minerais (Guarçoni \& Fanton, 2011).

As camas de aves são uma excelente fonte de nutrientes e quando manejadas adequadamente, podem suprir, parcial ou totalmente, o fertilizante químico na produção de grãos. Além do benefício como fonte de nutrientes, seu uso adiciona matéria orgânica que melhora os atributos físicos do solo, aumenta a capacidade de retenção de água, reduz a erosão, melhora a aeração proporcionando um ambiente mais adequado para o desenvolvimento da microbiota do solo, melhorando o ambiente radicular e estimulando o desenvolvimento das plantas (Menezes et al., 2004). Além disso, a adubação com dejeto fornecer elementos essenciais às plantas, como N, K, Fe, $\mathrm{Zn}, \mathrm{Mn}$ e $\mathrm{Cu}$.

\subsection{CAMA DE PERU}

Pode observar que o setor avícola é formado por diversas aves, podendo citar principalmente frangos e perus, além de aves menos comuns no processo e consumo, como avestruz, codornas, patos e galinhas d'angola. No decorrer dos últimos anos, a avicultura brasileira passou por importantes transformações, tornando o Brasil um dos maiores produtores e exportadores de aves do mundo (Revista Brasil Comex, 2011).

Nas regiões de grande concentração de produtores, há a geração de excesso de camas de aviário, que necessitam de uma destinação final adequada (Padilha et al., 2006). A cama de aviário é constituída por um material com a função, entre outras, de absorver umidade. Os materiais mais comuns são: casca de arroz, maravalha, sabugo de milho, capins e serragens. Todos irão determinar uma característica diferente à cama a ser manejada. Ela também contém fezes, urina, restos de ração, penas e outros materiais em pequena quantidade (Avila et al., 2007). Além disso, cabe ressaltar que as 
características das camas de aviário também serão determinadas em função do tipo de ave que ali se encontra.

A cama de peru é um resíduo com características bastante parecidas com a cama de frango, mas normalmente apresenta grandes teores de fósforo em sua composição. Com a expansão de unidades produtoras de perus no Brasil, hoje nas regiões produtoras encontra-se um grande volume deste resíduo (Lana et al., 2009).

Segundo Alves (2007), a cama de peru um composto orgânico libera gradativamente macro e micronutrientes para a solução do solo. A liberação se dá à medida que o material orgânico vai sendo mineralizado, e a quantidade liberada depende do grau de mineralização do composto, da matéria-prima que deu origem ao mesmo e da quantidade aplicada de composto.

Segundo Menezes et al. (2003), a utilização da cama de aves como insumo agrícola é recente. Sabe-se que os dejetos das aves, é uma excelente fonte de nutrientes, especialmente $\mathrm{N}$, e quando manejados adequadamente, podem suprir, parcial ou totalmente, os fertilizantes químicos.

Tecnicamente, a maneira adequada de se utilizar cama de peru como insumo agrícola é conhecer a composição química antes da aplicação. Com isso, muitas vezes, se torna difícil a execução, pode-se lançar mão de tabelas contendo os teores médios de nutrientes da amostra representativa do material disponível. A composição varia de acordo com o tipo de resíduo utilizado como cama, com o número de lotes que foram passados sobre o material, bem como com o tipo da criação, como por exemplo, frangos de corte ou galinhas de postura e com as condições de armazenamento após a sua retirada dos galpões de criação. Desta forma, o aproveitamento da cama de peru como fertilizante não deve ser generalizado, requerendo a adoção de análises químicas da cama de peru disponível para determinação de sua composição e possibilidade de um melhor aproveitamento dos nutrientes nela contidos (Menezes et al., 2003).

Com a chegada de empresas como a Perdigão e frigoríficos avícolas no Estado de Goiás e mais especificamente na região do Sudoeste Goiano nos últimos anos, houve também a preocupação com os dejetos que seriam gerados pela produção das aves. A cama de Peru pode ser reutilizada como adubo orgânico na adubação de lavouras e pastagens. Como o custo para adubação com a cama é inferior do que com adubos 
químicos, ela passou a ser utilizada para a recuperação de solos degradados com isso aumenta a eficiência produtiva na agropecuária, além de acarretar benefícios para propriedades químicas e físicas do solo, a médio e longo prazo (Ribeiro, 2009).

\section{CONSIDERAÇÕES FINAIS}

Os resultados alcançados para a produção agrícola de soja no Brasil indicam grande uso de maior quantidade de recursos. Portanto, qualquer melhoria na gestão desta fase resultará em uma melhoria de toda a cadeia da soja. Neste contexto, a adoção de sistemas de produção agrícola mais sustentáveis torna-se fundamental para a sustentabilidade de longo prazo da soja cadeia. Modelos de produção orgânica e integração de outros processos tecnologias devem ser introduzidas a fim de criar uma cadeia mais sustentável da soja. Esses procedimentos diminuem a dependência de recursos externos não renováveis, aumentando reciclagem e diminuindo o uso de insumos químicos. Como possibilidade de resíduos orgânicos para recuperação do solo, a cama de peru demonstra resultados promissores, além de alcançar os benefícios sustentáveis.

\section{REFERÊNCIAS}

ALVES, W. L. Efeito do composto orgânico de lixo na fertilidade do solo e na disponibilidade de nutrientes e de metais pesados para o sorgo. $1997.75 \mathrm{p}$. Dissertação (Mestrado em produção vegetal) - Faculdade de Ciências Agrárias e Veterinária, Universidade Estadual Paulista. AZAMBUJA, A. V. Forragicultura Plantas Forrageiras, 2007.

AMADO, T. J. C.; SCHLEINDWEIN, J. A.; FIORIN, J. E. Manejo do solo visando à obtenção de elevados rendimentos de soja sob sistema plantio direto. In: Thomas AL \& Costa JA (Eds.) Soja - Manejo para alta produtividade de grãos. Porto Alegre, UFRGS, p.35-97, 2010.

AVILA, V. S. de, ABREU, V. M. N., FIGUEIREDO, E. A. P. de, BRUM, P. A. R. de, OLIVEIRA, U. de. Valor Agronômico da Cama de Frangos após Reutilização por Vários Lotes Consecutivos: Comunicado Técnico 466. Concórdia: EMBRAPA-CNPSA, 2007.

BHATTACHARYYA, R. PANDEY, S. C.; CHANDRA, S.; KUNDU, S.; SAHA, S.; MINA, B. L.; SRIVASTVA, A. K.; GUPTA, $H$. Fertilization effects on yield sustainability and soil properties under irrigated wheat-soybean rotation of an Indian Himalayan upper valley. Nutrient Cycling in Agroecosystems, v. 86, n. 2, p. 255-268, 2010. 
BLANKENAU, K. Cálcio nos solos e nas plantas. Informações Agronômicas, Piracicaba, n. 117, p. 17-19, mar. 2007.

BOHRER, T. R. J.; HUNGRIA, M. Avaliação de cultivares de soja quanto à fixação biológica do nitrogênio. Pesquisa Agropecuária Brasileira, Brasília, v. 33, n. 6, p. 937-953, jun. 1998.

CAVALETT, O., \& ORTEGA, E. Emergy, nutrients balance, and economic assessment of soybean production and industrialization in Brazil. Journal of Cleaner Production, 17, 762-771, 2009.

CLASS, I. C.; MAIA, R. M. Manual básico de resíduos industriais de curtume. Porto Alegre: Senai-RS, 664p., 1994.

CORDEIRO, D. S.; SFREDO, G. J.; BORKERT, C. M.; SARRUGE, J. R.; PALHANO, J. B.; CAMPO, R. J. Calagem, adubação e nutrição mineral. In: EMBRAPA. Centro Nacional de Pesquisa de Soja. Ecologia, manejo e adubação da soja. Londrina, p.19-49, 1979.

COSTA, C. A. S. Mineralização do S orgânico e adsorção de sulfato em solos. $65 f$. Dissertação (Mestrado em Ciências do Solo) - Programa de Pósgraduação em Ciência do Solo, Universidade Federal do Rio Grande do Sul, 1980.

DECHEN, A. R.; NACHTIGALL, G. R. Elementos requeridos à nutrição de plantas. In: NOVAIS, R. F. ALVAREZ, V. V. H.; BARROS, N. F.; FONTES, R. L. F.; CANTARUTTI, R. B.; NEVES, J. C. L. (Ed.) Fertilidade do solo. Viçosa: SBCS, 1017p., 2007.

EMBRAPA. Centro Nacional de Pesquisa de Soja. Tecnologia de produção de soja Região Central do Brasil - 2001/2002. 267 p. Londrina: Embrapa Soja, 2001.

FAQUIN, V. Nutrição mineral de plantas. Fundação de Apoio ao Ensino, Pesquisa e Extensão - FAEPE. Universidade Federal de Lavras - UFLA. Lavras, 2005.

GIANELLO, C.; GIASSON, E. Fatores que afetam o rendimento das culturas e sistemas de cultivo. In: Bissani C. A.; Gianello C, Tedesco M. J \& Camargo FAO (Eds.) Fertilidade dos solos e manejo da adubação de culturas. Porto Alegre, UFRGS, p.21-32, 2004.

GUARÇONI M., A.; FANTON, C. J. Resíduo de beneficiamento do granito como fertilizante alternativo na cultura do café. Revista Ciência Agronômica, v. 42, n. 1, 2011.

LANA, R. M. Q.; SILVA, A. A.; LANA, A. M. Q.; ASSIS, D. F. Atributos químicos do solo após adubação com cama de peru e fontes minerais. Sigera. I Simpósio Internacional sobre Gerenciamento de Resíduos de Animais. Uso dos Resíduos da Produção Animal como Fertilizante. Florianópolis, SC, 2009. 
LIMA, L. M.; OLIVEIRA, M. C.; MENEZES, J. F. S. Desenvolvimento inicial de plantas de soja supridas com doses de cama de aviário. In: XV Encontro Latino Americano de Iniciação Científica e XI Encontro Latino Americano de Pós-Graduação, 2011, São José dos Campos. As Contribuições da Ciência para a Sustentabilidade do Planeta, 2011.

MALAVOlTA, E. Manual de Nutrição Mineral de Plantas. 1ed. São Paulo: Editora Agronômica Ceres, 638 p., 2006.

MENEZES, J. F. S.; ALVARENGA, R. C.; SILVA, G. P.; KONZEN, E. A.; PIMENTA, F. F. Cama de frango na agricultura: perspectivas e viabilidade técnica e econômica. Boletim técnico, n. 3, 28p. 2004.

MENEZES, J. F. S.; ANDRADE, C. de L. T.; ALVARENGA, R. C.; KONZEN, E. A.; PIMENTA, F. F. Cama de frango na agricultura: perspectivas e viabilidade técnico e econômica. Boletim técnico, n.3. Rio Verde: FESURV, 28 p., 2003.

MENEZES, J. F. S.; PRONER, S. C. P.; BENITES, V. de M.; SILVA, G. P.; KONZEN, E. A.; DUTRA, R. A. Estimativa da composição química de dejetos líquidos de suínos da região de Rio Verde-GO em função da densidade. Boletim Técnico/ FESURVUniversidade de Rio Verde. Ano IV $n^{\circ} 5$ (novembro- 2007) Rio Verde, GO. Fesurv, p. 15-16, 2007.

NASCIMENTO, J. A. L.; MORELLI, M. Enxofre em solos do Rio Grande do Sul. I. Formas no solo. Revista Brasileira de Ciência do Solo, Campinas, v.4, p.131-135, 1980.

NOVAIS, R. F.; ALVAREZ, V. V. H.; BARROS, N. F.; FONTES, R. L. F.; CANTARUTTI, R. B.; NEVES, J. C. L. Fertilidade do Solo. Viçosa, MG: Sociedade Brasileira de Ciência do Solo, 1017p., 2007.

ODLARE, M., PELL, M., ARTHURSON, J. V., ABUBAKER, J., \& NEHRENHEIM, E. Combined mineral $\mathrm{N}$ and organic waste fertilization - effects on crop growth and soil properties. The Journal of Agricultural Science, 152(01), 134-145, 2013.

OLIVEIRA, F. A.; SFREDO, G. J.; CASTRO, C. de; KLEPKER, D. Fertilidade do solo e nutrição da soja. Circular técnica 50 - Embrapa. Londrina, PR. Setembro, 8p., 2007.

O'KEEFE, S.; BIANCHI, L.; SHARMAN, J. SOYBEAN NUTRITION. SM J Nutr Metab. 2015;1(2):1006.

ORTEGA, E.; CAVALETT, O.; BONIFACIO, R.; WATANABE, M. Brazilian soybean production: emergy analysis with an expanded scope. Bulletin of Science, Technology \& Society 2005;25(4):323-34. 
PADILHA, A. C. M., SILVA, T. N., SAMPAIO, A. Desafios de adequação à questão ambiental no abate de frangos: o caso da perdigão agroindustrial - unidade industrial de Serafina Corrêa - RS. Teoria e Evidência Econômica, v. 14, p. 109-125, 2006.

PINTO, F. A.; SANTOS, F. L.; TERRA, F. D.; RIBEIRO, D. O.; SOUSA, R. R. J. SOUZA, E. D.; CARNEIRO, M. A.C.; PAULINO, H. B. Atributos de solo sob pastejo rotacionado em função da aplicação de cama de peru. Pesquisa Agropecuária Tropical, Goiânia, v. 42, n. 3, p. 254-262, 2012.

REVISTA BRASIL COMEX. "Exportação de frango está perto de estabelecer novo recorde". Disponível em: <http://www.brasilcomex.net/integra.asp?cd=4582> Acesso em 25/08/2015.

RIBEIRO, D. O. Efeitos da adição de diferentes doses de cama de peru nas propriedades químicas de um neossolo quartzarênico. 40 f. Monografia (Bacharel em Agronomia) - Faculdades Integradas de Mineiros, 2009.

RICHETTI, A. Viabilidade econômica da cultura da soja na safra 2011/2012, em Mato Grosso do sul. Comunicado Técnico, 168. Embrapa, Dourados, 2011.

SAMPAIO, J. A.; ALEMIDA, S. L. M. Calcário e Dolomito. In: Adão Benvindo da Luz e Fernando Freitas Lins. (Org.). Rochas \& Minerais Industriais. 2ed.Rio de Janeiro: CETEM, v. 1, p. 363-388, 2009.

SENGIK, E. Os macronutrientes e os micronutrientes das plantas. 2003. Disponível em: <http://www.nupel.uem.br/nutrientes-2003.pdf>. Acesso em: 08 Agosto 2016.

SERAFIM, M. E. et al. Umidade do solo e doses de potássio na cultura da soja. Revista Ciência Agronômica [online]. 2012, v. 43, n. 2 [Acessado 30 Maio 2021] , pp. 222227.

SFREDO, G. J.; BORKERT, C. M.; LANTMANN, A. F. Molibidênio e cobalto na cultura da soja. Londrina. EMBRAPA-CNPSo, Circular Técnica 16, 1997. 18p.

SFREDO, G. J.; BORKERT, C. M . Deficiências e toxicidades de nutrientes em plantas de Soja: descrição dos sintomas e ilustração com fotos. 1. ed. Londrina, PR: Embrapa Soja. Documentos/Embrapa Soja, n.231, v. 1., 22p, 2004.

SILVA, V. A.; MARCHI, G.; GUILHERME, L. R. G.; LIMA, J. M.; NOGUEIRA, F. GUIMARÃES, P. T. G. Kinetics of $K$ release from soils of Brazilian coffee regions: effect of organic acids. Revista Brasileira de Ciência do Solo, v. 32, p. 533-540, 2008.

TAIZ, L., ZEIGER, E. Fisiologia Vegetal. 5ed, Artmed, Porto Alegre, Brasil. 918p., 2013. 


\title{
CAPÍTULO XXI
}

\section{USO DA CAMA AVIÁRIA COMO ALITERNATIVA DE FERTIIITANIE ORCÂNICO NA CULTURA DA SOJA}

\section{DOI: 10.51859/amplla.mas481.1121-21}

\author{
Gabriel Brom Vilela ${ }^{1}$ \\ Manuel Rodriguez Carballal ${ }^{2}$ \\ Eric Mateus Nascimento de Paula 1,3 \\ Wilson Wagner Ribeiro Teixeira ${ }^{4}$
}

\footnotetext{
${ }^{1}$ Docente do Curso Superior em Tecnologia do Agronegócio. Universidade Estadual de Goiás - UEG.

2 Docente do Curso de Agronomia. Centro Universitário de Mineiros - UNIFIMES.

${ }^{3}$ Docente do Curso de Medicina Veterinária. Centro Universitário de Mineiros - UNIFIMES.

${ }^{4}$ Doutor em Ciências do Solo pela Universidade Federal do Paraná - UFPR.
}

\section{RESUMO}

A soja (Glycine max [L.] Merrill) é a oleaginosa mais cultivada do mundo, devido ao seu grande valor proteico e ao seu interesse econômico. Porém, sua produtividade é influenciada pela fertilidade do solo. Ao longo dos últimos anos, o preço dos fertilizantes minerais tem aumentado, onerando ainda mais a produção dessa commoditie. 0 emprego de materiais orgânicos, tais como os restos de cultura, os resíduos industriais e o esterco animal, vem despertando cada vez mais o interesse dos agricultores. Por melhora a produtividades devido ao aumento da fertilidade do solo, em suas características físicas, químicas e biológicas do solo. A região do Sudoeste Goiano abriga muitos frigoríficos de aves, gerando grande quantidade de resíduos que podem ser utilizados na adubação do solo, com um menor custo. 0 presente trabalho teve como objetivo avaliar a composição química do uso da cama de peru na cultura da soja. Para isso foi realizado uma pesquisa em artigos científicos, juntamente com uma análise da cama de peru na região sudoeste goiano e posteriormente, a comparação entre os demais estercos. Verificou-se que a cama de peru apresentou teores e proporções adequadas de nutrientes podendo ser opção de fertilizante na cultura da soja.

Palavras-chave: Adubação. Esterco. Peru.

\section{INTRODUÇÃO}

A soja (Glycine max [L.] Merrill) é a mais importante oleaginosa cultivada no mundo e uma das principais commodities agrícolas do Brasil, com produção de mais de 95 milhões de toneladas na safra 2015/2016, e produtividade média de $2870 \mathrm{~kg} \mathrm{ha}^{-1}$ (CONAB, 2016). A maioria dos estados brasileiros produz soja, com destaque para cinco 
estados (Mato Grosso, Mato Grosso do Sul, Paraná, Rio Grade do Sul e Goiás) que juntos, somam em torno de $80,4 \%$ da produção nacional (IBGE, 2016).

A obtenção de altas produtividades é o resultado de uma complexa interação entre os fatores climáticos, o solo e a planta (Thomas \& Costa, 2010). Entretanto, o manejo nutricional da cultura da soja é um dos principais fatores limitantes para o incremento de produtividade, principalmente em solos tropicais com predomínio de óxidos de ferro e alumínio, baixa fertilidade e alto teor de alumínio (Oliveira et al., 2007).

Nas últimas décadas com o aumento do custo dos fertilizantes minerais e a dependência da importação de fertilizantes é necessário alternativas de adubação. Os fertilizantes orgânicos são uma das opções principalmente em regiões com alta produção de aves e suínos e pelo seu valor em relação ao fertilizante mineral. Além disso, a utilização de esterco orgânico permite o correto descarte deste resíduo evitando impactos ambientais (Cassol et al., 2011).

Alguns trabalhos, principalmente no milho, trigo, soja, tem demonstrado a viabilidade da utilização de esterco de frango como fertilizantes. No entanto, são escassos os trabalhos que avaliaram a viabilidade técnica da utilização da cama de peru na cultura da soja. Além disso, as práticas de adubação química mineral e orgânica apresentam grandes diferenças, as quais devem ser reconhecidas, a fim de melhor recomendá-las.

Neste sentido, este trabalho tem importância principalmente pela carência de estudo com cama de peru e pela disponibilidade deste resíduo agrícola e seu potencial de utilização no município de Mineiros/GO.

\section{MATERIAL E MÉTODOS}

O trabalho foi dividido em três etapas. Primeira etapa constitui-se de pesquisa em artigos científicos, tese e dissertação sobre os teores de macro e micronutrientes no solo na planta e sua influência nos parâmetros fisiológicos, nutricionais, bioquímicos e produtivos da cultura da soja. Segunda etapa, análise química de esterco de peru, conforme metodologia laboratorial e comparação dos resultados com os valores de referências na literatura. Terceira etapa, discussão dos teores de nutrientes encontrados no esterco e comparação com quatro fontes animais distintos. 


\section{RESULTADOS E DISCUSSÃO}

Conforme Tabela 1 , os resultados demonstram uma grande variação na concentração de nutrientes no esterco de peru, sendo provável que essas diferenças estejam relacionadas a idade do animal, concentração de nutrientes nas rações, a região e o tempo de armazenamento.

Tabela 1. Teores de macro em esterco de peru de diferentes origens.

\begin{tabular}{cccc}
\hline Nutrientes & Pinto et al.,2012 & Goulart et al., 2015 & Presente trabalho \\
\hline$N$ & 32 & - & \\
$N$ & 35 & 16 & 37 \\
$\mathrm{P}_{2} \mathrm{O}_{5}$ & 25 & 14 & 45 \\
$\mathrm{~K}_{2} \mathrm{O}$ & 40 & 6,6 & 38,5 \\
$\mathrm{Ca}$ & 9 & 2,7 & - \\
$\mathrm{Mg}$ & \multicolumn{2}{c}{ Fonte: Autoria própria. }
\end{tabular}

Um dos benefícios da cama de peru, por ser um adubo orgânico rico em nutrientes, é que a sua aplicação tem sido associada às melhorias nos atributos químicos, físicos e biológicos do solo, elevando o $\mathrm{pH}$ do solo e aumentando a sua fertilidade, principalmente quando são aplicadas quantidades elevadas destes resíduos (Pinto et al., 2012).

O conhecimento das características químicas do esterco fornece subsídios para recomendação de adubação da cultura da soja de maneira equilibrada. E o acompanhamento da dieta que os animais estão submetidos também pode ser a resposta para a variação entre os teores de macronutrientes obtidos pelos diferentes autores.

$\mathrm{Na}$ Tabela 2, na qual se compara os teores de macro e micronutrientes em esterco de diferentes animais, os resultados confirmam as diferentes fontes de estercos possuem características próprias, dependendo do tipo de animal e mesmo animais oriundos da mesma espécie, o animal se diferencia conforme a idade, alimentação e o seu manejo, variando assim as quantidades dos nutrientes. 
Tabela 2. Teores de macro e micronutrientes em esterco de galinha, bovino, suíno e peru de diferentes origens

\begin{tabular}{ccccc}
\hline Nutrientes & Esterco Galinha & Esterco Bovino & $\begin{array}{c}\text { Esterco Suíno } \\
\text { (Lourenzi et al., } \\
\text { (Rós et al., 2013) }\end{array}$ & $\begin{array}{c}\text { Esterco Peru } \\
\text { (Ribeiro et al., }\end{array}$ \\
\hline $\mathrm{N}$ & 23,2 & (Martins et al., 2015) & 2015) \\
\hline $\mathrm{P}_{2} \mathrm{O}_{5}$ & 81 & 10,6 & 11,9 & 45 \\
$\mathrm{~K} \mathrm{~K}_{2}$ & 36 & 8,2 & 16,6 & 36,2 \\
$\mathrm{Ca}$ & 135 & 17,1 & 7,8 & 37,8 \\
$\mathrm{Mg}$ & 9 & 8,7 & 9 & - \\
$\mathrm{Zn}$ & - & 5,4 & 2,7 & - \\
$\mathrm{Cu}$ & - & - & 270 & - \\
$\mathrm{Fe}$ & - & 74,83 & 230 & - \\
$\mathrm{Mn}$ & - & 42,72 & - & - \\
\hline
\end{tabular}

Fonte: Autoria própria.

Comparando os teores de nutrientes do esterco de diferenças fontes é evidente que a cama de peru possui teores de nutrientes superiores às demais fontes, exceto a cama de galinha. No entanto, cabe salientar que a proporção entre os teores de nutrientes contidos nos dejetos orgânicos animais é relativamente fixa e de difícil controle, o que exige atenção especial na adubação com estes materiais, para se evitar o risco de serem adicionados nutrientes fora do balanço adequado à necessidade das culturas, nos diferentes tipos de solos (CQFS-RS/SC, 2004). Além disso, alguns nutrientes contidos nos adubos orgânicos podem estar na fração sólida do esterco, como compostos orgânicos e só podem ser absorvidos, quando ocorrer processo de mineralização microbiana.

Os maiores teores de $\mathrm{N}$ foram encontrados no esterco de peru, seguido do esterco de galinha. Esses resultados estão ligados à dieta que esses animais recebem. Visto que o peru tem uma dieta rica em farelo de soja e segundo Rostagno et al. (2005), possui $45 \%$ de proteína bruta (PB), enquanto o milho grão possui apenas $8 \%$. E a proteína bruta nada mais é que a quantificação de nitrogênio, multiplicado por um fator de correção.

Para a ração das galinhas, há variação entre a fase da ração, se é inicial, de crescimento ou terminação. Por isso sua formulação é variada. Uma ração de crescimento possui $63 \%$ de milho grão, $27 \%$ de farelo de soja (Figueiredo et al., 2007). 
Já para a ração dos suínos, segundo Favero (2003), a porcentagem de PB varia entre 13 e 15\%, dependendo da fase da ração, por isso menores valores para nitrogênio. Sakamoura (2007) evidencia os maiores valores de matéria seca, proteína bruta, fibra bruta, matéria mineral no farelo de soja, em relação ao milho e ao sorgo. Já para os bovinos, a média de PB está entre 12-18\% (Embrapa, 1993). Ou seja, conforme citados pelos diferentes autores, a ração que o animal recebe e a sua composição está diretamente relacionada aos macros e micronutrientes presentes no esterco utilizado.

$\mathrm{Na}$ adubação com cama de aves, o resíduo desse adubo pode permanecer por mais de um ano, ou seja, sempre estar avaliando esses valores antes de incorporá-lo ao solo, evitando assim, que o solo já contenha altos valores desses nutrientes e que ao depositar mais dejeto, esse valor sature e não seja aproveitado, sendo muitas vezes até tóxico. Antes de aplicar o recurso, o produtor deve fazer a análise de solo e do composto para a adubação, de acordo com a exigência nutricional da cultura a ser semeada.

Já no uso do esterco bovino, se torna prática útil e econômica para os pequenos e médios produtores de hortaliças e aos que ensejam melhoria na fertilidade e na conservação do solo e no seu fornecimento ao solo deve-se considerar o tipo, textura, estrutura e teor de matéria orgânica (Oliveira et al., 2007).

Weinärtner et al., (2006) relata que o esterco de aves é rico em $\mathrm{N}$, o esterco bovino são os mais ricos em fibras e o suíno tem sua composição variável em razão da quantidade de água que o acompanha, tipo de alimentação e idade dos animais. Este material é caracterizado pela boa quantidade de nitrogênio e de zinco. Como todos os outros dejetos, deve ser fermentado para uso na agricultura.

O esterco de suínos em função de suas características químicas tem um alto potencial fertilizante, podendo substituir em parte ou totalmente a adubação química e contribuir significativamente para o aumento da produtividade das culturas e a redução dos custos de produção (Scherer, 2001). Os suplementos minerais contendo cobre e zinco, comumente incluído na ração para suínos, resulta no enriquecimento do dejeto com esses elementos que, quando em excesso, podem ter efeito tóxico a plantas e animais. Assim, a definição da dose do dejeto suíno também deve considerar o risco de contaminação do solo e dos mananciais nas áreas de aplicação desse resíduo 
(Seganfredo, 2000). Sempre aliando a análise do dejeto com a análise do solo e da cultura.

E por último, na comparação entre as os diferentes dejetos de animais, temos a cama de peru, que apresentou os maiores valores para os macronutrientes que os demais animais. Por isso o uso crescente na região do sudoeste goiano. A sua utilização tem seu uso relacionado com a elevação dos teores fósforo, potássio, redução nos teores de alumínio e da acidez do solo.

A atividade microbiana também pode ser influenciada pela adição desse resíduo ao solo, bem como, a elevação dos teores e estoques de carbono orgânico e nitrogênio da fração orgânica particulada da matéria orgânica (Pinto et al., 2012).

Mas Trani et al., (2008) ressalta que o esterco não é um bom fornecedor de nutrientes às plantas a curto prazo, simplesmente porque os contém em baixas concentrações. Porém, a sua aplicação contínua por vários anos, contribui para a melhoria das características químicas do solo e aumento da produtividade das culturas.

\section{CONCLUSÕES}

A cama de peru apresentou teores e proporções adequadas de nutrientes, podendo assim ser utilizada como opção de adubação na cultura da soja. As características químicas da cama de peru e das demais fontes orgânicas variam conforme a idade do animal, concentração de nutrientes nas rações e do tempo de armazenamento. Sendo assim a cama de peru pode ser utilizado na adubação na cultura da soja, no entanto para recomendação de adubação é necessário realizar uma análise química solo e do esterco para determinar a dose adequada.

\section{REFERÊNCIAS}

CASSOL, P. C.; SILVA, C. P.; ERNANI P. R.; KLAUBERG FILHO, O.; LUCRÉCIO, W. Atributos químicos em Latossolo Vermelho fertilizado com dejeto suíno e adubo solúvel. Revista de Ciências Agroveterinárias, Lages, v. 10, n.2, p.103-112, 2011.

CONAB. Companhia Nacional de Abastecimento. Estimativa de safra 2012/2013. Disponível em: <http://www.conab.gov.br/>.10ㅇ Levantamento - Safra 2014/15. Acesso em: 14 jul. 2015. 
CQFS-RS/SC - COMISSÃO DE QUÍMICA E FERTILIDADE DO SOLO - RS/SC. Manual de adubação e calagem para os Estados do Rio Grande do Sul e de Santa Catarina. 10. ed. Porto Alegre: Sociedade Brasileira de Ciência do solo /Núcleo Regional Sul, 400p., 2004.

EMBRAPA. Recomendações para o estabelecimento e utilização do Stylosanthes guinensis cv Mineirão. Planaltina/ Campo Grande, 1993. 6p. (EMBRAPA-CPAC. Comunicado Técnico, 67; EMBRAPA-CNPGC. Comunicado Técnico, 49)

FAVERO, J. A. ; KUNZ, A. ; GIROTTO, A. F. ; MONTICELLE, C. J. ; KICH, J. D. ; LUDKE, J. V. ; MORES, N. ; ABREU, P. G. ; SILVEIRA, P. R. S. . Sistema de Produção de Suínos. Brasilia: Embrapa, 2003.

FIGUEIREDO, E. A. P.; SCHMIDT, G. S.; AVILA, V. S.; JAENISCH, F. R.; PAIVA, D. P.; BASSI, L.; ALBINO, J. Recomendações técnicas para produção, abate e processamento e comercialização de frangos de corte coloniais. Concórdia, SC: Embrapa, 2007 (Sistema de Produção).

GOULART, E. C.; RIBEIRO, M. C.; LIMA, L, M. de.; RODRIGUES, B. M. A.; Uso de cama de aves na adubação da cultura do milho. Enciclopédia conhecer, Centro Científico Conhecer-Goiânia, v. 11, n. 22, p. 2724 - 2748, 2015.

IBGE. Levantamento Sistemático da Produção Agrícola. 2016.

LOURENZI, C. R.; SCHERER, E. E.; CERETTA, C. A.; TIECHER, T. L.; CANCIAN, A.; FERREIRA, P. A. A.; BRUNETTO, G. Atributos químicos de Latossolo após sucessivas aplicações de composto orgânico de dejeto líquido de suínos. Pesquisa Agropecuária Brasileira, Brasília, v. 51, n. 3, p. 233-242, 2016.

MARTINS, J. D. L.; MOURA, M. F. de.; OLIVEIRA, J. P. F. de.; OLIVEIRA, M. de.; GALINDO, C. A. F. Esterco bovino, biofertilizante, inoculante e combinações no desempenho produtivo do feijão comum. Revista Agro@mbiente On-Line, v. 9, n. 4, p. 369-376, 2015.

OliVEIRA, A. P.; BARBOSA, A. H. D.; CAVALCANTE, L. F.; PEREIRA, W. E.; OlIVEIRA, A. N. P. Produção da batata-doce adubada com esterco bovino e biofertilizante. Ciência e Agrotecnologia, v.31, p.1722-1728, 2007.

OLIVEIRA, F. A.; SFREDO, G. J.; CASTRO, C. de; KLEPKER, D. Fertilidade do solo e nutrição da soja. Circular técnica 50 - Embrapa. Londrina, PR. Setembro, 8p., 2007.

PINTO, F. A.; SANTOS, F. L.; TERRA, F. D.; RIBEIRO, D. O.; SOUSA, R. R. J. SOUZA, E. D.; CARNEIRO, M. A.C.; PAULINO, H. B. Atributos de solo sob pastejo rotacionado em função da aplicação de cama de peru. Pesquisa Agropecuária Tropical, Goiânia, v. 42, n. 3, p. 254-262, 2012. 
RIBEIRO, D. O.; CARBALLAL, M. R.; SILVA, A. J. da.; SILVA, G. N. da.; MOREIRA, C. G. Produtividade da cana-de-açúcar e atributos químicos do solo em função de doses de resíduo orgânico. In: XXXV Congresso Brasileiro de Ciência do Solo, 2015, Natal. Anais..., 2015.

RÓS, A. B.; HIRATA, A. C. S.; NARITA, N. Produção de raízes de mandioca e propriedades química e física do solo em função de adubação com esterco de galinha. Pesquisa Agropecuária Tropical, Goiânia, v. 43, n. 3, p. 247-254, 2013.

ROSTAGNO, H. S.; ALBINO, L. F. T. ; DONZELE, J. L.; GOMES, P. C. ; OLIVEIRA, R. F. M. de ; LOPES, D. C.; FERREIRA, A. S.; BARRETO, S. L. de T.; EUCLYDES, R. F. Tabelas Brasileiras para Aves e Suinos - Composição de Alimentos e Exigencias Nutricionais. 3. ed. Visconde do Rio Branco, MG: Suprema, v. 01. 252p, 2011.

SAKOMURA, N. K.; ROSTAGNO, H. S. . Métodos de pesquisa em nutrição de monogástricos. 1. ed. Jaboticabal: FUNEP, 283p., 2007.

SCHERER, E. E. Aproveitamento do Esterco de Suínos como Fertilizante. Epagri, v.1, p.91101, 2001.

SEGANFREDO. A. M. Análise dos riscos de poluição do ambiente, quando se usa dejetos de suínos como adubo do solo. Concórdia: EMBRAPA - CNPSA, 2000. Comunicado Técnico.

THOMAS, A. L.; COSTA, J. A. Soja, Manejo para alta produtividade de grãos. 1.ed. Porto Alegre, Evangraf, 243p., 2010.

TRANI, P. E.: CAMARGO, M. S. do: TRANI, A. L.; PASSOS, F. A. Superfosfato simples com esterco animal: um bom fertilizante organomineral. 2008.

Weingartner, M. A.; ALDRIGHI, C. F. S.; MEDEIROS, C. A. B. Práticas Agroecológicas Adubação Orgânica. Pelotas: Embrapa Clima Temperado, 2006 (Recomendação Técnica). 


\title{
CAPITULO XXII
}

\section{CONIROLE QUIIMICO DE CAPIM AMARGOSO (DIGITARIA INSULARIS (L) FEDDE) COM DIFERENIES HERBICIDAS E APLCACGÕES}

\section{SEOUENCLAIS}

\section{DOI: 10.51859/amplla.mas481.1121-22}

\author{
Igor Gustavo Schneider ${ }^{1}$ \\ Caroline Olias ${ }^{2}$ \\ Aline Vanessa Sauer ${ }^{3}$ \\ Sandro Silva de Oliveira ${ }^{4}$ \\ Leocemar de Andrade Bellé 5 \\ Cristiano Reschke Lajús ${ }^{6}$
}

\begin{abstract}
1 Engenheiro Agrônomo. Egresso do Curso de Agronomia. Universidade Comunitária da Região de Chapecó (Unochapecó), Campus de Chapecó.

${ }^{2}$ Acadêmica do Curso de Agronomia. Universidade Comunitária da Região de Chapecó (Unochapecó), Campus de Chapecó.

${ }^{3}$ Doutora em Agronomia. Universidade Estadual de Maringá (UEM), Campus Maringá. Coordenadora e Docente do Curso de Agronomia na UNOPAR - Universidade Pitágoras Unopar, Campus Bandeirantes.

${ }^{4}$ Mestre em Ciências da Computação. Universidade Federal de Santa Catarina (UFSC), Campus Florianópolis. Docente do Curso de Ciências da Computação na Unochapecó. Universidade Comunitária da Região de Chapecó (Unochapecó), Campus de Chapecó.

${ }^{5}$ Egresso do Curso de Agronomia. Discente do Programa de Pós-Graduação Stricto Sensu em Tecnologia e Gestão da Inovação. Universidade Comunitária da Região de Chapecó (Unochapecó), Campus de Chapecó.

${ }^{6}$ Doutor em Agronomia. Universidade de Passo Fundo (UPF), Campus Passo Fundo. Docente e Pesquisador do Programa de PósGraduação Stricto Sensu em Tecnologia e Gestão da Inovação. Universidade Comunitária da Região de Chapecó (Unochapecó), Campus de Chapecó.
\end{abstract}

\section{RESUMO}

Objetivou-se verificar a incidência de rebrote de Capim-amargos ( $D$. Insularis) após utilização de diferentes herbicidas com aplicações sequenciais. O estudo foi realizado em Nova Itaberaba -SC, com 15 tratamentos e 3 repetições, com área de $2 \times 2 \mathrm{~m}$ cada. Os herbicidas utilizados foram Roundup Original DI ${ }^{\circledR} 3 \mathrm{~L} / \mathrm{ha}^{-1}$, Gramocil ${ }^{\oplus} 2 \mathrm{~L} / \mathrm{ha}^{-1}$ e Select ${ }^{\circledR}$ nas doses de $450 \mathrm{ml} / \mathrm{ha}^{-1}, 750$ $\mathrm{ml} / \mathrm{ha}^{-1}$ e $1000 \mathrm{ml} / \mathrm{ha}^{-1}$. Realizando aplicações com 14 dias de intervalo, utilizando um pulverizador costal pressurizado por bomba elétrica equipado combico tipo leque XR110.02 com calda estimada em $200 \mathrm{~L} / \mathrm{ha}^{-1}$. As avaliações foram realizadas 30 dias após a última aplicação. As variáveis respostas foram pautadas em Rebrote de $D$. insularis e Média de rebrote por tratamento. Os dados coletados foram submetidos a análise de variância (ANOVA) através do teste F. Avaliando diferenças médias pelo teste de Tukey $(P \leq 0,05)$ com o auxílio do Software Sisvar. Os tratamentos 9 e 14 se destacaram dos demais com números médios de rebrote de 1,33\% em ambos. Em seguida os tratamentos 5, 6, 7 e 10 com média de rebrote em 1,66\% para todos. Os tratamentos 8,13 e 15 apresentaram 3,66, 2,33 e 3,66\% respectivamente. Os de

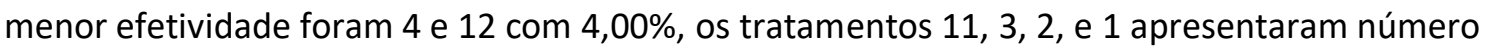
médio de rebrote de 4,99,6,33, 8,00,11,33\% respectivamente. Os tratamentos maiseficientes apresentaram maiores doses do Select ${ }^{\circledR}$ em relação a dose recomendada. As doses recomendadas do herbicida para controle do capim-amargoso não apresentaram eficiência de $100 \%$ quando já entouceirada.

Palavras-chave: Rebrote. Resistência. Plantas daninhas. 


\section{INTRODUÇÃO}

Capim-amargoso é uma planta herbácea e perene, podendo atingir até 150 cm de altura, que forma touceiras consideráveis a partir de curtos rizomas, que juntamente com as abundantes sementes produzidas são os responsáveis pela reprodução da espécie, sendo considerada de grande potencial como invasora (KISSMANN; GROTH, 1997). O controle químico de D. insularis não é eficaz quandoa planta está entouceirada, com os rizomas já formados (Machado et al., 2006), situação que normalmente ocorre durante o manejo de dessecação em pré- semeadura da cultura da soja.

O rendimento das culturas de soja e milho pode ser influenciado por diversos fatores, entre eles as plantas daninhas são de grande impacto no que diz respeito a rendimento. Pois com a competição por plantas daninhas a planta não consegue demostrar toda sua capacidade produtiva.

Em média, 30\% a 40\% de redução da produção agrícola mundial são atribuídos à interferência das plantas daninhas (LORENZI, 2006). No caso da soja, acompetição das plantas daninhas acontece principalmente por recursos básicos ao desenvolvimento da cultura, como luz, água e nutrientes, podendo resultar em perdas significativas a produção, podendo haver redução de mais de $90 \%$ da produção da oleaginosa. A competição também dificulta a operação de colheita, prejudicando a qualidade do grão e principalmente da semente (TECNOLOGIAS, 2008).

A planta de $D$. insularis quando disposta sobre uma lavoura de soja, propicia uma diminuição na produtividade, como também causa problemas no momento da colheita. Se não controlada quando ainda pequena, seu controle fica ainda pior.

Assim surge a necessidade de avaliar diversos tratamentos com diferentes herbicidas de diferentes moléculas químicas a fim de avaliar eficiência ou ineficiência diretamente sobre a daninhas. As aplicações de herbicidas realizadas na cultura necessitam de detalhamento técnico científico, identificando ou verificando o tipo de plantas daninha, e projetando uma escolha de herbicidas eficientes no controle dessas infestantes.

O propósito do trabalho buscou um controle efetivo para esta planta daninha, que a cada safra aumenta a preocupação de produtores, fazendo que as produtividades 
das áreas diminuam e aumentem os custos de controle. avaliando o controle químico de $D$. insularis com diferentes herbicidas e aplicações sequenciais.

\section{REVISÃO BIBLIOGRÁFICA}

\subsection{CAPIM AMARGOSO (DIGITARIA INSULARIS)}

Nativo de regiões subtropicais e tropicais da América, a D. insularis pertencente à família das Poaceae é herbácea, entouceirada, rizomatosa. Devido ao seu com metabolismo fotossintético tipo C4 e se desenvolve nas regiões Centro-Oeste, Nordeste, Sudeste e Sul do Brasil, podendo ser dispersa tanto por partes vegetativas como pela produção de sementes (MOREIRA; BRAGANÇA, 2010).

É considerada uma planta de alta capacidade de disseminação, pois suas sementes são revestidas por pelos que auxiliam na disseminação pelo vento para longas distâncias. Apenas uma touceira pode apresentar vários fluxos de florescimento, sendo que cada fluxo pode produzir em de 6,5 mil a 50 mil sementes por planta (LORENZI, 2000; KISSMANN; GROTH, 1997).

Essa espécie se caracteriza como uma planta de difícil controle em função de sua velocidade de crescimento, de sua adaptabilidade a diferentes condições edafoclimáticas, e principalmente da dificuldade de controle de plantas entouceiradas. Vale salientar que o aumento da população de biótipos resistentes ao glyphosate no Brasil agrava ainda mais a situação (CARVALHO et al., 2011; MONDO et al., 2010; MACHADO et al., 2006).

O capim-amargoso no início do seu desenvolvimento, entre 35 a 45 dias após sua emergência (DAE), por não ter rizoma, devido ao seu crescimento lento, o deixa menos competitivo em relação a outras invasoras. Porém, dos 45 aos 105 DAE seu crescimento é exponencial, no qual ocorre o desenvolvimento de rizomas, tornando - a mais vigorosa e competitiva, aumentando assim a dificuldade de controle, mesmo com herbicidas gramicidas.

\subsection{HERBICIDAS}

A adoção de graminicidas é a principal alternativa para o controle de biótipos de plantas daninhas resistentes ao ghlyfosate, com destaque para o capim-amargoso $D$. 
insularis (MACIEL et al., 2013). O uso incorreto de herbicidas a base deghlyfosate propiciou que as plantas daninhas produzem genes de resistência àmolécula do mesmo, reduzindo a eficácia no seu controle e de seus futuros exemplares.

Segundo Barroso et al., (2010), que mostraram a variabilidade na eficácia do controle de espécies invasoras com graminicidas, ou seja, todos os herbicidas desse grupo não apresentam a mesma eficiência no controle das gramíneas testadas. Por isso faz-se necessário a correta identificação dos melhores herbicidas para o controle das plantas de capim-amargoso $D$. insularis.

O glyphosate é o herbicida mais utilizado no mundo (HARTZLER, 2008). Seu uso elevou-se nos últimos anos devido à crescente adoção de culturas transgênicas principalmente soja e milho tolerantes ao herbicida. A facilidade de seu uso, em decorrência da baixa toxicidade, baixo custo, amplo espectro de controle e rápida adsorção no solo (VELINI et al., 2009).

O controle químico de capim-amargoso conta com poucas opções de herbicidas, além do glyphosate. O uso de herbicidas de contato, como o paraquat, é dificultado devido à formação de densas touceiras, que impedem que o herbicida atinja a planta toda, que geralmente rebrota. Essa rebrota acontece muitas vezes, pois o herbicida não atinge o rizoma (MELO et al., 2010).

Com a liberação comercial de sementes com genótipos resistentes ao glyphosate (GR), a sucessão soja-milho safrinha, que é realizada na maioria das regiões do Brasil, passa a usar este herbicida como principal alternativa químicapara o controle de plantas daninhas. Dentre as plantas daninhas de difícil controle está o $D$. insularis, sendo assim merecendo maior atenção em produtoresde Soja e Milho no Brasil (LICORINI et al., 2015).

\subsection{MECANISMOS DE AÇÃO}

O glyphosate é um herbicida foliar de aplicação em pós-emergência não seletivo que pertence ao grupo dos inibidores da síntese de aminoácidos. Suaatuação se dá pela inibição da atividade enzimática da enzima 5-enolpiruvilshiquimato-3-fosfato sintase (EPSPS) (SHANER; BRIDGES, 2003).

Nos primeiros dias após a aplicação do Paraquat os sintomas de clorose intensa e necrose dos tecidos já são vistos. As folhas das plantas demonstram que ouso desse 
herbicida proporciona médias de clorofila e carotenóides menores que aqueles das plantas controle (CATUNDA et al., 2005).

O paraquat pertence ao grupo químico dos bipiridílio, essa moléculas possuem atividades relacionadas com a formação de radicais superóxidos $(\mathrm{O} 2)$, cujadetoxificação pela enzima superóxido dismutase, resulta na formação de peróxido de hidrogênio $\left(\mathrm{H}^{2} \mathrm{O}^{2}\right)$, que peroxida lipídios e danifica as membranas do cloroplasto e ascélulas das plantas (VIDAL, 1997).

\section{MATERIAL E MÉTODOS}

\subsection{CARACTERIZAÇÃO DO AMBIENTE DA PESQUISA}

O experimento foi implantado na propriedade do Sr. Vilson Roque Fiori, na linha Espuma, no município de Nova Itaberaba/SC, situada na região Oeste de Santa Catarina. A altitude da área é de 300 metros em relação ao nível do mar, tendo latitude $26^{\circ} 56^{\prime} 30.03^{\prime \prime}$ S e longitude $52^{\circ} 54^{\prime} 43.12^{\prime \prime} \mathrm{O}$.

\section{1.\% CONDICOOES EDAFOCLIMÁTICAS}

O clima da região é mesotérmico úmido com verão quente (Cfa) conforme a classificação de Köppen (MOTA; BEIRSDORF; GARCEZ, 1970).

As temperaturas máxima, média e mínima do ar (ํㅡ) e precipitação durante o período do experimento foram registradas pela Estação Meteorológica do Cepaf- Epagri de Águas de Chapecó - TRMM.465 durante a experimentação.

\subsubsection{ESTRATÉGIA E DELINEAMENTO DA PESQUISA}

A presente pesquisa foi caracterizada como uma pesquisa explicativa e quantitativa com corte transversal (em um período especifico). Este tipo de pesquisa explica a razão e o porquê dos fenômenos, aprofunda o conhecimento de uma dada realidade, deste modo, geralmente utiliza as formas relativas á pesquisa experimental (FONSECA, 2002).

\subsection{TÉCNICAS DE COLETAS DE DADOS}

\subsubsection{TRATAMENTOS E DELINEAMENTO EXPERIMENTAL}

A pesquisa contou com quinze tratamentos, as alterações nas dosagens ocorreu somente no tratamento do herbicida graminicida Select ${ }^{\circledast} 240$ EC, tendo como 


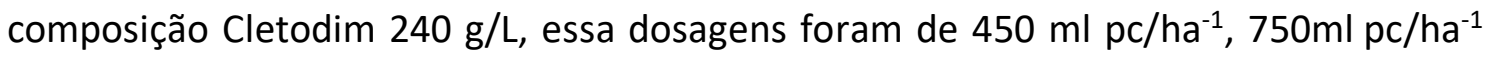

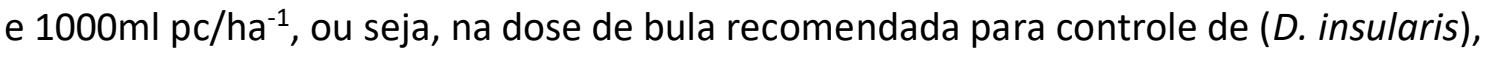
$66,66 \%$ a mais que a dose de bula e $122,22 \%$ a mais que a dose de bula, respectivamente e associado ao herbicida Roundup Original DI ${ }^{\circledR}$. Outro herbicida utilizado em 13 tratamentos foi o Roundup Original $\mathrm{DI}^{\circledR}$ não seletivo de ação sistêmica com composição Sal de Di-amônio de N- (phosphonomethyl) glycine (GLIFOSATO) 445 g/L e Equivalente ácido de N- (phosphonomethyl) glycine (GLIFOSATO) $370 \mathrm{~g} / \mathrm{L}$, esse herbicida não teve alterações em suas dosagens sendo ela de $3 \mathrm{~L}$ de $\mathrm{pc} /$ ha nos tratamentos utilizados.

O herbicida Gramocil $^{\circledR}$ não seletivo com ação não sistêmica tem como composição 1,1'-dimethyl-4,4'-bipyridinium (PARAQUATE) 200 g/L e 3-(3,4dichlorophenyl)-1,1-dimethylurea (DIUROM) 100 g/L, também não teve alterações em duas dosagens, sendo ela de $2 \mathrm{~L}$ pc/ha em todos os tratamentos utilizados.

As aplicações foram feitas com a utilização de um pulverizador costal pressurizado com $\mathrm{CO}^{2}$, equipado com bico amarelo XR 110.02, regulado para o volume de calda de $200 \mathrm{~L} / \mathrm{ha}^{-1}$.

Os tratamentos realizados foram:

- $\mathrm{T} 1$ - Roundup Original DI ${ }^{\circledR} 3 \mathrm{~L} / \mathrm{ha}^{-1}$;

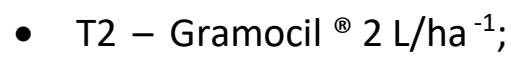

- $\mathrm{T} 3-$ Gramocil ${ }^{\circledR} 2 \mathrm{~L} / \mathrm{ha}^{-1} 14$ dias Gramocil ${ }^{\circledR} 2 \mathrm{~L} / \mathrm{ha}^{-1}$;

- T4 - Roundup Original DI ${ }^{\circledR} 3 \mathrm{~L} / \mathrm{ha}^{-1}+$ Select ${ }^{\circledR} 450 \mathrm{ml} / \mathrm{ha}^{-1}$;

- $\mathrm{T} 5$ - Roundup Original DI ${ }^{\circledR} 3 \mathrm{~L} / \mathrm{ha}^{-1}+$ Select ${ }^{\circledR} 450 \mathrm{ml} / \mathrm{ha}^{-1} 14$ dias Select ${ }^{\circledR} 450$ $\mathrm{ml} / \mathrm{ha}^{-1}$;

- $\mathrm{T} 6$ - Roundup Original $\mathrm{DI}^{\circledR} 3 \mathrm{~L} / \mathrm{ha}^{-1}+$ Select ${ }^{\circledR} 450 \mathrm{ml} / \mathrm{ha}^{-1} 14$ dias Select ${ }^{\circledR} 450$ $\mathrm{ml} / \mathrm{ha}^{-1} 14$ dias Gramocil ${ }^{\circledR} 2 \mathrm{~L} / \mathrm{ha}^{-1}$;

- $\mathrm{T7}$ - Roundup Original DI ${ }^{\circledR} 3 \mathrm{~L} / \mathrm{ha}^{-1}+$ Select ${ }^{\circledR} 450 \mathrm{ml} / \mathrm{ha}^{-1} 14$ dias Gramocil ${ }^{\circledR}$ 2L/ha- ${ }^{-1}$;

- $\quad$ T8 - Roundup Original DI ${ }^{\circledR} 3 \mathrm{~L} / \mathrm{ha}^{-1}+$ Select ${ }^{\circledR} 750 \mathrm{ml} / \mathrm{ha}^{-1}$;

- T9 - Roundup Original DI ${ }^{\circledR} 3 \mathrm{~L} / \mathrm{ha}^{-1}+$ Select ${ }^{\circledR} 750 \mathrm{ml} / \mathrm{ha}^{-1} 14$ dias Select ${ }^{\circledR} 750$ $\mathrm{ml} / \mathrm{ha}^{-1}$;

- $\mathrm{T} 10$ - Roundup Original DI ${ }^{\circledR}$ 3L/ha + Select ${ }^{\circledR} 750 \mathrm{ml} / \mathrm{ha} 14$ dias Select ${ }^{\circledR} 750$ $\mathrm{ml} / \mathrm{ha}^{-1} 14$ dias Gramocil ${ }^{\circledR} 2 \mathrm{~L} / \mathrm{ha}^{-1}$; 
- $\mathrm{T} 11$ - Roundup Original $\mathrm{DI}^{\circledR} 3 \mathrm{~L} / \mathrm{ha}^{-1}+$ Select ${ }^{\circledR} 750 \mathrm{ml} / \mathrm{ha}^{-1} 14$ dias Gramocil ${ }^{\circledR}$ 2L/ha ${ }^{-1}$;

- $\mathrm{T} 12$ - Roundup Original DI ${ }^{\circledR} 3 \mathrm{~L} / \mathrm{ha}^{-1}+$ Select ${ }^{\circledR} 1000 \mathrm{ml} / \mathrm{ha}^{-1}$;

- T13 - Roundup Original DI ${ }^{\circledR} 3 \mathrm{~L} / \mathrm{ha}^{-1}+$ Select ${ }^{\circledR} 1000 \mathrm{ml} / \mathrm{ha}^{-1} 14$ dias Select ه $1000 \mathrm{ml} / \mathrm{ha}^{-1}$;

- T14 - Roundup Original DI ${ }^{\circledR} 3 \mathrm{~L} / \mathrm{ha}^{-1}+$ Select ${ }^{\circledR} 1000 \mathrm{ml} / \mathrm{ha}^{-1} 14$ dias Select ๑ $1000 \mathrm{ml} / \mathrm{ha}^{-1} 14$ dias Gramocil ${ }^{\circledR} 2 \mathrm{~L} / \mathrm{ha}^{-1}$;

- $\mathrm{T} 15$ - Roundup Original DI ${ }^{\circledR} 3 \mathrm{~L} / \mathrm{ha}^{-1}+$ Select ${ }^{\circledR} 1000 \mathrm{ml} / \mathrm{ha}^{-1}$ 14dias Gramocil ${ }^{\circledR}$ 2L/ha-1.

O experimento foi realizado a campo, utilizando-se o delineamento em blocos casualizados (DBC), com três repetições, totalizando quinze tratamentos e 45 unidades experimentais. Cada unidade experimental (parcela) compreendeu uma área de $2 \times 2 \mathrm{~m}$ $\left(4 \mathrm{~m}^{2}\right)$, sendo que a área total utilizada para a pesquisa será de $180 \mathrm{~m}^{2}$, sendo somado 1 metro de corredor para transitar entre casa repetição (Figura 01).

Figura 01 - Croqui do experimento (Nova Itaberaba/SC - Safra 2018/2019).

\begin{tabular}{|c|c|c|c|c|c|c|c|c|c|c|c|c|c|c|}
\hline 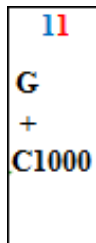 & $\begin{array}{c}12 \\
\\
\mathrm{G} \\
- \\
\mathrm{C} 450 \\
- \\
\mathrm{C} 450 \\
- \\
\mathrm{P}\end{array}$ & $\begin{array}{c}13 \\
\mathrm{G} \\
+ \\
\mathrm{C} 750 \\
+ \\
\mathrm{C} 750\end{array}$ & $\begin{array}{c}14 \\
\mathrm{G} \\
+ \\
\mathrm{C} 450 \\
+ \\
\mathrm{P}\end{array}$ & $\begin{array}{l}15 \\
\text { G }\end{array}$ & $\begin{array}{c}16 \\
\mathrm{G} \\
+ \\
\mathrm{C} 750 \\
+ \\
\mathrm{P}\end{array}$ & $\begin{array}{c}17 \\
\text { G } \\
- \\
\text { C1000 } \\
- \\
\text { C1000 } \\
- \\
\text { P }\end{array}$ & $\begin{array}{c}18 \\
\mathrm{G} \\
+ \\
\mathrm{C} 450 \\
+ \\
\mathrm{C} 450\end{array}$ & $\begin{array}{l}19 \\
\text { P }\end{array}$ & $\begin{array}{c}110 \\
\mathrm{G} \\
+ \\
\mathrm{C} 1000 \\
+ \\
\mathrm{P}\end{array}$ & $\begin{array}{c}111 \\
\mathrm{G} \\
+ \\
\mathrm{C450}\end{array}$ & $\begin{array}{c}112 \\
\mathrm{G} \\
- \\
\mathrm{C} 750 \\
- \\
\mathrm{C} 750 \\
- \\
\mathrm{P}\end{array}$ & $\begin{array}{c}113 \\
\mathrm{G} \\
+ \\
\mathrm{C} 1000 \\
+ \\
\mathrm{C} 1000\end{array}$ & $\begin{array}{c}114 \\
\\
\text { G } \\
+ \\
\text { C750 }\end{array}$ & $\begin{array}{c}115 \\
\mathrm{G} \\
- \\
\mathrm{C}_{450} \\
- \\
\mathrm{C}_{450} \\
- \\
\mathrm{P}\end{array}$ \\
\hline $\begin{array}{c}21 \\
\mathrm{G} \\
+ \\
\mathrm{C} 450 \\
+ \\
\mathrm{C} 450\end{array}$ & $\begin{array}{l}22 \\
P\end{array}$ & $\begin{array}{c}23 \\
\mathrm{G} \\
+ \\
\mathrm{C} 1000 \\
+ \\
\mathrm{P}\end{array}$ & $\begin{array}{c}24 \\
\mathrm{G} \\
+ \\
\mathrm{C450}\end{array}$ & $\begin{array}{c}25 \\
\mathrm{G} \\
- \\
\mathrm{C} 750 \\
- \\
\mathrm{C} 750 \\
\overline{\mathrm{P}}\end{array}$ & $\begin{array}{c}26 \\
\mathrm{G} \\
+ \\
\mathrm{C} 1000 \\
+ \\
\mathrm{C} 1000\end{array}$ & $\begin{array}{c}27 \\
\text { G } \\
+ \\
\text { C750 }\end{array}$ & $\begin{array}{c}28 \\
\mathrm{G} \\
- \\
\mathrm{C} 450 \\
- \\
\mathrm{C} 450 \\
- \\
\mathrm{p}\end{array}$ & $\begin{array}{c}29 \\
\mathrm{G} \\
+ \\
\mathrm{C} 1000\end{array}$ & $\begin{array}{c}210 \\
\mathrm{G} \\
+ \\
\mathrm{C} 450 \\
+ \\
\mathrm{P}\end{array}$ & $\begin{array}{c}211 \\
\\
\mathbf{G} \\
+ \\
\mathbf{C 7 5 0} \\
+ \\
\\
\text { C750 }\end{array}$ & $\begin{array}{c}212 \\
\mathbf{P} \\
+ \\
\mathbf{P}\end{array}$ & $\begin{array}{c}213 \\
\text { G }\end{array}$ & $\begin{array}{c}214 \\
\mathrm{G} \\
+ \\
\mathrm{C} 750 \\
+ \\
\mathrm{P}\end{array}$ & $\begin{array}{c}215 \\
\\
\text { G } \\
+ \\
\text { C1000 } \\
- \\
\text { C1000 } \\
+ \\
\text { P }\end{array}$ \\
\hline $\begin{array}{c}31 \\
\mathrm{G} \\
+ \\
\mathrm{C} 750\end{array}$ & $\begin{array}{l}32 \\
\mathbf{P} \\
+ \\
\mathbf{P}\end{array}$ & $\begin{array}{c}33 \\
\text { G } \\
+ \\
\text { C1000 } \\
+ \\
\text { C1000 }\end{array}$ & $\begin{array}{c}34 \\
\mathrm{G} \\
- \\
\mathrm{C} 750 \\
- \\
\mathrm{C} 750 \\
\dot{P}\end{array}$ & $\begin{array}{c}35 \\
\mathrm{G} \\
+ \\
\mathrm{C} 450\end{array}$ & $\begin{array}{c}36 \\
\\
\mathrm{G} \\
+ \\
\mathrm{Cl} 1000 \\
+ \\
\mathrm{P}\end{array}$ & $\begin{array}{l}37 \\
\mathbf{P}\end{array}$ & $\begin{array}{c}38 \\
\\
\mathrm{G} \\
+ \\
\mathrm{C450} \\
+ \\
\mathrm{C} 450\end{array}$ & $\begin{array}{c}39 \\
\mathbf{G} \\
- \\
\mathrm{Cl} 000 \\
- \\
\mathrm{C} 1000 \\
- \\
\mathbf{P}\end{array}$ & $\begin{array}{c}310 \\
\\
\mathrm{G} \\
+ \\
\mathrm{C} 750 \\
+ \\
\mathrm{P}\end{array}$ & $\begin{array}{c}311 \\
\text { G }\end{array}$ & $\begin{array}{c}312 \\
\\
\mathrm{G} \\
+ \\
\mathrm{C450} \\
+ \\
\mathrm{P}\end{array}$ & $\begin{array}{c}313 \\
\\
\mathrm{G} \\
+ \\
\text { C750 } \\
+ \\
\text { C750 }\end{array}$ & $\begin{array}{c}314 \\
\mathbf{P} \\
+ \\
\mathbf{P}\end{array}$ & $\begin{array}{c}315 \\
\text { G } \\
+ \\
\mathrm{C} 1000\end{array}$ \\
\hline
\end{tabular}

Fonte: Elaborado pelos autores (em que G significa Roundup Original DI ${ }^{\circledR} 3$ L/ha ${ }^{-1}$, C450 significa Select ${ }^{\circledR} 450 \mathrm{ml} / \mathrm{ha}^{-1}, \mathrm{C} 750$ significa Select ${ }^{\circledR} 750 \mathrm{ml} / \mathrm{ha}^{-1}, \mathrm{C} 1000$ significa Select ${ }^{\circledR} 1000 \mathrm{ml} / \mathrm{ha}^{-1}$ e P significa Gramocil $\left.{ }^{\circledR} 2 \mathrm{~L} / \mathrm{ha}^{-1}\right)$. 


\subsubsection{TRATOS CULTURAIS}

Foi realizada a coleta de solo, com trado holandês para fins de análise. Não teve nenhum manejo com herbicida na área até 45 dias que antecedia o experimento, somente então feito roçada das touceiras da planta daninha já com altura média maior que 1 metro, onde após 28 dias feita a roçada foram iniciados osmanejos com os herbicidas conforme cada parcela.

\subsubsection{VARIÁVEIS RESPOSTAS}

As variáveis estudadas foram pautadas de 0 a 100 em porcentagem nos seguintes aspectos.

a) Rebrote de $D$. insularis

b) Média de rebrote de D.insularis

\subsection{TÉCNICA DE ANÁLISE E INTERPRETAÇÃO DOS DADOS}

\subsubsection{ANÁLISE ESTATISTICA}

Os dados coletados foram submetidos a análise de variância (ANOVA) através do teste F. As diferenças entre as médias foram comparadas pelo teste de Tukey $(P \leq 0,05)$ com o auxílio do Software Sisvar.

\section{RESULTADOS E DISCUSSÃO}

\subsection{NÚMEROS DE PLANTAS POR PARCELA}

A análise de variância não revelou efeito significativo $(P>0,05)$ dos tratamentos em relação à variável resposta número de plantas por parcela (Tabela 01). 
Tabela 01 - Número de plantas por parcela do experimento (Nova Itaberaba, SC - 2019).

\begin{tabular}{lc}
\hline Tratamento & Número de plantas por parcela \\
\hline T1 & $13,33 \mathrm{a}$ \\
T2 & $9,67 \mathrm{a}$ \\
T3 & $10,33 \mathrm{a}$ \\
T4 & $10,00 \mathrm{a}$ \\
T5 & $8,67 \mathrm{a}$ \\
T6 & $9,33 \mathrm{a}$ \\
T7 & $7,00 \mathrm{a}$ \\
T8 & $9,67 \mathrm{a}$ \\
T9 & $8,33 \mathrm{a}$ \\
T10 & $11,00 \mathrm{a}$ \\
T11 & $10,67 \mathrm{a}$ \\
T12 & $9,67 \mathrm{a}$ \\
T13 & $11,33 \mathrm{a}$ \\
T14 & $11,33 \mathrm{a}$ \\
T15 & $11,33 \mathrm{a}$ \\
\hline
\end{tabular}

CV (\%) 21,72

Médias seguidas de mesma letra não diferem significativamente entre si pelo teste de Tukey $(P \leq 0,05)$. Fonte: elaborado pelos autores.

Em relação ao número de plantas por parcela não houve diferença estatisticamente $(P>0,05)$, podendo salientar que as parcelas apresentaram uns números médios muito parecidos entre as mesmas, o que diminuiu possíveis erros nos tratamentos utilizados por falta ou excesso de plantas e apresentou uma uniformidade. O coeficiente de variação foi de 21,72 para essa avaliação, onde esse resultado é considerado bom para experimentos desenvolvidos a campo.

\subsection{NÚMEROS DE REBROTE POR PARCELA}

A análise de variância revelou efeito significativo $(P \leq 0,05)$ dos tratamentos em relação à variável resposta número de rebrote por parcela (Tabela 02). 
Tabela 02 - Número de rebrote por parcela do experimento (Nova Itaberaba, SC - 2019).

\begin{tabular}{lc}
\hline Tratamento & Número de plantas por parcela \\
\hline T1 & $11,33 \mathrm{c}$ \\
T2 & $8,00 \mathrm{bc}$ \\
T3 & $6,33 \mathrm{abc}$ \\
T4 & $4,00 \mathrm{ab}$ \\
T5 & $1,66 \mathrm{ab}$ \\
T6 & $1,66 \mathrm{ab}$ \\
T7 & $1,66 \mathrm{ab}$ \\
T8 & $3,66 \mathrm{a}$ \\
T9 & $1,33 \mathrm{a}$ \\
T10 & $1,66 \mathrm{ab}$ \\
T11 & $4,99 \mathrm{ab}$ \\
T12 & $4,00 \mathrm{ab}$ \\
T13 & $2,33 \mathrm{ab}$ \\
T14 & $1,33 \mathrm{a}$ \\
T15 & $3,66 \mathrm{ab}$ \\
\hline
\end{tabular}

CV (\%) 57,20

Médias seguidas de mesma letra não diferem significativamente entre si pelo teste de Tukey $(P \leq 0,05)$. Fonte: elaborado pelos autores.

Uma estratégia utilizada no experimento e que vem sendo disseminada na agricultura é a aplicação de herbicidas de diferentes mecanismos de ação, mas com o mesmo espectro de controle, que podem ser manejadas com herbicidas emaplicações associadas, sequencias ou com rotação (CHRISTOFFOLETI et al., 2012). Na Tabela 02 observa-se o resultado do número de rebrote de plantas de $D$. insularis por parcela do experimento que teve um coeficiente de variação de $57,20 \%$, os quais apresentaram os tratamentos 9 e 14 destacados em relação aos demais, porém só diferem estatisticamente dos tratamentos 1 e 2.

A comprovação de que as plantas de $D$. insularis eram resistentes ao herbicida Glyphosate se deu pelo baixo controle apresentado no T1 utilizado apenas Roundup Original $\mathrm{DI}{ }^{\oplus}$ aplicado $3 \mathrm{~L} / \mathrm{ha}^{-1}$ isoladamente apresentou o menor controle dentre os demais tratamentos com eficiência em torno de 15,97\%, oque já seesperava pelas informações repassadas pelo produtor. Segundo autores, a dose recomendada para controle efetivo de $D$. insularis com o herbicida glyphosate é de 720 a 1080 g e.a/ha-1 
(RODRIGUES; ALMEIDA, 2011).

Também deve ser considerado a alta utilização de herbicidas inibidores de ACCase, sendo o principal Clethodim nas safras subsequentes, pode ser uma fonte para nova resistência da cultura à este mecanismo de ação (GEMELLI et al., 2012). Para o Ministério da Agricultura, Pecuária e Abastecimento (MAPA) a média de controle que um herbicida precisa promover para ser considerado viável e respeitar um registro junto ao órgão citado são de 80\% (MAPA, 2019).

Os tratamentos 2 e 3 não apresentaram estatisticamente diferença entre o tratamento 1 , porém seus valores de rebrote foram menores que o mesmo. 0 tratamento 2 com uma única aplicação de Gramocil ${ }^{\circledR}$ usando $2 \mathrm{~L} / \mathrm{ha}^{-1} \mathrm{em}$ ralação ao tratamento 3 que foram feitas duas aplicações com intervalo de 14 dias de Gramocil ${ }^{\circledR}$ também dosagem de $2 \mathrm{~L} / \mathrm{ha}^{-1}$.

Para os tratamentos 4, 5, 6 e 7 foram utilizados as mesmas dosagens do Herbicida Select ${ }^{\circledR}$ sendo essa de $450 \mathrm{ml} / \mathrm{ha}^{-1}$ recomendado em bula para o controlede CapimAmargoso (MAPA, 2019). Esses tratamentos não apresentaram diferença estatística entre si, porem no tratamento 4 Roundup Original DI ${ }^{\circledR} 3 \mathrm{~L} / \mathrm{ha}^{-1}+$ Select $^{\circledR} 450 \mathrm{ml} / \mathrm{ha}^{-1} \mathrm{em}$ uma única aplicação demonstrou o maior resultado entre eles.

Para o tratamento 5 Roundup Original DI ${ }^{\oplus} 3 \mathrm{~L} / \mathrm{ha}^{-1}+$ Select $^{\oplus} 450 \mathrm{ml} / \mathrm{ha}^{-1}$ intervalo de 14 dias Select ${ }^{\circledR} 450 \mathrm{ml} / \mathrm{ha}^{-1}$ que apresentou valor menor em relação ao tratamento 4 por ter uma aplicação secundaria do herbicida graminicida após 14dias, porém resultados iguais aos tratamentos 6 e 7 que também possuem aplicações sequencias, sendo no tratamento 6 utilizado Roundup Original $\mathrm{DI}^{\oplus} \mathrm{3L} / \mathrm{ha}^{-1}+$ Select $^{\oplus} 450 \mathrm{ml} / \mathrm{ha}^{-1} \mathrm{com}$ intervalo de 14 dias Select ${ }^{\circledR} 450 \mathrm{ml} / \mathrm{ha}^{-1}$ e intervalo de 14 dias Gramocil ${ }^{\circledR} 2 \mathrm{~L} / \mathrm{ha}^{-1}$ e no tratamento 7 utilizado Roundup Original $\mathrm{DI}^{\oplus} 3 \mathrm{~L} / \mathrm{ha}^{-1}+$ Select ${ }^{\circledR} 450 \mathrm{ml} / \mathrm{ha}^{-1}$ com intervalo de 14 dias Gramocil ${ }^{\circledR}$ 2L/ha-1 ${ }^{-1}$, podendo-se notar que a aplicação após 14 dias de Gramocil $^{\circledR} 2 \mathrm{~L} / \mathrm{ha}^{-1}$ utilizando dosagem de bula do graminicida não apresenta ganhos no controle de $D$. insularis.

Os resultados obtidos dos tratamentos $8,9,10$ e 11 estatisticamente a $(P \leq 0,05)$ não apresentaram diferencia entre si, por serem utilizadas as mesmas dosagens do Select ${ }^{\oplus} 750 \mathrm{ml} / \mathrm{ha}^{-1}$ sendo essa de $66,66 \%$ superior a dose de bula recomendada para controle de $D$. Insularis. No tratamento 11 apresentou o maior valor dentre eles, seguido 
do tratamento 8 oque pode-se observar é de que a utilização de Gramocil ${ }^{\circledR} 2 \mathrm{~L} / \mathrm{ha}^{-1}$ após 14 dias da aplicação de Roundup Original $\mathrm{DI}^{\circledR} 3 \mathrm{~L} / \mathrm{ha}^{-1}+$ Select $^{\oplus} 750 \mathrm{ml} / \mathrm{ha}^{-1}$ demonstrou maior rebrote em relação ao tratamento 8 que foi somente utilizado Roundup Original $\mathrm{DI}^{\oplus} 3 \mathrm{~L} / \mathrm{ha}^{-1}+$ Select $^{\oplus} 750 \mathrm{ml} / \mathrm{ha}^{-1}$, tal situação ocorreu por não haver mais tecido vivo após os 14 dias da aplicação inicial para que o Herbicida Gramocil ${ }^{\circledR}$ que é pertencente ao grupo dos bipiridilos, não seletivo, destruindo as pastes verdes das plantas, porem permitindo eventual rebrotepor apresentarem uma baixa translocação nas plantas (RODRIGUES; ALMEIDA, 2011).

Em relação aos tratamentos 12, 13, 14 e 15 as dosagens do Herbicida Select ${ }^{\circledR}$ foi de $1000 \mathrm{ml} / \mathrm{ha}^{-1}$ para os tais tratamentos, ou seja, uma dose de $122,22 \%$ superiorda presente na bula do químico, sendo assim esperava-se uma melhor eficiência destes tratamentos, porem o tratamento 12 teve um resultado igual ao tratamento 4 sendo esse utilizando dose de bula do herbicida. Já para o tratamento 13 os valores de rebrote foram maiores que os tratamentos 5 e 9, utilizando $450 \mathrm{ml} / \mathrm{ha}^{-1}$ e $750 \mathrm{ml} / \mathrm{ha}^{-1}$ respectivamente, resultado esse insatisfatório para o aumento de dose a 122,22\%.

Para o tratamento 14 os resultados do rebrote que se destacaram juntamente com o tratamento 9 dos demais foram satisfatórios, porém não diferem estatisticamente da maioria tratamentos, somente 1 e 2 . Pode-se notar que os tratamentos 14 e 9 foram os melhores em relação aos outros, tendo maiores eficiências, porém os tratamentos 5, 6, 7 e 10 apresentam resultados próximos e custos inferiores.

\subsection{NÚMEROS DA MÉDIA dOS REBROTES POR PARCELA EM PORCENTAGEM}

A análise de variância revelou efeito significativo $(P \leq 0,05)$ dos tratamentos em relação à variável resposta número da média de rebrote por parcela (Tabela 03). 
Tabela 03 - Número da média de rebrote por parcela do experimento em porcentagem(Nova Itaberaba, SC - 2019).

\begin{tabular}{lc}
\hline Tratamentos & Número da média de rebrote por parcela \\
\cline { 2 - 2 } T1 & $0,83 \mathrm{~d}$ \\
T2 & $0,80 \mathrm{~cd}$ \\
T3 & $0,60 \mathrm{bcd}$ \\
T4 & $0,40 \mathrm{abcd}$ \\
T5 & $0,20 \mathrm{ab}$ \\
T6 & $0,16 \mathrm{ab}$ \\
T7 & $0,23 \mathrm{ab}$ \\
T8 & $0,40 \mathrm{abcd}$ \\
T9 & $0,13 \mathrm{a}$ \\
T10 & $0,16 \mathrm{ab}$ \\
T11 & $0,36 \mathrm{abc}$ \\
T12 & $0,40 \mathrm{abcd}$ \\
T13 & $0,23 \mathrm{ab}$ \\
T14 & $0,13 \mathrm{a}$ \\
T15 & $0,33 \mathrm{ab}$ \\
\hline
\end{tabular}

$\mathrm{CV}(\%)$ 40,62

Médias seguidas de mesma letra não diferem significativamente entre si pelo teste de Tukey $(P \leq 0,05)$. Fonte: elaborado pelos autores.

Na Tabela 03 foram analisados os valores da média de rebrote entre os tratamentos, que apresentou um coeficiente de variação de 40,62\% aceitáveis para testes realizados a campo. Os Tratamentos 9 e 14 novamente apresentaram os melhores resultados da média, diferindo estatisticamente apenas dos tratamentos 1 , 2 e 3 , sendo este os inferiores, porem sendo iguais estatisticamente a $(P \leq 0,05)$ de que os Tratamentos 4, 8 e 12 .

As médias dos tratamentos foram feitas em relação às três repetições, sendo assim, podemos dizer que teríamos apenas 5 tratamentos dentre os 15 que são eficientes em relação ao Ministério da Agricultura, Pecuária e Abastecimento (MAPA) que registra somente herbicidas com eficiência superiores a 80\% (MAPA, 2019). Os Tratamentos 5, 6, 9, 10 e 14 apresentaram então eficiências superiores aos 80\%, podendo ser estes, recomendados para o controle efetivo do $D$. insularis.

Confirmando oque já tinha sido dito por (MELO et al., 2012), a associação de 
Glyphosate com clethodim associado à uma aplicação de Paraquat + diuron após 14 dias de intervalo apresentou uma alternativa viável de controle de $D$. insularis, sempre sendo analisado quantidade de perfilho e tamanho da touceira para administrar possível dosagens dos herbicidas.

\subsection{DESPESAS DOS TRATAMENTOS POR HECTARE}

Relação de despesas de cada tratamento com os herbicidas utilizados convertidos por hectare (Tabela 04).

Tabela 04 - Despesa dos tratamentos por hectare (Nova Itaberaba, SC - 2019).

\begin{tabular}{lll}
\hline Tratamentos & \multicolumn{2}{l}{ Despesas por Hectare } \\
\hline T1 & $R \$$ & 60,00 \\
T2 & $R \$$ & 50,00 \\
T3 & $R \$$ & 100,00 \\
T4 & $R \$$ & 107,25 \\
T5 & $R \$$ & 154,50 \\
T6 & $R \$$ & 204,50 \\
T7 & $R \$$ & 157,25 \\
T8 & $R \$$ & 138,75 \\
T9 & $R \$$ & 217,50 \\
T10 & $R \$$ & 267,50 \\
T11 & $R \$$ & 188,75 \\
T12 & $R \$$ & 165,00 \\
T13 & $R \$$ & 270,00 \\
T14 & $R \$$ & 320,00 \\
T15 & $R \$$ & 215,00 \\
\hline
\end{tabular}

Fonte: elaborado pelos autores.

Conforme Tabela 04, podem-se demonstrar tais custos de cada um dos 15 Tratamentos, dos quais se pode realizar uma análise conforme o custo e eficiência de cada Tratamento. Os Tratamentos 6 e 10 apresentaram eficiência muito próximas, porem os custos dos Tratamentos apresentaram uma diferença de $R \$ 63,00$ entre si por hectare, sendo assim seria mais indicado a utilização do Tratamento 6 por ser mais barato e ter uma eficiência próxima. 
Pode-se notar as mesmas situações em relação aos Tratamentos 9 e 14, os quais apresentam uma diferença de custo em média de $\mathrm{R} \$ 102,00$ por hectare e apresentando uma eficiência muito próximos entre si. Com estes dados também podemos recomendar a utilização do Tratamento 9 por ter a mesma eficiência e menor custo que o Tratamento 14.

\section{CONSIDERAÇÕES FINAIS}

Pode-se concluir que os Tratamentos 9 e 14 apresentaram o mesmo número de rebrote por parcela e a mesma média de rebrote por parcela, porém o Tratamento 9 teve um custo de $R \$ 217,50$ por hectare, já o Tratamento 14 teve um custo de $R \$ 320,00$ por hectare, diferença essa de $\mathrm{R} \$ 102,50$ por hectare, sendo então recomendado utilização do Tratamento 9.

Os Tratamento 5, 6, 7 e 10 apresentaram uma eficiência inferior em relação aos Tratamentos 9 e 14, porém também são aceitáveis com eficiência superior a 80\%. Ficou evidente resistência a Glyphosate pela efetividade do Tratamento 1.

Os dados obtidos neste experimento podem ter sido afetados por problema de deriva quando utilizado o herbicida Gramocil ${ }^{\circledR}$ por ter ação de contato, mesmo utilizando uma barreira entre uma parcela e outra.

\section{REFERÊNCIAS}

BARROSO, C. M.; FRANKE, L. B.; BARROSO, I. B. Substrato e luz na germinação das sementes de rainha-do-abismo. Horticultura Brasileira, v. 28, n. 2, p. 236-240, 2010.

CATUNDA, M. G., et al., Efeitos de herbicidas na atividade fotossintética e no crescimento de Abacaxi (Annanas comossus). Planta Daninha, Viçosa, v. 23, n. 1, p. 115- 121, 2005.

CHRISTOFFOLETI, P.J. Inovações na Prevenção e Manejo de Populações de Plantas Daninhas Resistentes a Herbicidas no Brasil. II Workshop HRAC-BR: Resistência de Plantas Daninhas a Herbicidas, SBCPD, Campo Grande, MS. Setembro de 2012.

Gemelli, A.; Oliveira Junior, R.S.; Constantin, J.; Braz, G.B.P.; Jumes, T.M.C.; Oliveira Neto, A.M.; et al. Aspectos da biologia de Digitaria insularis resistente ao glyphosate e 
implicações para o seu controle. Revista Brasileira de Herbicidas, v.11, n.2, p.231-240, 2012.

GILO, E. G., et al., Alternatives for chemical management of sourgrass. Bioscience Journal, Uberlândia, v. 32, n. 4, p. 881-889, 2016.

GAZZIERO, D. L. P et al., Manual de identificação de plantas daninhas da cultura dasoja. Embrapa Soja-Documentos (INFOTECA-E), Londrina, 114 p. 2006.

LICORINI, L. R. Resistência de biótipos de Digitaria insularis (L.) Fedde aos herbicidas glyphosate e clethodim. 2014. 32 f. Dissertação (Mestrado em Agronomia) Universidade Estadual do Norte do Paraná, Bandeirantes, 2014.

MAPA - Ministério da agricultura Pecuária e Abastecimento - AGROFIT Sistemas de Agrotóxicos Fitossanitários. Disponível em: <http://extranet.agricultura.gov.br/agrofit_cons/!ap_produto_form_detalhe_c ons?p_id_produto_formulado_tecnico $=7714 \& p \_t i p o \_j a n e l a=N E W>$. Acesso em: 20 jul. 2019.

MACHADO, A. F. L. et al., Caracterização anatômica de folha, colmo e rizoma de Digitaria insularis (L.) Fedde. Planta Daninha, Viçosa, MG, v. 26, n. 1, p. 1-8, 2008.

MACIEL, C.D. de G., et al., Eficácia do herbicida haloxyfop R (GR-142) isolado eassociado ao 2,4-D no controle de híbridos de milho $R^{(r)}$ voluntário. Revista Brasileira de Herbicidas, v.12, p.112-123, 2013.

MELO, M. S. C. et al., Alternativas para o controle químico de capim-amargoso (Digitaria insularis) resistente ao glyphosate. R. Bras. Herbic., v. 2, n. 11, p. 195-203, 2012

MOREIRA, H. J. C.; BRAGANÇA, H. B. N. Manual de identificação de plantasinfestantes. São Paulo: FMC Agricultural Products, 853 p, 2010.

MOTA, F. S.; BEIRSDORF, M. I. C.; GARCEZ, J. R. B. Zoneamento agroclimático doRio Grande do Sul e Santa Catarina. Porto Alegre: Ministério da Agricultura, Departamento Nacional de Pesquisa Agropecuária do Sul, 1970.

MONDO, V. H. V.,et al,. Efeitos da luz e temperatura na germinação de sementes de quatro espécies de plantas daninhas do gênero Digitaria. Revista Brasileira Sementes, Brasília, DF, v. 32, n. 1, p. 131-137, 2010.

OVEJERO, R. F. L., et al., Frequency and dispersal of glyphosate-resistant sourgrass (Digitaria insularis) populations across brazilian agricultural production areas. Weed Science, Champaign, v. 65, n. 2, p. 285-294, 2017.

KISSMANN, K.G.; GROTH, D. Plantas infestantes e nocivas. São Paulo: BASF, 2.ed., Tomo I, 825p, 1997. 
RODRIGUES, B.N.; ALMEIDA, F.S. (Ed.). Guia de herbicidas. 6 ed. Londrina, PR: Edição dos autores, 2011. $697 \mathrm{p}$.

TECNOLOGIAS de produção de soja - Região Central do Brasil -. Londrina: Embrapa Soja: Embrapa Cerrados: Embrapa Agropecuária Oeste, 2008. p. 153-170 (Embrapa Soja. Sistemas de Produção,13) 2010.

VELINI, E. D. et al., Modo de ação do glyphosate. Botucatu: Fundação de Estudos e Pesquisas Florestais, 2009. p. 113-133.

VIDAL, R. A. Herbicidas: mecanismos de ação e resistência de plantas. PortoAlegre: Palotti, 1997. 


\title{
CAPÍTULO XXIII
}

\section{ANÁUSE COMPORTAMENTAL DE CULTIVARES DO FEUNÃO CAUPI COM A UTIUTACÃO DE DIFERENTES SUBSTRATOS ORGÂNICOS}

\section{DOI: 10.51859/amplla.mas481.1121-23}

\author{
Raimara Reis do Rosário ${ }^{1}$ \\ Otoniel Monteiro da Costa Neto ${ }^{1}$ \\ Nazaro Cavalcante Bandeira Neto ${ }^{1}$ \\ Mateus Ferreira Barbosa ${ }^{1}$ \\ João Victor da Silva Pinheiro de Nazaré ${ }^{1}$ \\ Francimary da Silva Carneiro ${ }^{1}$
}

${ }^{1}$ Faculdade de Ciências Agrárias do Pará -UFRA

\section{RESUMO}

O estudo foi realizado com objetivo de avaliar o desenvolvimento das cultivares do feijão caupi BRS IMPONENTE e BRS TRACUATEUA de acordo com a produção de massa verde $(P M V)$, relação parte aérea raiz (RPAR) e matéria fresca da raiz (MFR). Os tratamentos utilizados no trabalho são constituídos do tratamento controle (TC) e doses de substratos orgânicos utilizando o caroço de açaí (CDA), a casca de castanha (CDC) e o esterco de ovino (EDO) que passaram por quatro repetições. O experimento foi conduzido em casa de vegetação na Universidade Federal Rural da Amazônia (UFRA), no período de 32 dias, e foi utilizado o delineamento inteiramente casualizado com plantas do grupo adubado e testemunha. O teste utilizado foi o de Tukey no programa Sisvar 5.6 com variância a 5\%. Concluiu-se que a casca de açaí obteve vantagens sobre os demais tratamentos como maior ganho de altura, produção de massa verde e massa fresca da raiz, portanto, deixando claro sua vantagem produtiva associada aos outros fertilizantes naturais.

Palavras-chave: Caroço de açaí. Casca de castanha. Esterco de ovino. Produção de massa verde. Relação parte aérea raiz.

\section{INTRODUÇÃo}

Os grãos de feijão caupi (Vigna unguiculata (L.) Walp.) possuem alto valor proteico e seu cultivo é realizado principalmente nos países da Ásia e da África (FREIRE FILHO et al., 2005). Eles possuem boas características de adaptabilidade a diferentes climas (FREIRE FILHO, 2011), o que representa o oportuno investimento na espécie a fim 
de produzir alimento de bom valor nutritivo para locais onde a baixa produtividade é constante.

Esse grão se tornou essencial na alimentação da população de baixa renda da região Norte do Brasil (RODRIGUES et al., 2015) já que o tipo BRS TRACUATEUA PURIFICADA é rico em proteína, aminoácidos, carboidratos, vitaminas, minerais e fibras (MOREIRA et al., 2017) e o tipo BRS IMPONENTE é rico em ferro e zinco, além de serem visualmente maiores, gerando maior aceitação do consumidor (EMBRAPA, 2016). Além disso, se torna alternativa econômica para os pequenos empresários e agricultores paraenses, que mesmo usando práticas tradicionais, conseguem se aproximar da produção média nacional, gerando assim, emprego e renda à população rural local (NEVES et al., 2008).

O feijão caupi não é muito exigente em termos de fertilidade do solo (SAMPAIO et al., 2009) o que não significa que esta cultura não seja responsiva a adubação e/ou irrigação, entre outros tratos culturais. Portanto, pesquisas voltadas a fisiologia e o manejo da adubação dessa planta podem contribuir para o desenvolvimento dessa cultura tão importante para o Brasil (CAMPANHARO et al., 2013).

A cultivar BRS Tracuateua ganha destaque pela crescente incorporação de alta tecnologia ao seu processo produtivo, o que tem exigido o uso de cultivares com porte, ciclo e grãos mais uniformes. Recomenda-se que seja feito um bom preparo do solo, e que a correção da acidez e a adubação sejam definidas com base nos resultados da análise de fertilidade do solo (SAMPAIO et al., 2009). Nos ecossistemas tropicais a matéria orgânica do solo apresenta demasiada importância, haja vista que seus benefícios à física, química e biologia do solo, tais como: retenção de água, melhor agregação, melhor CTC, maior disponibilidade de nutrientes e adição de microrganismos benéficos presentes no material orgânico, são fundamentais ao bom desenvolvimento dos vegetais (ZANDONADI et al., 2014).

A quantidade estocada de matéria orgânica no solo é determinada pela interação entre os fatores responsáveis pela sua formação e decomposição, isso para todo e qualquer agroecossistema (LEITE et al., 2003). A introdução de produtos de origem orgânica no solo reflete em melhorias significativas para o mesmo, as quais se 
caracterizam pela disponibilização gradual de nutrientes, contribuindo na redução de processos como erosão, lixiviação, volatilização e fixação (ZECH et al., 1997).

Segundo Junqueira et al. (2000), a agricultura orgânica passou a ganhar maior notoriedade e consolidação no início da década de 60, em virtude de alguns questionamentos acerca dos efeitos negativosque o modelo de agricultura convencional proporciona quando manuseado incorretamente. Tais como: perigos à saúde humana, oriundos do uso de agrotóxicos, redução da biodiversidade, desenvolvimento de plantas com pouca resistência ao ataque de pragas, doenças de desequilíbrio nutricional, solos mais susceptíveis a erosão e lixiviação e exclusão socioeconômica.

Em virtude deste cenário, o consumo de produtos orgânicos tem apresentado um crescimento de $50 \%$ ao ano (SANTOS et al., 2001). Isso porque a busca por uma alimentação mais saudável e pautada em cultivos orgânicos é crescente, dessa forma, a necessidade de uso de sistemas altamente produtivos que proporcione qualidade, quantidade e regularidade (FURLANI et al., 2010), que utilizem adubos de origem orgânica em conjunto com defensivos alternativos no controle de pragas e doenças, a fim de se evitar resíduos químicos nos produtos e melhorando a qualidade de vida dos produtores e consumidores, além depreservar a natureza (MEIRELLES, 1997).

Os estudos acerca da utilização da adubação orgânica, de diferentes formas e fontes apontam as vantagens de seu uso para melhoria da produtividade das culturas, além de seus efeitos benéficos para as características químicas, físicas e biológicas do solo, e o aproveitamento de resíduos de diferentes fontes para a produção dos compostos orgânicos (FINATTO et al., 2013).

Diante disso, são apresentados estudos que objetivam melhorar o desempenho das culturas mediante o uso da adubação orgânica, preconizando o melhor desenvolvimento das mesmas. Dessa forma, neste trabalho apresentamos os resultados obtidos de um estudo de 32 dias de acompanhamento, analisando as respostas e o desempenho das duas cultivares de feijão-caupi (BRS IMPONENTE e BRS TRACUATEUA PURIFICADA), submetidas a diferentes substratos orgânicos com a finalidade de discernir o seucomportamento. 


\section{METODOLOGIA}

O experimento foi conduzido no período de junho a julho de 2018 e foi realizado em casa de vegetação da área de Ciência do solo da Universidade Federal Rural da Amazônia, localizada no Município deBelém - PA, sob as coordenadas geográficas $48^{\circ}$ $26^{\prime} 28^{\prime \prime}$ de longitude Oeste de Greenwich e latitude sul 01일 $97^{\prime \prime}$, com altitude de 13 metros.

O clima do município, segundo a classificação de Köppen e Geiger, se enquadra no tipo Afi, caracterizado como clima tropical úmido ou superúmido, pluviosidade significativa ao longo do ano, com média anual de $2.537 \mathrm{~mm}$, temperatura média é de $26,8{ }^{\circ} \mathrm{C}$ e umidade relativa de $84 \%$ (BASTOS et al., 2002). O preparo do composto orgânico ocorreu na horta da Universidade Federal Rural da Amazônia, no campus de Belém, onde foi preparado utilizando casca de castanha do Pará, caroço de açaí e esterco de ovino comocomponente energético.

O delineamento experimental utilizado foi o inteiramente casualizado, com oito tratamentos distribuídos em quatro repetições, totalizando 32 unidades experimentais. O fatorial foi adubação x cultivar. Os tratamentos foram apenas o solo (TC - tratamento controle) e adubação orgânica (AO). Para a medição das variáveis de resposta - produção de massa verde (PMV), relação parte aérea raiz (RPAR), massa fresca daraiz (MFR) - foi utilizada uma balança simples, para pesagem do solo e dos compostos orgânicos foi utilizada a balança Balmak $^{\circledR}$, régua para a medição da parte aérea e raiz. O método estatístico foi o Tukey e o programautilizado foi o Sisvar 5.6 com variância a 5\%.

\section{RESULTADOS E DISCUSSÃO}

\subsection{PRODUÇÃO DE MASSA VERDE ENTRE AS CULTIVARES}

De acordo com Maranho et al. (2012), em seu trabalho relacionando diferentes porcentagens de resíduo orgânico de açaí na produção de mudas de Pau-de-Rosas (Physocalymma scaberrimum), foi constatado que o maior crescimento ocorreu com a utilização do substrato contendo 100\% de resíduo de açaí. Em relação a observação feita neste trabalho, a análise para a interação entre as cultivares com a adubação orgânica, de acordo com os dados obtidos, revelou que a cultivar BRS Imponente comportou-se 
como superior à BRS Tracuateua nos tratamentos com o caroço de açaí e esterco de ovino; o tratamento controle demonstrou a similaridade estatística que houve entre as mesmas; e que o substrato da casca de castanha foi o único em que a cultivar BRS Imponente esteve abaixo da cultivar BRS Tracuateua.

Gráfico 1: Gráfico relativo à produção de massa verde (PMV) entre as cultivares.

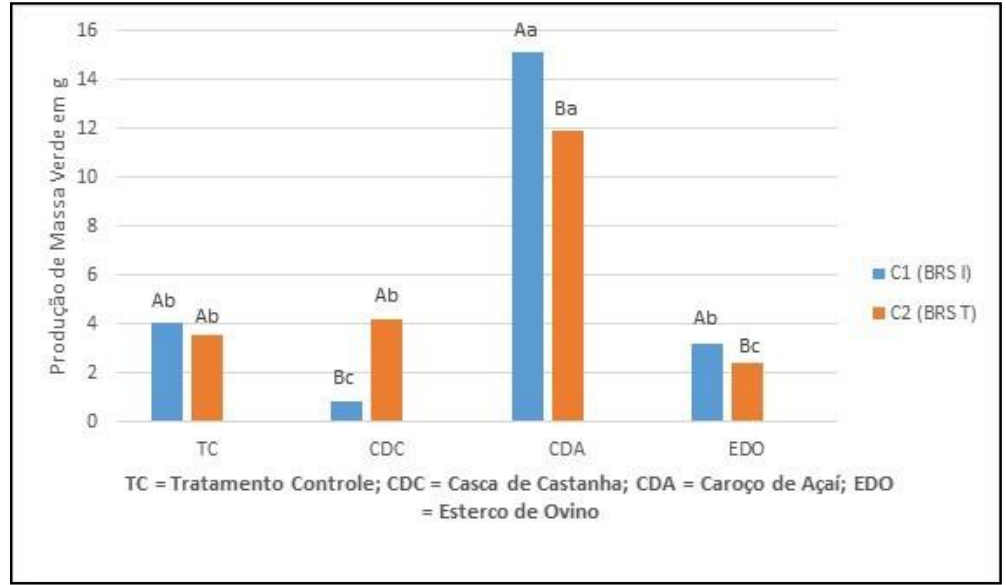

Os valores obtidos para a resposta das adubações para as cultivares de modo isolado indicou que a cultivar BRS Imponente obteve o melhor rendimento para o tratamento com o caroço de açaí, o qual teve amaior resposta de produção de massa verde no vegetal, seguido do tratamento controle e do tratamento com o esterco de ovino que tiveram similaridades de acordo com a análise estatística e o pior resultado apresentado pelo cultivar foi para o tratamento com a casca de castanha. De igual modo, analisando de formaisolada a cultivar BRS Tracuateua, os melhores resultados foram para os tratamentos utilizando o caroço deaçaí que teve expressiva diferença entre os demais, precedido pelos tratamentos com a casca de castanha eo tratamento controle que obtiverem resultados semelhantes de acordo com a análise estatística e o pior resultado foi para o tratamento com o esterco de ovino que demonstrou a menor produção de massa verde.

\section{PARTE AÉREA X RAIZ ENTRE AS CULTIVARES}

Segundo Erlacher et al. (2016), para todas as hortaliças estudadas em seu trabalho, notou-se que o número de folhas, área foliar e altura média das mudas foram 
significativamente influenciadas pelos diferentes tipos de substratos utilizados, com destaque para as mudas produzidas no substrato $A$ (caroço deaçaí triturado fermentado) e no substrato $B$ (composto à base de caroço de açaí triturado e esterco bovino).Em relação à presente análise do tema proposto, foi constatado que a BRS Tracuateua Purificada obteve um desenvolvimento satisfatório da parte aérea $\mathrm{x}$ raiz quando submetida a caroço de açaí, ao tratamento controle, a casca de castanha e ao esterco de ovino, respectivamente. Diferente da BRS Imponente que apresentou menor desenvolvimento a estes tratamentos, apesar desta ter obtido um resultado aproximadoa BRS Tracuateua no tratamento controle e com caroço de açaí.

Gráfico 2: Gráfico relacionado a parte aérea x raiz entre as cultivares sob os diferentes tratamentos orgânicos.

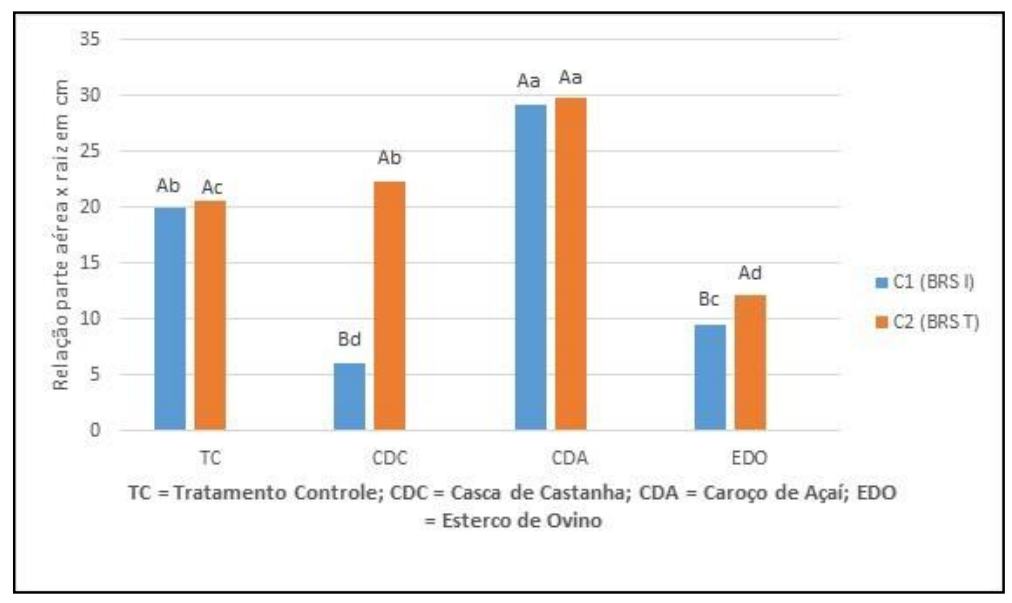

A cultivar C1 teve os tratamentos com o caroço de açaí e controle com os resultados estatisticamente semelhantes dentro do desdobramento da adubação e foram os melhores, seguido do tratamento com o esterco de ovino e casca de castanha que tiveram resultados semelhantes de acordo com a análise estatística.

\section{MASSA FRESCA DA RAIZ ENTRE AS CULTIVARES}

No trabalho de Erlacher et al. (2016), sua pesquisa verificou que a massa fresca (MFR) e seca (MSR) das raízes das mudas foram significativamente influenciadas pelos substratos utilizados, tendo como destaque os substratos A e B que apresentaram a maior MFR e MSR, em comparação aos substratos C e D (Figura 3). Tal fato pôde ser 
constatado no presente trabalho, em que a relação à massa fresca da raiz, tendoem vista que a BRS Imponente novamente apresentou uma melhor resposta ao tratamento com caroço de açaí, seguida do esterco de ovino quando comparada a BRS Tracuateua, porém apresentou seu pior desenvolvimento novamente quando cultivada na casca de castanha, enquanto que a BRS Tracuateua alcançou um melhor resultado com tratamento controle e casca de castanha.

Figura 3: Gráfico relacionado a massa fresca da raiz entre as cultivares sob os diferentes tratamentos orgânicos.

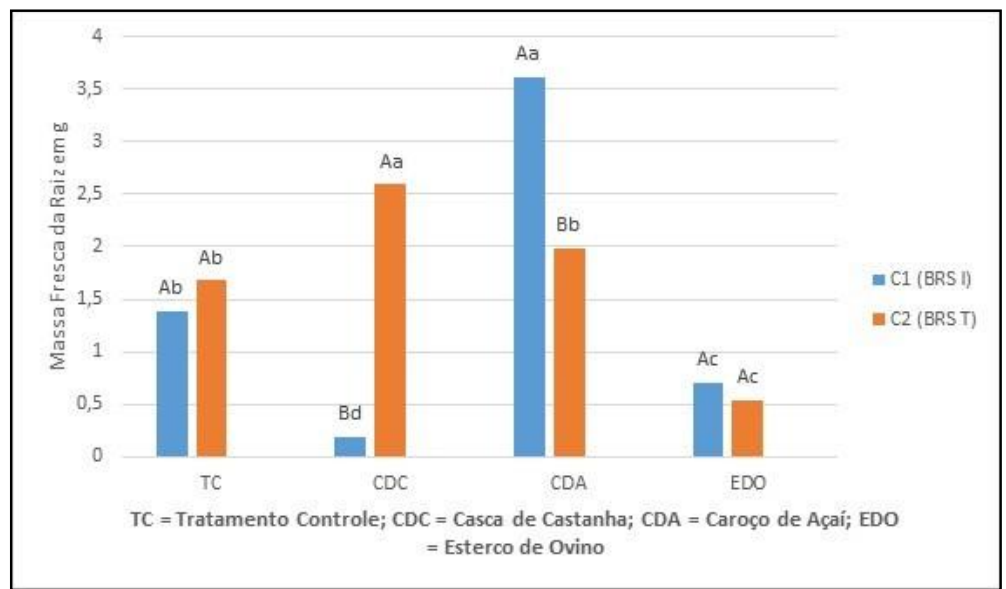

Consoante Figueiredo et al. (2012) diz que os estercos de caprinos e ovinos, por possuírem uma espécie de membrana que os revestem e tornam- os duros quando excretados, possuem uma maior resistência à decomposição. Tal situação é comprovada, em relação ao esterco de ovino utilizado, pois tantoa BRS Imponente quanto a BRS Tracuateua apresentaram baixa massa fresca da raiz devido a lenta decomposição do esterco, impedindo um maior fornecimento de nutrientes para as cultivares e consequentemente uma baixa produção de massa fresca da raiz.

\section{CONCLUSÃO}

O caroço de açaí obteve vantagens sobre os demais tratamentos como maior ganho de altura, produção de massa verde e massa fresca da raiz, deixando claro sua vantagem produtiva associada aos outrosfertilizantes naturais. 


\section{REFERÊNCIAS}

BASTOS, T. X.; PACHECO, N. A.; NECHET, D.; SÁ, T. D. A. Aspectos climáticos de Belém nos últimos cem anos Documentos 128. Manaus: Embrapa Amazônia Oriental, 2002.

CAMPANHARO, M.; MONNERAT, P. H.; ESPINDULA, M. C.; RABELLO, W. S.. Doses de níquel em feijão caupi cultivado em dois solos. Revista Caatinga, Mossoró, v.26, n.4, p.10-18, 2013.

ERLACHER, W. A.; OLIVEIRA, F. L.; SILVA, D. M. N.; QUARESMA, M. A. L.; MENDES, T. P.. Estratégias de uso de caroço de açaí para formulação de substratos na produção de mudas de hortaliças. Magistra, Cruz das Almas, v.28, n.1, p.119-130, 2016.

FIGUEIREDO, C. C.; RAMOS, M. L. G.; MCMANUS, C. M.; MENEZES, A. M.. Mineralização de esterco de ovinos e sua influência na produção de alface. Horticultura Brasileira, Brasília, v.30, n.1, p.175-179, 2012. DOI: https://doi.org/10.1590/S0102-05362012000100029

FINATTO, J.; ALTMAYER, T.; MARTINI, M. C.; RODRIGUES, M.BASSO, V.; HOEHNE, L.. A importância da utilização da adubação orgânica na agricultura. Revista Destaques Acadêmicos, v.5, n.4, 2013.

FREIRE FILHO, F. R.. Feijão-caupi no Brasil: produção, melhoramento genético, avanços e desafios. Teresina:Embrapa Meio-Norte, 2011.

FREIRE FILHO, F. R.; ROCHA, M. M.; RIBEIRO, V. Q.; LOPES, Â.C. A.. Adaptabilidade e estabilidade produtiva de feijão-caupi. Ciência Rural, v.35, n.1, p.24-30, 2005. DOI: https://doi.org/10.1590/S0103-84782005000100005

FURLANI, P. R.; PURQUERIO, L. F. V.. Avanços e desafios na nutrição de hortaliças. In: PRADO, R. M.; CECÍLIO FILHO, A. B.; CORREA, M. A. R.; PUGA, A. P.. Nutrição de plantas: diagnose foliar em hortaliças. Jaboticabal: FCAV, 2010. p.45-62.

JUNQUEIRA, A. H.; LUENGO, R. F. A. Mercados diferenciados de hortaliças. Horticultura Brasileira, Brasília,v.18, n.2, p.95-99, jul. 2000.

LEITE, L. F. C.; MENDONÇA, E. S.; NEVES, J. C. L.; MACHADO, P. L. O. A; GALVÃO, J. C. C.. Estoques totais de carbono orgânico e seus compartimentos em argissolo sob floresta e sob milho cultivado com adubação mineral e orgânica. Revista Brasileira de Ciência do Solo, Viçosa, v.27, n.5, p.821-832, 2003. DOI: http://dx.doi.org/10.1590/S0100-06832003000500006.

MARANHO, Á. S.; PAIVA, A. V.. Produção de mudas de Physocalymma scaberrimum em substratos compostos por diferentes porcentagens de resíduo orgânico de açaí. Floresta, v.42, n.2, p.399-408, 2012. 
MEIRELLES, L.. Produção e comercialização de hortaliças orgânicas. Horticultura Brasileira, v.15, p.205-210, 1997.

SAMPAIO, L. S.; BRASIL, E. C.. Exigência nutricional do feijão-caupi. In: CONGRESSO NACIONAL DE FEIJÃO-CAUPI: DA AGRICULTURA DE SUBSISTÊNCIA AO AGRONEGÓCIO, 2. Anais. Belém: Embrapa Amazônia Oriental, 2009.

SANTOS, R. H. S.; SILVA, F.; CASALI, V. W. D.; CONDE, A. R. Efeito residual da adubação com composto orgânico sobre o crescimento e produção de alface. Pesquisa Agropecuária Brasileira, Brasília, v.36, n.11, p.1395-1398, 2001.

ZANDONADI, D. B.; SANTOS, M. P.; MEDICI, L. O.; SILVA, J. Ação da matéria orgânica e suas frações sobre a fisiologia de hortaliças. Horticultura Brasileira, v.32, n.1, p.14-20, 2014.

ZECH, W.; SENESI, N.; GUGGENBERGER, G.; KAISER, K.. Factor controlling humification and mineralization of soil organic matter in the tropics. Geoderma, v.79, n.1-4, p.117-161, 1997. 


\section{CAPITTULO XXIV}

\section{CONTAMINACG̃O DO AR, DO SOLO E DA ÁGUA POR PESTICIDAS USADOS NA AGRICULTURA}

1,2,3,4,5 Programa de Pós-graduação Mestrado em Desenvolvimento de Processos Ambientais, Universidade Católica de Pernambuco - UNICAP. 50.050-900 Recife-PE, Brasil

${ }^{6}$ Pós-doutora em Microbiologia e Imunologia. Professora Titular da Universidade Católica de Pernambuco - UNICAP. 50.050-900 Recife-PE, Brasil

\section{RESUMO}

Conviver com um meio ambiente sadio é um direito fundamental da humanidade desde a Declaração de Estocolmo, redigida na Conferência das Nações Unidas em 1972, mas, apesar dos esforços mundiais na diminuição da contaminação do meio ambiente, cada país institui em seus territórios, recomendações e legislações pra evitar que a população seja exposta a substâncias nocivas. Essas substâncias recebem o nome de defensivos agrícolas ou pesticidas vem sendo amplamente empregados por décadas, visando ao aumento ad produção de alimentos, como medida para acabar a fome. Contudo, o resultado apenas beneficia grandes commodities em detrimento da contaminação dos alimentos e do ecossistema, incluindo o ser humano. Este trabalho aborda os vários tipos de pesticidas, seus mecanismos de ação, além dos efeitos na saúde humana e ao meio ambiente, visando esclarecer os processos de contaminação ambiental mediados por defensivos usados na agricultura.

Palavras-chave: Pesticidas. Meio Ambiente. Contaminação.

\section{INTRODUÇÃO}

De acordo com Barbieri (2012), tudo o que envolve ou cerca os seres vivos corresponde ao meio ambiente. O planeta com todos os elementos que o constituem são a própria condição da existência de vida na Terra. Para a lei 6.938 (1981), que gere a Política Nacional do Meio Ambiente no Brasil- AIA, o meio ambiente é "o conjunto de condições, leis, influências, alterações e interações de ordem física, química e biológica 
que permite, abriga e rege a vida em todas as suas formas." Os elementos naturais e construídos constituem o habitat, sendo o homem um agente que modifica e é modificado por ele, estando todos os elementos em constante interação e integração.

O processo de industrialização se expandiu com a Revolução Industrial e gerou desenvolvimento social e inovações tecnológicas em áreas como saúde, educação, transportes e agricultura, contudo, também levou ao maior consumo de recursos ambientais na mesma proporção em que jogava seus produtos danosos ao meio ambiente sem preocupação com os resultados à longo prazo (SILVA JUNIOR, 2019).

Um meio ambiente sadio é um direito fundamental da humanidade desde a Declaração de Estocolmo, redigida na Conferência das Nações Unidas em 1972. A Constituição Brasileira de 1988, descreve que é direito e dever dos cidadãos brasileiros um meio ambiente equilibrado.

Devido a suas propriedades de evitar ou conter efeitos indesejados com a presença de qumicro-organismos, insetos, ervas daninhas ou roedores na agricultura, os agrotóxicos são sinônimos de pesticidas, praguicidas, agroquímicos, entre outros, e evitam que as pragas afetem o desenvolvimento das plantações. Usado amplamente na agropecuária, por madeireiras, na preservação de estradas, no manejo florestal, desinfecção e desratização, contudo, constituem um grande fator de risco a saúde ambiental e humana (ROLIM, 2018). A exposição se dá de diversas maneiras, como o descarte de resíduos em efluentes usados para captação de água para abastecimento urbano, distribuição pelo vento ou lixiviados pela chuva, além do tratamento direto em sementes usadas para plantio, bem como a pulverização em folhas dos vegetais e frutos (CARVALHO, 2019).

Com a promessa de acabar com a fome mundial, a comercialização e o uso de agrotóxicos foram expandidos após a Segunda Guerra Mundial, visando ao aumento da produção agrícola e facilitando o desenvolvimento das plantações. Assim, espera-se garantir uma produção de qualidade e em quantidade para a população que se mantém em expansão, sem impactar negativamente o meio ambiente e ao próprio ser humano é um grande desafio (NASCIMENTO, 2016). 


\section{PESTICIDAS}

De acordo com o Artigo 2o da lei 7.802 de 11 de julho de 1989, agrotóxicos são definidos como "agentes e produtos de processos físicos, químicos ou biológicos destinados ao uso nos setores de produção, armazenamento e beneficiamento de produtos agrícolas, nas pastagens, proteção de florestas nativas ou implantadas, de outros ecossistemas e também ambientes urbanos, hídricos e industriais cuja finalidade seja alterar a composição da flora ou fauna, a fim de preservá-las das ações danosas de seres vivos considerados nocivos" (BRASIL, 1989).

Os pesticidas têm várias designações genéricas como biocidas e defensivos agrícolas, que levam a um significado comum, mas, quimicamente, eles se agrupam de acordo com a sua composição química. Os pesticidas matam ou controlam o processo reprodutivo de um organismo prejudicial à lavoura, sendo diferenciados segundo alguns critérios em antibacterianos, fungicidas, inseticidas e herbicidas. Todos os pesticidas químicos são desenvolvidos para alterar um processo metabólico que seja vital ao organismo alvo (NASCIMENTO, 2016).

Podem ser classificados de acordo com o grupo alvo, conforme a tabela 1 apresentada abaixo:

Tabela 1 - Classificação dos agrotóxicos segundo os organismos que controlam

\begin{tabular}{c|c}
\hline Grupos de pesticidas & Pestes controladas \\
\hline Acaricidas & Aves \\
Avicidas & Ácaros \\
Bactericidas & Bactérias \\
Carrapaticidas & Carrapatos \\
Columbicidas & Pombos \\
Cupinicidas & Cupins \\
Formicidas & Formigas \\
Fungicidas & Fungos \\
Herbicidas & Ervas Daninhas \\
Inseticidas & Insetos \\
Larvicidas & Larvas \\
Molusquicidas & Moluscos \\
Nematicidas & Vermes \\
\hline
\end{tabular}




\begin{tabular}{c|c} 
Piolhicidas & Piolhos \\
Pisticidas & Peixes \\
Predacitas & Vertebrados \\
Pulguicidas & Pulgas \\
Raticidas & Roedores
\end{tabular}

Fonte: Lima, 2017.

De acordo com LIMA (2017), quimicamente os pesticidas podem se dividir em dois grandes grupos: orgânicos e inorgânicos. Elementos como arsênio (As), mercúrio $(\mathrm{Hg})$, chumbo $(\mathrm{Pb})$ e cobre $(\mathrm{Cu})$, entre outros, são base para os pesticidas de origem inorgânica.

Os orgânicos constituem o grupo com mais alta atividade fisiológica, podendo ser de acordo com sua origem vegetal ou sintética. Grupos como piretrina, nicotina, rotenona e sabatina são os principais e compõem os pesticidas orgânicos de origem vegetal. Os orgânicos têm em sua composição cloro $(\mathrm{Cl})$ e anéis aromáticos, ésteres de ácido metilcarbônico, fósforo $(P)$ e variações as quais serão apresentadas adiante.

\subsection{ORGANOCLORADOS}

Os pesticidas organoclorados (PCO's) foram um dos primeiros grupos de pesticidas desenvolvidos. São substancias sintéticas com cadeia cíclica e possuem em sua composição cloro $(\mathrm{Cl})$, carbono $(\mathrm{C})$ e hidrogênio $(\mathrm{H})$, sendo a ligação química entre os dois primeiros elementos um tipo de ligação estável e de difícil quebra, o que caracteriza esta classe de defensivos como a que possui alta estabilidade e grande persistência no meio ambiente, com tendência forte a bioacumulação nos tecidos dos seres vivos do ecossistema (NASCIMENTO, 2016). Apesar de não ser tóxico para o ser humano, a cadeia alimentar expõe o homem a biomagnificação por acumulação ao se alimentar dos animais expostos a essas substancias de meia vida longa (CARVALHO, 2019).

Além dessas características, possuem baixa pressão de vapor e solubilidade em água, alta toxicidade para insetos e alta solubilidade em solventes orgânicos. O DDT ou diclorodeniltricloroetano é o mais antigo representante deste grupo, e possui como derivados o DDD ou para-diclorodeniltricloroetano, Metoxiclor e Dicofol, com as estruturas químicas dispostas abaixo na figura 1 abaixo: 
Figura 1 - Formas estruturais dos organoclorados DDT e seus derivados
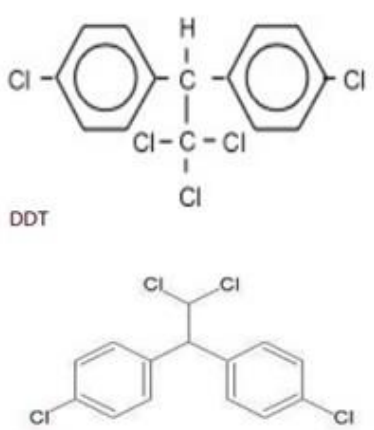

DDD
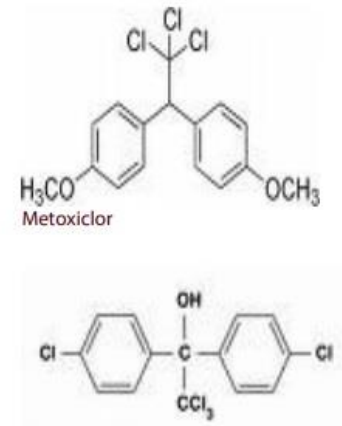

Dicofol

Fonte: Nascimento, 2016.

Além de seu uso na agricultura, foi muito utilizado para repelir pragas domésticas, na saúde pública para controle de vetores de doenças infecciosas, o uso dos PCO's foi banido de vários países há alguns anos. Alguns estudos associam os organoclorados a distúrbios metabólicos crônicos, como a diabetes mellitus 2, devido ao seu mecanismo de ação que interfere na função pancreática e consequente desequilíbrio da glicose no organismo, além de outros mecanismos que podem estar associados a redução de atividade metabólica, mas que ainda estão em estudo (CARVALHO, 2019).

\subsection{ORGANOFOSFORADOS}

Compostos organofosforados possuem ligação química forte e estável entre o fósforo e o carbono $(\mathrm{P}-\mathrm{C})$, constituindo um grande grupo de produtos químicos usados em larga escala nos últimos 60 anos não só para proteger a agricultura, mas também como na saúde e na indústria automobilística, polímeros, perfumes e removedores de tinta (BARBOZA, 2018). Quanto a química dos compostos, os mais comuns de inseticidas organofosforados estão apresentadas na figura 2. 
Figura 2 - Estrutura química dos principais organofosforados

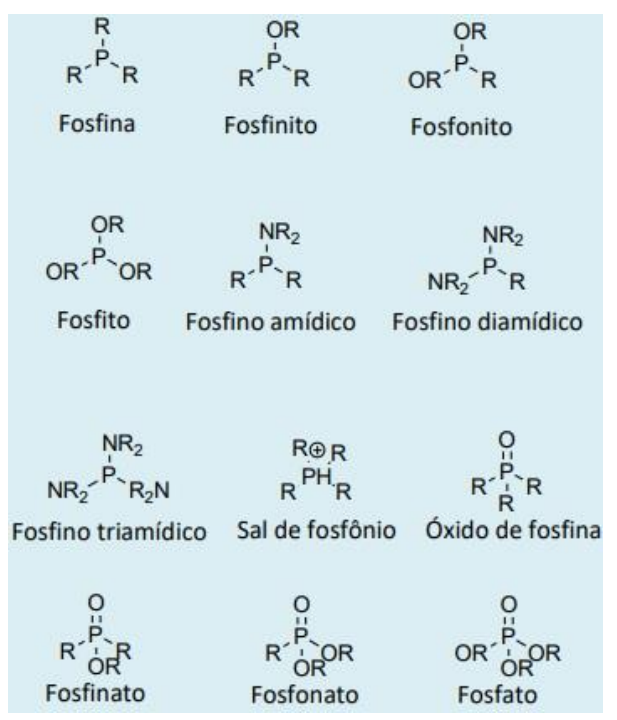

Fonte: Barboza, 2018.

Conhecidos "como gases dos nervos" na Segunda Guerra Mundial, utilizados como inibidores irreversíveis da acetilcolinesterase e apresenta maior toxicidade aguda aos mamíferos do que os organoclorados, levando a problemas imediatos de saúde, como alterações no sistema nervoso, toxicidade direta a diversos órgãos e tecidos, alterações endócrinas e imunológicas, entre outras (BASTOS, 2018). São altamente lipossolúveis e a exposição se dá por absorção pela pele, via inalatória ou ingestão e oferece perigo não só a pessoa exposta, mas a qualquer outra a qual tenha contato.

Se decompõem rapidamente e por isso seus efeitos crônicos são raramente observados, mas que possuem alto potencial carcinogênico. O principal meio de dispersão é pelo ar, onde os gases podem chegar até $2 \mathrm{~km}$ além do ponto onde foram aplicados, mas também podem se diluir na água, podendo causar infiltração no solo, e assim, contaminando mananciais, bem como o seu direto descarte sem o devido tratamento em efluentes e rios (NASCIMENTO, 2016).

A figura 3 apresenta as estruturas químicas dos dois mais conhecidos organofosforados, o Malathion e o Parathion: 
Figura 3 - Formas estruturais de dois pesticidas organofosforados<smiles>CCOC(=O)CC(SP(=S)(OC)OC)C(=O)OCC</smiles>

Malathion

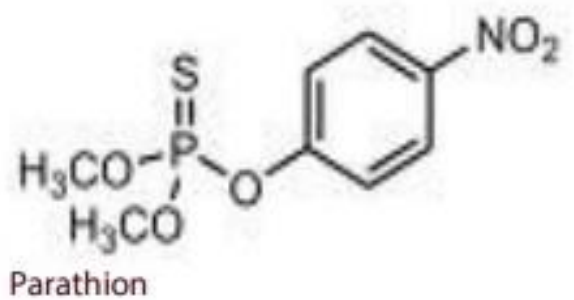

Fonte: Nascimento, 2016.

\subsection{CARBAMATOS}

Introduzidos no mercado em 1951, os carbamatos são o grupo de pesticidas mais versátil, pois a partir de substituições em radicais de sua estrutura química podem se obter inseticidas, herbicidas, fungicidas e até antibacterianos. São agrotóxicos orgânicos sintéticos e apresentam menor toxicidade e menor tempo de meia vida no meio ambiente em relação aos organoclorados e organofosforados. Apesar da pouca persistência, causa efeitos tóxicos como náuseas, diarreias, vômitos, sudorese, contração muscular e hiperatividade, possivelmente devido a acumulação de acetilcolina nos neurônios no sistema nervoso (NASCIMENTO, 2016; OLIVEIRA, 2017).

Os carbamatos chegam a água através de resíduos não tratados e descartados em rios e contaminam as águas superficiais, causando efeitos adversos também nos animais aquáticos, apesar de ser rapidamente decomposto. Quimicamente, são derivados do ácido carbâmico $\left[\mathrm{H}_{2} \mathrm{NCOOH}\right]$, com substituições em seus radicais que lhes confere versatilidade. A fórmula geral dos carbamatos com seus locais de possíveis substituições e as estruturas formadas. 
Figura 4 - Fórmula geral dos carbamatos e seus radicais<smiles>[R1]NC(=O)O[R2]</smiles>

Fonte: Oliveira, 2017.
a) Substituição em $R_{1}$ com metil: inseticidas carbamato;
b) Substituição em $R_{1}$ com porção aromática: herbicidas carbamato;
c) Substituição em $R_{1}$ com porção benzimidazol: fungicida carbamato;

Figura 5 - Estruturas formadas após substituições dos radicais da estrutura principal<smiles>CNC(=O)Oc1cccc2ccccc12</smiles>

Carbaril<smiles>CC(=O)Oc1nc(N)nc(C)c1C</smiles>

Pirimicarbo<smiles>CNC(=O)Oc1ccccc1OC(C)C</smiles>

Propoxur(Baygon)

Fonte: Nascimento, 2017.

\subsection{PIRETRÓIDES}

Apesar de apresentarem alta taxa de sucesso no tratamento de pragas a um custo menor de impacto ambiental e toxicidade, os piretróides contaminam ar, água e solo, trazendo diversos efeitos adversos mesmo que temporário, e são utilizados nos modelos de simulação de ecotoxicológica. Os piretróides são muito usados, tem apresentado um risco mais alto aos pássaros e mamíferos, devido à ação semelhante ao DDT no sistema nervoso central (NASCIMENTO, 2016).

Quimicamente, podem ter origem sintética ou natural e apresentam ésteres em sua estrutura, possibilitando as moléculas configurações Cis/Trans. Os isômeros Cis apresentam toxicidade maior em relação à configuração Trans, mas, a mistura racêmica varia de acordo com a relação entre os isômeros e com o veículo usado na dispersão do agrotóxico. A figura 6 mostra as estruturas mais conhecidas deste tipo de inseticida, 
entre elas a Deltametrina e a Permetrina, usados no controle e combate à escabiose humana.

Figura 6 - Fórmulas estruturais de alguns piretróides

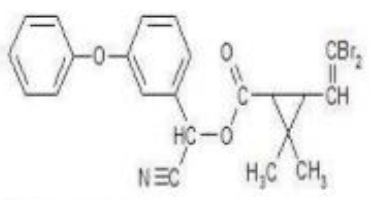

Deltametrina

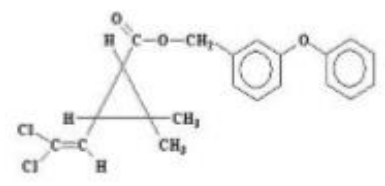

Permetrina

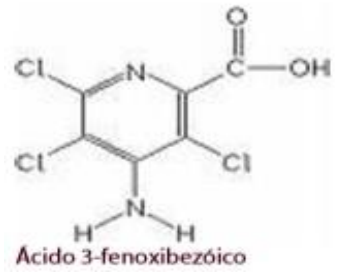

Fonte: Nascimento, 2016.

\section{TOXICIDADE DOS PESTICIDAS}

A toxicidade de uma substância é avaliada conforme sua capacidade de afetar a saúde de determinada população a partir de seu princípio ativo e formulação. Para isso, é usado parâmetro chamado Dose Média Letal ( $\left.D L_{50}\right)$, em que após estudos e cálculos, é feita a administração oral de dose referente à unidade $\mathrm{mg} / \mathrm{kg}$ do peso do animal necessário para matar metade da população da espécie. Este parâmetro determina a toxicidade aguda, e a partir dessa determinação é possível classificar os agrotóxicos pelo grau de toxicidade em quatro grupos ou classes, que devem os produtos comerciais apresentar o grau toxicológico por cores em seus rótulos (NASCIMENTO, 2016; OLIVEIRA, 2017), conforme tabela 2. 
Tabela 2 - Apresentação das classes de toxicidade dos agrotóxicos

\begin{tabular}{c|c|c}
\hline Classe toxicológica & Descrição & Faixa indicativa \\
\hline II & Extremamente tóxicos & Vermelho \\
$\left(\mathrm{DL}_{50}<50 \mathrm{mg} / \mathrm{kg}\right.$ de peso $)$ & Amarelo \\
III & Muito tóxicos & Azul \\
& $\left(\mathrm{DL}_{50}-50\right.$ a $500 \mathrm{mg} / \mathrm{kg}$ de peso $)$ \\
IV & $\left(\mathrm{DL}_{50}-500\right.$ a $5000 \mathrm{mg} / \mathrm{kg}$ de & \\
& peso $)$ & Verde \\
\end{tabular}

Fonte: Oliveira, (2017)

O potencial de periculosidade ambiental do agrotóxico é avaliado de acordo com os parâmetros de bioacumulação, potenciais mutagênicos, teratogênicos e carcinogênicos, toxicidade a diversas espécies, transporte e persistência como apresentado na tabela 3.

Tabela 3 - Grau de periculosidade dos agrotóxicos de acordo com as Classes

\begin{tabular}{c|c}
\hline Classe & Graduação \\
\hline I & Altamente perigoso \\
II & Muito perigoso \\
III & Perigoso \\
IV & Pouco perigoso \\
\hline
\end{tabular}

Fonte: Oliveira, (2017)

A persistência de uma substância é avaliada de acordo com os processos de degradação abiótica (hidrólise, oxidação e fotólise) e biótica (metabolismo e biodegradação), sendo medida como tempo de meia vida $\left(T^{1 / 2}\right)$. Este parâmetro é medido conforme a taxa de desprendimento do Carbono (C) em 28 dias, expressa em porcentagem (LIMA, 2017). 


\section{TOXICIDADE E MEIO AMBIENTE}

A contaminação direta é o tipo mais comum de disseminação de pesticidas no meio ambiente, onde há a aplicação direta em diversos segmentos sendo o principal deles a agricultura e por resíduos industriais da produção de pesticidas. Com facilidade os compostos toxicantes entram em contato com o solo e penetram em lençóis freáticos, chegando a rios que cortam cidades ou abastecem a população. Resíduos das embalagens também disseminam os pesticidas que se distribuir, degradar ou acumular nos vários compartimentos do meio ambiente.

Fatores como as propriedades físico-químicas do princípio ativo, características ambientais e a forma como são usados são fatores que vão determinar a dinâmica dos pesticidas no meio ambiente (NASCIMENTO, 2016).

\subsection{TOXICIDADE E SEUS EFEITOS NA SAÚDE HUMANA}

Os pesticidas são alvo de grande preocupação da comunidade de saúde pública, mesmo eles sendo muito importantes no aumento da conservação e produtividade dos alimentos. Isso porque o seu uso está diretamente relacionado também ao surgimento de desequilíbrios que desencadeiam doenças desde bactérias até os seres humanos, passando por várias espécies de animais e o próprio meio ambiente (SANTOS, 2018).

Seus efeitos nocivos são observados desde a mudança na constituição genética das bactérias até problemas de desregulação metabólica no homem, a depender do tipo, grau e tempo de exposição ao agente tóxico. Sobre a saúde humana, os efeitos podem ser agudos, capazes de causar danos aparente e efetivo dentro de 24horas, e os efeitos crônicos, resultada de uma exposição mais contínua e prolongada mesmo sendo em doses baixas do contaminante (NASCIMENTO, 2016).

A subnotificação das intoxicações por pesticidas no Brasil é um grande obstáculo para o mapeamento de casos, onde acredita-se que para cada registro, outros cinquenta sejam ignorados ou tenham seu registro feito de forma equivocada. A Organização Mundial da Saúde (OMS-WHO) estima que cerca de 70\% dos casos estejam ligados a ocupação do indivíduo na agricultura (NASCIMENTO, 2016). Abaixo apresenta-se a tabela 4, com os principais efeitos crônicos e agudos de acordo com a praga e o pesticida empregado. 
Tabela 4 -Principais efeitos crônicos e agudos relacionado aos grupos químicos dos inseticidas

\begin{tabular}{|c|c|c|c|}
\hline Classificação & Grupo químico & Intoxicação aguda & Intoxicação crônica \\
\hline \multirow[t]{3}{*}{ Inseticidas } & $\begin{array}{l}\text { Organofosforados e } \\
\text { Carbamatos }\end{array}$ & $\begin{array}{l}\text { Fraqueza, cólica } \\
\text { abdominal, espasmos } \\
\text { musculares, } \\
\text { convulsão }\end{array}$ & $\begin{array}{l}\text { Efeitos neurológicos } \\
\text { retardados, alterações } \\
\text { cromossomais, } \\
\text { dermatites de contato }\end{array}$ \\
\hline & Organoclorados & $\begin{array}{l}\text { Náuseas, vômitos, } \\
\text { contrações } \\
\text { musculares } \\
\text { involuntárias }\end{array}$ & $\begin{array}{l}\text { Arritmia cardíaca, lesões } \\
\text { renais, neuropatias } \\
\text { periféricas }\end{array}$ \\
\hline & Piretróides sintéticos & $\begin{array}{l}\text { Irritação das } \\
\text { conjuntivas, espirros, } \\
\text { excitação, convulsão }\end{array}$ & $\begin{array}{l}\text { Alergias, asma brônquica, } \\
\text { irritação das mucosas, } \\
\text { hipersensibilidade }\end{array}$ \\
\hline \multirow[t]{3}{*}{ Fungicida } & Dicarbamatos & $\begin{array}{l}\text { Tonteira, vômito, } \\
\text { tremores musculares, } \\
\text { de de cabeça }\end{array}$ & $\begin{array}{l}\text { Alergias respiratórias, } \\
\text { dermatites, doença de } \\
\text { Parkinson, cânceres }\end{array}$ \\
\hline & Fentalamidas & - & Teratogênese \\
\hline & $\begin{array}{l}\text { Dinitrofenóis } \\
\text { pentaclorofenol }\end{array}$ & $\begin{array}{l}\text { Dificuldade } \\
\text { respiratória, } \\
\text { hipertermia, } \\
\text { convulsão }\end{array}$ & Câncer, cloroacnes \\
\hline \multirow[t]{2}{*}{ Herbicida } & Fenoxicacéticos & $\begin{array}{l}\text { Perda de apetite, } \\
\text { enjoos, } \\
\text { fasciculação muscular }\end{array}$ & $\begin{array}{l}\text { Indução da produção de } \\
\text { enzimas hepáticas, } \\
\text { cânceres, teratogênese }\end{array}$ \\
\hline & Dipiridilos & $\begin{array}{l}\text { Sangramento nasal, } \\
\text { fraqueza, desmaio, } \\
\text { conjuntivite }\end{array}$ & $\begin{array}{l}\text { Lesões hepáticas, } \\
\text { dermatites de contato, } \\
\text { fibrose pulmonar }\end{array}$ \\
\hline
\end{tabular}

Fonte: Santos, (2017)

Os efeitos nocivos do uso dos pesticidas tiveram grande notoriedade na sociedade com a publicação em 1962 da obra de Rachel Carson chamada "Primavera Silenciosa", que relata o efeito dos defensivos agrícolas, principalmente o DDT, no meio ambiente e principalmente, nas aves que tiveram problemas na espessura da casca de seus ovos, causando problemas reprodutivos, levando a morte. Na primavera daquele ano não se viu a revoada dos pássaros nas ondas migratórias e a obra literária ajudou mais tarde na proibição de uso do DDT e saída do mercado (OLIVEIRA, 2017). 
A inibição da AChE (enzima Acetilcolinesterase) é o mecanismo de ação comum aos pesticidas orgânicos. Esta enzima encerra as transmissões colinérgicas na fenda sináptica, degradando o neurotransmissor Acetilcolina ( $\mathrm{ACh}$ ), que tem importância vital para os insetos. O bloqueio da atividade da AChE causa um acúmulo de ACh dentro das sinapses e consequente interrupção neurotransmissora em insetos. No ser humano, esse acúmulo causa problemas de contração na musculatura esquelética e lisa, mediada pelos receptores nicotínicos e muscarínicos, respectivamente, e que são ativados pela ACh (BARBOZA, 2018).

Ocorre uma superestimação dos receptores nicotínicos e muscarínicos no Sistema Nervoso Central (SNC) e Periférico (SNP), que leva a graves sintomas e até a morte. Isso porque a musculatura atingida se relaciona com músculos e também órgãos vitais, além de glândulas endócrinas importantes para a homeostase do corpo humano.

Contudo, os efeitos tóxicos do bloqueio da atividade da enzima anticolinesterase (AChE) podem ser usados de forma terapêutica e tratar doenças. Assim, podem atuar como fármacos, a exemplo, têm sido empregados como anti-retrovirais, no tratamento de Alzheimer e de doenças ósseas, além de anti-hemínticos para expulsar parasitas de animais domésticos (BARBOZA, 2018).

\section{CONSUMO NO BRASIL}

A base da economia da maioria dos países emergentes é a produção agrícola, principalmente, a monocultura de exportação e devido a isso, usa agrotóxicos em larga escala na lavoura. Mesmo não sendo o maior agroexportador mundial, desde 2008 o Brasil é o maior consumidor de agrotóxicos e ultrapassando até os Estados Unidos, consumindo cerca de $20 \%$ da produção do planeta (OLIVEIRA, 2017; ROLIM, 2018;)

Desde a década de 1960 e junto com a automação das lavouras brasileiras, os agrotóxicos tiveram seu uso estimulado com a implantação do Sistema Nacional de Crédito Rural (SNCR), que estipulava uma porcentagem para a compra dos produtos. Este tipo de incentivo fiscal associado a outros incentivos tributários, ausência de marco legal, o pouco conhecimento dos trabalhadores sobre os pesticidas e o retorno financeiro extremamente favorável formavam um grande mercado consumidor para estes produtos. (OLIVEIRA, 2017; ROLIM, 2018). 
A balança comercial positiva e os ganhos financeiros mascaram as perdas com os incentivos e com a saúde pública e meio ambiente para tratar os problemas decorrentes das contaminações com os toxicantes. Grandes fornecedores geralmente dominam todo o mercado, fornecendo as sementes, o medicamento e o próprio agrotóxico no país que é o terceiro produtor de alimentos do mundo (NOGUEIRA, 2019).

A rede criada em torno dos agrotóxicos não gira em torno apenas dos ganhos financeiros, mas também da contaminação que pode ser de forma direta ou indireta. Além dos próprios produtos agrícolas, contaminam-se os trabalhadores rurais e as pessoas próximas a ele e a plantação, o solo e lençóis freáticos. O produto vai para a indústria contaminado e segue a amplia para mais pessoas. A chuva faz a lixiviação do produto a lugares mais longe, rios e bacias que podem ser usadas para captação de água ou que passem por centros urbanos. Dessa forma, todo ciclo biogeoquímico é comprometido e mais indivíduos entram em contato com os poluentes (NOGUEIRA, 2019).

\section{CONSIDERAÇÕES FINAIS}

\subsection{CONTAMINAÇÃO DO AR}

Inseticidas de uso doméstico têm grande apelo e visibilidade da mídia e são comumente usados para contenção de insetos nas residências. As propriedades tóxicas são na maioria dos casos desconhecidas da maioria das pessoas, mas as formulações contêm não apenas os princípios ativos pesticidas, mas também, diversos solventes, adjuvantes e propelentes que também possuem efeitos nocivos sobre o ser humano. Segundo o estudo realizado por RIOS (2017), foram encontrados em exames laboratoriais evidências de distúrbios de imunidade humoral e celular. Sintomas neurológicos comuns também são observados e provém de intoxicação aguda, como distúrbios visuais e auditivos, redução de performance intelectual e polineuropatias sensitivo-motoras. A exposição crônica pode levar a problemas reprodutivos, respiratórios, cardiovasculares e sobre o sistema nervoso. 


\subsection{CONTAMINAÇÃO DO SOLO}

Os solos recebem grande quantidade de poluentes e são objeto de estudo de várias linhas de pesquisa quanto a permanência e influência desses contaminantes residuais nos alimentos e vegetação local. Cembranel (2017) avaliou as concentrações de organoclorados e organofosforados em sendimento de lago urbano no sul do Brasil. Coletando amostras a cada três meses entre abril de 2010 a junho de 2013, obteve modelos que abrangiam as quatro estações do ano, em pontos diferentes do mesmo lago.

Após a análise em aparelhos adequados, encontrou quantidades significativas de ambos os tipos de pesticidas, sendo os organoclorados de possíveis atividades do passado, enquanto que os organofosforados eram recentes e oferecia potencial risco de efeitos adversos nos organismos viventes do ambiente.

\subsection{CONTAMINAÇÃO DA ÁGUA}

Constituindo parte essencial para vida humana na terra, a água é o habitat natural de diversas espécies de seres que pertencem à cadeia alimentar do homem, que contribuem para o equilíbrio do ecossistema marinho como um todo. A contaminação da água é preocupante do ponto de vista da saúde pública, pois como elemento primordial e extremamente necessário, é utilizado em diversas atividades e inclusive a agricultura.

Em pesquisa realizada nos mananciais de cinco municípios do sudoeste do Paraná por Vieira (2017), buscou-se identificar e quantificar vinte e nove agrotóxicos em amostras coletadas entre 2015 e 2016, empregando análise cromatográfica. Os resultados indicaram oito compostos, estando entre eles o Malathion (presente em cinco amostras), a atrazina encontrada em duas amostras com concentração maior do que a permitida pela legislação brasileira.

A atrazina é um herbicida muito usado no Brasil, apesar de ser banido em diversos países, devido a sua elevada toxicidade. Como contaminante de águas tanto superficiais como subterrâneas, devido a elevada solubilidade apresenta grande capacidade adsortiva e pode ser carreado pelas moléculas de carbono (C) em suspensão, 
deixando a mensagem a elavada toxicidade e do perigo do uso dos defensivos na agricultura.

\section{AGRADECIMENTOS}

Os autores agradecem o suporte financeiro da Capes (Edital Pró-equipamentos, No. 843504/2017 e Bolsas PPGDPA-CAPES), CNPq (Processo No. 314422/2018-8), FACEPE (APQ-0638-2.01/19 e Bolsa Processo: IBPG-1803-3.06/19) e UNICAP, Bolsa PPGDPA-FASA(Fundação Pe. Abranches).

\section{REFERÊNCIAS}

BARBIERI, José Carlos. Gestão ambiental empresarial: conceitos, modelos e instrumentos. 3‥ ed. atual e ampliada. São Paulo: Saraiva, 2012, 376 p.

BRASIL. Lei no 6.938, de 31 de agosto de 1989. Dispõe sobre a Política Nacional do Meio Ambiente, seus fins e mecanismos de formulação e aplicação, e dá outras providências. Diário Oficial, Brasília, DF, 31 de ago. 1981. Seção 1, p. 2.

SILVA JUNIOR, H. O. et al. Perícia ambiental aplicada no controle da poluição do solo e águas superficial e subterrânea. Marupiara - Revista científica do centro de estudos superiores de Parintins. ISSN 2527-0753. N 5, 2019, p. 16-30.

ROLIM, C. R. C. Agrotóxicos e as repercussões na saúde dos trabalhadores rurais. Universidade Federal de Campina Grande, PB. 2018.

BRASIL. Lei no 7.802, de 11 de julho de 1989. Dispõe sobre a pesquisa, a experimentação, a produção, embalagem e rotulagem, transporte, armazenamento, comercialização, propaganda comercial, utilização, importação, exportação, destino final de resíduos, registros, classificação, controle, inspeção e fiscalização de agrotóxicos, seus componentes e afins, e dá outras providências. Diário Oficial, Brasília, DF, 11 de jul. 1989.

NASCIMENTO, L. MELNYK, A. A química dos pesticidas no meio ambiente e na saúde. Revista Mangaio Acadêmico - ISSN 2525-2801. V 1, n 1, 2016.

CARVALHO, A. P. G. da C. at al. Detecção de pesticidas organoclorados na água e a associação da exposição humana a esses poluentes com risco de diabetes mellitus tipo 2. Revista Destaques Acadêmicos Lajeado - ISSN 2176-3070, v 11, n 3, 2019. Disponível em <http://dx.doi.org/10.22410/issn.21763070.v11i3a2019.2171> 
BARBOZA, H. T. G. et al. Compostos organofosforados e seu papel na agricultura. Revista Virtual de Química, Sociedade Brasileira de Química (SBQ) - ISSN 1984-6835. V 10, n 1, 2018.

Bastos, P.L, Bastos, A.F.T.L, Gurgel, A.M, Gurgel, I.G.D.. Carcinogenicidade e mutagenicidade do malathion e seus dois análogos: Uma revisão sistemática. Cien Saude Colet. 2018. Disponível em: < http://www.cienciaesaudecoletiva.com.br/artigos/carcinogenicidade-e mutagenicidade-do-malathion-e-seus-dois-analogos-uma-revisaosistematica/17011? $\mathrm{id}=17011>$.

OLIVEIRA, K. C. Desenvolvimento e validação do método multiresíduos de carbamatos em pimentão. 2017. 75f. Dissertação (Mestrado em Química) - Programa de PósGraduação em Química, Universidade Federal do Rio Grande do Norte, Natal, 2017.

LIMA, J. T. da S. Remoção do pesticida Metomil de água e efluentes via fotólise e processos de oxidação avançada. 2017. 55f. Dissertação (Bacharelado em Engenharia Química) - Departamento de Engenharia Química, Universidade Federal da Paraíba, João Pessoa, 2017.

SANTOS, M. G. B. Integração dos processos de coagulação-floculação, foto-fenton e/ou fotocatálise para o tratamento de efluentes de pesticidas. 2018. 69f. Dissertação (Bacharelado em Química Industrial) - Universidade Federal de Uberlândia, Uberlândia, 2018.

NOGUEIRA, V. M. D. Uma síntese histórico jurídica da segurança alimentar e nutricional e do impacto ambiental dos agrotóxicos. Revista da Defensoria Pública da União, Brasília - DF. N. 12, p. 1-480, 2019.

RIOS, E. M. Determinação da distância de alcance dos pesticidas utilizados em forma de spray automático. 2017. 52f. Dissertação (Mestrado em Bioquímica) Universidade Federal do Pampa, Uruguaiana, 2017.

CEMBRANEL, A. S. Pesticidas em sedimento de lago urbano. 2017. 55f. Dissertação (Doutorado em Engenharia Agrícola) - Universidade Estadual do Oeste do Paraná Campus Cascavel, Cascavel, 2017.

VIEIRA, M. G. et a. Avaliação da contaminação por agrotóxicos em mananciais de municípios da região sudoeste do Paraná. Revista Virtual Química - Sociedade Brasileira de Química ISSN 1984-6835. V. 9, n. 5, p. 1800-1812, 2017. 


\section{CAPITULO XXV}

\section{GESSO E COPRODUTOS DE MINERACR̃O NA CORRECÃO DE UM SOLO SALNO-SÓDICO PARA PRODUCG̃OO NO SEMIÁRIDO}

DOI: 10.51859/amplla.mas481.1121-25

Maria José de Holanda Leite ${ }^{1}$

${ }^{1}$ Doutora em Ciências Florestais

\section{RESUMO}

A degradação dos solos pelo excesso de sais gera problemas ambientais e socioeconômicos. Para a recuperação dessas áreas há a necessidade de aplicação de corretivos. Por outro lado, a quantidade de rejeito de mineração causa grande problema ambiental, cujos subprodutos tem potencial para uso como corretivo agrícola. Percebese claramente que a gessagem é benéfica no condicionamento químico da subsuperfície do solo, possibilitando maior crescimento do sistema radicular em profundidade e, com isso, maior acesso das plantas à água e nutrientes no solo. Adicionalmente, como o gesso é fonte de enxofre, pode ser recomendado objetivando apenas o suprimento destes nutrientes para os cultivos. Recomenda cerca de $500 \mathrm{~kg} / \mathrm{ha}$ de gesso para 0 suprimento de $\mathrm{S}$ para uma sequência de até três ciclos de culturas anuais. A necessidade de fertilizar com $\mathrm{S}$ tem aumentado nos últimos anos devido ao uso de fertilizantes NPK concentrados, não mais contendo o S como nutriente acompanhante; ao menor uso de pesticidas ricos em $\mathrm{S}$ e à maior exportação deste nutriente pelas culturas em crescente aumento de produtividade e índices de colheita. Para tanto, deve-se utilizar aproximações de recomendações disponíveis nos diferentes manuais de adubação e calagem para as diferentes regiões brasileiras. A gessagem pode ser realizada em qualquer época do ano, devendo-se preferir a aplicação em períodos mais secos para preservar a estrutura do solo do tráfego de máquinas em solo úmido. A aplicação pode ser realizada juntamente com o calcário ou separadamente. A incorporação do gesso no solo acelera o efeito da gessagem na subsuperficie. Entretanto, não havendo possibilidade de incorporação, como em cultivos perenes ou em sistemas de plantio direto, ainda assim haverá condicionamento da subsuperfície, porém, podendo demandar mais tempo.

Palavras chave: Aridez. Corretivo Químico. Áreas Degradadas.

\section{INTRODUÇÃO}

As regiões áridas e semiáridas são caracterizadas por altas temperaturas, baixas precipitações e elevados índices de evaporação. Devido à irregularidade das chuvas 
nestas regiões, surge a necessidade do uso de irrigação reduzindo os prejuízos à agricultura. Na falta de orientação técnica, os pequenos agricultores se deparam com alguns problemas de salinização nos solos, provocando diminuições consideráveis na produção agrícola, o que proporciona o abandono de lotes.

No Brasil as áreas salinas localizam-se na região Nordeste ou mais especificamente nos perímetros irrigados, encontrados no Polígono das Secas e perfazem $57 \%$ da área total da região semiárida (RIBEIRO et al., 2003). São vários os perímetros irrigados no Nordeste: Morada Nova-CE, Lima Campos-CE, Moxotó-PE, Curu Paraipiacaba-CE, São Gonçalo-PB, Sumé-PB e Capoeira-PB.

Os solos com problemas de salinidade são caracterizados por profunda heterogeneidade, apresentando manchas desnudas e propriedades químicas e físicas desfavoráveis às plantas, especialmente os solos sódicos, que apresentam, normalmente, reação alcalina, com valores de $\mathrm{pH}$ superiores a 8,5 e elevada concentração de cátions desódio adsorvido no complexo trocável, resultando em solo impermeável. Nos solos salinos os sais acumulam-se rapidamente na superfície do solo, promovendo expressivo aumento da condutividade elétrica, devido à concentração excessiva de sais solúveis. Sob essas condições as plantas são prejudicadas, tendo que se adaptar osmoticamente, devido alteração do sistema fisiológico em consequência do acúmulo excessivo de íons em seus tecidos.

A presença de solos com excesso de sais nos perímetros irrigados é uma realidade na região semiárida. Fato que pode ser atribuído a utilização de água com altos índices de salinidade, adubações incorretas e elevadas taxas de evaporação. Para amenizar os danos causados pelos sais, algumas técnicas podem ser adotadas tais como: aplicação de gesso agrícola que reage quimicamente com os íons, favorecendo sua lixiviação para camadas mais profundas do solo, o emprego de cultivares mais resistente aos sais e a utilização de materiais mais grosseiros que aumentam a porosidade do solo, favorecendo a drenagem. Outros subprodutos como os rejeitos de caulim e vermiculita, mostram-se promissores, além de apresentarem baixo valor comercial e possuírem características favoráveis as espécies vegetais.

As mineradoras dos países desenvolvidos e subdesenvolvidos descartam o material de rejeito de suas matérias primas nas proximidades de suas indústrias, muitas 
vezes permitindo que seja carreado para rios, açudes e lagos, causando grande impacto ambiental em áreas adjacentes. Isto acontece frequentemente devido à desvantagem econômica no reaproveitamento do rejeito da matéria prima pelos custos adicionais com o seu transporte.

A exploração de minérios, apesar de sua expressão econômica, provoca, a princípio, impactos ambientais negativos na fauna e flora local, devido à retirada da cobertura vegetal. Durante o processo de extração, a paisagem é deformada resultando em crateras e túneis que deformam o solo e a paisagem. No beneficiamento há produção de rejeitos de partículas sólidas, águas residuárias, fumaças e subprodutos que degradam o ambiente e o solo. É comum no semiárido a remoção da camada superficial do solo destinada a olarias, caieiras e matéria-prima para construção civil.

O maracujazeiro-amarelo apresenta elevada sensibilidade à ação dos sais. Entretanto, algumas pesquisas têm demonstrado que, apesar da salinidade provocar reflexos negativos no crescimento, na capacidade produtiva da cultura e na qualidade dos frutos (CAVALCANTE et al., 2009), a utilização de fertilizantes orgânicos, como o biofertilizante bovino e rejeitos de mineração, pode amenizar os efeitos da salinidade da água de irrigação, resultando em maior desenvolvimento das mudas e produção das plantas (SOUZA et al., 2008).

Apesar de já existirem pesquisas nesse sentido, o presente trabalho busca novas alternativas na recuperação desses solos afetados por sais e, ao mesmo tempo, dá um destino adequado à grande quantidade de rejeitos acumulados nos pátios das mineradoras da região. Oaproveitamento dos rejeitos de vermiculita e de caulim reduzirá o impacto ambiental causado pelo decapeamento dos solos, os custos de produção de mudas e a quantidade de rejeitos expostos nas áreas de Caatinga.

Ademais, por se tratar de uma revisão de literatura, usaremos como metodologia de pesquisa: artigos, revistas acadêmicas, sites - Google Acadêmico, SciELO, e Periódico (portal da CAPES), TCC's, dissertações e teses. 


\section{REVISÃO DE LITERATURA}

\subsection{ORIGEM E CLASSIFICAÇÃO DOS SOLOS AFETADOS POR SAIS}

Os solos afetados por sais, também conhecidos por solos halomórficos ou solos salinose sódicos, são solos desenvolvidos em condições imperfeitas de drenagem, que se caracterizam pela presença dos sais solúveis, sódio trocável ou ambos, em horizontes ou camadas próximas à superfície.

Segundo o mesmo autor na classificação Americana de 1938, os solos halomórficos foram incluídos na ordem dos solos Intrazonais, aqueles que refletiam na sua formação a influência dominante de um fator local, no caso o excesso de sais solúveis. Estão relacionados, portanto, com condições imperfeitas de drenagem, em regiões áridas ou semiáridas, onde a baixa precipitação pluvial, a presença de camadas impermeáveis e a elevada evapotranspiração contribuem para o aumento das concentrações de sais solúveis na solução do solo (salinidade) e/ou o aumento da percentagem de sódio trocável (sodicidade), interferindo no desenvolvimento normal das plantas.

Os efeitos prejudiciais da salinidade e da sodicidade no crescimento das plantas são conhecidos pelo homem a mais de 2100 anos, quando os sais foram, inclusive, usados como instrumento de guerra pelos Romanos que, após sua vitória sobre os Cartagineses, incorporaram cloreto de sódio nos solos dos arredores da destruída cidade de Cartago, com o intuito de torná-los improdutivos e impedir o ressurgimento da cidade (BRADY; WEIL, 2008).

No Brasil o sistema utilizado para a classificação de solos afetados por sais é baseado nas características propostas por Richards (1954), de acordo com os atributos presentes na Condutividade Elétrica do extrato de saturação (CE) e Percentagem de Sódio Trocável (PST) conforme a classificação de solos afetados por sais: Normal (CE < 4 $\mathrm{dSm}{ }^{-1}$ e PST < 15\%) Salino (CE > $4 \mathrm{dSm}^{-1}$ e PST < 15\%), Salino-sódico (CE > $4 \mathrm{dSm}^{-1}$ e PST >15\%), e Sódico(CE < 4 dSm ${ }^{-1}$ e PST > 15\%).

Os solos com altos teores de sódio no complexo de troca apresentaram condições físicas desfavoráveis que decorrem da dispersão dos colóides e da degradação da estrutura. Estes fenômenos reduzem a permeabilidade do solo à água e 
ao ar. Em razão dos problemas dos sais, os solos podem ser classificados como salinos e salino-sódicos e sódicos (TAVARES FILHO (2010). A salinidade refere-se à concentração de sais solúveis do solo e aos aspectos tóxicos e osmóticos dos nutrientes, relacionados com a nutrição mineral das plantas. A alcalinidade relaciona-se mais à ação dos sais sobre os solos, que promovem a alteração da estrutura, diminuição da infiltração de água, da condutividade hidráulica e da aeração, além de concentrar o solo em sódio trocável, carbonato e bicarbonato (CAVALCANTE et al., 2000).

Os solos que apresentam altas concentrações de sais solúveis e altos teores de sódio trocável são chamados de solos salino-sódicos. Para ascondições do Nordeste brasileiro estes solos possuem CE do extrato de saturação $>4 \mathrm{dS} \mathrm{m}^{-1}$, PST > 15\% e pH raramente $>8,5$. Geralmente na correção desses solos o uso de corretivos minerais como o gesso associados à lixiviação tem efeitos benéficos (BARROS et al., 2005).

\subsection{FATORES DE SALINIZAÇÃO E EFEITOS DOS SAIS SOBRE O SOLO}

É frequente o surgimento de solos salinizados nas regiões áridas e semiáridas, em razão das altas temperaturas e baixo índice de precipitação. Isso pode ocorrer também em função dá não eficiência nouso da água na irrigação associados à mineralogia do solo, ocorrendo principalmente em áreasque apresentam algumas restrições para a produção agrícola no mundo inteiro e em especial na região do Nordeste brasileiro.

Assim como outras características químicas e físicas, os sais presentes no solo e na água são fatores muito variáveis tanto no espaço, quanto no tempo. Os fatores mais diretamente responsáveis por esta salinidade são: a natureza química dos solos, as interações com outros fatores, aumentando na perda de permeabilidade, elevação do nível do lençol freático e as variáveis climáticas, como pluviosidade, irregularidade de distribuição das chuvas, além das perdas hídricas por evaporação e evapotranspiração (ARAÚJO, 2009).

Os solos que apresentam grandes quantidades de sódio trocável não dispõem de condições favoráveis para agricultura, devido aos efeitos presentes nas propriedades do solo, como por exemplo, solo menos permeável, o que dificulta a infiltração da água e consequentemente a produção agrícola (SANTOS et al., 2010). 
O principal problema de áreas com solos salinizados e salinização secundaria, estão mais visíveis no Nordeste do semiárido, em que se observa maior quantidade de áreas irrigadas, principalmente nos perímetros irrigados, sobretudo aqueles que usam o sistema de inundação, pois proporciona elevação do lençol freático (OLIVEIRA, 1997).

\subsection{EFEITO DOS SAIS SOBRE AS PLANTAS}

Os mecanismos fisiológicos primários das plantas que promovem redução no crescimento submetidas ao estresse salino se manifestam, inicialmente, em escala de horas ou dias, resultantes dos efeitos osmóticos dos sais presentes no solo, que ocasionam estresse hídrico. Posteriormente, após semanas ou meses de exposição ao estresse salino, os declínios na atividade meristemática e no alongamento celular decorrem quando os sais absorvidos se acumulam nos diferentes tecidos vegetais, provocando desequilíbrio nutricional, toxicidade iônica e consequentes distúrbios funcionais e injúrias no metabolismo das plantas (MUNNS; TESTER, 2008).

Os efeitos negativos dos sais nas plantas também estão associados ao desbalanço nutricional em decorrência da redução da disponibilidade de $\mathrm{K}^{+}, \mathrm{Ca}^{2+}{\mathrm{e} \mathrm{Mg}^{2+}}^{2+}$ pela alta concentração de $\mathrm{Na}^{+}$no solo ou na água de irrigação; à toxidez por elevado teor de íons como o $\mathrm{Na}^{+}, \mathrm{Cl}^{-}$ou $\mathrm{SO}_{4}{ }^{2-}$ nas plantas, com prejuízos nas funções dos sistemas enzimáticos e síntese proteica. Essas inconveniências interferem na estrutura, na função de enzimas ou do $\mathrm{K}^{+}$e no efeito osmótico, restringindo a absorção de água pelas raízes, sob baixo potencial hídrico da solução do solo, resultando em diminuição na turgescência celular, abertura estomática e assimilação líquida de $\mathrm{CO}_{2}$ (FREIRE, 2011).

Algumas frutíferas produzem rendimentos aceitáveis sob condições salinas, em virtudeda melhor adaptação osmótica, com maior capacidade de absorção de água, mesmo em ambientes com potenciais osmóticos muito baixos (FLOWERS, 2004). Conforme Silveira et al. (2010), os primeiros efeitos causados pelo excesso de sais às plantas são de natureza biofísica, destacando-se os efeitos osmóticos com restrições ao transporte de água no interior das células vegetais.

\subsection{USO DE CORRETIVOS EM SOLOS SALINIZADOS}

A correção de solos afetados por sais tem como objetivo principal a redução daconcentração dos sais solúveis e do sódio trocável no perfil do solo a um nível não 
prejudicial ao desenvolvimento das culturas. A diminuição do teor de sódio trocável envolve o seu deslocamento do complexo de troca pelo cálcio antes do processo de lixiviação.

Por apresentar baixo custo e relativa abundância, pois é encontrado em várias partesdo mundo, o gesso é o corretivo mais utilizado na correção de solos sódicos e salino-sódicos. O corretivo é fonte de cálcio responsável pelo deslocamento do sódio trocável, e de íon sulfato, que neutraliza o sódio da solução, originando o sulfato de sódio decahidratado $\left(\mathrm{Na}_{2} \mathrm{SO}_{4} \cdot 10 \mathrm{H}_{2} \mathrm{O}\right)$ que é mais facilmente lixiviado.

Para correção de solos salinos a lixiviação de sais pode ser feita de duas maneiras: Lavagem contínua - a água é adicionada a ponto de cobrir a superfície do solo com uma lâmina de $10 \mathrm{~cm}$ de altura pela adição frequente de água (PIZARRO, 1985). Esse método permite que os sais sejam removidos mais rapidamente e que o cultivo seja feito mais cedo. Este tipo de lavagem é recomendado para solos de boa permeabilidade, lençol freático profundo e alta taxa de evaporação. Lavagem intermitente - essa prática é mais recomendada para solos com reduzida capacidade drenagem, lençol freático elevado e água subterrânea de baixa salinidade. Deve ser aplicada nos períodos de baixa taxa de evaporação.

\subsection{GESSO AGRICOLA E MATÉRIA ORGÂNICA}

Os solos salino-sódicos e sódicos por serem ricos em sódio trocável, não podem ser recuperados apenas com a lavagem. Nesses solos há necessidade da aplicação de um corretivo químico, de preferência à base de cálcio, que através das reações disponibilize este cátion (Ca), com a finalidade de substituir o sódio do complexo de troca e transferi-lo para a solução do solo (VITAL et al., 2005).

O gesso de jazidas é um minério que ocorre abundantemente em todo o mundo e quando moído sua solubilidade é cerca de $2,04 \mathrm{~g} \mathrm{~L}^{-1}$ a $25^{\circ} \mathrm{C}$. Usualmente, ocorre como a forma dihidratada $\left(\mathrm{CaSO}_{4} \cdot 2 \mathrm{H}_{2} \mathrm{O}\right)$, embora a semi-hidratada $\left(\mathrm{CaSO}_{4} \cdot 1 / 2 \mathrm{H}_{2} \mathrm{O}\right)$ e a anidra $\left(\mathrm{CaSO}_{4}\right)$, sejam encontrados naturalmente. No Brasil, o gesso é encontrado na Chapada do Araripe, na divisa dos estados do Ceará e Pernambuco. Os depósitos de gesso podem apresentar impurezas de carbonatos de cálcio e magnésio, sais de sulfato, assim como óxidos de cálcio, magnésio e ferro (TAVARES FILHO, 2010. 
O gesso agrícola, independente de incorporado ou aplicado na superfície, diminuiu a força de retenção de água, aumentou a macroporosidade e a dinâmica da água no solo. Entretanto, os resultados mais expressivos corresponderam aos tratamentos com o gessoincorporado na dose de $75 \%$ da necessidade de gesso do solo (MORAIS et al., 1997).

A matéria orgânica exerce ação de condicionador físico e contribui para a melhoria química e biológica dos solos (BAYER; MIELNICZUK, 1999). Entretanto, por ser qualitativamente o mais completo dos insumos, quantidades elevadas podem incrementar consideravelmente o conteúdo salino do solo ou do substrato, prejudicando a germinação das sementes, o crescimento das mudas e o rendimento das plantas (SÁ, 1999).

Adição de esterco, resíduos de colheitas e resíduos industriais orgânicos no solo, melhora diversos aspectos de um solo degradado por sais e sódio, como por exemplo a estrutura e a infiltrabilidade de água no solo.

Para Nunes (2008), a adição de esterco bovino, e resíduos orgânicos do solo, melhoram vários aspectos de um solo afetado por sais e sódio degradado, como exemplo a estrutura e a infiltração de água no solo e que o uso do gesso em combinação com matéria orgânica melhora a condutividade hidráulica dos solos degradados por sódio.

\subsection{COPRODUTOS DE MINERAÇÃO}

Para Pereira et al. (2008), a mineração causa vários danos ao meio ambiente, o que relaciona-se com a forma inadequada de descarte dos rejeitos e resíduos oriundos da lavra,que acaba afetando a superfície do terreno, degradando o solo e comprometendo sua paisagem. A grande quantidade de rejeitos das mineradoras podem causar diversos problemas para os produtores rurais da região. A quantidade de argila produzida a partir do processo de lavra ou mineração provoca a degradação física, na maioria das vezes de forma drástica, podendo causar grande impacto visual, alterações na topografia, erosão do solo, assoreamentode drenagens, dentre outros.

As diversas atividades de mineração, talvez a extração de Rochas e Minerais Industriais, seja uma das operações que mais prejudica o meio ambiente, e em muitos casos deforma irreversível, pois a quantidade de resíduos gerados quase sempre é muito 
grande, isso acaba agredindo bastante o meio ambiente, alterando as características ecológicas e prejudicando a fauna e a flora do local (Perez, 2001).

Segundo o mesmo autor, além dos danos que podem causar pelo volume de resíduos gerado, é preciso considerar outras características ambientais negativas decorrentes das explorações minerais: a primeira é que a localização das pedreiras e minas tem de ser feita no lugar onde existe o jazimento, o que não ocorre com outros tipos de indústrias; este fato pode causar danos ecológicos ou paisagísticos.

A segunda é que a mineração é sempre agressiva ao meio em que se situa; os enormes volumes que são necessários tratar formam sinais visíveis na superfície terrestre difíceis de ocultar, afetando a fauna e a flora, e o clima, pelas explosões, poeira e contaminação química por compostos de tratamento, piorando a qualidade de vida dos habitantes mais próximos, entre os quais se encontram os próprios mineiros.

A terceira característica está ligada à produção de resíduos que tem a ver com a possível contaminação de leitos fluviais e de aquíferos e a possibilidade, portanto, de transferir o dano para lugares afastados da própria mina.

\subsection{CAULIM}

O caulim pode ser utilizado para diversos fins, como para a produção de cerâmicas, porcelanas, tintas, alimentos, cosméticos entre outros.

Apesar de a exploração de caulim ter grande importância socioeconômica, apresenta elevado índices de poluição, já que 70\% da matéria-prima empregada no beneficiamento é descartada no meio ambiente na forma de rejeito, o que resulta em grandes impactos ambientais, sobre o solo, os mananciais de água, a vegetação e um grande impacto visual (ROLIM, 2003). Durante seu processamento, ocorre produção de rejeitos líquidos, que são lançados nos rios, e sólidos, geralmente aterrados (PEREIRA et al., 2008).

A exploração industrial do minério caulim, apesar de sua importância econômica, tem demonstrado um grande potencial poluidor, uma vez que em média $70 \%$ da matéria-prima empregada no beneficiamento é descartada no ambiente, na forma de rejeito, resultando em impactos ambientais generalizados sobre o solo, o ar, os mananciais hídricos, a vegetação e a paisagem (ROLIM, 2003). 
Para Feitosa et al. (2007), a utilização agrícola desse rejeito na composição de substratos parece ser uma alternativa ecologicamente correta para o seu aproveitamento racional, o que pode contribuir para minimizar os impactos ambientais provocados pelo mau emprego dos rejeitos desse mineral.

\subsection{VERMICULITA}

A vermiculita é um mineral que pertence ao grupo das micas e forma um silicato hidratado de magnésio, ferro e alumínio. A extração domineral, no estado da Paraíba, realizado na mineradora do Sítio Serrote Branco, localizado no município de Santa Luzia - PB. Na sua forma natural é fonte de Ca, K e Mgpara as plantas no período de estiagem, constituindo-se, também, em ótimo condicionador de solos ácidos e argilosos. Na construção civil, é amplamente utilizado como isolante térmico acústico redutor de peso de estruturas de concreto, produção de tijolos refratários, blocos e placas de cimento resistentes a altas temperaturas, proteção de estruturas de aço contra altas temperaturas e como enchimento para isolamento térmico em construções (ANDRADE; OLIVEIRA; GÓES 2001).

No Brasil há depósitos e jazidas de vermiculita no estado da Paraíba, Goiás e Piauí. Osminérios brasileiros não contêm asbestos, o que confere aos concentrados de vermiculitamaior valor agregado, além de favorecer o melhor aproveitamento econômico do bem mineral. Uma aplicação atrativa para a vermiculita é como material adsorvente/absorvente, devido às propriedades de troca iônica que possui semelhante a algumas argilas e zeólitas, podendo ser utilizada em processos de remoção de contaminantes orgânicos e na purificação de águas residuais contendo sais dissolvidos (OLIVEIRA; UGARTE, 2004).

Sabe-se que, a vermiculita apresenta um grande valor comercial, porém, a prática extrativista tem acarretado um grande número de rejeito na natureza no entorno das mineradoras, pois há poucos estudos sobre o aproveitamento do rejeito produzidos pelas mineradoras, acumulando-se assim o material que poderia ter uma utilidade. 


\section{CONSIDERAÇÕES FINAIS}

Recomenda-se o emprego do gesso em solo salino-sódico. Aconselha-se o uso de matéria orgânica, por melhorarem os atributos químicos dos solos salinizados do semiárido, tornando-os mais propícios para cultivo.

\section{REFERÊNCIAS}

ANDRADE, M.S.; GÓES, M. A. C.; OLIVEIRA, N. M. M. Métodos de prétratamentode vermiculita para caracterização química. 13p. UFRJ, 2001.

ARAÚJO, A. P. B. Análise técnico-econômica da recuperação de um solo sódico no perímetro irrigado Curu-pentecoste-CE. Fortaleza, 2009. 61 f. Dissertação Mestrado. Programa de Pós-Graduação em Engenharia Agrícola. Centro de Ciências Agrárias. Universidade Federal do Ceará. Fortaleza.

BAYER, C.; MIELNICZUK, J. Dinâmica e função da matéria orgânica. In: SANTOS, G. A.; CAMARGO, F. A. O. Fundamentos da matéria orgânica do solo. Porto Alegre: Gênesis, 1999. p. 9-26.

BARROS, M. F. C.; FONTES, M. P. F.; ALVAREZ, V.; V. H.; RUIZ, H. A. Aplicação de gesso e calcário na recuperação de solos salino-sódicos do Estado de Pernambuco.

Revistabrasileira engenharia agrícola e ambiental, v.9, p.320-326, 2005.

CAVALCANTE, L. F.; SOUSA, G. G.; GONDIM, S. C.; FIGUEIREDO, F. L.;CAVALCANTE, I. H. L.; DINIZ, A. A. Crescimento inicial do maracujazeiro amarelo manejado em dois substratos irrigados com água salina. Irriga, Botucatu, v. 14, n. 4, p. 504-517, 2009.

CAVALCANTE, L. F.; ANDRADE, R.; FEITOSA FILHO, J. C.; OLIVEIRA, F. A.; LIMA,

E. M.; CAVALCANTE, I. H. L. Resposta do maracujazeiro-amarelo (Passiflora edulis $\mathrm{f}$. flavicarpa Deg) ao manejo e salinidade da água de irrigação. Agropecuária Técnica, Areia,v. 23, n. 1/2, p.27-33, 2002.

FEITOSA, R. C. Utilização do rejeito de caulim na composição de Substratos para emergência de plântulas de Cuité (crescentia cujete I.) In: Anais do VIII Congresso deEcologia do Brasil, 2007, Caxambu - MG.

FREIRE, J. L. O. Crescimento e desenvolvimento de maracujazeiro amarelo sob salinidade e uso de biofertilizante e cobertura. Areia-PB, 2011, 212 p. PósGraduação emAgronomia da UFPB, Área de Concentração: Solos e Nutrição das Plantas. 
FLOWERS, T. J. Improving crop salt tolerance. Journal of Experimental Botany, v. 55, n. 396, p. $307-319,2004$.

MORAIS, C. D.; CAVALCANTE, L. F.; ARRUDA, N. T. Ação do gesso agrícola sobrealgumas propriedades físico-hídricas de um solo irrigado. Anais do Curso de PósGraduação em Manejo de Solo e Água, Areia, v.17, p.5-16, 1997.

NUNES, E. M. Efeito do gesso, fósforo e adubo verde na absorção de nutrientes pelo feijoeiro (Vigna unguiculata (L.) Walp.) cultivado em solo salino sódico. PATOSPB, 2008. 58 p. Dissertação (Mestrado) - Unidade Acadêmica de Engenharia Florestal, Universidade Federal de Campina Grande.

OLIVEIRA, L. S. M.; UGARTE, J. F. O. Utilização da vermiculita Como adsorvente de óleo da indústria petrolífera. XII Jornada de Iniciação Científica -CETEM, 2004.

OLIVEIRA, M. Gênese, classificação e extensão de solos afetados por sais. In: GHEYI, H. R.; QUEIROZ, J. E.; MEDEIROS, J. M. (ed). Manejo e controle da salinidade na agricultura irrigada. Campina Grande: UFPB/ SBEA, 1997 p 1- 37.

PEREZ, B. C. As rochas e os minerais industriais como elemento de desenvolvimento sustentável. Série Rochas e Minerais Industriais; 3. Centro de Tecnologia Mineral, 37p. Riode Janeiro: CETEM/MCT, 2001.

PIZARRO, F. Drenaje agrícola y recuperación de suelos salinos. Madrid: Española. 521p., 1985.

RIBEIRO, M.R.; FREIRE, F.J. \& MONTENEGRO, A.A.A. Solos Halomórficos do Brasil: Ocorrência, Gênese, Classificação, Uso e Manejo Sustentável. In: CURI, N.; MARQUES,J.J.; GUILHERME, L.R.G.; LIMA, J.M.; LOPES, A.S. \& ALVAREZ, V.H. Tópicos em Ciência do Solo. Soc. Bras de Cic do Solo. v. 3, Viçosa, 2003.

ROLIM, H. O. Potencial de uso agrícola do rejeito de caulim. 2003. 100f. il. Dissertação deMestrado (Manejo de Solo e Água) - Universidade Federal da Paraíba, Centro de Ciências Agrárias, Areia, PB.

SÁ, J. R. Níveis de salinidade da água sob o comportamento do maracujazeiro-amarelo (Passiflora edulis f. flavicarpa Deg) cultivado em recipientes de polietileno. 1999, $53 f$.

Trabalho de conclusão de curso (Graduação em Eng. Agronômica) - Centro de Ciências Agrárias, Universidade Federal da Paraíba, Areia, 1999.

SANTOS, R. V.; HERNANDEZ, F. F. F. Recuperação de solos afetados por sais. In: CONGRESSO BRASILEIRO DE ENGENHARIA AGRÍCOLA, 26., 1997, Campina Grande. Anais... Campina Grande: UFPB, 1997. p. 319-361. 
SOUZA, G. B. DE; CAVALCANTE, L. F.; CAVALCANTE, I. H. L.; BECKMAN-CAVALCANTE, M. Z.; NASCIMENTO, J. A. M. Salinidade do substrato contendo biofertilizante para a formação de mudas de maracujazeiro irrigado com água salina. Revista Caatinga, v.21, p.172-180, 2008.

TAVARES FILHO, A. N. Níveis da necessidade de gesso sobre as características físicoquímicas e na correção de solos salino sódicos do Perímetro Irrigado de Ibimirim-PE. Recife-PE, 2010. 82 p. Dissertação de Mestrado em Engenharia Agrícola, Área de Concentração (Manejo Integrado de Água e Solo), Recife, 2010.

VITAL, A. F. M.; SANTOS, R. V.; CAVALCANTE, L. F., SOUTO, J. S. Comportamento de atributos químicos de um solo salino-sódico tratado com gesso agrícola e fósforo. Revista Brasileira de Engenharia Agrícola e Ambiental, Campina Grande, v. 9, n. 1, 30-36, 2005. 


\title{
CAPITTULO XXVI
}

\section{USO SUSTEMTÁIVEL DE ABELHAS MELIFERAS (APIS MEUIFERA) E ABELHAS NATTYAS SEM FERRÃO (APIDAE: MEUPONINII) NA POLNIZACG̃OO DE CULTURAS AGRÍCOLAS EM AMBIENTES PROTEGIDOS}

\author{
DOI: 10.51859/amplla.mas481.1121-26
}

Mikail Olinda de Oliveira ${ }^{1}$

1 Professor Adjunto do Departamento de Zootecnia, Universidade Federal Rural de Pernambuco, Unidade Acadêmica de Serra Talhada, UFRPE/UAST, Pernambuco, Brasil

\section{RESUMO}

No ambiente agrícola a polinização realizada por abelhas proporciona um aumento tanto na produção de frutos e sementes, como na qualidade dos frutos produzidos. Entretanto, em várias regiões do mundo a produção agrícola tem o clima como fator determinante para uma boa produtividade, assim a utilização de casas de vegetação passou a ser uma ótima ferramenta para minimizar os efeitos do clima. Com essa forma de cultivo em ascensão a utilização de abelhas no interior das casas de vegetação tornou-se um fator de produção essencial para uma melhoria na produtividade das culturas agrícolas. Assim, esta revisão bibliográfica se propõe fazer um levantamento das informações sobre a utilização de abelhas melíferas (Apis mellifera) e das abelhas nativas sem ferrão (meliponíneos) no processo de polinização agrícola em ambientes protegidos (casas de vegetação).

Palavras-chave: Agricultura. Casa de vegetação. Produção agrícola.

\section{INTRODUÇÃO}

A polinização é um dos mais importantes processos na manutenção da diversidade e abundância das maiorias das espécies vegetais com flores (KEVAN E VIANA, 2003; KLEIN et al., 2007), sendo um fator de fundamental importância na condução de muitas culturas agrícolas ao redor do mundo. Uma polinização bem realizada promove várias melhorias na cadeia produtiva da agricultura, como o aumento no número de vagens ou frutos vingados, aumento no número de grãos por vagem, produção de frutos mais bem conformados e de qualidade superior (WILLIAMS et al., 1991), aumentando, consequentemente, a rentabilidade e a lucratividade do produtor. 
Em várias regiões do mundo produção agrícola tem o clima como fator determinante para uma boa produtividade, portanto a utilização de casas de vegetação (ambiente protegido) passou a ser, a bastante tempo, uma ótima ferramenta para minimizar os efeitos do clima. No Brasil, o uso do cultivo protegido para produção de para produção de hortaliças é bastante utilizado, principalmente a partir do início da década de 90 (GRANDE et al., 2003). Com essa forma de cultivo em ascensão em todo mundo, a utilização de abelhas no interior das casas de vegetação tornou-se um fator de produção essencial para uma melhoria na produtividade das culturas agrícolas.

A abelha Apis mellifera, é uma das mais utilizadas no mundo para a polinização agrícola (FREITAS, 1998), com o uso dessa espécie em ambientes protegidos bastante difundido (SADEH et al., 2007). Diversos estudos apontam para a eficiência A. mellifera, na elevação da produção, formação de mais frutos mais facilmente comercializáveis, e na redução de frutos deformados (CALVETE et al, 2010; RUIJTER, 1990; HIGO et al., 2003; KATUKANI et al., 1993). Características inerentes a espécie e a atividade da apicultura como: biologia bastante conhecida, facilidade no manejo (colmeias padronizadas), grande número de operárias, entre outras, contribuem para seu uso na polinização dirigida em áreas agrícolas (HOGENDOORN, 2004; MORAIS et al., 2012; WINSTON, 2003).

Contudo, a presença do ferrão e, em certos casos, a elevada agressividade das operárias dificultam os trabalhos diários das pessoas e, além disso, as operárias não se adaptam muito bem às casas de vegetação (FREE, 1993), tal fato criou a necessidade de alternativas, utilizando abelhas nativas, para o processo de polinização em ambientes protegidos.

Entre as espécies nativas, destacam-se os meliponíneos, essas abelhas, por não apresentarem um ferrão funcional, são especialmente adequadas para a polinização em ambientes fechados (SLAA et al., 2000). Do ponto de vista agrícola, a utilização racional de abelhas para a polinização, é considerada importante e indispensável no aumento de produtividade de diversas culturas, McGregor (1976) já mostrava a importância econômica dos polinizadores nativos para as culturas agrícolas, essa importância tem sido comprovada por pesquisas que testaram essas abelhas na polinização em ambiente protegido (CRUZ et al., 2005; MALAGODI-BRAGA E KLEINERT, 2004). 
Entretanto o extrativismo, o uso indevido da terra e a intensificação da agropecuária estão dizimando a população dessas abelhas, já existem pesquisas que comprovam o declínio das abelhas nativas em vários países do mundo (KLEIJN E RAEMAKERS, 2008). O desenvolvimento de técnicas e pesquisas que permitam o criatório racional direcionado para a polinização agrícola, são sempre muito importantes, e poderiam contribuir para a conservação das espécies manejadas, porém poucas espécies de abelhas nativas são criadas com sucesso para esse fim (KREMEN, 2004).

Diante desse cenário atual, e da importância do uso das abelhas no interior de casas de vegetação, é de extrema importância o levantamento de dados já existentes na literatura que tratam sobre os incrementos em características produtivas, causados pelo uso de abelhas melíferas e abelhas nativas sem ferrão na polinização de culturas agrícolas em ambientes protegidos. E assim, permitir um melhor conhecimento sobre o assunto, e valorizar os serviços de polinização prestados por essas abelhas, especificamente em ambientes controlados. Portanto, essa revisão bibliográfica se propõe fazer um levantamento de informações sobre o uso sustentável de abelhas melíferas (Apis mellifera) e abelhas nativas sem ferrão (meliponíneos) no processo de polinização agrícola em ambientes protegidos (casas de vegetação).

\section{METODOLOGIA EMPREGADA}

Esta revisão da literatura especializada foi realizada através da consulta a livros e artigos científicos selecionados através de busca nos bancos de dados na internet. A seleção dos artigos baseou-se na conformidade dos limites dos assuntos aos objetivos deste trabalho.

Ao todo foram consultados e utilizados como fonte bibliográfica 44 trabalhos sobre o tema, entre eles: manuscritos publicados em periódicos internacionais $(n=17)$, publicações em periódicos nacionais $(n=13)$, Teses de Doutorado $(n=1)$, Dissertação de Mestrado $(n=1)$, livros $(n=11)$ e Monografia de Graduação $(n=1)$. 


\section{REVISÃO DE LITERATURA}

\subsection{A PRODUÇÃO AGRICOLA EM AMBIENTE PROTEGIDO}

A utilização do cultivo protegido tem como principal objetivo minimizar os efeitos do clima na produção agrícola (MOTA et al., 2008), e em muitos países, inclusive no Brasil, o uso desse tipo de tecnologia na produção agrícola, já está bastante difundido e diverso. Em algumas regiões, altas pluviosidades e altas temperaturas interferem na qualidade e produção de hortaliças, criando condições favoráveis para o aparecimento de doenças, já em outras regiões, o frio e os ventos do inverno acabam prolongando o ciclo de algumas culturas (GOTO E TIVELLI, 1998).

Diante dessas diferentes realidades o uso do ambiente protegido (casas de vegetação) possibilitou modificações nas variáveis do microclima como radiação solar, temperatura do ar, precipitação pluviométrica, umidade relativa do ar e a incidência de ventos (CARDOSO et al., 2008), que são considerados elementos meteorológicos de grande influência sobre características como a duração do ciclo, a fitossanidade e a qualidade dos frutos (MOURA et al., 2009). Esse tipo de cultivo tem sido utilizado a muito tempo e possui um significado bastante amplo, que engloba um conjunto de práticas e tecnologias utilizadas pelos produtores, com intuito de se obter um cultivo mais seguro e protegido.

\subsection{ABelHAS APIS MELLIFERA NA POLINIZAÇÃo DIRIGIDA EM}

\section{AMBIENTE PROTEGIDO}

O uso da Apis mellifera para polinização em ambientes protegidos é bastante difundido (SADEH et al., 2007), essa espécie possui hábito alimentar generalista, muitos indivíduos na mesma colônia, grande habilidade de recrutar várias campeiras para o forrageamento, perfeita possibilidade de manejo devido a utilização de colmeias padronizadas, biologia conhecida e grande intensidade na coleta de recursos, que faz com que as operárias visitem uma grande quantidade de flores por minuto (HOGENDOORN, 2004; MORAIS et al., 2012; WINSTON, 2003).

Todas essas características acabam contribuindo, para o processo de polinização provocando ganhos na produção e produtividade final da cultura agrícola, como 
podemos observar na tabela 01, que mostram como o uso de abelhas melíferas (Apis mellifera), no interior de casas de vegetação, pode interferir nas características produtivas de interesse econômico, como no número e massa dos frutos produzidos, no formato e no tamanho.

Tabela 01: O uso da espécie Apis mellifera na polinização de culturas agrícolas em ambiente protegido e os incrementos na produção causados pela sua utilização.

\begin{tabular}{|c|c|}
\hline Cultura agrícola & Incrementos na produção devido ao uso de Apis mellifera \\
\hline Morango (Fragaria $x$ ananassa) & $\begin{array}{l}\text { Maior produção obtida com a presença das abelhas. A } \\
\text { utilização de abelhas Apis mellifera resultou na formação de } \\
\text { mais frutos comercializáveis, melhoria da polinização e } \\
\text { redução do número e da porcentagem de frutos } \\
\text { deformados (Calvete et al, 2010). }\end{array}$ \\
\hline \multicolumn{2}{|l|}{ Pimentão (Capsicum annuum L.) } \\
\hline & $\begin{array}{l}\text { A polinização por Apis mellifera resultou na produção de } \\
\text { frutos maiores e mais pesados, e com uma maior } \\
\text { quantidade de sementes e menores índices de má formação }\end{array}$ \\
\hline \multirow[t]{2}{*}{ Tomate (Lycopersicon esculentum) } & (Ruijter, 1990). \\
\hline & $\begin{array}{l}\text { A polinização suplementar realizada por A. mellifera, } \\
\text { produziu frutos mais largos quando comparados com as } \\
\text { abelhas Bombus sozinhas (Higo et al., 2003). }\end{array}$ \\
\hline Morango (Fragaria x ananassa) & $\begin{array}{l}\text { O percentual de deformação dos frutos, foi menor em flores } \\
\text { polinizadas por A. mellifera (Katukani et al., 1993). }\end{array}$ \\
\hline
\end{tabular}

FONTES: Calvete et al, 2010; Ruijter, 1990; Higo et al., 2003; Katukani et al., 1993.

Pesquisas que comprovam a eficiência de $A$. mellifera em ambiente protegido não são tão recentes, Spangler e Moffett (1977) já relatavam que as flores do tomate que receberam visitas de abelhas, produziram frutos $22 \%$ mais pesados, Free (1993) mencionou que colônias de $A$. mellifera são manejadas em diversos países para a produção de morango em ambiente protegido. O melão também é altamente dependente da polinização realizada por abelhas, para a polinização dessa cultura é 
utilizado colmeia com duplo alvado que permite o acesso ao interior e ao exterior da casa de vegetação (KATO, 1997).

As abelhas $A$. mellifera são potenciais polinizadores de diversas culturas agrícolas, porém nem sempre elas são as mais indicadas para algumas culturas agrícolas especificas (BANDA E PAXTON, 1991), além disso, as operárias de Apis mellifera não se adaptam muito bem no interior da casa de vegetação (FREE, 1993), devido ao estresse do próprio confinamento e às flutuações de temperatura (FREE, 1993; GUERRA SANZ, 2008). Além do mais, o seu comportamento extremamente defensivo, a presença de ferrão e sua organização no ataque de possíveis inimigos próximos à colmeia, dificulta a realização dos tratos culturais e os trabalhos no interior da casa de vegetação, causando transtornos aos produtores e aos trabalhadores, (AMANO, 2004; CRUZ E CAMPOS, 2009).

\subsection{ABELHAS NATIVAS SEM FERRÃO COMO POLINIZADORES DE CULTURAS AGRICOLAS EM AMBIENTES PROTEGIDOS}

Muitas espécies de abelhas nativas se ferrão, das tribos Meliponini e Trigonini, podem ser mantidas em caixas racionais (FABICHAK, 1989), facilitando um manejo direcionado para polinização em ambiente protegido, além disso, essas abelhas não apresentam ferrão funcional, possuem um nível de organização social comparável ao das abelhas melíferas, apresentam uma baixa defensibilidade, uma menor amplitude do voo de forrageamento, as colônias são perenes e se adaptam muito bem às condições de confinamento (MALAGODI-BRAGA et al., 2004; CRUZ et al., 2005). Várias pesquisas têm mostrado que abelhas sem ferrão são polinizadores efetivos em ambientes fechados (Tabela 02) e podem, portanto, ser uma ótima alternativa para a polinização de diversas culturas cultivadas sob essas condições.

Entretanto, as abelhas nativas encontram-se em processo acelerado de desaparecimento, isto ocorre por a vários fatores, como a introdução de Apis mellifera para produção de mel, desmatamentos, queimadas, fragmentação do ecossistema, ação de meleiros (extrativismo), aplicação pesada de inseticidas, intensificação agrícola e uso indevido da terra (LOPES et al. 2005; KEER, et al., 2005). Pesquisas estão mostrando um grande declínio das abelhas nativas, em vários países do mundo, devido à intensificação 
agrícola (KLEIJN E RAEMAKERS, 2008; FREITAS et al., 2009), essa evolução do uso da terra, provoca efeitos negativos na disponibilidade de alimentos, tornando-o menos abundante, menos previsível e presente durante períodos mais curtos de tempo.

Existem métodos gerais de criação para essas abelhas (NOGUEIRA-NETO, 1997; VENTURIERI et al., 2003), porém poucas espécies foram criadas ou testadas para serem utilizadas na polinização agrícola, em especial em ambientes protegidos (IMPERATRIZFONSECA et al, 2004). Na tabela a seguir podemos verificar algumas dessas pesquisas, onde o uso de abelhas nativas sem ferrão, na polinização de culturas agrícolas em ambiente protegido causou incrementos produtivos para a cultura em questão.

Tabela 02: O uso de abelhas nativas sem ferrão, na polinização de culturas agrícolas em ambiente protegido e os incrementos na produção causados pela sua utilização.

\section{Espécie/Cultura agrícola}

Melipona quadrifasciata/Tomate

Melipona subnitida/Pimentão

Nanotrigona testaceicornis Morango

Melipona quadrifasciata/Pimentão

Melipona quadrifasciata/Pimentão
Incrementos na produção devido ao uso de

diferentes espécies de abelhas

Aumento na qualidade dos frutos, e diminuição das injúrias mecânicas quando comparadas à polinização manual tradicional (Del Sarto et al., 2005).

Frutos mais pesados, mais largos, com um maior número de sementes e menor proporção de deformações. (Cruz et al., 2005).

Frutos maiores, tanto no comprimento, como na circunferência. (Roselino, 2005).

Frutos foram mais pesados, quando comparados àqueles produzidos nas casas de vegetação sem a presença de abelhas (Malagodi-Braga, 2004).

Os frutos mais pesados, maiores e com mais sementes do que aqueles em que a transferência polínica foi realizada através da auto-polinização natural (Roselino et al., 2010). 
Tetragonisca angustula/Morango

Plebeia nigriceps/Morango
Foram obtidas elevadas melhorias no rendimento de quatro variedades testadas, e aumento na porcentagem de frutos comerciáveis (Antunes et al., 2007).

Redução no percentual de frutos deformados, proporcionando um produto de melhor qualidade (Witter et al., 2012).

Incremento na quantidade e qualidade dos frutos resultantes da polinização por essa espécie (Bomfim, 2013).

FONTES: Del Sarto et al., 2005; Roselino, 2005; Malagodi-Braga, 2004; Roselino et al., 2010; Antunes et al., 2007; Witter et al., 2012; Bomfim, 2013.

\section{CONSIDERAÇÕES FINAIS}

Com o advento do cultivo protegido no Brasil, o uso de abelhas no interior das casas de vegetação aparece, cada vez mais, como uma ótima ferramenta para proporcionar benefícios na qualidade dos frutos produzidos.

A espécie Apis mellifera continua sendo uma ótima saída para a polinização de algumas culturas em ambientes protegidos, entretanto limitações encontradas e citadas nesta revisão dificultam o seu uso, além do mais, a utilização de abelhas no processo de polinização agrícola em ambientes controlados não deve se restringir a apenas uma espécie. Especialmente quando se trata do território brasileiro, que possui uma vasta e rica diversidade de abelhas nativas, entre elas muitas espécies de meliponíneos (abelhas sem ferrão).

É essencial o aprimoramento e o desenvolvimento das técnicas de criação racional para as mais variadas espécies de abelhas sem ferrão (meliponicultora sustentável), pois sem dúvida, entre elas, poderíamos achar polinizadores eficientes para muitas de nossas culturas.

É de extrema importância que entidades governamentais e instituições de ensino e pesquisa, promovam e incentivem projetos que envolvam a criação racional das abelhas sem ferrão (meliponicultora). Pois isso irá contribuir na geração de novas informações e no desenvolvimento de técnicas de manejo que irão permitir a criação 
racional de novas espécies, e consequentemente, sua utilização na polinização de culturas agrícolas em ambientes protegidos, e na introdução em regiões onde elas vêm diminuindo.

Com os avanços das pesquisas nessa área, num futuro bem próximo, essa comprovação da eficiência das abelhas nativas irá, além de contribuir para uma agricultura brasileira mais sustentável e mais produtiva, favorecer a preservação das espécies nativas do território brasileiro.

\section{REFERÊNCIAS}

AMANO, K. Attempts to introduce stingless bees for the pollination of crops under greenhouse conditions in Japan. Laboratory of Apiculture, National Institute of Livestock and Grassland Science, Japan, 2004. Disponível em:

<http://www.fftc.agnet.org/library.php?func=view\&id=20110913145638>.

ANTUNES, O.T.; CALVETE, E.O.; ROCHA, H.C.; NIENOW, A.A.; CECCHETTI, D.; RIVA, E.; MARAN, R.E. Produção de cultivares de morangueiro polinizadas pela abelha jataí em ambiente protegido. Horticultura Brasileira, v. 25, p. 094-099, 2007.

BANDA, H.J.; PAXTON, R.J. Pollination of greenhouse tomatoes by bees. In: VI International Symposium on Pollination. Acta Horticulturae, (ISHS) 288, p. 194198, 1991.

BOMFIM, I.G.A. Uso de abelhas sem ferrão (Meliponinae: Apidae) em casa de vegetação para polinização e produção de frutos de minimelancia [Citrullus lanatus (Thunb.) Matsum. \& Nakai] com e sem semente. Tese (Doutorado em Zootecnia), Universidade Federal do Ceará, Fortalezapp. 141 p., 2013.

CAlVete, E. O.; ROCHA, H. C.; TESSARO, F.; CECCHETTI, D.; NIENOW, A. A.; LOSS, J. T. Polinização de morangueiro por Apis mellifera em ambiente protegido. Revista Brasileira de Fruticultura, v. 32, n. 1, p. 181-188, 2010.

CARDOSO, L.S.; BERGAMASCHI, H.; COMIRAM, F.; CHAVARRIA, G.; MARODING, A.B.; DALMAGO, G.A.; SANTOS, H.P.; MANDELLI, F. Alterações micrometeorológicas em vinhedos pelo uso de coberturas de plástico. Pesquisa Agropecuária Brasileira, v. 43, p. 441-447, 2008.

CRUZ, D. O.; FREITAS, B. M.; SILVA, L. A.; SILVA, E. M. S.; BOMFIM, I. A. Pollination efficiency of the stingless bee Melipona subnitida on greenhouse sweet pepper (Capsicum annuum). Revista Agropecuária Brasileira, v.40, p.1197-1201 2005.

CRUZ, D.O.; CAMPOS, L.A.O. Polinização por abelhas em cultivos protegidos. Revista Brasileira de Agrociência, v. 15, n. 1-4, p. 5-10, 2009. 
DEL SARTO, M.C.L.; PERUQUETTI, R.C.; CAMPOS, L.A.O. Evaluation of the Neotropical stingless bee Melipona quadrifasciata (Hymenoptera: Apidae) as pollinator of greenhouse tomatoes. Journal of Economic Entomology, v. 98, p. 260-266, 2005.

FABICHAK, I. Abelhas indígenas sem ferrão Jataí. São Paulo: Nobel, 1989.

FREE, J.B. Insect pollination of crops. 2a ed. London: Academic Press, 684 pp., 1993.

FREITAS, B.M. Uso de programas racionais de polinização em áreas agrícolas. Messagem Doce, v. 46, p.16-20, 1998.

FREITAS, B.M.; IMPERATRIZ-FONSECA, V.L.; MEDINA, L.M.; KLEINERT, A.M.P.; GALETTO, L.; NATES-PARRA, G. QUEZADA-EUÁN, J.J.G. Diversity, threats and conservation of native bees in the Neotropics. Apidologie, v. 40, p. 332-346, 2009.

GOTO, R.; TIVELLI, S.W. Produção de hortaliças em ambiente protegido: condições subtropicais. In: TIVELLI, S.W. Manejo do ambiente em cultivo protegido. São Paulo: UNESP, p.15-30, 1998.

GRANDE, L.; LUZ, J.M.Q.; MELO, B.; LANA, R.M.Q.; CARVALHO, J.O.M. O cultivo protegido de hortaliças em Uberlândia-MG. Horticultura Brasileira, v. 21, n. 2, p. 241-244, 2003.

GUERRA SANZ, J.M. Crop pollination in greenhouses. In: Bee pollination in agricultural ecosystems. JAMES, R.R.; PITTS-SINGER, T.L. (eds.). New York: Oxford University Press, Inc., cap. 3, p. 27-47, 2008.

HIGO, H.A.; RICE, N.D.; WINSTON, M.L.; LEWIS, B. Honey Bee (Hymenoptera: Apidae) Distribution and Potential for Supplementary Pollination in Commercial Tomato Greenhouses During Winter. Journal of Economic Entomology, v. 97, n. 2, p. 163170, 2004.

HOGENDOORN, K. On promoting solitary bee species for use as crop pollinators in greenhouses. In: Solitary bees: conservation, rearing and management for pollination. FREITAS, B.M.; PEREIRA, J.O.P. (eds.), Fortaleza: Imprensa Universitária, p. 213-221, 2004.

IMPERATRIZ-FONSECA, V.L.; DIAS, B.F.S. Brazilian Pollinator Initiative. In: Solitary bees and their role in pollination. In: Freitas \& Pereira (ed.), Solitary bees: conservation, rearing and management for pollination. Fortaleza, CE, p. 27-34, 2004.

KAKUTANI, T.; INOUE, T.; TEZUKA, T.; MAETA, Y. Pollination of strawberry by the stingless bee, Trigona minangkabau, and the honey bee, Apis mellifera: An experimental study of fertilization efficiency. Researches on Population Ecology, v. 35, Issue 1, p. 95-111, 1993.

KATO, E.C. Polinização em melão (Cucumis melo L.) no Nordeste (campo aberto) e Sul (estufa) do Brasil, testando atrativo para Apis mellifera. Jaboticabal, 
Monografia (Graduação em Zootecnia) - Universidade Estadual Paulista, 82 p.,1997.

KERR, W.E.; CARVALHO, G.A.; SILVA, A.C.; ASSIS, M.G.P. Aspectos pouco mencionados da biodiversidade amazônica. Mensagem doce, v. 12, n. 80, 2005.

KEVAN, P.G.; VIANA, B.F. The global decline of pollination services. Biodiversity, v.4, n. 4, p. 3-8, 2003.

KLEIJN, D.; RAEMAKERS, A. A retrospective analysis of pollen host plant use by stable and declining bumblebee species. Ecology, v. 89, n. 7, p.1811-1823, by the Ecological Society of America, 2008.

KLEIN, A.M.; VAISSIERE, B.E.; CANE, J.H.; STEFFAN-DEWENTER, I.; CUNNINGHAM, S.A.; KREMEN, C.; TSCHARNTKE, T. Importance of pollinators in changing landscapes for world crops. Proceedings of the Royal Society B: Biological Sciences, v. 274, p. 303-313, 2007.

KREMEN, C; WILLIAMS, N.M; BUGG, R.L; FAY, J.P; THORP, R.W. The area requirements on an ecosystem service: crop pollination by native bee communities in California. Ecology Letters, v. 7, p.1109-1119, 2004.

LOPES, M.; FERREIRA, J. B.; SANTOS, G. Abelhas sem-ferrão: a biodiversidade invisível. Agriculturas, v.2, n.4, 2005.

MALAGODI-BRAGA, K.S.; KLEINERT, A.M.P. Could Tetragonisca angustula (Apinae, Meliponini) be effective as strawberry pollintor in greenhouse. Australian Journal of Agricultural Research, v. 55, n. 7, p. 771-773, 2004.

MALAGODI-BRAGA, K.S.; KLEINERT, A.M.P.; IMPERATRIZFONSECA, V.L. Abelhas sem ferrão e polinização. Revista Tecnologia e Ambiente, v. 10, p. 59-70, 2004.

McGREGOR, S.E. Insect pollination of cultivated crop plants. USDA Agriculture Handbook, n. 494, 411 p.,1976.

MORAIS, M.M.; DE JONG, D.; MESSAGE, D.; GONÇALVES, L.S. Perspectivas e desafios para o uso das abelhas Apis mellifera como polinizadores no Brasil. In: Polinizadores no Brasil: contribuição e perspectivas para a biodiversidade, uso sustentável, conservação e serviços ambientais. IMPERATRIZ-FONSECA, V.L.; CANHOS, D.A.L.; ALVES, D.A.; SARAIVA, A.M. (eds.), São Paulo: Edusp, cap. 10, p. 203-212, 2012.

MOTA, C.S.; AMARANTE, C.V.T.; SANTOS, H.P.; ZANARDI, O.Z. Comportamento vegetativo e produtivo de videiras 'Cabernet Sauvignon' cultivadas sob cobertura plástica. Revista Brasileira de Fruticultura, v. 30, p.148-153, 2008.

MOURA, M.S.B.; TEIXEIRA, A.H.C.; SOARES, J.M. Exigências climáticas. In: SOARES J. M., LEÃO, P. C. S. A vitivinicultura no Semiárido Brasileiro. Embrapa Semi-Árido, Petrolina, p. 37-69, 2009. 
NOGUEIRA-NETO, P. Vida e criação das abelhas indígenas sem ferrão. São Paulo, SP: Ed. Nogueirapis. 442p., 1997.

ROSELINO, A.C. Polinização em culturas de pimentão - Capsicum annuum por Melipona quadrifasciata anthidioides e Melipona scutellaris e de morango Fragaria $x$ ananassa por Scaptotrigona aff. depilis e Nannotrigona testaceicornis (Hymenoptera, Apidae, Meliponini). Ribeirão Preto. Dissertação (Mestrado em Ciências), Universidade de São Paulo, 95 p., 2005.

ROSELINO, A.C.; SANTOS, S.A.B.; BEGO, L.R. Qualidade dos frutos de pimentão (Capsicum annuum L.) a partir de flores polinizadas por abelhas sem ferrão (Melipona quadrifasciata anthidioides Lepeletier 1836 e Melipona scutellaris Latreille 1811) sob cultivo protegido. Revista Brasileira de Biociências. Disponível on-line em: http://www.ufrgs.br/seerbio/ojs/index.php/rbb/article/view/1377, 2010.

RUIJTER, A.; EIJNDE, J.V.D; STEEN, JV.D. Pollination of sweet pepper (Capsicum annuum L.) in greenhouses by honeybees. Acta Horticulturae, 288: VI International Symposium on pollination, 1990.

SADEH, A.; SHMIDA, A.; KEASAR, T. The carpenter bee Xylocopa pubescens as an agricultural pollinator in greenhouses. Apidologie, v. 38, p. 508-517, 2007.

SLAA, E.J.; SANCHEZ, L.A. SANDI, M.; SALAZAR, W. A scientific note on the use of stingless bees for commercial pollination in enclosures. Apidologie, v. 31, p. 141-142, 2000.

SPANGLER, H.G.; MOFFETT, J.O. Honeybee visits to tomato flowers in polyethylene greenhouses. American Bee Journal, v. 117, p. 580-582, 1977.

VENTURIERI, G.C.; RAIOL, V.F.O.; PEREIRA, C.A.B. Avaliação da introdução da criação racional de Melipona fasciculata (Apidae: Meliponina), entre os agricultores familiares de Bragança, PA, Brasil. Biota Neotropica, v. 3, n. 2, p. 1-7, 2003.

WILLIAMS, I.H.; CORBET, S.A.; OSBORNE, J.L. Beekeeping, wild bees, wild bees and pollination in the European Community. Bee World, v. 72, p. 170-180, 1991.

WINSTON, M.L. A biologia da abelha. Tradução de Carlos A. Osowski - Porto Alegre: Magister, 276 p., 2003.

WITTER, S.; RADIN, B.; LISBOA, B.B.; GALASCHI, J.S.T; BLOCHTEIN, B.; IMPERATRIZ-FONSECA, V.L. Desempenho de cultivares de morango submetidas a diferentes tipos de polinização em cultivo protegido. Pesquisa agropecuária brasileira, v. 47, n. 1, p. 58-65, 2012. 


\title{
CAPITULO XXVII
}

\section{IMPACTOS AMBIENTAIS DO HERBIODA TIEBUHIUURON E SOLUCGOEES BIOTECNOLÓGICAS DE REMEDIACÃO POR MICRORGANISMOS}

\section{DOI: 10.51859/amplla.mas481.1121-27}

\author{
Edivaldo Wilson de Lima ${ }^{1}$ \\ Yanca Araujo Frias ${ }^{2}$ \\ Bruno Rafael de Almeida Moreira ${ }^{3}$ \\ Laura Silva Nantes ${ }^{4}$ \\ Bruno Pinheiro Brunaldi ${ }^{5}$ \\ Paulo Renato Matos Lopes ${ }^{6}$
}

\footnotetext{
'Mestre em Agronomia - Sistemas de Produção. Universidade Estadual Paulista - Unesp

2 Doutoranda em Agronomia - Sistemas de Produção. Universidade Estadual Paulista - Unesp

3 Doutorando em Agronomia - Produção Vegetal. Universidade Estadual Paulista - Unesp

${ }^{4}$ Graduanda em Engenharia Agronômica. Universidade Estadual Paulista - Unesp

${ }^{5}$ Graduando em Engenharia Agronômica. Universidade Estadual Paulista - Unesp

6 Professor Assistente Doutor do Departamento de Produção Vegetal da Faculdade de Ciências Agrárias e Tecnológicas. Universidade Estadual Paulista - Unesp
}

\section{RESUMO}

A cultura da cana-de-açúcar (Saccharum spp.), devido a sua produção em larga escala, necessita da aplicação de produtos químicos para o controle de plantas daninhas. Assim, é comum o uso de herbicidas principalmente pela sua eficiência e baixo custo. Neste sentido, o tebuthiuron é um dos herbicidas mais usados no cultivo da cana-de-açúcar no país. Embora os pesticidas possam ter um efeito benéfico sobre a produtividade agrícola, deve-se considerar o risco potencial desses compostos químicos no ambiente, o que tem despertado o interesse científico para sua degradação e seu comportamento ambiental junto aos compostos relacionados. Em vista dos efeitos adversos da sua utilização, como toxicidade para espécies não-alvo e produção de compostos intermediários no ambiente, ele tem chamado a atenção para melhor compreensão da persistência no ambiente e no desenvolvimento de métodos eficientes de descontaminação.

Palavras-chave: Biorremediação. Cana-de-açúcar. Solo. Toxicidade.

\section{INTRODUÇÃO}

A produção de cana-de-açúcar possui grande importância nacional devido à sua alta produtividade, com destaque nos setores energético e econômico. Nesta cultura, as plantas invasoras representam o maior fator biótico com capacidade de interferir 
negativamente na produtividade, pois competem pelos recursos disponíveis e elevam os custos de produção pelos tratos culturais (MACIEL et al., 2008; BERGMANN, 2019).

Assim, visando uma alta produtividade em cultivos agrícolas o método químico é o mais empregado para o controle de plantas daninhas. Neste sentido, o Brasil é o líder do ranking da utilização de pesticidas, ressaltando sua utilização ao longo de todo ano para inúmeras culturas (NASCIMENTO, 2016).

O aumento na demanda global por alimentos intensificou o uso de herbicidas nas lavouras, o que promoveu o lançamento intensificado desses compostos no ambiente, cujo potencial de deslocamento no solo ocasiona impactos ambientais maiores. A contaminação das águas superficiais e subterrâneas pelos processos de lixiviação e percolação em áreas agrícolas maximiza o impacto ao meio ambiente e à saúde humana (MACIEL et al., 2008).

Somado a isso, diversas transformações podem ocorrer quando pesticidas são lançados no meio ambiente. Esta série de reações pode modificar ou degradar partes da sua molécula e, desta forma, alterar sua estrutura química, e gerar outros compostos intermediários (AZANIA et al., 2005). No processo de degradação, o resultado ideal seria originar compostos com menor efeito tóxico que a molécula original, mas em muitos casos os compostos gerados podem ter efeito ainda mais nocivo ao meio ambiente (VILLAVERDE et al., 2017).

Logo, a biorremediação apresenta-se como estratégia ecologicamente viável no tratamento de áreas impactadas com resíduos orgânicos, como os aplicados na lavoura de cana-de-açúcar. Seu principal fundamento baseia-se na aceleração dos processos biológicos de degradação, estimulando a ação de microrganismos sobre compostos orgânicos a fim de metabolizá-los em moléculas menos tóxicas (VILLAVERDE et al., 2017; FRANCISCO; QUEIROZ, 2018).

Desta forma, conhecer o comportamento ambiental de moléculas massivamente utilizadas na agricultura e propor estratégias ecologicamente viáveis de mitigar os seus impactos negativos no meio ambiente tornam-se fundamentais para obtenção de um modelo de produção baseado na sustentabilidade. 


\section{REVISÃO BIBLIOGRÁFICA}

\subsection{CANA-DE-AÇÚCAR}

A cana-de-açúcar está no grupo das gramíneas do gênero Saccharum spp. e representa uma cultura perene introduzida no Brasil junto à colonização portuguesa. Atualmente, há um interesse crescente no desenvolvimento desta cultura pela alta produtividade em biomassa, energia, bioetanol e açúcar (GOLDEMBERG et al., 2008; SPAROVEK et al., 2009; WALTER et al., 2011; ADAMI et al., 2012).

Esta cultura representa um dos setores mais importantes da economia brasileira, sendo o país o maior produtor mundial de cana-de-açúcar, gerando uma riqueza equivalente a US\$ 43 bilhões por ano, ou seja, cerca de 2,0\% do PIB nacional. Em aproximadamente 8,5 milhões de hectares na safra 2019/20 foi cultivado cerca de 642,7 milhões de toneladas na produção nacional de cana-de-açúcar (CONAB, 2020).

$\mathrm{O}$ investimento em fontes energéticas com baixa demanda de carbono e 0 aumento pela busca por fontes de energia renováveis estimularam o mercado mundial de biocombustíveis, o que propiciou um significativo aumento na produção e no consumo no setor sucroenergético (CALDARELLI, 2018). Além disso, destaca-se seu impacto positivo na geração de empregos diretos e indiretos na cadeia produtiva, mas também de forma negativa no extenso uso de recursos naturais e geração dos resíduos agroindustriais (ASSAD, 2017; UNICA, 2019).

Neste contexto, o Brasil possui uma alta produtividade devido às condições favoráveis ao seu cultivo como área e características edafoclimáticas. No entanto, esses fatores ambientais favorecem também o desenvolvimento de uma alta diversidade de espécies daninhas, as quais interferem no desenvolvimento e produtividade da cultura da cana-de-açúcar (NASCIMENTO, 2016).

A diversidade nos fatores ecológicos proporciona base para o surgimento de uma grande variedade de espécies vegetais, as quais competem com as culturas por recursos como: água, luz e nutrientes (OLIVEIRA; BRIGHENTI, 2011). Consequentemente, as extensas áreas da lavoura canavieira devem ter um sistema eficiente de controle dessas espécies infestantes, o que é representado pela aplicação de herbicidas com ações prée pós-emergentes (MACIEL et al., 2008; BERGMAN, 2019). 


\section{1\%1. IMPACTO AMBIENTAL DE HERBICIDAS}

O método químico é o mais utilizado para o controle de plantas daninhas visando uma alta produtividade em cultivos agrícolas. Neste sentido, o Brasil é o líder do ranking da utilização de pesticidas, ressaltando sua utilização ao longo de todo ano para inúmeras culturas (NASCIMENTO, 2016).

Os herbicidas são substâncias que agem na germinação e/ou no desenvolvimento de plantas específicas e sua eficácia e seletividade neste controle estão relacionadas à intensidade em que ocorrem os processos de sorção, transformação e transporte (CHRISTOFFOLETI et al., 2008).

O aumento na demanda global por alimentos intensificou o uso de herbicidas nas lavouras, o que promoveu o acúmulo desses compostos no ambiente, cujo potencial de deslocamento no solo ocasiona impactos ambientais maiores. A contaminação das águas superficiais e subterrâneas pelos processos lixiviação e percolação em áreas agrícolas maximiza o impacto destas substâncias ao meio ambiente e à saúde humana (CHRISTOFFOLETI et al., 2008; MACIEL et al., 2008).

Somado a isso, diversas transformações ocorrem quando pesticidas são lançadas no meio ambiente. Esta série de reações pode modificar ou degradar partes da sua molécula e, desta forma, alterar sua estrutura química, gerando outros compostos intermediários (AZANIA et al., 2005).

\subsubsection{TEBUTHIURON}

Como grande produtor agrícola, o Brasil assume igualmente o papel de grande consumidor de pesticidas no mundo. Dentre os herbicidas empregados na produção de cana-de-açúcar, destacam-se o tebuthiuron, a hexazinona, o diuron e a ametrina (BRASIL, 2020).

O tebuthiuron possui ação pré-emergente, que atua na fotossíntese ao interromper o transporte de elétrons no fotossistema II nas plantas. Assim, o modo de ação é pela inibição da fotossíntese, se ligando ao sítio de ligação da plastoquinona QB, e proteína D1 do fotossistema II. Há ainda nesse processo um bloqueio de transporte de elétrons, que resulta na paralisação da fixação de $\mathrm{CO}_{2}$ e produção de ATP e $\mathrm{NADH}_{2}$, elementos fundamentais para a sobrevivência da planta. Desta forma, é induzida a morte da planta invasora (WANG et al., 2019; BRASIL, 2020). 
Sua molécula (N-t5-(1,1-dimetiletil)-1,3,4-thiadazol-2-yll-N,N-dimetilureia) pertence ao grupo das ureias substituídas, sendo seletivo e de ação sistêmica (MORTON; HOFFMAN, 1976; BRASIL, 2020). Ele é altamente solúvel em água e, portanto, torna-se altamente persistente no solo e em águas superficiais e subterrâneas. Assim, pertence à Classe II, sendo considerado perigoso ao meio ambiente (IBAMA, 2019), e apresenta elevada toxicidade e persistência no ambiente (PRETE et al., 2017; FERREIRA et al., 2021).

Pelas suas características e por ser amplamente utilizado, este herbicida representa um dos principais contaminantes em áreas agrícolas, uma vez que possui um tempo de meia vida muito alto, sendo possível encontrar resíduos por dois anos ou mais após sua aplicação (RODRIGUES; ALMEIDA, 2011; HUSSAIN et al., 2015; PRETE et al., 2017).

\subsection{BIORREMEDIAÇÃO}

Como forma de remediar impactos ambientais pelas ações antrópicas, processos físicos, químicos e biológicos podem ser utilizados em diferentes formas de tratamento. Neste sentido, a biorremediação utiliza organismos vivos com capacidade de transformar ou eliminar compostos poluentes no meio e, assim, surge como uma importante alternativa econômica e ecologicamente viável para a descontaminação de áreas contaminadas (CORIOLANO; MORAIS FILHO, 2016).

Várias técnicas podem ser empregadas na biorremediação com o intuito de atenuar ou eliminar o efeito prejudicial dos contaminantes nos ecossistemas, tais como: biodegradação microbiana, vermicompostagem com minhocas e fitorremediação com espécies vegetais (MORILLO; VILLAVERDE, 2017).

A microbiota natural do solo possui um alto potencial de mineralizar transformar pesticidas em moléculas orgânicas menos tóxicas e/ou inertes (MORILLO; VILLAVERDE, 2017). O modelo de remediação utilizando a própria capacidade do ambiente denomina-se atenuação natural. Logo, sua eficiência pode ser melhorada por técnicas que minimizam ainda mais os efeitos negativos de moléculas poluentes (FASANELLA; CARDOSO, 2016; MORILLO; VILLAVERDE, 2017).

Porém, alguns compostos orgânicos, como os herbicidas, podem gerar compostos intermediários com toxicidade maior que a molécula original, quando

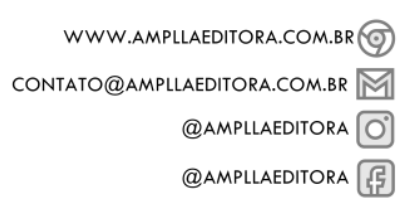


submetidos à ação microbiana. Este processo maximiza o impacto ambiental e seus efeitos deletérios à biodiversidade, aumentando o potencial ecotoxicológico da contaminação (MORILLO; VILLAVERDE, 2017; ROCHA et al., 2018).

\subsubsection{TEBUTHIURON}

Vários estudos já relataram o impacto do tebuthiuron residual em diferentes ecossistemas aquáticos e no entorno da área plantada com cana-de-açúcar (MICKELSON et al., 2001; SIBER et al., 2009; LEWIS et al., 2012; FLORES et al., 2013), assim como a sua bioacumulação nos organismos, impactando negativamente na biodiversidade de espécies vegetais e animais em diferentes ecossistemas (DAM et al., 2004; SIBER et al., 2009; QIAO et al., 2014). Assim, há prejuízo à saúde humana devido a ingestão de alimentos contaminados ou através do contato com contaminante (BOUWMAN et al., 2012).

Diante do exposto, surge como alternativa a utilização de cepas de microrganismos bioprospectados com o intuito de diminuir os efeitos tóxicos deste herbicida. A microbiota natural do solo possui um alto potencial para degradar e transformar pesticidas em moléculas orgânicas menos tóxicas e/ou inertes (VILLAVERDE et al., 2017). O modelo de remediação utilizando a própria capacidade do ambiente denomina-se atenuação natural. Logo, sua eficiência pode ser melhorada por técnicas que minimizam os efeitos negativos de moléculas poluentes (CARDOSO, 2016; MORILLO; VILLAVERDE, 2017).

\section{CONSIDERAÇÕES FINAIS}

É importante salientar que a necessidade de pesquisas para detalhar o comportamento ambiental de herbicidas, como o tebuthiuron, associados ou não a outros em compostos em solos agrícolas.

Além disso, novas abordagens podem ser conduzidas a partir do uso de microrganismos como ferramentas biotecnológicas na mitigação de impactos ambientais de compostos xenobióticos no meio ambiente. 


\section{AGRADECIMENTOS}

Os autores agradecem ao GAIA (Grupo de Ação em Impactos Ambientais) e à FAPESP - Fundação de Amparo à Pesquisa do Estado de São Paulo (Processos 2018/22144-8 e 2019/24036-0).

\section{REFERÊNCIAS}

ADAMI, M.; RUDORFF, B. F. T.; FREITAS, R. M.; AGUIAR, D. A.; SUGAWARA, L. M.; MELLO, M. P. Remote sensing time series to evaluate direct land use change of recent expanded sugarcane crop in Brazil. Sustainability, v. 4, n. 4, 574-585, 2012.

ASSAD, L. Aproveitamento de resíduos do setor sucroalcooleiro desafia empresas e pesquisadores. Ciência e Cultura, v. 69, n. 4, p.13-16, 2017. Disponível em: http://dx.doi.org/10.21800/2317-66602017000400005. Acesso em: 22 de ago. 2020.

AZANIA, C. A. M.; ROLIM, J. C.; CASAgRANDE, A. A.; LAVORENTI, N. A.; AZANIA, A. A. P. $M$. Seletividade de herbicidas: I-Utilização do método de testemunhas pareadas em experimento com cana-de-açúcar. Planta Daninha, v. 23, n. 4, p. 661-667, 2005.

BERGMANN, G. E. Impacts of pesticide pollution on soil microbial communities, ecosystem function and human health. Reference module in earth systems and environmental sciences, p.1-12, 2019. Disponível em: http://dx.doi.org/10.1016/b978-0-12-409548-9.11269-2. Acesso em: 22 de ago. 2020.

BOUWMAN, H.; KYLIN, H.; SEREDA, B.; BORNMAN, R. Níveis elevados de DDT no leite materno: Ingestão, risco, duração da lactação e envolvimento do gênero. Poluição Ambiental, v. 170, p. 63-70, 2012.

BRASIL. Ministério da Agricultura, Pecuária e Abastecimento. AGROFIT: Sistema de Agrotóxico $\quad$ Fitosanitário. $2020 . \quad$ Disponível em: http://extranet.agricultura.gov.br/agrofit_cons/principal_agrofit_cons. Acesso em: 22 de ago. 2020.

CALDARELLI, C. E.; PERDIGÃO, C. A agroindústria canavieira e seus impactos socioeconômicos na Região Centro-sul do Brasil. Revista Brasileira de Estudos Regionais e Urbanos, v. 12, n. 1, p. 35-50, 2018.

CARDOSO, R. S.; NOVAES, C. P. Variáveis limnológicas e macroinvertebrados bentônicos como bioindicadores de qualidade da água. Revista Nacional de Gerenciamento de Cidades, v. 1, n. 5, 2013. 
CHRISTOFFOLETI, P. J.; LÓPEZ-OVEJERO, R. F. Resistência das plantas daninhas a herbicidas: definições, bases e situação no Brasil e no mundo. Aspectos de Resistência de Plantas Daninhas a Herbicidas, v. 3, p. 9-34, 2008.

CONAB - COMPANHIA NACIONAL DE ABASTECIMENTO. Acompanhamento da safra brasileira de cana-de-açúcar. Safra 2019/20, v. 4, n. 3, Brasília, DF, p. 1-77, 2017. Disponível em: http://www.conab.gov.br. Acesso em:22 de ago. 2020.

CORIOLANO, A. C. F.; MORAIS FILHO, M. C. Biorremediação, uma alternativa na utilização em áreas degradadas pela indústria petrolífera. Holos, v. 7, p.133-133, 2016. Disponível em: http://dx.doi.org/10.15628/holos.2016.4278. Acesso em: 22 de ago. 2020.

DAM, R. A.; CAMILLERI, C.; BAYLISS, P.; MARKICH, S. J. Ecological risk assessment of tebuthiuron following application on tropical Australian wetlands. Human and Ecological Risk Assessment, v. 10, n. 6, p. 1069-1097, 2004.

FASANELLA, C. C.; CARDOSO, E. J. B. N. Biorremediação. In: ANDREOTE F. D.; CARDOSO, E. J. B. N. (org.). Microbiologia do solo. 2. ed. Piracicaba: ESALQ, v. 1, p. 197-210, 2016.

FERREIRA, L. C.; MOREIRA, B. R. A.; MONTAGNOLLI, R. N.; PRADO, E. P.; VIANA, R. S.; TOMAZ, R. S.; CRUZ, J. M.; BIDOIA, E. D.; FRIAS, Y. A.; LOPES, P. R. M. Green manure species for phytoremediation of soil with tebuthiuron and vinasse. Frontiers in Bioengineering and Biotechnology, v. 8, p. 613642, 2021.

FLORES, F.; COLLIER, C. J.; MERCURIO, P.; NEGRI, A. P. Phytotoxicity of four photosystem II herbicides to tropical seagrasses. PLoS One, v. 8, 2013.

FRANCISCO, W. C.; DE QUEIROZ, T. M. Biorremediação. Nucleus, v. 15, n. 1, p. 249-256, 2018.

GOLDEMBERG, J.; COELHO, S.; GUARDABASSI, P. The sustainability of ethanol production from sugarcane. Energy Policy, v. 36, p. 2086-2097, 2008.

HUSSAIN, S.; ARSHAD, M.; SPRINGAEL. D.; SØRENSEN, S.R.; BENDING, G. D.; DEVERSLAMRANI, M.; MAQBOOL, Z.; LAURENT, M. F. Abiotic and biotic processes governing the fate of phenylurea herbicides in soils: a review. Critical Reviews in Environmental Science and Technology, v. 45, n. 18, p. 1947-1998, 2015.

IBAMA - Instituto Brasileiro do Meio Ambiente e dos Recursos Naturais Renováveis. Manual para requerimento de avaliação ambiental: agrotóxicos e afins. Brasília: IBAMA, p. 180, 2009. 
LEWIS, S. E.; SCHAFFELKE, B.; SHAW, M.; BAINBRIDGE, Z. T.; ROHDE, K. W.; KENNEDY, K. Avaliando os riscos aditivos da exposição a herbicidas PSII à Grande Barreira de Corais. Boletim 65 de Poluição Marinha, p. 280-291, 2012.

MACIEL, C. D. G.; POLETINE, J. P.; VELINI, E. D.; AMARAL, J. G. C.; ZANI, L. P.; SANTOS, R. F.; RODRIGUES, M.; RAIMONDI, M. A.; RIBEIRO, R. B. Possibilidade de aplicação de misturas de herbicidas de ação total com jato dirigido em mamoneira de porte anão. Planta Daninha, v. 26, n. 2, p. 457-464, 2008.

MICKELSON, S. K.; BOYD, P.; BAKER, J. L.; AHMED, S. I. Tillage and herbicide incorporation effects on residue cover, runoff, erosion, and herbicide loss. Soil and Tillage Research, v. 60, p. 55-66, 2001.

MORILLO, E.; VILLAVERDE, J. Advanced technologies for the remediation of pesticidecontaminated soils. Science of the Total Environment, v. 586, p. 576-597, 2017.

MORTON, D. M.; HOFFMAN, D. G. Metabolism of a new herbicide, tebuthiuron \{1-[5-(1, 1-dimethylethyl)-1, 3, 4-thiadiazol-2-yl]-1, 3-dimethylurea\}, in mouse, rat, rabbit, dog, duck, and fish. Journal of Toxicology and Environmental Health, Part A Current Issues, v. 1, n. 5, p. 757-768, 1976.

NASCIMENTO, A. Eficácia de herbicidas aplicados em pré-plantio incorporado na cultura da cana-de-açúcar. 2016. 37 f. Dissertação (Mestrado em Agronomia) Faculdade de Engenharia, Universidade Estadual Paulista, UNESP, Ilha Solteira, 2016.

OLIVEIRA, M. F.; BRIGHENTI, A. M. Comportamento dos herbicidas no ambiente. In: OLIVEIRA J. R. R. S.; CONSTANTIN, J.; INOUE, M. H. Biologia e manejo de plantas daninhas. Curitiba: Ominipax, 2011. v. 20, cap. 11.

PRETE, M. C.; DE OLIVEIRA, F. M.; TARLEY, C. R. T. Assessment on the performance of nano-carbon black as an alternative material for extraction of carbendazim, tebuthiuron, hexazinone, diuron and ametryn. Journal of Environmental Chemical Engineering, v. 5, n. 1, p. 93-102, 2017.

QIAO, J.; ZHANG, C.; LUO, S.; CHEN, W. Bioremediation of highly contaminated oilfield soil: Bioaugmentation for enhancing aromatic compounds removal. Frontiers of Environmental Science \& Engineering, v. 8, n. 2, p. 293-304, 2014.

RODRIGUES, M. N; ALMEIDA, F. S. Tebuthiuron e Hexazinona. In: GUIA de herbicidas. Londrina: IAPAR. p. 102-697, 2011

SIBER, R.; STAMM, C.; REICHERT, P. Modeling potential herbicide loss to surface waters on the Swiss plateau. Journal of Environmental Management, v. 91, n. 1, p. 290302, 2009. 
SPAROVEK, G.; BARRETTO, A.; BERNDES, G.; MARTINS, S. Environmental, land-use and economic implications of Brazilian sugarcane expansion 1996-2006. Mitigation and Adaptation Strategies for Global Change, v. 14, n. 3, p. 285-298, 20 nov. 2008.

UNICA - União da Agroindústria Canavieira de São Paulo. Alimento e energia sustentável do brasil para o mundo. São Paulo, 2019. Disponível em: https://www.unica.com.br. Acesso em: 12 ago. 2019.

VILLAVERDE, J.; RUBIO-BELLIDO, M.; MERCHAN, F.; MORILLO, E. Bioremediation of diuron-contaminated soils by a novel degrading microbial consortium. Journal of Environmental Management, v. 188, p. 379-386, 2017.

WALTER, A.; DOLZAN, P.; QUILODRÁN, O.; DE OLIVEIRA, J. G.; DA SILVA, C.; PIACENTE, F.; SEGERSTEDT, A. Sustainability assessment of bio-ethanol production in Brazil considering land use change, GHG emissions and socio-economic aspects. Energy Policy, v. 39, n. 10, p. 5703-5716, out. 2011. Disponível em: http://dx.doi.org/10.1016/j.enpol.2010.07.043. Acesso em: 22 de ago. 2020.

WANG, J.; AWAYA, J.; ZHU, Y.; MOTOOKA, P. S.; NELSON, D. A.; LI, Q. X. Tests of hexazinone and tebuthiuron for control of exotic plants in Kauai, Hawaii. Forests, v. 10, n.7, p. 576, 2019. 


\title{
CAPITULO XXVIII
}

\section{NANOCOMPÓSITOS MAGNÉTICOS NA REMOCÃO DE COMPOSTOS ORGÂMICOS AROMÁTICOS}

\section{DOI: 10.51859/amplla.mas481.1121-28}

\author{
Franciele da Silva Bruckmann ${ }^{1}$ \\ Liana da Silva Fernandes ${ }^{2}$ \\ Cristiano Rodrigo Bohn Rhoden ${ }^{3}$
}

\begin{abstract}
Mestranda do Programa de Pós-Graduação em Nanociências, Universidade Franciscana - UFN
2 Professora Adjunta do curso de Engenharia Química e do Programa de Pós-Graduação em Nanociências, Universidade Franciscana - UFN

3 Professor Adjunto do curso de Engenharia Química e do Programa de Pós-Graduação em Nanociências, Universidade Franciscana - UFN
\end{abstract}

\section{RESUMO}

O intenso crescimento populacional e a ascensão dos processos industriais levaram a um aumento substancial da necessidade de abastecimento de água potável e minimização da exposição aos poluentes emergentes. No entanto, as técnicas convencionais empregadas no tratamento de efluentes ainda não contemplam a efetiva remoção/degradação destes microcontaminantes presentes na grande maioria dos resíduos domésticos e industriais. Em vista disso, diversas tecnologias vêm sendo empregadas e dentre estas, a adsorção têm se mostrado um recurso promissor. Neste contexto, a nanotecnologia surge como uma alternativa, possibilitando a manipulação da matéria a nível atômico e molecular, fornecendo novas propriedades e aplicações aos compostos. Os nanomateriais de carbono têm despertado grande interesse, em virtude de suas características e propriedades únicas. Entre estes, o óxido de grafeno destaca-se pela sua elevada área superficial, estabilidade química, alta processabilidade aquosa e grupos funcionais disponíveis para formação de nanocompósitos. Os nanocompósitos são materiais multifásicos formados por matriz e reforço, onde pelo menos um de seus componentes apresentam dimensões nanométricas funcionais. Uma vez em escala nano, os compósitos tendem a apresentar propriedades distintas e melhoradas, possibilitando o emprego nas mais diversas áreas em que estão inseridas a nanociência e a nanotecnologia. Este trabalho visou descrever o emprego de nanocompósitos magnéticos baseados em óxido de grafeno na adsorção de compostos orgânicos aromáticos descrevendo a influência de alguns parâmetros experimentais nos resultados da capacidade de adsorção dos microcontaminates.

Palavras-chave: Nanopartículas magnéticas. Óxido de grafeno. Poluentes emergentes. Nanotecnologia. 


\section{INTRODUÇÃO}

Atualmente, o descarte inadequado de resíduos químicos, nos mais diversos segmentos da sociedade, tem despertado muita preocupação. Neste contexto, merecem atenção uma classe de compostos químicos nos quais estão contemplados os hidrocarbonetos aromáticos e seus derivados policíclicos. Estes resíduos, por sua vez, são responsáveis por desencadear efeitos nocivos ao meio ambiente e à saúde humana. Devido as suas propriedades físicas e químicas, esses poluentes são inalados e/ou apresentam facilidade em permear membranas celulares (MOJIRI et al., 2019).

Salienta-se, baseados em dados da literatura, que a exposição crônica aos compostos orgânicos aromáticos (Aromatic Organic Compounds-AOCs) está associada a alterações na homeostasia, ocasionando problemas cardíacos, respiratórios, além de efeitos mutagênicos e carcinogênicos (MILAZZO et al., 2019; DEHGHANI et al., 2018). Não obstante, os AOCs são capazes de interferir no sistema endócrino, atuando sobre seus órgãos, prejudicando a sua funcionalidade; interagindo com receptores e mimetizando os efeitos biológicos; inibindo a síntese hormonal (MOVAHEDINIA; SALAMAT; KHERADMAND, 2018). Cabe, ainda, ressaltar que a exposição aos AOCs tem desencadeado efeitos tóxicos tanto em microrganismos quanto em animais aquáticos. Um estudo desenvolvido por Collier et al. (2013) demonstrou a associação da exposição a compostos orgânicos ao desenvolvimento de neoplasias, danos hepáticos e bioacumulação em peixes.

A atividade antropogênica em sua grande maioria associada aos processos industriais, contribui de maneira significativa para a produção e exposição a estes compostos. No entanto, a ação do ser humano não é a única fonte para a geração desses poluentes (MALETIĆ et al., 2019). A degradação da matéria orgânica, as erupções vulcânicas e a combustão de compostos petrolíferos também contribuem com este processo.

Entretanto, esta problemática é acentuada em virtude destes micropoluentes não serem efetivamente removidos das águas residuárias, por diversos fatores, entre eles, sua complexidade estrutural, lipofilicidade, $\mathrm{pH}$, baixa biodegradabilidade, entre outros fatores. Como consequência da não remoção, a presença destas substâncias tem 
sido amplamente reportada, persistindo tanto no solo quanto nas águas superficiais e subterrâneas (LÓPEZ-MACIAS et al., 2019).

No que tange às práticas de remediação ambiental, diversas técnicas e materiais vêm sendo empregados para a remoção de AOCs de corpos d'água, contemplando os métodos biológicos, químicos e físicos. As técnicas biológicas utilizam da ação de microrganismos (bactérias e fungos) e de plantas permitindo a degradação/metabolismo do contaminante (SHAHSAVARI et al., 2019). Enquanto, os métodos físicos e químicos utilizam de propriedades físicas para conversão ou remoção dos poluentes do meio em que estão contidos. Dentre estes métodos, a adsorção tem se mostrado um dos recursos mais promissores para a remoção de poluentes orgânicos, tendo em vista a versatilidade, baixo custo e eficiência na remoção de um grande número de contaminantes aquáticos (DE GISI et al., 2016; FERNANDES et al., 2019).

Para este processo, uma ampla variedade de materiais tem sido utilizada como adsorventes, tais como os carbonáceos, silicosos, magnéticos e poliméricos (SHAHRAKI et al., 2020; XIONG et al., 2019; GAUTAM; HOODA, 2020). De acordo com o diâmetro médio dos poros, os adsorventes podem ser classificados em nanoporosos ( $D<2 \mathrm{~nm}$ ), microporosos ( $2<D<50 \mathrm{~nm}$ ) e macroporosos (D>50 nm) (YOUSEF; QIBLAWEY; EL-NAAS, 2020).

Este trabalho teve como objetivo descrever o emprego de nanocompósitos magnéticos na adsorção de compostos orgânicos aromáticos e demonstrando a influência do $\mathrm{pH}$, concentração inicial do adsorbato, tempo de contato entre adsorvente/adsorbato, temperatura, dosagem do adsorvente e força iônica na capacidade de adsorção dos microcontaminantes.

\section{ADSORÇÃO}

A adsorção é um fenômeno de superfície em que ocorre interação entre íons, átomos e moléculas (adsorbato) com a superfície do adsorvente. Diferentes modelos isotérmicos e cinéticos têm sido utilizados para descrever o processo de adsorção, fornecendo informações importantes acerca do tipo de interação existente (GHAZI et al., 2018). Os mecanismos de adsorção incluem basicamente dois tipos de interações, a adsorção química que corresponde a ligações químicas entre o sistema 
adsorvente/adsorbato e a adsorção física relacionada as forças de Van der Waals e de troca iônica (Figura 1). Esses mecanismos são investigados por meio de dados do equilíbrio, cinética e caracterização do adsorvente antes e após o processo (MOHAMMED; KAREEM, 2019; LIU et al., 2020). Além disso, os cálculos de pseudopotenciais e de bases atômicas numéricas localizadas baseados na Teoria do Funcional da Densidade (Density Functional Theory - DFT) também são bastante úteis para descrever o fenômeno (AHMAD et al., 2020).

Figura 1- Mecanismos de adsorção em mono e multicamadas

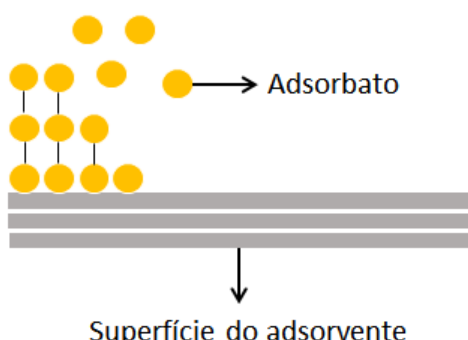

Interações de Van der Waals ocorrem entre o adsorbato e a superfície do adsorvente

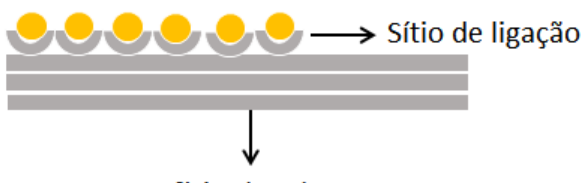

Superfície do adsorvente

Ligações químicas são formadas entre o adsorbato e a superfície do adsorvente

Fonte: Autoria própria.

As isotermas de adsorção desempenham uma função importante, pois são capazes de descreverem a interação existente entre o adsorvente e o adsorbato, podendo então auxiliar na otimização tanto do uso de adsorventes quanto do tipo de projeto de adsorção (WONG et al., 2004). As isotermas de adsorção mais comuns e relatadas pela literatura são os modelos de Langmuir, Freundlich e Temkin. A isoterma de Langmuir assume que o processo de adsorção ocorre em monocamadas, com distribuição homogênea dos sítios ativos, energia constante na qual os solutos adsorvidos não interagem entre si (PÉREZ-MARín et al., 2007; LANGMUIR, 1917). Enquanto, a isoterma de Freundlich, um dos modelos mais antigos descreve que o processo, ocorre em multicamadas, com distribuição logarítmica dos sítios ativos e de energia não uniforme (FREUNDLICH, 1906; AHMARUZZAMAN, 2008).

A isoterma de Temkin é um modelo que presume que a adsorção é um processo em multicamadas, assumindo que o calor de adsorção reduz à medida que os sítios de 
ligação são ocupados (distribuição uniforme de energia) (FOO; HAMEED, 2010; YANG, 1993). Entretanto, os modelos de Freundlich e Temkin são considerados apenas equações empíricas e sem significado físico e, portanto, não são capazes de descrever qualquer fenômeno físico ou químico de adsorção (WANG; GUO, 2020a).

Os estudos cinéticos têm sido amplamente utilizados e baseiam-se na retirada de alíquotas da amostra em tempos pré-determinados. Estes experimentos têm como objetivo traçar o perfil cinético, fazer o ajuste dos dados experimentais e por fim, descrever o processo de adsorção (NETHAJI; SIVASAMY; MANDAL, 2013). Dentre os diversos modelos, os mais comuns são os de pseudo-primeira-ordem (PPO) e pseudosegunda-ordem (PSO).

O modelo PPO ou também conhecido como modelo de Langergren, descreve que a adsorção dos íons ou moléculas independe da concentração inicial e o processo de transporte do adsorbato ocorre por meio de difusão externa (SILVA et al., 2018). As hipóteses sugeridas para este modelo são listadas abaixo:

a. Nos estágios iniciais de adsorção, a fração de sítios ativos ocupados do adsorvente se aproxima do zero;

b. A concentração inicial de adsorbato na solução é muito alta;

c. Existem alguns sítios ativos no adsorvente.

Em termos de mecanismos de adsorção, se este modelo apresentar maiores valores para o coeficiente de determinação $\left(R^{2}\right)$, a adsorção ocorre por meio de interações de Van der Waals, indicando um processo de fisiossorção (WANG; GUO, 2020b).

O modelo de PSO assume que a adsorção nos sítios ativos é o principal mecanismo e a etapa de controle do processo de adsorção, ou seja, a taxa de adsorção aumenta proporcionalmente com os sítios de adsorção disponíveis. Desta forma, algumas hipóteses são descritas:

a. O número de sítios ocupados ao final do processo aumenta;

b. O adsorvente apresenta muitos sítios ativos;

c. A concentração inicial do adsorbato na solução é baixa. 
De acordo com esse modelo cinético, infere-se que a etapa limitante do processo envolve a transferência de elétrons entre o adsorvente/adsorbato, indicando uma adsorção de natureza química (QIU et al., 2009; WANG; GUO, 2020b).

\section{3. ÓXIDO DE GRAFENO}

Os nanomateriais derivados do carbono apresentam características e propriedades únicas, motivo pelo qual inúmeros estudos exploram suas aplicações nas mais diversas áreas (FRACZEK-SZCZYPTA et al., 2018). Descoberto por Novoselov et al (2004), o grafeno tem sido alvo de inúmeras pesquisas devido as suas excelentes propriedades tais como, alta resistência, condutividade elétrica e elevada área superficial.

O grafeno consiste em uma folha bidimensional de átomos de carbono com hibridização $\mathrm{sp}^{2}$, possui uma estrutura cristalina, com seu formato semelhante a um favo de mel. A partir da sua estrutura elementar e pela utilização de diferentes rotas sintéticas obtém-se os demais alótropos do carbono, como por exemplo os nanotubos de carbono e o óxido de grafeno (SADHUKHAN et al., 2019).

Por meio da oxidação e exfoliação química do grafite, obtém-se o óxido de grafeno (Graphene Oxide - GO) (Figura 2) (SALLES et al., 2020). Processo no qual alguns átomos de carbono com hibridização $\mathrm{sp}^{2}$ são convertidos a hibridização $\mathrm{sp}^{3}$ através da adição de grupos oxigenados (RHODEN et al., 2017). Devido as suas propriedades térmicas e eletrônicas consideráveis, e ainda, em virtude de sua elevada área superficial e alta processabilidade aquosa, o GO tem se mostrado um bastante material promissor para criação de novos nanocompósitos (ZHANG et al., 2019).

Não obstante, também tem se mostrado como um agente oxidante forte para oxidar partículas de $\mathrm{Fe}^{+2}$ e $\mathrm{Fe}^{+3}$ em nanopartículas de $\mathrm{Fe}_{3} \mathrm{O}_{4}$, as quais são depositadas sobre sua superfície (RHODEN et al., 2017). O GO decorado com magnetita $\left(\mathrm{Fe}_{3} \mathrm{O}_{4}\right)$ apresenta comportamento magnético, possibilitando sua utilização na remoção de contaminantes aquáticos (MIAO et al., 2019). 
Figura 2- Estrutura química do óxido de grafeno

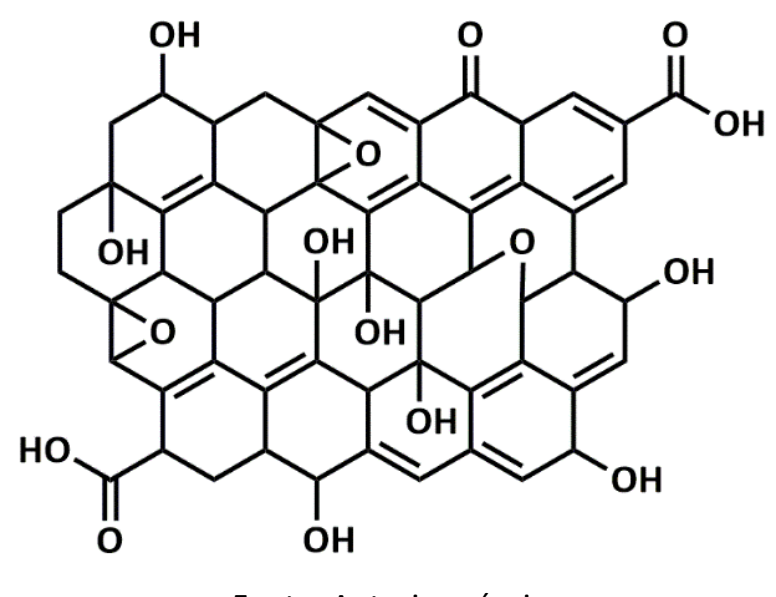

Fonte: Autoria própria.

\section{NANOPARTICULAS MAGNÉTICAS}

As nanopartículas magnéticas, especialmente, os óxidos de ferro (magnetita e maghemita) apresentam diversas aplicações, devido a sua baixa toxicidade, biodegradabilidade e área superficial disponível para funcionalização e modificação química (BRUCKMANN et al., 2020). Além disso, estas nanopartículas caracterizam-se por exibirem comportamento magnético somente pela aplicação de um campo magnético externo. Não obstante, as nanopartículas de óxido de ferro (Iron Oxide NanoParticles - IONPs) demonstram-se promissoras em estudos de adsorção devido a fácil preparação, baixo custo e facilidade de remoção da fase líquida pós-adsorção, sem necessidade de filtração, centrifugação e do emprego de outros compostos químicos (CHEN et al., 2016; RHODEN et al., 2017).

Figura 3- Separação magnética do complexo adsorvente/adsorbato após o processo de adsorção

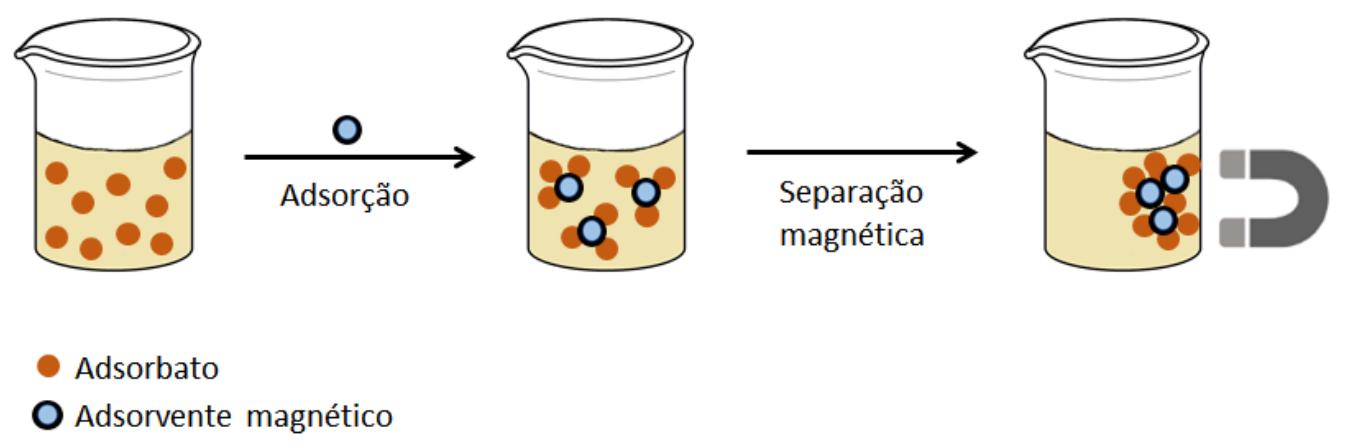

Fonte: Autoria própria. 
Diferentes métodos de preparação têm sido empregados para a obtenção de nanopartículas magnéticas (Magnetic NanoParticles - MNPs), incluindo os métodos químicos, físicos e biológicos. Cerca de $90 \%$ das metodologias sintéticas que promovem a obtenção de nanopartículas compreendem os métodos químicos, nos quais estão contempladas as técnicas de microemulsão, hidrotermais, co-precipitação e solvotermais. Estas, diferem-se quanto a morfologia, tamanho, cristalinidade e estabilidade química das nanopartículas (MAJIDI et al., 2016; MYLKIE et al., 2021).

A técnica de co-precipitação é a metodologia mais usual para obtenção de MNPs de tamanho e morfologia controlados. A co-precipitação baseia-se na mistura de sais férricos $\left(\mathrm{Fe}^{2+}\right)$ e ferrosos $\left(\mathrm{Fe}^{3+}\right)$, na proporção 1:2, em solução aquosa desoxigenada e pH controlado (9-14). Além disso, este método é conduzido sob condições reacionais brandas, sem utilização de solventes orgânicos e altas temperaturas, tornando-se menos agressivo ao meio ambiente, de acordo com os princípios de "química verde" (RHODEN et al., 2017; BRUCKMANN et al., 2020).

\section{NANOCOMPÓSITOS MAGNÉTICOS}

Os nanocompósitos são materiais multifásicos que apresentam pelo menos uma dimensão em escala nanométrica ativa, formados por uma matriz polimérica, cerâmica ou carbonácea. Geralmente, os nanocompósitos são sintetizados com o intuito de combinar as propriedades individuais de cada constituinte tornando-os multifuncionais (RANE et al., 2018; NADAR et al., 2018). Os nanocompósitos magnéticos são constituídos de uma fase (nanopartícula magnética), suportada em uma matriz orgânica ou inorgânica (MARCELO et al, 2020). Em função do seu diâmetro crítico, as MNPs são instáveis e tendem a formar agregados. Em virtude destas limitações, diversas alternativas vêm sendo investigadas, como o revestimento polimérico, cerâmico e a imobilização sob a superfície de nanomateriais de carbono. As modificações químicas podem também tornar os materiais ainda mais funcionais e biocompatíveis (HUSSEINAL-ALI et al., 2014; SMITH; MCKEAGUE; DEROSA, 2019). 


\section{ADSORÇÃO DE COMPOSTOS ORGÂNICOS EM NANOCOMPÓSITOS MAGNÉTICOS BASEADOS EM ÓXIDO DE GRAFENO}

As referências encontradas referentes à remoção de AOCs foram agrupadas e apresentadas na tabela 1, com o objetivo de abordar a capacidade de adsorção dos diferentes nanocompósitos magnéticos baseados em óxido de grafeno. Uma análise comparativa foi conduzida apenas para os adsorbatos investigados em mais de um estudo com o uso de diferentes adsorventes. Além disso, descreveu-se os mecanismos envolvidos no processo de adsorção com base no pH e modelo cinético.

Tabela 1- Adsorção de AOCs em nanocompósitos magnéticos

\begin{tabular}{|c|c|c|c|c|}
\hline Adsorvente & $\begin{array}{l}\text { Área superficial } \\
\text { (BET) }\end{array}$ & Poluente & $\begin{array}{l}\text { Capacidade } \\
\text { máxima de } \\
\text { adsorção } \\
\text { (q } \text { qáx }_{\text {mán }}\end{array}$ & Referência \\
\hline \multirow{3}{*}{$\mathrm{GO} \mathrm{Fe}_{3} \mathrm{O}_{4}$} & \multirow{3}{*}{$272,59 \mathrm{~m}^{2} / \mathrm{g}$} & Naftaleno & $\begin{array}{c}5,72 \\
\mathrm{mmol} / \mathrm{g} / \mathrm{g}^{-1}\end{array}$ & \multirow{3}{*}{$\begin{array}{l}\text { (YANG et al., } \\
\text { 2013). }\end{array}$} \\
\hline & & $\alpha$-Naftol & $\begin{array}{c}2,70 \\
\mathrm{mmol} / \mathrm{g} / \mathrm{g}^{-1}\end{array}$ & \\
\hline & & 1-Naftilamina & $\begin{array}{c}2,85 \\
\mathrm{mmol} / \mathrm{g} / \mathrm{g}^{-1}\end{array}$ & \\
\hline MCG & - & $\begin{array}{c}p- \\
\text { fenilenodiamina }\end{array}$ & $1112,58 \mathrm{mg} / \mathrm{g}^{-1}$ & $\begin{array}{c}\text { (WANG et al., } \\
\text { 2015). }\end{array}$ \\
\hline \multirow{2}{*}{$\mathrm{GO}-\mathrm{Fe}_{3} \mathrm{O}_{4} / \mathrm{PRd}$} & \multirow{2}{*}{$30,74 \mathrm{~m}^{2} / \mathrm{g}$} & Fenol & $191,00 \mathrm{mg} / \mathrm{g}^{-1}$ & \multirow{2}{*}{$\begin{array}{l}\text { (PARVIN et al., } \\
\text { 2020). }\end{array}$} \\
\hline & & $\beta$-Naftol & $226,20 \mathrm{mg} / \mathrm{g}^{-1}$ & \\
\hline $\mathrm{GO} \mathrm{Fe}_{3} \mathrm{O}_{4}$ & $145,80 \mathrm{~m}^{2} / \mathrm{g}$ & $\begin{array}{c}\text { 2,4,4 } \\
\text { Triclorobifenil }\end{array}$ & $0,718 \mathrm{mg} / \mathrm{g}^{-1}$ & $\begin{array}{l}\text { (ZENG et al., } \\
\text { 2013). }\end{array}$ \\
\hline MGOC & - & 1-Naftilamina & $7,25 \mathrm{mg} / \mathrm{g}^{-1}$ & $\begin{array}{c}\text { (REBEKAH et al., } \\
\text { 2021). }\end{array}$ \\
\hline $\begin{array}{c}\mathrm{Fe}_{3} \mathrm{O}_{4} @ \mathrm{SiO}_{2} @ \mathrm{PANI}- \\
\mathrm{GO}\end{array}$ & - & Bisfenol A & $454,56 \mathrm{mg} / \mathrm{g}^{-1}$ & $\begin{array}{c}\text { (ZEESHAN et al., } \\
\text { 2021). }\end{array}$ \\
\hline \multirow{3}{*}{ MCGO } & \multirow{3}{*}{$387,85 \mathrm{~m}^{2} / \mathrm{g}$} & Bisfenol A & $28,98 \mathrm{mg} / \mathrm{g}^{-1}$ & \multirow{3}{*}{$\begin{array}{l}\text { (SHAH et al., } \\
\text { 2020). }\end{array}$} \\
\hline & & 4-terc-butil-fenol & $33,22 \mathrm{mg} / \mathrm{g}^{-1}$ & \\
\hline & & 4-terc-octil-fenol & $24,31 \mathrm{mg} / \mathrm{g}^{-1}$ & \\
\hline
\end{tabular}




\begin{tabular}{|c|c|c|c|c|}
\hline MMIPS & - & Bisfenol A & $106,38 \mathrm{mg} / \mathrm{g}^{-1}$ & $\begin{array}{c}\text { (WANG et al., } \\
\text { 2016). }\end{array}$ \\
\hline MGOC & $20,93 \mathrm{~m}^{2} / \mathrm{g}$ & \multirow{3}{*}{ Bisfenol A } & $86,22 \mathrm{mg} / \mathrm{g}^{-1}$ & \multirow{3}{*}{$\begin{array}{c}\text { (REKOS et al., } \\
\text { 2019). }\end{array}$} \\
\hline GO-PSm & $10,00 \mathrm{~m}^{2} / \mathrm{g}$ & & $50,25 \mathrm{mg} / \mathrm{g}^{-1}$ & \\
\hline GO-PANIm & $35,78 \mathrm{~m}^{2} / \mathrm{g}$ & & $31,76 \mathrm{mg} / \mathrm{g}^{-1}$ & \\
\hline \multirow{3}{*}{$\mathrm{Fe}_{3} \mathrm{O}_{4} @ \mathrm{PANI}-\mathrm{OO}$} & \multirow{3}{*}{ - } & Bisfenol A & $14,43 \mathrm{mg} / \mathrm{g}^{-1}$ & \multirow{3}{*}{$\begin{array}{c}\text { (ZHOU et al., } \\
\text { 2017). }\end{array}$} \\
\hline & & $\alpha$-Naftol & $13,19 \mathrm{mg} / \mathrm{g}^{-1}$ & \\
\hline & & 4-terc-octil-fenol & $24,15 \mathrm{mg} / \mathrm{g}^{-1}$ & \\
\hline
\end{tabular}

$\mathrm{GO} . \mathrm{Fe}_{3} \mathrm{O}_{4} / \mathrm{PRd}=$ nanocompósito óxido de grafeno magnético/polirodanina; $\mathrm{Fe}_{3} \mathrm{O}_{4} @ \mathrm{PANI}-\mathrm{GO}=$ nanocompósito magnético polianilina/óxido de grafeno; $\mathrm{MGOC}=$ nanocompósito óxido de grafeno magnético/quitosana; $\mathrm{MCGO}=$ nanocompósito quitosana magnética/óxido de grafeno; $\mathrm{MCG}=$ nanocompósito ciclodextrina magnética/óxido de grafeno; MMIPS= nanocompósito magnético de polímeros impressos molecularmente; GO-PSm= nanocompósito magnético óxido de

grafeno/poliestireno; GO-PANIm= nanocompósito magnético óxido de grafeno/polianilina; $\mathrm{Fe}_{3} \mathrm{O}_{4} @ \mathrm{SiO}_{2} @ \mathrm{PANI}-\mathrm{GO}=$ nanocompósito magnético dióxido de silício/polianilina/óxido de grafeno.

$\mathrm{Na}$ tabela 1, observa-se que Yang et al. (2013) utilizaram o $\mathrm{GO}_{\mathrm{Fe}} \mathrm{O}_{4}$ para adsorver naftaleno, $\alpha$-naftol e 1-naftilamina de soluções aquosas. Os experimentos de adsorção foram realizados em regime de batelada, em ambiente protegido da luz, temperatura $\left(10,30\right.$ e $\left.50^{\circ} \mathrm{C}\right)$ e $\mathrm{pH}$ controlado para avaliação da influência na capacidade de adsorção e nos mecanismos de adsorção.

De acordo com estudo, o pH da solução demonstrou controle sob a capacidade de adsorção dos três compostos. Em pH ácido, a presença de íons na solução resultou na formação de um ácido e base de Lewis, fazendo do $\mathrm{GO}^{-\mathrm{Fe}_{3} \mathrm{O}_{4}} \mathrm{um}$ aceptor de prótons e os adsorbatos doadores de prótons, favorecendo a interação do sistema adsorvente/adsorbato. Conforme o aumento do $\mathrm{pH}$, observou-se o aumento da capacidade máxima de adsorção ( $q_{\text {máx }}$ ) do $\alpha$-naftol e da 1-naftilamina, sugerindo que a interação eletrostática não é o único mecanismo envolvido neste processo.

O estudo isotérmico demonstrou que a adsorção dos AOCs ocorreu de maneira heterogênea, com interação entre os solutos adsorvidos e energia não uniforme nos sítios de adsorção. A cinética de adsorção é descrita pelo modelo de pseudo-segundaordem (PSO), e os mecanismos envolvidos neste processo são as interações $\pi-\pi, n-\pi$ e as ligações de hidrogênio. A termodinâmica de adsorção indicou que a remoção dos poluentes orgânicos é um processo favorável, endotérmico com entropia positiva, ou seja, à medida que a temperatura aumenta ocorre consequentemente um aumento na capacidade de adsorção. 
Para remover $p$-fenilenodiamina de soluções aquosas, Wang et al. (2015) desenvolveram um nanocompósito magnético de $\beta$-ciclodextrina e óxido de grafeno (MCG). O estudo de adsorção foi avaliado quanto ao efeito do pH (4-9), concentração inicial do adsorbato e temperatura. Os resultados demonstraram que a capacidade de adsorção máxima foi atingida em pH 8, devido a não competição dos íons em solução pelos sítios de ligação do adsorvente. Em relação a temperatura, os estudos termodinâmico e isotérmico mostraram que o aumento da temperatura e da concentração inicial do adsorbato são diretamente proporcionais a $q_{\text {máx. }} \quad 0$ comportamento da adsorção foi melhor descrito pela isoterma de Langmuir e pela cinética de PSO, suportando a hipótese de um processo em superfície homogênea, energia uniforme e com a maioria dos sítios ocupados no estágio final da adsorção.

Parvin et al. (2020) sintetizaram um nanocompósito de óxido de grafeno magnético/polirodanina e estudaram a remoção de fenol e 2-naftol. Os ensaios de adsorção foram realizados e condições experimentais investigadas quanto ao $\mathrm{pH}$ do meio, tempo de contato, concentração inicial e temperatura.

Conforme reportado pelos autores, a capacidade máxima de adsorção aumentou gradativamente com a concentração inicial. A condição ideal de adsorção foi estabelecida em pH 7, considerando a alta taxa de remoção e a intensidade das interações $\pi-\pi$ e de hidrogênio na faixa de pH próxima à neutralidade. O efeito do tempo de contato indicou que nas etapas iniciais do processo, houve uma elevada taxa de adsorção seguido do equilíbrio nos estágios seguintes, como consequência da ocupação dos sítios livres.

Semelhante ao estudo de Yang e colaboradores (2013), um trabalho desenvolvido por Zeng et al. (2013) reportou a remoção de 2,4,4-triclorobifenil

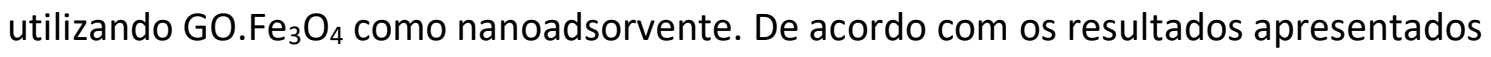
neste trabalho, verificou-se que a capacidade máxima de adsorção é atingida nos primeiros 30 minutos de experimento, com tendência ao equilíbrio nos estágios seguintes. Em relação ao estudo do pH, constatou-se que condições básicas favorecem a desprotonação dos grupos oxigenados presentes no adsorvente e impedem a interação do adsorbato com os sítios de ligação, resultando em menor capacidade de adsorção. O modelo de PSO representou de forma satisfatória os dados experimentais 
e indicou que o processo de adsorção ocorreu por meio de interações de hidrogênio e interações $\pi-\pi$.

Rabekah et al. (2021) sintetizaram um nanocompósito de óxido de grafeno magnético funcionalizado com quitosana e utilizaram como adsorvente de 1naftilamina. A eficiência da adsorção foi avaliada pelo pH da solução, concentração inicial do adsorbato, tempo de contato e quantidade de adsorvente. Os estudos cinéticos e isotérmicos foram conduzidos com o objetivo de compreender o equilíbrio, a interação entre adsorvente/adsorbato e o mecanismo da adsorção.

Diante dos resultados encontrados, observou-se que a condição mais favorável para a remoção de 1-naftilamina foi em $\mathrm{pH}$ 8, corroborando com os reportados por Yang et al. (2013) ao empregarem $\mathrm{GO}^{-} \mathrm{Fe}_{3} \mathrm{O}_{4}$. O efeito do tempo de contato entre adsorvente/adsorbato e da dosagem de MGOC mostraram que percentual de remoção não está diretamente relacionado com a quantidade de adsorvente e o tempo reacional, uma vez que a maior taxa de remoção foi atingida em 45 minutos utilizando $8 \mathrm{mg}$ de adsorvente.

Não obstante, o percentual de 1-naftilamina adsorvido da solução é diretamente proporcional com a concentração do adsorbato. O equilíbrio de adsorção e a interação MGOC/1-naftilamina foi ajustado pela isoterma de Freundlich, assumindo distribuição logarítmica dos sítios ativos. O parâmetro empírico $n$ apresentou valor entre 1-10, indicando um processo favorável. Todavia, a cinética da adsorção é representada pelo modelo de pseudo-segunda-ordem, indicando uma adsorção química

Shah et al. (2020) estudaram a remoção simultânea de três disruptores endócrinos químicos (Endocrine-Disrupting Chemicals - EDCs), bisfenol A (bisphenol A BPA), 4-terc-butil-fenol e 4-terc-octil-fenol empregando um nanocompósito de quitosana magnética/óxido de grafeno (MCGO). Neste estudo, alguns parâmetros foram investigados, tais como $\mathrm{pH}$ da solução, massa do adsorvente e temperatura. De acordo com o estudo, a qmáx foi observada em pH 5 em virtude da carga superficial do adsorvente (Potencial de carga zero $-P C Z=5,2$ ). Em relação a quantidade de $M C G O$ empregado no estudo, um aumento significativo na taxa de remoção foi observado entre 1-3 mg do adsorvente. 
O estudo termodinâmico realizado Shah e colaboradores (2020) demonstrou que a adsorção dos EDCs é um processo exotérmico e espontâneo. Contudo, o aumento dos valores $\Delta \mathrm{G}^{\circ}$ indicam que a adsorção é desfavorecida com a elevação da temperatura. Os parâmetros cinéticos e isotérmicos utilizados demonstraram que a isoterma de Langmuir e o modelo PSO representaram melhor ajuste dos dados experimentais, sugerindo uma adsorção de natureza química. Em razão da qmáx ser observada em pH 5 e da estrutura química dos compostos orgânicos, alguns mecanismos foram sugeridos. Os mecanismos químicos envolvidos neste processo incluem o empilhamento das ligações $\pi-\pi$ entre as regiões com defeitos presentes na superfície do adsorvente e na molécula do adsorbato rica em elétrons, interações $n-\pi$ e interações de hidrogênio.

Zeeshan et al. (2021) sintetizaram um nanocompósito magnético ( $\left.\mathrm{Fe}_{3} \mathrm{O}_{4} @ \mathrm{SiO}_{2} @ \mathrm{PANI}-\mathrm{GO}\right)$ e avaliaram seu desempenho na remoção de BPA. Os experimentos realizados neste estudo foram conduzidos em lote, explorando parâmetros como pH da solução (2-10), o efeito da quantidade de adsorvente, o tempo de contato e a temperatura. $\mathrm{O}$ estudo do $\mathrm{pH}$ demonstrou que o percentual máximo de remoção do BPA ocorreu em pH neutro. Em pH básico, o bisfenol A sofre especiação química e passa a existir nas formas aniônica e dianiônica o que favorece a ocorrência de repulsões eletrostáticas com o nanoadsorvente desprotonado.

Foi constatada a relação existente entre a quantidade do adsorvente e a eficiência na remoção de BPA. Observou-se que a quantidade $(100 \mathrm{mg})$ se mostrou mais eficiente na remoção do BPA, devido a maior disponibilidade de sítios para a adsorção. Em relação ao tempo de contato e o percentual de adsorbato removido, verificou-se que a taxa de remoção nos primeiros 60 minutos é alta e segue a tendência de equilíbrio até o final do experimento. Salienta-se que o modelo de PSO é o que melhor representou o ajuste dos dados experimentais, sugerindo que a adsorção ocorre por meio de interações de hidrogênio, $\pi-\pi$ e $n-\pi$ entre adsorvente/adsorbato. A isoterma de adsorção é descrita pelo modelo de Freundlich, assumindo uma distribuição de energia não uniforme nos sítios de adsorção.

De semelhante modo, Zhou et al. (2017) desenvolveram um nanocompósito magnético de polianilina/óxido de grafeno $\left(\mathrm{Fe}_{3} \mathrm{O}_{4} @ P A N I-G O\right)$ e investigaram a eficiência do adsorvente na remoção de BPA, $\alpha$-Naftol e 4-terc-octil-fenol. O estudo foi realizado 
em regime de batelada, utilizando diferentes condições, tais como, quantidade de adsorvente, tempo de contato, força iônica, ácido húmico, temperatura e pH da solução. Os resultados obtidos no trabalho revelaram que o percentual de remoção dos contaminantes aumentou proporcionalmente com a dosagem do adsorvente. No entanto, observou-se uma alta taxa de remoção nos estágios iniciais e uma rápida tendência ao equilíbrio nos estágios subsequentes, sugerindo uma saturação dos sítios de adsorção.

Em contrapartida, os autores verificaram que o aumento da concentração da solução salina provocou um decréscimo na capacidade de adsorção do BPA e $\alpha$-Naftol a partir da concentração de 10 e 15\%, respectivamente. O ácido húmico é um interferente no processo de adsorção, tendo em vista a capacidade de competição pelos sítios ativos. Conforme observado no estudo, verificou-se que a concentração de 0,1 mg L-1 promoveu um aumento na taxa de remoção dos compostos. Todavia, o aumento gradativo da concentração resultou em um decréscimo no percentual de remoção do BPA.

Corroborando com os resultados reportados por Shah et al (2020), a $\mathrm{q}_{\text {máx }}$ de adsorção dos poluentes orgânicos ocorreu em pH próximo a neutralidade. Além disso, o equilíbrio e a cinética de adsorção também são melhor representados pelos modelos de Langmuir e PSO, respectivamente. Conforme observado pelos autores neste trabalho, a adsorção dos AOCs foi espontânea ( $\Delta \mathrm{G}^{\circ}$ negativo) e endotérmica, considerando um acréscimo na capacidade de adsorção à medida que a temperatura aumenta (ZHOU et al., 2017).

Em um estudo recente, Rekos et al. (2019) sintetizaram três nanocompósitos magnéticos para remoção de BPA. Diferentes parâmetros foram avaliados para determinar a eficiência do processo, tais como, pH da solução (3-9), força iônica ( $\mathrm{NaCl}$ 0,1-1 $\mathrm{mol} \mathrm{L}^{-1}$ ) e tempo de contato (0-180 minutos). Com base nos resultados obtidos, pôde-se verificar uma influência da estrutura química do nanocompósito na capacidade de adsorção do EDC. Conforme demonstrado no estudo, a área superficial específica dos nanoadsorventes não apresenta uma correlação direta com a capacidade de adsorção, visto que o nanocompósito MGOC apresentou uma área superficial de 20,93 $\mathrm{m}^{2} / \mathrm{g} \mathrm{e}$ capacidade de adsorção de $86,22 \mathrm{mg} / \mathrm{g}^{-1}$, enquanto os nanocompósitos GO-PSm e GO- 
PANIm apresentaram uma área de superfície e $q_{\text {máx }}$ de $\left(10,00 \mathrm{~m}^{2} / \mathrm{g}\right.$ e 50,25 86,22 mg/g$\left.{ }^{1} 35,78 \mathrm{~m}^{2} / \mathrm{g}, 31,76 \mathrm{mg} / \mathrm{g}^{-1}\right)$, respectivamente.

$\mathrm{O}$ estudo da variação do $\mathrm{pH}$ e da concentração de $\mathrm{NaCl}$ realizado por Rekos e colaboradores (2019) demonstrou que a capacidade de adsorção do BPA é dependente de cargas iônicas e das interações eletrostáticas existentes no meio. Baseado nisto, verificou-se que o $\mathrm{pH} 5$ e a concentração de $1 \mathrm{~mol} \mathrm{~L}^{-1}$ de $\mathrm{NaCl}$ representaram a melhor condição experimental para a remoção de BPA empregando o nanocompósito MGOC. O equilíbrio da adsorção foi atingido em 1 hora e ajustado a isoterma de Langmuir (maior valor de $\mathrm{R}^{2}$ ), assumindo uma adsorção em monocamadas com distribuiç̧ão uniforme de energia. A cinética de adsorção é mais bem descrita pelo modelo de PSO e que a transferência de elétrons entre o sistema adsorvente/adsorbato é a etapa limitante, indicando um processo de quimiossorção.

Wang et al. (2016) desenvolveram um nanocompósito magnético de polímeros impressos molecularmente para remover BPA de soluções aquosas. A capacidade de adsorção foi investigada por meio da variação do pH (2-10), tempo de contanto, concentração inicial de BPA (10-100 mg L-1) e seletividade do adsorvente empregando fenol, tetrabromobisfenol A e 2,4-diclorofenol. Corroborando com os estudos anteriores, a capacidade máxima de adsorção do BPA foi atingida em pH 6 e os principais mecanismos envolvidos neste processo são as interações $\pi-\pi$ entre os anéis aromáticos presentes no adsorbato e na estrutura do GO. Em meio básico, a formação de espécies aniônicas resultou em repulsão eletrostática, o que justifica os resultados obtidos.

O estudo da influência da concentração de BPA, demonstrou que houve um aumento proporcional na capacidade de adsorção com a concentração inicial, o que sugere uma maior probabilidade de ligação do BPA com os sítios de ligação do adsorvente. $\mathrm{O}$ estudo cinético e o equilíbrio avaliado pelas isotermas, indicam uma adsorção de natureza química, com energia constante e sem interação entre solutos adsorvidos. Apesar dos compostos apresentarem similaridade estrutural, o nanocompósito demonstrou-se seletivo na remoção do BPA, isto explica-se pelo arranjo espacial dos compostos bem como pela maior afinidade do bisfenol A pelos sítios de ligação promovidos pela impressão molecular. 


\section{CONSIDERAÇÕES FINAIS}

O intenso crescimento populacional e a ascensão dos processos industriais levaram a um aumento substancial da necessidade de abastecimento de água potável e minimização da exposição aos poluentes emergentes. No entanto, as técnicas convencionais empregadas no tratamento de efluentes ainda não contemplam a efetiva remoção/degradação destes microcontaminantes presentes na grande maioria dos resíduos domésticos e industriais. Em vista disso, diversas tecnologias vêm sendo empregadas e dentre estas, a adsorção têm se mostrado um recurso promissor, devido a versatilidade, fácil operacionalidade e baixo custo. Entretanto, a eficiência do processo depende de fatores intrínsecos ao adsorvente, tais como área superficial, tamanho e volume de poros.

Este trabalho visou abordar o emprego de nanocompósitos magnéticos baseados em óxido de grafeno na adsorção de compostos orgânicos aromáticos. Por meio deste estudo foi possível constatar que a adsorção é uma tecnologia em grande expansão, com inúmeras possibilidades e potencialidades para a remoção de contaminantes dos mais diversos. Todavia, observou-se que a eficiência do processo depende das condições experimentais, tais como o pH da solução, concentração inicial do adsorbato, o tempo de contato entre adsorvente/adsorbato, temperatura, dosagem do adsorvente e força iônica. Os estudos termodinâmicos, em sua grande maioria indicam que a adsorção é um processo favorável, espontâneo, de custo acessível, aplicação bastante diversa e com enormes benefícios ao meio ambiente e a natureza.

\section{REFERÊNCIAS}

AHMAD, R. et al. Terbium extraction by functionalized surface: experimental and DFT approach. Adsorption, v. 26, n. 1, p. 117-125, 2020.

AHMARUZZAMAN, M. Adsorption of phenolic compounds on low-cost adsorbents: a review. Advances in colloid and interface science, v. 143, n. 1-2, p. 48-67, 2008.

BRUCKMANN, F. S. et al. Synthesis, characterization and cytotoxicity evaluation of magnetic nanosilica in 2929 cell line. Disciplinarum Sciential Naturais e Tecnológicas, v. 21, n. 3, p. 1-14, 2020. 
CHEN, L. et al. Functional magnetic nanoparticle/clay mineral nanocomposites: preparation, magnetism and versatile applications. Applied Clay Science, v. 127, p. 143-163, 2016.

COLLIER, T. K. et al. Effects on fish of polycyclic aromatic hydrocarbons (PAHs) and naphthenic acid exposures. Fish physiology, v. 33, 195-255, 2013.

DE GISI, S. et al. Characteristics and adsorption capacities of low-cost sorbents for wastewater treatment: a review. Sustainable Materials and Technologies, v. 9, p. 10-40, 2016.

DEHGHANI, M. et al. Characteristics and health effects of BTEX in a hot spot for urban pollution. Ecotoxicology and environmental safety, v. 155, p. 133-143, 2018.

FERNANDES, $A$. et al. Integrated photocatalytic advanced oxidation system (TiO2/UV/O3/H2O2) for degradation of volatile organic compounds. Separation and Purification Technology, v. 224, p. 1-14, 2019.

FOO, K. Y.; HAMEED, B. H. Insights into the modeling of adsorption isotherm systems. Chemical engineering journal, v. 156, n. 1, p. 2-10, 2010.

FRACZEK-SZCZYPTA, A. et al. Carbon nanomaterials coatings - Properties and influence on nerve cells response. Diamond and Related Materials, v. 84, p. 127-40, 2018.

FREUNDLICH, H. M. F. et al. Over the adsorption in solution. J. Phys. Chem, v. 57, n. 385471, p. 1100-1107, 1906.

GAUTAM, D.; HOODA, S. Magnetic Graphene Oxide/Chitin Nanocomposites for Efficient Adsorption of Methylene Blue and Crystal Violet from Aqueous Solutions. Journal of Chemical \& Engineering Data, v. 65, n. 8, p. 4052-4062, 2020.

GHAZI, Z. A. et al. Adsorptive removal of $\mathrm{Cd}^{2+}$ from aqueous solutions by a highly stable covalent triazine-based framework. New Journal of Chemistry, v. 42, n. 12, p. 10234-10242, 2018.

HUSSEIN-AL-ALI et al. Synthesis, characterization, and antimicrobial activity of an ampicillin-conjugated magnetic nanoantibiotic for medical applications. International journal of nanomedicine, v. 9, p. 3801-3814, 2014.

LANGMUIR, I. The constitution and fundamental properties of solids and liquids. II. Liquids. Journal of the American chemical society, v. 39, n. 9, p. 1848-1906, 1917.

LIU, Z. et al. Adsorption of $\mathrm{Hg}$ (II) in an Aqueous Solution by Activated Carbon Prepared from Rice Husk Using KOH Activation. ACS omega, v. 5, n. 45, p. 29231-29242, 2020. 
LÓPEZ-MACIAS, R. et al. Presence and spatial distribution of polynuclear aromatic hydrocarbons (PAHs) in groundwater of Merida City, Yucatan, Mexico. Bulletin of environmental contamination and toxicology, v. 102, n. 4, p. 538-543, 2019.

MAJIDI, S. et al. Current methods for synthesis of magnetic nanoparticles. Artificial cells, nanomedicine, and biotechnology, v. 44, n. 2, p. 722-734, 2016.

MALETIĆ, S. P. et al. State of the art and future challenges for polycyclic aromatic hydrocarbons is sediments: sources, fate, bioavailability and remediation techniques. Journal of hazardous materials, v. 365, p. 467-482, 2019.

MARCELO, L. R. et al. Synthesis of iron-based magnetic nanocomposites and applications in adsorption processes for water treatment: a review. Environmental Chemistry Letters, p. 1-46, 2020.

MIAO, J. et al. The adsorption performance of tetracyclines on magnetic graphene oxide: A novel antibiotics absorbent. Applied Surface Science, v. 475, p. 549-558, 2019.

MILAZZO, M. J. et al. Potential for city parks to reduce exposure to BTEX in air. Environmental Science: Processes \& Impacts, v. 21, n. 1, p. 40-50, 2019.

MOHAMMED, A. A.; KAREEM, S. L. Adsorption of tetracycline from wastewater by using Pistachio shell coated with $\mathrm{ZnO}$ nanoparticles: Equilibrium, kinetic and isotherm studies. Alexandria Engineering Journal, v. 58, n. 3, p. 917-928, 2019.

MOJIRI, A. et al. Comprehensive review of polycyclic aromatic hydrocarbons in water sources, their effects and treatments. Science of the total environment, v. 696, p. 133971, 2019.

MOVAHEDINIA, A.; SALAMAT, N.; KHERADMAND, P. Effects of the environmental endocrine disrupting compound benzo [a] pyrene on thyroidal status of abu mullet (Liza abu) during short-term exposure. Toxicology reports, v. 5, p. 377382, 2018.

MYLKIE, K. et al. Polymer-Coated Magnetite Nanoparticles for Protein Immobilization. Materials, v. 14, n. 2, p. 248, 2021.

NADAR, S. S. et al. Recent progress in nanostructured magnetic framework composites (MFCs): Synthesis and applications. Journal of the Taiwan Institute of Chemical Engineers, v. 91, p. 653-677, 2018.

NETHAJI, S.; SIVASAMY, A.; MANDAL, A. B. Adsorption isotherms, kinetics and mechanism for the adsorption of cationic and anionic dyes onto carbonaceous particles prepared from Juglans regia shell biomass. International Journal of Environmental Science and Technology, v. 10, n. 2, p. 231-242, 2013.

NOVOSELOV, K. S. et al. Electric field effect in atomically thin carbon films. Science, v. 306, n. 5696, p. 666-669, 2004. 
PARVIN, N. et al. Removal of phenol and $\beta$-naphthol from aqueous solution by decorated graphene oxide with magnetic iron for modified polyrhodanine as nanocomposite adsorbents: Kinetic, equilibrium and thermodynamic studies. Reactive and Functional Polymers, v. 156, p. 104718, 2020.

PÉREZ-MARÍN, A. B. et al. Removal of cadmium from aqueous solutions by adsorption onto orange waste. Journal of hazardous materials, v. 139, n. 1, p. 122-131, 2007.

QIU, H. et al. Critical review in adsorption kinetic models. Journal of Zhejiang UniversityScience A, v. 10, n. 5, p. 716-724, 2009.

RANE, A. V. et al. Methods for synthesis of nanoparticles and fabrication of nanocomposites. Synthesis of inorganic nanomaterials. Woodhead Publishing, 2018. p. 121-139.

REBEKAH, A. et al. Removal of 1-napthylamine using magnetic graphene and magnetic graphene oxide functionalized with Chitosan. Environmental Nanotechnology, Monitoring \& Management, v. 15, p. 100450, 2021.

REKOS, K. et al. Graphene Oxide Based Magnetic Nanocomposites with Polymers as Effective Bisphenol-A Nanoadsorbents. Materials, v. 12, n. 12, p. 1987, 2019.

RHODEN, C. R. B. et al. Síntese fácil e direta do óxido de grafeno magnético. Disciplinarum Scientia| Naturais e Tecnológicas, v. 18, n. 2, p. 149-147, 2017.

SADHUKHAN, S. et al. Green synthesis of cadmium oxide decorated reduced graphene oxide nanocomposites and its electrical and antibacterial properties. Materials Science and Engineering: C, v. 99, p. 696-709, 2019.

SALLES, T. R. et al. Graphene oxide optimization synthesis for application on laboratory of Universidade Franciscana. Disciplinarum Scientia| Naturais e Tecnológicas, v. 21, n. 3, p. 15-26, 2020.

SHAH, J. et al. Microextraction of selected endocrine disrupting phenolic compounds using magnetic chitosan biopolymer graphene oxide nanocomposite. Journal of Polymers and the Environment, v. 28, n. 6, p. 1673-1683, 2020.

SHAHRAKI, S. et al. Improving the adsorption potential of chitosan for heavy metal ions using aromatic ring-rich derivatives. Journal of colloid and interface science, $v$. 576, p. 79-89, 2020.

SHAHSAVARI, E. et al. Biological degradation of polycyclic aromatic compounds (PAHs) in soil: a current perspective. Current Pollution Reports, v. 5, n. 3, p. 84-92, 2019.

SILVA, J. E. et al. Estudo de cinética e equilíbrio de adsorção empregando a casca do coco modificada quimicamente para a remoção de $\mathrm{Pb}$ (II) de banho sintético. Rev. Virtual Quim, v. 10, n. 5, p. 1248-1262, 2018. 
SMITH, M.; MCKEAGUE, M.; DEROSA, M. C. Synthesis, transfer, and characterization of core-shell gold-coated magnetic nanoparticles. MethodsX, v. 6, p. 333-354, 2019.

WANG, D. et al. Adsorbent for $p$-phenylenediamine adsorption and removal based on graphene oxide functionalized with magnetic cyclodextrin. Applied Surface Science, v. 329, p. 197-205, 2015.

WANG, J.; GUO, X. Adsorption isotherm models: Classification, physical meaning, application and solving method. Chemosphere, p. 127279, 2020a.

WANG, J.; GUO, X. Adsorption kinetic models: physical meanings, applications, and solving methods. Journal of hazardous materials, v. 390, p. 122156, $2020 \mathrm{~b}$.

WANG, R. Z. et al. Selective removal of BPA from aqueous solution using molecularly imprinted polymers based on magnetic graphene oxide. RSC advances, v. 6, n. 108, p. 106201-106210, 2016.

WONG, Y. C. et al. Adsorption of acid dyes on chitosan-equilibrium isotherm analyses. Process Biochemistry, v. 39, n. 6, p. 695-704, 2004.

XIONG, C. et al. Selective adsorption of $\mathrm{Pb}$ (II) from aqueous solution using nanosilica functionalized with diethanolamine: equilibrium, kinetic and thermodynamic. Microchemical Journal, v. 146, p. 270-278, 2019.

YANG, C. Statistical mechanical aspects of adsorption systems obeying the Temkin isotherm. The Journal of Physical Chemistry, v. 97, n. 27, p. 7097-7101, 1993.

YANG, X. et al. Adsorption of naphthalene and its derivatives on magnetic graphene composites and the mechanism investigation. Colloids and Surfaces A: Physicochemical and Engineering Aspects, v. 422, p. 118-125, 2013.

YOUSEF, R.; QIBLAWEY, H.; EL-NAAS, M. H. Adsorption as a Process for Produced Water Treatment: A Review. Processes, v. 8, n. 12, p. 1657, 2020.

ZEESHAN, M. et al. Removal of Bisphenol-A from Aqueous Samples Using Graphene Oxide Assimilated Magnetic Silica Polyaniline Composite. Journal of Inorganic and Organometallic Polymers and Materials, v. 31, n. 5, p. 2073-2082, 2021.

ZENG, S. et al. Enrichment of polychlorinated biphenyl 28 from aqueous solutions using Fe304 grafted graphene oxide. Chemical engineering journal, v. 218, p. 108-115, 2013.

ZHANG, X. et al. Trimodal synergistic antitumor drug delivery system based on graphene oxide. Nanomedicine: Nanotechnology, Biology and Medicine, v. 15, n. 1, p. 142-152, 2019. 
ZHOU, Q. et al. Fabrication and characterisation of magnetic graphene oxide incorporated Fe304@polyaniline for the removal of bisphenol A, t-octyl-phenol, and $\alpha$-naphthol from water. Scientific reports, v. 7, n. 1, p. 1-11, 2017. 


\title{
CAPITULO XXIX
}

\section{SIMULACÃO DA CONCENTRACÕO DE MATIERRIA ORGÂMICA EM CANAIS URBANOS: ESTUDO DE CASO CANAL DO PRADO, CAMPINA GRANDE-}

\section{DOI: 10.51859/amplla.mas481.1121-29}

\author{
Jessica Kaori Sasaki ${ }^{1}$ \\ Higor Costa de Brito ${ }^{2}$ \\ Manoel Mariano Neto $^{3}$ \\ Yáscara Maia Araújo de Brito ${ }^{4}$ \\ Sinara Martins Camelo ${ }^{5}$ \\ Andréa Carla Lima Rodrigues ${ }^{6}$
}

\begin{abstract}
${ }^{1}$ Mestranda em Engenharia Civil e Ambiental. Programa de Pós-Graduação em Engenharia Civil e Ambiental - UFCG
${ }^{2}$ Bacharel em Engenharia Civil, mestre e doutorando em Engenharia Civil e Ambiental. Universidade Federal de Campina Grande (UFCG).

${ }^{3}$ Bacharel em Ciência e Tecnologia e em Engenharia Ambiental e Sanitária, mestre em Planejamento e Dinâmicas Territoriais no Semiárido, doutorando em Engenharia Civil e Ambiental. Universidade Federal de Campina Grande (UFCG).

${ }^{4}$ Bacharela em Engenharia Civil, mestra em Engenharia Civil e Ambiental, Doutoranda em Engenharia e Gestão de Recursos Naturais. Universidade Federal de Campina Grande (UFCG).

${ }^{5}$ Doutoranda em Engenharia Ambiental. Programa de Pós-Graduação em Ciência e Tecnologia Ambiental. Universidade Estadual da Paraíba- UEPB

${ }^{6}$ Professora Adjunta da Universidade Federal de Campina Grande - UFCG
\end{abstract}

\section{RESUMO}

A urbanização ocasionou inúmeros impactos na população e no meio ambiente. Esses efeitos foram intensificados pela falta de gerenciamento e pela deficiência nos serviços de saneamento básico. $O$ sistema de drenagem urbana entra nesse contexto transportando as águas pluviais poluídas, principalmente pelas contribuições de esgoto que são lançados no sistema de forma ilegal. Nesse âmbito, o objetivo deste trabalho é estudar a influência desse lançamento de esgoto, em termos de matéria orgânica, no canal do Prado localizado na cidade de Campina Grande-PB. A metodologia desenvolvida foi dividida em três etapas, primeiro delimitou-se a área de estudo que compreende a parte do canal com leito construído em concreto e em seguida, através de visitas in loco, realizou-se o diagnóstico do sistema de drenagem. A segunda etapa consistiu no mapeamento das entradas de esgoto e na medição de suas respectivas vazões. A terceira etapa, compreendeu a modelagem através do Storm Water Management Model - SWMM onde realizou-se as simulações com diferentes cenários. Os resultados obtidos mostraram que os altos valores de concentração de $\mathrm{DBO}$ e DQO, indicam a grande quantidade de matéria orgânica presente no sistema. Na análise dos cenários propostos, percebe-se que retirando as entradas mais críticas obtémse resultados mais significativos no que diz respeito a redução dos valores de concentração.

Palavras-chave: Drenagem pluvial. SWMM. Poluição Hídrica. 


\section{INTRODUÇÃO}

O desenvolvimento urbano e o aumento populacional vivenciados nas últimas décadas têm gerado consequências diretas ao meio ambiente e aos recursos naturais. No âmbito da drenagem urbana, o crescimento de maneira desordenada com ocupação de áreas de mananciais, impermeabilização de superfícies e canalização do escoamento superficial, modificam o curso natural das águas, aumentando a frequência de alagamentos e inundações.

Além disso, a maioria das cidades adotam o sistema de esgotamento sanitário do tipo separador absoluto, cujas águas pluviais são transportadas separadamente dos efluentes domésticos. Entretanto, o lançamento de esgoto de forma ilegal nos canais de drenagem é um problema recorrente que afeta diretamente a qualidade dos corpos hídricos.

Diante da complexidade envolvida no manejo eficiente das bacias hidrográficas urbanas, o desenvolvimento de ferramentas que avaliem e comparem projetos alternativos e que possibilitem o diagnóstico da situação do sistema de drenagem e a previsão de impactos decorrentes das atividades antrópicas, são de grande importância para o direcionamento das ações dos órgãos gestores (BEHROUZ et al., 2020).

A modelagem computacional é uma dessas ferramentas que permite entender o comportamento quantitativo e qualitativo das águas pluviais e auxiliar na gestão da qualidade e poluição da água urbana, uma vez que o monitoramento da qualidade do escoamento urbano requer recursos extensos (ZHU et al., 2012; TUOMELA; SILLANPÄÄ; KOIVUSALO, 2019).

Modelos capazes de simular a qualidade e a quantidade da água da chuva apareceram na década de 1970, e foram desenvolvidos principalmente por agências do governo dos EUA, como a Agência de Proteção Ambiental - USEPA. Dentre os vários modelos disponíveis, o Storm Water Management Model (SWMM) é um software de domínio público, utilizado mundialmente nas simulações de cenários de drenagem urbana, o modelo tem capacidade para modelar a quantidade e a qualidade do escoamento urbano (BABAEI; GHAZAVI; ERFANIAN, 2018). Entretanto, poucos trabalhos têm sido desenvolvidos no âmbito do monitoramento qualitativo (PETRUCCl et al., 2014). 
A cidade de Campina Grande, segunda maior do estado da Paraíba, vem apresentando, nos últimos anos, poluição na maioria dos seus corpos hídricos, principalmente devido à contribuição de esgotos domésticos, conforme estudos realizados por Caminha (2014), Henriques (2014), Camelo (2019), Vidal (2019) e França (2020).

Diante do exposto, o presente trabalho teve o objetivo de estudar a influência dessas contribuições clandestinas de esgoto, por meio da modelagem matemática das concentrações de DBO e DQO, no sistema de drenagem do canal do Prado localizado na cidade de Campina Grande-PB.

\section{REVISÃO BILBIOGRÁFICA}

\subsection{POLUIÇÃO DAS ÅGUAS DE DRENAGEM URBANA}

Existem diversas fontes de poluição das águas de drenagem urbana. As fontes denominadas pontuais referem-se àquelas onde a água poluída é descarregada em um único local, ou seja, a fonte é facilmente identificada. As principais contribuições dessa natureza se devem ao lançamento de esgotos domésticos não tratados ou parcialmente tratados, bem como os efluentes industriais, minas subterrâneas e navios petroleiros (BARROS, 2008).

As fontes não-pontuais ou difusas não apresentam um ponto específico de lançamento ou um foco de poluição, tornando difícil sua identificação e controle. Ocorre pela ação das águas da chuva ao lavarem e transportarem a poluição nas suas diversas formas, espalhadas sobre a superfície para os corpos receptores (RIGHETTO; GOMES; FREITAS, 2017).

O grau de poluição das águas é medido através de características físicas, químicas e biológicas das impurezas existentes que podem ser identificadas por indicadores de qualidade das águas. O monitoramento desses parâmetros é essencial para o controle da poluição e para detectar as fontes poluidoras e controlar a qualidade das águas para atender aos padrões estabelecidos pela legislação vigente (FRANÇA, 2020).

Vários indicadores são utilizados para realizar a mensuração da poluição hídrica. Neste estudo, optou-se por analisar a Demanda Bioquímica de Oxigênio (DBO) e 
Demanda Química de Oxigênio (DQO) que representam, através do consumo de oxigênio dissolvido, a matéria orgânica presente.

\subsection{MODELO STORM WATER MANAGEMENT MODEL (SWMM)}

O SWMM é um modelo dinâmico chuva-vazão que simula a quantidade e a qualidade do escoamento superficial em áreas urbanas. Esse software foi desenvolvido a partir de resultados obtidos em pesquisas americanas, portanto é necessária a realização da calibração e da validação para as condições brasileiras, garantindo que os resultados obtidos no modelo sejam representativos para a área em estudo (RIGHETTO; MOREIRA; SALES, 2009).

Segundo Rossman (2009) o SWMM permite simular o percurso dos escoamentos e cargas poluidoras gerados pelos dados de precipitações de eventos chuvosos isolados ou simulação de séries históricas. Além disso, o software possibilita avaliar a qualidade da água transportada pelo sistema de drenagem através da simulação do comportamento de um poluente específico ou sua relação em função de outro. 0 modelo considera várias fontes de poluentes que contribuem para a degradação da qualidade das águas urbanas.

De forma geral, o modelo é baseado em quatro módulos, Atmosférico, Superfície Terrestre, Água Subterrânea e módulo de Transporte, que contém uma rede com elementos de transporte e unidades de armazenamento e tratamento. O software atua conforme as equações de conservação de massa e de quantidade de movimento para fluxo não permanente, que é regido pelas equações de Saint-Venant (COSTA; TSUJI; KOIDE, 2021).

\section{METODOLOGIA}

\subsection{AREA DE ESTUDO}

O município de Campina Grande - PB está localizado no agreste paraibano, situado entre as regiões do baixo e médio curso do Rio Paraíba. De acordo com o IBGE a população estimada de Campina Grande em 2020 é de 411.807 habitantes, sendo a segunda maior população do estado da Paraíba. 
A cidade está inserida em uma área que abrange três grandes sub-bacias denominadas de bacias B (Bacia do Riacho do Bodocongó), C (Bacia do Riacho das Piabas) e D (Bacia do Riacho do Prado). A bacia urbana do Riacho do Prado (Figura 1) é composta por 13 sub-bacias, possui uma área de aproximadamente $24,7 \mathrm{Km}^{2} \mathrm{e}$ perímetro de $24,7 \mathrm{Km}$, abrangendo cerca de 22 bairros. A área em estudo corresponde ao canal do prado inserido nessa bacia. Esse canal tem início no açude velho e termina no bairro jardim paulistano, onde segue seu curso natural, conforme mostra a Figura 1.

Figura 1 - Localização da Bacia do Prado

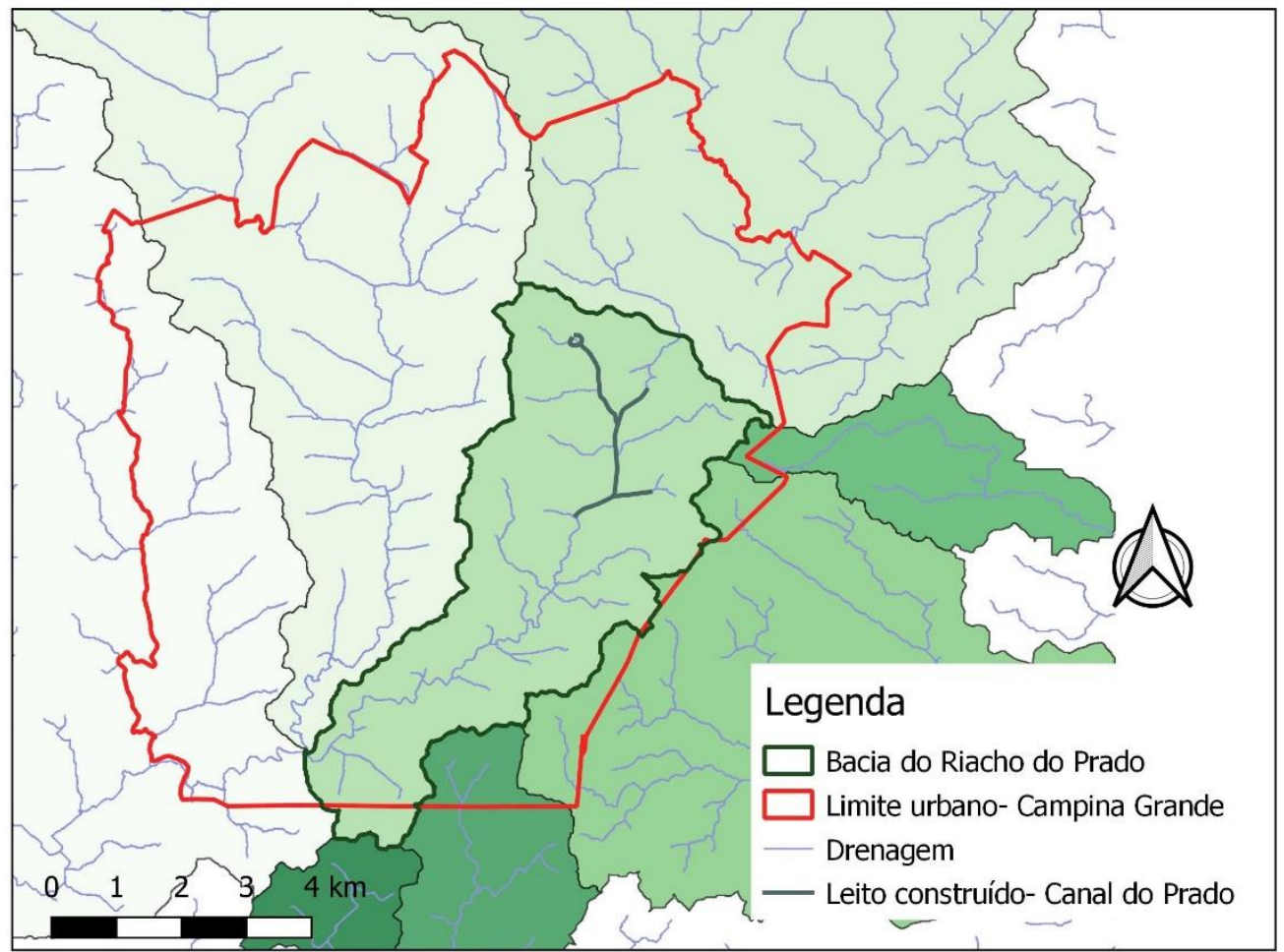

Fonte: Adaptado de Tsuyuguchi (2015)

\subsection{AQUISIÇÃO DE DADOS}

Com o intuito de compreender o comportamento da qualidade de água que escoa pelo Canal do Prado foram necessárias visitas in loco que permitiram analisar os componentes estruturais e características do ambiente que os envolvem, permitindo o mapeamento do sistema de macrodrenagem com a identificação de entradas de esgoto ao longo do canal. 
Além disso, para a modelagem da qualidade da água do canal, utilizou-se os dados dos estudos de Vidal (2019) e Camelo (2019) que realizaram o monitoramento qualitativo das águas de drenagem entre março e agosto de 2018, com as amostras coletadas com frequência semanal.

O Canal do Prado possui parte do seu leito construído em concreto e, a partir de um determinado ponto, segue com leito natural. Para este estudo, optou-se por analisar apenas a região que compreende o leito construído, abrangendo 6 sub-bacias e 5 pontos de monitoramento, como apresentado na Figura 2.

Figura 2 - Ponto de coleta

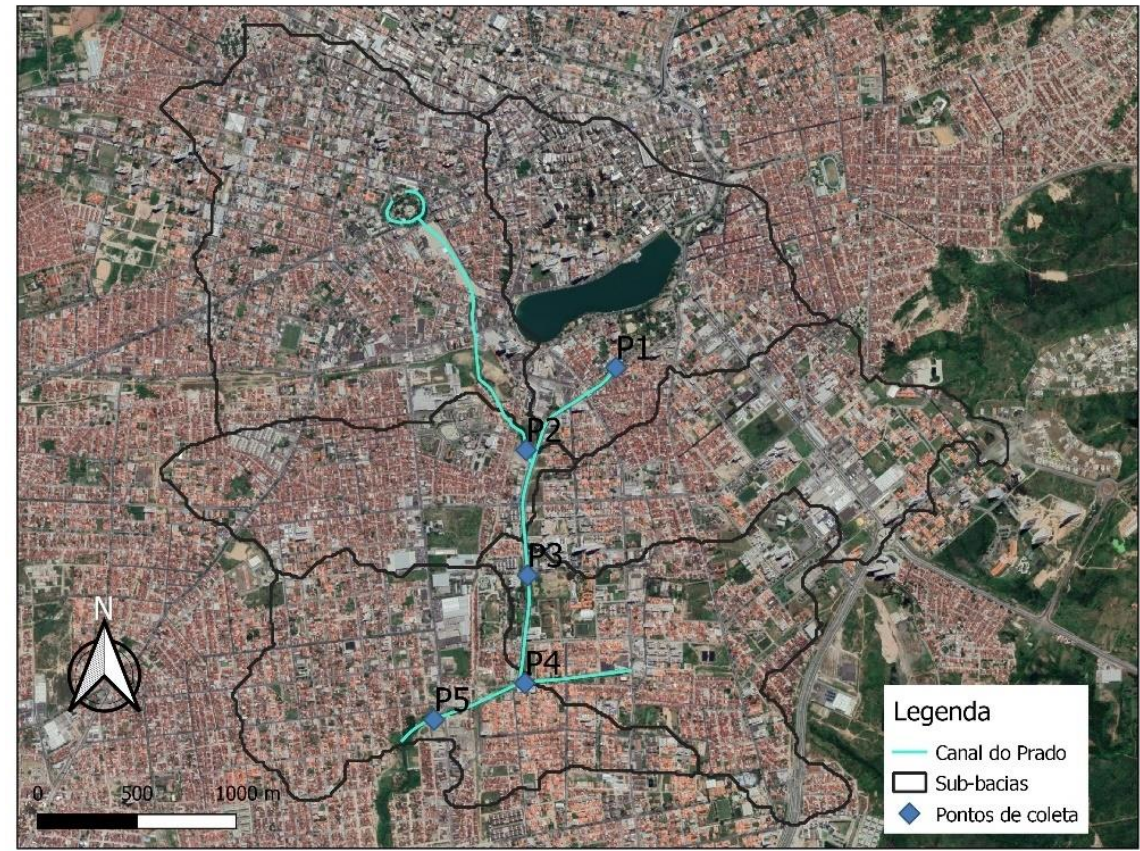

Fonte: Adaptado de Google Earth, 2021.

Conforme descrito anteriormente, os parâmetros de qualidade utilizados neste estudo foram as concentrações de DBO e DQO que caracterizam a matéria orgânica do efluente e são parâmetros de grande relevância no diagnóstico da poluição dos corpos hídricos.

Para avaliar a contribuição dos esgotos sem a interferência das chuvas, situação verificada na maioria dos meses do ano na área, utilizou-se os valores encontrados nas medições dos dias secos. As Tabelas 1 e 2 apresentam as concentrações de DBO e DQO em $\mathrm{mg} / \mathrm{l}$, respectivamente, medidas nos pontos de coleta em dias sem precipitação. 
Tabela 1- Concentração de DBO (mg/l)

\begin{tabular}{|c|c|c|c|c|c|}
\hline \multicolumn{6}{|c|}{ Concentração de DBO (mg/l) } \\
\hline Dias Secos & P1 & P2 & P3 & P4 & P5 \\
\hline Média & 72,45 & 310,46 & 227,29 & 454,25 & 131,25 \\
\hline
\end{tabular}

Tabela 2- Concentração de DQO (mg/l)

\begin{tabular}{|c|c|c|c|c|c|}
\hline \multicolumn{7}{|c|}{ Concentração de DQO (mg/l) } \\
\hline Dias Secos & P1 & P2 & P3 & P4 & P5 \\
\hline Média & 190,01 & 582,24 & 453,46 & 784,93 & 354,23 \\
\hline
\end{tabular}

No mapeamento das entradas de esgoto foram consideradas apenas as contribuições que apresentaram vazões significativas durante o período de monitoramento. Para a medição dessas vazões, foi utilizado o método do flutuador que relaciona a velocidade de escoamento com a lâmina de água presente no canal. Para a medição de vazão nas entradas de esgoto, além do método do flutuador, utilizou-se o método volumétrico que relaciona o tempo necessário para encher determinado recipiente com volume conhecido.

\subsection{MODELAGEM SWMM}

A representação do sistema de drenagem no SWMM é feita através das subbacias, dos condutos e nós. Os condutos representam canais naturais ou artificiais e são caracterizados por sua seção transversal, já os nós são posicionados no início e no fim dos condutos e podem representar a confluência de canais superficiais, naturais, ou elementos de conexão de tubulações (ROSSMAN, 2009; CAMELO, 2019).

As declividades nos trechos foram calculadas através dos dados de cotas do radier do canal encontradas nos projetos cedidos pela Secretaria de Planejamento de Campina Grande (SEPLAN) juntamente com o Modelo Digital de Elevação elaborado por Tsuyuguchi (2015). O coeficiente de rugosidade de Manning foi adotado considerando o material do leito, neste caso, o concreto. As seções transversais do canal foram observadas e medidas in loco. 
Os dados hidrológicos utilizados no processo de modelagem correspondem ao evento do dia 08/06/2018, esses dados foram adquiridos da Estação Agrometeorológica Experimental (Est-Agro) da Unidade Acadêmica de Ciências Atmosféricas da Universidade Federal de Campina Grande.

\subsubsection{CALIBRAÇÃO E VALIDAÇÃO DO MODELO}

A calibração foi realizada manualmente, pelo processo de tentativa e erro até que se obtivesse valores simulados próximos aos observados durante o monitoramento. Foram ajustados parâmetros como largura, declividades e porcentagem impermeável das sub-bacias, devido às incertezas quanto à sua determinação.

A validação do método tem por objetivo legitimar os resultados obtidos durantes as simulações por meio da interpretação e análise desses resultados. Para essa etapa foram considerados o relatório de simulação e o resumo dos erros de continuidade de cada simulação levando em consideração o limite de $10 \%$ recomendado pela literatura.

\subsection{CENÁRIOS PROPOSTOS}

No primeiro cenário (Cenário 1), não foi feita nenhuma intervenção na área de estudo, nos demais Cenários ( 2 e 3) foram propostas intervenções visando nortear o gestor em relações a medidas que podem ser implantadas para a melhoria da qualidade das águas.

O Cenário 2 corresponde a simulação do comportamento da qualidade da água no canal caso fossem retiradas as contribuições de esgoto com maior concentração de DBO e DQO e o Cenário 3 representa a retirada das entradas mais críticas do canal, ou seja, as que apresentam maior potencial poluidor, correspondendo as Entradas E, F e G. Na Figura 3 é apresentada uma descrição gráfica dos cenários propostos. 
Figura 3 - Fluxograma dos cenários avaliados

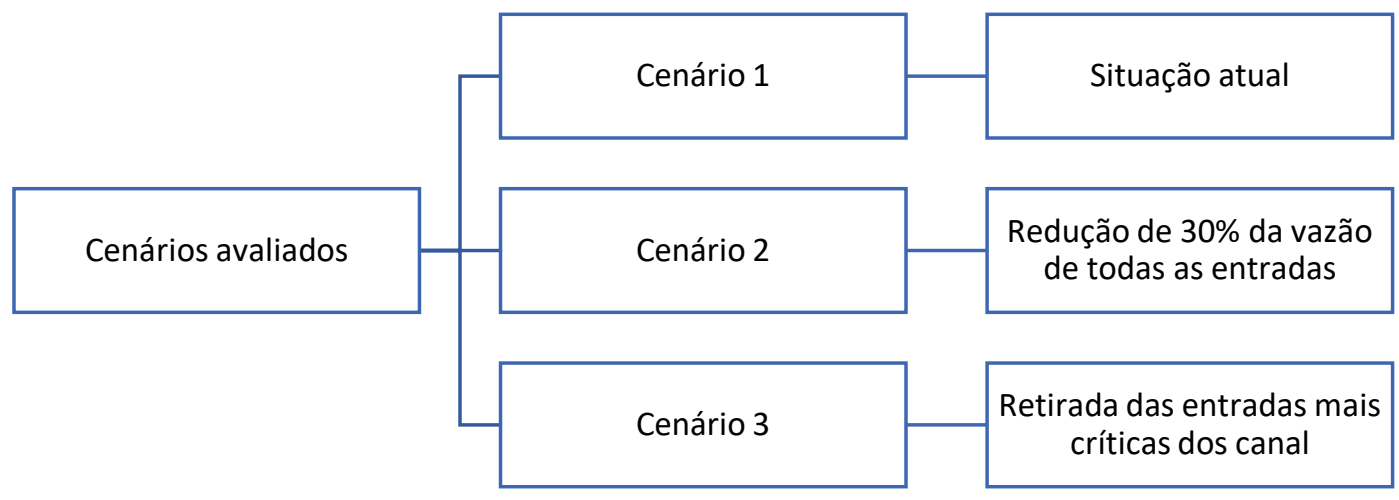

Fonte: Autoria Própria

\section{RESULTADOS E DISCUSSÕES}

\subsection{CONTRIBUIÇÕES DE ESGOTO NO CANAL}

Durante o mapeamento das entradas de esgoto no canal, contatou-se 8 contribuições diretas denominadas de A, B, C, D, E, F, G e H. As maiores vazões de esgoto correspondem as contribuições denominadas de E, G e H. Nesses três pontos foram obtidos valores de vazão superiores a $0,01 \mathrm{~m}^{3} / \mathrm{s}$ (864.000 l/dia), chegando a mais que $0,02 \mathrm{~m}^{3} / \mathrm{s}$ na entrada $\mathrm{H}$.

Além disso, percebeu-se que diversas casas lançavam diretamente seu efluentes no canal. Devido a impossibilidade de realizar a medição individualmente de cada contribuição, realizou-se uma estimativa desse valor com base no número de residências localizadas nas margens do canal e na produção de esgoto média por habitante. Denominou-se essa estimativa de Entrada I. A Figura 4 mostra a localização de todas as contribuições de esgoto mapeadas e a Tabela 3 apresenta os valores médios adotados. 
Figura 4- Localização das entradas de esgoto

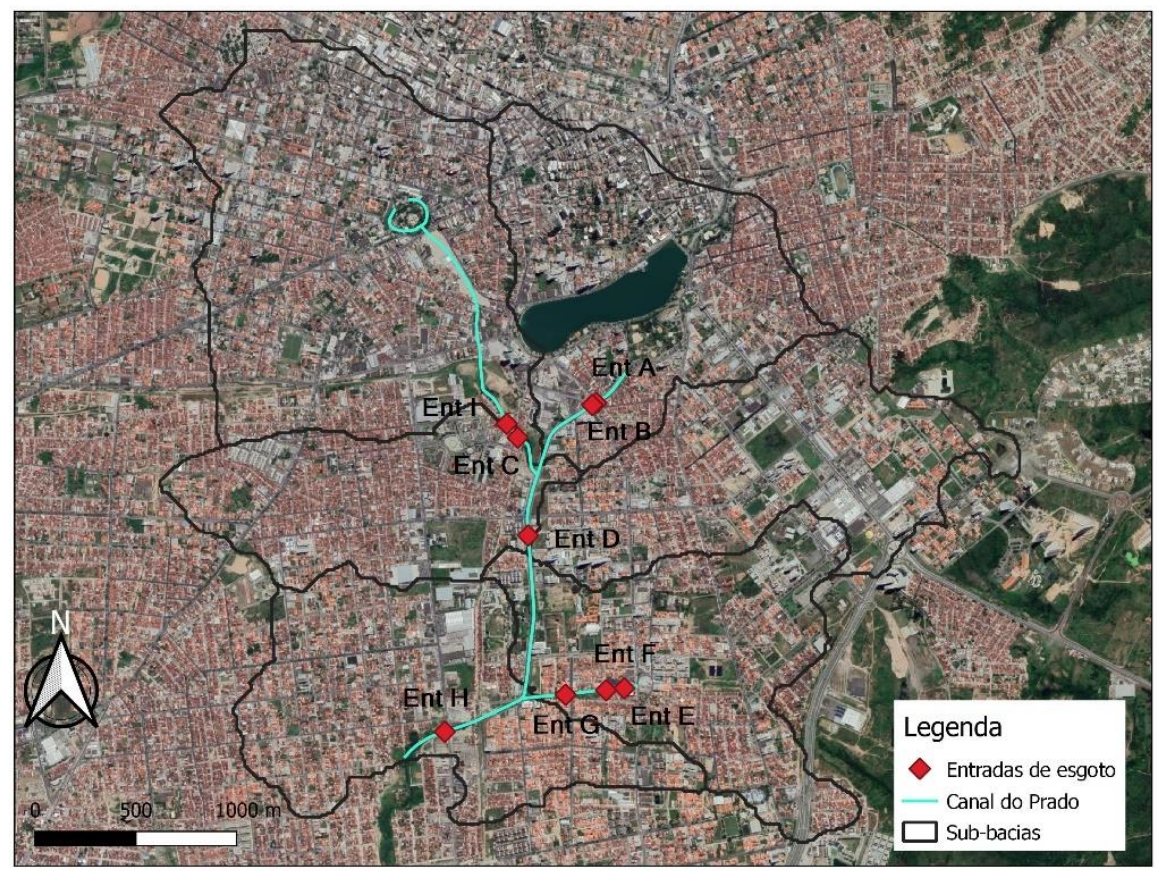

Fonte: Adaptado de Google Earth, 2021.

Tabela 3 - Vazões médias de esgoto medidas no canal do Prado

\begin{tabular}{|c|c|}
\hline Entradas de esgoto & Vazão $\left(\mathrm{m}^{3} / \mathrm{s}\right)$ \\
\hline ENT A & 0,000700 \\
\hline ENT B & 0,000360 \\
\hline ENT C & 0,000190 \\
\hline ENT D & 0,001860 \\
\hline ENT E & 0,015410 \\
\hline ENT F & 0,000510 \\
\hline ENT G & 0,013270 \\
\hline ENT H & 0,024170 \\
\hline ENT I & 0,000788 \\
\hline
\end{tabular}

Fonte: Autoria Própria.

\subsection{RESULTADOS DA MODELAGEM MATEMÁTICA}

\subsubsection{CALJBRAÇÃO}

Os resultados das calibrações foram satisfatórios, obtendo-se valores próximos dos valores reais. A Figura 5 apresenta o resultado da calibração das concentrações de DBO e DQO 
Figura 5 - Calibração da concentração de DBO e DQO

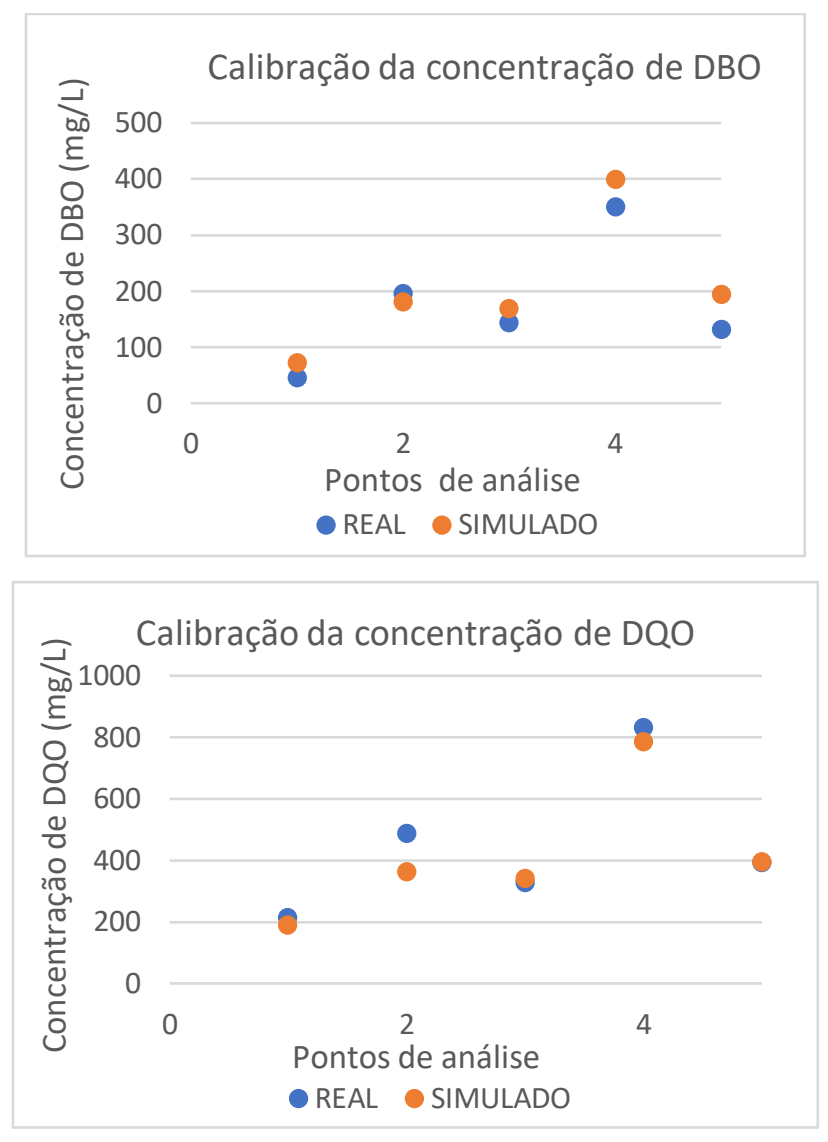

Fonte: Autoria Própria.

\subsubsection{RESULTADOS DOS CENÁRIOS PROPOSTOS}

Os resultados obtidos das simulações dos três cenários propostos são apresentados na Figura 6. Inicialmente realizou-se a simulação do cenário atual (Cenário 1) considerando fluxo de tempo seco, ou seja, sem eventos de chuvas. Os valores de concentração de DBO variaram de $50 \mathrm{mg} / \mathrm{L}$ a $400 \mathrm{mg} / \mathrm{L}$ e DQO variaram de $190 \mathrm{mg} / \mathrm{l} \mathrm{a}$ $785 \mathrm{mg} / \mathrm{l}$ como mostra a Figura 6a e 6b.

No Cenário 2 foi considerada a redução em 30\% da vazão de todas as entradas. Comparando os resultados obtidos nesse cenário com o diagnóstico atual (Cenário 1), observa-se que essa intervenção tem como consequência, uma diminuição da concentração de DBO de cerda de $4 \%$ e $6 \%$, e de $4 \%$ a $5 \%$ da concentração de DQO, ou seja, não representa muita eficiência pois ainda se percebe que os pontos críticos permanecem com valores elevados.

Para a modelagem do Cenário 3 foram retiradas as vazões das Entradas E, F e G que correspondem as contribuições mais críticas, tanto em termos de concentração de 
DBO e DQO como de volume representando aproximadamente $20 \%$ da vazão total escoada no canal. Avaliando os mapas e comparando com o Cenário 1, constatou-se que de fato, essas entradas são as mais relevantes, apresentando com suas retiradas, mudanças significativas a jusante, com redução de $20 \%$ a $24 \%$ na concentração de DBO e $20 \%$ a $23 \%$ na concentração de DQO.

Figura 6- Resultados dos Cenários simulados

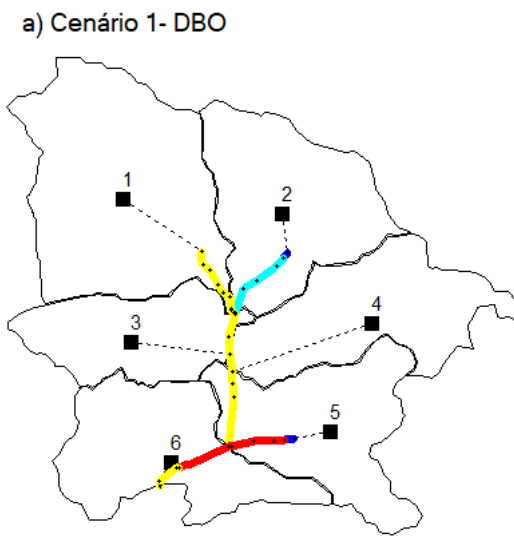

c) Cenário 2- DBO

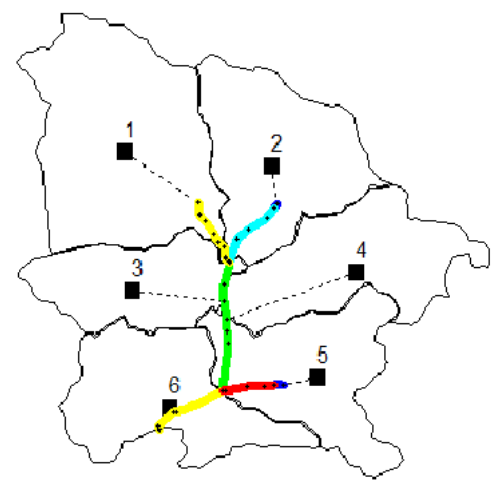

e) Cenário 3- DBO

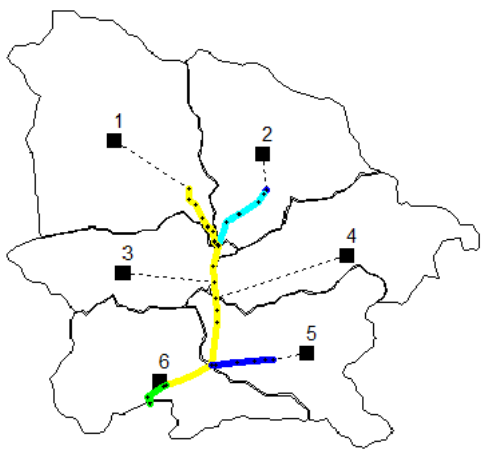

$\mathrm{DBO}(\mathrm{mg} / \mathrm{L})$

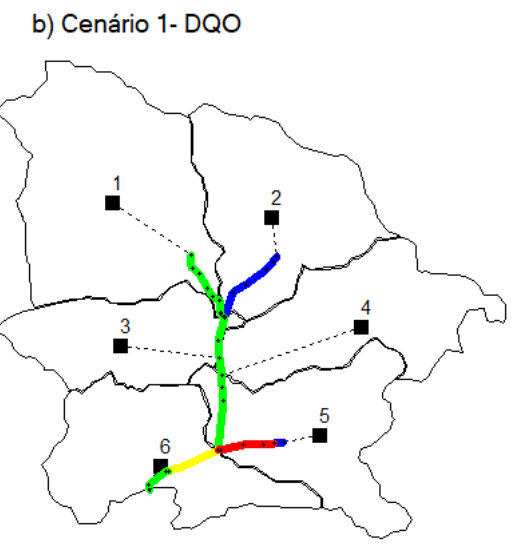

d) Cenário 2- DQO

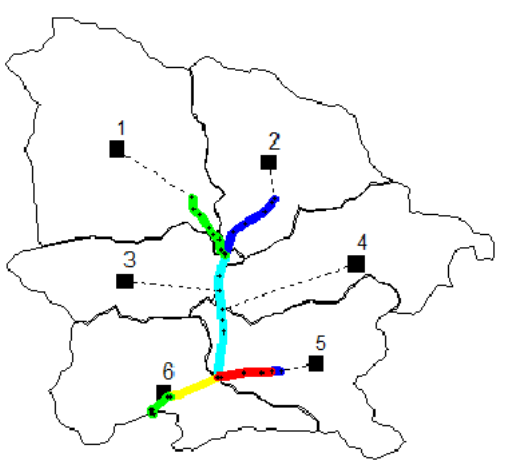

f) Cenário 3- DQO

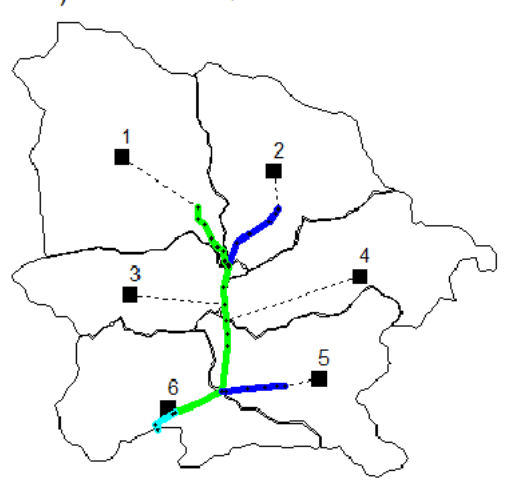

$\mathrm{DQO}(\mathrm{mg} / \mathrm{L})$ \begin{tabular}{llll}
270 & $340 \quad 410 \quad 480$ \\
\hline & 1 & 1 & 1
\end{tabular}

Fonte: Autoria Própria. 
Em termos de melhoria na qualidade da água do canal, o Cenário 3 apresentou resultados mais promissores. Contrapondo este cenário com o Cenário 2, percebe-se que em relação a concentração este se apresenta como a melhor intervenção, apesar de ser uma interferência localizada e não no canal como um todo.

Na prática, para a aplicação do Cenário 2 seriam necessárias medidas não estruturais de gestão com foco na diminuição da produção de esgoto doméstico por parte da população que contribui para essa poluição. O Cenário 3 requer medidas estruturais de relocação das entradas, entretanto como apresenta uma abrangência maior, contendo três entradas de esgoto, apresenta maiores dificuldades, tanto por questões financeiras como pela própria questão construtiva. Em contrapartida, avaliando o aspecto ambiental, essa alternativa sem dúvida traz melhores resultados em relação aos demais cenários avaliados.

Após as visitas in loco, pode-se constatar que o problema de poluição no canal se deve, principalmente, a ausência de gestão tanto das águas pluviais urbanas como do sistema de esgotamento sanitário. Apesar da existência do sistema separador absoluto e das legislações sobre o tema, muitos esgotos ainda desaguam em redes e galerias pluviais da cidade. Outra questão relevante e de grande impacto na qualidade das águas de drenagem do sistema estudado é a frequente disposição de lixo no interior do canal.

\section{CONSIDERAÇÕES FINAIS}

As simulações dos cenários de intervenção foram realizadas utilizando dados de tempo seco, ou seja, sem precipitação, já expondo a ineficiência do sistema separador absoluto uma vez que só deveria conter águas pluviais.

Comparando o cenário da situação atual com os cenários propostos, observa-se que retirando as contribuições que apresenta maior potencial poluidor, representados pelas Entradas E, F e G, tem-se uma melhor resposta em relação a diminuição da concentração e da carga poluidora final. Apesar de necessitar de maiores investimentos por parte dos gestores.

A partir das análises de água feitas nos dias sem precipitação, constata-se que, segundo as resoluções do CONAMA, as águas que escoam pelo canal possuem alto índice de matéria orgânica representado pelos altos valores de concentração de DBO e 
DQO. A ocorrência de altos valores destes indicadores causa uma diminuição dos valores de oxigênio dissolvido na água, o que pode provocar mortes de peixes e eliminação de outros organismos aquáticos, além da ocorrência de odores, gerando desconforto a população residente nas proximidades do canal.

Neste sentido, o uso de modelos matemáticos que preveem o comportamento de poluentes é de grande valia para auxiliar os gestores na difícil tarefa de tomada de decisão, que na grande maioria das vezes, requerem avaliação da viabilidade técnica, ambiental, econômica e social. A modelagem utilizada neste estudo mostrou-se eficiente e apresentou respostas coerentes com relação ao esperado na prática.

\section{AGRADECIMENTOS}

Os autores agradecem ao Programa de Pós-Graduação em Engenharia Civil e Ambiental da UFCG no qual essa pesquisa foi desenvolvida e à Coordenação de Aperfeiçoamento de Pessoal de Nível Superior (CAPES) e ao Conselho Nacional de desenvolvimento Científico e Tecnológico (CNPq) pela concessão de bolsas aos pesquisadores envolvidos.

\section{REFERÊNCIAS}

BABAEI, S.; GHAZAVI, R.; ERFANIAN, M. Urban Flood Simulation and Prioritization of Critical Urban SubCatchments using SWMM Model and PROMETHEE II Approach. Physics and Chemistry of the Earth, v. 105, p. 3-11, jun. 2018.

BARROS, A. M. de L. Modelagem da poluição pontual e difusa: aplicação do modelo Moneris à Bacia hidrográfica do rio Ipojuca. 193f. Dissertação (Mestrado em Engenharia civil) - Universidade Federal de Pernambuco, Recife, 2008.

BEHROUZ, M.S.; ZHU, Z.; MATOTT, L.S.; RABIDEAU, A.J. A New Tool for Automatic Calibration of the Storm Water Management Model (SWMM), Journal of Hydrology, v. 581, fev. 2019.

CAMELO, S. M. Modelagem da poluição difusa em sistemas de macrodrenagem de bacias urbanas. 113f. Dissertação (Mestrado em Engenharia Civil e Ambiental) Universidade Federal de Campina Grande, Campina Grande, 2019.

CAMINHA, M. J. Degradação da qualidade de água do sistema de drenagem de subbacias urbanas de Campina Grande- Paraíba. Dissertação (Mestrado em Engenharia Civil e Ambiental) - Universidade Federal de Campina Grande, Campina Grande, 2014. 
COSTA, M. E.L. Monitoramento e modelagem das águas de drenagem urbana na bacia do lago Paranoá. 179p. Dissertação (Mestrado em Tecnologia Ambiental e Recursos Hídricos), Departamento de Engenharia Civil e Ambiental, Universidade de Brasília, Brasília, DF, 2013.

COSTA, M. E. L.; TSUJI, T. M.; KOIDE, S. Modelagem hidrológica e hidráulica usando o SWMM - Storm Water Management Model na bacia urbana do Riacho Fundo I Distrito Federal. Research, Society and Development, v. 10, n. 1, 2021.

COLLODEL, M. G. Aplicação do modelo hidrológico SWMM na avaliação de diferentes níveis de detalhamento da bacia hidrográfica submetida ao processo de transformação chuva-vazão. 225 p. Dissertação (Mestrado em Engenharia Hidráulica e Saneamento) - Escola de Engenharia de São Carlos da Universidade de São Paulo, São Carlos, 2009.

FRANÇA, L. R. C. Aplicação de técnicas de desenvolvimento de baixo impacto no controle da poluição de águas em sistemas de drenagem urbano. 202f. Dissertação (Mestrado em Engenharia Civil e Ambiental) Universidade Federal de Campina Grande, Campina Grande, 2020.

FREIRE, J. R. P. Análise do sistema separador absoluto no âmbito da drenagem pluvial da cidade de Campina Grande - Estudo de caso do Canal das Piabas. 91 p. Dissertação (Mestrado) - Universidade Federal de Campina Grande, Campina Grande. 2014.

GOOGLE EARTH (2018). Disponível em < https://www.google.com.br/intl/pt-BR/earth/> Acesso em: 04 jun. 2018.

HENRIQUES, J. A. Distribuição da contaminação fecal em águas de drenagem afluentes do canal do prado, Campina Grande-PB. Dissertação (Mestrado em Engenharia Civil e Ambiental) - Universidade Federal de Campina Grande. Campina GrandePB, 2014.

IBGE (Instituto Brasileiro de Geografia e Estatística). Disponível em: $<$ https://cidades.ibge.gov.br/brasil/pb/campina-grande/panorama>. Acesso em: 03 de junho de 2021.

PETRUCCI, G.; RODRIGUEZ, F.; DEROUBAIX, J.-E.; TASSIN, B. Linking the management of urban watersheds with the impacts on the receiving water bodies: the use of flow duration curves. Water Science Technology, v. 70, n.1, p. 127-135, 2014.

RIGHETTO, A.M.; MOREIRA, L.F.F.; SALES, T.E.A. Manejo de Águas Pluviais Urbanas. 1. ed. Rio de Janeiro: ABES, 2009.

RIGHETTO, A. M.; GOMES, K. M.; FREITAS, F. R. S. Poluição difusa nas águas pluviais de uma bacia de drenagem urbana. Engenharia Sanitária e Ambiental. v.22, n.6, p.1109-1120, 2017. 
ROSSMAN, L. A. Storm Water Management Model, User's Manual Version 5.1. Cincinnati: USEPA- U.S. Environmental Protection Agency, 2015.

ROSSMAN, L. A. Storm Water Management Model User's Manual Version 5.0. Cincinatti: USEPA U.S. Environmental Protection Agency, 2009.

SOUZA, F.P. Monitoramento e modelagem hidrológica da sub-bacia do Lago Paranoá Brasília/DF - e avaliação de bacias de detenção.139f. Dissertação (Mestrado em Tecnologia Ambiental e Recursos Hídricos), Departamento de Engenharia Civil e Ambiental, Universidade de Brasília, Brasília, 2014.

TUOMELA, C., SILLANPÄÄ, N., KOIVUSALO, H. Assessment of stormwater pollutant loads and source area contributions with storm water management model (SWMM). Journal of Environmental Management, 233, p. 719-727, 2019.

TSUYUGUCHI, B. B. Macrodrenagem e a ocupação do solo no município de Campina Grande - PB, caracterização, simulação e análises sistêmicas. 96f. Dissertação (Mestrado em Engenharia Civil e Ambiental), Universidade Federal de Campina Grande, 2015.

VIDAL, I. C. A. Avaliação da poluição difusa no sistema de macrodrenagem de Campina Grande-PB; 123f. Dissertação (Mestrado em Engenharia Civil e Ambiental), Universidade Federal de Campina Grande, Campina Grande, 2019.

ZHU, H., XU, Y., YAN, B., GUAN, J. Snowmelt runoff: a new focus of urban nonpoint source pollution. International Journal of Environmental Research and Public Health, v. 9, n. 12, p. 4333-4345, 2012 


\title{
CAPITULO XXX
}

\section{A APLCACÃO DA QUITINA NO TRATAMENTO DE EFLUENIES DE INDÚSTRIA TEAXTIL: UM ESTUDO DE REVISÃO}

\section{DOI: 10.51859/amplla.mas481.1121-30}

\author{
Darlei Gutierrez Dantas Bernardo Oliveira ${ }^{1}$ \\ Damião Alves dos Santos Silva ${ }^{2}$ \\ Itamar de Miranda Pereira ${ }^{3}$ \\ José Altair Pereira Dantas ${ }^{4}$ \\ Marcelo Bento da Silva ${ }^{5}$ \\ Winício de Abreu Alves ${ }^{6}$
}

\footnotetext{
${ }^{1}$ Mestrando em Química . Programa de Pós-Graduação em Química - UEPB

${ }^{2}$ Mestrando em Química. Programa de Pós-Graduação em Química - UFPB

${ }^{3}$ Graduando em Licenciatura em Química. Universidade Federal de Campina Grande - UFCG

${ }^{4}$ Graduando em Engenharia Ambiental. Universidade Federal de Campina Grande - UFCG

${ }^{5}$ Graduando em Licenciatura em Química. Universidade Federal de Campina Grande -UFCG

${ }^{6}$ Graduando em Licenciatura em Química. Universidade Federal de Campina Grande - UFCG
}

\section{RESUMO}

O ramo têxtil possui grande relevância na economia mundial, empregando cerca de 1,6 milhão de pessoas apenas no Brasil. Entretanto este setor provocar relevantes problemas ambientais, como: elevado consumo dos recursos hídricos e efluentes ricos em corantes causadores de desequilíbrio ao meio ambiente. O objetivo deste trabalho foi realizar um levantamento bibliográfico sobre tópicos de conceitos, estrutura, obtenção e as principais aplicações da quitina no tratamento de efluentes gerados pelas indústrias têxteis, enfatizando os processos de adsorção de corantes em soluções aquosas geradas por este setor. Uma vez que existem cerca de dez mil tipos de corantes, este se caracteriza como um dos principais desafios, referentes ao tratamento dos efluentes. Para atender aos objetivos estabelecidos, este estudo foi baseado em buscas aos bancos de dados: CAFé da CAPES e Scielo. Restringindo as buscas para os últimos dez anos e refinando com as seguintes palavras chaves, chitin applications, textile industrial effluents, dye adsorption, chitin production processes, chitin structure. A atoxidade, biocompatibilidade e biodegradabilidade são propriedade da quitina que favorecem seu uso como adsorvente de corantes, bem como outros tipos de aplicações em biotecnologia. Estudos utilizando filmes de quitosana, quitina e algumas faixas de $\mathrm{pH}$, para os corantes azul de metileno, corante verde brilhante, vermelho congo, corante preto 5, azul brilhante, amarelo crepúsculo e amarelo tartrazina comprovam o uso promissor da quitina e outros biopolimeros que podem ser incorporados as técnicas de tratamento de efluentes, diminuindo assim seus impactos de forma mais significativa.

Palavras-chave: Meio Ambiente; Recursos Hídricos; Biopolimeros. 


\section{INTRODUÇÃO}

A indústria têxtil possui grande importância para a economia, tanto que no Brasil o setor emprega cerca de 1,6 milhão de pessoas (ABIT, 2018). Em contrapartida, o mesmo apresenta graves problemas ambientais, como, o alto consumo de água e os efluentes produzidos e descartados de maneira irregular (KUNZ et al, 2002). Muitos desses efluentes veem acompanhados de corantes, grande quantidade de material orgânico e entre outros poluidores, que, sem o devido tratamento, prejudica a vida aquática quando despejados nos corpos hídricos (LIMA et al, 2020).

A remoção dos corantes, produtos químicos altamente poluentes, tem sido um dos principais desafios dos pesquisadores no tratamento de água provenientes das atividades produtivas têxteis. De acordo com Silveira (et al., 2012), existem cerca de 10.000 tipos de corantes e pigmentos empregados no ramo. No Brasil, são consumidos anualmente 26.500 toneladas, de modo que $15 \%$ dessa quantidade chega a ser perdida durante a produção. A principal preocupação com esses compostos se dá devido à sua natureza recalcitrante, pois diversos métodos são necessários para realizar a descoloração do efluente, até apresentar condições recomendáveis para o descarte no meio (ETSHINDO et al, 2017).

Diante disso, a busca por soluções tecnologicamente viáveis vem se tornando cada vez mais frequente pelos pesquisadores e empresas (CHEN et al., 2017; HASANBEIGI, PRICE, 2015). De acordo com Lucena e colaboradores (2018), já existem vários tipos de processos capazes de remover os corantes da água, dentre eles: o tratamento biológico, o uso de membranas, processos oxidativos, técnicas de eletroquímica, processos de adsorção utilizando biossorventes, entre outros. Chama atenção a aplicação de produtos naturais, como os biopolímeros, para o tratamento de efluentes, que vem apresentando um grande crescimento nas pesquisas cientificas relacionadas a biossorventes (CHEN et al., 2017; HASANBEIGI, PRICE, 2015; VERMA et al., 2011).

Existem vários tipos de biopolímeros com aplicações em áreas como a medicina, a farmacêutica, a biológica e a industrial. A quitina é um dos principais e mais utilizados por sua capacidade de interação com diversas substâncias, tais como proteínas, corantes, íons metálicos entre outros componentes químicos (SANTOS, 2020). Devido a 
essas propriedades, essa biomolécula é capaz de atuar na adsorção de efluentes contaminados pela produção têxtil, tornando-se uma importante aliada no combate aos problemas ambientais gerados pelo setor.

Deste modo, objetou-se na pesquisa em tela realizar um levantamento bibliográfico sobre tópicos de conceitos, estrutura, obtenção e as principais aplicações da quitina no tratamento de efluentes gerados pelas indústrias têxteis. Destacando, principalmente os processos de adsorção de corantes em soluções aquosas produzidas pelo setor industrial discutido neste trabalho.

Para responder os objetivos proposto, realizou-se buscas nos bancos de dados, tais como: CAFé da CAPES e Scielo. Foram identificados artigos científicos, teses, dissertações e monografias, publicadas nos últimos dez anos, cuja busca foi pautada e refinada nas seguintes palavras-chaves: chitin applications, textile industrial effluents, dye adsorption, chitin production processes, chitin structure.

\section{REVISÃO BIBLIOGRÁFICA}

\subsection{PRINCIPAIS PROBLEMAS AMBIENTAIS DAS INDÚSTRIAS TÊXTEIS}

A poluição industrial tem como problema principal a alteração das relações existente entre seres vivos e fatores abióticos (clima, vento, água, energia e etc), prejudicando assim, o equilíbrio biológico dos ecossistemas (FACCIOLI et al, 2020). Dentre as áreas industriais, a têxtil destaca-se por produzir uma alta quantidade de corantes e despejar efluentes contaminados em rios, lagos e mares, prejudicando não só a vida aquática, mais também contribuindo para a escassez de água potável (ALMEIDA, DILARI, CORSO, 2016; CORREIA et al., 2020).

Dentre as várias etapas na produção têxtil, o tingimento é certamente a mais preocupante e responsável pelos problemas ambientais. Pois, de acordo com Almeida e colaboradores (2016) a mesma chega a produzir de 50 a $100 \mathrm{~L}$ de efluentes por quilo de tecido. Vale ressaltar que esse processo consiste na adição de corantes aos tecidos e os resíduos gerados possuem grande potencial poluente (HORVAT et al., 2012).

Sobre os danos ambientais causados pelo despejo inapropriado dos efluentes de indústria têxtil Lalnunhlimi e Krishnaswamy (2016, p. 40) destacam que: 


\begin{abstract}
Quando os corantes estão disponíveis no sistema de água, a penetração da luz solar nas camadas mais profundas é bastante reduzida, o que perturba a atividade fotossintética, resultando na deterioração da qualidade da água, diminuindo a solubilidade do gás e, finalmente, causando efeitos tóxicos agudos na flora e fauna aquáticas. A maioria dos corantes que são liberados das águas residuais, incluindo seus produtos de degradação, é tóxico, cancerígenos ou mutagênicos para humanos e outras formas de vida.
\end{abstract}

De acordo com o que foi supracitado, percebe-se o quanto o não tratamento desses efluentes pode prejudicar o meio ambiente. Sendo assim, torna-se necessário o desenvolvimento de medidas de descoloração de águas residuais, isto é, buscar técnicas que venham a contribuir na diminuição desses poluidores, de modo a não interferir na produção fabril, tendo em vista que esse é um dos principais setores econômicos do Brasil e do mundo.

Os problemas ambientais causados pelas indústrias têxteis não se resumem apenas a aspectos hídricos, mais também, aos danos causados no ar e no solo. Tratandose do ar, é necessário atenção com os aerodipersóides, partículas toxicas oriundas de materiais como o algodão, prejudicial à saúde dos trabalhadores. Outro fator danoso é a emissão de fuligem e gases como dióxido de carbono $\left(\mathrm{CO}_{2}\right)$ e dióxido de enxofre $\left(\mathrm{SO}_{2}\right)$, provenientes da combustão de óleo e lenha nas fabricas, contribuindo assim para a ocorrência de fenômenos maléficos a natureza, como por exemplo, efeito estufa e chuva ácida (SANTOS, 1997).

O estudo realizado por Gois et al (2016) relata a poluição do solo originada pelo descarte indiscriminado de efluentes das fábricas. Isso acontece devido ao acumulo de metais pesados como chumbo, cobre, cádmio, entre outros no substrato terrestre. Santos (1997) destaca a necessidade de medidas de controle, tais como tratamento dos efluentes e o uso de filtros para os particulados. As unidades fabris que apresentam preocupações com a forma em que as produções são geridas, com a diminuição dos impactos ambientais e que buscam uma maneira sustentável e eficiente de produzir, são exemplos de comprometimento com a sociedade e o meio ambiente.

\title{
2.2. OBTENÇÃO, PROPRIEDADES E ESTRUTURA DA QUITINA
}

Biopolímero biologicamente importante, a quitina pode ser encontrada em $70 \%$ dos organismos vivos do mundo. Desde 1811 já haviam estudos relacionados à quitina, 
quando o então químico francês Henri Braconnot isolou-a pela primeira vez. Entretanto, como os estudos eram promissores e a compreensão sobre suas propriedades e reatividade eram limitadas, as aplicações só começaram a surgir em 1970. Estudos sugerem que a quitina apresente uma estrutura cristalina com três formas alomórficas, a mais comum é a $\alpha$-quitina, seguida da $\beta$-quitina e $\gamma$-quitina (KAYA et al., 2017; SANTOS, 2020).

Existem diversos estudos sobre obtenção da $\alpha$-quitina, por exemplo, no trabalho desenvolvido por Ehrlich (et al., 2013) foi identificado em fibras esqueléticas da esponja de água doce Spongilla lacutris a presença desse composto. Para a obtenção e caracterização uma multiplicidade de técnicas analíticas foi empregada, tais como: CNMR de estado sólido, FT-IR, Raman, NEXAFS, ESI-MS, ensaio Morgan-Elson e coloração com Calcofluor White (EHRLICH et al., 2013).

A respeito da $\beta$-quitina, Brunner (et al., 2009) identificou sua presença nas paredes celulares da T.pseudonana. Para a extração da mesma os autores adotaram um método de tratamento com dodecilsulfato de sódio e EDTA (ácido etilenodiamina tetracético) frente a espécie de fitoplâncton, e a confirmação da $\beta$-quitina foi dada por observações em espectroscopia de RMN de estado sólido.

Com relação à estrutura, a quitina é um polímero linear formado por uma ligação glicosídica constituída por 2-acetamido-2desoxi-d-glicopiranose como estrutura majoritária (80\%), e 2-amino-2desoxi-D-glicopiranose (5-10\%), esse, proveniente do processo de desacetilação parcial ocorrido nos processos de síntese (CAMPANHA FILHO et al., 2007). Na Figura 01 observa-se a estrutura primária da quitina, na qual $n$ representa o grau de polimerização.

Figura 1 - Estrutura primária da Quitina

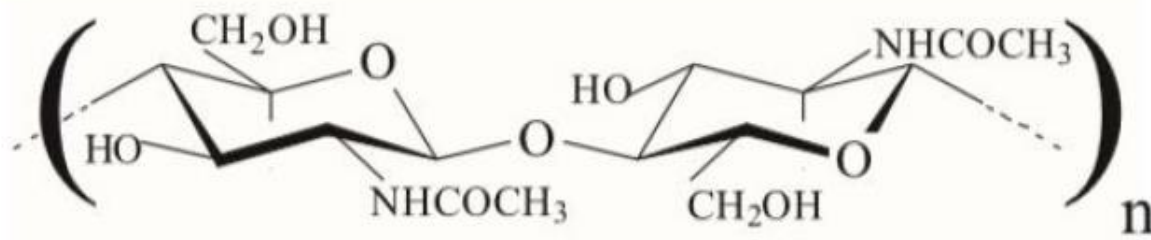

Fonte: Campanha Filho et al (2007). 
Esse aspecto estrutural da quitina, assim como na celulose, confere-a ligações do tipo ?(194), deste modo, as extremidades contendo os grupos hidroxila livres ligadas aos carbonos do anel da glicopiranose, define-se como terminal redutor (carbono 01) e nãoredutor (carbono 4). As orientações dessas cadeias diferenciam as chamadas $\alpha, \beta, \gamma$ quitina, que consequentemente afeta a cristalinidade das amostras (CAMPANHA FILHO et al., 2017; SANTOS, 2020).

A diferenciação dessas quitinas é descrita por Kuya (et al., 2016), como sendo camadas catenárias, em que a $\alpha$-quitina apresenta a extremidade com direção ou sentindo diferente configurando uma estrutura antiparalela, a $\beta$-quitina com camadas adjacentes paralelas e direções iguais e na $\mathcal{Y}$-quitina a cada três camadas há uma com direção oposta em relação as anteriores. A compreensão da diferenciação dessas estruturas pode ser observada na figura 02.

Figura 2 - Representação das estruturas poli fórmicas da quitina

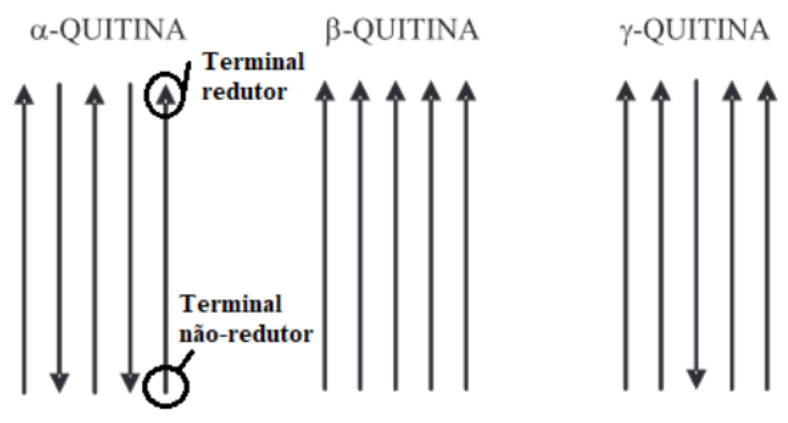

Fonte: Campanha Filho et al (2017).

Como pode ser observada, a estrutura da $\alpha$-quitina favorece as ligações de hidrogênio envolvendo inter e intra-cadeias de lamelas com cadeias iguais e diferentes, resultando em um arranjo compacto. Em contra partida, a $\beta$-quitina apresenta uma estrutura com compactação menor, pois as ligações de hidrogênio são dificultadas devido ao arranjo paralelo das diferentes cadeias lamelares. Em relação à estrutura da $\gamma$-quitina, seu arranjo sugere uma possível combinação ou distorção entre as estruturas $\beta$-quitina e $\alpha$-quitina, corroborando com poucos estudos sobre tal estrutura (CAMPANHA FILHO et al., 2017). 


\subsection{ESTUDOS SOBRE APLICAÇÃo DA QUITINA NO TRATAMENTO DE EFLUENTES DE INDÚSTRIA TÊXTIL}

A natureza química e biológica da quitina confere-a uma atoxidade, biocompatibilidade e biodegradabilidade, essas características promoveram estudos de aplicações em diversas áreas (SANTOS, 2020). Porém, neste trabalho, foi dada ênfase as atuações da quitina no tratamento de efluentes têxteis, destacando principalmente a capacidade de adsorção de corantes.

Em um estudo desenvolvido por Dassanayakea (et al.,2016), a quitina foi usada para remover azul de metileno (corante empregado no processo de tingimento) de uma solução liquida. Inicialmente, obteve-se um híbrido dióxido de manganês $\left(\mathrm{MnO}_{2}\right)$ quitina, sendo esse caracterizado por espectroscopia de energia dispersa de raio $\mathrm{x}$, espectroscopia de infravermelho com transformada de Fourier, difração de raios-X e análise termogravimétrica. Os resultados da pesquisa mostraram que $8,5 \mathrm{~g}$ do hibrido de quitina foi capaz de descolorir $25 \mathrm{~mL}$ da solução de azul de metileno em um período de 2,5 min (DASSANAYAKEA et al., 2016).

Os estudos de Santos (2020), demostram resultados de adsorção para o corante verde brilhante, nos quais o valor máximo obtido, foi de $2,0 \mathrm{mg}$ de corante para cada grama de quitina usada. Nesse trabalho, também foram feitos ensaios para a absorção do corante vermelho congo, e a capacidade máxima de adsorção foi de 172,4 mg do corante por grama de quitina.

Nos trabalhos de Moura (2014) sob condições básicas foi feita a desacetilização dos grupos amidas da quitina, para formar grupos amina que são característicos da quitosana, na qual as estruturas das duas substâncias diferem apenas na substituição do grupo acetamino na posição 2. Utilizou-se filmes biopoliméricos de quitosana como agente adsorvente para a remoção do corante preto 5 , e os experimentos que apresentaram melhores resultados, foram os realizados em $\mathrm{pH} 4$, onde o filme de quitosana apresentou capacidade de adsorção de $385 \mathrm{mg}$ do corante para cada grama quitosana.

Os resultados de Dotto et al (2011), apresentam percentuais de remoção dos corantes têxteis, azul brilhante, amarelo crepúsculo e amarelo tartrazina usando a quitina como agente adsorvente, obtendo o melhor aproveitamento nos ensaios 
realizados em condições de pH 3. Os percentuais de remoção para os corantes foram, $30 \%$ para o azul brilhante, $35 \%$, para o amarelo crepúsculo e $25 \%$ para o amarelo tartrazina. De acordo com os próprios autores, o baixo percentual de remoção da quitina, deve-se aos poucos grupos aminos que a molécula do adsorvente possui, dificultando a interação química quitina-corante.

\section{CONSIDERAÇÕES FINAIS}

Tendo em vista que os corantes usados nos processos de tingimento dos produtos têxteis, confere aos rejeitos líquidos desse setor industrial, um grande potencial poluidor de rios e mananciais. Se faz necessário a buscar aplicar métodos acessíveis, práticos e eficientes que possam eliminar ou reduzir a concentração desses compostos nos efluentes têxteis, o que é essencial para evitar a contaminação do ar, do solo e de ambientes aquáticos.

O uso da quitina como agente adsorvente para a remoção de corantes têxteis, apresenta-se como uma alternativa promissora e ecológica. Considerando que os métodos convencionais usados para a remoção desse poluente, utilizam produtos químicos nos quais os rejeitos gerados, podem ser tão poluidores quanto o efluente antes do tratamento.

Os biopolímeros se colocam como materiais promissores para serem integrados as técnicas de tratamento dos efluentes têxteis, principalmente as biomoléculas que apresentam porosidade, como é o caso da quitina. Na qual seu uso, combinado com outros métodos pode promover alternativas mais eficazes, sustentáveis e ecologicamente corretas na recuperação desses efluentes.

\section{REFERÊNCIAS}

ABIT. Associação Brasileira da Indústria Têxtil e de Confecção. O Poder Da Moda: Cenários, Desafios, Perspectiva. Agenda de Competitividade da Indústria Têxtil e De Confeç̧ão Brasileira 2015-2018. 2019. Disponível em: https://www.abit.org.br/adm/Arquivo/Publicacao/120429.pdf. Acessado em 11 de maio de 2021

ALMEIDA, Érica Janaína Rodrigues; DILARRI, Guilherme; CORSO, Carlos Renato. A indústria têxtil no Brasil: uma revisão dos seus impactos ambientais e possíveis 
tratamentos para os seus efluentes. Projeto Qualidade da Água, Boletim das Águas - Ministério Público Federal, Brasília/DF, p. 1 - 18, 23 nov. 2016.

Brunner, E., Richthammer, P., Ehrlich, H., Paasch, S., Simon, P., Ueberlein, S., \& van Pee, K. H. Chitin-based organic networks: An integral part of cell wall biosilica in the diatom thalassiosira pseudonana. Angewandte Chemie-International Edition, 48(51), 9724-9727, 2009.

Chen, L et al. A process-level water conservation and pollution control performance evaluation tool of cleaner production technology in textile industry. Journal of Cleaner Production, 143, 1137-1143, 2017.

DOTTO, Guilherme Luiz; VIEIRA, Mery Luiza Garcia; GONCALVES, Janaína Oliveira e PINTO, Luiz Antônio de Almeida. Removal of acid blue 9, food yellow $\mathbf{3}$ and FD\&C yellow no 5 dyes from aqueous solutions using activated carbon, activated earth, diatomaceous earth, chitin and chitosan: equilibrium studies and thermodynamic. Quím. Nova [online]. 2011, vol.34, n.7 [citado 2021-04-14], pp.1193-1199. Disponível em: <http://www.scielo.br/scielo.php?script=sci_arttext\&pid=S0100404220110007 00017\&lng=pt\&nrm=iso $>$. Acesso em 14 abr. 2021.

ETSHINDO, Lourdes Akaho et al. Aplicações da quitosana no tratamento de efluentes têxteis. Anais do XIV Congresso Nacional do Meio Ambiente, Minas Gerais, 2017.

FACCIOLI, Gabriel et al. Sustentabilidade na gestão da indústria têxtil: aplicações enzimáticas no tratamento de efluentes. Prospectus, v. 2, n. 1, p. 190-233, 2020.

GOIS, F. A.; SOUZA, G. A.; OLIVEIRA, M. J.; LIMA, R. S.; KOSLOWSKI, L. A. D. Análise da qualidade da água quanto ao despejo industrial têxtil no rio dos índios. Caderno Meio Ambiente e Sustentabilidade. v.9 n.5. 2016.

Hamed, I; Özogul, F; Regenstein, J. M. Industrial applications of crustacean by-products (chitin, chitosan, and chitooligosaccharides): A review. Trends in Food Science \& Technology. 48, 40-50, 2016.

Hasanbeigi, A; Price, L. A technical review of emerging technologies for energy and water efficiency and pollution reduction in the textile industry. Journal of Cleaner Production, 95, 30-44, 2015.

HORVAT, A. J. M, et al. Analysis, occurrence and fate anthelmintcs and their transformation products in the environment. Trends in Analytical Chemistry, $v$. 31, p. 61-24, 2012. Kaya, Murat et al. On Chemistry of $y$-chitin. Carbohydrate Polymers, 177-186, 2017.

LALNUNHLIMI, Sylvine; KRISHNASWAMY, Veenagayathri. Decolorization of azo dyes (Direct Blue 151 and Direct Red 31) by moderately alkaliphilic bacterial 
consortium. Braz. J. Microbiol., São Paulo, v. 47, n. 1, p. 39-46, 2016. Disponível em:

<http://www.scielo.br/scielo.php?script=sci_arttext\&pid=S1517838220160001 00039\&lng=en\&nrm=iso>. Acesso em: 13 outubro de 2020.

LIMA, B. C et al. Aplicação do extrato de Abelmoschus esculentus (L.) Moench como floculante para a remoção de cor no tratamento de águas com corante têxtil. Revista Ibero-Americana de Ciências Ambientais, v.11, n.4, p.424-431, 2020.

LUCENA, Guilherme Leocárdio et al. Remoção de corantes têxteis de soluções aquosas por quitosana modificada com tioacetamida . Rev Ambient. Água [online]. vol.8, n.1, p. 144-154, 2013.

MOURA, Jaqueline Motta de. Avaliação da hidrólise alcalina da quitina e elaboração de filmes de quitosana para aplicação na adsorção do corante têxtil reativo preto 5. 105 f. Dissertação (Mestrado em Química Tecnológica e Ambiental) - Escola de Química e Alimentos, Universidade Federal do Rio Grande, Rio Grande - RS, 2014.

KUNZ, A.; PERALTA-ZAMORA, P.; MORAES, S. G.; DÚRAN, N.Novas Tendências no Tratamento de Efluentes Têxteis. Revista Química nova, v.25, n.1, p.78-82, 2002.

SANTOS, Marcia Cristina. Obtenção de quitina a partir do exoesqueleto de camarão (Litopenaeus Vannamei) e avaliação da sua aplicabilidade para utilização como adsorvente na remoção de corantes de meio aquoso. 80 f. Dissertação (Mestrado em Ciência e Tecnologia de Materiais) - Escola de Engenharia, Universidade Federal do Rio Grande do Sul, Porto Alegre RS, 2020.

SANTOS, Simone. Impacto ambiental causado pela indústria têxtil. UFSC-Engenharia de Produção e Sistemas-PPGEP-Centro Tecnológico-Trindade-Florianópolis, SC, 1997.

SILVEIRA NETA et al. Remoção de corantes Reactive Blue 21 e Direct Red 80 utilizando resíduos de sementes de Mabea fistulifera Mart. como biossorvente. Ambiente e Água, Taubaté, v. 7, n. 1, p. 104-119, abr. 2012.

VERMA, A. K et al. A review on chemical coagulation/flocculation technologies for removal of colourfrom textile wastewaters. Journal of Environmental Management, 93, 154-168, 2011. 


\title{
CAPITULO XXXI
}

\section{QUAUDADE E USO DA ÁGUA DE UM IGARAPÉ, UMA MASCENIIE E UM RESERVATÓRIO NA ZONA RURAL DO MUNICÍPIO DE NOVA TIMBOTEUA - PA}

\section{DOI: 10.51859/amplla.mas481.1121-31}

\author{
Brendo Luiz Araújo Alves ${ }^{2}$ \\ Vitor Glins da Silva Nascimento ${ }^{1}$ \\ Antônio Pereira Júnior ${ }^{1}$ \\ Francimary da Silva Carneiro ${ }^{2}$ \\ Leoni Serrão Belato ${ }^{2}$ \\ Klewton Adriano Oliveira Pinheiro ${ }^{3}$ \\ Irlane Quaresma da Silva ${ }^{2}$
}

\footnotetext{
1 Universidade do Estado do Pará-UEPA, Brasil

${ }^{2}$ Secretaria do estado de Meio Ambiente-SEMAS-PA, Brasil

${ }^{3}$ Instituto Federal de Educação, Ciência e Tecnologia do Pará-PA, Brasil
}

\section{RESUMO}

A zona rural das cidades, historicamente, sempre foi desprovida de um saneamento básico adequado, especificamente no que diz respeito ao abastecimento de água encanada. Essa pesquisa objetivou quantificar e qualificar a importância socioambiental das nascentes hídricas e verificar o nível da qualidade da água consumida em uma comunidade rural do município de Nova Timboteua - PA por intermédio do índice de Qualidade da Água (IQA) que é o principal instrumento de análise de parâmetros físicoquímicos e biológicos utilizado no Brasil. O método aplicado foi o dedutivo e a pesquisa apresentou abordagem quantitativa e qualitativa, de caráter exploratório. Quanto ao IQA do igarapé, da nascente e do reservatório no período chuvoso, a qualidade da água foi classificada de três formas: maio, os conceitos variaram entre "bom e ótimo"; junho, "bom" e julho, variou de "aceitável a ótimo"; no período seco, assinalou: agosto, "ótimo"; em setembro e outubro, "bom e ótimo". Logo, conhecer a qualidade da água na zona rural é uma forma de resguardar a vida das populações que lá habitam, bem como garantir a manutenção dos ecossistema.

Palavras-chave: Contaminação. Recursos Hídricos. Saneamento Básico.

\section{INTRODUÇÃO}

A zona urbana das cidades sempre foi privilegiada no que concerne à implantação de sistemas de água encanada e potável, em detrimento à zona rural 
(Bisognin et al., 2017; Rockstrom et al., 2009). Tal fato é justificado pelo grande contingente populacional existente em regiões majoritariamente urbanizadas, fato que retém a maioria dos investimentos em saneamento; o que torna grande parte das comunidades rurais dependentes, quase que exclusivamente, das nascentes hídricas para sobreviver e desenvolver qualquer tipo de atividade econômica campestre (Pinto, Araújo e Silva Júnior, 2015).

Quanto à gênese das nascentes, sabe-se que a ocorrência delas é oriundos, principalmente, pela formação dos denominados lençóis freáticos, classificados como artesianos e cársticos (Falavinha; Degenhardt, 2014). Esses tipos de lençóis são alguns dos fatores que contribuem para que as nascentes sejam caracterizadas como perenes (dispõem de água durante todo o ano), intermitentes (vertem em períodos distintos do ano), e, por último, as nascentes temporárias ou efêmeras, essas, apresentam vazão apenas em períodos chuvosos (Pereira et al., 2016).

No sistema hidrológico, as nascentes hídricas desempenham um papel importante: promover o fluxo da água do subterrâneo para a superfície terrestre (Buzelli; Cunha-Santino, 2013). As mesmas são o marco dos canais de drenagem, sendo responsáveis pela maioria da porção dos recursos hídricos usada pela sociedade, em especial, as águas superficiais. A maioria desses ambientes, atualmente, inclusive em zonas rurais, encontram-se modificados, em razão de ações antrópicas diretas e/ou indiretas, como por exemplo, o desmatamento (Pinto, Roma e Balieiro, 2012; Roberto et al., 2017).

Nesse cenário, atualmente, a problemática da qualidade da água e do gerenciamento dos recursos hídricos, tornou-se um dos mais graves entraves enfrentados pelo poder público, bem como pela sociedade, pois é nítida a vulnerabilidade socioambiental existente em um corpo social totalmente urbanizado, de forma específica, quando se enfoca a interação entre os recursos hídricos e o homem. No entanto, essa fragilidade ultrapassou os limites urbanos e permeia cada vez mais as zonas rurais, via uso e ocupação abusiva do solo (Clasen et al., 2014; Santos; Hernandez, 2013;).

Essa afirmativa concatena com a utilização intensiva dos recursos naturais que tem sido uma das principais características do desenvolvimento econômico agrícola no 
Brasil nos vinte últimos anos (Guedes et al., 2012; Vanzela, Hernandez e Franco, 2010). Como consequência desse processo, aumenta-se a incidência de carreamentos de grandes quantidades de solo, matéria orgânica e insumos agrícolas para o leito de cursos d'águas, fatores esses que modificam a fauna, flora, e, sobretudo, alteram a qualidade da água, bem como diminuem a disponibilidade hídrica de uma localidade (Bucci; Oliveira, 2014; Souza et al., 2014).

Ademais, a água é um dos recursos naturais mais significativos do planeta e, também, é caracterizada como um recurso finito. $O$ aumento exacerbado e desenfreado da população, entre outros fatores interligados a este, ocasionaram a degradação dos recursos hídricos em função dos usos múltiplos e regularmente sem controle, como o lazer, a pecuária e a agricultura (Piratoba et al., 2017).

De maneira global, a crise hídrica - seja pela escassez ou má qualidade - ocupa a segunda posição como principal causa de morte na infância, abaixo apenas das infecções respiratórias (Leoneti, Prado e Oliveira, 2012; Macedo; Schuntzemberger, 2015). No Brasil, de acordo com especialistas, no ano de 2015, 65\% das internações no Sistema Único de Saúde (SUS) de crianças menores de 10 anos, foram provocadas pela deficiência na disponibilização de água potável e, anualmente, os gastos com o tratamento de doenças relacionadas à potabilidade da água aproximam-se dos $\mathrm{R} \$ 300$ milhões (Coradi, Fia e Pereira-Ramirez, 2009).

Nesse sentido, para averiguar a qualidade da água em muitos casos, é necessária a aplicação e verificação de índices relacionados aos parâmetros físico-químicos e biológicos da mesma, como o elaborado na década de 70, nos Estados Unidos, pela National Sanitation Foundation. No Brasil, foi utilizado pela primeira vez pela Companhia Ambiental do Estado de São Paulo (CETESB); posteriormente, outros estados brasileiros aderiram ao Índice de Qualidade da Água (IQA) que, atualmente, é o principal índice utilizado em território nacional (ANA, 2018; Frinhani; Carvalho, 2010).

Dessa forma, conhecer a qualidade da água de uma determinada comunidade rural, que não dispõe de um sistema de água potável encanada, muito menos de um adequado saneamento rural; faz-se extremamente importante frente a realidade de vulnerabilidade socioambiental ocasionada por esses fatores. Por isso, essa pesquisa objetivou quantificar e qualificar a importância socioambiental das nascentes hídricas e 
verificar o nível da qualidade da água consumida em uma comunidade rural do município de Nova Timboteua - PA por intermédio do IQA.

\section{MATERIAL E MÉTODOS}

\subsection{FISIOGRAFIA DO MUNICIPIO}

A pesquisa foi realizada no município de Nova Timboteua, no nordeste do estado do Pará, Brasil, com latitude de 02 02' 47" S e longitude de 47 33' 02" W, e população estimada em 14.942, apresenta área total de $489.853 \mathrm{~km}^{2}$ e com densidade demográfica de 27,91 habitantes por km² $^{2}$ (IBGE, 2017). Em relação ao solo, há predominância do latossolo amarelo e do concessionário laterítico que são caracterizados como ácidos e porosos; quanto à vegetação, prevalece a floresta secundária, em razão do desmatamento que ocorreu na década de 1990 com a finalidade de desenvolver economicamente a região (Rodrigues et al., 2009). A área da pesquisa foi escolhida em razão da ausência de um sistema de abastecimento de água na comunidade, além de não possuir nenhuma forma de saneamento básico, bem como pela presença de um igarapé, uma nascente e reservatório (Figura 1).

Figura 1 - Localização da área da pesquisa - Sítio Jonas. Nova Timboteua - PA.

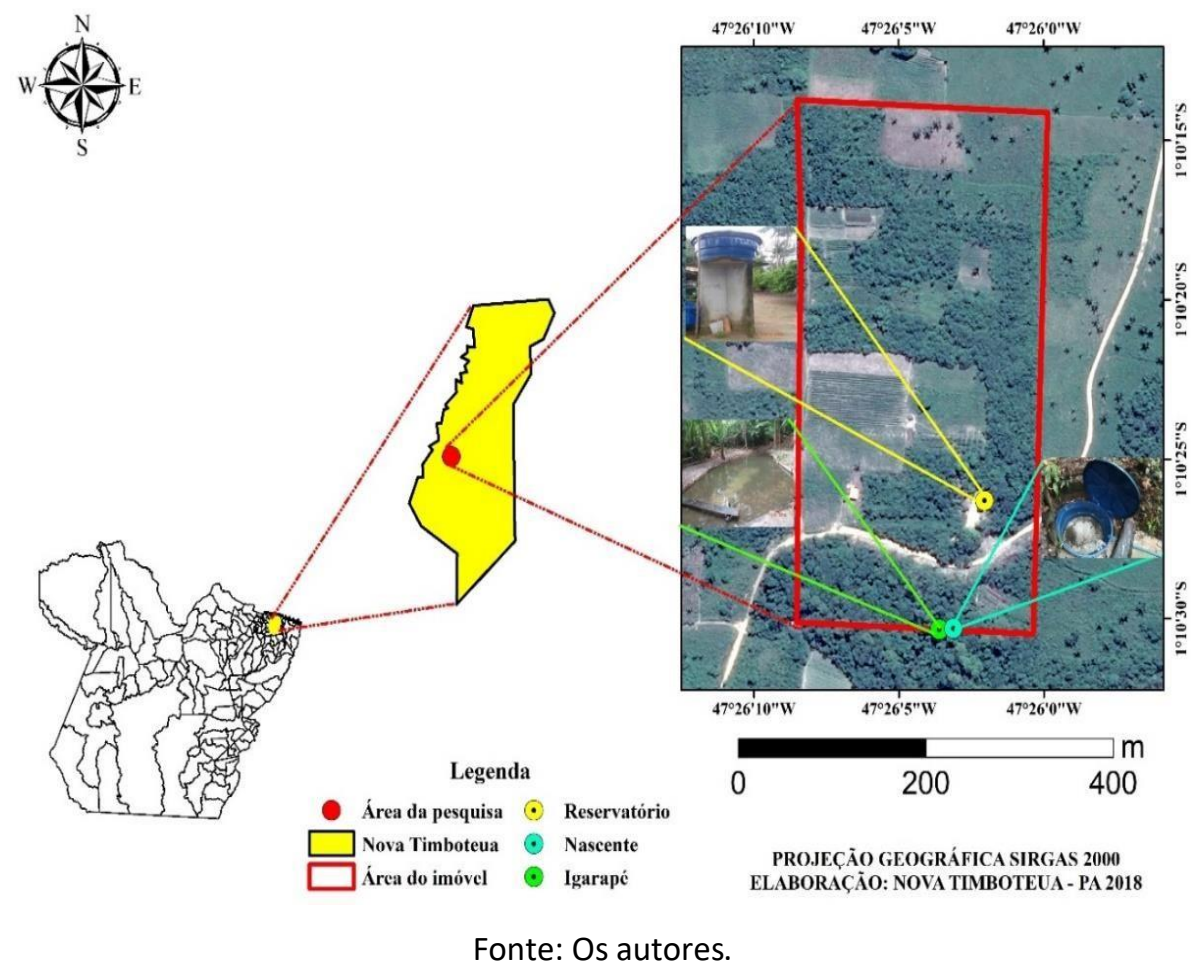




\subsection{MÉTODO APLICADO À PESQUISA}

Quanto ao método aplicado, utilizou-se o dedutivo, pois partiu-se de duas premissas positivas para uma conclusão verdadeira: (1) a zona rural brasileira apresenta um elevado déficit no que diz respeito ao saneamento básico, (2) tal deficiência compromete diretamente a qualidade da água usada e consumida pela população. Logo, essa problemática prejudica de forma proeminente a qualidade de vida das comunidades rurais através da poluição e/ou contaminação dos corpos hídricos (Borges; Pereira, 2014).

A pesquisa apresenta abordagem qualitativa e quantitativa, de natureza aplicada, com procedimento exploratório, de acordo com o exposto por Sakamoto e Silveira (2014), pois, na comunidade Sapucaia, esse tipo de pesquisa ainda não ocorreu. Nesse sentido, o método foi associado ao levantamento de dados documentais com o recorte temporal compreendido entre os anos de 2009 e 2018, em razão dos trabalhos científicos com grande significância sobre a temática dos recursos hídricos qualidade da água e a zona rural se concentrarem nesse período, além de apresentarem atualidade de dados no intervalo selecionado. Associaram- se a isso, os estudos das características físicas da propriedade alocada na zona rural do município de Nova Timboteua, em face das relações havidas entre as atividades agrícolas e o uso dos recursos hídricos.

\subsection{ELABORAÇÃO DE MAPAS}

Foram elaborados mapas de localização da área da pesquisa, realizado o memorial fotográfico, confecção dos mapas das direções de fluxo de escoamento superficial e a geração de um Modelo Digital de Elevação (MDE), bem como a quantificação e localização geográfica (coordenadas) dos pontos que se encontram as nascentes hídricas, áreas de cultivo agrícola e reservatórios de água. As coordenadas planas East (E) e North (N) em Universal Transversa de Mercator (UTM) foram obtidas com o uso do Global Positioning System (GPS).

\subsection{APLICAÇÃO DE FORMULÁRIOS}

A aplicação dos formulários foi antecedida por uma reunião (16 de julho de 2018), com os moradores da comunidade Sapucaia (zona rural do município de Nova Timboteua), para a apresentação do objetivo principal do projeto e alinhamento das 
visitas nas propriedades rurais que dependem exclusivamente das nascentes para desenvolver atividades diversas, para dessa maneira, realizar coleta de dados primários a partir da aplicação dos formulários semiestruturados contendo cinco questões objetivas e cinco subjetivas (Figura 2).

Figura 2 - Questões aplicadas aos indivíduos amostrados. Nova Timboteua - PA.

$$
\begin{aligned}
& \text { UNIVERSIDADE DO ESTADO DO PARÁ } \\
& \text { CENTRO DE CIÊNCIAS NATURAIS E TECNOLOGIA } \\
& \text { DEPARTAMENTO DE ENGENHARIA AMBIENTAL } \\
& \text { CAMPUS VI - PARAGOMINAS }
\end{aligned}
$$

\section{Gênero:}
( ) Masculino
( ) Feminino

Faixa etária:
( ) até 18 anos
( ) entre 18 a 23 anos
( ) entre 24 e 30 anos
( ) entre 31 e 40 anos
( ) entre 41 e 54 anos
( ) acima de 55 anos

\section{Escolaridade:}

Ensino fundamental
( ) completo
( ) incompleto

Ensino superior

\section{( ) completo}

( ) incompleto

\section{Outros}

\section{( ) não letrado}

( ) semi-letrado

1 - Em um grau de importância de 0 a 10, onde 0 é nada importante e 10 extremamente importante, qual grau você atribui para importância das nascentes para a comunidade?

$$
\begin{array}{|l|l|l|l|l|l|l|l|l|l|l|}
\hline 0 & 1 & 2 & 3 & 4 & 5 & 6 & 7 & 8 & 9 & 10 \\
\hline
\end{array}
$$

2 - Considerando os fatores abaixo, qual a principal finalidade do uso da água?
( ) Dessedentação
( ) Irrigação
( ) Uso doméstico

3- Você considera que a água das nascentes apresenta boa qualidade?
( ) $\mathrm{Sim}$
( ) Não

4 - Você sofre com frequência de enfermidades estomacais como diarreia?
( ) Sim
( ) Não

5 - Você considera essencial a preservação/conservação das nascentes para que água se mantenha dentro dos padrões para consumo humano?
( ) $\mathrm{Sim}$
( ) Não

6 - De que forma você considera que as atividades agrícolas podem influenciar na qualidade da água?

7 - A administração municipal realiza atividades de orientação quanto ao uso dos recursos hídricos na zona rural? Se positivo, quais? Se negativo, expresse quais medidas seriam necessárias para que se possa ter uma água de qualidade na zona rural.

8 - Você considera que a água consumida das nascentes precisa de algum tipo de tratamento? Por quê?

9-Quais sugestões seriam importantes para manter e/ou melhorar a qualidade da água?

10 - Com que frequência você encontra animais nas proximidades das nascentes? Qual influência esse fator pode exercer sobre a qualidade da água?

Fonte: Os autores. 
Ressalta-se que devido à exigência do Conselho Nacional de Saúde, Resolução n. 510, art. 2, inciso X, houve a aplicação do Termo de Compromisso Livre e Esclarecido TCLE (Brasil, 2016). Justifica-se que a quantidade de trinta formulários aplicados é referente ao conjunto universo na comunidade rural sapucaia.

\subsection{Amostragem da água}

As coletas de amostragem, a esterilização dos recipientes $(v=500 \mathrm{~mL})$ e a preservação das amostras foram realizadas conforme o Guia Nacional de Coleta e Preservação de Amostras (Brandão, 2011), a Associação Brasileira de Norma Técnicas (ABNT), Norma Brasileira Regulamentadora ABNT NBR 9897:1987 que dispõe sobre o planejamento de amostragem de efluentes líquidos e corpos receptores e a ABNT NBR 9898:1987 que dispõe de técnicas de preservação de amostragem de efluentes líquidos e corpos receptores.

Nesse sentido, as amostras foram obtidas em três pontos distintos: (1) igarapé, que situa-se nas coordenadas $229102.41 \mathrm{~m} \mathrm{E}$ - $9869993.91 \mathrm{~m} \mathrm{~S}$; (2) nascente, delimitada por um tanque plástico de Poliacrilato de Vinila (PVC), e localiza-se em 229118.77 m E 9870000.67 m S - e (3) reservatório em PVC - 229151.74 m E - 9870123.94 m S. O processo de amostragem compreendeu uma coleta mensal em cada um dos pontos durante 6 meses do ano de 2018 (07/05, 04/06, 02/07, 06/08, 03/09 e 01/10), sempre no primeiro final de semana de cada mês, o que totalizou 18 amostras, sendo seis para cada ponto.

Após coleta, as amostras foram hermeticamente fechadas, etiquetadas e mantidas sob a temperatura ideal $\left(10^{\circ} \mathrm{C}\right)$ e, então, foram transportadas e encaminhadas ao Laboratório F. Torres (localizado no município de Paragominas) para a análise de nove parâmetros: Oxigênio Dissolvido (OD); Coliformes Totais e Termotolerantes (CT); Potencial Hidrogeniônico (pH); Demanda Bioquímica de Oxigênio (DBO); Temperatura da Água (To); Turbidez (TURB); Nitrogênio (NT); Fósforo Total (FT) e Resíduo Total (RT) conforme os métodos analíticos presentes no Standard Methods For The Analysis Of Water Abd Wastewater 20 TH (Baird, 2017).

Em relação ao tempo de translado das amostras, foi seguido rigorosamente de acordo com o Manual da ANA e as NBR's supracitadas. O processo de coleta sempre ocorreu às $06 \mathrm{~h} 00$ e foi entregue no laboratório por volta de 11 h00. 


\subsection{CÁlCULOS}

Para o cálculo do IQA, foi aplicada a Equação 1 (ANA, 2018):

$$
I Q A=\prod_{i=1}^{n} q i^{w} i
$$

Onde: IQA = Índice de Qualidade das Águas (0-100)qi = qualidade do i-ésimo parâmetro wi = peso correspondente ao i-ésimo parâmetro.

$\mathrm{n}=$ o número de parâmetros que entram no cálculo do IQA

\subsection{TRATAMENTO ESTATISTICO DOS DADOS}

Os dados obtidos foram estatisticamente tratados com o uso da Estatística Descritiva: média e desvio padrão (Larson; Farber, 2010; Milan, 2011), a partir de planilhas eletrônicas disponíveis no software MicrosoftExcel (Microsoft Corporation, 2016). Para a tabulação gráfica dos dados utilizou-se o software OriginLab Graphing \& Analysis - Versão 8.0 (Origin Lab, 2016). O Software QualiGraf (Versão 1.17) foi utilizado para cálculo automático do IQA a partir dos dados obtidos nas análises laboratoriais. Esse software apresenta padrões de análise estatística estabelecidos pela CETESB (FUNCEME, 2015).

\section{RESULTADOS E DISCUSSÕES}

\subsection{QUANTIFICAÇÃO E QUALIFICAÇÃo SOCIOAMBIENTAL}

Os dados obtidos e analisados indicaram que, do total de indivíduos amostrados, em relação ao gênero, 16 (53,30\%) pertencem ao feminino e 14 (46,70\%) são do masculino. Quanto a faixa etária, 10 (33,33\%) possuem idade entre 41 e 54 anos; 7 $(23,3 \%)$ entre 31 e 40 anos. Quanto ao grau de escolaridade, 11 (36,66\%) dos entrevistados possuem o Ensino fundamental incompleto.

Sobre a maior percepção da sociedade acerca dos problemas ambientais, foi efetuado um estudo por Rodrigues et al. (2012), no município de São Paulo (SP). Nele, os autores concluíram que quanto maior a percepção da sociedade sobre os problemas ambientais, maior a aproximação entre os gestores e a população; os principais fatores para tal percepção, são o nível de escolaridade e a faixa etária dos indivíduos. No município de Nova Timboteua, apesar de ter sido verificado na comunidade sapucaia 
que a maior parcela dos indivíduos amostrados possui idade entre 41 e 54 anos (33,33\%), $11(36,66 \%)$ pessoas não concluíram o ensino fundamental, fatores que podem ou não influenciar na obtenção de dados, assim como na percepção ambiental dos indivíduos entrevistados, conforme o estudo efetuado em São Paulo.

\subsection{DA ANÁLISE DOS FORMULÁRIOS}

A análise dos dados obtidos indicou que, quanto às nascentes, 30 (100\%) indivíduos amostrados atribuíram o valor máximo (10) para a importância delas para a comunidade rural. Assim, percebe-se que todos os moradores da comunidade consideram as nascentes essenciais para a sobrevivência dos mesmos. No estudo efetuado por Bisognin et al. (2017), em Três Passos (RS), conclui-se que os corpos hídricos, principalmente as nascentes, são de fundamental importância às comunidades rurais e, dessa forma, a disponibilidade em quantidade e qualidade devem por obrigação serem suficientes para atender a população. Isso corrobora com a pesquisa realizada em Nova Timboteua, pois as nascentes são a principal forma de obtenção de água da comunidade rural Sapucaia.

Quanto a principal finalidade do uso da água (Figura 3), houve tendências a divergências, pois, os dados obtidos indicaram que 16 (54\%) dos 30 indivíduos amostrados acreditam que o uso doméstico é preponderante, para irrigação 7 (23\%) e dessedentação 7 (23\%).

Figura 3 - Dados inerentes à principal finalidade do uso da água. Nova Timboteua - PA.

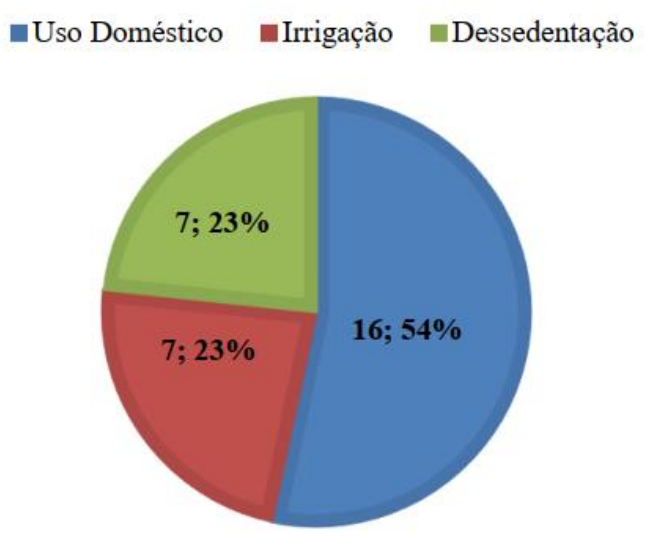

Fonte: Os autores

Em relação ao crescimento populacional e a percepção quanto a finalidade da 
água, foi efetuado um estudo em Barcarena (PA), por Piratoba et al. (2017). Os pesquisadores concluíram que esse crescimento estáatrelado a outros fatores como, por exemplo a urbanização, e isso contribuiu para que a água fosse utilizada em diversas finalidades (Ex.: abastecimento público; a agricultura - irrigação; indústria e geração de energia).Em Nova Timboteua, as principais finalidades são para a dessedentação, uso doméstico e agricultura - irrigação, nos quais, são similares aos reportados em Barcarena.

Em relação à qualidade da água, os dados obtidos indicaram que $28(93,34 \%)$ dos indivíduos amostradosafirmaram que a mesma apresenta boa qualidade, enquanto dois $(6,66 \%)$ se opuseram a essa afirmativa, logo, para eles, a qualidade da água não é satisfatória (Figura 4).

Figura 4 - Dados obtidos acerca da qualidade da água de acordo com a percepção dos indivíduos

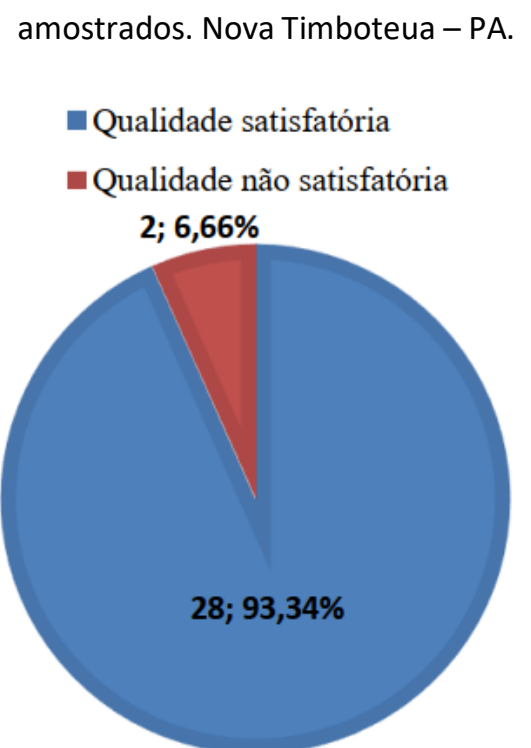

Fonte: Os autores.

Frinhani e Carvalho (2010), efetuaram pesquisa no município de Joaçaba (SC), acerca do desempenho do IQA e os dados por eles obtidos indicaram que esse índice é uma das ferramentas utilizadas para a avaliaçãoda qualidade da água por intermédio de análises físico-químicas e microbiológicas e, dessa forma, é considerada a mais representativa para a caracterização da água, além de ser capaz de informar ao público nãotécnico sobre a qualidade dos recursos hídricos, inclusive das nascentes. Em Nova 
Timboteua, esse índice foicalculado para averiguar se a água apresenta qualidade satisfatória e informar a população sobre a mesma.

Para as enfermidades estomacais de veiculação hídrica, houve tendência a informações divergentes, poisa análise dos dados obtidos indicou que 26 (86,67\%) dos indivíduos amostrados garantiram que não sofrem com tais enfermidades, em contrapartida, 4 (13,33\%) afirmaram que apresentam, com frequência, doenças estomacais (Figura 5).

Figura 5 - Dados sobre enfermidades estomacais de veiculação hídrica. Nova Timboteua - PA.

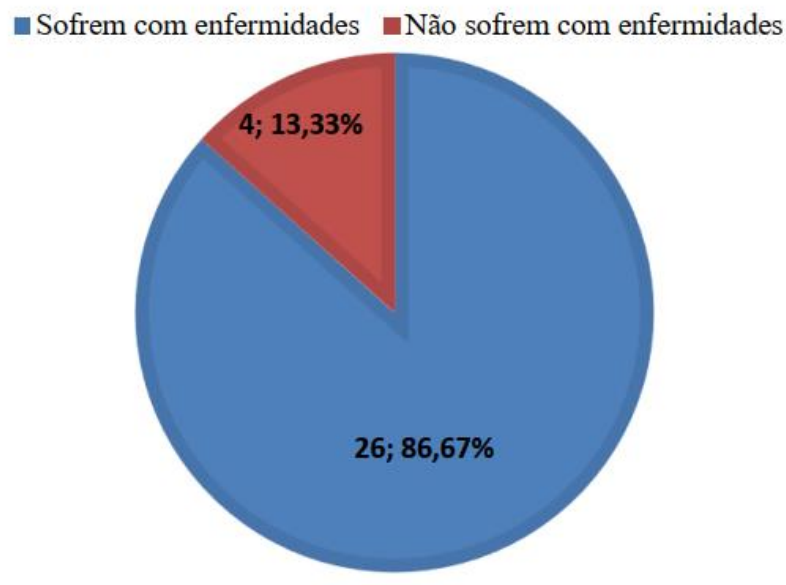

Fonte:Os autores.

Essa diferença pode estar associada ao tratamento doméstico (adição de cloro $\mathrm{Cl}$ ) utilizado pela maioria em detrimento da minoria, porém, essa ação não foi objeto desta pesquisa. Clasen et al. (2014), na Índia, efetuaram estudo sobre as doenças de veiculação hídrica, no município de Odisha, e concluíram que a ausência do saneamento básico está associada a uma série de doenças infecciosas, inclusive as estomacais como, por exemplo, a diarreia; tal doença apresenta a maior taxa de morbidade e mortalidade, com 1,4 milhões de mortes anuais. Na comunidade rural Sapucaia, os entrevistados confirmaram que a diarreia é a doença de maior frequência na comunidade rural, o que corrobora com o estudo efetuado na Índia.

A respeito da preservação/conservação das nascentes, os dados obtidos indicaram uma disposição a unanimidade quanto a esse tema, pois os $30(100 \%)$ indivíduos amostrados garantiram que a proteção das nascentes é essencial para que 
água mantenha os padrões necessários para o consumo. No sul de Salvador (BA), a pesquisa realizada por Souza et al. (2014), indicou que a água é prejudicada por impactos ambientais negativos das ações naturais e antrópicas, as quais modificam significativamente a qualidade e a quantidade de água disponível. Em Nova Timboteua, a comunidade rural conserva a mata ciliar no entorno dos corpos hídricos com a finalidade de garantir uma boa qualidade da água e diminuir os impactos ocasionados pelas ações antrópicas, o que se opõe à pesquisa realizada no sul de Salvador.

Para a influência das atividades agrícolas na qualidade da água, a análise dos dados obtidos indicou duas principais ações antrópicas: o desmatamento, 21 (34,43\%) e a utilização dos agroquímicos 21 (34,43\%). Além destas, 17 (27,87\%) dos 30 indivíduos amostrados, afirmaram que o adubo utilizado na agricultura familiar da comunidade pode influenciar na qualidade dos corpos hídricos; 1 (1,64\%) deles indicou a erosão do solo e, em contraposição a isso, 1 (1,64\%) evidenciou que as atividades agrícolas não possuem qualquer influência sobre a qualidade da água (Figura 6).

Figura 6 - Influência das atividades agrícolas na qualidade da água. Nova Timboteua - PA.
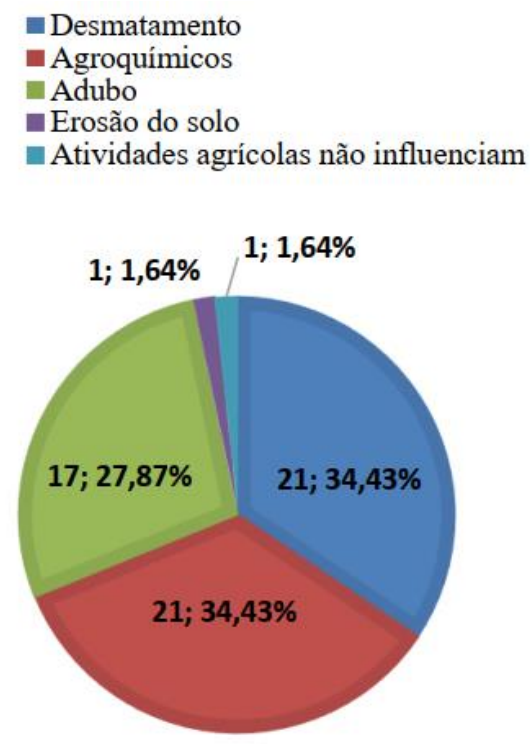

Fonte: Os autores.

Em Pelotas (RS), Coradi, Fia e Pereira-Ramirez (2009) realizaram estudo acerca dessas atividades antrópicas e concluíram que elas são os fatores de maior significância para a alteração da qualidade da água, sejam por intermédio da geração de efluentes domésticos ou pela utilização de defensivos agrícolas e o manejo inadequado do solo. 
Na pesquisa realizada em Nova Timboteua, a ação antrópica de maior influência observada na comunidade e que pode alterar a qualidade da água é a utilização de adubos para a agricultura familiar.

Inerente a administração dos recursos hídricos, houve predisposição à uniformidade nos dados obtidos, pois todos os indivíduos amostrados, ou seja, 30 (100\%), afirmaram que não há participação da administração municipal sobre os recursos hídricos, pois, o município não auxilia de forma direta e/ou indireta como, por exemplo, com atividades, projetos e orientações quanto ao uso dos recursos hídricos na comunidade sapucaia. Com isso, verificou-se que na comunidade, 17 (51,51\%) dos 30 indivíduos amostrados, garantiram que o município deve realizar o tratamento da água para o consumo na zona rural; $9(27,27 \%)$ ressaltaram que a melhor alternativa é a implantação do saneamento básico; 4 (12,12\%), indicaram a implantação da educação ambiental; 2 (6,06\%), a construção de poços tubulares, e 1 (3,03\%), o incentivo à pesquisa científica na localidade (Figura 7).

Figura 7 - Dados sobre a administração dos recursos hídricos. Nova Timboteua - PA.

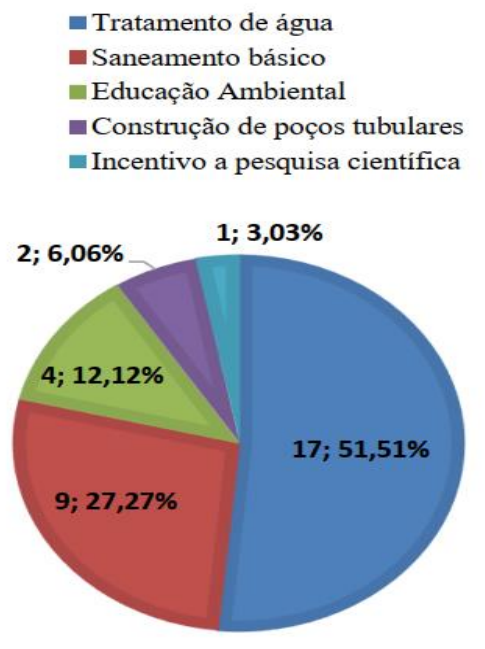

Fonte: Os autores.

Na pesquisa realizada por Leoneti, Prado e Oliveira (2012), no Rio de Janeiro (RJ), foi indicado que as políticas públicas relacionadas à melhoria nas condições do saneamento básico (Ex.: qualidade da água), são extremamente eficientes para diminuir a ocorrência de doenças de veiculação hídrica e contribui para a redução da mortalidade infantil no Brasil. Dessa maneira, corrobora com a necessidade da aplicação de políticas 
públicas no município de Nova Timboteua, em especial, na zona rural, além do incentivo à pesquisa científica, conforme descrito por um dos entrevistados.

No que diz respeito ao tratamento da água para consumo humano, após análise dos dados obtidos, verificou-se que 13 (43,33\%) indivíduos amostrados indicaram que os corpos hídricos precisam de tratamentoem razão das frequências de doenças de veiculação hídrica como, por exemplo, a diarreia, ocasionadas na zonarural, enquanto que, 17 (56,66\%) responderam que a água não necessita de nenhum tratamento por ser uma fonte natural, pois no conceito da maioria da comunidade rural, a água proveniente de fonte natural significa água de boa qualidade. (Figura 8).

Figura 8 - Dados sobre a necessidade de tratamento da água. Nova Timboteua - PA.

n Corpos hídricos precisam de tratamento

• Corpos hídricos não precisam de tratamento

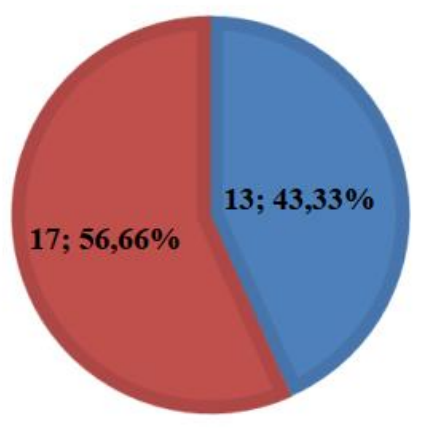

Fonte: Os autores.

Nesse contexto, Guedes et al. (2012) elaboraram um estudo no Rio Pomba (MG) e concluíram que os recursos naturais utilizados pelo homem, nas mais variadas atividades, como a agricultura, associada aos processos naturais de intemperismo, precipitação e erosão modificam significativamente a qualidade da água e podem tornála imprópria para o consumo. Essa qualidade também sofreu alterações em Nova Timboteua, devido à presença da comunidade rural humana, das construções de residências, ramais, o desmatamento, entre outros fatores antrópicos.

Sobre sugestões de melhoria da qualidade da água, os dados obtidos e analisados indicaram que $16(43,24 \%)$ indivíduos amostrados, afirmaram que a melhor ação para melhoria da qualidade da água seria a preservação da natureza, seguidos pela 
proteção das nascentes e a diminuição do desmatamento, com 9 (24,32\%) indivíduos amostrados para cada sugestão. Outras questões foram mencionadas, como a sensibilidade ambiental, o tratamento da água e o reflorestamento, individualmente foram sugeridas por 1 (um) entrevistado (2,7\%) cada sugestão (Figura 9).

Figura 9 - Sugestões para melhoria da qualidade da água. Nova Timboteua - PA.

\begin{tabular}{|c|c|}
\hline Preservação da natureza & Proteção das nascentes \\
\hline Diminuição do desmatamento & = Sensibilidade ambiental \\
\hline Tratamento da água & Reflorestamento \\
\hline
\end{tabular}

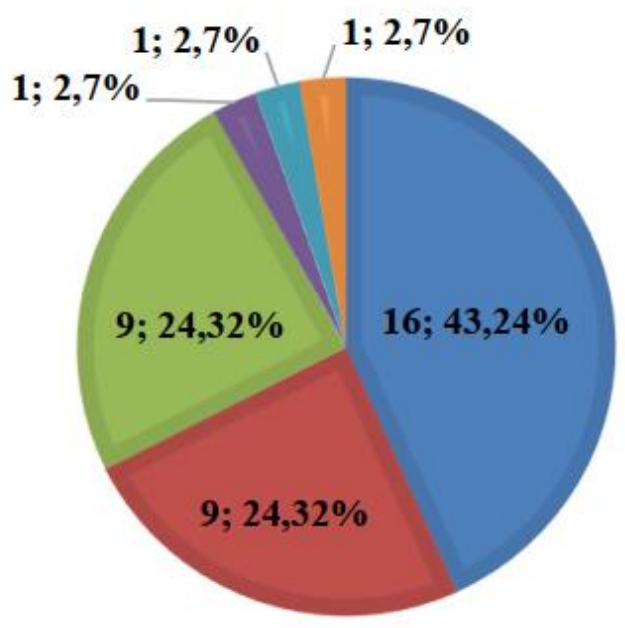

Fonte: Os autores.

Na pesquisa realizada por Pinto, Roma e Balieiro (2012), no município de Inconfidentes (MG), os dados indicaram que o desmatamento das matas ciliares colabora com a alteração da qualidade da água, seja por intermédio do assoreamento, do aumento da turbidez, bem como, a alteração no regime das cheias. Em Nova Timboteua, esses tipos de desflorestamentos também ocorrem, e podem afetar a qualidade da água da comunidade rural Sapucaia, fato que corrobora com a pesquisa realizada em Inconfidentes.

Quanto a presença de animais próximos as nascentes, a análise dos dados obtidos indicou que $23(76,66 \%)$ indivíduos amostrados, evidenciaram existir pouca ou nenhuma presença de animais (ruminantes e caninos) enquanto, $7(23,33 \%)$ ressaltaram uma grande frequência de animais próximos aos corpos hídricos. Tal diferença nas respostas pode ser justificada do seguinte modo: algumas famílias utilizam-se de 
cachorros para fazer a segurança das residências e outras possuem pequena quantidade de bovinos (Figura 10).

Figura 10 - Dados sobre a presença de animais nas proximidades das nascentes. Nova Timboteua - PA.

E Pouca ou nenhuma presença de animais $\quad$ Presença de animais

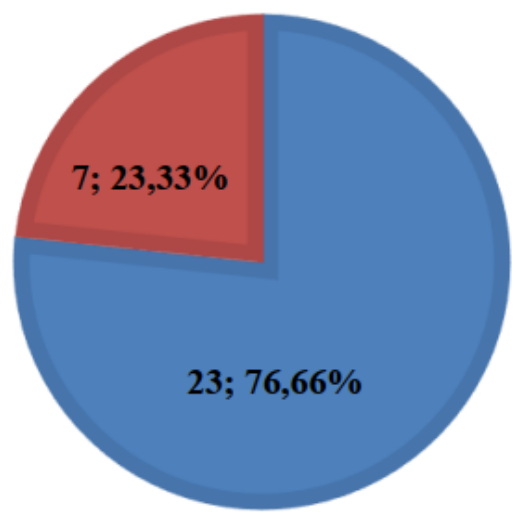

Fonte: Os autores.

Em Guaraí (TO), um estudo sobre a presença de animais em nascentes e corpos hídricos de Roberto et al. (2017) concluiu que os animais homeotérmicos (sangue quente), em conjunto com os seres humanos, são os maiores responsáveis pela propagação dos coliformes totais e termotolerantes, haja vista que, tais bactérias, são comumente encontradas na microbiota intestinal dos animais. Na pesquisa realizada em Nova Timboteua, os dados acerca dos coliformes fecais no mês de junho (Igarapé - 150 NMP e Nascente - 90 NMP) foram positivos, o que a torna similar àquela realizada em Guaraí - TO.

\subsection{FORMAS DE ACESSO E CAPTAÇÃO DA ÅGUA}

Em relação ao acesso e à captação da água na comunidade rural, 29 (96,6\%) das 30 famílias que são totalmente dependentes das nascentes para realizar qualquer tipo atividade que necessite do recurso hídrico como, por exemplo, o consumo humano, não dispõe de nenhum mecanismo tecnológico que auxilie na captação e/ou ao acesso à água. Por esse motivo, os moradores utilizam recipientes de volume conhecido (baldes e potes de cerâmica) para coletar e transportar água para reservatórios e residências. 
A situação revela a dimensão do déficit em que a zona rural se encontra no que tange o saneamento básico, sobretudo, o acesso à água potável. Dados contidos na Pesquisa Nacional por Amostra de Domicílios (PNAD) realizada em 2015 pelo IBGE, concluíram que das aproximadamente 31 milhões de pessoas residentes em zonas rurais, cerca de 24 milhões não possuíam acesso a água potável encanada. Na pesquisa realizada na zona rural do município de Nova Timboteua, os dados obtidos refletiram o cenário da calamidade em que se encontra a zona rural do Brasil no que diz respeito ao saneamento básico, pois maciça maioria das famílias não dispõe de água advinda de um sistema de abastecimento ou soluções alternativas (Ex.: poços tubulares).

Em contraste as 29 famílias com acesso à água de forma primitiva, o Sítio Jonas é o único na comunidade a utilizar um motobomba de 40HP de potência interligado a um sistema de encanação adaptado, que transporta a água do igarapé para reservatórios da residência e para irrigação da horticultura. Em estudo realizado por Rockstrom et al. (2009) em Londres, indicou que o avanço da tecnologia e o uso de ferramentas atreladas (Ex.: motobomba), minimizou em grande escala as insuficiências e inseguranças da humanidade, em especial, o acesso facilitado a água no campo. No Sítio Jonas, o emprego da tecnologia de motobomba, proporciona aos moradores uma significativa comodidade no processo de captação da água, considerando que em aproximadamente 20 minutos são preenchidos 1800 Litros correspondentes aos dois reservatórios existentes na residência; sendo também indispensável para o cultivo de horticultura da propriedade.

\subsection{QUANTO AO RELEVO}

Em relação ao relevo da propriedade rural em que as nascentes se encontram, os dados obtidos indicaram que, para o sitio Jonas, o intervalo de maior valor $(51,76 \mathrm{~m})$ concentra-se na extremidade norte, enquanto que o intervalo de menor valor $(34,07 \mathrm{~m})$, está localizado no limite sul da propriedade (Figura 11a), eles também indicaram que a área onde as nascentes se alocam (extremidade sul a direita do terreno), apresentam as menores elevações, bem como o menor grau de declividade (Figura 11b). 
Figura 11 - a) Modelo Digital de Elevação (MDE) do terreno; b) Mapa de declividade do terreno. Sítio Jonas. Nova Timboteua - PA.

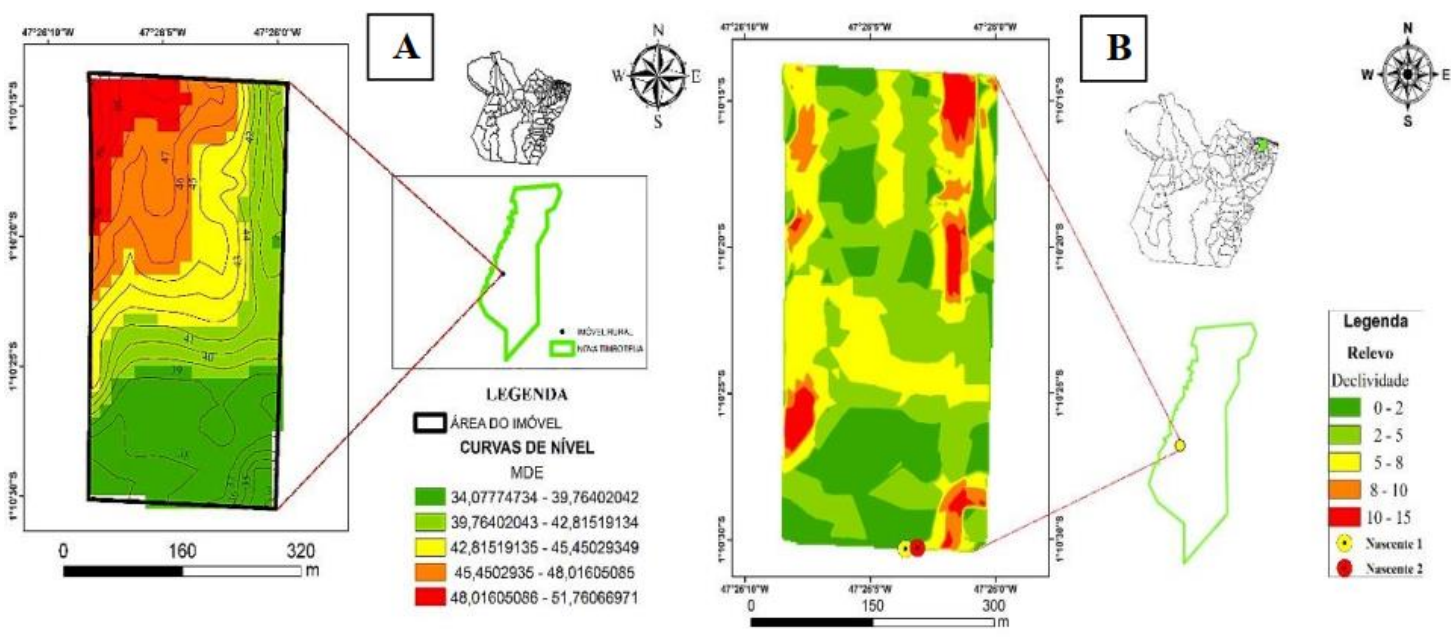

Fonte: Os autores.

Consoante ao exposto, Santos e Hernandez (2013), com a pesquisa realizada em Ilha Solteira (SP), constatou que a ausência de uma correta utilização de técnicas de manejo do solo, sobretudo, em Áreas de Preservação Permanente (APP), como em caso de nascentes, pode acarretar processos erosivos e o assoreamento de corpos hídricos, principalmente em terrenos que apresentam irregularidades no relevo. Nesse cenário, a característica da elevação da propriedade rural analisada é favorável a ocorrência de erosões e assoreamentos, haja vista que as elevações variam abruptamente de uma extremidade a outra do terreno, fator que pode comprometer a qualidade da água consumida pela comunidade, devido à presença de substâncias no solo com potencial de contaminação, principalmente defensivos agrícolas.

\subsection{USO E OCUPAÇÃO DO SOLO}

Os dados obtidos mostraram que as $30(100 \%)$ famílias utilizam o solo para cultivos diversos em nível da agricultura familiar, em que praticam fruticultura (Ex.: maracujá - Passiflora spp.); mandiocultura (Manihot esculenta Crantz), horticultura (Ex.: cheiro verde - Petroselinum crispum) e, em menor escala, a piscicultura (Ex.: tambaqui - Colossoma macropomum Cuvier). No sítio Jonas, há prática intensiva da horticultura, que é desenvolvida durante todo ano, mas, durante o período seco os cultivos são implantados, como forma de estratégia, nas proximidades das nascentes, o que facilita o acesso à água para irrigação. 
A análise dos dados também evidenciou que a distância entre o igarapé e a horticultura equivale a 55 metros e, em relação a nascente, dista 40 metros. Por isso, o perímetro existente entre a nascente e a área cultivada infringe a Lei n. 12.651:2012 que institui o Novo Código Florestal, no artigo 4으, inciso IV: delimita como Área de Proteção Permanente (APP), um raio de no mínimo 50 metros no entorno de nascentes e olhos d'água. Na área da pesquisa realizada em Nova Timboteua, a nascente encontra-se parcialmente protegido, com um reservatório plástico de PVC, com tampa, colocado pela comunidade.

No município de Juiz de Fora (MG), uma pesquisa realizada por Bucci e Oliveira (2014), a análise dos dados por eles obtidos, indicou que os mananciais e cursos d'água do Brasil apresentaram crescente poluição e/ou contaminação no que diz respeito à qualidade das águas, em decorrência do incorreto lançamento de efluentes, sejam eles domésticos ou industriais, bem como da utilização de agroquímicos em áreas de cultivo, sobretudo, do uso e ocupação do solo de maneira indevida e exacerbada. Em Nova Timboteua, pode-se perceber que, na ausência de um monitoramento e controle do uso do solo, principalmente por atividades agrícolas, nas proximidades das nascentes do Sítio Jonas, o risco de a qualidade das águas ser comprometida é significativamente alto, pois há existência do cultivo de horticultura.

\subsection{AVALIAÇÃO do INDICE dE QUALIDADE DA ÅGUA (IQA - CETESB) - PERIODO CHUVOSO}

Quanto ao IQA das duas nascentes e do reservatório, os dados obtidos indicaram que, no primeiro trimestre da pesquisa, a qualidade da água foi classificada de três formas em função dos valores alcançados: maio (Figura 12a), os conceitos variaram entre "bom (77) e ótimo (83)"; junho (Figura 12b), concentrou-se em "bom (63 a 76) e julho (Figura 12c) os valores alternaram-se entre "aceitável (39) e ótimo (92). Vale ressaltar que o recorte temporal analisado faz parte do período chuvoso da região nordeste do estado do Pará, na qual se localiza os pontos analisados, na zona rural do município de Nova Timboteua. 
Figura 12 - IQA para os meses de: a) maio; b) junho; c) ju Iho. Sítio Jonas. Nova Timboteua -PA.

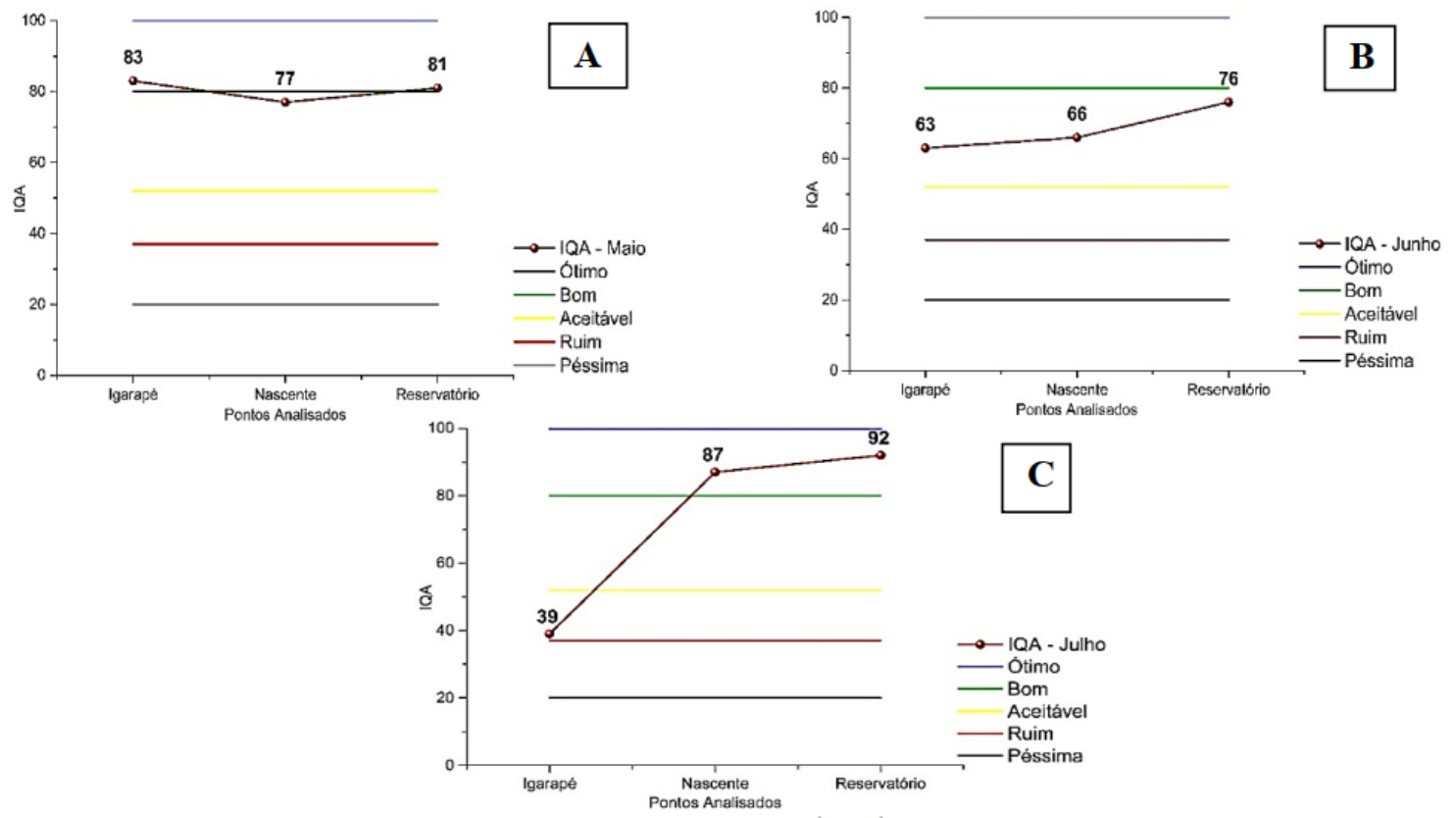

Fonte: Os autores.

Bisognin et al. (2017) realizaram estudo no município de Três Passos (RS), e concluíram que a qualidade da água no meio rural pode ser influenciada diretamente pela presença de atividades agropecuárias, em especial a agricultura familiar, bem como a criação de bovinos e suínos nas proximidades das nascentes. Na pesquisa realizada em Nova Timboteua, o sítio Jonas, assim como a maioria das propriedades rurais da comunidade Sapucaia, desenvolve de forma preponderante, a agricultura familiar, logo, a qualidade da água dos corpos hídricos analisados, estar suscetível à contaminação por essas atividades, fator que corrobora com a pesquisa realizada em Três Passos (RS).

Ainda mais, os dados também evidenciaram que no mês de junho, os conceitos do IQA (CETESB), foram identificados como "bom" em todas as amostras analisadas em laboratório, contudo, houve a ocorrência de coliformes totais e termotolerantes (fecais) nos pontos 1 (500 NMP/100mL e $150 \mathrm{NMP} / 100 \mathrm{~mL})$ e 2 (300 NMP/100mL e 90 $\mathrm{NMP} / 100 \mathrm{~mL}$ ), correspondentes ao igarapé e a nascente, respectivamente.

Não obstante, no mês de maio não foi acusado a presença de coliformes em nenhuma das amostras, por esse motivo realizou-se uma investigação junto à comunidade e aos proprietários do imóvel rural, com intuito de ter conhecimento acerca 
de eventualidades que possam ter interferido na qualidade da água via coliformes. Como consequência da apuração, os proprietários do Sítio Jonas relataram um evento de instalação estrutural ocorrente no último dia (31) de maio (Figura 13a) com finalidade de estocar adubo biológico (Figura 13b) de origem bovina e avícola nas proximidades do cultivo de horticultura, bem como das nascentes.

Figura 13 - Utilização de adubo biológico a) estrutura para armazenamento de adubo; b) adubo de origem bovina e avícola. Sítio Jonas. Nova Timboteua - PA.

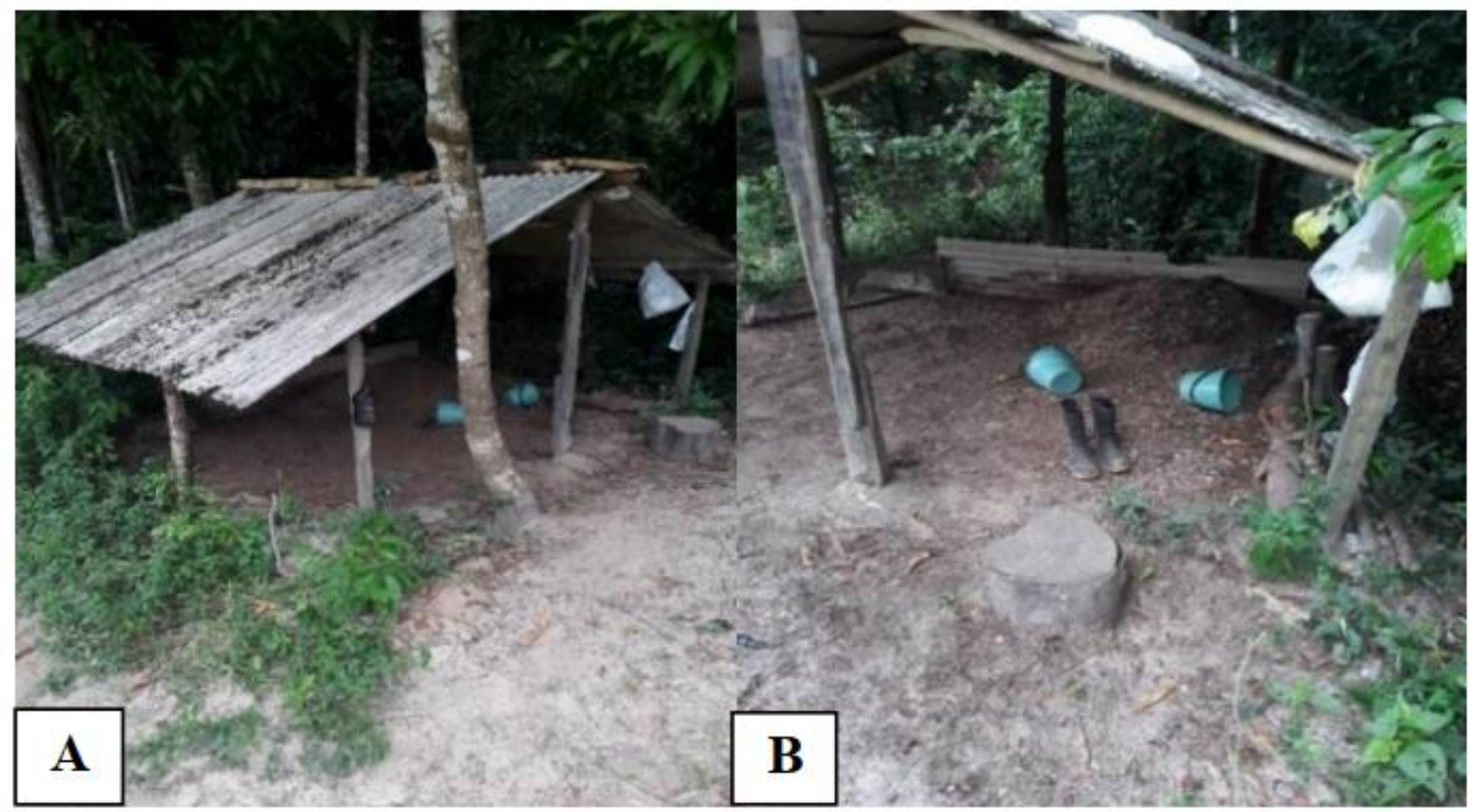

Fonte: Os autores.

Seguindo orientação e acatando o alerta feito pelos pesquisadores a respeito dos riscos à saúde humana ocasionada pela contaminação da água por coliformes termotolerantes, os moradores removeram a estrutura estocadora juntamente com o adubo, fator que influenciou diretamente nos dados obtidos no terceiro mês de campanha (julho) da pesquisa, que mesmo indicando um conceito de qualidade da água como "aceitável", foi verificado a ausência de coliformes termotolerantes em todas as amostras, porém, a amostra do ponto 1 apresentou coliformes totais (400 NMP/100mL).

Nesse sentido, a Política Nacional de Educação Ambiental (PNEA), Lei $\mathrm{n}$. 9.795:1999, cap. I, e art. 1ํ, define educação ambiental como "qualquer construção e disseminação de conhecimento, habilidades, atitudes e competências direcionadas à 
conservação do meio ambiente, garantindo a sadia qualidade de vida e sustentabilidade das comunidades". Em face dessa definição, houve a orientação para que a comunidade procedesse a remoção da fonte de estocagem de adubo da propriedade rural com objetivo de garantir, nas nascentes, a qualidade da água por ela utilizada, e isso corrobora com os princípios da Lei 9.975:1999.

\subsection{QuALIdAdE DA ÁGUA (IQA - CETESB) NO PERIOdO SECO}

Em relação ao IQA das nascentes e do reservatório no segundo e último trimestre da pesquisa, correspondente ao início do período seco da região onde a pesquisa realizou-se, a qualidade da água assinalou: no mês de agosto (Figura 14a) o IQA esteve concentrado como "ótimo (86 a 94)"; em setembro (Figura 14b), centralizou-se entre "bom (75) e ótimo (81)"; e, por final, o mês de outubro apresentou um IQA em que os valores estiveram entre "bom (77) e ótimo (85)" (Figura 14c).

Figura 14 - IQA no mês de: a) agosto; b) setembro; c) outubro. Sítio Jonas. Nova Timboteua - PA.
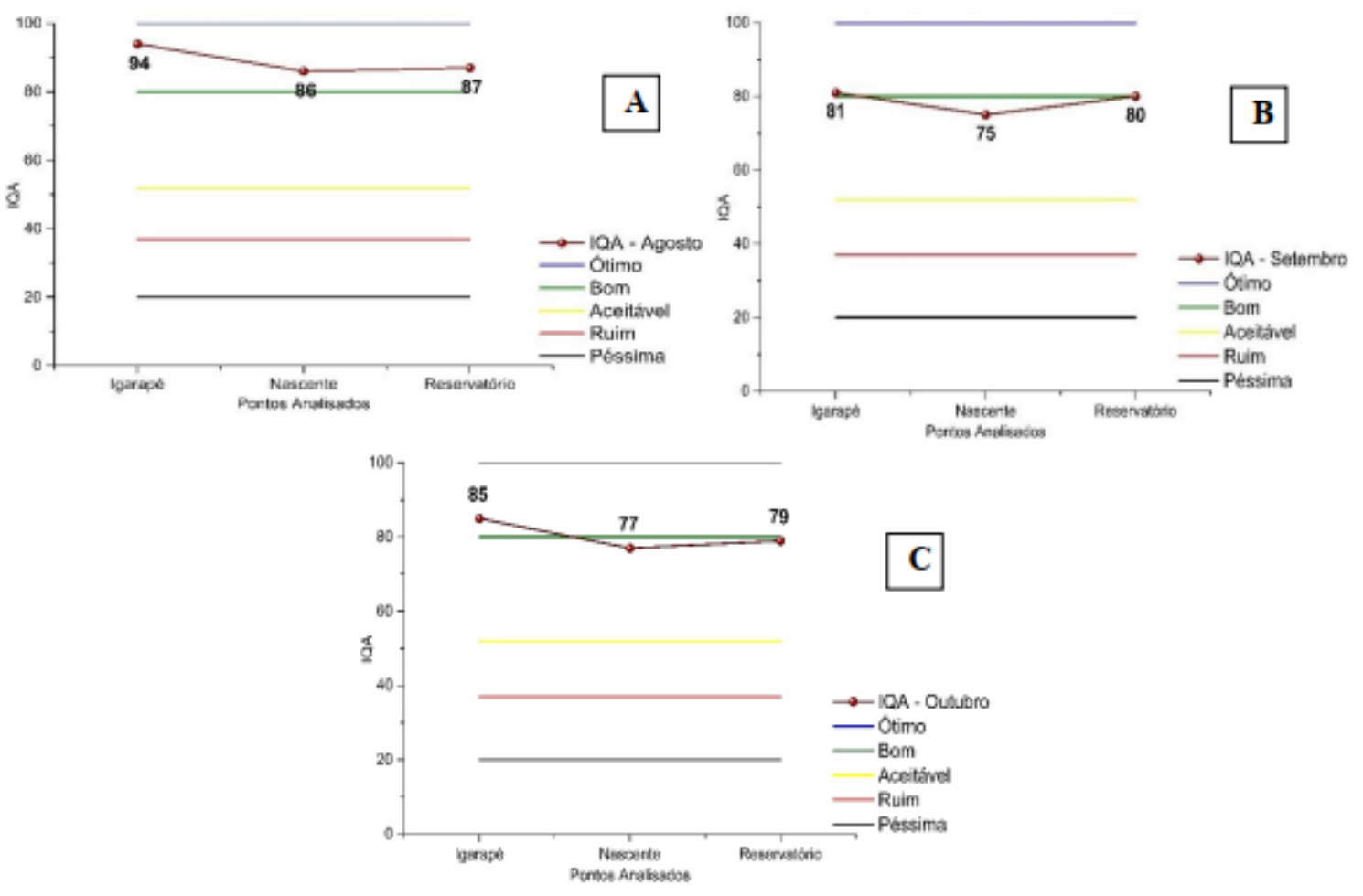

Fonte: Os autores.

Pereira et al. (2016) efetuaram estudo sobre a qualidade da água em Peixe - Boi (PA), e constataram que a qualidade da água de corpos hídricos está diretamente 
relacionada à preservação da mata nativa, principalmente, vegetação majoritariamente arbórea, pelo fato da baixa incidência de escoamento superficial e da maior cobertura do solo. Na pesquisa realizada no sítio Jonas, em Nova Timboteua, foi verificado que as nascentes estão sob uma cobertura vegetal em grande parte densa e nativa e na ausência de substâncias alóctones, como insumos agrícolas no solo, que acarretam contaminação do recurso hídrico, a qualidade água permanece entre os conceitos de "bom e ótimo", fator que corrobora com a pesquisa realizada em Peixe - Boi.

\section{CONCLUSÃo}

$\mathrm{Na}$ comunidade rural Sapucaia foi possível perceber que as nascentes desempenham papel social e econômico insubstituível na vida de cada morador, sendo primordial tanto para o consumo quanto para o desenvolvimento de atividades agrícolas. Além do mais, a água proveniente delas, também, é a única fonte de recurso hídrico que a comunidade possui, por isso ressalta-se a magnitude da importância exercida por elas à cada produtor.

Nesse cenário, o IQA mostrou-se como uma ferramenta útil no ato de informação da qualidade da água das nascentes e do reservatório da comunidade rural Sapucaia, apesar de em algumas situações, superestimar o nível de qualidade da água, por tratar-se de conclusões qualitativas. Todavia, para o público não técnico, o IQA exerce função importante para o conhecimento acerca da qualidade do recurso, pois não necessita, em primeiro momento, de análises específicas.

Por esses motivos, ao conhecer a realidade da comunidade rural estudada, recomenda-se que o poder público atue de forma efetiva, proporcione ao cidadão do meio rural condições de garantia à qualidade de vida, desenvolvimento social e econômico, através do uso sustentável dos recursos naturais, principalmente os hídricos.

\section{REFERÊNCIAS}

ABNT. ASSOCIAÇÃO BRASILEIRA DE NORMAS TÉCNICAS. NBR 9897: Planejamento de amostragem de efluente líquidos e corpos receptores. 20 ed. Rio de Janeiro, 1987. $14 \mathrm{p}$. 
ABNT. ASSOCIAÇÃO BRASILEIRA DE NORMAS TÉCNICAS. NBR 9898: Técnicas de preservação de amostragem de efluentes líquidos e corpos receptores.

ANA. Agência Nacional das Águas. Guia nacional de coleta e preservação de amostras: água, sedimento, comunidades aquáticas e efluentes líquidas/ Companhia Ambiental do Estado de São Paulo; Organizadores: Carlos Jesus Brandão et al. São Paulo: CETESB; Brasília, 2011.

ANA. Agência Nacional das Águas. Indicadores de Qualidade: Índice de Qualidade das Águas (IQA). 2018. http://portalpnqa.ana.gov.br/indicadores-indice-aguas.aspx.

BAIRD, R. B. Standard Methods for The Examination of Water and Wastewater. 23. ed. : Pharmabooks, 2017.

BISOGNIN, R. P. et al. Análise e divulgação da qualidade da água de nascentes, afluentes e ponto de captação do Arroio Lajeado Erval Novo no município de Três Passos - RS. Revista Gestão \& Sustentabilidade Ambiental, Florianópolis, v. 6, n. 2, p.4455, ago. 2017.

BORGES, N. R. M. B.; PEREIRA, V. T. Manual de metodologia científica do ILES. Itumbiara - GO. Itumbiara: ILES/ULBRA, 2014.

BRASIL. Congresso. Senado. Constituição (1999). Lei no 9.975, de 27 de maio de 1999. Dispõe Sobre a Educação Ambiental, Institui a Política Nacional de Educação Ambiental e dá outras Providências. Brasília. http://www.planalto.gov.br/ccivil_03/LEIS/L9795.htm.

BRASIL. Congresso. Senado. Constituição (2012). Lei no 12.651, de 25 de maio de 2012. Dispõe Sobre a Proteção da Vegetação Nativa; Altera As Leis 6.938, de 31 de agosto de 1981, 9.393, de 19 de dezembro de 1965, e 7.754, de 14 de abril de 1989, e A Medida Provisória no 2.166-67, de 24 de agosto de 2001; e Dá Outras Providências. Brasília.

http://www.planalto.gov.br/ccivil_03/_Ato20112014/2012/Lei/L12651.htm.

BRASIL. Congresso. Senado. Constituição (2016). Resolução no 510, de 07 de abril de 2016. O Plenário do Conselho Nacional de Saúde em Sua Quinquagésima Nona Reunião Extraordinária, Realizada nos Dias 06 e 07 de Abril de 2016, no Uso de Suas Competências Regimentais e Atribuições Conferidas Pela Lei N O 8.080, de 19 de Setembro de 1990, Pela Lei № 8.142, de 28 de Dezembro de 1990, Pelo Decreto no 5.839, de 11 de Julho de.2006. Brasília. http://bvsms.saude.gov.br/bvs/saudelegis/cns/2016/res0510_07_04_2016. htmL.

BUCCI, M. H. S.; OLIVEIRA, L. F. C. Índices de qualidade da água e de estado trófico na represa Dr. João Penido (Juiz de Fora, MG). Revista Ambiente e Água, Taubaté, v.9, n.1, jan./mar. 2014. 
BUZELLI, G. M.; CUNHA-SANTINO, M. B. Análise e diagnóstico da qualidade da água e estado trófico do reservatório de Barra Bonita - SP. Revista Ambiente e Água, Taubaté, v.8, n.1, p.186-205, jan. 2013.

CLASEN, T. et al. Effectiveness of rural sanitation programa on diarrhoea, soiltransmitted helminth infection, and child malnutrition in Odisha, India: a clusterrandomised trial. Lancet Glob Health, v.2, n.1, p.645-653, out. 2014.

CORADI, P. C.; FIA, R.; PEREIRA-RAMIREZ. O Avaliação da qualidade da água superficial dos cursos de água do município de Pelotas-RS, Brasil. Revista Ambiente e Água, Taubaté, v.4, n.2, p. 46-56, jan. 2009.

FALAVINHA, G.; DEGENHARDT, R. Qualidade microbiológica da água de nascentes e poços da Comunidade de Barro Branco, Capinzal, SC. Unoesc \& Ciência - ACBS, Joaçaba, v. 5, n. 2, p.209-216, jul./dez. 2014.

FRINHANI, E. M. D.; CARVALHO, E. F. Monitoramento da qualidade das águas do Rio do Tigre, Joaçaba, SC. Unoesc \& Ciência - ACET, Joaçaba, v.1, n.1, p.49-58, jan./jun. 2010.

FUNCEME. Fundação Cearense de Metereologia, 2015QUALIGRAF.Version.1.17. http://www3.funceme.br/qualigraf/mi/midia/show/3.

GUEDES, H. A. S. et al. Aplicação da análise estatística multivariada no estudo da qualidade de água do Rio Pomba, MG. Revista Brasileira de Engenharia Agrícola e Ambiental, v.16, n.5, p.558-563, fev. 2012.

IBGE. Instituto Brasileiro de Geografia e estatística -. Pesquisa Nacional por Amostra de $\begin{array}{llll}\text { Domicílios. Rio je } 105 . & \end{array}$ https://biblioteca.ibge.gov.br/visualizacao/livros/liv98887.pdf.

Acesso em: 03 fev. 2018.

IBGE. Instituto Brasileiro de Geografia e Estatística -. Panorama do município de Nova Timboteua - Pará. 2017. cidades.ibge.gov.br/brasil/pa/novatimboteua/panorama.

LARSON, R.; FARBER, B. Estatística Aplicada; tradução Luciane Ferreira Paulleti Vianna 4. ed., São Paulo: Pearson Prentice Hall, 2010.

LEONETI, A. B.; PRADO, E. L.; OLIVEIRA, S. V. W. B. Saneamento básico no Brasil: considerações sobre investimentos e sustentabilidade para o século XXI. Revista de Administração Pública, v.45, n.2, p.331-348, mar./abr. 2012.

MACEDO, J. J.; SCHUNTZEMBERGER, A. M. S. Saneamento básico e ampliações das liberdades substantivas. Revista Economia e Desenvolvimento. Santa Maria, v. 27, n. 2, p.297-307, jul./dez. 2015. 
MICROSOFT Office 2016: Microsoft Excel. Version 2016. Microsoft Corporation, 2016. MILAN, L. A. Estatística Aplicada. São Carlos: UAB-UFSCAR, 2011.

ORIGINLAB. Graphing \& Analysis. Version 8.0. Origin Lab, 2016.

PEREIRA, B. W. F.et al. Uso da terra e degradação na qualidade da água na bacia hidrográfica do rio Peixe- Boi, PA, Brasil. Rev. Ambient. Água, Taubaté, v.11, n.2, p.472-485, abr.-jun. 2016.

PINTO, C. M. A.; ARAÚJO, N. A.; SILVA JÚNIOR, D. Diagnóstico Preliminar do Saneamento Rural na Comunidade de Engenho Velho no Município de João Pessoa/PB. Revista Ambiental, João Pessoa, v. 1, n. 1, p.26-36, jan. /mar. 2015.

PINTO, L. V. A.; ROMA, T. N.; BALIEIRO, K. R. C. Avaliação qualitativa da água de nascentes com diferentes usos do solo em seu entorno. Cerne, Lavras, v. 18, n. 3, p.495-505, jul./set. 2012.

PIRATOBA, A. R. A. et al. Caracterização de parâmetros de qualidade da água na área portuária de Barcarena, PA, Brasil. Revista Ambiente e Água, Taubaté, v.12, n.3, p.435-456, mai./jun. 2017.

ROBERTO, M. C et al. Avaliação do pH, turbidez e análise microbiológica da água do córrego Guará Velho em Guaraí, Estado de Tocantins. Revista Desafios, v.04, n.04, p.03-11, out. 2017.

ROCKSTROM, J. et al. A safe operating space for humanity. Nature. London, GB, n.461, p.472-475, Jan. 2009.

RODRIGUES, T. E et al. Caracterização e classificação dos solos do município de PeixeBoi, Estado do Pará. Belém: Embrapa Amazônia Oriental, 2009.

RODRIGUES, M. L. A percepção ambiental como instrumento de apoio na gestão e na formulação de políticas públicas ambientais. Revista Saúde e Sociedade, São Paulo, v.21, n.3, p.96-110, 2012.

SAKAMOTO, C. K; SILVEIRA, I. O. Como fazer projetos de iniciação científica. São Paulo: Paulus, 2014.

SANTOS, G. O.; HERNANDEZ, F. B. T. Uso do solo e monitoramento dos recursos hídricos no córrego do Ipê, Ilha Solteira, SP. Revista Brasileira de Engenharia Agrícola Ambiental, Campina Grande, v. 17, n. 1, p.60-68, out. /dez. 2013.

SOUZA, J. R. A et al. A importância da qualidade da água e os seus múltiplos usos: Caso rio Almada, sul da Bahia, Brasil. Revista eletrônica do Prodema, Fortaleza, v.8, n.1, p.26-45, abr. 2014.

VANZELA, L. S.; HERNANDEZ, F. B.; FRANCO, R. A. M. Influência do uso e ocupação do solo nos recursos hídricos do córrego Três Barras, Marinópolis. Revista Brasileira 
de Engenharia Agrícola e Ambiental, Campina Grande, v.14, n.1, p.55-64, jun. 2010. 


\title{
CAPITULO XXXII
}

\section{ABORDAGEM MULTIDISCIPUNAR DAS CARACTERIISTICAS DA ÁGUA DO RIO IGARASSU (PE, BRASIL)}

\section{DOI: 10.51859/amplla.mas481.1121-32}

\author{
Eduardo da Silva França ${ }^{1}$ \\ Jaqueline dos Santos Marinho ${ }^{2}$ \\ Uiara Maria de Barros Lira Lins ${ }^{3}$ \\ Ilka Djanira Ferreira do Nascimento ${ }^{4}$ \\ Marcos Antônio Barbosa de Lima $^{5}$ \\ Rosileide Fontenele da Silva Andrade ${ }^{6}$ \\ Galba Maria de Campos Takaki ${ }^{7}$
}

\begin{abstract}
1,2,3,4 Mestrado em Desenvolvimento de Processos Ambientais. Universidade Católica de Pernambuco - UNICAP ${ }^{5}$ Doutor em Biologia de Fungos. Professor da Universidade Federal Rural de Pernambuco- UFRPE

${ }^{6}$ Pós-doutora em Ciências Biológicas. Professora Assistente da Universidade Católica de Pernambuco - UNICAP

7 Pós-doutora em Microbiologia e Imunologia. Professora Titular da Universidade Católica de Pernambuco- UNICAP
\end{abstract}

\section{RESUMO}

A água é o recurso fundamental para conservação da vida, responsável pelo equilíbrio dos ecossistemas através da manutenção dos ciclos biológicos, geológicos e químicos. É um insumo indispensável para agricultura, recurso estratégico para o desenvolvimento socioeconômico, fonte para micro-organismos com potencial biotecnológico e ameaçada pela presença de patógenos, devido ao lançamento de rejeitos industriais e de origem doméstica. Os efluentes da indústria de papel, têm como principais contaminantes a celulose e subprodutos. A celulose é um polissacarídeo estrutural dos tecidos vegetais, principal fonte de energia que mais se acumula no planeta, sob diferentes formas: tecidos mortos ou resíduos agroindustriais. O processo de degradação microbiana da celulose possui grande importância industrial. A decomposição dessa matéria orgânica envolve conhecimento sobre o potencial tecnológico microbiano, além de induzir a produção de enzimas hidrolíticas, também utilizam os produtos dessa reação.Neste trabalho foram investigados: aspectos físicoquímicos, isolamento e bioprospecção da produção de celulase por fungos filamentosos presentes na superfície da água do Rio Igarassu/PE. Quatro fungos filamentosos foram isolados da água coletada do rio Igarassu e identificados a nível de gênero, sendo duas amostras Aspergillus spp., uma Rhizopus spp. e outra de fungo da ordem Mucorales spp. As quatro amostras foram avaliadas quanto à produção de celulase, considerando o local de coleta, avaliando também a detecção de novas enzimas. Dentre os fungos filamentosos isolados, o da amostra identificada como Aspergillus spp., demonstrou elevado potencial celulolítico com Índice Enzimático (IE) de 1,28, sugerindo estudos aprofundados no processo de otimização da produção.

Palavras-chave: Água. Enzima. Bioprospecção. Degradação de celulose. 


\section{INTRODUÇÃO}

A água é um bem, um recurso natural efetivo à vida e a manutenção e desenvolvimento socioeconômico da humanidade. Considerada uma reserva mineral "baixo custo e inesgotável" pertence a todos, independente da condição socioeconômica, devendo atender a todas as necessidades humanas fisiológicas, econômicas e domésticas com quantidade, continuidade, cobertura e custo. (MATOS; DA SILVA, 2002; FRACALANZA, 2015; DE CARVALHO SIQUEIRA, 2019;BASSO, 2020).

No entanto, o acesso a esse recurso vem sendo escasso por diversas ações antrópicas, logo estas interferem na disponibilidade de água, contribuindo com a poluição dos recursos hídricos, o desmatamento de matas ciliares, até mesmo o desvio de rios e córregos para fins particulares (DA COSTA 2020; OLIVEIRA et al., 2015).

As enzimas estão presentes em todas as células vivas, logo são consideradas como catalisadores biológicos em processos industriais devido ao seu elevado grau de especificidade, seletividade e desempenho. O mercado global de enzimas industriais está estimado em US\$ 7,0 bilhões até 2023, contudo, são componentes onerosos e isso estimula a bioprospecção de espécies microbianas produtoras de enzimas, além de estratégias de cultivo e produção para a obtenção de novas enzimas com características específicas variadas e que possam ser produzidas a baixo custo (SILVA et al., 2018; MORAIS, 2020; ARAÚJO et al.,2021).

Celulases constituem um complexo enzimático capaz de atuar sobre materiais celulósicos, promovendo sua total hidrólise. Estas enzimas são catalisadores altamente seletivos e específicos, que atuam em sinergia para a liberação de açúcares, dos quais glicose é o que desperta maior interesse industrial, devido à possibilidade de sua conversão em vários produtos de interesse industrial, destacando-se atualmente, a produção de biocombustíveis (LYND et al., 2002; TOLAN, 2002; TUSHAR , DUTTA, 2020).

Neste sentido, destaca-se que as celulases, amplamente empregadas em outros setores industriais como alimentos, têxtil, farmacêutico, bebidas, cosméticos, dentre outras, (VALVÁZQUEZ, 2020). Portanto, o presente trabalho apresenta os aspectos físico-químicos, isolamento e bioprospecção de celulase produzida por fungos filamentosos da água superficial do Rio Igarassu/PE. 


\section{MATERIAIS E MÉTODOS}

\subsection{CARACTERISTICAS DO LOCAL DA AMOSTRAGEM}

O rio Igarassu com $10 \mathrm{~km}$ de extensão fica localizado na região norte do estado de Pernambuco, nascendo a sudoeste da cidade homônima e recebe, a cerca de 2,5 km da nascente, o rio Monjope, seu principal afluente pela margem direita. O rio Monjope é formado pela junção dos rios Utinga e Bonança a qual se dá dois quilômetros antes da confluência desse rio com o Igarassu. Observa-se que, a parte relacionada ao cruzamento com o perímetro urbano, onde o Igarassu sofre degradação devido ao lançamento de resíduos de industriais, principalmente relacionados às indústrias têxtil, metalúrgica, alimentícia, química, sucro-alcooleira, de bebidas e de essências, além de origem doméstica. Portanto, a entrada desses efluentes industriais caracterizam o comprometimento com a qualidade da água, além de elevados valores de $\mathrm{pH}$ no período chuvoso (CPRH 2003; 2004). Portanto, neste local destaca-se o ponto de coleta como apresentado na Figura 1-A continuidade do rio, vegetação nas margens juntamente com montante de areia e alta turbidez; na Fig. 1-B é o ponto da coleta, observa-se vegetação nas margens e uma quantidade substancial de matéria orgânica em decomposição e suspensa na superfície do córrego e na Fig. 1-C está situada em uma área contaminada em uma comunidade sem saneamento, cercada por vegetação, a qual a água é usada para vários fins.

Figura 1 - Imagens da área selecionada para coleta da água superficial do rio Igarassu/Pernambuco
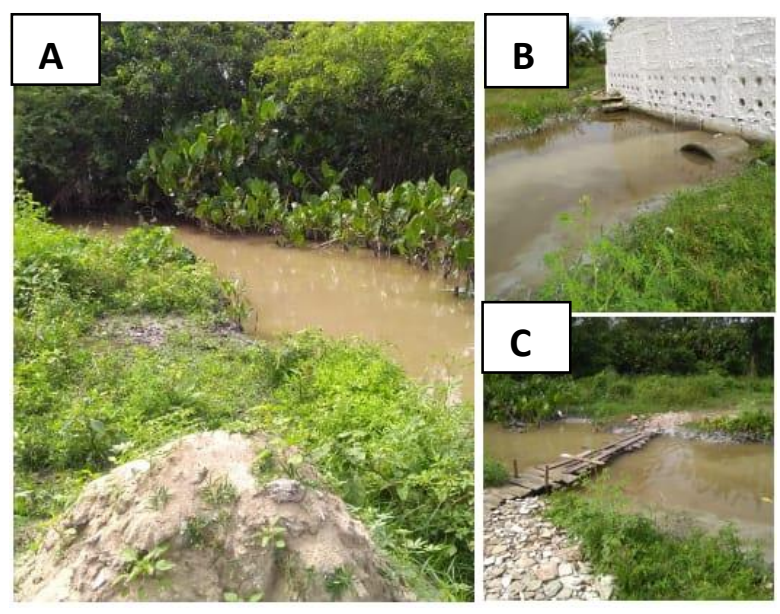

Fonte: Autoria própria. 
As coletas das amostras foram realizadas no Município de Igarassu/PE, na superfície do rio Igarassu/PE, Brasil, no local com as seguintes coordenadas $7^{0} 49^{\prime}$ $53.425^{\prime \prime} \mathrm{S} 34^{0} 54^{\prime} 53.626^{\prime \prime} \mathrm{W}$, em 30.10 .2019 , às $08: 00 \mathrm{~h}$, temperatura de $27^{\circ} \mathrm{C}$, umidade relativa de $75 \%$, vento de $14 \mathrm{~km} / \mathrm{h}$ e pluviosidade de $0 \mathrm{~mm}$. Foram feitas coletas de água superficial no trecho situado no km 41,7 da BR 101/PE. Nesse trecho o Rio Igarassu cruza o perímetro urbano, o qual sofre interferência através do lançamento de resíduos de origens industriais e doméstica.

\subsection{COLETA DAS AMOSTRAS}

As amostras de água destinadas aos estudos foram coletadas de acordo com a metodologia descrita por Parron et al (2011). Foram coletados $1,5 \mathrm{~L}$ da água superficial, utilizando 3 frascos coletores de plástico Polipropileno estéril de $500 \mathrm{~mL}$. A coleta foi realizada com a remoção da tampa, seguido de inversão da base inferior com a boca para baixo, mantendo nessa posição, realizando o mergulho do frasco na profundidade de $15 \mathrm{~cm}$. Com o frasco submerso, virou-se para horizontal no sentido contrário a correnteza. Depois da coleta os fracos foram vedados, secos e identificados e acondicionados em caixa isotérmica, mantendo-se na temperatura $4^{\circ} \mathrm{C}$. Em seguida, foi transportada ao Laboratório do Núcleo de Pesquisas em Ciências Ambientais e Biotecnologia - NPCIAMB da Universidade Católica de Pernambuco, onde imediatamente realizadas as análises físico-químicas e microbiológicas e posteriormente, o material coletado foi armazenado a uma temperatura de $4^{\circ} \mathrm{C}$.

\subsection{ANÁLISE DOS PARÂMETROS FISICO-QUIMICOS:}

\subsubsection{DETERMINAÇÃO DO PHE TEMPERATURA:}

$\mathrm{O} \mathrm{pH}$ e a temperatura da amostra de água foram determinados utilizando um pHmetro modelo (TECNAL - TEC - 7).

\subsubsection{DETERMINAÇÃO DA TURBIDEZ}

A turbidez da amostra de água foi determinada utilizando um turbidimetro modelo (ALFAKIT). 


\subsubsection{DETERMINAÇÃO DA CONDUTIVIDADE ELÉTRICA}

A condutividade elétrica da amostra de água foi determinada utilizando um condutivimetro modelo (mCA 150).

\subsubsection{DETERMINAÇÃO DA COR}

A cor da amostra foi determinada usando colorímetro visual (DLNH-100).

\subsubsection{DETERMINAÇÃO DE SÓLIDOS TOTAIS (ST), SÓLIDOS (SF) E SÓLIDOS VOLÁTEIS (SV):}

Para a determinação dos sólidos totais utilizou-se a metodologia descrita pelo instrumento de trabalho do MAPA - Ministério da Agricultura, Pecuária e Abastecimento (2014). Uma cápsula de porcelana previamente aquecida em estufa $105^{\circ} \mathrm{C}$ por \pm 1 hora e esfriada em dessecador foi pesada até peso constante em balança digital Mettler. Transferiu-se $100 \mathrm{~mL}$ da amostra e foi colocada em estufa a $105^{\circ} \mathrm{C}$ até secagem completa. Retirou a capsula de porcelana, em seguida colocada em dessecador até peso constante. Posteriormente, o peso foi calculado através da seguinte equação:

$$
\mathrm{ST}=\frac{(M S-M R) \times 1000}{V a}(\text { Eq. 1) }
$$

Onde:

$\mathrm{ST}=$ Sólidos totais em $\mathrm{mg} / \mathrm{L}$

MS = Massa da amostra seca a $105^{\circ} \mathrm{C}$, em mg

$\mathrm{MR}=$ Massa da capsula de porcelana em $\mathrm{mg}$

$\mathrm{VA}=$ Volume da amostra em $\mathrm{mL}$

Para calcular os sólidos fixos foi utilizado a seguinte equação:

$$
S F=\frac{(M C-M R) \times 1000}{V a}(\text { Eq. 2) }
$$

Onde:

$\mathrm{SF}=$ Sólidos fixos em $\mathrm{mg} / \mathrm{L}$

$M C=$ Massa cinza + massa capsula de porcelana em $\mathrm{mg}$

$\mathrm{MR}=$ Massa da capsula de porcelana em $\mathrm{mg}$

$\mathrm{VA}=$ Volume da amostra em $\mathrm{Ml}$

Para calcular sólidos voláteis, foi utilizado a seguinte equação: 


$$
S V=\frac{(S T-S F) \times 1000}{V a}(\text { Eq. 3) }
$$

Onde:

$\mathrm{SV}=$ Sólidos voláteis em $\mathrm{mg} / \mathrm{L}$

$\mathrm{ST}=$ Sólidos totais em $\mathrm{mg} / \mathrm{L}$

$\mathrm{SF}=$ Sólidos fixos em $\mathrm{mg} / \mathrm{L}$

\subsection{ANÁLISE MICROBIOLÓGICA:}

\subsubsection{ISOLAMENTO DE FUNGOS FILAMENTOSOS}

O isolamento de fungos filamentosos foi realizado pelo método da diluição seriada, diluindo $1 \mathrm{~mL}$ da amostra de água do Rio Igarassu para $9 \mathrm{~mL}$ de água destilada estéril, usando o método de pour-plate, onde $1 \mathrm{~mL}$ da diluição (1:10) foi incorporada ao meio de cultura ágar Sabouraud contendo Cloranfenicol,como inibidor de bactérias. Composição do meio (40 g/L dextrose, $10 \mathrm{~g} / \mathrm{L}$ de peptona, $20 \mathrm{~g} / \mathrm{L}$ de ágar, 0,05 g/L de cloranfenicol pH $5.6 \pm 2$. As placas de Petri foram incubadas a $28{ }^{\circ} \mathrm{C}$ por 96 horas, conforme o protocolo Rego (2010). Após 96 horas de crescimento foram observadas colônias diferentes distantes uma das outras. As colônias individuais foram transferidas no centro da placa de Petri contendo meio Sabouraud contendo cloranfenicol para obtenção de culturas puras.

\subsubsection{MANUTENÇÃO DAS AMOSTRAS}

As linhagens foram mantidas em meio ágar Sabouraud em tubos e placas. Os repiques foram mantidos a temperatura de $28^{\circ} \mathrm{C}$ durante uma semana e posteriormente armazenados a $4^{\circ} \mathrm{C}$ até o próximo repique.

\subsubsection{IDENTIFICAÇÃO DOS FUNGOS}

Para identificação dos fungos em nível de gênero, os fungos foram analisados micromorfologicamente utilizando a metodologia de microcultivo, montagem de lâminas segundo Souza et al (2015). 


\subsection{SCREENING DOS FUNGOS PRODUTORES DE CELULASE}

As amostras foram analisadas quanto a sua produção de enzimas celulolíticas através da fermentação solida em meio de cultura contendo carboximetil celulase (CMC) como única fonte de carbono. Os fungos incubados no centro da colônia e incubados por 5 dias a $28^{\circ} \mathrm{C}$. Para visualização da ocorrência da produção enzima, foi utilizado Vermelho Congo com tampão Tris $\mathrm{HCl}$, com posterior lavagem em $\mathrm{NaCl}$. Revelando-se as placas de ágar-CMC com corante Congo, a zona em forma de halos ao redor da colônia indica a produção da celulase, mediante a ação hidrolítica da celulose, enquanto que a parte onde não ocorreu a difusão da enzima cora-se de vermelho , segundo Ruegger; Tauk-Tornisielo (2004).

\subsection{DETERMINAÇÃO ENZIMÅTICA}

A determinação enzimática foi expressa como índice enzimático (IE), mediante a relação do diâmetro médio do halo de degradação, subtraindo o valor do poço e o diâmetro médio da colônia, subtraindo o valor do poço, segundo a metodologia de Hankin; Anagnostakis (1975), segundo a fórmula abaixo:

$$
I E=\frac{\text { diâmetro do halo-furo }}{\text { diâmetro da colônia-furo }} \quad \text { (Eq. 4) }
$$

Dessa forma, os isolados que exibiram os maiores halos apresentaram também os maiores índices enzimáticos nos meios de cultura testados, como também foram observados que a produção da enzima foi extracelular, possibilitando a seleção dos fungos produtores de celulases.

\section{RESULTADOS E DISCUSSÃO}

\subsection{CARACTERIZAÇÃO FISICO-QUIMICA DA ÁGUA DO RIO IGARASSU}

Os resultados físico-químicos realizados com as águas superficiais no rio Igarassu (Igarassu, PE, Brasil), foram interpretados e comparados com o padrão de qualidade para águas classe 2 - Resolução CONAMA № 367/05, Resolução CONAMA № 430/11 com padrão de qualidade da água para consumo humano - Portaria № 518/2004 representados na Tabela 1. 
Nesse trabalho, a água superficial do rio Igarassu/PE apresentou elevada condutividade, elevada cor aparente, alta turbidez conforme Tabela 1, sendo classificanda como comprometida. Segundo Von Sperling (2007), a condutividade elétrica da água é um parâmetro que não discrimina quais são os íons presentes na água, mas é um indicador importante das possíveis fontes poluidoras, podendo estar associada a salinização do solo. Quanto maior a condutividade elétrica, maior a contaminação da água. De acordo com a CETESB, a condutividade elétrica acima de $0,100 \mathrm{mS} / \mathrm{cm}$, indica que o ambiente foi impactado por ações antrópicas, além de indicar características corrosivas da água. Nesse estudo foi identificado o valor de 696,40 $\mathrm{mS} / \mathrm{cm}$, supondo-se que as atividades industriais predominantes no entorno contribuem para o aporte de íons nas águas superficiais do rio Igarassu.

A caracterização físico-química da cor do local da amostra excedeu os limites da Resolução CONAMA 367/05. Estudos referem que a presença de cor nas águas superficiais caracteriza a presença de íons metálicos, plâncton, resíduo industrial, húmus, entre outros materiais orgânicos. Adicionalmente a cor, a turbidez é um parâmetro que indica a redução da intensidade dos raios luminosos que penetram no corpo d'água, influenciando decisivamente nas características do ecossistema. Esgotos sanitários e efluentes industriais também provocam elevações determinações da turbidez da água. (GALVAN et al, 2020). Considerando, a turbidez superior a 5 NTU encontrado na água superficial do rio Igarassu é possível relacionar o período de seca, o qual ocorre à permanência do material em suspensão por meio de menor precipitação com ações antrópicas. (VIEIRA et al, 2020) 
Tabela 1 - Parâmetros físico-químicos de água superficiais do rio Igarassu (PE, Brasil)

\begin{tabular}{|c|c|c|c|c|}
\hline Parâmetros & $\begin{array}{l}\text { Concentração } \\
\text { (mg/L) }\end{array}$ & $\begin{array}{l}\text { Resolução } \\
\text { CONAMA } \\
\text { №367/05 }\end{array}$ & $\begin{array}{l}\text { Resolução } \\
\text { CONAMA } \\
\text { N430/11 }\end{array}$ & $\begin{array}{c}\text { Portaria No } \\
518 / 2004\end{array}$ \\
\hline $\begin{array}{c}\text { Determinação do } \\
\text { pH }\end{array}$ & 7,24 & $6-9$ & $6-9$ & $6,0-9,5$ \\
\hline Turbidez (NTU) & 77,62 & 100 & & 5 \\
\hline $\begin{array}{l}\text { Condutividade } \\
\text { Elétrica }(\mathrm{mS} / \mathrm{cm})\end{array}$ & 696,40 & & & 450 \\
\hline Temperatura (으) & 23 & & & \\
\hline Cor (uH/L) & 100 & 75 & & 15 \\
\hline Sólidos Totais (ST) & 784 & 500 & 500 & \\
\hline Sólidos Fixos (SF) & 185 & & & \\
\hline $\begin{array}{c}\text { Sólidos Voláteis } \\
\text { (SV) }\end{array}$ & 5,99 & & & \\
\hline
\end{tabular}

Fonte: Autoria própria.

Assim como no presente estudo Vieira et al (2020) e Piratoba (2017) analisaram o potencial Hidrogeniônico, pH e o índice de alcalinidade, observaram que estão de acordo com o padrão estabelecido pela legislação, revelando sua importância para flora e fauna aquática. A Resolução CONAMA n 430/2011, determina que o pH dos resíduos lançados no corpo do rio, tem uma margem de tolerância de 5 a 9 . No mesmo contexto a Portaria $n^{\circ}$ 518/2004 do Ministério da Saúde, recomenda uma variação de $\mathrm{pH}$ entre 6,0 a 9,5 que seria apropriada para consumo humano. $\mathrm{O}$ pH é um parâmetro sensível a mudanças e variações nos recursos hídricos, e pode oscilar de acordo com a dissolução de sais, matéria orgânica decomposta, processos de lixiviação, tipos litológicos de solo, e, principalmente, devido à temperatura (JENIFER; JHA, 2018).

A temperatura da água determinada foi de $23^{\circ} \mathrm{C}$. De acordo com Portella, (2020) e Arruda et al (2015), a temperatura tem influência sobre a vida aquática, uma vez que quanto mais elevada for esta, menos oxigênio dissolvido a água possuirá. Não consta na legislação valores máximos ou mínimos estipulados para esta variável. Entretanto, os resultados obtidos para essa variável estão de acordo com a condição climática da região, cujo clima é considerado de transição entre os climas tropical e subtropical e as estações anuais não são bem definidas. 
Todas as impurezas contribuem para a carga de sólidos na água, com exceção dos gases dissolvidos. As frações de sólidos suspensos, estão amparados, na legislação ambiental pelos valores de turbidez. Esses podem aumentar a turbidez e prejudicar a água esteticamente, assim como reduzir a produtividade do ecossistema pela pouca penetração de luz. (PORTO et al., 1991, DE ARRUDA, 2015). De acordo com os dados obtidos através das análises nota-se a partir da Tabela 1 que os valores para sólidos totais, ultrapassam os valores permitidos pela resolução 357/2005 do CONAMA que preconiza, valor máximo permitido de $500 \mathrm{mg} / \mathrm{L}$ de sólidos totais para águas para consumo humano, classe 1 . Os resultados obtidos indicam como principais poluidoras a atividade industrial (produtos alimentares, têxtil, matéria plástica, metalúrgica, bebidas, indústrias do ramo sucro-alcooleiro, química, papel/ papelão e perfume/sabões/velas) e a ocupação urbana. A disposição dos resíduos industriais e sólidos urbanos próximos ao rio torna-se um perigo para a saúde humana e animal, além de contaminar as águas, favorece a proliferação de vetores de doenças por veiculação hídrica (ratos, escorpiões, baratas, etc.) (LEITE et al., 2021).

\subsection{ISOLAMENTO DE FUNGOS FILAMENTOSOS DO RIO IGARASSU E CARACTERIZAÇÃO FENOTIPICA}

A partir da fase de isolamento dos micro-organismos, foram obtidos 10 fungos, dos quais foram isolados 04 . Os dados de coloração e características morfológicas para os fungos isolados estão apresentados na Tabela 2.

Tabela 2 - Características de fungos filamentosos do rio Igarassu e caracterização fenotípica

\begin{tabular}{ccccc}
\hline Código & Cor & Textura & Borda & Tipo \\
\hline UCP 05 & Preta & Aveludada & Não Uniforme & Filamentoso \\
\hline UCP 06 & Cinza & Algodoada & Uniforme & Filamentoso \\
\hline UCP 07 & Branca & Algodoada & Uniforme & Filamentoso \\
\hline UCP 08 & Preta & Aveludada & Não Uniforme & Filamentoso \\
\hline
\end{tabular}

Fonte: Autoria própria.

A Figura 2 apresenta o resultado obtido para a identificação dos gêneros dos fungos isolados através da microscopia óptica. 
Figura 2 - Microscopia óptica aumento 10X para identificação dos fungos isolados. (a) Aspergillus spp.;

(b) Rhizopus spp.; (c) Mucorales spp.; (d) Aspergillus spp
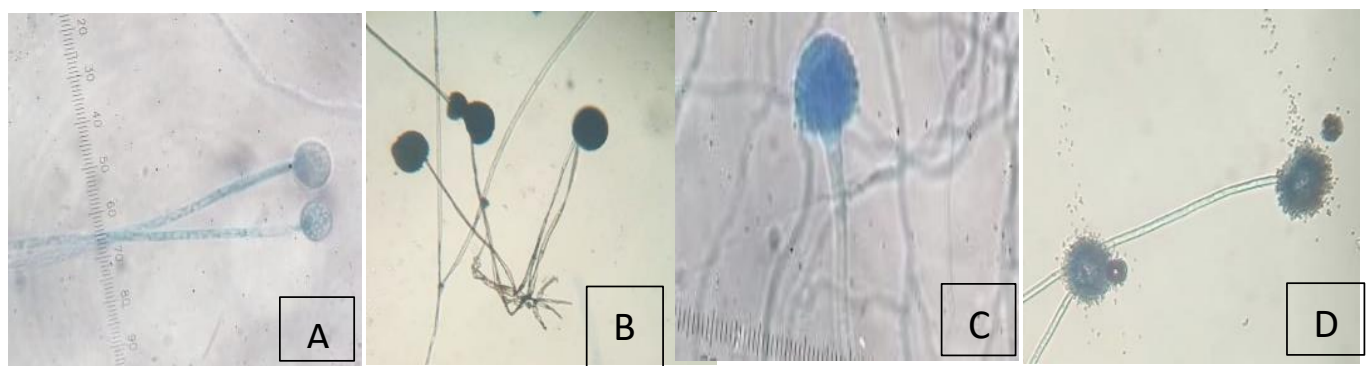

Fonte: Autoria própria.

A Figura 3 apresenta o resultado obtido para a seleção de micro-organismos produtores de enzimas celulolíticas. O halo formado indica a hidrólise da carboximetilcelulose e é caracterizado pela área mais clara ao redor da colônia. 0 indicativo da degradação de celulose microcristalina foi demonstrado pela formação de um halo de $55 \mathrm{~mm}$ observado apenas na amostra 08, identificada como Aspergillus sp.

Figura 3 - Halo de degradação de celulase

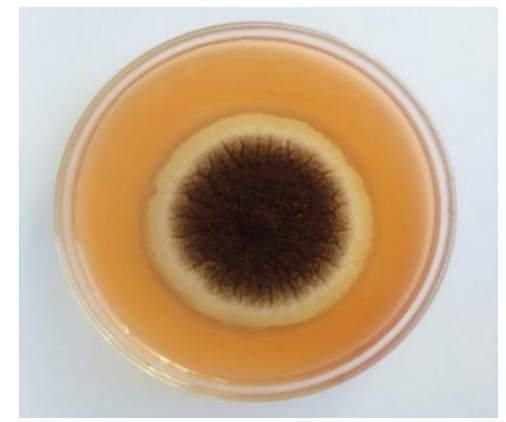

Fonte: Autoria própria.

O valor encontrado para o índice enzimático (IE) foi de aproximadamente 1,28 para degradação de celulase, foi observando que houve um crescimento significativo do fungo. No presente trabalho, seguiu-se a escala do índice enzimático estabelecido por SILVA et al. (2015) que classifica os micro-organismos de acordo com a intensidade de produção de enzimas, utilizando o IE como parâmetro, em amostras fracamente produtoras $(1,0 \leq \mathrm{IE}<1,5)$, moderadamente produtoras $(1,5 \leq \mathrm{IE}<2,0)$, fortemente produtoras (IE $\geq 2$ ) e não produtoras (IE $=0$ ) de celulase. Contudo, vale ressaltar que a atividade enzimática de celulases também está relacionada com a origem de onde foi 
obtido o micro-organismo, além de fatores como pH e temperatura. Novos estudos são sugeridos avaliando os efeitos de diferentes valores de $\mathrm{pH}$ e temperatura visando um maior rendimento da enzima, assim como avaliação da produção de outros bioprodutos de interesse industrial.

\section{CONSIDERAÇÕES FINAIS}

Os resultados obtidos no decorrer do estudo demonstram a importância na preservação dos recursos hídricos, no controle ambiental dos rejeitos industriais e da sustentabilidade dos ecossistemas e melhor qualidade da saúde. A biodiversidade da micobiota destaca a presença de fungos filamentosos como Aspergillus spp., demonstrando um potencial biotecnológico dirigido para a enzima hidrolítica celulase, com destacada atividade enzimática, sugerindo que novas condições de cultivo e parâmetros físico-químicos devem ser investigados, considerando o potencial e possíveis aplicações futuras.

\section{AGRADECIMENTOS}

Os autores agradecem o suporte financeiro da Fundação de Amparo a Ciência e Tecnologia do Estado de Pernambuco - FACEPE (IBPG.1484-2.0618), da Coordenação de Aperfeiçoamento de Pessoal de Nível Superior - CAPES (Processo № 88887.353524/2019-00, Processo № 8887.343350/2019-00, Processo № 88887.353532/2019-00) e do Conselho Nacional de Desenvolvimento Científico e Tecnológico - CNPq (Processo №. 314422/2018-8).

\section{REFERÊNCIAS}

ARAÚJO, N. L. et al. Produção de biomassa micelial e enzimas lignocelulolíticas de Pleurotus spp. em meio de cultivo líquido. Research, Society and Development, v. 10, n. 1, p. e6810111406-e6810111406, 2021.

BRASIL. Portaria no 518/GM, de 25 de março de 2004. Disponível em: < http://dtr2001. saude. gov. br/sas/PORTARIAS/Port2004/GM/GM-518.> Acesso em: 12 de março de 2020. 
BRASIL. Resolução $\mathrm{n} \div 430$, de 13 de maio de 2011. Disponível em: < http://www2.mma.gov.br/port/conama/legiabre.cfm?codlegi=646>. Acesso em 06 nov. 2019

BRASIL. Resolução no. 357 de 17 de março de 2005. Disponível em: < http://www2.mma.gov.br/port/conama/legiabre.cfm?codlegi=459> .Acesso em 06 nov. 2019

BRASIL. RESOLUÇÃO № 357, de 17 de março de 2005. Disponível em:< http://www. mma. gov. br/conama/>. Acesso em março, 2020.

BASSO, E. R.; DE CARVALHO, S. L. Avaliação da qualidade da água em duas represas e uma lagoa no município de Ilha Solteira (SP). Holos Environment, v. 7, n. 1, p. 1629, 2020.

COMPANHIA AMBIENTAL DO ESTADO DE SÃO PAULO (CETESB). Variáveis de qualidade de água. São Paulo, 2009. Disponível em: < https://cetesb.sp.gov.br/aguasinteriores/publicacoes-e-relatorios/>. Acesso em: 19 Dez. 2019

DA COSTA, M. C. R. et al. Contextualização do uso racional da água pelas escolas públicas de Limoeiro do Norte (Ceará-Brasil): Experiência formativa na Extensão Universitária. Revista Brasileira de Meio Ambiente, v. 8, n. 1, 2020.

DE ARRUDA, G. B.; CORREIA, K.V.; OLIVEIRA, T.R.S.; BRAINER NETO, J.E.; ARAÚJO, F.P.; CARNEIRO, K.W.F.S. Análise da Qualidade da Água do Riacho Moraes em Área Influenciada Pela Produção de Gesso no Município de Araripina, PEBrasil. Geologia, v. 28, n. 1, 2015.

DE CARVALHo SIQUeIRA, A. C.; MAGALHÃES, R. D. P; IACOMINI, V. Privatização dos recursos hídricos no Chile e sua prevalência sobre o direito fundamental à água. Brazilian Journal of Animal and Environmental Research, v. 2, n. 2, p. 846-849, 2019.

DE OLIVEIRA, L. B.et al. Gerenciamento comunitário de recursos hídricos, uma questão de saúde: a água que temos e a água que queremos: percepção dos usuários de sociedades de água em um município rural da sub-bacia hidrográfica do Forqueta, RS Community management of water.... Ambiência, v. 11, n. 2, p. 359374, 2015.

EMBRAPA - Empresa Brasileira de Pesquisa Agropecuária. Manual de procedimento de amostragem e análise físico-química de água. Colombo/PR: 2011. Disponível em: https://ainfo.cnptia.embrapa.br/digital/bitstream/item/57612/1/Doc232ultima -versao.pdf. Acesso em: 26.09.2019. 
FRACALANZA, A. P.; FREIRE, T. M. Crise da água na Região Metropolitana de São Paulo: A injustiça ambiental e a privatização de um bem comum. GEOUSP: Espaço e Tempo (Online), v. 19, n3, p 464-478, 2015.

GALVAN, K. A. et al. Análise ambiental macroscópica e a qualidade da água de nascentes na bacia do Rio São Domingos/SC, Brasil. Revista Ibero-Americana de Ciências Ambientais, v. 11, n. 1, p. 165-176, 2020.

HARGREAVES, P. I.; PEREIRA JR, N. Bioprospecção de novas celulases de fungos provenientes da floresta amazônica e otimização de sua produção sobre celulignina de bagaço de cana. Rio de Janeiro, 2008.

JENIFER, M. A. ; JHA, M. K. Comprehensive risk assessment of groundwater contamination in a weathered hard-rock aquifer system of India. Journal of Cleaner Production, v. 201, p. 853-868, 2018.

LEITE, N. M. G. et al. A influência da disposição final dos resíduos sólidos nos recursos hídricos: uma revisão sistemática. Brazilian Journal of Development, v. 7, n. 2, p. 12997-13006, 2021.

LYND, L. R.; WEIMER, P. J.; VAN ZYL, W. H.; PRETORIUS, I. S. Microbial Cellulose Utilization: Fundamentals and Biotechnology. Microbiology and Molecular Biology Reviews, v. 66, n. 3, p. 506-577, 2002.

MAPA - Ministério da Agricultura, Pecuária e Abastecimento. Instrumento de trabalho, Goiás/GO: 2014. Disponível em: <Downloads/IT\%20POA\%20422\%20\%20\%20Determina\%C3\%A7\%C3\%A3o\%20de\%20S\%C3\%B3lidos\%20Totais\%20em\% 20\%C3\%81gua\%20de\%20Abastecimento\%20e\%20Gelo.pdf>. Acesso em: 30.09.2019.

MATTOS, M. L. T; DA SILVA, M. D. Controle da qualidade microbiológica das águas de consumo na microbacia hidrográfica Arroio Passo do Pilão. Embrapa Clima Temperado - Comunicado Técnico (INFOTECA-E), 2002.

MORAIS, M. V. M.; LIMA, H. J. D.'Avila. Nutritional techniques for reducing the environmental impact of intensive non-ruminant animal production. Research, Society and Development, v. 9, n. 1, p. 11911560, 2020.

PARRON, L. M.; MUNIZ, D. H. F.; PEREIRA, C. M. Manual de procedimentos de amostragem e análise físico-química de água. Colombo: Embrapa Florestas, $2011 . \quad$ Disponível em: <https://www.infoteca.cnptia.embrapa.br/bitstream/doc/921050/1/Doc232ulti maversao.pdf.> Acesso em: 19 outubro 2019.

PIRATOBA, A. R. A.; RIBEIRO, H. M. C., MORALES, G. P. et al. Caracterização de parâmetros de qualidade da água na área portuária de Barcarena, PA, 
Brasil. Ambiente \& Água-An Interdisciplinary Journal of Applied Science, v. 12, n. 3, p. 435-456, 2017.

PORTO, M.F.A.; BRANCO, S.M.; LUCA, S.J. Caracterização e alterações da qualidade da água. In: PORTO, R.L. (Org.). Hidrologia Ambiental. São Paulo: Editora da Universidade de São Paulo, Associação Brasileira de Recursos Hídricos. v. 3, 3-4 p e 27-66 p. 1991

PORTELLA, M. D. et al. Avaliação da qualidade da água de rios em bacias urbanizadas na bacia da Lagoa da Conceição, Florianópolis (SC). 2020.

REGO, J. C. V. Qualidade sanitária de água e areia de praias da baía de Guanabara. Fundação Oswaldo Cruz; 2010.

RUEGGER, M. J. S.; TAUK-TORNISIELO, S. M. Atividade de celulase de fungos isolados do solo da Estação Ecológica de Juréia-Itatins, São Paulo-Brasil. Brazilian Journal of Botany, vol. 27, n², São Paulo, 2004.

SILVA, V.M.A; BRITO, F.A.E.; RAMOS, K.A.; SILVA, R.M.; MARTINS, C.M.; MARTINS, S.C.S. Atividade enzimática de actinobactérias do semiárido. Revista Brasileira de Geografia Física, v. 8, número especial IV SMUD, p. 560-572, 2015a.

SOUZA, J. B.; AMÂNCIO, F. L. R.; RUZENE, D. S.; MENDONÇA, M. C.; LOPEZ, J. A.; SILVA, D. P. Produção de enzimas celulolíticas de fungos coletados em Sergipe, utilizando CMC como indutor sob diferentes tipos de cultivo submerso. Simpósio de Engenharia de Produção de Sergipe, 2015.

TOLAN, J. S. Logens process for producing ethanol from cellulosic biomass. Clean Technologies and Environmental Policy, v. 3, n. 4, p. 339-345, 2002.

TUSHAR, MSHK; DUTTA, A - Efficiency Analysis of Crude Versus Pure Cellulase in Industry. Biofuel Production Technologies: Critical Analysis for Sustainability. Clean Energy Production Technologies book series, Neha Srivastava, Manish Srivastava, P. K. MishraVijai and Kumar Gupta (Ed.), Springer, pp 283-298, 2020.

VÁZQUEZ-MONTOYA, Elva Lorena et al. Palha de moringa como indutor de produção de celulase e fonte de fungos celulolíticos. Revista Argentina de Microbiologia, v. 52 , n. 1, p. 4-12, 2020.

VIEIRA, I. F. B.; NETO, F. C. R., CARVALHO, M. N et al. Water Security Assessment of Groundwater Quality in an Anthropized Rural Area from the Atlantic Forest Biome in Brazil. Water, v. 12, n. 3, p. 623, 2020.

VON SPERLING, M. Introdução à qualidade das águas e ao tratamento de esgotos. Editora UFMG, 1996. 


\title{
CAPITULO XXXIII
}

\section{FONIES RENOVÁYVIS DE ENERGIA NO BRASIL E SEU USO EM TECNOLOGIAS ELIRROQUÍMICAS NO TRATAMENIO DE EFLUENIES}

\section{DOI: 10.51859/amplla.mas481.1121-33}

\author{
Danillo César Reggiani Cunha ${ }^{1}$ \\ Geoffroy Roger Pointer Malpass ${ }^{2}$ \\ Cláudio Márcio de Castro $^{3}$
}

\begin{abstract}
Graduando do curso de Pós-Graduação em Saneamento Ambiental. Instituto Federal de Ciência e Tecnologia do Triângulo Mineiro - IFTM

2 Professor do Programa de Mestrado Profissional em Inovação Tecnológica, Universidade Federal do Triângulo Mineiro - UFTM

${ }^{3}$ Professor do Programa de Pós-Graduação Lato Sensu na Área Ambiental, Instituto Federal de Educação, Ciência e Tecnologia do Triângulo Mineiro - IFTM
\end{abstract}

\section{RESUMO}

O consumo de produtos industrializados cada vez mais diversificados tem como consequência a geração de diferentes classes de contaminantes que apresentam elevada toxicidade mesmo à baixas concentrações. Diferentes métodos têm sido usados para o tratamento de água contaminada. Porém, métodos convencionais usados, tais como químicos, físicos e biológicos, apresentam dificuldades na degradação de algumas classes de compostos orgânicos. Os estudos usando Processo Oxidativo Avançado Eletroquímico (POAE) no tratamento de efluentes apresentam resultados cada vez mais promissores sobre o uso desta tecnologia para remoção de diferentes classes de poluentes danosos. Esta mini revisão tem como objetivo fornecer uma visão geral sobre o uso de POAE, bem como apresentar algumas dificuldades encontradas para sua implantação em larga escala no tratamento de efluentes domésticos e industriais.

Palavras-chave: Processo Oxidativo Avançado. Tratamento de efluente. Energia Renovável.

\section{INTRODUÇÃO}

Estudos relacionados ao meio ambiente têm como objetivo buscar formas cada vez mais eficazes de conservação do solo, da água e do ar. Os efluentes produzidos pelos diferentes setores da sociedade possuem composição bastante diversificada, que contém diferentes contaminantes emergentes tóxicos e que apresentam elevada resistência à degradação são persistentes e altamente danosos mesmo em baixas 
concentrações. Dessa forma, utilizar os sistemas com etapas convencionais de tratamento como floculação, sedimentação e decantação não garante eficiência na remoção desses poluentes (CARTAXO et al., 2020). Neste contexto, faz-se necessário o desenvolvimento de tecnologias ecologicamente corretas e economicamente viáveis para o tratamento destes efluentes.

Atualmente existem vários métodos para o tratamento dos mais diferentes efluentes, porém o custo de alguns ainda impossibilita sua aplicação industrial. Métodos químicos, físico-químicos e microbiológicos são os mais utilizados em larga escala. $\mathrm{Na}$ literatura é possível encontrar muitos trabalhos dedicados a revisar detalhadamente as características e aplicações de diferentes metodologias, tais como técnicas à base de membranas (PAN et al., 2019), aerogéis (HASANPOUR; HATAMI, 2020), eletroquímica (GARCIA-SEGURA; OCON; CHONG, 2018), biológico (RAMBABU et al., 2020), Fenton (RAMOS et al., 2019), fotoquímico (BRILLAS, 2020) e sonoquímico (SERNA-GALVIS; TORRES-PALMA, 2021). Cada uma delas possui vantagens e desvantagens em seu uso e a escolha do método depende de vários fatores, tais como o volume de efluente a ser tratado, $\mathrm{pH}$, temperatura e quantidade de matéria orgânica presente no efluente (BRILLAS; MARTINEZ-HUITLE, 2015).

Dentre os diferentes métodos conhecidos, destaca-se o uso de tecnologias eletroquímicas como sendo bastante promissoras no tratamento de água e solo contaminados. O método eletroquímico apresenta-se como uma ferramenta poderosa de pré-tratamento e/ou pós-tratamento com diversas vantagens quando comparado ao tratamento biológico, tais como a produção de uma variedade de oxidantes in situ, versatilidade no tratamento com o uso de diferentes condições reacionais e eficiência na remoção de cor e carga orgânica sem restrição de pH (GANIYU; MARTíNEZ-HUITLE; OTURAN, 2021).

O principal requisito dessas tecnologias é a eletricidade e atualmente, principalmente no Brasil, os sistemas são alimentados com fontes de energia elétrica gerada por hidrelétricas, conforme dados do Ministério de Minas e Energia (MINISTÉRIO DE MINAS E ENERGIA, 2021). Além da forma de energia ser originada através de processos que causam grandes impactos ambientais, o uso de sistemas eletroquímicos no tratamento de água e solo contaminados ficam limitados a regiões que tenha 
previamente instalado um sistema de distribuição de energia. As tecnologias de geração de energia ambientalmente amigável, como energia solar, eólica ou biomassa, além de diminuir os impactos ambientais, podem ser instaladas em áreas remotas ou comunidades rurais e ter seu funcionamento sustentável.

Neste contexto, este trabalho apresenta uma breve revisão sobre os Processos Oxidativos Avançados e seus desafios para sua implementação em larga escala.

\section{METODOLOGIA}

O trabalho desenvolvido seguiu os preceitos exploratórios, através de pesquisa bibliográfica de materiais publicados de fontes científicas confiáveis, coleta e análise dos dados. Para o levantamento bibliográfico, foram realizadas buscas na plataforma Science Direct com os termos em inglês "advanced oxidative processes", "persulfate degradation", "renewable energy \& electrochemical" em diferentes períodos. Posteriormente foi realizada seleção e análise dos artigos originais, revisões e capítulos de livro mais recentes para apresentação de conceitos atualizados.

\section{REVISÃO BIBLIOGRÁFICA}

\subsection{PROCESSO OXIDATIVO AVANÇADO (POA)}

Os POAs vêm ganhando cada vez mais destaque quanto ao seu emprego como uma alternativa para o tratamento de efluentes provenientes da indústria. Segundo dados obtidos na plataforma Science Direct, na última década houve um crescimento significativo de publicações relacionadas ao tema, conforme observado na Figura 1, que justificam e comprovam cada vez mais a importância, bem como a relevância e eficiência desse processo. 
Figura 1 - Número de publicações por ano de acordo com a palavra-chave "Processo Oxidativo Avançado" entre 2010-2020 no Science Direct.

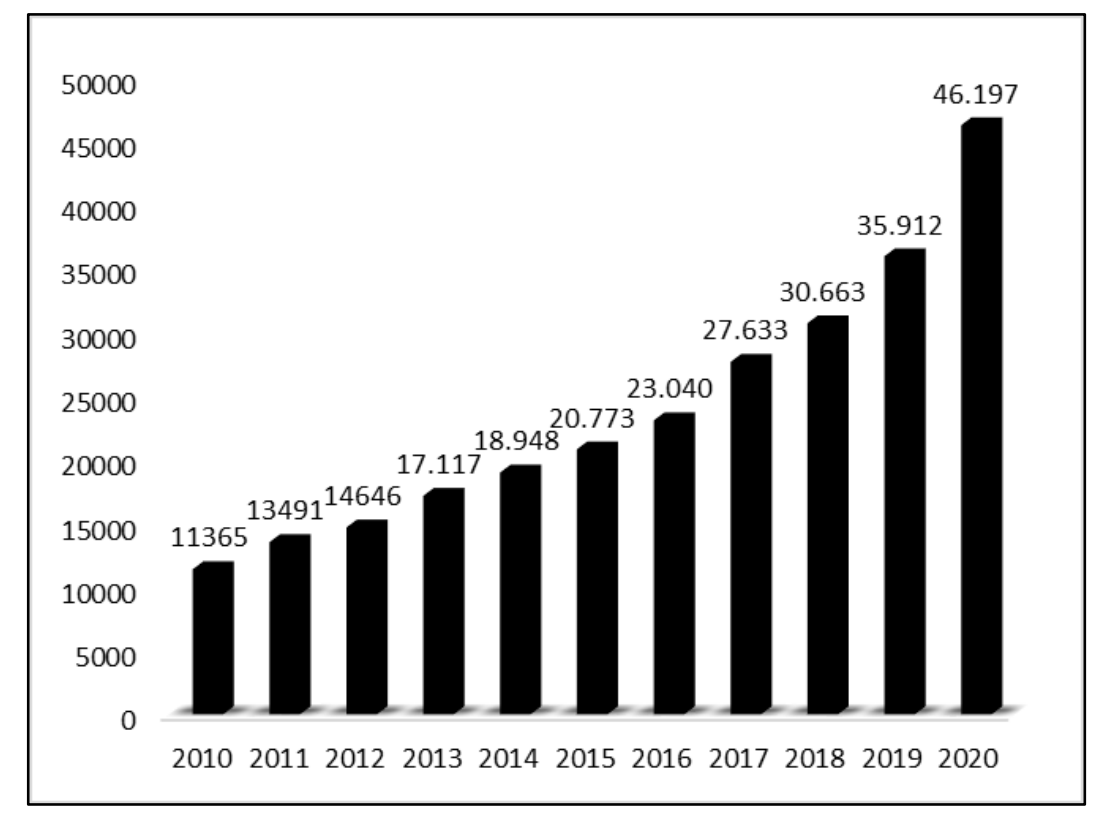

Fonte: Autoria própria.

O que se evidencia no crescimento dos estudos baseados nesses processos é o fato de que eles são responsáveis por preencher o hiato destacado entre as formas de tratamentos convencionais de efluentes e o tratamento de efluentes mais complexos. Isso é especialmente verdade quando se trata de efluentes provenientes de atividades industriais, que em certos casos possuem uma carga orgânica muito elevada que não são degradadas simplesmente por processos como floculação, decantação e sedimentação. Nesse sentido, os POAs são necessários para que individualmente, ou de forma combinada realizem a degradação e diminuição da carga de poluentes presentes nessas águas respeitando os parâmetros estabelecidos em legislações para o lançamento final em corpo receptor (DEWIL et al., 2017), como o estabelecido pela Resolução do Conselho Nacional do Meio Ambiente - CONAMA 430/2011 (CONAMA, 2011).

Estudos comprovam que uma maior eficiência na mineralização de matéria orgânica é observada quando tratamentos eletroquímicos, foto-Fenton, sonoquímicos, fotoquímicos, químicos e biológicos são usados de forma combinada na degradação e mineralização da carga orgânica poluidora (BRILLAS, 2020; SU et al. 2021; SHARMA; SIMSEK, 2019; GUJAR; GOGATE, 2021; BEIGBEDER; BOBOESCU; LAVOIE, 2021; FANAEI; 
MOUSSAVI; SHEKOOHIYAN, 2020; SAAD; WIRZAL; PUTRA, 2021). Além disso os procedimentos escolhidos devem ser muito bem estudados para cada tipo de poluente, uma vez que, após a aplicação de um processo, ou uma combinação deles é possível que se obtenha substâncias mais nocivas do que as inicialmente observadas (BRILLAS, 2020).

O processo eletroquímico surgiu como tecnologia alternativa bastante promissora no tratamento de efluentes. Antes do ano 2000, poucos trabalhos tinham sido publicados utilizando essa metodologia. Atualmente, muitos grupos de pesquisa tanto no setor acadêmico quanto no setor industrial têm-se dedicado a estudos de tratamentos de efluentes utilizando tecnologia eletroquímica. Esse aumento refletiu diretamente na quantidade de publicações, patentes e conferências internacionais observadas nos últimos 5 anos. O tratamento eletroquímico é uma via ambientalmente promissora com um sistema limpo sem adição de substâncias tóxicas para catálise e estando de acordo com o que defende a química verde.

Além da compatibilidade ambiental, a tecnologia eletroquímica é versátil, com alta eficiência energética sem restrição de $\mathrm{pH}$, promove a degradação eficaz de diferentes poluentes orgânicos e inativação de microrganismos. Além disso, pode ser utilizado em temperatura e pressão ambientes, pode ser aplicado como pré ou póstratamento de efluentes em combinação com outras tecnologias, é versátil, de fácil automação e robusto (BRILLAS; MARTINEZ-HUITLE, 2015).

Um dos fatores mais importantes que garante o sucesso na degradação de matéria orgânica com o uso de processo de oxidação avançada eletroquímico é a geração in situ de espécies reativas, tais como diferentes espécies de cloro ativo, radicais sulfato e radicais hidroxila. O entendimento do mecanismo de ação de cada um dos oxidantes e intermediários orgânicos formados durante a degradação de poluentes é de extrema importância. É sabido que a natureza do eletrodo, composição do efluente, pH e outros parâmetros reacionais influenciam tanto a natureza quanto a concentração das espécies oxidantes formadas durante a eletrólise (GANIYU; MARTÍNEZ-HUITLE; OTURAN, 2020).

Espécies reativas de cloro são altamente eficientes na descoloração e degradação de matéria orgânica, mas possui a desvantagem de formar compostos organoclorados que apresentam elevada toxicidade e resistência à mineralização. Como 
alternativa ao uso de cloro ativo, radicais sulfato formados a partir de ânions persulfato estão sendo cada vez mais estudados com resultados bastante promissores (GANIYU; MARTÍNEZ-HUITLE; OTURAN, 2020).

\subsection{PERSULFATOS}

Os persulfatos, também conhecidos como peroxidissulfato $\left(\mathrm{S}_{2} \mathrm{O}_{8}{ }^{2}\right)$, formados por radicais sulfato $\left(\mathrm{SO}_{4}{ }^{\bullet-}\right)$ vêm ganhando bastante destaque em função do alto potencial de degradação de poluentes emergentes com carga orgânica elevada e persistentes que podem ser encontrados em grande parte dos efluentes industriais. Se apresentam como uma excelente alternativa para aplicação nos POAs como um excelente oxidante, principalmente pela característica não seletiva, elevada estabilidade, não gerarem organoclorados e, além disso, por serem consumidos por completo na reação diminuindo consideravelmente as chances de se originarem compostos mais tóxicos e menos suscetíveis a processos de degradação posteriores (YANG et al., 2019; YANG et al., 2020). A alternativa promissora no uso do persulfato é evidenciado na (Figura 2) que apresenta um aumento exponencial de publicação de estudos com este oxidante.

Figura 2 - Número de publicações por ano de acordo com a palavra-chave "Persulfate" e "Degradation" entre 2010-2020 no Science Direct.

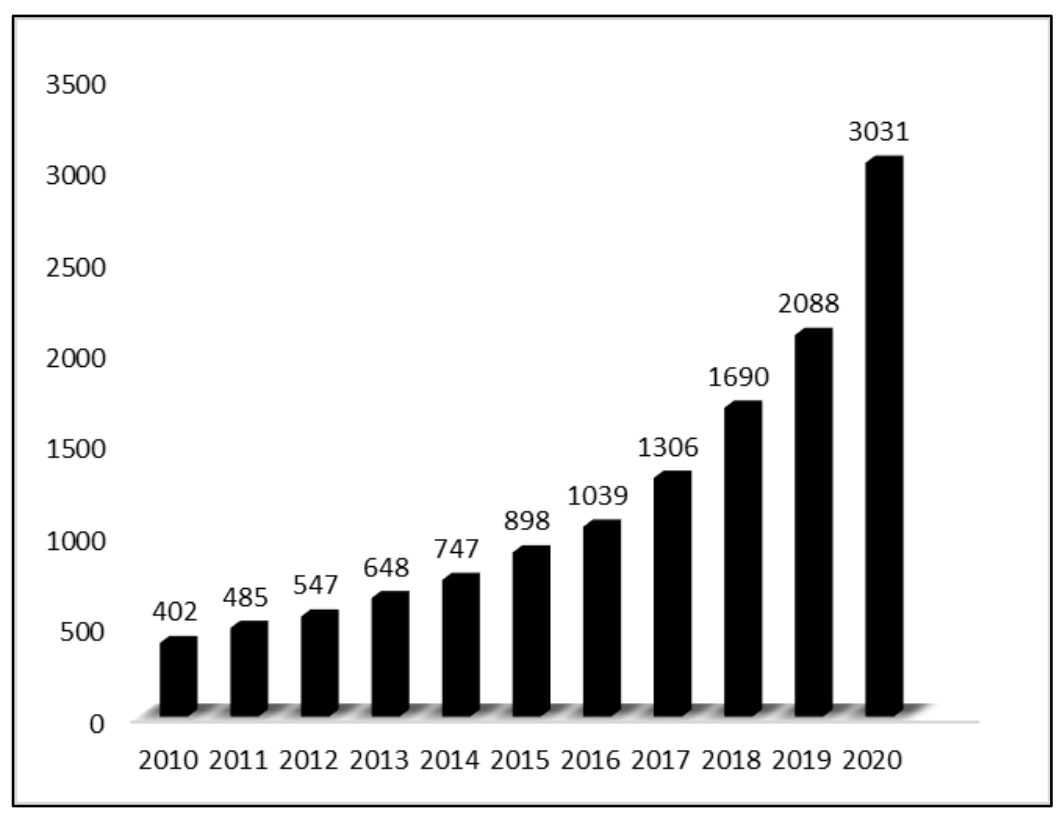

Fonte: Autoria própria. 
Estudos indicam um progresso no entendimento dos papéis do $\mathrm{SO}_{4}{ }^{--}$e $\mathrm{S}_{2} \mathrm{O}_{8}{ }^{2-}$ que estão sendo reportados como responsáveis pela degradação de ampla classe de contaminantes. É sabido que o radical sulfato apresenta vantagens sobre o radical hidroxila na oxidação de compostos orgânicos refratários. $\mathrm{O} \mathrm{SO}_{4}{ }^{{ }^{-}}$tem potencial padrão de oxidação-redução $\left(E^{\circ}\right)$ de $2.5-3.1$ V vs. ENH, contra $E^{\circ}=2.74 \mathrm{~V}$ vs. ENH do HO. Sua

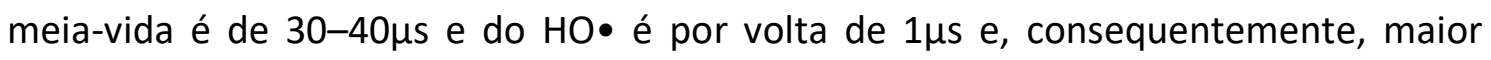
transferência de massa. Além disso, pode reagir de forma eficiente com os compostos alvo com pH do efluente entre 2,0 e 8,0. (YU et al., 2016; HOU et al., 2019; WANG et al., 2019).

Segundo a literatura, a ativação do persulfatos pode ser ocasionada através de uso de álcalis, ultravioleta, calor, carbono, metais de transição e ultrassom (YABALAK, 2021; CHEN et al., 2020; WACLAWEK., 2017). Na ativação por calor, a aplicação de energia térmica pode ocasionar na quebra da ligação O-O de persulfatos, dando origem a radicais sulfatos, conforme o desenvolvimento apresentado na Equação 1 (MATZEK; CARTER, 2016).

Radicais hidroxila podem ser formados a partir da reação entre ânion sulfato e água. Neste caso, a cinética de formação destes radicais é mais lenta, porém pode ser acelerada com o aumento da temperatura, como apresentado na Equação 2 em que $\Delta$ representa a variação de temperatura (YABALAK, 2021).

$$
\begin{aligned}
& \mathrm{S}_{2} \mathrm{O}_{8}{ }^{2-}+\Delta \rightarrow 2 \mathrm{SO}_{4}{ }^{--} \\
& \mathrm{SO}_{4}{ }^{{ }^{-}}+\mathrm{H}_{2} \mathrm{O} \rightarrow \mathrm{SO}_{4}{ }^{2-}+\mathrm{HO}^{\bullet}+\mathrm{H}^{+}
\end{aligned}
$$

Dentre os metais de transição, o ferro apresenta larga vantagem no uso e estudo como um ativador de persulfato para formar radicais sulfato. Como representado pelas equações 3 e 4 é possível compreender que tanto o íon ferroso $\left(\mathrm{Fe}^{2+}\right)$ quanto o Ferro elementar (Ferro de valência zero) têm potencial para ativação de persulfato (DEVI; DAS; DALAl, 2016). Esta técnica demanda uma energia de ativação menor (14,8 kcal mol-1) quando comparada a outras metodologias de ativação para produção de radicais sulfato. (DEVI; DAS; DALAI, 2016) 


$$
\begin{aligned}
& \mathrm{S}_{2} \mathrm{O}_{8}{ }^{2-}+\mathrm{Fe}^{2+} \rightarrow \mathrm{Fe}^{3+}+\mathrm{SO}_{4}{ }^{2-}+\mathrm{SO}_{4}{ }^{--} \\
& \mathrm{S}_{2} \mathrm{O}_{8}{ }^{2-}+\mathrm{Fe} \rightarrow \mathrm{Fe}^{2+}+2 \mathrm{SO}_{4}{ }^{2-}
\end{aligned}
$$

No entanto, o mecanismo de ativação de radical sulfato utilizando ferro ainda é controverso na literatura. Hou e colaboradores publicaram uma revisão crítica com o objetivo de discutir as ambiguidades e controvérsias sobre o mecanismo de ativação (HOU et al., 2020). Porém é sabida a vantagem do uso de radical sulfato frente às espécies de cloro ativo pela não formação de organoclorados. Semelhante à ativação por calor, o uso de radiação ultravioleta também pode provocar tal fenômeno (He et al., 2021), por meio da fragmentação da ligação O-O (Equação 5). Nesse caso, o comprimento de onda tem papel fundamental e influência direta no rendimento da reação responsável pela ativação dos persulfatos. Na literatura, determinados autores consideram como o valor mais usual e com maior rendimento um comprimento de onda de 254nm (WANG, J.; WANG, S., 2018).

$$
\mathrm{S}_{2} \mathrm{O}_{8}{ }^{2-}+\mathrm{hu} \rightarrow 2 \mathrm{SO}_{4}{ }^{\bullet-}
$$

A formação eletroquímica de radical sulfato também é largamente estudada (LIU; ZHOU; TENGA; YOU, 2019; SANTOS; EGUILUZ; SALAZAR-BANDA; SÁEZ; RODRIGO, 2020; CHEN, et al., 2018; CAI, et al., 2019; HADI, et al., 2021; GIANNAKIS; LIN; GHANBARI, 2021; ERKAN; ENGIN, 2020; MOSTAFA; BALTRUSCHAT; GARCIA-SEGURA, 2021; WANG et al., 2021; DIVYAPRIYA; NIDHEESH, 2021; SHIN et al., 2019, CHANIKYA, 2021). Em soluções com ácido sulfúrico, $\mathrm{SO}_{4}{ }^{2-}, \mathrm{HSO}_{4}{ }^{-}$e $\mathrm{H}_{2} \mathrm{SO}_{4}$ coexistem, mas somente o ânion bissulfato ou ácido sulfúrico reagem com radical hidroxila para produzir in situ o radical sulfato. Este, por sua vez, em alta concentração pode favorecer a sua combinação e formar o ânion persulfato (Equações 6, 7 e 8).

$$
\mathrm{HSO}_{4}{ }^{-}+\mathrm{HO} \bullet \rightarrow \mathrm{SO}_{4}{ }^{-}+\mathrm{H}_{2} \mathrm{O}
$$




$$
\begin{aligned}
& \mathrm{H}_{2} \mathrm{SO}_{4}+\mathrm{HO} \bullet \rightarrow \mathrm{SO}_{4} \bullet^{-}+\mathrm{H}_{3} \mathrm{O}^{+} \\
& \mathrm{SO}_{4}{ }^{--}+\mathrm{SO}_{4}{ }^{--} \rightarrow \mathrm{S}_{2} \mathrm{O}_{8}^{2-}
\end{aligned}
$$

\subsection{FONTES DE ENERGIA ALTERNATIVAS RENOVÅVEIS}

Um dos principais desafios para o uso da tecnologia eletroquímica no tratamento de efluentes domésticos e industriais é a energia necessária para alimentar o sistema. Linhas de pesquisa são dedicadas ao estudo de otimização de novos ânodos e reatores para que a eficiência do tratamento seja cada vez maior. Porém, mesmo com esses esforços, a energia ainda é um fator limitante para a implantação de tecnologia eletroquímica em larga escala.

A Figura 3 apresenta o número de publicações com o uso de sistemas com tecnologia eletroquímica alimentado com energia renovável.

Figura 3 - Número de publicações por ano de acordo com a palavra-chave "renewable energy" e "electrochemical" entre 1998-2020 no Science Direct.

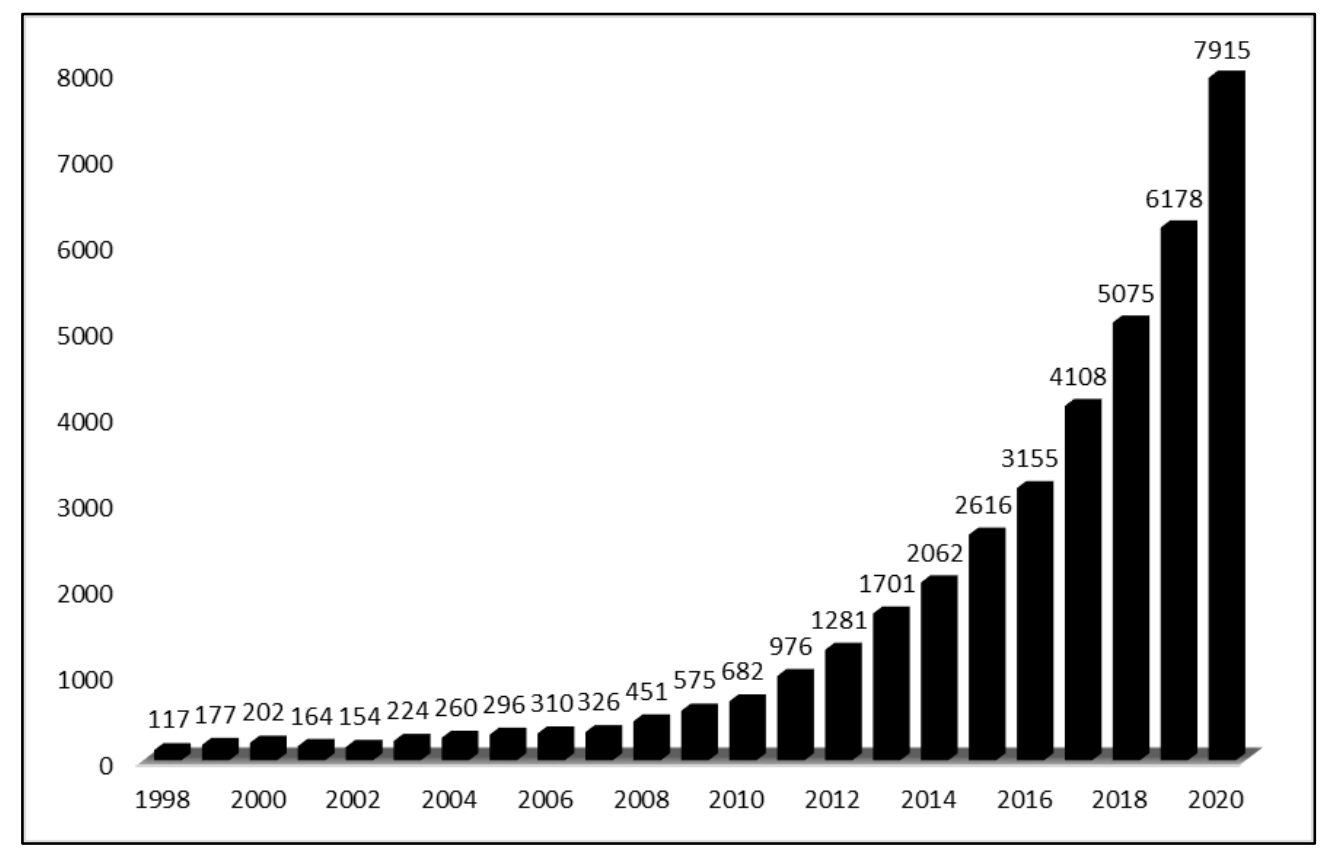

Fonte: Autoria própria.

É possível observar um aumento exponencial no número de trabalhos, indicando uma alternativa bastante promissora no tratamento de efluentes. Em escala de laboratório é possível encontrar diversos estudos na literatura utilizando tecnologias 
eletroquímicas no tratamento de efluentes com fonte de energia fotovoltaica. $\mathrm{Na}$ literatura é possível encontrar vários trabalhos dedicados a revisar de forma crítica os conceitos fundamentais e aplicações de tecnologias eletroquímicas movidas a energias renováveis para o tratamento de poluentes perigosos em águas residuais e solos contaminados. (GANIYU; MARTÍNEZ-HUITLE; RODRIGO, 2020b; KUMAR; PAN, 2020; GANIYU; MARTINEZ-HUITLE, 2020a)

Atualmente $83 \%$ da matriz elétrica brasileira é originada de fontes renováveis, sendo composta por geração hidrelétrica $(63,8 \%)$, seguida de fóssil $(16,6 \%)$, eólica (9,3\%), biomassa e biogás (8,9\%) e solar (1,4\%) (MINISTÉRIO DE MINAS E ENERGIA, 2021). Em 2006, o Brasil inverteu a balança de importação de petróleo e hoje tem a possibilidade de se tornar um grande produtor de combustíveis fósseis com atuação internacional. Além disso, o Brasil faz parte do grupo de países em que a produção de eletricidade é proveniente, na sua maior parte, de usinas hidrelétricas. Porém, de acordo com estudo publicado por pesquisadores da UTFPR já apontava em 2008 que com a demanda cada vez maior de energia, as formas de geração de energia por hidrelétrica e combustíveis fósseis estão próximas do potencial máximo de exploração (BRONZATTI; NETO, 2008). Para compor esse novo quadro de matriz energética, existe um enorme potencial nas fontes renováveis, como a biomassa, energia eólica e solar.

Em relação à energia eólica, o Brasil possui um potencial de $143 \mathrm{GW}$ (CRESESB/CEPEL). Já em relação à energia solar, o país tem capacidade para alimentar o equivalente a 170 países de mesmo tamanho, recebendo entre $4.444 \mathrm{Wh} / \mathrm{m}^{2}$ a 5.483 $\mathrm{Wh} / \mathrm{m}^{2}$ de radiação solar diariamente (GLOBAL SOLAR ATLAS, 2021). Os dados indicam fortemente que energia solar e eólica se destacam como estratégias em um planejamento de longo-prazo para a diversificação das matrizes energéticas. A possibilidade de implementação de placas fotovoltaicas surgiu no final de 2012 e de acordo com o relatório Power Transition Trends 2020 do Bloomberg NEF (HENZE, 2020), solar e eólica juntas, foram responsáveis por $67 \%$ da capacidade de geração adicionada à rede elétrica do mundo, em 2019. Do ponto de vista econômico as fontes, eólica e solar, estão entre as mais competitivas. Já em relação à questão socioambiental estão disparadas na frente das demais alternativas, como as mais atrativas. 
Existe potencial a ser aproveitado, no entanto, é necessário investimentos em tecnologia para redução dos custos de implantação e geração e financiamentos mais acessíveis. A energia solar apresenta uma vantagem sobre as demais fontes que é sobre sua adaptabilidade de acordo com cada realidade. Atualmente no Brasil estes sistemas alternativos de geração de energia já são realidade em casas, empresas, indústrias e no agronegócio. Estes sistemas de geração de energia poderiam ser implementados de acordo com o consumo de energia específico de cada estação de tratamento através do número de placas fotovoltaicas a serem instaladas.

\section{CONSIDERAÇÕES FINAIS}

Com contaminantes cada vez mais diversificados compondo os efluentes, buscase implementar tecnologias alternativas cada vez mais eficazes para o tratamento dos efluentes gerados, frente aos tratamentos convencionais. Uma das formas mais promissoras é o uso de POAs. Porém, estudos levantados indicam que, um dos principais fatores limitantes para seu uso em larga escala é sua fonte de alimentação. Diferentes fontes de energias alternativas renováveis são estudadas a décadas, porém faltam investimentos no setor para que a adaptação comercial e sua implementação em larga escala seja realizada. Dentre as opções de fontes de energias renováveis (solar, eólica e biomassa), a energia solar captada por meio de painéis e/ou placas fotovoltaicas e utilizada para alimentar um sistema eletroquímico, apresenta um maior percentual de crescimento nos últimos anos. Porém, mesmo com essa tendência, ainda são necessárias reduções nos custos de implantação e políticas específicas para a oferta de financiamentos mais acessíveis.

\section{AGRADECIMENTOS}

Agradeço em primeiro lugar a Deus por me guiar e dar forças para que eu possa cada vez mais crescer e evoluir de forma a atingir todos meus objetivos. Agradeço ainda, toda minha família e namorada pelo apoio incondicional nos momentos mais difíceis, que pensei em desistir pelas dificuldades ao longo dessa caminhada. Agradeço todos meus professores e mestres, especialmente meu professor orientador por toda paciência e conhecimentos compartilhados ao longo das diversas etapas, que foram 
fundamentais para conclusão dessa jornada tão importante. A todos, meu muito obrigado. Os autores agradecem, adicionalmente, as agências de fomento FAPEMIG, CNPq e CAPES.

\section{REFERÊNCIAS}

BEIGBEDER, J-P.; BOBOESCU, L. Z.; LAVOIE, J-M. Treatment and valorization of municipal solid waste gasification effluent through a combined advanced oxidation microalgal phytoremediation approach. Journal of Cleaner Production, v. 299, p. 126926, 2021.

BRILLAS, E. A review on the photoelectro-Fenton process as efficient electrochemical advanced oxidation for wastewater remediation. Treatment with UV light, sunlight, and coupling with conventional and other photo-assisted advanced technologies. Chemosphere, v. 250, p. 126198, 2020.

BRILLAS, E; MARTINEZ-HUITLE, C. A. Descontamination of wastewaters containing syntetic organic dyes by electrochemical methods. An update review. Applied catalysis B: Environmental, v. 166-167, p. 603-643, 2015.

BRONZATTI, F. L.; NETO, A. I.; Matrizes energéticas no Brasil: Cenário 2010-2030. Anais do XXVIII Encontro Nacional de Engenharia de Produção, 2008. Disponível em: http://www.abepro.org.br/biblioteca/enegep2008_tn_sto_077_541_11890.pdf . Acesso em: 03 mar. 2021.

CAI, J. et al., Degradação eletroquímica extremamente eficiente de poluentes orgânicos

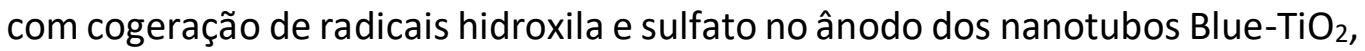
Catálise B aplicada: Ambiental, v. 257, p. 117902, 2019.

CARTAXO, A. S. B. et al. Contaminantes emergentes presentes em águas destinadas ao consumo humano: ocorrência, implicações e tecnologias de tratamento. Brazilian Journal of Development, v. 6, n. 8, p. 14, 2020.

CHANIKYA, P. et al. Treatment of dyeing wastewater by combined sulfate radical based electrochemical advanced oxidation and electrocoagulation processes, Separation and Purification Technology, v. 254, p. 117570, 2021.

CHEN, L. et al. Electrochemical activation of sulfate by BDD anode in basic medium for efficient removal of organic pollutants. Chemosphere, v. 210, p. 516-523, 2018.

CHEN, F. et al. Catalytic degradation of ciprofloxacin by a visible-light-assisted peroxymonosulfate activation system: Performance and mechanism. Water research, v. 173, p. 115559, 2020. 
CONAMA - CONSELHO NACIONAL DO MEIO AMBIENTE. Resolução CONAMA 430/2011 - Dispõe sobre as condições e padrões de lançamento de efluentes. Brasil, 2011.

DEVI, P; DAS, U; DALAI, A. K. In-situ chemical oxidation: Principle and applications of peroxide and persulfate treatments in wastewater systems. Science of the total environment, v. 571, p. 643-657, 2016.

DEWIL, R. et al. New perspectives for Advanced Oxidation Processes. Journal of environmental management, v. 195-2, p. 93-99, 2017.

DIVYAPRIYA, G.; NIDHEESH, P. V., Electrochemically generated sulfate radicals by boron doped diamond and its environmental applications, Current Opinion in Solid State and Materials Science, v. 25, p. 100921, 2021.

FANAEI, F.; MOUSSAVI, G.; SHEKOOHIYAN, S. Enhanced treatment of the oilcontaminated soil using biosurfactant-assisted washing operation combined with $\mathrm{H}_{2} \mathrm{O}_{2}$-stimulated biotreatment of the effluent. Journal of Environmental Management, v. 271, p. 110941, 2020.

HE, L. et al. Synergistic heat/UV activated persulfate for the treatment of nanofiltration concentrated leachate. Ecotoxicology and Environmental Safety, v. 208, p. 111522, 2021.

ERKAN, H. S.; ENGIN, G. O., A comparative study of waste activated sludge disintegration by electrochemical pretreatment process combined with hydroxyl and sulfate radical based oxidants, Journal of Environmental Chemical Engineering, v. 8, p. 103918, 2020.

GANIYU, S. O.; MARTÍNEZ-HUITLE, C. A. The use of renewable energies driving electrochemical technologies for environmental applications. Current opinion in electrochemistry, v. 22, p. 211-220, 2020a.

GANIYU, S. O.; MARTÍNEZ-HUITLE, C. A.; RODRIGO, M. A. Renewable energies driven electrochemical wastewater/soil decontamination technologies: A critical review of fundamental concepts and applications. Applied Catalysis B: Environmental, v. 270, p. $118857,2020 b$.

GANIYU, S. O.; MARTÍNEZ-HUITLE, C. A.; OTURAN, M. A. Electrochemical advanced oxidation processes for wastewater treatment: Advances in formation and detection of reactive species and mechanisms. Current Opinion in Electrochemistry, V. 27, p. 100678, 2021.

GARCIA-SEGURA. S; OCON, J. D; CHONG, M, N. Electrochemical oxidation remediation of real wastewater effluents - A review. Process safety and environmental protection, v. 13, p 48-67, 2018. 
GIANNAKIS, S.; LIN, K-Y. A.; GHANBARI, F. A review of the recent advances on the treatment of industrial wastewaters by Sulfate Radical-based Advanced Oxidation Processes (SR-AOPs), Chemical Engineering Journal, v. 406, p. 127083, 2021.

GUJAR, S. K.; GOGATE, P. R., Application of hybrid oxidative processes based on cavitation for the treatment of commercial dye industry effluents. Ultrasonics Sonochemistry, v. 75, p. 105586, 2021.

GLOBAL SOLAR ATLAS, 2021. Solar power potential and solar resources globally. Disponível em: https://globalsolaratlas.info/map?c=36.173357,-5.625,2. Acesso em: 03 mar. 2021.

HADI, S. et al., Advanced oxidation of 4-chlorophenol via combined pulsed light and sulfate radicals methods: Effect of co-existing anions, Journal of Environmental Management, v. 291, p. 112595, 2021.

HASANPOUR, M; HATAMI, M. Photocatalytic performance of aerogels for organic dyes removal from wastewaters: Review study. Journal of molecular liquids, v. 309, p. 113094, 2020.

HENZE, V. Solar and Wind Reach 67\% of New Power Capacity Added Globally in 2019, while Fossil Fuels Slide to 25\%, 2020. Disponível em: https://about.bnef.com/blog/solar-and-wind-reach-67-of-new-power-capacityadded-globally-in-2019-while-fossil-fuels-slide-to-25/. Acesso em: 03 mar. 2021.

HOU, X. et al. Persulfate activation induced by ascorbic acid for efficient organic pollutants oxidation. Chemical Engineering Journal, v. 382, p. 122355, 2019.

HOU, K. et al. A critical review on the mechanisms of persulfate activation by iron-based materials: Clarifying some ambiguity and controversies. Chemical Engineering Journal, v. 407, p. 127078, 2021.

KUMAR, A.; PAN, S.-Y. Opportunities and challenges of electrochemical water treatment integrated with renewable energy at the water-energy nexus. Water-energy nexus, v. 3, p. 110-116, 2020.

LIU, G.; ZHOU, H.; TENGA, J.; YOU, S. Electrochemical degradation of perfluorooctanoic acid by macro-porous titanium suboxide anode in the presence of sulfate. Chemical Engineering Journal, v. 371, p. 7-14, 2019.

MATZEK, L. W; CARTER, K. E. Activated persulfate for organic chemical degradation: A review. Chemosphere, v. 151, p. 178-188, 2016.

MINISTÉRIO DE MINAS E ENERGIA. Fontes de energia renováveis representam 83\% da matriz elétrica brasileira. Governo do Brasil, 2021. Disponível em: https://www.gov.br/pt-br/noticias/energia-minerais-e- 
combustiveis/2020/01/fontes-de-energia-renovaveis-representam-83-damatriz-eletrica-brasileira. Acesso em: 03 mar. 2021.

MOSTAFA, E.; BALTRUSCHAT, H.; GARCIA-SEGURA, S., Unraveling the role of electrolytes during electrochemical oxidation by differential electrochemical mass spectrometry, Electrochimica Acta, In Press, p. 138521, 2021.

PAN, Z. et al. Membrane technology coupled with electrochemical advanced oxidation processes for organic wastewater treatment: Recent advances and future prospects. Chemical Engineering Journal, v. 376, p. 120909, 2019.

RAMBABU, K. et al. Biological remediation of acid mine drainage: Review of past trends and current outlook, Environmental science and ecotechnology, v. 2, p. 100024, 2020.

RAMOS, J. M. P. et al. Printing ink efluente remediation: A comparsion between electrochemical and Fenton treatments. Jounal of water process engineering, $\mathrm{v}$. 31, p. 100803, 2019.

SAAD, M. S.; WIRZAL, M. D. H.; PUTRA, Z. A., Review on current approach for treatment of palm oil mill effluent: Integrated system. Journal of Environmental Management, v. 286, p. 112209, 2021.

SANTOS, G. O. S.; EGUILUZ, K. I. B.; SALAZAR-BANDA, G. R.; SÁEZ, C.; RODRIGO, M. A., Understanding the electrolytic generation of sulfate and chlorine oxidative species with different boron-doped diamond anodes, Journal of Electroanalytical Chemistry, v. 857, p. 113756, 2020.

SERNA-GALVIS, E. A.; TORRES-PALMA, R. A. Recent developments in sonochemical treatments of contaminated wastewaters. In: SHARMA, S. K. Green Chemistry and Water Remediation: Research and Applications. Cambridge: Elsevier, 2021, p. $299-315$.

SHARMA, S.; SIMSEK, H., Treatment of canola-oil refinery effluent using electrochemical methods: A comparison between combined electrocoagulation + electrooxidation and electrochemical peroxidation methods. Chemosphere, v. 221, p. 630-639, 2019.

SHIN, Y-U. et al. Electrochemical oxidation of organics in sulfate solutions on borondoped diamond electrode: Multiple pathways for sulfate radical generation, Applied Catalysis B: Environmental, v. 254, p. 156-165, 2019.

SU et al. Advanced treatment of secondary effluent organic matters (EfOM) from an industrial park wastewater treatment plant by Fenton oxidation combining with biological aerated filter. Science of The Total Environment, v. 784, p. 147204, 2021. 
WACLAWEK, S. et al. Chemistry of persulfates in water and wastewater treatment: A review. Chemical engineering journal, v. 330, p. 44-62, 2017.

Wang, W. et al., Different activation methods in sulfate radical-based oxidation for organic pollutants degradation: Catalytic mechanism and toxicity assessment of degradation intermediates, Science of The Total Environment, v. 772, p. 145522, 2021.

WANG, B., LI, Y.-N., WANG, L. Metal-free activation of persulfates by corn stalk biochar for the degradation of antibiotic norfloxacin: activation factors and degradation mechanism. Chemosphere, v. 237, p. 124454, 2019.

WANG, J; WANG, S. Activation of persulfate (PS) and peroxymonosulfate (PMS) and application for the degradation of emerging contaminants. Chemical engineering journal, v. 334, p. 1502-1517, 2018.

YANG, L. et al. Persulfate-based degradation of perfluorooctanoic acid (PFOA) and perfluorooctane sulfonate (PFOS) in aqueous solution: Review on influences, mechanisms and prospective. Journal of hazardous materials, v. 393, p. 122405, 2020.

YANG, L; XUE, L; HE, L; WU, L; MA, Y; CHEN, H. et al. Z. Review on ultrasound assisted persulfate degradation of organic contaminants in wastewater: Influences, mechanisms and prospective. Chemical engineering journal, v. 378, p. 122146, 2019.

Yabalak, E. Treatment of agrochemical wastewater by thermally activated persulfate oxidation method: Evaluation of energy and reagent consumption. Journal of Environmental Chemical Engineering, v. 9, n. 3, p. 105201, 2021.

YU, Y. et al. Degradation of diuron by electrochemically activated persulfate. Water. Air. Soil, v. 227, p. 1-9, 2016. 


\section{CAPITULO XXXIV}

\section{A INFFUUÊNCIA DA ÁGUA NA QUEBRA DE DORMÊNCIA DA TECTONA GRANDIS LF}

\section{DOI: 10.51859/amplla.mas481.1121-34}

Marcos Willian dos Santos Farias ${ }^{1}$

Natiely de Araújo Silva Farias ${ }^{2}$

\footnotetext{
1 Bacharel e Licenciado em Ciências Biológicas. Faculdade de Ciências Biomédicas de Cacoal - FACIMED.

${ }^{2}$ Farmacêutica Residente em Saúde da Família. Programa de Residência Multiprofissional em Saúde da Família da Fundação Universidade Federal de Rondônia - UNIR/RO.
}

\section{RESUMO}

Tectona grandis L.f (Teca), é uma espécie exótica no Brasil, bem adaptada à região Norte e utilizada desde 1994 no reflorestamento. Esta espécie tem grande procura no mercado internacional pela qualidade da madeira. O processo de germinação da teca é irregular, para obter ótimos resultados na germinação é necessário um clima seco. Este estudo teve como objetivo analisar a influência da água na quebra de dormência da espécie Tectona grandis L.f. Foram realizados três experimentos de quebra de dormência da teca, em todos os experimentos foram substituídas a água a cada 6 horas, as sementes foram diferenciadas por tempo de permanência na água. 0 primeiro experimento permaneceu por 72 horas no recipiente, o segundo permaneceu 48 horas no recipiente, o terceiro permaneceu 24 horas. Após esta primeira fase da quebra de dormência na água, as sementes foram postas em um canteiro de areia média, misturadas com pó de serra. Após 90 dias de experimento não houve nenhuma semente germinada nos três experimentos. Possivelmente o principal fator inibidor da germinação foram as chuvas que ocorreram no período e a presença de uma frente fria. Conclui-se que as sementes germinam com altas temperaturas. Sendo assim as chuvas que ocorreram no início do experimento podem ter influenciado na germinação, fazendo com que as sementes ficassem saturadas. Portanto, para obter ótimos resultados na germinação, faz-se necessário realizar o experimento na época de estiagem, com poucas probabilidades de chuvas.

Palavras-chave: Germinação. Madeira. Teca. Verbenaceae.

\section{INTRODUÇÃO}

Nos últimos anos foram plantados no Brasil diversas espécies de árvores, através de programas de reflorestamento, com a criação de incentivos concedidos pelo governo 
federal, o que resultou no plantio de grandes áreas formadas com acelerado crescimento vegetativo (MOTTA, 2011).

A madeira da teca tem um alto valor comercial pela sua qualidade e resistência, apresentando vasta importância no setor madeireiro e construção naval, por isso é amplamente utilizada no reflorestamento em várias partes do mundo (FIGUEIREDO, 2005).

A teca foi introduzida no Brasil, com a finalidade de reposição florestal, sendo muito utilizada na Região Norte desde 1994. Atendendo a legislação ambiental vigente, que exigia uma espécie com fácil adaptação para reflorestamento, repondo as áreas que foram desmatadas. A espécie na região tornou-se a preferida, pelo seu valor comercial e por seu desenvolvimento mais rápido do que as espécies nativas (FIGUEIREDO, 2005).

Segundo Cáceres Florestal (1997), o clima que favorece o desenvolvimento da teca é o tropical úmido, com verão chuvoso e inverno seco, sendo seguido por vários fatores, tais como: A precipitação anual: entre $1.250 \mathrm{~mm}$ a $2.500 \mathrm{~mm}$, período seco em média de três a cinco meses, favorecendo a qualidade da madeira.

Sendo assim, o presente estudo tem como objetivo analisar a influência da água na quebra de dormência da espécie Tectona grandis L.f.

\section{REFERENCIAL TEÓRICO}

A teca, conhecida cientificamente como Tectona grandis L.f. classificada na família botânica Verbenaceae, é originária de florestas tropicais, ocorre principalmente na Índia, Burma, Mianmar, Tailândia, Laos incluindo a Indonésia, particularmente em Java, mas foi introduzida em diversos outros países. No entanto é considerada exótica no Brasil, apresenta altura de 20 a 30 metros (LORENZI et al. 2003). A madeira desta espécie tem como vantagem a grande aceitação no mercado mundial (REMADE, 2004; USDA, 2010).

O principal produto dessa espécie é a qualidade da madeira, sendo utilizada em diversos setores comerciais, tais como: carpintaria, produção de peças e móveis finos, marcenaria e construção naval. Tudo isso deve-se pelo fato de resistir ao sol, calor e umidade extrema (RONDON; MACEDO; TSUKAMOTO, 1998). 
A madeira da teca é valorizada por apresentar grande resistência em relação ao peso, flexão, quanto a tração e outros esforços mecânicos na produção de móveis, oferecendo leveza e alta resistência, além de apresentar características estéticas e alta durabilidade natural. (MOTTA, 2011).

O seu plantio, tem como principal objetivo a produção de madeira para serraria. A espécie começou a ganhar importância no século XVIII, quando os britânicos a utilizavam para a construção naval (FIGUEIREDO, 2001).

Entre os maiores produtores da teca destaca-se os países: Indonésia, Mianmar e Sri Lanka, e os maiores importadores da madeira encontram-se a Alemanha, Austrália, Japão, Itália e Reino Unido. O Brasil apresenta um mercado de grande consumo e produção, além de possuir áreas ideais para o plantio, decorrentes de uma floresta tropical existente (SEMENTES CAIÇARA, 2010).

Angeli e Stape (2003), afirmam que a teca é uma espécie com ótima adaptação a vários ambientes, tolerando uma precipitação anual de 800 a 2.500 mm, e a temperatura de $2{ }^{\circ} \mathrm{C}$ a $42{ }^{\circ} \mathrm{C}$, porém não resiste a geadas. As folhas podem obter disposição oposta, sendo em grupo de três, são as coriáceas e podem medir cerca de 30 a $60 \mathrm{~cm}$ de comprimento por 20 a $35 \mathrm{~cm}$ de largura.

O elemento água é de extrema importância para o crescimento e desenvolvimento da espécie, podendo estar presente nas porções de madeira verde, na forma livre nos lumes das células e na forma impregnada nas paredes das células (SZUCS et al. 2016)

Calil Junior et al. (2000) destaca que a umidade da madeira é facilmente entendida quando se relaciona à fisiologia da espécie Tectona grandis L.f., que desde a absorção de água e nutrientes do solo pelas raízes até as folhas, compondo a seiva bruta, e das folhas até as raízes, compondo a seiva elaborada, composta por água e substâncias produzidas pela fotossíntese.

De acordo com Lima Júnior et al. (2008) há uma influência direta da umidade em algumas propriedades de resistência da madeira, e desta forma afeta o seu grau de utilidade, rendimento e qualidade da celulose, reduzindo seu poder calorífico e aumentando a susceptibilidade da madeira ao ataque de fungos.

O teor de umidade da madeira é de fácil determinação, e expressa em porcentagem a quantidade de água existente nos vazios de sua estrutura. Para esta 
determinação realiza a pesagem de amostras em condição úmida e após secagem em estufa, sob temperatura constante de $103 \pm 2{ }^{\circ} \mathrm{C}$ ou pode ser feito por meio de técnicas não destrutivas, utilizando medidores elétricos (OLIVEIRA, 2007).

Deste modo a madeira quando exposta ao meio ambiente sofre influências das variações de temperatura e umidade, além de ação das substâncias químicas e biológicas como organismos vivos tais como: fungos, bactérias e insetos. Podendo ocasionar deteriorações nos seus componentes impactando negativamente a sua qualidade (SGAI, 2000).

A durabilidade natural da madeira determina sua utilização, principalmente em regiões de clima tropical, onde as condições de temperatura e umidade proporcionam ótimas condições para o desenvolvimento de fungos e insetos, que em sua maioria utilizam a madeira como única ou principal fonte de alimento. Estes organismos têm uma atividade tão intensa que o ataque pode ocorrer até em uma árvore viva (ROCHA, 2001).

Segundo dados da Associação Brasileira de Produtores de Florestas Plantadas (ABRAF), no Brasil em 2009, teve uma área de 65.240 hectares plantados; dentre os Estados com maiores plantações estão: Mato Grosso, Amazonas e Acre (ABRAF 2009).

Um estudo realizado por Vieira (2017), demonstra que há 16 plantios particulares instalados nas principais regiões do Estado de Rondônia indicando resultados promissores para a implantação de reflorestamentos com teca no Estado.

A Tectona grandis encontra-se entre as preferidas para o reflorestamento, para a produção de madeira sólida e laminados, estando distribuídos pelo mundo. Sua madeira é considerada imune à ação dos fungos, bactérias e insetos, podendo ser enterrada, exposta ao tempo ou à água do mar sem sofrer grandes danos. (MOTTA, 2011).

Nos últimos anos houve um aumento significativo no plantio da teca no Brasil (SCHUHLI; PALUDZYSZYN, 2010). No entanto, apesar de variados estudos realizados em todo o mundo, ainda são escassos no Brasil pesquisas que avaliem o período de ciclo de produção da espécie (TONINI et al., 2009). 


\section{MATERIAIS E MÉTODOS}

Trata-se de uma pesquisa experimental, descritiva e longitudinal de caráter randomizado. Para o desenvolvimento do estudo utilizou-se 300 unidades de sementes da Tectonas grandis.

Os experimentos foram realizados entre os meses de junho a setembro de 2017, em um viveiro de reflorestamento localizado no município de Rolim de Moura no estado de Rondônia.

Os procedimentos foram executados conforme descreve estudo realizado por Cáceres Florestal (1997), em que foram divididas em três lotes, contendo 100 sementes cada.

Primeiro lote: Foram adicionadas 100 sementes em um recipiente de plástico contendo 7 litros de água, em temperatura ambiente, durante 72 horas. Foram realizadas a substituição da água a cada 6 horas. Após o tempo estipulado utilizou-se um total de 84 litros de água.

Segundo lote: Foram adicionadas 100 sementes em um recipiente de plástico contendo 7 litros de água, em temperatura ambiente, durante 48 horas. Foram realizadas a substituição da água a cada 6 horas. Após o tempo estipulado utilizou-se um total de 56 litros de água.

Terceiro lote: Foram adicionadas 100 sementes em um recipiente de plástico contendo 7 litros de água, em temperatura ambiente, durante 24 horas. Foram realizadas a substituição da água a cada 6 horas. Após o tempo estipulado utilizou-se um total de 28 litros de água.

Ao término do período estipulado de hidratação das sementes em cada lote, as mesmas foram separadas de acordo com cada lote pertencente e postas em um canteiro de areia média, misturado com pó de serra.

As sementes permaneceram com $1 \mathrm{~cm}$ de profundidade do solo e $2 \mathrm{~cm}$ de distância umas das outras. Logo em seguida colocou-se uma lona plástica de polietileno da cor preta sobre as sementes, a qual permaneceu por mais dois dias. A lona preta tem como objetivo principal realizar o aquecimento do canteiro posto as sementes e despertar a germinação da teca. 
Passados os dois dias, a lona de polietileno foi retirada, sendo iniciado a análise do experimento.

O experimento foi acompanhamento durante 90 dias, sendo vistoriado uma vez ao dia. A irrigação era ativada diariamente em forma de aspersão, no período da tarde, durante 7 minutos.

Durante o monitoramento do experimento, foram observados que o canteiro se encontrava úmido por 2 dias toda vez que chovia. Passados os 90 dias do experimento, as sementes foram retiradas do canteiro.

\section{RESULTADOS E DISCUSSÃO}

Observou-se que todas as sementes se encontravam podres e encharcadas. Após o período de 90 dias, não verificou-se a germinação de nenhuma semente. Durante o tempo do experimento houve uma frente fria nos dois primeiros dias e duas chuvas em um intervalo de 10 dias, fazendo com que o canteiro ficasse umedecido e consequentemente as sementes não germinasse. Possivelmente, essas estocasticidades ambientais ocasionaram a não germinação das sementes.

A germinação da teca é um processo demorado e irregular, necessitando de umidade e calor para germinação, havendo chuvas e frente fria as sementes podem apodrecer. A temperatura do solo não deve ficar abaixo da temperatura ambiente, pois para obter uma ótima porcentagem de germinação, é necessário o aumento significativo da temperatura (CÁCERES FLORESTAL, 1997).

O contato com a água em excesso ou temperatura extremamente baixas ocasiona a morte do embrião da teca, pela ação do calor úmido, ocorrendo maior penetração na semente do que o calor seco, afetando a germinação (VIEIRA et al., 2009).

Conforme Cáceres Florestal (1997), existem várias técnicas de quebra de dormência da teca, podendo obter ótimos resultados na germinação. Tais como realizar a quebra de dormência com escarificação mecânica, uso de produtos químicos e água quente, resultando em uma porcentagem maior de germinação. 


\section{CONSIDERAÇÕES FINAIS}

O fator principal para a germinação da Tectona grandis L.f, é o clima quente. O solo onde for semeada as sementes, não pode encontrar-se abaixo de $25^{\circ} \mathrm{C}$. Havendo chuva, o canteiro pode ficar inundado, ocorrendo o calor úmido, consequentemente prejudicando a germinação da teca.

Portanto para a obtenção de resultados na germinação, sugere-se a realização do experimento na época de estiagem, no mês de agosto a outubro no respectivo estado de Rondônia, esses meses são mais favoráveis para a germinação da Tectona grandis L.f, devido ao clima quente e pouca probabilidade de chuvas.

\section{REFERÊNCIAS}

ANGELI A., STAPE J.L. Tectona grandis (Teca). IPEF-Instituto de Pesquisas e Estudos Florestais. Departamento de Ciências Florestais-ESALQ/USP (2003). Disponível: http://www.ipef.br/identificacao/tectona.grandis.asp

ABRAF. ASSOCIAÇÃO BRASILEIRA DE PRODUTORES DE FLORESTAS PLANTADAS. ano base 2009/ABRAF. Brasília, DF (2010). Pg: 38 Disponível: http://www.ipef.br/estatisticas/relatorios/anuario-ABRAF-2010-BR.pdf

CALIL JÚNIOR, C. et al. Estruturas de madeira. São Carlos: USP - Departamento de Engenharia de Estruturas, 101p, 2000.

FIGUEIREDO, E. O. Reflorestamento com Teca (Tectona grandis LF) no estado do Acre. Embrapa Acre. Documentos (2001). Embrapa, documentos 65, pg: 8. Disponível:http://www.almanaquedocampo.com.br/imagens/files/Teca\%20Em brapa\%20reflorestamento.pdf

FIGUEIREDO, E. O., OLIVEIRA, L. C., BARBOSA, L. K. F. Teca (Tectona grandis L. f.): principais perguntas do futuro empreendedor florestal. Embrapa Acre. Documentos (2005). Embrapa, documentos 97, pg: 18. Disponível: http://iquiri.cpafac.embrapa.br/pdf/doc97.pdf

FLORESTAL, CÁCERES. Manual do reflorestamento da Teca. Cáceres: Cáceres Florestal SA (1997).Disponível:http://www.caceresflorestal.com.br/Manual_do_cultivo_ da_teca Caceres_Florestal.pdf

LIMA JUNIOR, D. L. et al. Madeira de lei. Universidade do Amazonas - UNAMA. 27p. 2008. Disponível em: <http://www.ebah.com.br/madeira-de-lei- pdfa14501.html>. 
LORENZI, H. Árvores exóticas no Brasil: madeireiras, ornamentais e aromáticas. Instituto Plantarum de Estudos da Flora, 2003. Pág. 368.

MOTTA, J. Technological properties of teak (Tectona grandis L.f.) from the Vale do Rio Doce, Minas Gerais, Brasil. 2011. 126 f. Dissertação (Mestrado em Ciências Florestais) - Universidade Federal do Espírito Santo, Jerônimo Monteiro, 2011.

REMADE - REVISTA DA MADEIRA. Madeira - Teca. Qualidade e aspecto rústico agradam o mercado. Revista da madeira, n. 86, 2004.

RONDON NETO R.M., MACEDO R.L.G., TSUKAMOTO A.A. 1998. Formação de povoamentos florestais com Tectona grandis L.f. (Teca). Boletim Técnico Série Extensão 7 (33): 1-29.

SCHUHLI, G.S.; PALUDZYSZYN FILHO, E. O cenário da silvicultura de teca e perspectivas para o melhoramento genético. Pesquisa Florestal Brasileira, v.30, n.63, p.217230, $2010 . \quad$ Disponível em: <http://www.cnpf.embrapa.br/pfb/index.php/pfb/article/view/84/148>. Acesso em: 5 jun. 2011. doi: 10.4336/2010.pfb.30.63.217.

SEMENTES CAIÇARA. Teca. 2010. Disponível em: <http://www.sementesca icara.com.br/Sementes/Teca/steca.pdf>.

SGAI, R. D. Fatores que afetam o tratamento para preservação de madeiras. 2000. 130p. Dissertação (Mestrado em Engenharia Civil) - Universidade Estadual de Campinas, Faculdade de Engenharia Civil. Campinas, SP. 2000. Disponível em: <http://cutter.unicamp.br/document/?code=vtls000212330>. Acesso em: 11 nov. 2010.

SZÜCS, C. A. et al. Estruturas de madeira. Universidade Federal de Santa Catarina, Florianópolis. 2006. 186p.

TONINI, H. et al. Crescimento da teca (Tectona grandis) em reflorestamento na Amazônia Setentrional. Pesquisa Florestal Brasileira, n.59, p.05-14, 2009. Disponível em: <http://www.cnpf.embrapa.br/pfb/index.php/pfb/article/download/11/39>. Acesso em: 5 jun. 2011. doi: 10.4336/2009.pfb.59.05.

UNITED STATES DEPARTAMENT OF AGRICULTURE FOREST SERVICE - USDA FOREST SERVICE. Wood Technology Transfer Fact Sheet - Tectona grandis (Teak). Center for wood anatomy research. Research and Development: Forest Products Laboratory, Madison. 2010.2 Disponível: <http://www.fpl.fs.fed.us/documnts/TechSheets/Chudnoff/SEAsian_Oceanic/h t mIDocs_SEAsian/tectonagrandis.html>. Acesso em: 17 dez. 2010. 
VIEIRA, A.H. Ed.; (2007) Sistemas agroflorestais agroecológicos em Rondônia-classes de solos e crescimento de espécies florestais. Embrapa, documentos 30 pág. 14 a 17. Disponível://ainfo.cnptia.embrapa.br/digital/bitstream/item/55883/1/spteca.pdf

VIEIRA, A.H.; ROCHA, R. B.; REBELO, A. M. Avaliação de métodos para superação de dormência de diásporos de teca (Tectona grandis L. f.). Floresta, Curitiba, PR, v. 39, n. 2, p. 273-278, 2009. Disponivel: http://revistas.ufpr.br/floresta/article/viewFile/14555/9777 


\title{
CAPITULO XXXV
}

\section{IMPORTÂNICA DA QUANTIDADE E QUAUDADE DOS RECURSOS HÍDRICOS DE ÁGUA DOCE}

\section{DOI: 10.51859/amplla.mas481.1121-35}

\author{
Renata Raianny da Silva ${ }^{1}$ \\ Lucas Albuquerque Rosendo da Silva ${ }^{2}$ \\ Thayná Rhomana da Silva Cândido ${ }^{3}$ \\ Valberto Barbosa de Oliveira ${ }^{4}$ \\ Yslla Emanuelly da Silva Faccioli ${ }^{5}$ \\ Galba Maria de Campos Takaki ${ }^{6}$
}

\begin{abstract}
1,2,3,4,5 Programa de Pós-graduação Mestrado em Desenvolvimento de Processos Ambientais, Universidade Católica de Pernambuco - UNICAP. 50.050-900 Recife-PE, Brasil

${ }^{6}$ Pós-doutora em Microbiologia e Imunologia. Professora Titular da Universidade Católica de Pernambuco - UNICAP. 50.050-900 Recife-PE, Brasil
\end{abstract}

\section{RESUMO}

A água possui um grande valor econômico, social e ambiental. É fundamental ao bemestar do homem, dos ecossistemas e é um bem comum de toda humanidade. Apesar de ser um recurso natural abundante e renovável, é finito. Está presente em cerca de $70 \%$ da superfície terrestre onde a grande parte está nos oceanos e dos $2,5 \%$ do percentual restante de água doce, apenas uma pequena fração está disponível. A água doce superficial ocorre em lagos, rios e reservatórios, enquanto as águas subterrâneas estão em aquíferos no subsolo. A água é utilizada para os mais diversos fins, principalmente, o consumo humano, a agricultura e indústria, geração de energia, lazer, navegação e pesca. Estima-se que a quantidade total de água no Planeta Terra é de cerca de 1.386 milhões de $\mathrm{Km}^{3}$, porém, a parte que se encontra disponível corresponde a 0,007\% para uso humano, e não está distribuída igualmente, em toda a Terra. Menos de 10 países concentram $60 \%$ do suprimento global de água doce disponível. O Brasil dispõe cerca de $12 \%$ de água doce do mundo, apesar disso, as variações locais dentro dos próprios países podem ser muito significativas. Milhões de pessoas no mundo ainda coletam água não tratada, além da má distribuição, os recursos de água doce do mundo estão cada vez mais poluídos com resíduos orgânicos, micro-organismos patógenos, fertilizantes e pesticidas, metais pesados e outros poluentes. Nesta revisão apresenta também a degradação dos ecossistemas, como uma das principais causas dos crescentes desafios relativos à gestão da água.

Palavras-chave: Água. Ecossistemas. Meio Ambiente. 


\section{INTRODUÇÃO}

De acordo com a Academia Brasileira de Ciências (2014), a água é um recurso natural renovável essencial à vida, seu ciclo sustenta a biodiversidade e mantém o funcionamento dos ciclos nos ecossistemas, as comunidades e populações. Os recursos hídricos são essenciais, a disparidade no suprimento de água em regiões, nações e continentes causam grandes diferenças no processo de desenvolvimento e gera conflitos, desigualdades sociais e oportunidades diferentes em relação à saúde adequada, além de trabalho, renda e educação.

Os recursos hídricos de água doce são as águas superficiais ou subterrâneas que estão disponíveis para o uso nos mais diversos fins. As fontes hídricas são abundantes, porém mal distribuídas na superfície do planeta, possui uma grande importância e valor inestimável, em alguns locais. A retirada de água é maior que a oferta causando um desequilíbrio nos recursos hídricos que estão disponíveis. A água doce é, principalmente, o mais vulnerável dos recursos naturais. Os recursos hídricos têm sofrido diversas interferências antrópicas, o que tem ocasionado poluição e o comprometimento na qualidade de água (COSTA et al., 2012).

\section{A ÁGUA E SUA IMPORTÂNCIA}

A água é um recurso natural de valor inestimável, é abundante e renovável, porém, finito. A água está presente em aproximadamente $70 \%$ da superfície terrestre e é um bem de uso comum e essencial à vida na Terra, possui um ciclo que sustenta a biodiversidade e mantém os ecossistemas, as populações e as comunidades nos ambientes terrestres e aquáticos (LEITE, 2019; TALAMONI, 2019).

Na escala mundial, há uma grande diferença entre o volume de água salgada e a pequena fração de água doce (SOITO, 2019). A maior parte da água na Terra está nos oceanos. Uma pequena fração está presente na forma de vapor da água nas nuvens, a maior parte da água doce restante, está em estado sólido como gelo, massa de neve, geleiras e nas calotas polares. Uma pequena quantidade da água total da Terra está disponível para participar de processos na geosfera, atmosfera e biosfera. A água 
superficial ocorre em lagos, rios e reservatórios, enquanto as águas subterrâneas estão em aquíferos no subsolo (MANAHAN, 2016; MANAHAN, 2017).

De acordo com a Agência Nacional das Águas (ANA) e o Ministério do Meio Ambiente (MMA), estima-se que $97,5 \%$ da água existente no mundo estão nos oceanos, sendo salgada não é adequada ao consumo direto nem à irrigação da plantação. Dos 2,5\% da parcela de água doce grande parte, cerca de $68,9 \%$ é de difícil acesso, pois estão concentradas nas geleiras, calotas polares e regiões montanhosas; $29,9 \%$ são águas subterrâneas, ou seja, armazenadas em aquíferos; $0,9 \%$ compõe a umidade do solo e dos pântanos e $0,3 \%$ constitui a porção superficial de água doce presente em rios e lagos.

A presença da água na superfície terrestre se fundamenta no ciclo hidrológico, cujo resultado é o escoamento de $42.700 \mathrm{Km}^{3} /$ ano de água pelos rios, distribuídos de forma irregular, gerando áreas de notável abundância, como por exemplo, a Amazônia; e outras áreas de elevado estresse hídrico, como as regiões do norte da África e da Península Arábica (SILVA; PEREIRA, 2019).

A água é o composto inorgânico mais abundante e importante para todos os seres vivos, constitui cerca de 55 a $60 \%$ da massa corporal de um adulto magro. Com algumas poucas exceções, a água compõe a maior parte do volume das células e dos líquidos do corpo humano. A água é um solvente universal que transporta nutrientes, oxigênio e resíduos por todo o corpo, dissolve uma variedade de substâncias diferentes. É um meio ideal para as reações químicas, participando ativamente de algumas reações de síntese e de decomposição. A hidrólise, por exemplo, é uma reação das hidrolases que, na presença de água, permite com que os nutrientes da dieta sejam absorvidos pelo corpo (TORTORA; DERRICKSON, 2016).

A água no corpo também regula os efeitos das temperaturas ambientais, mantém a homeostasia da temperatura corporal. Quando a água presente no suor evapora da superfície da pele, leva grande quantidade de calor e propicia um excelente mecanismo de resfriamento. A água também atua como lubrificante, ela é o componente principal da saliva, do muco e de outros líquidos lubrificantes. A lubrificação é necessária nas cavidades torácica e abdominal, pois os órgãos internos encostam e deslizam uns sobre os outros, a água também é de grande importância nas 
articulações onde os ossos, ligamentos e tendões entram em atrito (TORTORA; DERRICKSON, 2016).

A água e os sais minerais contidos nela são básicos para uma nutrição equilibrada. Ela é fundamental para diversos processos dentro do organismo, como a reprodução das células e a eliminação de toxinas, sujeira e gordura. A água faz a limpeza do organismo, faz com que haja um bom funcionamento dos rins e intestinos, além de deixar a pele saudável. Um ser humano pode sobreviver até cinco semanas sem se alimentar, mas sem água sua sobrevivência não passa de uma semana (CASARIN; SANTOS, 2018).

A água e a hidrosfera são de grande importância para os processos envolvidos no destino e transporte químico no ambiente, esses processos podem ser físicos ou químicos. Os processos físicos incluem a volatilização, dissolução, precipitação, absorção e liberação ocorrida em sedimentos. Os processos químicos envolvidos no destino e transporte químicos na água são reações químicas que resultam em dissolução ou precipitação, hidrólise, complexação, oxidação-redução e reduções fotoquímicas. Tais processos sofrem grandes influências de fenômenos bioquímicos, como a bioacumulação, a biomagnificação em cadeias alimentares e a biodegradação (MANAHAN, 2016).

A água possui um grande valor econômico, social e ambiental, é fundamental ao bem-estar do homem, dos ecossistemas e um bem comum de toda humanidade (NOVICKI; CAMPOS, 2016). Segundo o Ministério do Meio Ambiente, a água é utilizada para os mais diversos fins, como utilização na agricultura e indústria, geração de energia, lazer, navegação e pesca.

Para que a água seja adequada ao consumo humano, deve apresentar características microbiológicas, físicas-químicas que atendam a um padrão de potabilidade estabelecido. O objetivo do exame microbiológico da água é fornecer subsídio a respeito da ausência de risco de ingestão de micro-organismos patogênicos (vírus, bactérias protozoários e helmintos), ou seja, causadores de doenças, que são provenientes da contaminação pelas fezes humanas e de animais de sangue quente. Nas análises físico-químicas são realizadas análises titulométricas, como alcalinidade total, gás carbônico livre, cloretos, pH; análises colorimétricas como cloro residual livre, cor, 
alumínio, turbidez, temperatura e fluoretos (FUNASA, 2013). Por isto, antes de chegar as casas, a água passa por estações de tratamento para ser realizados processos de desinfecção para garantir o consumo da água sem riscos à saúde.

A agricultura é a maior usuária de água do mundo, sendo responsável por cerca de $70 \%$ do total de água retirada para prover as demandas da humanidade, mas esse valor pode chegar a $95 \%$ em alguns países em desenvolvimento. O crescimento populacional exerce uma grande pressão sobre o uso da água, o desenvolvimento econômico e a saúde individual tem alterado o padrão das dietas da população, muitas dessas mudanças requer a utilização de mais água para sua produção. Para a produção de $1 \mathrm{~kg}$ de arroz são necessários 3.500 litros de água, para a produção de $1 \mathrm{~kg}$ de carne é utilizado cerca de 15.000 litros, enquanto para a produção de uma xícara de café, são necessários 140 litros (FAO, 2017; SILVA; PEREIRA, 2019).

Segundo o WWAP (2014), existe outro fator que pressiona o consumo de água na agricultura que é a demanda por produtos agrícolas para a produção de biocombustíveis. Como os biocombustíveis também de precisam de água para suas fases de transformação, o consumo de água para produzir combustíveis a partir de culturas irrigadas pode ser muito maior do que o utilizado na produção de combustíveis fósseis.

Segundo a Agência Nacional das Águas (ANA), a irrigação é uma atividade da agricultura adotada para suprir a carência total ou parcial da água utilizada para a produção. A agricultura irrigada é uma prática na qual seu uso é a que mais consome água no Brasil e no mundo. A utilização da água na indústria representa o terceiro maior uso, atrás do abastecimento humano urbano e da agricultura irrigada.

De acordo com a Agência Internacional de Energia (IEA), o fornecimento de energia depende da água, e a interdependência entre a água e a energia deve aumentar nos próximos anos, com grandes implicações para a segurança hídrica. A água enfrenta demandas e restrições crescentes em muitas regiões como consequência do crescimento econômico, populacional e das mudanças climáticas. Análises da IEA constataram que nos dias de hoje, o setor de energia retira um volume de cerca de 340 bilhões $\mathrm{m}^{3}$ de água removido de uma fonte. Atualmente, o setor de energia responder 
por $10 \%$ da captação de água no mundo. A água é essencial para todas as fases da produção de energia, de combustíveis fósseis a biocombustíveis e geração de energia.

\section{RECURSOS HIDRICOS DE ÅGUA DOCE}

A água doce é de grande importância para manutenção da vida. Ela está relacionada com a saúde e à dignidade humana. É um componente imprescindível para os ecossistemas, sendo responsável pela variação climática, manutenção dos rios, lagos e oceanos e cria condições favoráveis para o desenvolvimento de plantas e animais (RIBEIRO; ROLIM, 2017).

Ecossistemas relacionados à água doce como lagos, rios e pântanos com vegetação, estão entre os ambientes biologicamente diversos do mundo e oferecem múltiplos benefícios e serviços à sociedade. Além disso, eles fornecem um hábitat para quase $10 \%$ das espécies conhecidas no mundo, em ambientes áridos as fontes de água abrigam mais da metade das espécies, esses ecossistemas ajudam a sustentar os ciclos hidrológicos, de carbono e outros nutrientes globais (WAPP, 2020).

As águas subterrâneas são aquelas que são encontradas sob a superfície da Terra, preenchendo os espaços vazios que existem entre os grãos do solo, rochas e fissuras. Elas têm um importante papel no abastecimento, dando suporte aos ecossistemas e no funcionamento dos cursos d'água. Os aquíferos podem ser classificados segundo a sua posição e estrutura: Aquíferos livres são aqueles que se localizam mais próximos à superfície; Aquíferos confinados são aqueles que existe a presença de uma camada de menos permeabilidade (confinante), que submete as águas a uma pressão maior que a atmosférica; e, os Aquíferos semi-confinados possuem uma situação intermediária entre os dois anteriores. O acesso de seres humanos as água subterrâneas se dá por meio de perfuração de poços (MMA; SRHU, 2007; NOVO, 2018).

As águas subterrâneas possuem elevado padrão de qualidade físico-química e bacteriológica devido ser naturalmente protegidas dos agentes de poluição e contaminação. O nível da água nos aquíferos varia de acordo com a precipitação ocorrida, a extração de água subterrânea, os efeitos de maré nos aquíferos costeiros, variação súbita da pressão atmosférica principalmente no período de inverno, com as 
alterações do regime de escoamento de rios influentes que recarregam os aquíferos e a evaporação (ANA, 2014; MMA; SRHU, 2007).

Nas últimas décadas, em diversos países, tem-se tornado notório a relevância das águas subterrâneas, tanto para o abastecimento da população, quanto para os mais variados usos. A Figura 1 ilustra esquematicamente os recursos hídricos do planeta (MMA; SRHU, 2007). A Tabela 1 apresenta alguns aquíferos distribuídos nos diversos continentes.

Figura 1 - Mapa dos recursos hídricos do mundo

Principais bacias hidrogeológicas com aquiferos altamente produtivos.

Área com estrutura complexa incluindo alguns aquíferos. importantes

Área com aquíferos geralmente pobres, localmente coberto por aquíferos aluvionares

Gelo permanente

Lagos Grandes

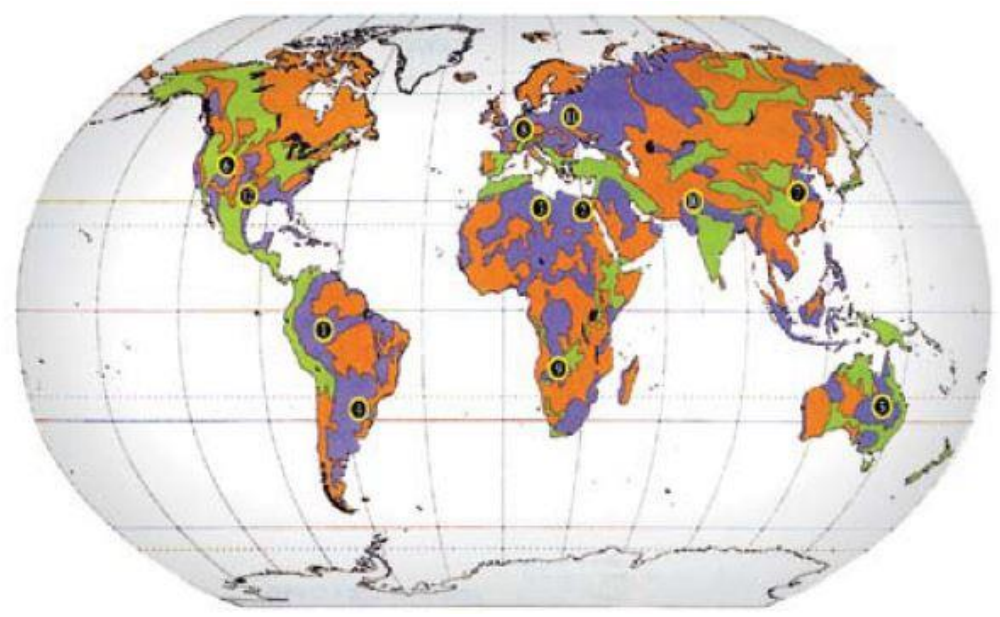

Fonte: MMA; SRHU, 2007. 
Tabela 2 - Os principais aquíferos apresentados por continente

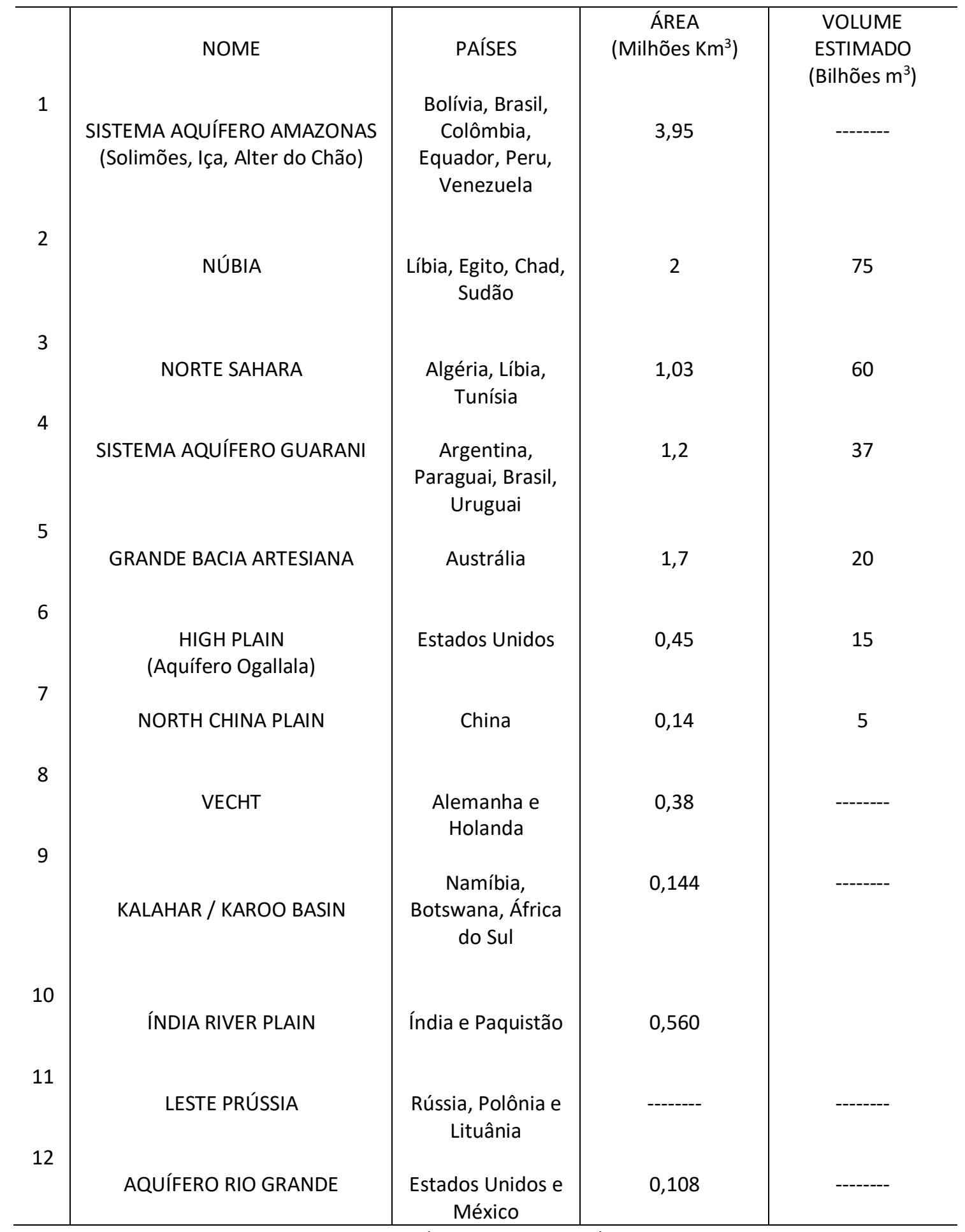

Fonte: (MMA; SRHU, 2007). 


\section{Distribuição de Água no planeta, Quantidade e Qualidade DISPONIVEL}

Estima-se que a quantidade total de água no Planeta Terra é de cerca de 1.386 milhões de $\mathrm{Km}^{3}$, e esse número tem se mantido de modo aproximadamente constante durante os últimos 500 milhões de anos. Todavia, as águas estocadas na Terra sob diferentes formas, em diferentes reservatórios, tiveram sua quantidade variada durante esse período. Dos $2,5 \%$ do total da água constituída por água doce grande parte é inacessível, sendo encontrado na forma de geleiras. Então, é considerado que as águas doces contidas em rios e lagos são as formas mais acessíveis ao uso humano e de ecossistemas, um percentual muito pequeno de água está disponível, correspondendo a $0,007 \%$ do volume total de água. Assim, embora a Terra apresente 1.386 milhões de $\mathrm{Km}^{3}$ de água, apenas 0,007\% está disponível para uso humano (PAZ, 2004).

De acordo com a ANA e CEBDS (2009), a água não está distribuída igualmente em toda a Terra. Menos de 10 países concentram $60 \%$ do suprimento global de água doce disponível. São eles: Brasil, Rússia, China, Canadá, Indonésia, Estados Unidos da América, Índia, Colômbia e a República Democrática do Congo. Apesar disso, variações locais dentro dos próprios países podem ser muito significativas.

De toda a água doce disponível para o consumo, 96\% é proveniente de águas subterrâneas. Elas são as responsáveis pela garantia da sobrevivência de grande parte da população ao redor do mundo. Países como Arábia Saudita, Dinamarca e Malta utilizam exclusivamente as águas subterrâneas para todo o abastecimento humano, enquanto que países como a Áustria, Alemanha, Bélgica, França, Hungria, Itália, Holanda, Marrocos, Rússia e Suíça, têm 70\% da demanda por água atendida por manancial hídrico subterrâneo (MMA; SRHU, 2007).

O Brasil dispõe em torno de $12 \%$ da água doce do mundo (CASARIN; SANTOS, 2018). Segundo o Instituto Brasileiro de Geografia e Estatísticas (2000), cerca de $55 \%$ dos estados brasileiros são abastecidos por água subterrânea. Cidades como Ribeirão Preto (SP), Maceió (AL), Mossoró (RN) e Manaus (AM), suprem todas as suas necessidades hídricas utilizando águas subterrâneas, além de atender as demandas da 
população, estes recursos são utilizados na indústria, na agricultura para a irrigação agrícola, lazer e outras atividades.

Devido à grande e crescente demanda, as águas subterrâneas estão sob forte pressão. A utilização de água em volume maior do que o reposto pela natureza pode causar a redução da quantidade de água que abastece os rios, pode ocasionar a seca de nascentes, o esgotamento dos reservatórios e vários outros impactos negativos (MMA; SRHU, 2007).

Mais de 2 bilhões de pessoas vivem em países com alto estresse hídrico. Embora o estresse hídrico médio global seja de 11\%, estimativas recentes mostram que 31 países experimentam o estresse hídrico entre $25 \%$ (que é o percentual definido como limite mínimo de estresse hídrico) e 70\%, outros 22 países estão acima do nível de 70\% e se encontram em um nível grave de estresse hídrico (UN, 2018).

O uso da água tem aumentado no mundo inteiro em cerca de $1 \%$ por ano desde a década de 80. A demanda mundial por água continuará aumentando a um percentual similar até 2050. Esse aumento constante é liderado principalmente pela demanda crescente em países em desenvolvimento e economias emergentes. Porém, o uso de água per capita na maioria dos países em desenvolvimento permanece muito abaixo em relação aos países desenvolvidos (WWAP, 2019).

A cobertura dos serviços de água gerenciados com segurança varia consideravelmente entre as regiões no mundo inteiro, indo de apenas $24 \%$ na África Subsaariana a $94 \%$ na Europa e América do Norte, também pode haver variabilidade significativa dentro dos países entre áreas rurais e urbanas. Até 2015, 181 países alcançaram uma cobertura de mais de $75 \%$ para pelo menos serviços básicos de água potável. Dos 159 milhões de pessoas que ainda coletam água não tratada (e frequentemente contaminada) diretamente de fontes de água de superfície, $58 \%$ viviam na África Subsaariana (WHO/UNICEF, 2017).

\section{POLUIÇÃO dA ÁGUA}

Os recursos de água doce do mundo estão cada vez mais poluídos com resíduos orgânicos, patógenos, fertilizantes e pesticidas, metais pesados e poluentes emergentes. A poluição da água por matéria orgânica está crescendo devido ao 
aumento da descarga de águas residuais municipais e industriais, à intensificação da agricultura (incluindo pecuária) e à redução da capacidade de diluição dos rios devido à diminuição do escoamento e extração de água. A eutrofização é um fenômeno generalizado em todo o mundo devido à liberação de enriquecimentos de nutrientes feitos pelo homem nas águas superficiais, como resultado do gerenciamento ineficaz de águas residuais e escoamento agrícola (WWAP, 2020).

Em muitos países desenvolvidos, a poluição agrícola causada pelo uso de nitrogênio e fósforo, inseticidas, herbicidas, fungicidas e bactericidas ultrapassou a contaminação causada por assentamentos e indústrias como a principal causa de eutrofização no interior e no litoral. Isso resulta em explosões tóxicas de algas, perda de habitat e biodiversidade e redução ou perda em longo prazo das capturas de peixes. $\mathrm{O}$ escoamento de produtos químicos agrícolas e de agroprocessamento para correntes de superfície e sua infiltração em aquíferos introduz riscos para a saúde humana e o meio ambiente. (WWAP, 2020)

A contaminação por patógenos é o problema de qualidade da água mais difundido nos países em desenvolvimento devido à água e saneamento inseguros. Os poluentes emergentes apresentam um novo desafio global da qualidade da água nos países desenvolvidos e em desenvolvimento, com ameaças potencialmente graves à saúde e aos ecossistemas humanos. Cidades e indústrias competem com a agricultura pelo uso da água e um número crescente de países, ou regiões dentro de países, está atingindo níveis alarmantes de estresse e poluição da água (FAO, 2017).

A poluição reduz a água disponível para uso benéfico e aumenta o custo do tratamento da água. A água poluída tem um alto custo para a saúde humana: um décimo da carga global de doenças pode ser atribuído à água. Outros custos de poluição incluem limpeza, tratamento adicional e danos à pesca, ecossistemas e recreação. A poluição também reduz as oportunidades de abordar a escassez de água pelo reuso de fluxos de retorno na agricultura ou em qualquer outro setor que consome água, e, embora existam opções para limpar ou diluir a poluição das águas superficiais, os aquíferos poluídos são muito difíceis de restaurar (FAO, 2017). 


\section{GESTÃO DOS RECURSOS HIDRICOS}

A degradação dos ecossistemas é uma das principais causas dos crescentes desafios relativos à gestão da água (WWAP, 2018).

O termo gerenciamento aplicado a recursos hídricos, pode ser definido como um subconjunto da governança, conceito amplo e que implica a existência de conjuntos de sistemas políticos, sociais, econômicos e administrativos que afetam, direta ou indiretamente, a administração, o uso, consumo, impacto, preservação e serviços, entre outros aspectos relativos a esses recursos. A gestão dos recursos hídricos no Brasil se baseia na necessidade de gerenciar o uso da água com o intuito de prevenir os conflitos gerados através da utilização do mesmo, tendo em vista que ao longo dos anos a problemática de demanda e oferta cresceu significativamente (CARNEIRO et al., 2018).

Para uma caracterização adequada da qualidade de água para definir padrões qualitativos, faz-se necessário realizar campanhas contínuas de educação ambiental e monitoramento da qualidade da água através de amostragem e análises dos parâmetros físico-químicos e bacteriológicos dos recursos hídricos.

\section{CONSIDERAÇÕES FINAIS}

A água é fundamental para os seres vivos, exerce um papel biológico indispensável para a vida e é imprescindível para os ecossistemas. Sua intensa utilização associada ao crescimento populacional e industrial, além de interferências antrópicas tem acarretado na geração de fontes poluidoras. A água está intrinsicamente associada à dignidade humana e considerando a grande importância desse recurso natural é necessário que haja uma melhor gestão desse bem comum tão valioso, para que seja possível o reuso com diferentes níveis de qualidade, como medida de enfrentamento da falta de água, para que não se torne escassa para a atual e futuras gerações. É fundamental haver uma rigorosa gestão da água e dos recursos hídricos criando estratégias de recuperação dos recursos hídricos, com a finalidade de impedir que problemas decorrentes da poluição e outros fatores venham a comprometer seu aproveitamento múltiplo e integrado. 
Os autores agradecem o suporte financeiro da Capes (Edital Pró-equipamentos, No. 843504/2017 e Bolsas PPGDPA-CAPES), CNPq (Processo No. 314422/2018-8), FACEPE (APQ-0638-2.01/19 e Bolsa Processo: IBPG-1803-3.06/19) e UNICAP, Bolsa PPGDPAFASA (Fundação Pe. Abranches).

\section{REFERÊNCIAS}

ACADEMIA BRASILEIRA DE CIÊNCIAS. Recursos Hídricos no Brasil, Problemas, Desafios e Estratégias para o Futuro. Rio de Janeiro: 2014.

AGÊNCIA NACIONAL DAS ÁGUAS (ANA). Ciclo Hidrológico e Águas Subterrâneas. Brasília: 2014.

em: <http://arquivos.ana.gov.br/institucional/sge/CEDOC/Catalogo/2014/CicloHidrologico eAguasSubterraneas2014.pdf> Acesso em 04 Jul 2020.

AGÊNCIA NACIONAL DAS ÁGUAS (ANA). Panorama das águas. Água no Mundo. Disponível em: <https://www.ana.gov.br/panorama-das-aguas/agua-no-mundo>. Acesso em 30 Jun 2020.

AGÊNCIA NACIONAL DAS ÁGUAS (ANA); CONSELHO EMPRESARIAL BRASILEIRO PARA O DESENVOLVIMENTO SUSTENTÁVEL (CEBDS). No Rumo da Mudança. Fatos e Tendências. Água. $2009 . \quad$ Brasília, Disponível em:<http://arquivos.ana.gov.br/imprensa/publicacoes/fatosetendencias/edicao_2.pdf >. Acesso: 01 Jul 2020.

CARNEIRO, M.C.M.O. et al. A Gestão Do Saneamento No Brasil E Sua Relação Com A Gestão De Recursos Hídricos. INOVAE-Journal of Engineering, Architecture and Technology Innovation (ISSN 2357-7797), v. 6, n. 1, p. 101-116, 2018.

CASARIN, F.; SANTOS, M.. Água: o ouro azul: Usos e abusos dos recursos hídricos. Editora Garamond, 2018.

COSTA, A.F.S. et al. Recursos Hídricos. Caderno de Graduação - Ciências Exatas e Tecnológicas, v. 1, n.15, p. 67-73, 2012.

FAO - FOOD AND AGRICULTURE ORGANIZATION OF THE UNITED NATIONS. Water for Sustainable Food and Agriculture. A report produced for the G20 Presidency of Germany. Rome, 2017.

FIEDLER, M.F.M. Modelagem da qualidade da água em reservatórios. 2020.

FUNDAÇÃO NACIONAL DE SAÚDE (FUNASA). Manual Prático de Análise de água. 4 ed. Brasília, 2013. Disponível em: <http://www.funasa.gov.br/site/wp- 
content/files_mf/manual_pratico_de_analise_de_agua_2.pdf >. Acesso em 30 Jun 2020.

GRASSI, M.T. As Águas do Planeta Terra. Cadernos Temáticos de Química na Nova Escola. Ed especial, 2001.

IBGE - Instituto Brasileiro de Geografia e Estatística. Pesquisa Nacional de Saneamento Básico, 2000.

IEA. International Energy Agency. Energy and Water. Disponível em: <https://www.iea.org/topics/energy-and-water>. Acesso em 03 Jul 2020.

LEITE, M.A. et al. Usos múltiplos da água. In: DORNFELD, C. B.; TALAMONI, A. C. B.; QUEIROZ, T. V. O Jogo digital na sala de aula - ÁGUA, AÇÃO E REFLEXÃO: elaboração de jogo digital para a Educação Básica. Ilha Solteira: Unesp, 2019. Cap. 4. p. 44-57.

MANAHAN, S.E. Química ambiental. Bookman Editora, 9 ed.2016.

MANAHAN, S.E. Environmental chemistry. CRC press, 10 ed. p. 25. 2017.

MEDEIROS, S. Química Ambiental. 3 ed. p. 43-44. 2005.

MINISTÉRIO DO MEIO AMBIENTE (MMA). Água. Disponível em: < https://www.mma.gov.br/estruturas/sedr_proecotur/_publicacao/140_publicacao090 62009025910.pdf>. Acesso em 30 Jun 2020.

MINISTÉRIO DO MEIO AMBIENTE (MMA); SECRETARIA DE RECURSOS HÍDRICOS E AMBIENTE URBANO (SRHU). Águas Subterrâneas. Um Recurso a Ser Conhecido e Protegido. Brasília: 2007.

NOVICKI, C.; CAMPOS, R.F.F. Análise da potabilidade das águas de fontes naturais, junto ao município de Fraiburgo-SC. Revista Monografias Ambientais, v. 15, n. 1, p. 323-336, 2016.

NOVO, M. et al. Projecto Bingo: O Impacto das Alterações Climáticas na Componente Subterrânea do Ciclo Hidrológico. Recursos Hídricos, v. 39, n. 2, 2018.

PAZ, A.R. Hidrologia Aplicada. 138p, Universidade Estadual do Rio Grande do Sul. 2004.

RIBEIRO, L.G.G.; ROLIM, N. D.. Planeta água de quem e para quem: uma análise da água doce enquanto direito fundamental e sua valoração mercadológica. Revista Direito Ambiental e sociedade, v. 7, n. 1, 2017.

SANTOS, F.; ALEXANDRE, C.; COELHO, R. Relações solo-água-planta. 2017. Cap. 7. p. 156- 
SILVA, J.F.A; PEREIRA, R.G. Panorama global da distribuição e uso de água doce. Revista Ibero-Americana de Ciências Ambientais, v. 10, n. 3, p. 263-280, 2019.

SOITO, J. Usos múltiplos da água. Boletim de Conjuntura, n. 5, p. 21-27, 2019.

TALAMONI, J.L.B. Água: sistema ecológico e fonte de vida. In: DORNFELD, C. B.; TALAMONI, A. C. B.; QUEIROZ, T. V. O Jogo digital na sala de aula - ÁGUA, AÇÃO E REFLEXÃO: elaboração de jogo digital para a Educação Básica. Ilha Solteira: Unesp, 2019. Cap. 5. p. 58-73.

TORTORA, G.J.; DERRICKSON, B. Corpo Humano-: Fundamentos de Anatomia e Fisiologia. Artmed Editora, p. 31. 2016.

VITÓ, C.V.G. et al. Avaliação da qualidade da água: determinação dos possíveis contaminantes da água de poços artesianos na região noroeste fluminense. Acta Biomedica Brasiliensia, v. 7, n. 2, p. 59-75, 2016.

UN (United Nations). 2018a. Sustainable Development Goal 6: Synthesis Report 2018 on Water and Sanitation. New York, United Nations.

WHO/UNICEF (World Health Organization/United Nations Children's Fund). 2017a. Progress on Drinking Water, Sanitation and Hygiene: 2017 Update and SDG Baselines. Geneva, WHO/UNICEF.

WWAP. World Water Assessment Programme. The United Nations World Water Development Report 2014: Water and Energy. Paris: UNESCO, 2014.

WWAP. World Water Assessment Programme. Relatório Mundial das Nações Unidas sobre Desenvolvimento dos Recursos Hídricos. Relatório 2018: Soluções Baseadas na Natureza para a Gestão da Água. Itália: UNESCO, 2018.

WWAP. World Water Assessment Programme. The United Nations World Water Development Report: 2019: Leaving No One Behind. Paris: UNESCO, 2019.

WWAP. World Water Assessment Programme. Relatório Mundial das Nações Unidas sobre Desenvolvimento dos Recursos Hídricos. Relatório 2020: . Paris: UNESCO, 2020. 


\title{
CAPITULO XXXVI
}

\section{COBRANGA PELO USO DA ÁGUA NA BACAA HIDROGRÁFICA DO RIO PARAÍBA - PB: DESAFIOS E NECESSIDADES DE MELHORIAS}

\section{DOI: 10.51859/amplla.mas481.1121-36}

\author{
Guilherme Callou Ribeiro e Silva ${ }^{1}$ \\ Wanessa Dunga de Assis ${ }^{2}$ \\ Dayse Luna Barbosa ${ }^{3}$ \\ Andréa Carla Lima Rodrigues ${ }^{4}$ \\ José Augusto de Souza ${ }^{5}$
}

Engenheiro Civil. Universidade Federal de Campina Grande - UFCG.

2 Engenheira Ambiental. Doutoranda em Engenharia Civil e Ambiental. Programa de Pós-Graduação em Engenharia Civil e Ambiental. Universidade Federal de Campina Grande - UFCG.

${ }^{3}$ Engenheira Civil. Doutora em Recursos Naturais. Professora da Universidade Federal de Campina Grande - UFCG.

${ }^{4}$ Engenheira Civil. Doutora em Recursos Naturais. Professora da Universidade Federal de Campina Grande - UFCG.

5 Geógrafo. Mestre em Engenharia Civil e Ambiental. Programa de Pós-Graduação em Engenharia Civil e Ambiental. Universidade Federal de Campina Grande - UFCG.

\section{RESUMO}

A cobrança pelo uso da água é definida como um dos cinco instrumentos de gestão de recursos hídricos no Brasil previstos na Lei Federal n 9.433/97. A cobrança não é um imposto, mas uma remuneração pelo uso de um bem público que tem por objetivo reconhecer a água como bem econômico, incentivar o uso racional dos recursos hídricos e arrecadação de recursos financeiros. Neste trabalho, foi realizada uma análise do modelo de cobrança pelo uso da água na Bacia Hidrográfica do Rio Paraíba (BHPB-PB), mediante uma metodologia de análise comparativa, de cunho qualitativo. A região escolhida corresponde a uma importante área socioeconômica na região semiárida do nordeste brasileiro, sobretudo no Estado da Paraíba. Os resultados consistem na identificação de aspectos passíveis de melhorias no modelo de cobrança da BHPB-PB e na proposição de alguns aperfeiçoamentos. Em seguida, concluímos com os desafios e falhas na implementação desse instrumento econômico em pequenas bacias estaduais, como a estudada, e a sua grande influência na gestão de recursos hídricos.

Palavras-chave: Instrumentos de gestão de recursos hídricos. Instrumentos econômicos. Política Nacional de Recursos Hídricos.

\section{INTRODUÇÃo}

A gestão hídrica no Brasil está consolidada numa legislação forte e clara, originada a partir da Política Nacional de Recursos Hídricos (PNRH), através da Lei Federal $\mathrm{n}$-9.433/97, cujos fundamentos definem os principais aspectos que envolvem 
estes recursos como dominialidade, limitações quantitativas e qualitativas, hierarquização de usos, peculiaridades territoriais e gestão participativa e descentralizada.

Para garantir a implementação e a observância destes fundamentos a referida lei apresenta um conjunto de instrumentos de gestão, quais sejam: os planos de recursos hídricos, o enquadramento dos corpos de água em classes de qualidade, a outorga dos direitos de uso, a cobrança pelo uso da água e o sistema de informações dos recursos hídricos que servem como instrumentos norteadores para uma gestão firme, eficiente e justa (BRASIL. 1997).

A cobrança pelo uso da água é o único instrumento econômico da PBRH e é reconhecida como o instrumento de maior grau de complexidade dentre os demais previstos nessa lei. Esse instrumento encontra-se em funcionamento em algumas bacias com rios de domínio da União, como, por exemplo, nas bacias hidrográficas interestaduais do rio Paraíba do Sul, do rio São Francisco, e dos rios Piracicaba-CapivariJundiaí (PCJ), assim como em bacias hidrográficas estaduais, a exemplo de bacias hidrográficas no estado do Ceará, do Rio de Janeiro, São Paulo e Paraíba (ANA, 2019).

Por outro lado, a literatura sobre o papel do instrumento da cobrança pelo uso da água no Brasil tem demonstrado que a implementação desse mecanismo encontra inúmeros desafios, que as vezes, se tornam limitadores para que a cobrança seja efetivamente praticada. Para melhor se adequar às características hidrogeográficas do Brasil estudos de formulação dos modelos de cobrança pelo uso da água propõem que esta cobrança seja feita com base num preço mínimo em relação a um volume captado e, considerando um ou um conjunto de coeficientes que ponderam esta cobrança de acordo com a realidade local (ASSIS; RIBEIRO; MORAES, 2018).

Na Bacia Hidrográfica do Rio Paraíba-PB, a cobrança é prevista pela Lei Estadual $n^{\circ}$ 6.308/96 a qual sofreu modificações dispostas na Lei $n=8.447 / 07$, e regulamentada pelo Decreto no 33.613/12. O instrumento de gestão foi aprovado em 2008 e implementado em janeiro 2015 (CBH-PB, 2008; ANA, 2020). Com um viés arrecadatório, a cobrança no Estado da Paraíba está propensa a ter seus valores arrecadados aplicados no sistema de fiscalização do uso da água, monitoramento hidrometerológico e de 
qualidade da água, elaboração e atualização dos planos diretores da bacia, dentre outros (PARAÍBA, 2012).

O presente trabalho tem como objetivo analisar o modelo de cobrança pelo uso da água na Bacia Hidrográfica do Rio Paraíba-PB. Para isto, considera o disposto na Deliberação CBH-PB no 001/08, que aprova a implementação da cobrança e determina valores da cobrança pelo uso dos Recursos Hídricos na Bacia Hidrográfica do Rio Paraíba. Ao mesmo tempo em que analisa o atual cenário, este trabalho busca contribuir com algumas sugestões para o aperfeiçoamento do modelo de cobrança.

\section{A COBRANÇA PELO USO dA ÁGUA}

Pearce e Turner (1990) descrevem que, os instrumentos econômicos, como a cobrança pelo do uso da água, servem para adequações nas formas de consumo do usuário. Seja por meio de incentivos ou penalidades de caráter oneroso, quando o usuário é cobrado pelo uso de um bem de uso comum ou penalizado por um externalidade ou dano causado. Por exemplo, a partir desse "incentivo" o usuáriopagador busca mudar seus padrões de consumo, evitando despesas desnecessárias.

A cobrança pelo uso da água tem seus fundamentos ancorados na gestão ambiental, especificamente nos princípios do usuário-pagador e do poluidor-pagador (OECD, 1972; OECD, 1987; ANA, 2013). Por isso, a cobrança não é um imposto, mas uma compensação pelo uso de um recurso natural, que conforme os fundamentos da PNRH se trata de um bem público, dotado de valor econômico, e por isso, deve deter-se de um uso racional (ANA, 2020). Inclui licenças não-comercializáveis para a captação, consumo e/ou lançamento de efluentes considerando os diferentes tipos de usuários, a capacidade de pagamento dos mesmos, bem como, outros parâmetros variáveis (FINNEY, 2013).

A complexidade deste instrumento pode acarretar em processos burocráticos e de difícil compreensão dos entes envolvidos. A necessidade de se ter sistemas de cobrança eficazes e condizentes com a realidade econômica, social e ambiental da bacia hidrográfica faz com que os estudos necessários para a efetivação e adaptação deste instrumento seja interdisciplinar (ASSIS; RIBEIRO; MORAES, 2018; VERA; MONTENEGRO; SILVA, 2017). 
Nas bacias hidrográficas localizadas na região nordeste, a exemplo das paraibanas, pode-se incluir um aspecto a mais: variabilidade e mudanças climáticas. Nessas bacias, observa-se uma grande variabilidade climática ao longo do ano, o que pode gerar consequências diretas no sistema de cobrança. Além disso, é prudente também que se tenha condições de avaliar fatores relacionados às mudanças climáticas, como forma de proteger e adaptar o recurso hídrico aos diferentes cenários futuros. Em bacias do semiárido, os modelos de cobrança podem absorver itens a serem observados para a determinação dos valores a serem cobrados como coeficientes, tais como: natureza e classe do corpo hídrico, disponibilidade hídrica, sazonalidade, localização do usuário na bacia, entre outros (THOMAS, 2008; RIBEIRO; SOUZA; VIEIRA, 2013).

Durante a implementação e operacionalização da cobrança, deve-se promover a articulação com instrumentos implementados e em funcionamento, regularizar os usos da água e usuários sujeitos à cobrança e criar um banco de dados com as informações necessárias. Por esse motivo, a cobrança é um instrumento que pode ser utilizado como indicativo do estágio atual da aplicação dos demais instrumentos de gestão da PNRH, pela sua capacidade de integração com todos os outros instrumentos (PRAES, 2014; ANA, 2007; 2017).

Apesar dos valores arrecadados com a cobrança serem expressivos, a visão arrecadatória não deve ser utilizada como único propósito. Problemas ainda são encontrados nos sistemas de cobrança atuais, tais como conflitos entre os usuários, descontentamentos com os preços adotados e a ausência de aspectos que promovam a adoção de medidas poupadoras e de redução da poluição, que estimulem a proteção do recurso hídrico, a distinção entre os usos e entre os usuários, numa visão econômica capaz de cumprir com as ações de gestão de recursos hídricos (ASSIS, 2016).

\section{CASO DE ESTUDO}

Localizada na região semiárida do cariri paraibano, a Bacia Hidrográfica do rio Paraíba - BHPB-PB (Figura 1) caracteriza-se por ser a segunda maior dentre as onze bacias que dividem o estado. A maior é a Bacia Hidrográfica do rio Piancó-Piranhas-Açu, cujas águas são de domínio da União (AESA, 2020). 
A BHPB-PB abrange uma área de drenagem de aproximadamente $20.000 \mathrm{~km}^{2}$, o que equivale a $32 \%$ do território do estado da Paraíba e é utilizada como fonte de abastecimento de cidades da região. No entanto, o uso das suas águas para fins agrícolas e industriais são expressivos (PARAÍBA, 2006; AESA, 2020). Essa bacia desempenha um papel socioeconômico de grande importância por englobar 85 municípios e uma população acima dos dois milhões de habitantes, com destaque para a cidade de Campina Grande, e para a capital João Pessoa, principais centros tecnológicos e comerciais do estado, além de enfrentar graves problemas de escassez hídrica (REGO et al., 2017; RIBEIRO; SOUZA; VIEIRA, 2013).

Figura 1 - Bacia Hidrográfica do Rio Paraíba

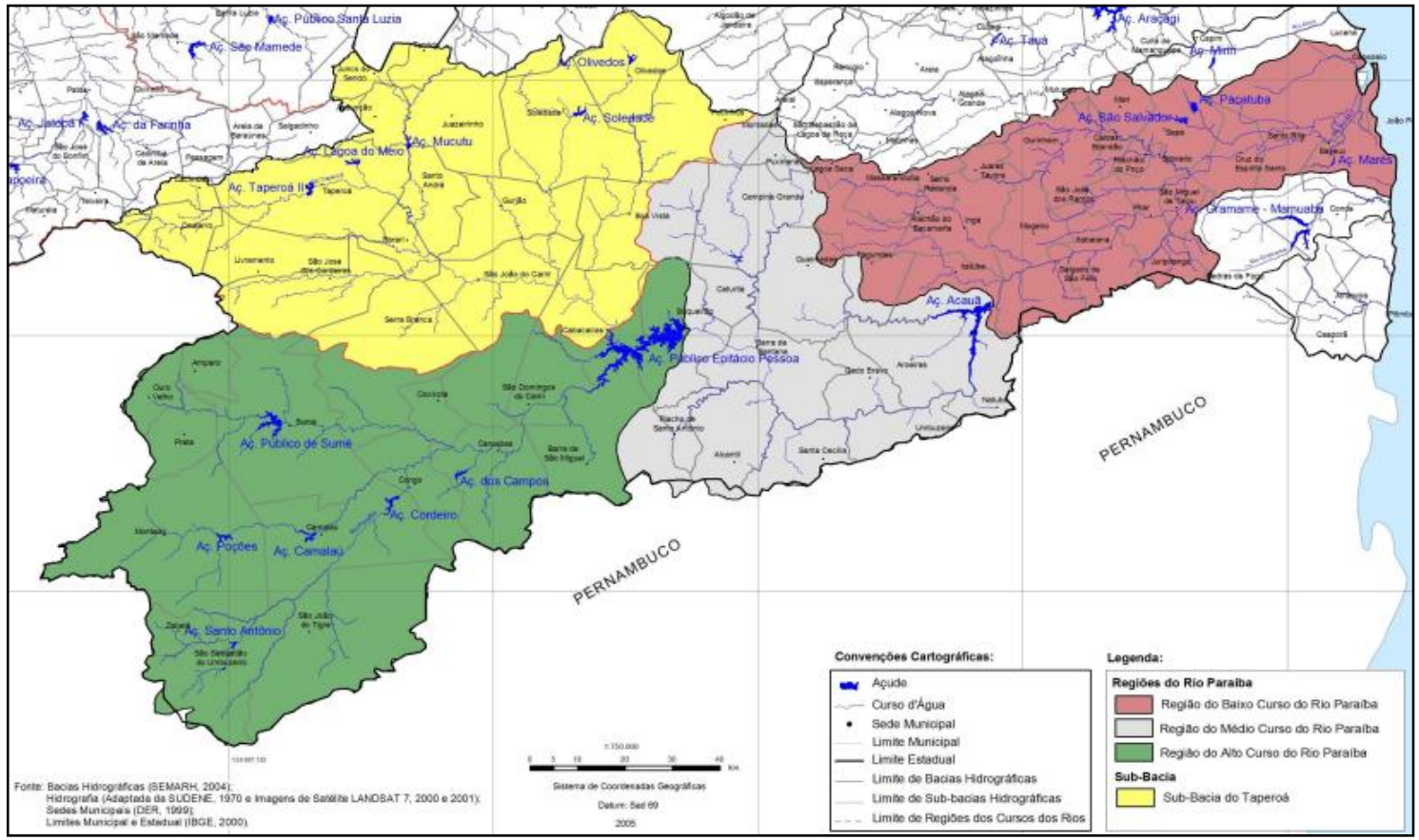

Fonte: AESA, 2018.

\subsection{A COBRANÇA PELO USO dA ÅGUA NA BACIA HIDROGRÁFICA dO RIO PARAIBA}

A cobrança pelo uso de água na Paraíba foi definida como um dos instrumentos de gerenciamento da Política Estadual de Recursos Hídricos. Os critérios definidos para a cobrança no estado são: (I) considerar as peculiaridades da bacia para realização da 
cobrança; (II) considerar a classe de uso preponderante; e (III) estabelecer a cobrança por captação, diluição, transporte e assimilação de efluentes (PARAíBA, 2012).

A Deliberação CBH-PB n 001/08, aprovou a cobrança, em caráter provisório, para o período de 3 (três) anos, para as captações das entidades responsáveis por abastecimento público, esgotamento sanitário e indústrias que excederem 200 mil $\mathrm{m}^{3} /$ ano, e dos usuários agropecuários que excederem $350 \mathrm{mil} \mathrm{m}^{3} / \mathrm{ano}$. Além desses, são cobrados os lançamentos de efluentes em corpos de água com o fim de sua diluição, transporte ou disposição final e outros usos que alterem o regime, quantidade ou qualidade dos corpos hídricos.

O cálculo de cobrança na BHPB-PB é realizado de acordo com a Equação 1.

$$
\mathrm{VT}=\mathrm{k} \times \mathrm{P} \times \mathrm{Vol}
$$

Onde:

$\mathrm{VT}=$ Valor total a ser cobrado, em reais ( $\mathrm{R} \$$ ).

$\mathrm{Vol}=$ Base de cálculo: Parcela que representa o volume de água captado ou lançado, em $\mathrm{m}^{3}$.

$\mathrm{P}=$ Preço unitário: Definido de acordo com o tipo de uso, dado em $\mathrm{R} \$ / \mathrm{m}^{3}$.

$\mathrm{k}=$ Coeficientes multiplicadores: Permitem a variação do valor a ser cobrado com base nas particularidades da bacia e/ou de seus usuários, adimensional.

A base de cálculo está relacionada às derivações ou captações de água e ao lançamento de efluentes em corpos de água com finalidade de diluição, transporte ou disposição final, bem como, outros usos que alterem a qualidade ou quantidade de água em um corpo hídrico. Compreende apenas aspectos quantitativos, ao considerar o volume de água captado e/ou lançado por cada usuário. Não há consideração de aspectos qualitativos, a exemplo da concentração de poluentes no efluente lançado.

A parcela " $k$ ", que corresponde aos coeficientes multiplicadores, não foi desenvolvido na metodologia inicial, sendo atribuído um valor fixo e igual a 1 (um), durante o período provisório (três anos iniciais), a partir da implementação da cobrança. Ficando para posterior aperfeiçoamento, coeficientes para adequar a cobrança às características e peculiaridades da bacia e dos usuários envolvidos, como a disponibilidade hídrica da região, natureza dos corpos hídricos, área de captação dos 
usuários, tipos de tecnologias adotadas para captação ou tratamento de efluentes, dentre outros.

Os preços unitários (Tabela 1) foram definidos a partir do debate nas reuniões dos comitês das bacias envolvidas, mediante estudos de potencial de pagamento dos usuários, cabendo aos órgãos gestores da bacia o estabelecimento de novos valores que substituam os valores utilizados durante o período provisório (CBH-PB, 2008).

Tabela 1 - Valores dos preços unitários por tipo de uso na BHPB-PB.

\begin{tabular}{lccc}
\hline TIPO DE USO & $\mathbf{1}^{\circ}$ ANO & $\mathbf{2}^{\circ}$ ANO & $\mathbf{3}^{\circ}$ ANO \\
\hline Irrigação/Agropecuária & $\mathrm{R} \$ 0,003 / \mathrm{m}^{3}$ & $\mathrm{R} \$ 0,004 / \mathrm{m}^{3}$ & $\mathrm{R} \$ 0,005 / \mathrm{m}^{3}$ \\
Piscicultura/Carcinicultura & $\mathrm{R} \$ 0,005 / \mathrm{m}^{3}$ & $\mathrm{R} \$ 0,005 / \mathrm{m}^{3}$ & $\mathrm{R} \$ 0,005 / \mathrm{m}^{3}$ \\
Abastecimento Público & $\mathrm{R} \$ 0,012 / \mathrm{m}^{3}$ & $\mathrm{R} \$ 0,012 / \mathrm{m}^{3}$ & $\mathrm{R} \$ 0,012 / \mathrm{m}^{3}$ \\
Setores do Comércio & $\mathrm{R} \$ 0,012 / \mathrm{m}^{3}$ & $\mathrm{R} \$ 0,012 / \mathrm{m}^{3}$ & $\mathrm{R} \$ 0,012 / \mathrm{m}^{3}$ \\
Lançamento de efluentes & $\mathrm{R} \$ 0,012 / \mathrm{m}^{3}$ & $\mathrm{R} \$ 0,012 / \mathrm{m}^{3}$ & $\mathrm{R} \$ 0,012 / \mathrm{m}^{3}$ \\
Indústria & $\mathrm{R} \$ 0,015 / \mathrm{m}^{3}$ & $\mathrm{R} \$ 0,015 / \mathrm{m}^{3}$ & $\mathrm{R} \$ 0,015 / \mathrm{m}^{3}$ \\
\hline
\end{tabular}

Fonte: Elaborado pelos autores a partir de CBH-PB (2008).

\section{METODOLOGIA}

Este trabalho é de cunho qualitativo, composto por uma análise comparativa, na qual compara o sistema de cobrança atual da BHPB-PB com outras bacias brasileiras federais e estaduais - com vistas a analisar o processo de implementação do instrumento de cobrança, os parâmetros utilizados nas equações, os volumes cobrados e valores adotados. Para tal, foram utilizadas as deliberações, decretos e leis, atas de comitês e estudos técnicos, além de modelos sugeridos pela literatura, para o embasamento da análise comparativa.

Após análise comparativa, são propostas medidas de aperfeiçoamento para cada aspecto passível de melhoria identificado nos três componentes do mecanismo de cobrança (base de cálculo, preços e coeficientes), mediante as experiências de outras bacias. Ao final, uma proposta de estruturação do sistema de cobrança é apresentada, que engloba o conjunto das modificações para uma nova formulação de cobrança na BHPB-PB. 


\section{RESULTADOS E DISCUSSÃO}

Os aspectos passíveis de melhoria nos três parâmetros da fórmula de cobrança utilizada na BHPB-PB, são apresentados nos tópicos que se segue:

\subsection{BASE DE CÁLCULO}

O atual modelo de cobrança da BHPB-PB considera apenas o volume outorgado como base de cálculo para os diversos tipos de usos da água. A consideração de apenas um parâmetro torna-se um problema nas fórmulas de cobrança por não haver a diferenciação para cada tipo de uso. Um exemplo disso está nos usuários com outorgas de lançamento de efluentes, para eles a cobrança incide apenas sobre o volume lançado, sem nenhum aspecto qualitativo.

Um aspecto passível de melhoria seria a diferenciação desse componente para cada tipo de uso, ou seja, a consideração da vazão outorgada para a captação e a carga orgânica da Demanda Bioquímica de Oxigênio $\left(\mathrm{DBO}_{5,20}\right)$ dos efluentes lançados, como utilizado por outras bacias. Deste modo, é proposta a criação de novos parâmetros diferenciados que substituem o parâmetro volume anual outorgado (Vol), são eles: QcAP e $\mathrm{CO}_{\mathrm{DBO}}$.

O parâmetro Qcap representa o volume anual de captação, dado em $\mathrm{m}^{3}$. Esse parâmetro entraria na equação de captação, considerando as retiradas de águas superficiais ou subterrâneas para os diversos tipos de uso, como por exemplo abastecimento urbano, irrigação, pecuária, entre outros. A proposta mantém os valores mínimos, definidos pela BHPB-PB, que dispensa a cobrança por captação para volumes inferiores a $200 \mathrm{mil} \mathrm{m}^{3} /$ ano para uso geral e $350 \mathrm{mil} \mathrm{m}^{3} /$ ano para uso agropecuário. A cobrança por captação de águas subterrâneas, não considerada até então, também deve ser considerada em seu sistema de gestão.

O parâmetro $\mathrm{CO}_{\mathrm{DBO}}$, dado em (Kg de $\mathrm{DBO}$ ), representa a carga orgânica da DBO5,20 dos efluentes lançados. A proposta para esse parâmetro mantém o estabelecido pela Deliberação no 1/08 do CBHPB-PB onde são cobrados quaisquer volumes de lançamento de efluentes nos corpos hídricos de domínio do estado, ficando restrito apenas a DBO, tendo em vista a dificuldade de operacionalização da cobrança com a inserção de outros parâmetros, a exemplo de metais pesados ou pesticidas. 


\subsection{PREÇOS UNITÁRIOS (P)}

Foram identificados dois aspectos passíveis de melhorias com relação aos preços unitários utilizados na BHPB-PB. O primeiro está relacionado à forma como os preços são adotados. A BHPB-PB adota os preços unitários de acordo com o tipo de usuário, desconsiderando assim os valores por tipo de uso (usuários com outorga de lançamento de efluente não são diferenciados pelo seu aspecto qualitativo, apenas pela quantidade de efluente gerado), como ocorre na maior parte das bacias com bom desempenho. A diferenciação por usuário pode ser melhor executada através do uso de coeficientes que ajustam a cobrança às distintas situações.

Uma proposta de modificação seria o estabelecimento dos preços de acordo com o tipo de uso - Captação e Lançamento. O preço para captação é utilizado em reais por metro cúbico $\left(\mathrm{R} \$ \mathrm{~m}^{3}\right)$, sob uma abordagem quantitativa, enquanto que o preço para lançamento segue um parâmetro qualitativo - reais por kg de $\mathrm{DBO}_{5,20}$ lançada.

Outro aspecto preocupante identificado são os baixos valores estabelecidos. Isso pode ser justificado mediante a necessidade inicial de se diferenciar os preços por usuários, em virtude da inexistência de coeficientes com tal finalidade. A progressividade dos preços só foi determinada para os usuários de irrigação e agropecuária (mais vulneráveis). Para os demais, os preços continuam estáveis durante os três primeiros anos.

A atualização dos preços é um ponto fundamental para evitar defasagem dos valores ao longo dos anos. A Resolução CNRH no 192/2017 estabeleceu que "para o exercício de 2018 e anos subsequentes, aplicar-se-á a variação do IPCA/IBGE ao preço público unitário vigente no interstício de 12 meses, apurado em outubro do ano anterior". Tal atualização ainda não ocorreu. Deste modo, sugere-se como melhoria o ajuste dos valores por tipos de uso, usando como referência os valores atualizados das bacias interestaduais para o ano de 2019 com base o IPCA/IBGE dos 12 meses anteriores, conforme recomendação da resolução supracitada. Deste modo, para a BHPB-PB sugere-se novos preços de 0,013 $\mathrm{R} \$ / \mathrm{m}^{3}$ para usuários de captação e de $0,015 \mathrm{R} \$ / \mathrm{Kg}$ de $\mathrm{CO}_{\mathrm{DBO}}$.

A progressão de preços anuais trazida pela resolução de cobrança do estado não pode ser reproduzida, tendo em vista a necessidade de ajustes anuais para se adequar ao sugerido pela Resolução CNRH no 192/2017. O cuidado em não fazer grandes variações ou 
longo dos anos é importante para não causar conflitos nem reduzir a aceitação por parte dos usuários. A maior diferença com a atualização seria percebida para os usuários de Irrigação/Agropecuária e Piscicultura/Carcinicultura, que eram cobrados com preços de $0,005 \mathrm{R} \$ / \mathrm{m}^{3}$.

Para reduzir o impacto nesses usuários, e em outros, não ser tão significativo, os coeficientes devem ajustar as equações de forma a reduzir o valor a ser pago pelos mesmos. O tipo de uso lançamento possui os maiores valores cobrados por ser o mais impactante, pois reduz a qualidade da água do corpo hídrico.

\subsection{COEFICIENTES MULTIPLICADORES (K)}

Atualmente o modelo de cobrança executado na BHPB-PB utiliza apenas um coeficiente multiplicador na sua fórmula de cobrança, que teve seu valor fixado como 1 (um) por não ter sido desenvolvido para variações das características dos usuários e das particularidades da bacia. Deste modo, para uma melhor eficiência do sistema de cobrança na bacia, se faz necessária a elaboração de coeficientes específicos para cada equação de tipo de uso, que considerem, dentre outros aspectos, as peculiaridades da bacia, os objetivos a serem alcançados com a cobrança e o perfil dos usuários envolvidos no sistema.

Para o tipo de uso captação é proposta a criação do Kcap, que abrange o somatório de três coeficientes - $\mathrm{K}_{\text {CLASSE }}$ e $\mathrm{K}_{\mathrm{T}}$. O lançamento de efluentes compreende $\mathrm{o}$ somatório de dois coeficientes, o mesmo K KLASSE utilizado para a captação e um segundo coeficiente, o K KRAT. Todos são apresentados na Tabela 2.

Tabela 2 - Coeficientes sugeridos.

\begin{tabular}{|c|c|c|c|}
\hline \multicolumn{2}{|c|}{$\begin{array}{c}\text { Coeficiente de Captação } \\
\mathbf{K}_{\text {Cap }}=\mathbf{K}_{\text {CLASSE }}+\mathbf{K}_{\mathrm{T}}\end{array}$} & \multicolumn{2}{|c|}{$\begin{array}{c}\text { Coeficiente de Lançamento } \\
\mathrm{K}_{\mathrm{Lanç}}=\mathrm{K}_{\mathrm{CLASSE}}+\mathrm{K}_{\mathrm{TRAT}}\end{array}$} \\
\hline \multirow{6}{*}{$K_{\text {CLASSE }}$} & \multirow{6}{*}{$\begin{array}{l}\text { Coeficiente que considera a } \\
\text { qualidade da água, com base } \\
\text { na classe de enquadramento } \\
\text { dos corpos hídricos. }\end{array}$} & Classe & Valor \\
\hline & & Especial & 1,2 \\
\hline & & 1 & 1,1 \\
\hline & & 2 & 1 \\
\hline & & 3 & 0,9 \\
\hline & & 4 & 0,8 \\
\hline \multicolumn{2}{|l|}{$\mathrm{K}_{\mathrm{T}}$} & Tipos de usuários & Valor \\
\hline
\end{tabular}


Coeficiente de boas práticas de uso e conservação da água

\begin{tabular}{|c|c|}
\hline \multirow{2}{*}{ Agropecuária/Piscicultura/Carcinicultura } & 0,25 \\
\hline & \\
\hline Gotejamento & 0,25 \\
\hline Microaspersão & 0,30 \\
\hline Pivô central & 0,35 \\
\hline Autopropelido & 0,35 \\
\hline Aspersão Convencional & 0,40 \\
\hline Sulcos de infiltração & 0,45 \\
\hline Inundação & 0,50 \\
\hline Não informado & 0,50 \\
\hline Abastecimento Público: & \\
\hline Perdas $\leq 20 \%$ & 0,85 \\
\hline $20 \% \leq$ Perdas $\leq 25 \%$ & 0,90 \\
\hline $25 \% \leq$ Perdas $\leq 30 \%$ & 0,95 \\
\hline $30 \% \leq$ Perdas $\leq 35 \%$ & 1,00 \\
\hline $35 \% \leq$ Perdas $\leq 40 \%$ & 1,05 \\
\hline Perdas $>40 \%$ & 1,10 \\
\hline Não informado & 1,10 \\
\hline Comércio/Indústria/Demais usuários & 1 \\
\hline Porcentagem do tratamento & Valor \\
\hline $0-20 \%$ & 1,4 \\
\hline $21 \%-40 \%$ & 1,2 \\
\hline $41 \%-60 \%$ & 1,0 \\
\hline $61 \%-80 \%$ & 0,8 \\
\hline $81 \%-100 \%$ & 0,4 \\
\hline
\end{tabular}

Fonte: Elaborado pelos autores.

O K LLASSE considera o enquadramento dos corpos hídricos em classes de qualidade, segundo os usos preponderantes da água. Os valores desse coeficiente estão relacionados ao enquadramento dos corpos hídricos em classe definidos pela Resolução CONAMA $n^{\circ} 357 / 05$, os valores estabelecidos são semelhantes aos já utilizados por outras bacias, de forma que quanto melhor a qualidade da água captada maior será o valor do $\mathrm{K}_{\mathrm{CLASS}}$, e consequentemente, maior o valor a ser pago. Devido a inexistência de proposta de enquadramento em grande parte dos rios brasileiros, adota-se a classe 2 como referência nos sistemas de cobranças existentes.

O K $\mathrm{K}_{\mathrm{T}}$, coeficiente de boas práticas de uso e conservação da água, já é utilizado nas metodologias de cobrança de diversas bacias, a exemplo das bacias dos rios PCJ, rio Doce e rio São Francisco. Sua finalidade é de ajustar os valores cobrados para a irrigação e para saneamento, considerando a tecnologia de irrigação para os usuários irrigantes e 
o índice de perdas do sistema de abastecimento para os usuários de saneamento, aplicando-se valores específicos também para outros usuários. Os valores propostos em cada classe foram estabelecidos com base nos utilizados por outras bacias e por Assis, Ribeiro e Moraes (2018).

O KTRA, coeficiente de porcentagem de tratamento do efluente, com variação dos valores em faixas percentuais, basearam-se em coeficientes semelhantes de outras bacias. A variação a cada 0,2 promove uma redução/aumento significativo que deve ser usado como estímulo para a redução do potencial poluidor do efluente lançado, uma vez que, quanto pior for a qualidade do efluente que está sendo lançado no corpo hídrico maior será o valor a ser cobrado.

Além disso, se faz necessária também a implementação de um coeficiente administrativo, o $\mathrm{K}_{\text {GESTÃo }}$ para todos os tipos de uso. Esse coeficiente, utilizado no sistema de cobrança de várias bacias no Brasil, considera o efetivo retorno à BHPB-PB dos recursos arrecadados com a cobrança pelo uso da água em sua área. Sua metodologia comum define seu valor igual a 1 (um). No entanto seu valor poderá ser 0 (zero) caso, no ano subsequente da cobrança, não estiverem incluídas as despesas relativas à aplicação das receitas da cobrança pelo uso de recursos hídricos para a área no qual os recursos foram arrecadados.

\subsection{MODELO FINAL}

A partir da proposição de aperfeiçoamentos são apresentadas as novas equações sugeridas de captação (Equação 2), diluição de efluentes (Equação 3) e a equação total, que define o valor geral a ser pago pelo usuário (Equação 4) para a cobrança pelo uso da água na Bacia Hidrográfica do rio Paraíba.

$$
\begin{aligned}
& \text { Valor }(\text { cap })=\text { Qcap * Pcap * Kcap } \\
& \text { Valor }(\text { lanç })=\text { Qlanç * Planç * Klanç } \\
& \text { Valor }(\text { total })=(\text { Valor }(\text { cap })+\text { Valor }(\text { lanç })) * \text { K gestão }
\end{aligned}
$$

\section{CONSIDERAÇÕES FINAIS}

A cobrança pelo uso da água é um importante instrumento de gestão de recursos hídricos no estado da Paraíba, com destaque para a Bacia Hidrográfica do Rio Paraíba- 
$\mathrm{PB}$, que concentra a maior parte dos usuários e engloba os conflitos mais perceptíveis. Os resultados obtidos nesse trabalho mostram que o instrumento de cobrança pelo uso da água na Bacia Hidrográfica do rio Paraíba possui algumas falhas e que o atual sistema adotado precisa passar por um processo de atualização. Os aperfeiçoamentos na fórmula de cobrança propostos nesta pesquisa consideram fatores importantes que, até então, não compõem o modelo de cobrança da bacia.

As diferenciações dos valores cobrados por tipos de uso podem servir de parâmetro para melhor entendimento da cobrança por parte dos usuários, tornando-se uma proposta interessante para o atual modelo de cobrança da bacia. A atualização anual dos preços adotados é um passo importante por evitar defasagens nos valores cobrados ao longo dos anos, como ocorria na maioria das bacias brasileiras com cobrança implementada. Os coeficientes sugeridos consideram uma ampla quantidade de fatores, necessários para adaptar a cobrança à realidade da bacia e às caraterísticas dos usuários, tornando assim a cobrança mais justa e capaz de incentivar a mudança de comportamento daquele usuário que é cobrado por um valor mais alto em virtude da tecnologia de irrigação que utiliza, por exemplo.

A reformulação proposta pode colaborar com a minimização dos conflitos pelo uso da água e aumentar a conscientização do usuário, na medida em que promove o uso racional dos recursos hídricos. Devido à grande importância social e econômica que a cobrança agrega a uma bacia hidrográfica, deve estar em constante aperfeiçoamento, para, cada vez mais, torná-la mais eficiente e justa. No entanto, um grande problema da cobrança paraibana ainda está nos altos índices de inadimplência. A conscientização da importância e fortalecimento desse instrumento, através do uso de sanções para maus pagadores devem ser utilizadas para solucionar tal problema.

A cobrança por captação de águas subterrâneas, não consideradas até então pelo sistema atual, também deve ser considerada em seu sistema de gestão. Espera-se que o processo de regularização dos usos subterrâneos, importante aspecto para a implementação da cobrança, seja finalizado para que este instrumento seja aplicado a todos os usos nas bacias hidrográficas do estado.

Recomenda-se também a adoção de novos coeficientes, à medida que o sistema for aprimorado. Se faz necessária uma mudança gradual e consistente, para se evitar 
conflitos e desconhecimento dos usuários pelo que está pagando. Coeficientes que considerem aspectos de escassez hídrica em uma região semiárida como o estado da Paraíba são essenciais. Além disso, aspectos como tipo de cultura irrigada, tipo de poluentes nos efluentes lançados, eficiência no tratamento dos efluentes podem apresentar resultados positivos na mudança de comportamento dos usuários e na valorização desse bem de uso comum.

\section{REFERÊNCIAS}

AESA - Agência Executiva de Gestão das Águas do Estado da Paraíba. Rio Paraíba. 2020. Portal da AESA (on-line). Disponível em: http://www.aesa.pb.gov.br/aesawebsite/comite-de-bacias/rio-paraiba/ Acesso em: 13 de maio de 2020.

ANA - Agência Nacional de Águas e Saneamento Básico. Cobrança. Portal da ANA (online). $2020 . \quad$ Disponível em: http://www2.ana.gov.br/Paginas/servicos/cobrancaearrecadacao /cobrancaearrecadacao.aspx Acesso em: 24 de maio de 2020.

. Cadernos de Capacitação em Recursos Hídricos - Volume 7: Cobrança por uso da água. E-book. v. 7. Brasília: ANA, 2013. Disponível em: https://capacitacao.ana.gov.br/conhecerh /handle/ana/259 Acesso em: 20 de julho de 2020.

. Conjuntura dos recursos hídricos no Brasil 2017: relatório pleno. Brasília - DF: ANA, 2017. Disponível em: http://www.snirh.gov.br/portal/snirh/centrais-deconteudos/ conjuntura-dos-recursos-hidricos Acesso em: 20 de julho de 2020.

. Conjuntura dos recursos hídricos no Brasil 2019: informe anual. Brasília - DF: ANA, 2019. Disponível em: http://www.snirh.gov.br/portal/snirh/centrais-deconteudos/ conjuntura-dos -recursos-hidricos Acesso em: 20 de julho de 2020.

ASSIS, W. D. Proposição de melhorias para o sistema de cobrança da bacia hidrográfica do rio São Francisco. Dissertação (Mestrado em Engenharia Civil e Ambiental) Campina Grande: UFCG, 2016.

ASSIS, W. D.; RIBEIRO, M. M. R.; MORAES, M. M. A. M. (2018). "Proposição de melhorias para o sistema de cobrança pelo uso da água bruta da Bacia Hidrográfica do rio São Francisco". Engenharia Sanitária e Ambiental. v. 23. n. 4.

BRASIL. Lei $\mathbf{n}^{\circ}$ 9.433, de 8 de janeiro de 1997. Institui a Política Nacional de Recursos Hídricos e cria o Sistema Nacional de Gerenciamento de Recursos Hídricos. Brasília - DF: Diário Oficial da União (09/01/1997), Seção 1, p. 470, 1997.

CNRH - Conselho Nacional de Recursos Hídricos. Resolução CNRH no 192, de 19 de dezembro de 2017. Dispõe sobre o procedimento para atualização dos preços 
públicos unitários cobrados pelo uso de recursos hídricos de domínio da União, de que trata a Lei no 9.433, de 8 de janeiro de 1997. Brasília - DF: Diário Oficial da União (26/01/2018), 2017.

CBH-PB - Comitê da Bacia Hidrográfica do Rio Paraíba. Deliberação CBH-PB no 001, de 26 de fevereiro de 2008. Aprova a implementação da cobrança e determina valores da cobrança pelo uso dos Recursos Hídricos da Bacia Hidrográfica do Rio Paraíba, a partir de 2008 e dá outras providências. 2008. Disponível em: http://www.aesa.pb.gov.br/aesa-website/wpcontent/uploads/2017/06/DELIBERA\%C3 \%87\%C3\%830-N\%C2\%BA-01-de-26de-fevereiro-de-2008-CBH-PB.pdf Acesso em: 20 de julho de 2020.

CONAMA - Conselho Nacional do Meio Ambiente. Resolução ${ }^{\circ}$ 357, de 17 de março de 2005. Dispõe sobre a classificação dos corpos de água e diretrizes ambientais para o seu enquadramento, bem como estabelece as condições e padrões de lançamento de efluentes, e dá outras providências. Brasília - DF: Diário Oficial da União (18/03/2005), 2005.

FINNEY, C. Water abstraction charges as a water management tool. Irrigation and Drainage, v. 62, p. 477-487, 2013.

OECD - Organisation for Economic Co-operation and Development. On guiding principles concerning international economic aspects of environmental policies. Paris: OECD, 1972.

. Economics Instruments for Environmental protection. Paris: OECD, 1987.

PARAÍBA (Governo Estadual). Decreto no 33.613, de 14 de dezembro de 2012. Regulamenta a cobrança pelo uso da água bruta de domínio do Estado da Paraíba, prevista na Lei no 6.308, de 02 de julho de 1996, e dá outras providências. João Pessoa - PB: Diário Oficial do Estado (16/12/2012), 2012.

. Lei $\mathrm{n}^{\circ}$ 6.308, de 02 de julho de 1996. Institui a Política Estadual de Recursos Hídricos, suas diretrizes e dá outras providências. João Pessoa-PB: Diário Oficial do Estado (03/07/1996), 1996.

. Lei $\mathbf{n}^{\circ} \mathbf{8 . 4 4 7}$, de 28 de dezembro de 2007. Dá nova redação e acrescenta dispositivos à Lei no. 6.308, de 02 de julho de 1996, que institui a Política Estadual de Recursos Hídricos, e determina outras providências. João Pessoa - PB: Diário Oficial do Estado (29/12/2007), 2007.

. Plano Estadual de Recursos Hídricos do Estado da Paraíba: Versão estendida. Brasília, DF: Consórcio TC/BR - Concremat, 2006. Disponível em: http://www.aesa.pb.gov.br/aesa-website/documentos/planoestadual/resumo-estendido/ Acesso em: 27 de julho de 2020. 
PEARCE, D. W.; TURNER, R. K. Economics of Natural Resources and the Environment. Harvester Wheatsheaf. 1 ed. Baltimore: The Johns Hopkins University Press, 1990.

PRAES, E. O. Cobrança pelo uso dos recursos hídricos no rio São Francisco. Dissertação (Mestrado em Desenvolvimento e Meio Ambiente). São Cristovão: UFSE, 2014.

RÊGO, J. C.; GALVÃO, C. O.; ALBUQUERQUE, J. P. T.; RIBEIRO, M.M.R.; NUNES, T.H.C. (2017). A Gestão de Recursos Hídricos e a Transposição de Águas do Rio São Francisco para o açude Epitácio Pessoa - Boqueirão. In: Simpósio Brasileiro de Recursos Hídricos, 22, Anais... Florianópolis: ABRH, 2017.

RIBEIRO, M. M. R.; SOUZA, J. A.; VIEIRA, Z. M. C. L. Cobrança de água bruta na bacia hidrográfica do Rio Paraíba do Norte - Brasil: discussão, aprovação e perspectivas de implementação. In: Simposio Iberoamericano Sobre Sistemas de Abestecimiento y Drenaje, 12, Anais... Urbano. INA: Buenos Aires, 2013.

THOMAS, P. T. Proposta de cobrança pelo uso das águas transpostas da bacia do rio São Francisco. Tese (Doutorado em Engenharia de Recursos Hídricos). Rio de Janeiro: COPPE/UFRJ, 2008.

VERA, L. H. A.; MONTENEGRO, S. M. G. L.; SILVA, S. R. Performance of water usage charge in the Nation's domain as a water resource management tool in the São Francisco River basin. RBRH. v. 22, e7, 2017. 


\title{
CAPITTULO XXXVII
}

\section{AMÁLISE DOS IMPACTOS AMBIENTAUS SOBRE OS RECURSOS HÍDRICOS NO SEMILÁRIDO BRAS|LEIRO}

\section{DOI: 10.51859/amplla.mas481.1121-37}

\author{
Manoel Mariano Neto ${ }^{1}$ \\ Yáscara Maia Araújo de Brito ${ }^{2}$ \\ Jéssica Kaori Sasaki ${ }^{3}$ \\ Higor Costa de Brito ${ }^{4}$
}

\begin{abstract}
${ }^{1}$ Bacharel em Ciência e Tecnologia e em Engenharia Ambiental e Sanitária, mestre em Planejamento e Dinâmicas Territoriais no Semiárido, doutorando em Engenharia Civil e Ambiental. Universidade Federal de Campina Grande (UFCG).

2 Bacharela em Engenharia Civil, mestra em Engenharia Civil e Ambiental, Doutoranda em Engenharia e Gestão de Recursos Naturais. Universidade Federal de Campina Grande (UFCG).

${ }^{3}$ Bacharela em Engenharia Civil, mestranda em Engenharia Civil e Ambiental. Universidade Federal de Campina Grande (UFCG).

${ }^{4}$ Bacharel em Engenharia Civil, mestre e doutorando em Engenharia Civil e Ambiental. Universidade Federal de Campina Grande (UFCG).
\end{abstract}

\section{RESUMO}

Este trabalho teve por objetivo analisar os impactos incidentes sobre os usos múltiplos associados à Lagoa do Apodi, na porção semiárida do estado do Rio Grande do Norte, Brasil. Para tanto, empregou-se a Análise de Cadeia Causal (ACC), com a finalidade de identificar os impactos ambientais negativos e classificar de acordo com suas respectivas causas. Constatou-se que este ambiente aquático é de grande valia socioambiental, tendo em vista seus usos múltiplos, que permitiram a fixação e o desenvolvimento da população, a partir das práticas agropecuárias e da pesca artesanal. Todavia, na atualidade este reservatório sofre um processo de degradação que compromete a qualidade hídrica e ambiental, devido às falhas no gerenciamento dos sistemas de recursos locais. Quanto aos impactos ambientais incidentes, enfatiza-se a redução da qualidade da água, ocorrência de perdas de biodiversidade, eutrofização e redução do volume hídrico. Tais problemas decorrem, principalmente, do lançamento de esgotos in natura e disposição irregular dos resíduos sólidos, entendidos como questões políticogerenciais; das condições climáticas ed a irrigação, que configuram aspectos de cunho técnico; da pesca artesanal e da pecuária familiar, classificadas como atividades econômico-culturais. Assim, as principais recomendações, com vistas a mitigação dos impactos, fazem menção ao melhoramento do sistema de governança, ampliação dos investimentos em educação ambiental, melhoria do monitoramento e aplicação de sanções, e a ampliação dos serviços de saneamento.

Palavras-chave: Recursos hídricos. Avaliação de Impactos Ambientais. Qualidade ambiental. 


\section{INTRODUÇÃO}

A água, conforme os fundamentos da Política Nacional de Recursos Hídricos (PNRH), é definida como um recurso natural limitado, dotado de valor econômico e de domínio público. Logo, destaca-se a importância conferida aos usos múltiplos, com ênfase ao abastecimento humano e dessedentação animal (BRASIL, 1997).

Nenhum outro recurso, exceto o ar, apresenta tantos usos quanto à água. Neste contexto, os múltiplos usos são classificados em duas categorias: consuntivos, quando impõe a retirada de água do corpo hídrico, favorecendo a ocorrência de perdas entre o que é derivado e o que retorna às reservas; e não consuntivos, caracterizados pela não ocorrência de retiradas da água (DERISIO, 2012).

Aspectos diversos comprometem a disponibilidade hídrica, tais como a exploração desordenada, o crescimento populacional e a poluição advinda das atividades antrópicas (BRAGA et al., 2005; OLIVEIRA; SANTOS, 2017). No semiárido brasileiro, essa questão se torna ainda mais relevante face às limitações impostas pelas condições climáticas e geomorfológicas, visto que a precipitação anual varia entre 250 $\mathrm{mm}$ e $800 \mathrm{~mm}$, distribuídos de forma irregular, e, aproximadamente $70 \%$ dessa porção territorial se encontra sobre a formação do cristalino, que dificulta a estocagem de água no subsolo (MALVEZZI, 2007; TINÔCO et al., 2018).

Inserida nesse cenário está a Lagoa do Apodi, localizada na região do Alto Oeste, no semiárido Potiguar. O corpo hídrico em questão situa-se em uma área de transição entre os ambientes urbano e rural, fato que contribui para que ocorram usos diversificados, como a pesca, agricultura e pecuária familiar, diluição de esgotos e práticas de lazer (NASCIMENTO; PINTO FILHO; SILVA, 2019; SOARES et al., 2019; PINTO FILHO; NOBRE; SILVA, 2020).

Mediante tais discussões, este trabalho tem por finalidade analisar os impactos incidentes sobre os usos múltiplos associados à Lagoa do Apodi/RN. Para tanto, aplicouse a Análise de Cadeia Causal (ACC), desenvolvida pela Global International Waters Assessment (GIWA), em 2002 (BELAUSTEGUIGOITIA, 2004). A aquisição dos dados e informações foi realizada mediante consultas às pesquisas anteriores, que pautam o objeto de estudo. 
A ACC empregada parte da unificação das abordagens realizadas por Wang, Cai e Fang (2009), que identificam os impactos ambientais associados ao problema, os correlacionam às causas e propõem medidas para mitiga-los; e Silva, Ribeiro e Miranda (2017), que organizam as causas em categorias: técnicas, político-gerenciais, socioeconômico e culturais. A unificação desses modelos é justificável por propiciar maiores informações acerca das causas que impulsionam os impactos aos usos do recurso hídrico e, assim, favorecer a proposição de medidas mais coerentes às condições do caso em estudo.

Para além deste texto introdutório, o artigo é constituído por outras três seções: a "Área de estudo", que contextualiza a Lagoa do Apodi; a "Análise dos impactos ambientais sobre os usos múltiplos do ambiente aquático"; e as "Considerações finais". Por fim, está disposta a lista de referências, consultadas para elaboração do texto.

\section{2. ÁREA DE ESTUDO}

A Lagoa do Apodi (Figura 1) está situada na Bacia Hidrográfica do Rio ApodiMossoró. Esse ambiente aquático, possui grande relevância socioambiental, uma vez que favoreceu a fixação da população na localidade na qual se encontra, dando origem ao bairro Malvinas, consolidando uma área de transição entre os espaços urbano e rural (SOARES et al., 2019). Na atualidade, dar-se destaque aos usos consuntivos, tais como a irrigação e dessedentação animal, e não consuntivos, dentre eles, a pesca artesanal, recreação, harmonia paisagística e diluição de esgotos. 
Figura 1 - Localização da Lagoa do Apodi/RN.

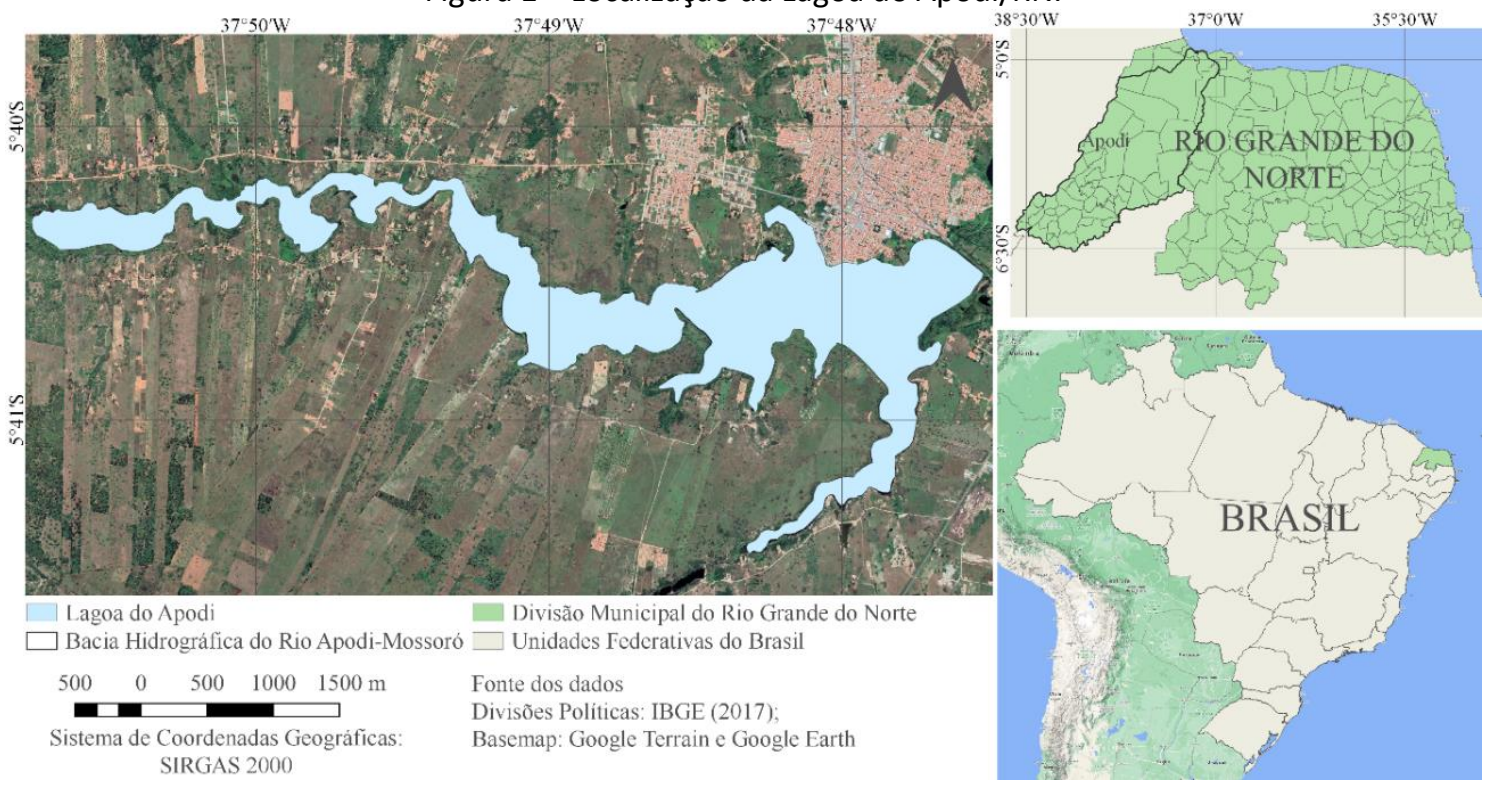

Fonte: Elaborado pelos autores (2020).

O município de Apodi, conforme o Instituto Brasileiro de Geografia e Estatística (IBGE, 2020), possui uma área correspondente a 1.602,477 km². Em 2010, a população correspondia a 34.763 pessoas, já as estimativas mais recentes indicam um pequeno acréscimo, chegando a 35.874 pessoas, em 2020.

No tocante ao relevo e à geologia da área, nota-se a ocorrência de declividades próximas a $2 \%$, permitindo caracterizar como uma região plana, situada em uma zona sedimentar cristalina (SANTANA JÚNIOR, 2010). A precipitação média anual varia entre, aproximadamente, 740 mm e 820 mm (MEDEIROS; CAVALCANTE; PINHEIRO, 2018), com um período seco de 7 a 8 meses ao longo do ano (DINIZ; PEREIRA, 2015). Enfatiza-se ainda a ocorrência de evaporação potencial média de aproximadamente $2000 \mathrm{~mm} / \mathrm{ano}$ (LIMA, 2007).

\section{ANÁLISE DOS IMPACTOS AMBIENTAIS SOBRE OS USOS MÚLTIPLOS}

Face às limitações e inconformidades existentes no Sistema de Recursos que constitui a Lagoa do Apodi, um dos problemas mais preponderantes é o comprometimento dos usos múltiplos. Diante disso, busca-se, a partir da matriz de cadeia causal (Figura 2) analisar os impactos, correlacionando-os às respectivas causas, bem como propor medidas para mitiga-los. 
Figura 2 - Matriz de cadeia causal: comprometimento dos usos múltiplos na Lagoa do Apodi/RN.

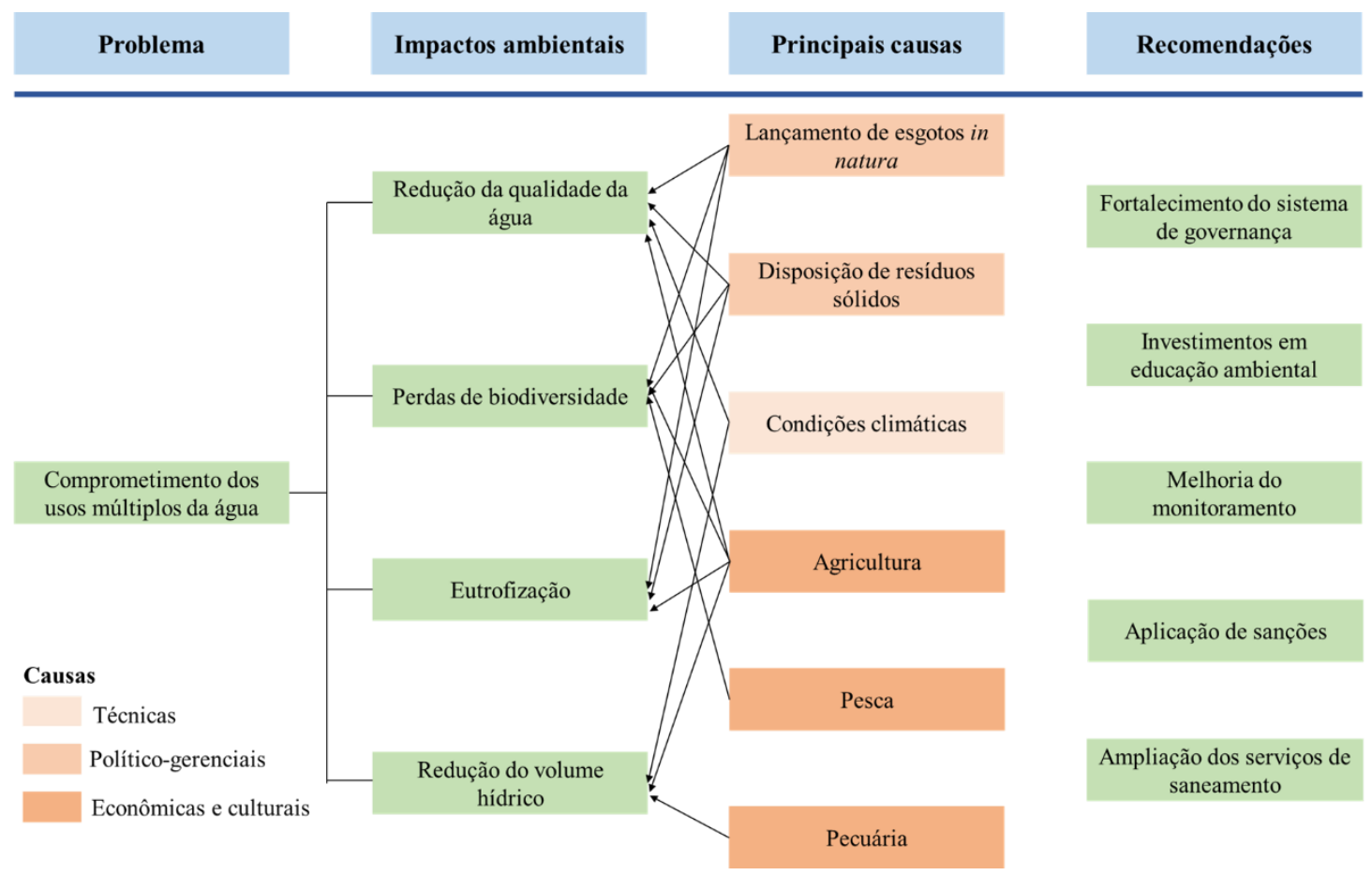

Fonte: Elaborado pelos autores (2020).

Os impactos foram relacionados às causas mais preponderantes, que por sua vez foram definidas como técnicas, político-gerenciais e econômicas, e culturais. Entendese como causas técnicas aquelas oriundas da ausência das ações políticas e gerenciais ou decorrentes do quadro econômico-cultural, possíveis de serem atenuadas mediante emprego de soluções técnicas. As causas político-gerenciais resultam, primordialmente, de fragilidades na conjuntura política e, quando solucionadas, melhoram a operação do sistema. Já as causas econômicas e culturais, são estabelecidas por aspectos de cunhos econômico e cultural, propiciando prejuízos às diversas camadas sociais (SILVA; RIBEIRO; MIRANDA, 2017).

\subsection{LANÇAMENTO DE ESGOTOS}

A interferência antrópica, mediante a geração e lançamento de despejos domésticos ou industriais, contribui para a introdução de compostos na água, afetando a qualidade. Com isso, são desencadeados efeitos indiretos, que recaem sobre as formas de vida aquática, culminando na alteração da biodiversidade (VON SPERLING, 2014).

No caso da Lagoa do Apodi, o lançamento de esgotos é um problema que surgiu e se intensificou ao longo dos últimos 20 anos. Com isso, $43,7 \%$ da população o 
considera como principal agente de poluição desse corpo hídrico (MOREIRA, 2017). A gravidade dessa questão decorre da ausência da coleta e tratamento dos esgotos, fato que reflete nas medidas adotadas pela população (NASCIMENTO, 2018). Assim, 89,32\% dos moradores do bairro Malvinas destinam o esgoto para a lagoa, (SOARES et al., 2019).

Como consequência dos despejos, nota-se a perda dos usos essenciais, dentre eles, o abastecimento humano (SOARES et al., 2019). Lemos, Ferreira Neto e Dias (2010) identificaram a ocorrência de contaminação desse ambiente aquático por coliformes, comprometendo a qualidade da água e a proteção da fauna aquática. Além disso, constata-se que o Índice de Qualidade de Água (IQA), entre 2009 e 2010, variou de médio a ruim, fato relacionado à ausência de esgotamento sanitário (PINTO FILHO; SANTOS; SOUZA, 2012). Estudos mais recentes também revelam alterações nos parâmetros físico-químicos, com destaque ao potencial de oxirredução, que apresentou valores elevados, ao longo do ano de 2017, indicando condições de degradação do recurso hídrico (SILVA, 2018).

\subsection{DISPOSIÇÃO DE RESIDUOS SÓLIDOS}

A disposição irregular dos resíduos é uma problemática que ocasiona impactos socioambientais indesejados, como poluição do solo, contaminação das águas superficiais e subterrâneas, e o comprometimento da saúde pública, devido a proliferação de vetores transmissores de doenças (PESSOA et al., 2018).

No entorno da Lagoa do Apodi, a falta de coleta de lixo é apontada pela população, como um dos principais problemas (NASCIMENTO, 2018). Diante disso, constatou-se que os resíduos são dispostos no corpo hídrico pelos moradores, comerciantes locais e pelos frequentadores do calçadão, que usam esse ambiente para as práticas de exercícios e lazer (CHAVES, 2017).

O contato dos resíduos sólidos com os corpos hídricos finda por culminar na poluição e contaminação, devido à presença de matéria orgânica, nutrientes e outros componentes solúveis em água, que variam de acordo com as características dos resíduos (PEREIRA, 2019; KAPELEWSKA et al., 2019). Com isso, ocorrem perdas diretas, como a redução da qualidade da água, eutrofização e perdas de biodiversidade aquática. 


\subsection{CONDIÇÕES CLIMÁTICAS}

De acordo com a Normal Climática 1981-2010 (Figura 3), disponibilizada pelo Instituto Nacional de Meteorologia (INMET, 2018), a precipitação pluviométrica anual média e a evapotranspiração potencial anual média em Apodi correspondem a 829,7 $\mathrm{mm}$ e $2348,5 \mathrm{~mm}$, respectivamente.

Figura 3 - Dados da Normal Climática 1981-2010, para Apodi/RN.

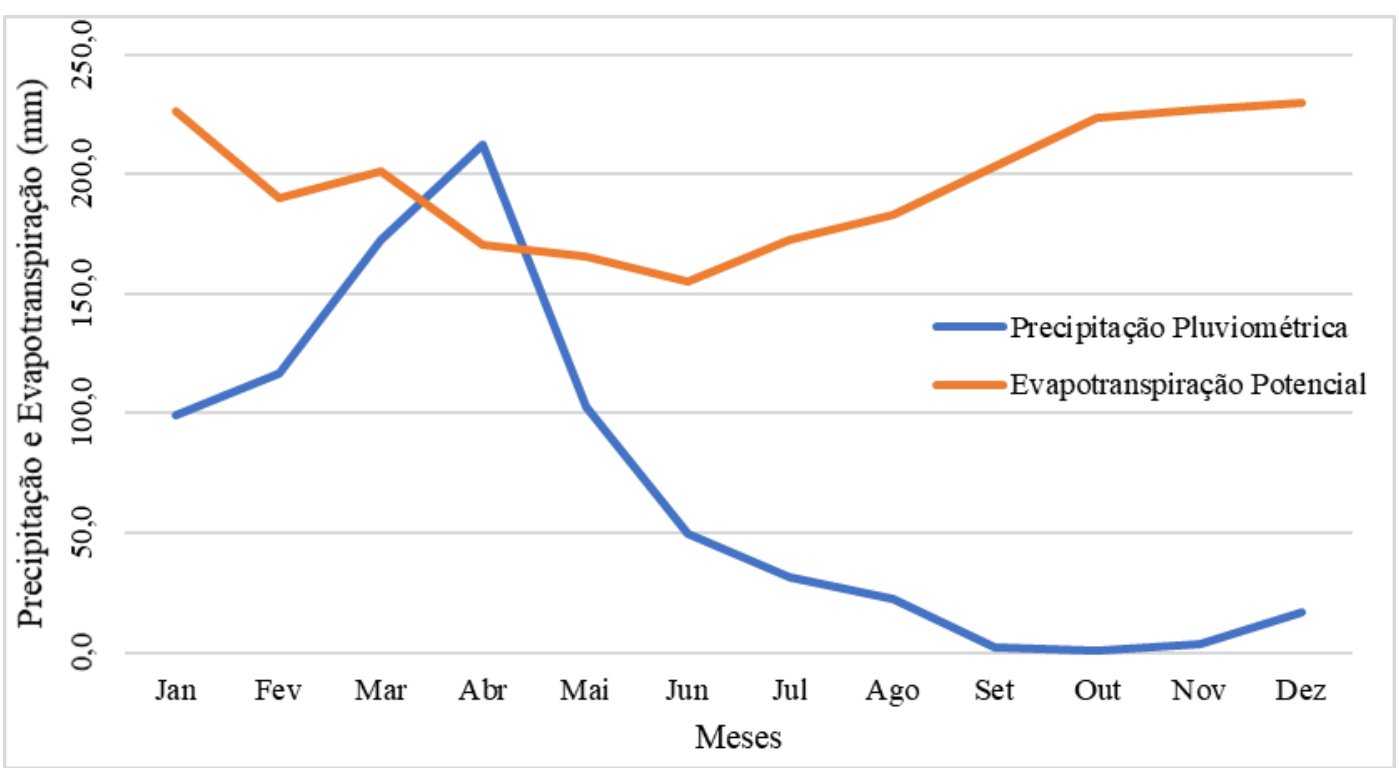

Fonte: INMET (2018). Adaptado pelos autores.

Como se observa, a partir dos dados mensais, as chuvas tendem a ocorrer de forma irregular ao longo do ano, de modo que os maiores volumes são concentrados entre os meses de março a maio. Em contrapartida, a evapotranspiração potencial se mostra muito acentuada e, superior à precipitação em quase todo o ano, exceto nos meses de abril e maio.

Tais condições findam por determinar um déficit hídrico médio de 1518,9 $\mathrm{mm} / \mathrm{ano}$, refletido, principalmente, em perda de grandes volumes em reservatórios superficiais ao longo do ano, comprometendo a disponibilidade hídrica para as atividades agrícolas e, em casos de longos períodos secos, afetando a pesca.

As pesquisas conduzidas na localidade mostram que as condições climáticas também interferem na qualidade da água, visto que favorecem o aumento da salinidade e, por consequência, da condutividade elétrica. Ocorre ainda a elevação na 
concentração de sólidos e a diminuição do IQA (LEMOS; FERREIRA NETO; DIAS, 2010; PINTO FILHO; SANTOS; SOUZA, 2012; SILVA, 2018).

\subsection{AGRICULTURA E PECUÅRIA}

A agricultura, juntamente com a pecuária e à pesca, foram as atividades que mais favoreceram a fixação da população às margens da Lagoa do Apodi (MOREIRA, 2017).

Todavia, nota-se que a forma como tais atividades são desenvolvidas, proporciona perdas ambientais, decorrentes, sobretudo, do uso de agrotóxicos, realização de queimadas e desmatamentos, criação de animais no entorno do reservatório e da retirada de água para irrigação e dessedentação animal, sem a existência de outorgas ou outras licenças, emitidas pelo Instituto de Gestão de Águas do Estado do Rio Grande do Norte - IGARN (NASCIMENTO, 2018).

Diante disso, afirma-se que o segmento agropecuário, mesmo que desenvolvido em pequena escala, contribui para a contaminação da água, devido ao carreamento de contaminantes; favorece a redução do volume hídrico disponível e a ocorrência de eutrofização; e, ocasiona perdas à biodiversidade.

\subsection{PESCA}

A pesca na Lagoa do Apodi pode ser considerada uma atividade tradicional, uma vez que é uma prática que retoma as origens da localidade, sendo passada entre as gerações e desenvolvida artesanalmente, por usuários locais (PINTO FILHO; NOBRE; SILVA, 2020).

No entanto, trata-se de uma atividade que compromete, a biodiversidade aquática, devido à falta de cuidados e monitoramento. Nesse sentido, 41,56\% dos pescadores consideram que a pesca é desenvolvida de forma predatória e 14,29\% relatam a escassez de peixes (PINTO FILHO; NOBRE; SILVA, 2020).

\subsection{RECOMENDAÇÕES}

As recomendações para solucionar os problemas discutidos e assim proporcionar maior sustentabilidade ao uso do sistema de recursos representado pela Lagoa do Apodi, perpassam pelo melhoramento do sistema de governança, com ênfase ao 
protagonismo dos atores locais, de modo a alcançar maior representatividade, minimizar a ocorrência de conflitos e a degradação desse ambiente aquático.

Cita-se também a necessidade de melhorar o monitoramento e a fiscalização, essenciais para viabilizar a aplicação de sanções aos usuários que infringem as regras e colocam a disponibilidade dos recursos em risco. A ampliação do acesso aos serviços de saneamento pela população residente no entorno da lagoa também permite ganhos socioambientais, por minimizar a proliferação de vetores de doenças e a poluição ambiental (CAIRNCROSS, 2018).

Ressalta-se ainda a urgência e relevância da ampliação dos investimentos em educação ambiental em curto, médio e longo prazo. Por se tratar de um instrumento que permite o fortalecimento e construção da cidadania, possibilita alcançar o senso de responsabilidade individual e coletiva com o meio ambiente, confere sentido às relações entre indivíduos e natureza, e, modifica as formas de pensar as práticas sociais (JACOBI, 2003).

\section{CONSIDERAÇÕES FINAIS}

A Lagoa do Apodi se configura como um ambiente aquático de grande valia socioambiental, tendo em vista seus usos múltiplos, que permitiram a fixação e o desenvolvimento da população, a partir das práticas agropecuárias e da pesca artesanal. Todavia, na atualidade este reservatório sofre um processo de degradação que compromete a qualidade hídrica e ambiental, devido às falhas no gerenciamento dos sistemas de recursos locais.

Quanto aos impactos ambientais que comprometem os usos múltiplos do recurso hídrico, enfatiza-se a redução da qualidade da água, ocorrência de perdas de biodiversidade, eutrofização e redução do volume hídrico. Tais problemas decorrem, principalmente, do lançamento de esgotos in natura e disposição irregular dos resíduos sólidos, entendidos como questões político-gerenciais; das condições climáticas e da irrigação, que configuram aspectos de cunho técnico; da pesca artesanal e da pecuária familiar, classificadas como atividades econômico-culturais.

Assim, as principais recomendações, com vistas a mitigação dos impactos, fazem menção ao melhoramento do sistema de governança, ampliação dos investimentos em 
educação ambiental, melhoria do monitoramento e aplicação de sanções, e a ampliação dos serviços de saneamento.

\section{AGRADECIMENTOS}

Os autores agradecem à Coordenação de Aperfeiçoamento de Pessoal de Nível Superior (CAPES) e ao Conselho Nacional de Desenvolvimento Científico e Tecnológico (CNPq), pelo apoio financeiro.

\section{REFERÊNCIAS}

BELAUSTEGUIGOITIA, J. C. Causal chain analysis and root causes: the GIWA approach. AMBIO: A Journal of the Human Environment, v. 33, n. 1, p. 7-12, 2004.

BRAGA, B.; HESPANHOL, I.; CONEJO, J. G. L.; MIERZWA, J. C.; BARROS, M. T. L.; SPENCER, M.; EIGER, S. Introdução à Engenharia Ambiental: o desafio do desenvolvimento sustentável. 2 Ed. São Paulo: Pearson Prentice Hall, 2005.

BRASIL. Lei 9.433 de 08 de janeiro de 1997. Institui a Política Nacional de Recursos Hídricos, cria o Sistema Nacional de Gerenciamento de Recursos Hídricos. Disponível em: http://www.planalto.gov.br/ccivil_03/Leis/19433.htm. Acesso em: 07 de abril de 2020.

CAIRNCROSS, S. The public health benefits of urban sanitation in low and middle income countries. Utilities Policy, v. 51, p. 82-88, 2018.

CHAVES, M. L. Q. Diagnóstico ambiental do lazer e turismo na Lagoa do Apodi-RN com foco nos empreendimentos. 2017. TCC (Graduação), Bacharelado em Ciência e Tecnologia, UFERSA, Pau dos Ferros, 2017.

DERISIO, J. C. Introdução ao controle de poluição ambiental. 4. ed. São Paulo: Oficina de Textos, 2012.

DINIZ, M. T. M.; PEREIRA, V. H. C. Climatologia do estado do Rio Grande do Norte, Brasil: Sistemas atmosféricos atuantes e mapeamento de tipos de clima. Boletim goiano de geografia, v. 35, n. 3, p. 488-506, 2015.

INSTITUTO BRASILEIRO DE GEOGRAFIA E ESTATÍSTICA (IBGE). IBGE Cidades: Apodi. 2020. Disponível em: https://cidades.ibge.gov.br/brasil/rn/apodi/panorama. Acesso em 07 mai. 2021. 
INSTITUTO NACIONAL DE METEOROLOGIA (INMET). Normais Climatológicas do Brasil. 2018.

http://www.inmet.gov.br/portal/index.php?r=clima/normaisClimatologicas.

Acesso em: 15 jun. 2020.

JACOBI, P. Educação ambiental, cidadania e sustentabilidade. Cadernos de pesquisa, n. 118, p. 189-206, 2003.

KAPELEWSKA, J.; KOTOWSKA, U.; KARPIŃSKA, J.; ASTEL, A.; ZIELIŃSKI, P.; SUCHTA, J.; ALGRZYM, K. Water pollution indicators and chemometric expertise for the assessment of the impact of municipal solid waste landfills on groundwater located in their area. Chemical Engineering Journal, v. 359, p. 790-800, 2019.

LEMOS, M.; FERREIRA NETO, M.; DIAS, N. S. Sazonalidade e variabilidade espacial da qualidade da água na Lagoa do Apodi, RN. Revista Brasileira de Engenharia Agrícola e Ambiental, v. 14, n. 2, p. 155-164, 2010.

LIMA, K. S. D. Alterações dos parâmetros climáticos no município de Apodi/RN, antes e após a construção da barragem de Santa Cruz do Apodi, e formação do lago. 2007. 68 f. Dissertação (Mestrado) - Curso de Mestrado em Geografia, UFRN, Natal, 2007.

MALVEZZI, R. Semiárido: uma visão holística. Brasília: Confea, 2007. 140 p.

MEDEIROS, D. H. M.; CAVALCANTE, A. A.; PINHEIRO, L. S. Aspectos pluviométricos e heterogeneidade do relevo na disponibilidade hídrica da Bacia Hidrográfica do Rio Apodi/Mossoró (RN, Brasil). Revista Geotemas, v. 8, n. 3, p. 29-41, 2018.

MOREIRA, L. N. S. História Ambiental da Lagoa do Apodi-RN. 2017. TCC (Graduação), Bacharelado em Ciência e Tecnologia, UFERSA, Pau dos Ferros, 2017.

NASCIMENTO, P. J. Percepção ambiental dos agricultores da Lagoa do Apodi-RN. 2018. TCC (Graduação), Bacharelado em Ciência e Tecnologia, UFERSA, Pau dos Ferros, 2018.

NASCIMENTO, P. J.; PINTO FILHO, J. L. O.; SILVA, M. M. N. Percepção ambiental dos agricultores da Lagoa do Apodi-RN. In: SEABRA, G. (Org.). Terra: habitat urbanos e rurais. Ituiutaba: Barlavento, 2019. p. 2420-2432.

PEREIRA, Eduardo Vinícius. Resíduos sólidos. São Paulo: Editora Senac, 2019.

PESSOA, D. S.; COSME, A. M. F.; SILVA, V. F.; COSTA, R.; LIMA, V. L. A.; FERREIRA, A. C. Resíduos sólidos: evidências científicas sobre sua disposição final e impactos ambientais. Revista Ibero-Americana de Ciências Ambientais, v. 9, n. 7, p. 202210, 2018. 
PINTO FILHO, J. L. O.; SANTOS, E. G.; SOUZA, M. J. J. B. Proposta de índice de qualidade de água para a Lagoa do Apodi, RN, Brasil. Holos, v. 2, p. 69-76, 2012.

PINTO FILHO, J. L. O.; NOBRE, S. B.; MARIANO NETO, M. O perfil socioeconômico e a percepção ambiental dos pescadores da Lagoa do Apodi, Rio Grande do Norte, Brasil. Interações (Campo Grande), v. 21, n. 4, p. 721-737, 2020.

OLIVEIRA, K. I. S.; SANTOS, L. R. P. Química Ambiental. Curitiba: Intersaberes, 2017.

SANTANA JÚNIOR, H. E. Zoneamento agroecológico do município de Apodi/RN. 2010. 121 f. Dissertação (Mestrado) - Curso de Mestrado em Desenvolvimento e Meio Ambiente, UFRN, Natal, 2010.

SILVA, P. H. P.; RIBEIRO, M. M. R.; MIRANDA, L. I. B. Uso de cadeia causal na análise institucional da gestão de recursos hídricos em reservatório no semiárido da Paraíba. Engenharia Sanitária e Ambiental, v. 22, n. 4, p. 637-646, 2017.

SILVA, M. M. N. Monitoramento da qualidade da água da Lagoa do Apodi-RN. 2018. TCC (Graduação), Bacharelado em Engenharia Ambiental e Sanitária, UFERSA, Pau dos Ferros, 2018.

SOARES, L. L. L. O.; PINTO FILHO, J. L.; FEITOSA, A. P.; BEZERRA, J. M. Perfil socioeconômico e percepção ambiental dos moradores do entorno da Lagoa do Apodi, Rio Grande do Norte. Revista Verde de Agroecologia e Desenvolvimento Sustentável, v. 14, n. 1, p. 111-119, 2019.

TINÔCO, I. C. M.; BEZERRA, B. G.; LUCIO, P. S.; BARBOSA, L. M. Characterization of rainfall patterns in the semiarid Brazil. Anuário do Instituto de Geociências, v. 41, n. 2, p. 397-409, 2018.

VON SPERLING, M. Introdução à qualidade das águas e ao tratamento de esgotos. Belo Horizonte: UFMG, 2014.

WANG, L; CAI, Y; FANG, L. Pollution in Taihu Lake China: causal chain and policy options analyses. Frontiers of Earth Science in China, v. 3, n. 4, p. 437, 2009. 


\title{
CAPITULO XXXVIII
}

\section{DIAGNÓSTICO DO FECHAMENTO DE MINA DOS MUNIĆ́PIOS DE JANAÚBA E PORTEIRINHA}

\section{DOI: 10.51859/amplla.mas481.1121-38}

\author{
Ana Clara Barbosa Cardoso ${ }^{1}$ \\ João Victor Alves Ribeiro' \\ Bruno Nobre Evangelista ${ }^{1}$ \\ Leonardo Azevedo Sá Alkmin² \\ Jônatas Franco Campos da Mata²
}

\begin{abstract}
${ }^{1}$ Graduandos do curso de Engenharia de Minas. Universidade Federal dos Vales do Jequitinhonha e Mucuri - UFVJM

${ }^{2}$ Professores do curso de Engenharia de Minas. Universidade Federal dos Vales do Jequitinhonha e Mucuri - UFVJM
\end{abstract}

\section{RESUMO}

O fechamento de mina consiste em uma fase essencial e, por muitas vezes, negligenciada em empreendimentos de mineração. Este conceito se fundamenta na obrigação legal e responsabilidade social dos empreendedores em, ao final do ciclo de vida da mina, entregar as áreas impactadas à sociedade em ótimas condições para serem utilizadas em fins úteis. Isto resulta em reabilitar as áreas de lavra e servidões da mina, além de desmobilizar as instalações e equipamentos utilizados em todas as suas operações. O presente trabalho é direcionado para o diagnóstico do estágio atual do fechamento de mina em empreendimentos minerários localizados nos municípios de Janaúba e Porteirinha, situados na região Norte do Estado de Minas Gerais. Tal pesquisa utilizou, em seu desenvolvimento, duas fontes principais: levantamentos feitos pela FEAM no âmbito do Projeto Reconversão de Territórios, com relação a minas paralisadas e abandonadas nos municípios da área de estudo, além dos processos minerais cadastrados no sistema SIGMINE, gerenciado pela Agência Nacional de Mineração (ANM). Tais minas foram vistoriadas no campo. Através da utilização de ferramentas de georreferenciamento e programas computacionais adequados, foram mapeadas as áreas impactadas pela mineração, avaliando se a reabilitação ambiental está sendo conduzida conforme o Plano de Recuperação de Áreas Degradadas (PRAD) e outros instrumentos de planejamento do fechamento de mina. O objetivo geral desta pesquisa é a definição de alternativas tecnológicas sustentáveis para que a requalificação das áreas mineradas seja feita de forma sustentável e consistente, em consonância com as características socioeconômicas e ambientais da região.

Palavras-chave: Fechamento de mina. Reabilitação ambiental. Sustentabilidade na mineração. Norte de Minas Gerais. Meio ambiente. Recuperação de áreas degradadas. 


\section{INTRODUÇÃO}

Na economia brasileira, a mineração vem cada vez mais ganhando seu espaço e se tornando um campo essencial, principalmente no estado de Minas Gerais. Analisando-se dados obtidos pelo IBRAM (2018), pode-se constatar que, no ano de 2017, a indústria extrativa mineral representou aproximadamente $4 \%$ do Produto Interno Bruto. Neste mesmo ano, a Produção Mineral Brasileira atingiu a cifra de US\$ 32 bilhões, empregando de forma direta, 180.969 pessoas. Destaca-se o estado de Minas Gerais, que colaborou com 49.968 pessoas, contribuindo assim com $27,61 \%$ do total.

Em vista dessas particularidades, tem-se uma demanda de implementação da gestão de sustentabilidade, segurança operacional e mecanismos efetivos de controle. O intuito principal é permitir que as minerações sejam reconhecidas como organizações sustentáveis, levando em consideração o ponto de vista da preservação ambiental e, não menos importante, a melhoria da qualidade de vida das gerações presentes e futuras. Adotando-se essas medidas, é possível prevenir a ocorrência de tragédias ambientais.

O plano de fechamento de mina é utilizado para ter-se uma direção do melhor caminho a ser feito. Os procedimentos de fechamento de mina foram regulamentados, no Brasil, pela Portaria DNPM no 237, a qual instituiu, dentre outras normas, a Norma Reguladora da Mineração (NRM) no 20 - Suspensão, Fechamento de Mina e Retomada das Operações Mineiras (DNPM, 2001).

No estado de Minas Gerais, estabeleceu-se de forma mais extensa essa legislação. Neste estado, o plano de fechamento de mina deve ser conduzido durante toda vida da mina, desde os estudos de viabilidade técnico-econômica até o descomissionamento, reabilitação e utilização futura da área recuperada. A Deliberação Normativa COPAM no 220 estabelece os critérios e procedimentos para o Plano Ambiental de Fechamento de Mina (PAFEM) (COPAM, 2018).

O presente trabalho tem, como principal objetivo, verificar alternativas tecnológicas e legais para o fechamento de minas na região Norte de Minas, sem esquecer suas particularidades sociais e econômicas. Desta forma, pretende-se obter um conhecimento do real estágio de reabilitação ambiental das minas, e efetuar a comparação com as exigências dos órgãos de regulação mineral (ANM) e ambiental 
(FEAM). Após esta análise, serão propostas uma metodologia de resolução dos problemas descobertos.

\section{REFERENCIAL}

O Sistema Estadual de Meio Ambiente e Recursos Hídricos (SISEMA) é responsável pelo desdobramento da política ambiental federal, no âmbito do estado de Minas Gerais, sendo composto pelas seguintes instituições (PORTAL MEIO AMBIENTE MG, 2019):

- Secretaria de Estado de Meio Ambiente e Desenvolvimento Sustentável (SEMAD);

- Conselho Estadual de Política Ambiental (COPAM);

- Conselho Estadual de Recursos Hídricos (CERH);

- Órgãos vinculados: Fundação Estadual do Meio Ambiente (FEAM); Instituto Estadual de Florestas (IEF); e Instituto Mineiro de Gestão das Águas (IGAM).

A Figura 1, a seguir, apresenta, de forma esquemática, a inter-relação organizacional destes órgãos.

Figura 1 - Esquema da organização do SISEMA

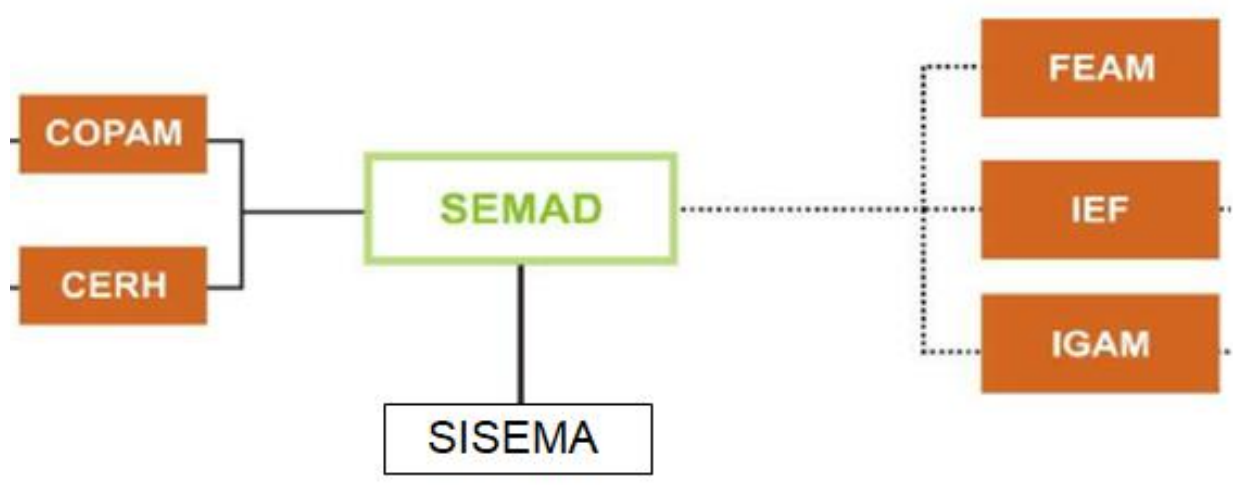

Fonte: próprio autor (2019).

A ANM, órgão responsável pela regulação e fiscalização das atividades minerárias no Brasil, possui norma específica para o fechamento de mina, suspensão e retomada das operações mineiras, a NRM 20. 
De acordo com a NRM 20, o fechamento de uma mina pode ocorrer quando as operações são irregulares de forma definitiva. Portanto, a suspensão ocorre quando as atividades da mina são paralisadas por um certo período de tempo, sendo prevista a retomada futura da mesma (DNPM, 2001).

O caso de suspensão das atividades, a mesma presume que o empreendedor precisa protocolar o pedido ao Ministério de Minas e Energia, juntamente com os documentos comprobatórios de vários aspectos da mina, como: relatório de operações realizadas, atual estado da mina e perspectivas futuras de retomada; informações sobre recursos e reservas remanescentes da jazida mineral; caracterização completa das frentes de lavra, instalações e infraestrutura atual; planos de monitoramento da área, contemplando a preservação das coberturas vegetais remanescentes, águas superficiais e subterrâneas; detalhamento das áreas impactadas e forma de recuperação a ser adotada; sinalização e isolamento de todas as áreas de lavra, instalações de beneficiamento, depósitos de estéril e barragens de rejeitos (DNPM, 2001). Para reativar as operações, deve ser solicitada a ANM com antecedência, sem deixar de atender a vários requisitos já definidos pela agência regulatória.

Antes do fechamento de mina deve haver a comunicação à ANM, devidamente justificada e comprovada pelos relatórios pertinentes, por exemplo as atividades realizadas na mina, as reservas remanescentes presente na área, o planejamento do descomissionamento, desmontagem, limpeza das instalações físicas e equipamentos do projeto. Não só isso, mas também deve ser planejada a caracterização completa das áreas impactadas pela lavra e beneficiamento, contemplando o planejamento de reabilitação ambiental e todas as intervenções tendo em vista que a área será devolvida à sociedade, planos de monitoramento e controle ambiental de depósitos de estéril, barragem de rejeito, drenagens superficiais e das águas subterrâneas (DNPM, 2001)

Além disso esse decreto define regras para que ocorra a suspenção temporárias das atividades na lavra. Essa suspensão é permitida, desde que seja justificada através de relatório entregue à ANM, em que deve conter os motivos da paralisação de maneira clara, bem como a expectativa futura de retorno às operações. É dever da ANM aceitar ou rejeitar tal requerimento, de acordo com à análise crítica dessa justificativa. Na hipótese da solicitação de suspenção for aceita, é dever do empreendedor comunicar, 
com antecedência à ANM, a data de previsão de paralisação, além de monitorar as áreas paralisadas durante todo o período paralisado (BRASIL, 2018).

No estado de Minas Gerais, a legislação é mais restritiva e avançada quando comparada à NRM no 20 (DNPM, 2001), principalmente em relação aos deveres do empreendedor no fechamento de mina. Segundo a Deliberação Normativa COPAM no 220, os responsáveis legais pelo empreendimento de mineração devem definir, de forma mais transparente e objetiva, qual o caminho a seguir com esses empreendimentos se houver uma paralisação ou até mesmo encerramento (COPAM, 2018). Com tais considerações, a paralisação da mina é definida como um fechamento temporário da mesma, que pode ter sido acorrentado por problemas técnicos (obras de infraestrutura, oscilação de demanda e outros eventos), incidentais (acidentes materiais ou humanos, desastres naturais e outros) ou judiciais (recuperação econômica, embargo da mina e outros eventos), havendo a intenção de reinício de operação após a resolução destes problemas. Quando ocorre o fechamento da mina, esta é a última etapa do ciclo de vida da mina, assim deve-se ser representada através de um projeto com ideias de uso futuro da área que foi transformada pela mineração. Esse projeto, todos que estão envolvidos tem que estar de acordo, sejam da comunidade, da iniciativa privada ou até mesmo do Estado. Além de ser executado, através de documentação juntamente com os órgãos competentes, garantindo que haja a reabilitação das áreas degradadas (COPAM, 2018).

Para que ocorra a paralisação das atividades da mina, os responsáveis legais pelo empreendimento de mineração devem comunicar este fato à SUPRAM de sua área de abrangência, protocolando o Relatório de Paralisação de Atividade Minerária. A FEAM é o órgão responsável por orientar e emitir pareceres técnicos sobre o Relatório de Paralisação de Atividade Minerária, solicitando novas informações sempre que necessário (COPAM, 2018). No período de paralisação, o empreendimento deve satisfazer todas as exigências e condicionantes da licença ambiental e mineral vigente. E para a retomada das operações da mina, deve ser comunicada à SUPRAM em até 30 dias após iniciadas. 


\subsection{CADASTRO DE MINAS PARALISADAS E ABANDONADAS NO ESTADO DE MINAS GERAIS}

A FEAM realizou visitas em campo para conseguir identificar a situação ambiental das áreas. Além disso, foram analisados dados obtidos em Boletins de Ocorrência da Polícia Militar Ambiental e levantamentos efetivados pelas SUPRAMs e Prefeituras (FEAM, 2016).

Os mapas de informações e análises geradas foram compilados e apresentados, de forma resumida, no arquivo Lista de Minas Paralisadas e Abandonadas, contemplando 400 áreas e estando disponível para consulta no arquivo "Lista de Minas Paralisadas e Abandonadas", disponível no site da FEAM (FEAM, 2016).

\section{1.\% ANÁLISE E ESTRA TIFICAÇÃO DOS RESULTADOS}

Para apresentação e avaliação dos resultados deste trabalho, foi realizado uma consolidação dos dados e uma vasta análise estatística, onde foi dado como embasamento os seguintes parâmetros: fontes de informação, distribuição geográfica das áreas mineradas por SUPRAM, situação do empreendimento de acordo ao abandono ou paralisação e substância explorada. Ressalta-se que este cadastro perfaz 400 minas abandonadas ou paralisadas, consistindo em um mapeamento preliminar, que deverá ser aprimorado nos próximos anos. Totalizando as minas cadastradas, temse 169 áreas que são denominadas como abandonadas e 231 como paralisadas, concluindo estas últimas $73 \%$ do montante. As minas paralisadas são divididas em 97 áreas, sendo paralisadas com controle ambiental (42\%) e 134 áreas paralisadas sem controle ambiental ( $58 \%$ do total de minas paralisadas).

De acordo com as normas da COPAM (2009), áreas abandonadas são descritas como áreas que estão em situação de inatividade, sem previsões de reinício de operações e com ausência de medidas de controle ou monitoramento ambiental. Logo, caracteriza-se o abandono da área, bem como ausência ou incompletude do processo de reabilitação ambiental.

Minas paralisadas são áreas mineradas onde a ausência temporária de operações, isto é, existe previsão de reinício de atividades. Nas minas paralisadas com controle ambiental, são identificadas medidas de controle e monitoramento ambiental 
na área, em plena execução, enquanto nas minas paralisadas sem controle ambiental, tais medidas inexistem (COPAM, 2018).

A Figura 2, a seguir, demonstra uma estratificação quantitativa por SUPRAM. Notamos que a grande parte das minas paralisadas e abandonadas se localiza nos territórios da SUPRAM Central Metropolitana, SUPRAM Triângulo Mineiro e Alto Paranaíba. Por sua vez, a SUPRAM Norte de Minas contém apenas 3,5 \% do total.

Figura 2 - Distribuição das minas por SUPRAM

\begin{tabular}{c|c|c}
\hline SUPRAM & $\mathbf{N}^{\circ}$ de minas & $\%$ \\
\hline $\begin{array}{c}\text { Central Metropolitana } \\
\text { Triângulo Mineiro e Alto }\end{array}$ & 87 & 21,8 \\
$\begin{array}{c}\text { Paranaíba } \\
\text { Alto São Francisco }\end{array}$ & 62 & 15,5 \\
Jequitinhonha & 56 & 14,0 \\
Sul de Minas & 54 & 13,5 \\
Leste Mineiro & 48 & 12,0 \\
Zona da Mata & 38 & 9,5 \\
Noroeste & 26 & 6,5 \\
Norte & 15 & 3,8 \\
\hline
\end{tabular}

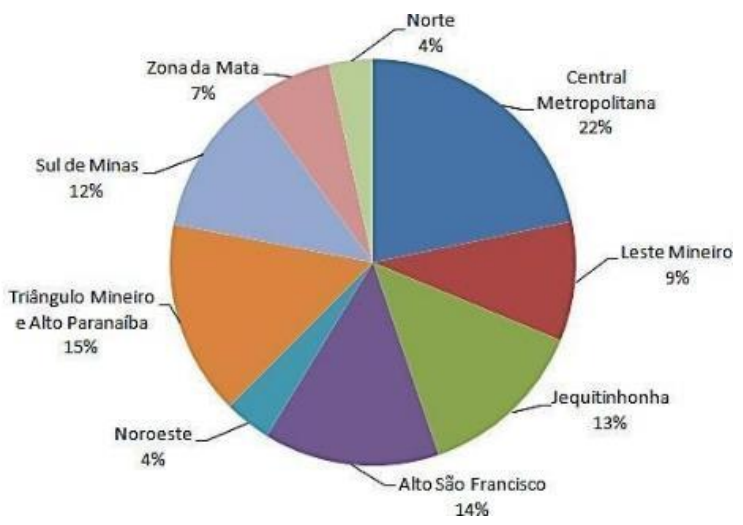

Fonte: FEAM (2016).

Em relação às minas levantadas no território da SUPRAM Norte de Minas, foi observada uma grande distância relativa entre as mesmas, se comparadas às minas levantadas em regiões com maior aptidão mineral, como a SUPRAM Central Metropolitana. Logo, para levantamentos futuros deve ser levado em conta um planejamento antecipado de questões logísticas, como o deslocamento e acomodação da equipe que fará a análise de campo.

Aos tipos de bens minerais que são encontrados relativamente, tem-se os seguintes destaques: 72 áreas de explotação de granito,33 áreas de explotação de diamante, 59 áreas de extração de areia, 32 áreas de extração de argila e 32 áreas de minerais metálicos. Nestas últimas, existem 16 áreas de minério de ferro, 10 áreas de ouro e 6 minas de bauxita.

A Figura 3, a seguir, apresenta o número de minas de acordo com a classe de risco ambiental. A Figura 4, por sua vez, denota a localização destas minas pelo estado de Minas Gerais. 
Analisando as figuras 3 e 4, podemos observar a predominância de minas com risco ambiental baixo a médio. Além disso, identifica-se que a maior parte das minas classificadas se localizava distante de perímetros urbanos, possuindo tendência neste quesito, consequentemente, a ter riscos humanos reduzidos. Apesar disso, os riscos ambientais podem ser bem maiores ou menores, de modo a ser proporcional à vulnerabilidade natural da área, em outras palavras, a sua capacidade de recuperação frente às alterações antrópicas. Com relação às minas que estão localizadas na região Norte de Minas Gerais, possui grandes distâncias relativas entre si, estando localizadas, prevalecendo, em cidades pouco populosas.

Figura 3 - Risco ambiental por área minerada

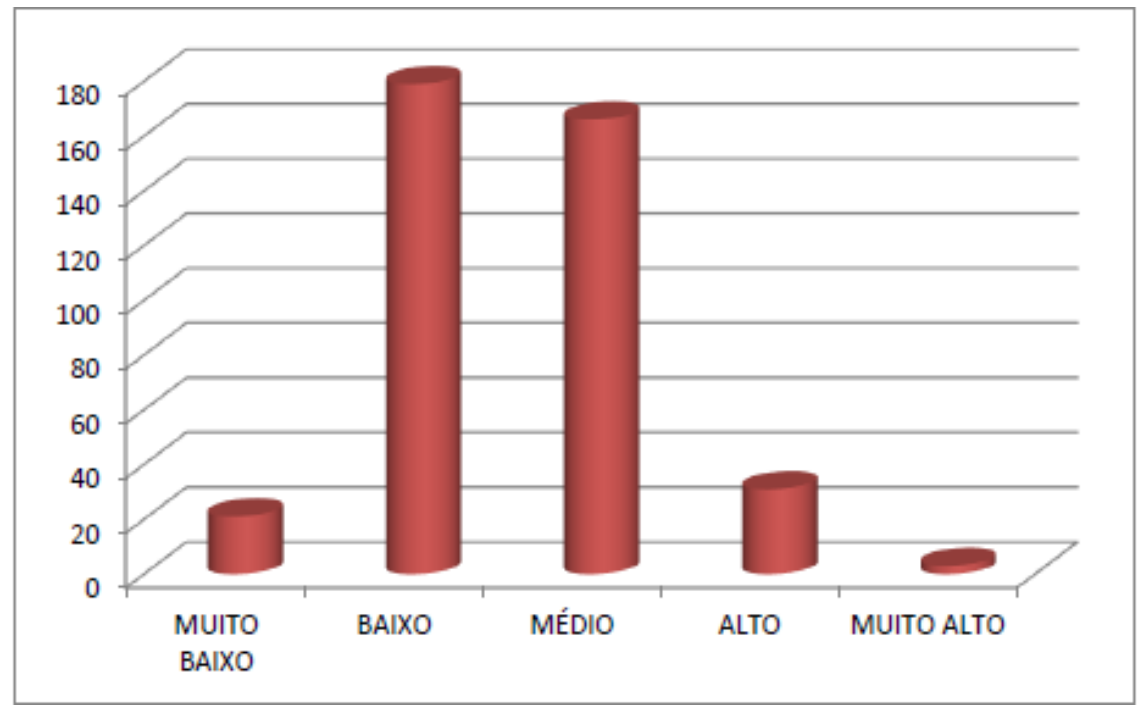

Fonte: FEAM (2016). 
Figura 4 - Localização das minas classificadas segundo o Risco Ambiental

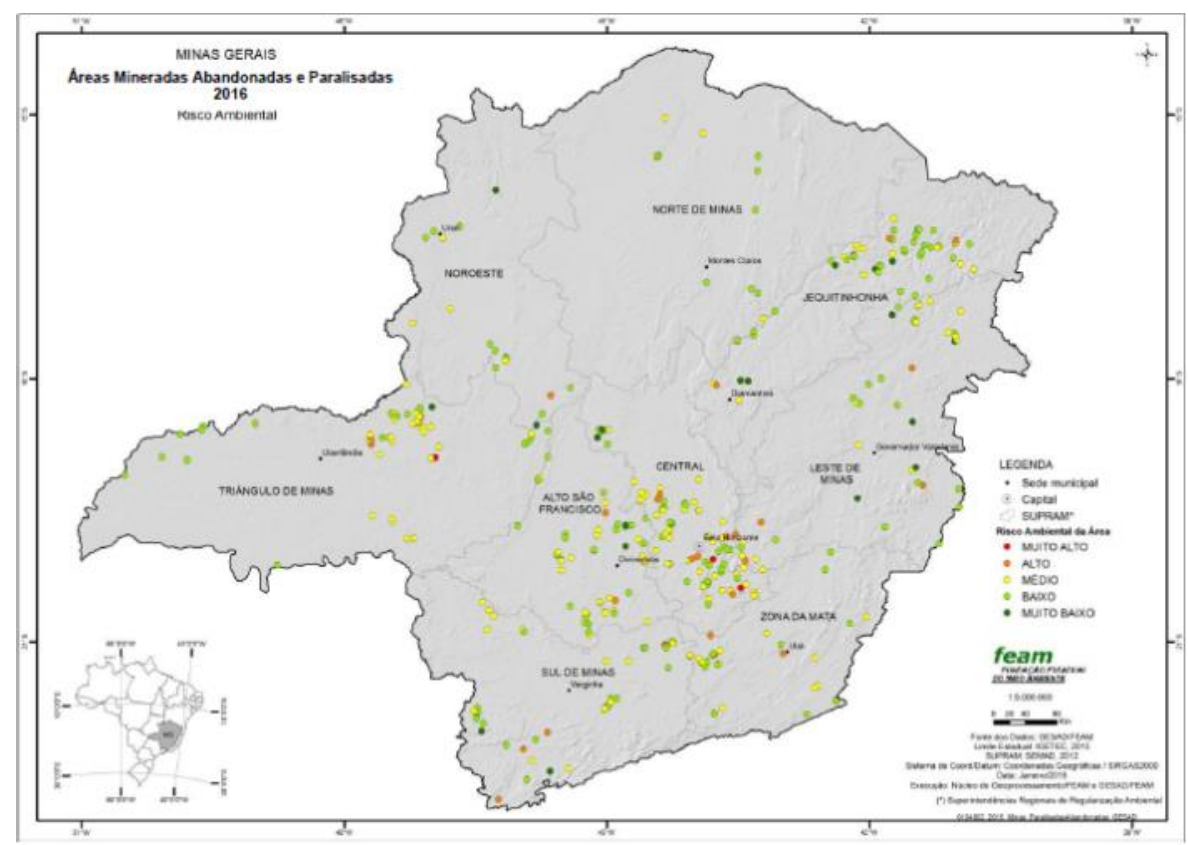

Fonte: FEAM (2016)

\section{METODOLOGIA}

O presente estudo desenvolveu, inicialmente, pesquisas bibliográficas sobre a legislação ambiental aplicada às questões relativas ao fechamento de mina no Estado de Minas Gerais, bem como a situação atual das minerações em operação, suspensas ou fechadas na região Norte de Minas. A partir desta base de dados, foi efetuada uma análise in loco das minerações em operação nos municípios das cidades de Janaúba, Nova Porteirinha e Porteirinha, localizadas no Norte de Minas Gerais.

O objetivo, neste caso, é verificar se tais empresas trabalham de forma sustentável em relação à recuperação ambiental das áreas mineradas e a utilização dos recursos naturais. Desta forma, será possível inferir se há a devida responsabilidade com as gerações futuras em relação ao cumprimento da legislação ambiental, principalmente com o fechamento da mina e devolução posterior à sociedade em condições adequadas.

A pesquisa se baseou no Cadastro de Minas Paralisadas e Abandonadas do Estado de Minas Gerais (FEAM, 2016). Os pesquisadores desenvolveram este projeto no âmbito da Universidade Federal dos Vales do Jequitinhonha e Mucuri (UFVJM), Campus Janaúba. Portanto, tal pesquisa focou a região do Norte de Minas, mais especificamente os municípios de Janaúba, Nova Porteirinha e Porteirinha. 
Para a definição dos trajetos a serem percorridos, utilizou-se o aplicativo Google MAPS (2019). Foi traçado o deslocamento rodoviário englobando como ponto inicial a cidade de Janaúba, passando por Nova Porteirinha e indo até Porteirinha.

\section{RESULTADOS E DISCUSSÃO}

Ao longo do segundo semestre de 2019 , os pesquisadores iniciaram as visitas de campo, efetuando levantamentos em minerações ativas na cidade de Janaúba. Infelizmente, as atividades de campo tiveram de ser paralisadas nos anos de 2020 e 2021, devido à pandemia da COVID-19 e a inexistência de condições seguras para os levantamentos presenciais.

As cidades de Janaúba, Nova Porteirinha e Porteirinha possuem, como bens minerais mais conhecidos e valorizados: argila aplicada à fabricação de tijolos e telhas; areia para construção civil; e calcário utilizado para produção de brita. Portanto, a equipe de pesquisadores efetuou um planejamento preliminar centrado nos empreendimentos relativos à tais setores industriais. Os resultados das primeiras visitas de campo são apresentados a seguir.

\subsection{CERÂMICA JANAÚBA}

A Cerâmica Janaúba é uma empresa com mais de 60 anos de existência, produzindo tijolos e telhas para a indústria da construção civil em Janaúba e cidades do entorno. A empresa possui uma planta de beneficiamento de argila e produção de artefatos cerâmicos pouco mecanizada, demandando um grande número de funcionários para o manuseio e fabricação de seus produtos.

A empresa tem passado por dificuldades financeiras devido ao desaquecimento do mercado da construção civil, tendo de buscar uma adaptação para sobreviver. Com relação à lavra de argila, a antiga mina, distante apenas 1 (um) km da empresa, está exaurida. Portanto, houve a necessidade de iniciar a lavra de uma mina mais distante de sua sede. Como foi feito um grande estoque de argila proveniente da mina desativada, o minério da nova mina está passando por um teste gradativo, a fim de permitir a adequação dos processos às características da matéria prima. 
O pesquisador fez uma visita de campo às cavas desativadas, percebendo que as mesmas não se encontram reabilitadas. A Figura 5 apresenta uma fotografia ilustrativa deste fato.

Figura 5 - Cava abandonada da Cerâmica Janaúba

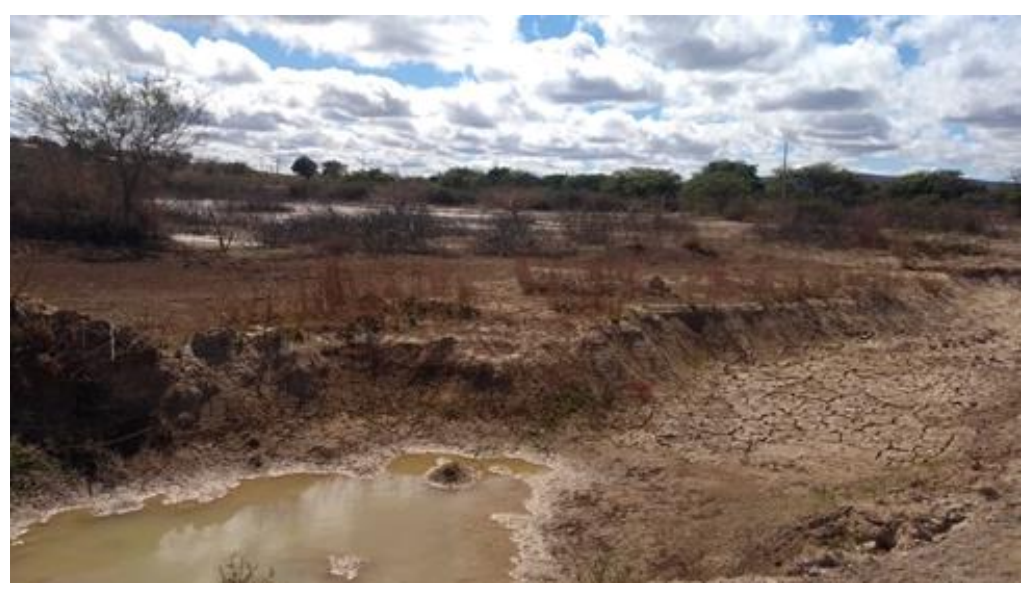

Fonte: autores da pesquisa (2019)

Portanto, percebe-se que a cava está aberta e irregular, sem cobertura de solo orgânico, bem como a vegetação nativa não está nascendo, seja de forma natural ou artificial. Portanto, os procedimentos de recuperação e reabilitação das áreas degradadas não foram efetuados, ao final da extração de argila.

Como primeiras proposições de alternativas para um fechamento adequado, os pesquisadores propuseram, em tratativas junto à Secretaria Municipal de Meio Ambiente, a cobertura das cavas com material argiloso remanescente, o qual está depositado em pilhas próximo das cavas. Entretanto, existem comunidades, em um bairro próximo à área afetada, que utilizam a argila para a produção de tijolos artesanais, maciços. Tais tijolos são utilizados para o revestimento de cisternas e fossas sépticas para as moradias populares da região. Portanto, uma solução conjugada à cobertura das cavas, que traria bons ganhos sociais é o transporte de parte desta argila remanescente para um terreno próximo a estes produtores artesanais de tijolo. Desta forma, esta atividade tradicional irá sobreviver e estas famílias manterão sua sobrevivência. As Figura 6 e 7 exibem algumas fotos da fabricação de tijolos artesanais. 
Figura 6 - Secagem de tijolos artesanais

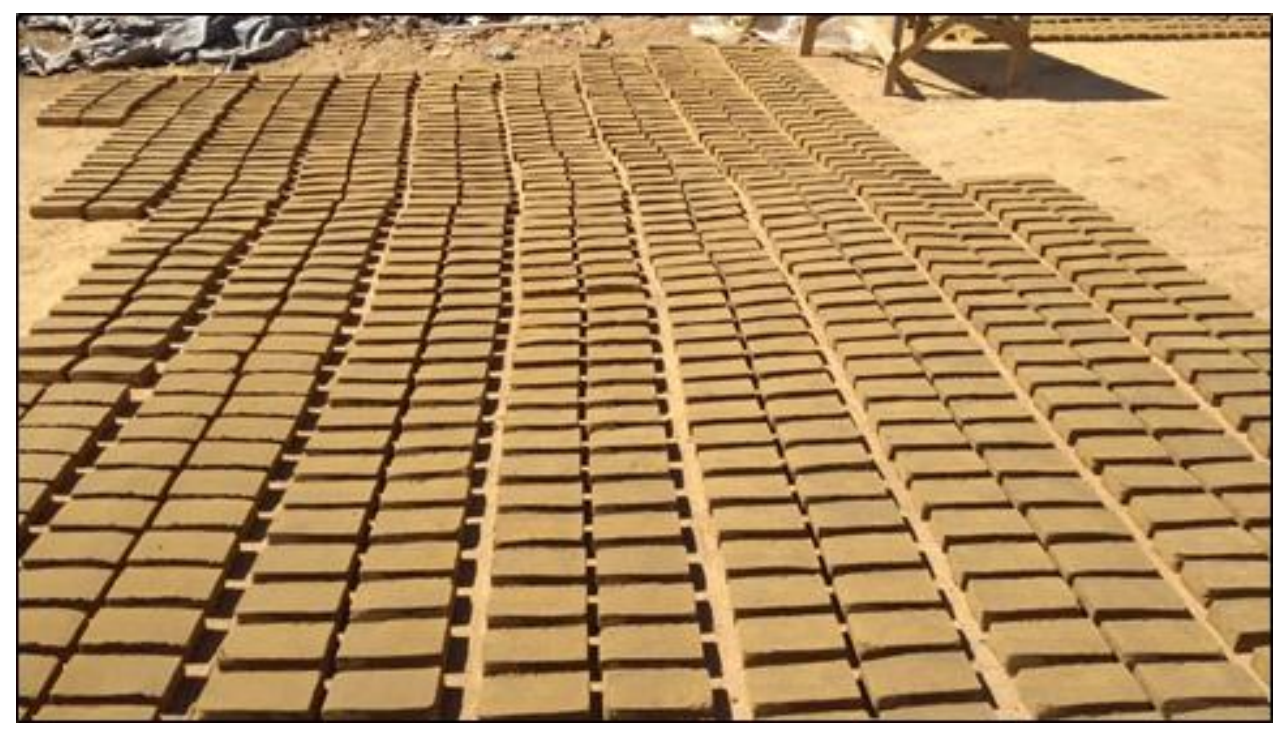

Fonte: autores da pesquisa (2019)

Figura 7 - Processo de queima de tijolos artesanais

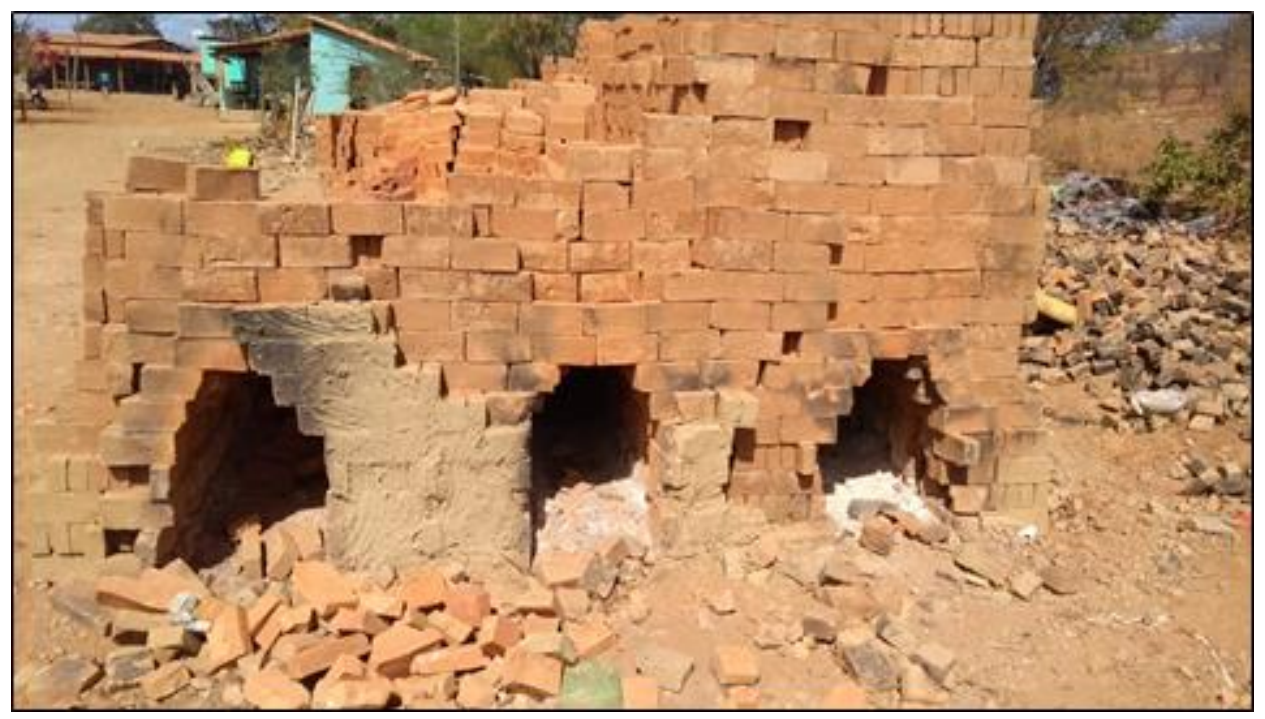

Fonte: autores da pesquisa (2019)

\subsection{CERÂMICA GORUTUBA}

A cerâmica Gorutuba é uma empresa tradicional da cidade de Janaúba, localizada a aproximadamente $12 \mathrm{~km}$ do centro do município. Ela produz tijolos de 8 e 12 furos, blocos estruturais, canaletas, telhas do tipo Americanas, Plan e Cumeeira de argila vermelha. A empresa em questão realiza a produção de forma mecanizada, desse modo, o desperdício de matéria-prima é minimizado. 
As etapas acima, em geral, são etapas padrão para a produção cerâmica, podendo ocorrer pequenas variações devido a propriedade da matéria-prima disponível em cada região. Outra variação existente é sobre a mecanização do processo, podendo ser em alguns casos mais tecnológico e automatizado, e em outros casos pode envolver etapas manuais de produção de telhas e tijolos.

Serão destacadas, a seguir, as etapas que ocorrem na mina, quais sejam: extração de Argila (matéria prima da indústria cerâmica) e recuperação das áreas degradadas (atividade de reabilitação ambiental das cavas exauridas).

\subsubsection{EXTRAÇÃO DA ARGILA}

Todo o processo inicia com a extração da argila. Por se tratar de uma matériaprima com baixa dureza e constituídas por sedimentos de argilominerais, não necessita de uma complexidade para realizar a extração. A jazida de argila fica a aproximadamente $40 \mathrm{Km}$ da cerâmica e pertence à cidade de Porteirinha. Apesar da distância relativamente grande para o transporte da argila, a extração se torna viável devido à jazida ser de propriedade da Cerâmica Gorutuba, evitando-se assim a necessidade de pagamento de royalties na atividade de lavra. Outro aspecto vantajoso é a simplicidade das atividades de escavação e carregamento dos caminhões. Como a argila é uma rocha friável, não há a necessidade de utilização de explosivos e sua remoção, na jazida, é feita com o auxílio de uma retroescavadeira de médio porte, que carrega caminhões rodoviários, os quais transportam este bem mineral até a indústria cerâmica. Pode-se citar, também, o fato de o próprio motorista de caminhão operar a retroescavadeira e carregar o seu caminhão, evitando assim a necessidade de um operador de retroescavadeira específico. A Figura 8 exibe a atividade de extração da argila. 
Figura 8 - Extração da matéria-prima com a escavadeira

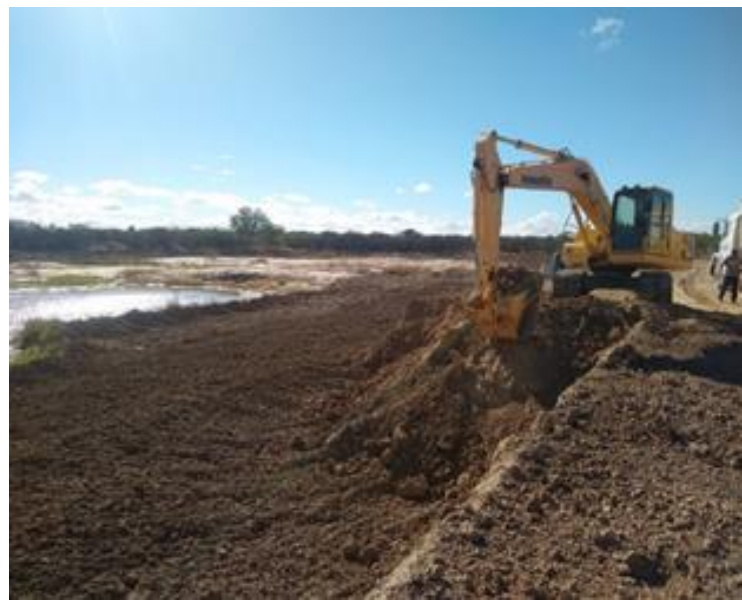

Fonte: autores da pesquisa (2019)

\subsubsection{RECUPERAÇÃO DAS ÁREAS MINERADAS}

A mineração é uma atividade que gera muitos danos ambientais. Pensando nisso, a empresa trabalha de forma sustentável, buscando meios de mitigar os danos, atendendo à legislação e ao PRAD registrado junto aos órgãos ambientais. A área de extração da argila é de responsabilidade da empresa. Através de ações de revitalização da área afetada, as cavas que não são mais utilizadas passam por processos de reflorestamento, com o plantio de espécies nativas. Na Figura 9 a seguir, mudas de Jurema (Mimosa hostilis), já desenvolvidas, convivem com outras espécies rasteiras, como o capim-capivara (Echinochloa cruz-galli).

Figura 9 - Revegetação das cavas

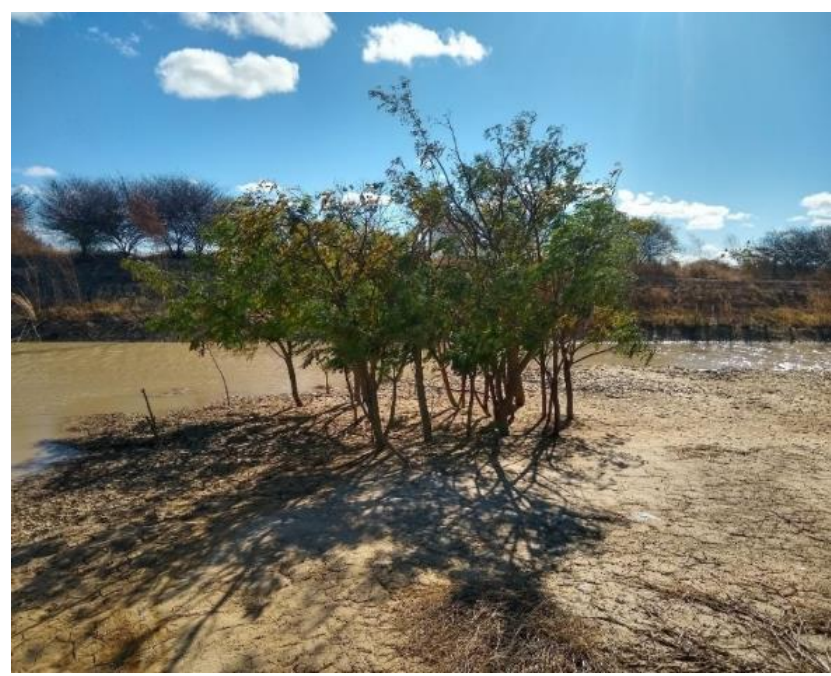

Fonte: autores da pesquisa (2019)

$$
\begin{array}{r}
\text { WWW.AMPLLAEDITORA.COM.BR } 97 \\
\text { CONTATO@AMPLLAEDITORA.COM.BR } \\
\text { @AMPLLAEDITORA O } \\
\text { @AMPLLAEDITORA @5 }
\end{array}
$$


Além da preocupação com as cavas, a empresa se prontificou a molhar as vias por onde a argila passa até a chegada na cerâmica. Desta forma, diminui-se a quantidade de poeira em suspensão, beneficiando os moradores da região.

\section{CONCLUSÃO}

A presente pesquisa trouxe à tona a importância de se planejar o fechamento futuro de empreendimentos minerários desde as fases iniciais do projeto. Desta forma, é possível garantir a adequada recuperação ambiental da mina, devolvendo a área impactada com uma função nobre para a sociedade. As visitas de campo permitiram a identificação de situações distintas: mineração onde o processo de fechamento não foi devidamente completo, deixando danos ao meio ambiente que necessitarão de reparos; e empresa responsável, onde a revegetação das cavas exauridas é feita paulatinamente, durante a fase produtiva da mina. A segunda situação é desejável, pois a gestão da empresa fará o fechamento da mina de forma mais econômica e efetiva, obtendo o aval das comunidades do entorno da empresa.

Na região norte de Minas Gerais, há grandes desigualdades econômicas e sociais, as quais devem ser levadas em conta no processo de fechamento de mina. Portanto, a gestão da mineração deve ouvir a sociedade, a fim de identificar de que forma a área deve ser devolvida para que beneficie da melhor forma possível as pessoas envolvidas.

\section{AGRADECIMENTOS}

Os pesquisadores agradecem ao corpo docente do curso de Engenharia de Minas da Universidade Federal Vales do Jequitinhonha e Mucuri (UFVJM) - Campus Janaúba, pelo apoio na elaboração deste trabalho.

\section{REFERÊNCIAS}

BRASIL. Presidência da República. Decreto no 9.406, de 12 de junho de 2018. Regulamenta o Decreto-Lei no 227, de 28 de fevereiro de 1967, a Lei no 6.567, de 24 de setembro de 1978, a Lei no 7.805, de 18 de julho de 1989, e a Lei no 13.575, de 26 de dezembro de 2017. Brasília, 2018a.

COPAM. Conselho Estadual de Política Ambiental. Deliberação Normativa COPAM № 220, de 21 / 03 / 2018. Estabelece diretrizes e procedimentos para a paralisação 
temporária da atividade minerária e o fechamento de mina. Belo Horizonte, 2018.

COPAM. Conselho Estadual de Política Ambiental. Deliberação Normativa COPAM № 217, de 06 / 12 / 2017. Estabelece critérios para classificação, segundo o porte e potencial poluidor, bem como os critérios locacionais a serem utilizados para definição das modalidades de licenciamento ambiental de empreendimentos e atividades utilizadores de recursos ambientais no Estado de Minas Gerais e dá outras providências. Belo Horizonte, 2017.

COPAM. Conselho Estadual de Política Ambiental. Deliberação Normativa COPAM № 220, de 21 / 03 / 2018. Estabelece diretrizes e procedimentos para a paralisação temporária da atividade minerária e o fechamento de mina. Belo Horizonte, 2018.

COPAM. Conselho Estadual de Política Ambiental. Deliberação Normativa COPAM № 217, de 06 / 12 / 2017. Estabelece critérios para classificação, segundo o porte e potencial poluidor, bem como os critérios locacionais a serem utilizados para definição das modalidades de licenciamento ambiental de empreendimentos e atividades utilizadores de recursos ambientais no Estado de Minas Gerais e dá outras providências. Belo Horizonte, 2017.

COPAM. Conselho Estadual de Política Ambiental. Deliberação Normativa COPAM №145, de 18 / 12 / 2009. Dispõe sobre a declaração de informações relativas à identificação e classificação de áreas mineradas abandonadas no Estado de Minas Gerais. Belo Horizonte, 2009.

DNPM. Departamento Nacional de Produção Mineral. Portaria № 237, de 18 / 10 / 2001. Aprova as Normas Regulamentadoras de Mineração - NRM. Brasília, 2001.

FEAM. Fundação Estadual de Meio Ambiente. Cadastro de Minas Paralisadas e Abandonadas no Estado de Minas Gerais. Belo Horizonte, 2016.

IBRAM. Instituto Brasileiro de Mineração. Economia Mineral: Dados do Brasil e Estado de Minas Gerais. Brasília, 2018.

PORTAL MEIO AMBIENTE MG. SEMAD, IEF, IGAM e FEAM. Disponível em: http://www.meioambiente.mg.gov.br/. Acessado em 15/04/2021. 20121. 


\title{
CAPITULO XXXIX
}

\section{CARACTERIIAGÃO DA FAUNA TRLATOMIINICA DA COMUNIDADE QUILOMBOLA DO CEDRO EM MINEIROS/GO E CONHECIMENTO DOS MORADORES SOBRE A DOENCA DE CHAGAS}

\section{DOI: 10.51859/amplla.mas481.1121-39}

\author{
Robert Deiverson de Oliveira ${ }^{1}$ \\ Gabriel Brom Vilela ${ }^{2}$ \\ Carolina de Alvarenga $\mathrm{Cruz}^{3}$ \\ Raphaella Barbosa Meirelles Bartoli ${ }^{4}$ \\ Raquel Loren dos Reis Paludo ${ }^{5}$ \\ Ísis Assis Braga ${ }^{5}$ \\ Andresa de Cássia Martini ${ }^{5}$ \\ Priscila Chediek Dall'Acqua ${ }^{5}$ \\ Eric Mateus Nascimento de Paula ${ }^{5}$
}

\footnotetext{
${ }^{1}$ Médico Veterinário Autônomo. Graduado pelo Centro Universitário de Mineiros - UNIFIMES.

${ }^{2}$ Docente da Unidade Universitária de Mineiros da Universidade Estadual de Goiás - UEG.

${ }^{3}$ Médica Veterinária Autônoma. Doutora em Medicina Veterinária Preventiva - UNESP/FCAV.

4 Docente do Curso de Medicina Veterinária da Universidade Federal de Jataí - UFJ.

${ }^{5}$ Docente do Curso de Medicina Veterinária do Centro Universitário de Mineiros - UNIFIMES.
}

\section{RESUMO}

A comunidade Quilombola do Cedro localizada no município de Mineiros-GO, corresponde a um grupo de moradores que são destaques na preservação da cultura africana, além de terem um papel importante na produtividade em ervas medicinais que possuem um papel significativo tanto para a comunidade quanto para o município. Trata-se de uma área onde algumas residências possuem edificações antigas, como casas de pau-a-pique e de madeira, onde se utilizam em suas estruturas vários elementos retirados da biodiversidade local, além de possuírem hábitos de agricultura e de criação de animais como galinhas e porcos. Devido ao cenário peculiar da região e o mesmo ser típico dos triatomíneos, é de suma importância a caracterização da fauna triatomínea na comunidade Quilombola do Cedro. Para o desenvolvimento deste trabalho afim, objetivou-se descrever a fauna triatomínea existente por meio de entrevistas com moradores da região e pesquisa entomológica por meio da busca ativa nos locais propícios para ocorrência dos triatomíneos. Observou-se que a população da Comunidade possui conhecimentos sobre o inseto, passadas por seus antepassados que vivenciaram a fase da infestação dos triatomíneos no Brasil, porém carecem de informação e conhecimento científico sobre esses vetores, bem como sobre a Doença de Chagas. Além disso, foram encontrados exemplares de triatomíneos, pertencente ao gênero Rhodnius o qual representa grande importância em saúde pública.

Palavras-chave: Pesquisa entomológica. Triatomíneos. Doença de Chagas. 


\section{INTRODUÇÃO}

A doença de chagas é considerada uma antropozoonose, doença primária de animais, a qual pode ser transmitida aos humanos, e é ocasionada pelo protozoário Trypanosoma cruzi. Pode apresentar duas fases em seu quadro clínico, a fase aguda e a fase crônica, a qual se divide em quatro formas: indeterminada, digestiva, cardíaca e cardiodigestiva (BRASIL, 2017).

É caracterizada pela Organização Mundial de Saúde (OMS) e pela Organização Panamericana de Saúde (OPAS) como uma das doenças parasitárias mais ocorrente em população de baixa renda. Sendo endêmica em aproximadamente 21 países da América Latina. Estima-se que cerca de 6 a 7 milhões de pessoas do mundo estão infectadas pelo Trypanosoma cruzi (OMS, 2019).

Entre os anos de 2012 e 2016, no Brasil, foram constatados cerca de 1.190 casos de doença de chagas, em que $73 \%$ contaminaram por via oral, $8,9 \%$ por transmissão vetorial e os outros $18,1 \%$ adquiriram a doença por outros meios (BRASIL, 2019).

Os insetos que estão envolvidos na transmissão do protozoário, pertencem a subfamília Triatominae (Hemiptera, Reduviidae), tendo vários nomes populares, que variam de região para a região, podendo ser conhecidos como barbeiro, bicudo, procotó ou chupão. Possuem hábito alimentar hematófago, podendo ser de aves, roedores, humanos e outros animais. Seus habitats são diversos e dinâmicos, eles podem habitar tanto em regiões silvestres, como também em ambientes urbanos, tendo facilidade em se acostumar com regiões domiciliares e peridomiciliares (BRASIL, 2017).

A Doença de Chagas é uma infeç̧ão com grande relevância no mundo, tendo elevado impacto econômico e social. Na América Latina existem registros de cerca de 6 a 8 milhões de pessoas estejam infectadas, e aproximadamente 65 milhões correm o risco da infecção. Por ano morrem torno de 12.000 pessoas no mundo vítimas da doença. No Brasil, de 2 a 3 milhões são portadoras de Chagas e mortes acometidas pela doença são em torno de 6.000 mortes (OMS, 2019).

Na região Centro-Oeste em dois Estados específicos (Mato Grosso e Goiás), entre os anos de 2000 e 2013, foram detectadas 27 pessoas portadoras da doença de chagas, onde $51,85 \%$ adquiriram a doença por transmissão vetorial. Dentre os infectados 23 pertenciam ao Estado de Goiás e os outros 4 ao Estado do Mato Grosso. Já entre os anos 
de 2012 e 2016 da Região Centro-Oeste somente o Estado de Goiás teve relatos de pessoas infectadas, onde foram constatadas 3 pessoas (BRASIL, 2015; BRASIL, 2019).

Em Goiás entre os períodos de 1999 a 2002 foram registrados através dos Dados do Sistema de Mortalidade (SIM) um total de 3.321 óbitos causados pela enfermidade de chagas e a sua maioria de pessoas com faixas etárias mais elevadas, o que possivelmente se deu a uma infecção que aconteceu anos atrás (LIMA COSTA et. al. 2004).

Em março de 2000 o Estado de Goiás recebeu o certificado da Organização PanAmericana da Saúde (OPAS), constatando eliminado do seu território o Triatoma infestans considerado o principal vetor da Doença de Chagas da região. No entanto a captura de outras espécies que foram constatadas infectadas pelo Trypanosoma cruzi no Estado induzem atenção, mesmo com baixo prevalecimento de infestação (DE OLIVEIRA; DA SILVA, 2007).

Santana et al., (2013) recomendam a permanência de um trabalho frequente de vigilância e entomologia nos municípios do Estado de Goiás, a fim de ser possível identificar quaisquer mudanças no comportamento das atuais espécies, e impedir uma nova infestação do Triatoma infestans, vetor que ainda está presente no estado da Bahia, a qual faz divisa com o nordeste goiano. Desta forma, o objetivo deste trabalho é descrever a fauna triatomínea existente na Comunidade Quilombola do Cedro, localizada no município de Mineiros/GO, avaliando o conhecimento da população local sobre esse grupo de insetos, realizando busca ativa de exemplares de triatomíneos; identificando as espécies dos exemplares capturados e analisando se há impactos em saúde pública das espécies capturadas e identificadas.

\section{METODOLOGIA}

\section{1. ÁREA dO ESTUdO - COMUNIDADE QUILOMBOLA DO CEDRO - MINEIROS/GO}

A região Quilombola do Cedro está localizada no município de Mineiros, microrregião Sudoeste do Estado de Goiás, o qual faz parte do Centro-Oeste brasileiro. A comunidade faz divisa com os Estados de Mato Grosso e Mato Grosso do Sul. Sua vegetação é representada pelo típico cerrado (SILVA, 2005). 
Thiago (2011) menciona que a comunidade possui uma cultura preservada a várias gerações, como por exemplo a maneira de lidarem com a terra criando poucos animais, e a maneira de utilizarem plantas para fins medicinais. É uma comunidade caracterizada por ter grande proximidade com a natureza.

A comunidade do Cedro foi adquirida em meados do século XIX, de uma forma diferente das de costume dos quilombos da época. Um escravo que foi trazido de Minas Gerais, Francisco Antônio de Moraes conhecido como Chico Moleque, conseguiu comprar sua liberdade, como também de sua esposa e filha, e logo após comprou 31 partes de terras, equivalentes a 284,95 alqueires da Fazenda Flores do Rio Verde, onde hoje está localizado a comunidade do cedro. A área territorial da região Quilombola do Cedro diminuiu cerca de $80 \%$, podendo ser pelo fato de muitas propriedades serem vendidas (SILVA, 2003; BAIOCCHI, 1983; THIAGO, 2011). Algumas residências de décadas passadas ainda se fazem presente na comunidade, e possuem aspectos característicos, como casas feitas de pau-a-pique ou adobe, cobertas com telhas e com piso queimado, e além dessas muitas foram reconstruídas com alvenaria (THIAGO, 2011; GALDINO e SILVA, 2009).

\subsection{PESQUISA ENTOMOLÓGICA}

Esta etapa se deu por meio da escolha de uma amostra de 10 residências, habitadas pela população da região Quilombola do Cedro, localizada no município de Mineiros - GO. A escolha das casas ocorreu de forma aleatória, buscando residências com características peculiares, como casas antigas, feitas de pau-a-pique, de madeira e onde podia se encontrar a criação de porcos, galinhas, cachorros e gatos. As residências foram escolhidas conforme aspectos típicos nos quais são comuns para a habitação dos triatomíneos. Em seguida foram distribuídas algumas armadilhas a fim de se capturar triatomíneos. Elas eram deixadas na parte da tarde, em torno das 17:00 horas e recolhidas no dia seguinte por volta das 7:00 horas da manhã.

As armadilhas utilizadas, na tentativa de capturar os triatomíneos, foram confeccionadas com garrafa pet de dois litros, em que ela foi cortada ao meio e a parte superior colocada de forma invertida dentro da inferior, colando ambas as partes com fita adesiva. Dentro das armadilhas foram colocadas iscas, a fim de atrair os 
triatomíneos. As iscas escolhidas foram polpa de açaí comercializada. O modelo da armadilha pode ser verificado na figura 1.

Figura 1 - Armadilhas utilizadas para captura dos triatomídeos, confecciondas com garrafa plástica.

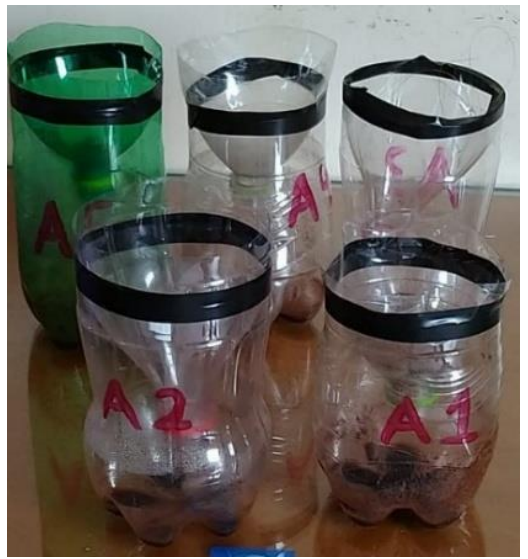

Fonte: Autoria própria.

As armadilhas foram espalhadas em lugares propícios, com mais facilidade de se capturar os triatomíneos (figura 2). Os lugares escolhidos para a distribuição foram troncos de palmeiras, galinheiros, chiqueiros, casas de pau-a-pique e ocorreu de armadilhas serem colocadas dentro da própria residência em lugares específicos. A identificação do exemplar de triatomíneo obtido com a pesquisa, se deu pela utilização do aplicativo Triatokey, uma ferramenta desenvolvida pela Fiocruz, por meio da visualização de características físicas dos insetos. E, por meio da literatura, pode-se relacionar a espécie encontrada, e verificar se é alguma espécie de risco à saúde pública. 
Figura 2 - Locas de distribuição e instalação das armadilhas. A - Palmeira. B - Galinheiro. C Intradomicílio. D - Pocilga.

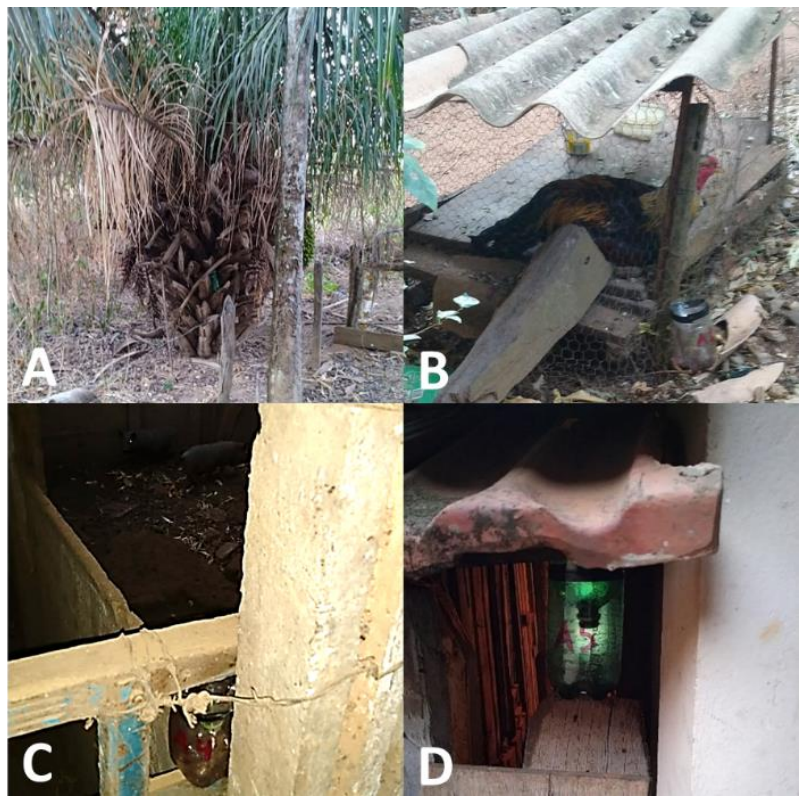

Fonte: Autoria própria.

\section{RESULTADOS E DISCUSSÃO}

\subsection{PESQUISA ENTOMOLÓGICA}

Ao todo foram disponibilizadas 20 armadilhas em locais variados na Comunidade Quilombola do Cedro, como descrito na metodologia. As armadilhas ficaram instaladas durante uma média de 12 horas em cada residência e elas foram dispostas em lugares estratégicos visto a possibilidade de haver triatomíneos. Entretanto, nenhum exemplar de triatomíneo foi capturado pelas armadilhas. Os únicos insetos capturados foram formigas e besouros. Contudo, uma moradora do quilombo, relatou possuir um inseto guardado já há algum tempo, em que ele foi capturado por ela dentro de sua residência por suspeitar ser um barbeiro. Esta moradora disponibilizou o inseto para este estudo a fim da identificação do exemplar.

Após observar o inseto pode-se notar algumas características visíveis a olho nu, como cor, tamanho e que ele possuía cabeça alongada e antenas junto ao ápice da cabeça, atributos pertencentes ao gênero Rhodnius sp., o barbeiro em questão possuía coloração castanho amarelado com algumas manchas espalhadas pelo corpo na cor castanho escuro. O que se assemelha muito com as espécies $R$. prolixus, $R$. neglectus e 
R. robustus se comparadas com as imagens dos mesmos (PONTES, 2010; JURBERG et al., 2014).

Neves (2016) traz que a espécie Rhodnius prolixus é uma espécie com elevada importância epidemiológica em alguns países da América do Sul, sendo que são capazes de se alimentar de qualquer vertebrado terrestre, e podem se deslocar com muita facilidade e constantemente entre $\mathrm{o}$ habitat silvestres e regiões domiciliar e peridomiciliar. Sua coloração é no geral castanho amarelado com várias manchas no corpo e apêndices na cor castanho escuro. Essa espécie tem como ecotipo natural o babaçu (Orbihny martiana) que é uma palmeira muito comum de ser encontrada na região de Goiás (GALVÃO, 2014).

A espécie Rhodnius neglectus é típica do cerrado e possui uma vasta distribuição geográfica, podendo ser encontradas no Nordeste, Centro Oeste, Sudeste e no Sul. São insetos associados a palmeiras, abrigos de mamíferos e ninhos de pássaros, além disso é comum de ser encontrada dentro das habitações humana pois são facilmente atraídos pela luz. Possuem coloração na cor marrom claro com algumas manchas na região da cabeça na cor marrom escuro (GALVÃO, 2014).

O Rhodnius robustus é muito parecido com o Rhodnius prolixus fator que faz ambos serem confundidos. Sua coloração no geral é castanha amarelado com manchas em várias regiões do corpo na cor castanho escuro. São insetos que preferem regiões peridomiciliares, principalmente palmeiras, e são raramente encontrados em domicílios. Sua distribuição geográfica se dá no Norte e Nordeste e na região do Mato Grosso (GALVÃO, 2014).

Vale ressaltar a existência de muita semelhança das três espécies com a espécie obtida através deste trabalho, sendo que não foi possível identificá-la através do aplicativo Triatokey. Destacando ainda que para a identificação correta é necessário estudos mais aprofundados.

No município de Mineiros o órgão responsável pelo controle e levantamento de dados de algumas doenças epidemiológicas é a Secretaria de Saúde do Município, sendo assim através desse órgão foi obtido a informação que no Município foram encontrados dois barbeiros sendo um na zona urbana e um na zona rural no ano de 2018 , e ainda 
que nesse mesmo ano tinham relatos de dois novos casos de infecção pelo Trypanosoma cruzi, os quais vieram de outro Estado já com a doença de Chagas.

Vale ressaltar que existem outras armadilhas mais eficazes na captura desses insetos, onde são utilizados animais vivos como iscas. Entretanto optou-se por utilizar uma armadilha sustentável e possível de ser desenvolvida por qualquer pessoa.

\subsection{ENTREVISTA COM A POPULAÇÃO}

Villela et al., (2009) e Dias et al., (2015) trazem que é essencial que a população tenha conhecimento e informações sobre os triatomíneos como também sobre a Doença de Chagas, sendo essa uma estratégia primordial no Controle da vigilância entomológica, pois é a partir daí que se pode ter um combate eficaz quanto ao vetor da doença. Diversos autores utilizaram como meio de pesquisa entrevistas com a população, tanto de áreas endêmicas como também de não endêmicas, a fim de verificar o conhecimento dos envolvidos quanto a assuntos relacionados a Doença de Chagas.

Dias et al., (2015) e Silveira et al., (2011), por exemplo, trouxeram em suas pesquisas o envolvimento da população através de entrevistas relacionadas aos triatomíneos. As questões envolvidas nas análises eram relacionadas ao conhecimento dos triatomíneos: (se alguma vez já tinham visto o inseto, se o entrevistado ou algum familiar já teria sido picado pelo mesmo, quais ações eram necessárias caso encontrassem um desses vetor); sobre a doença de chagas (se conheciam sobre a doença, se conhecem alguém que tenha); além de perguntas abertas sobre o que eles deveriam fazer para evitar os barbeiros.

Para esta pesquisa, baseada na ideia desses dois autores, foram entrevistadas 20 pessoas residentes na Comunidade Quilombola do Cedro. Tendo que o perfil dos entrevistados foi de $69 \%$ do sexo masculino e $31 \%$ do sexto feminino. A idade média dos moradores correspondia a 55 anos de idade, sendo a faixa etária entre 26 e 75 anos. Os que possuíam idade superior a 50 anos de idades era correspondente a $61,54 \%$. A grande maioria residia na região do Cedro desde o nascimento.

Inicialmente, foi perguntado aos entrevistados se eles conheciam sobre os triatomíneos, e 77\% mencionaram não conhecer. Porém quando questionados sobre o inseto "barbeiro", todos que foram consultados, de alguma forma, conhecem ou 
ouviram falar. Fator que evidencia que eles não compreendem que o barbeiro é o nome vulgar do triatomíneo. Ainda buscou-se saber se algum dos moradores já havia avistado algum exemplar do "barbeiro" no Cedro, 100\% mencionaram que recentemente não foi visto o inseto nos arredores da região. Muitos dos entrevistados disseram que na infância era muito comum encontrar o barbeiro, e um dos moradores relatou que quando era criança a família queimou todos os colchões para afastar esses insetos.

Sobre a Doença de Chagas, todos os entrevistados disseram conhecer sobre a doença. E quando perguntados se conheciam alguém que possui a enfermidade, $38,45 \%$ afirmaram positivamente; e que se tratava principalmente de familiares, sendo mãe, irmã e avó os mais citados. Adicionalmente, os mesmos entrevistados informaram que seus conhecidos contraíram o protozoário antes de virem morar no município de Mineiros.

Buscou-se saber também se a população conhecia a forma de transmissão da doença de Doença de Chagas, 53,8\% afirmaram saber como a enfermidade ocorria. Dentre as formas de transmissão mencionaram: pela alimentação do barbeiro, pela picada do inseto, através do barbeiro, pelas fezes do barbeiro e alimentos não processados. Pode-se notar com as respostas, que dos 53,8\% dos moradores que disseram saber como a doença era transmitida, somente $28,6 \%$ realmente sabiam a forma correta da infecção.

Além disso, também foi abordada o conhecimento desses populares sobre a maneira de se prevenir essa enfermidade. $70 \%$ disseram não conhecer as medidas preventivas. Os demais mencionaram que a forma correta de se evitar a Doença de Chagas seria pela limpeza do ambiente, evitar lugares onde há a possibilidade de criação do vetor bem como frestas nas residências, evitar a presença do barbeiro, pulverização e dedetização do ambiente.

Se comparado os resultados com os obtidos por Dias et al., (2015) e Silveira et al., (2011) todos os entrevistados possuíam algum tipo de conhecimento sobre o barbeiro e a doença de Chagas. Pode-se notar uma semelhança com a pesquisa de Silveira et al., (2011) quanto a idade dos entrevistados relacionados com o conhecimento geral do barbeiro. As pessoas com idade superior a 50 anos mostraram conhecer mais sobre a doença, onde dentro dessa faixa etária a grande maioria afirmou 
conhecer o barbeiro, saber como a doença era transmitida, além de alguns citarem formas de prevenção.

Sobre as formas de prevenção, em ambas as pesquisas de Silveira et al., (2011) e Dias et al., (2015) as formas mais citadas para se prevenir os barbeiros foi a frequente limpeza da casa, seguida do uso de inseticida, resultados semelhantes com os obtidos com o presente trabalho.

\section{CONSIDERAÇÕES FINAIS}

Através do presente estudo, pode-se verificar que o barbeiro ainda é motivo de atenção epidemiológica para o Estado de Goiás juntamente com seus municípios, pois mesmo sendo praticamente extinta as aparições do inseto ou casos da doença, ainda existem resquícios dessa epidemiologia, principalmente pelo fato de ainda se terem esses triatomíneos em algumas regiões no Estado, como é o caso da região Quilombola do Cedro, dentro do Município de Mineiros, onde foi encontrado uma espécie de barbeiro.

Por meio da pesquisa entomológica foi possível constatar, que a população do Cedro, carece e muito de informações cientificas sobre o transmissor da doença de Chagas, como também emitem informações de importância epidemiológica dos centros responsáveis pelo controle no Município, pois como medida de prevenção e controle é necessário que a população entregue aos órgãos municipais qualquer espécie suspeita encontrada, sendo ainda importante ressaltar a existência de falta de medidas instituídas pelo município quanto ao assunto da doença como também suas formas de transmissão.

Mediante ao barbeiro obtido por esta pesquisa, pode-se notar que ele pertencia ao gênero Rhodnius, sendo difícil identificar sua espécie, pois ele era muito parecido com o $R$. prolixus, $R$. neglectus e $R$. robustus. Vale destacar que as três espécies são vetores do Tripanosoma cruzi, o protozoário da doença de Chagas tendo assim muita importância epidemiológica, pois se não aplicados medidas de prevenção e controle no Município tem-se o risco de haver infestação desses insetos. 


\section{REFERÊNCIAS}

BAIOCCHI, M. N. Negros de Cedro: Estudo Antropológico de um Bairro Rural de Negros em Goiás. São Paulo: Ática, 1983.

Brasil. Ministério da Saúde. Secretaria de Vigilância em Saúde. Departamento de Vigilância Epidemiológica. Guia de vigilância epidemiológica / Ministério da Saúde, Secretaria de Vigilância em Saúde, Departamento de Vigilância Epidemiológica. - 2. ed. - Brasília : Ministério da Saúde, 2017.

Brasil. Ministério da Saúde. Secretaria de Vigilância em Saúde. Departamento de Vigilância Epidemiológica. Boletim Epidemiológico / Ministério da Saúde, Secretaria de Vigilância em Saúde, Departamento de Vigilância Epidemiológica. - v. 46 - Brasília : Ministério da Saúde, 2015.

Brasil. Ministério da Saúde. Secretaria de Vigilância em Saúde. Departamento de Vigilância Epidemiológica. Boletim Epidemiológico / Ministério da Saúde, Secretaria de Vigilância em Saúde, Departamento de Vigilância Epidemiológica. - v. 50 - Brasília : Ministério da Saúde, 2019.

DE OLIVEIRA, A.W.S.; DA SILVA, I.G. Distribuição geográfica e indicadores entomológicos de triatomíneos sinantrópicos capturados no estado de Goiás. Revista Brasileira de Medicina Tropical. v. 40, no 2, p: 204-208. 2007.

DIAS, J. V. L. Fatores envolvidos na distribuição de triatomíneos e seu controle no município de Diamantina, Minas Gerais, Brasil, entre 2011 e 2014. Tese (Doutorado em Ciências) - Centro de Pesquisas René Rachou, Fundação Oswaldo Cruz. Belo Horizonte, p. 208. 2015.

JURBERG. J.; RODRIGUES, J. M. S.; MOREIRA, F. F. F.; DALE, C.; CORDEIRO, I. R. S.; LAMAS, J. R. V. D.; et al. Atlas Iconográfico dos triatomíneos do Brasil - vetores da doença de Chagas. Fiocruz, Rio de Janeiro, 2014.

GALDINO, Y.; SILVA, C. J., Casa e Paisagem Pantaneira. Cuiabá: Carlini \& Caniato, 2009.

GALVÃO, C. Vetores da doença de chagas no Brasil. Curitiba: Sociedade Brasileira de Zoologia, 289 p., 2014.

LIMA-COSTA, M. F.; PEIXOTO, S. V.; GIATTI, L. Tendência da mortalidade entre idosos brasileiros (1980-2000). Epidemiologia e Serviços de Saúde. v. 13, no 217-228, 2004.

NEVES, D. P. Parasitologia Humana. 13ạ ed. São Paulo: editora Atheneu, 2016.

OMS. Organização Mundial de Saúde. Doença de Chagas (Tripanossomíase Americana), 2019. Disponivel em: <https://www.who.int/en/news-room/fact- 
sheets/detail/chagas-disease-(american-trypanosomiasis)\#>

acesso

em $24 / 09 / 2019$

PONTES, G. B. Comportamento sexual de Rhodnius prolixus. (Heteroptera: Reduviidae), Tese (Doutorado em Ciências) - Centro de Pesquisas René Rachou, Fundação Oswaldo Cruz. Belo Horizonte, p. 172. 2010.

SANTANA, K. S. O.; BAVIA, M. E.; RIBEIRO-JR, G. J. S.; SANTOS, C. G. S.; GUIMARÃES, I. C. S.; SILVA, M. M. N.; DIAS-LIMA, A. G. Presence of Triatoma tibiamaculata (PINTO) nymphs in peridomiciles, in Salvador, Bahia. Revista de Patologia Tropical/Journal of Tropical Pathology, v. 42, n. 4, 2013.

SILVA, M. J., Quilombos do Brasil Central: Violência e Resistência Escrava 1919-1888. Goiânia: Kelps, 2003.

SILVA, M. J., Parque das emas: última pátria do cerrado. Goiânia, Kelps, 2005.

SILVEIRA, A. C. Os novos desafios e perspectivas futuras do controle. Rev. Soc. Bras. Med. Trop., Uberaba, v. 44, supl. 2, p. 122-124, 2011.

SOUZA-LIMA, R. C. et al. Outbreak of acute Chagas disease associated with oral transmission in the Rio Negro region, Brazilian Amazon. Rev. Soc. Bras. Med. Trop., Uberaba, v. 46, n. 4, p. 510-514, 2013.

THIAGO, F. A Comunidade Quilombola do Cedro, Mineiros, Goiás: etnobotânica e educação ambiental. Dissertação (Mestrado em Ciências Ambientais) Universidade do Estado de Mato Grosso. Cáceres, p. 110. 2011.

VILLELA M. M. et al. Vigilância entomológica da doença de Chagas na região CentroOeste de Minas Gerais, Brasil, entre os anos de 2000 e 2003. Cad. Saúde Pública, Rio de Janeiro, v. 21, n. 3, p. 878-886, 2005. 


\section{MEIO AMBIENTE E SUSTENTABILIDADE}

\section{PESQUISA, REFLEXÕES E DIÁLOGOS EMERGENTES}




\section{MEIO AMBIENTE E SUSTENTABILIDADE}

\section{PESQUISA, REFLEXÕES E DIÁLOGOS EMERGENTES}

